
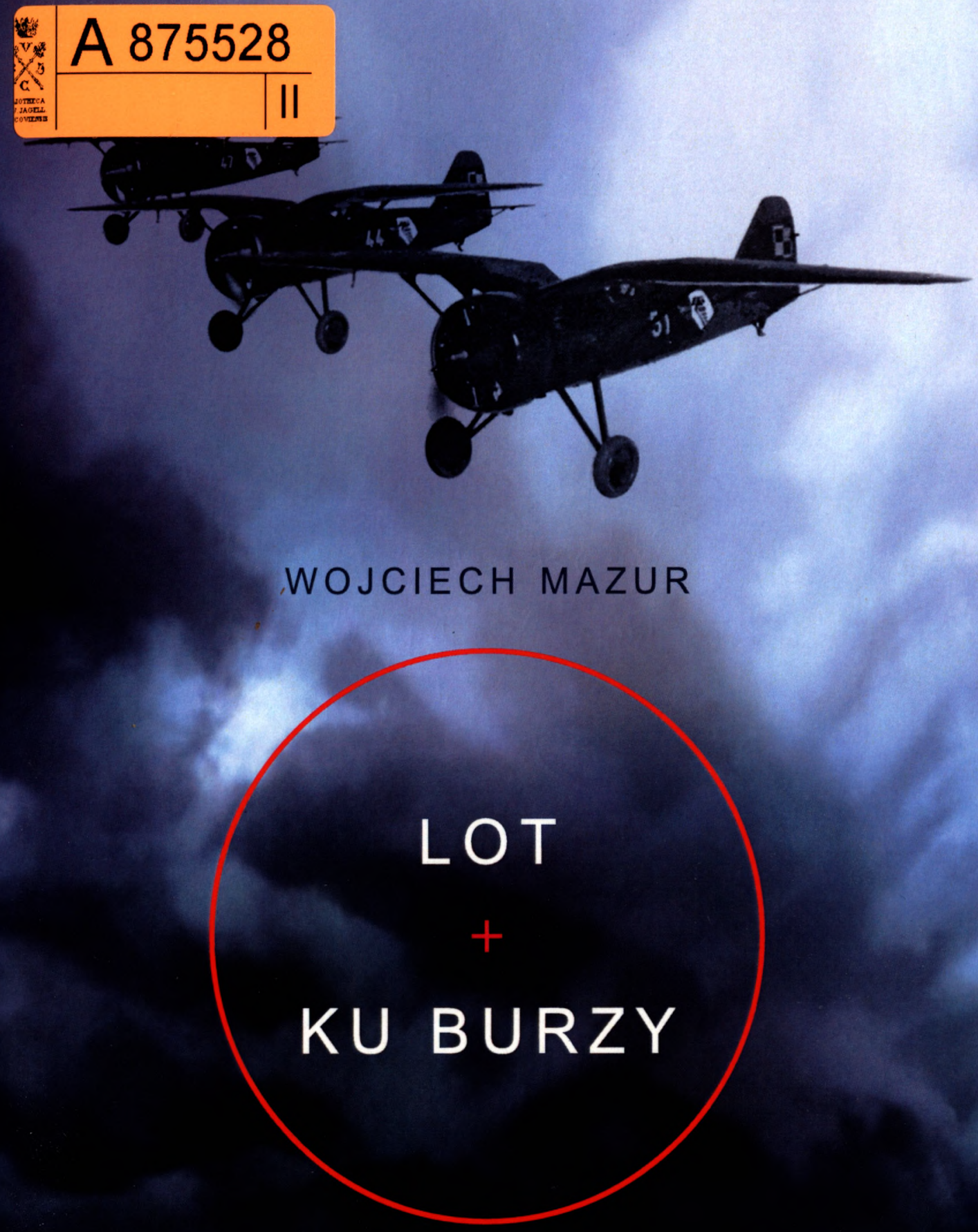

Polska w przygotowaniach mocarstw Zachodu do wojny powietrznej marzec-sierpień 1939 roku 



\section{Lot ku burzy}




\section{8 \\ SOCIETAS \\ seria pod redakcja \\ BOGDANA SZLACHTY}

99 
Wojciech Mazur

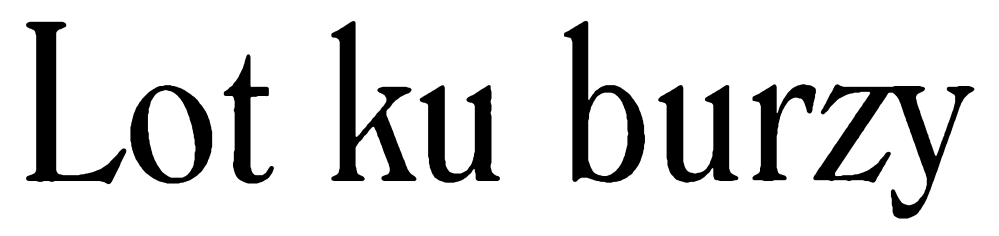

Polska w przygotowaniach mocarstw Zachodu do wojny powietrznej marzec-sierpień 1939 roku 
(c) Copyright by Wojciech Mazur, 2017

Recenzent

dr hab. Piotr Biliński

\author{
Redakcja \\ Justyna Wójcik \\ Projekt okładki \\ Magdalena Dębicka
}

Publikacja dofinansowana przez Instytut Studiów Międzykulturowych Uniwersytetu Jagiellońskiego w Krakowie

ISBN 978-83-7638-853-3

\title{
KSIĘGARNIA AKADEMICKA
}

ul. św. Anny 6, 31-008 Kraków

tel./faks: 124312743,124211387

e-mail: akademicka@akademicka.pl

Księgarnia internetowa:

www.akademicka.pl 


\section{Spis treści}

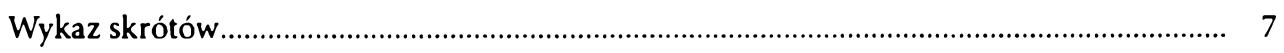

Wstęp ……................................................................................................................... 9

Rozdział 1. Uwertura (styczeń - 15 marca 1939) ……....................................................... 17

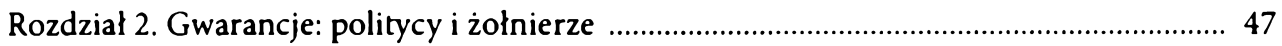

Rozdział 3. Sojusznik, którego nie było (29 marca - 4 kwietnia 1939 roku) ........................ 69

Rozdział 4. „Nowa hipoteza”........................................................................................ 91

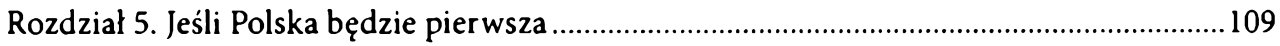

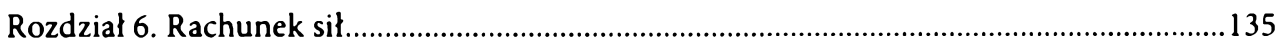

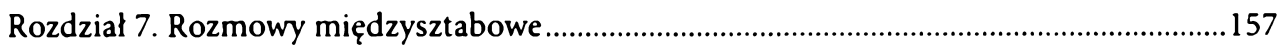

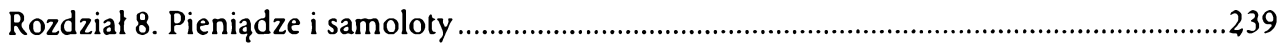

Rozdział 9. Między błyskiem a gromem (23-31 sierpnia 1939 roku)...................................291

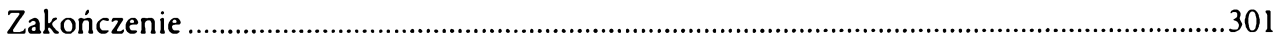

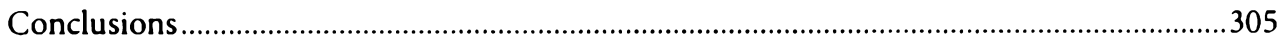

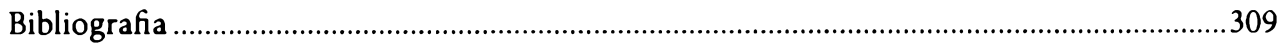

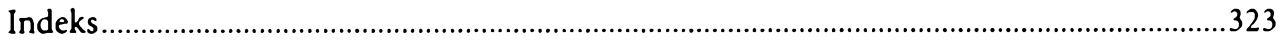





\section{Wykaz skrótów}

\begin{tabular}{|c|c|c|}
\hline AAN & - & Archiwum Akt Nowych w Warszawie \\
\hline $\mathrm{AD}$ & - & Archives diplomatiques (La Courneuve) \\
\hline AdA & - & Armée de l'Air \\
\hline AN & - & Archives Nationales (Pierrefitte-sur-Seine) \\
\hline ASD & - & Archivio Storico Diplomatico (Rzym) \\
\hline AW & - & Attachaty Wojskowe \\
\hline CAEF & - & Centre des Archives Économiques et Financières (Savigny-le-Temple) \\
\hline CAW & - & Centralne Archiwum Wojskowe (Warszawa-Rembertów) \\
\hline CID & - & Committe of Imperial Defence \\
\hline $\cos$ & - & Chiefs of Staff Sub-Committee \\
\hline DCOS & - & Deputy Chiefs of Staff Sub-Committee \\
\hline EMAA & - & État-major de l'Armée de l'Air \\
\hline FO & - & Foreign Office \\
\hline GISZ & - & Generalny Inspektorat Sił Zbrojnych \\
\hline IPMS & - & $\begin{array}{l}\text { Archiwum Instytutu Polskiego i Muzeum im. gen. Władysława Sikorskiego } \\
\text { w Londynie }\end{array}$ \\
\hline JPC & - & Joint Planning Sub-Committee \\
\hline KPZWKW & $N-$ & Komisja Powołana w Związku z Wynikiem Kampanii Wojennej 1939 roku \\
\hline MAE & - & Ministère des Affaires étrangères \\
\hline MSWojsk. &.- & Ministerstwo Spraw Wojskowych \\
\hline O. I SG & - & Oddział I Sztabu Generalnego/Glównego \\
\hline O. II SG & - & Oddział II Sztabu Generalnego/Głównego \\
\hline PZL & - & Państwowe Zakłady Lotnicze \\
\hline SHD-DAA & $A-$ & $\begin{array}{l}\text { Service historique de la Défense - Département de l'Armée de l'Air (Vin- } \\
\text { cennes) }\end{array}$ \\
\hline SHD-DAT & $\Gamma-$ & $\begin{array}{l}\text { Service historique de la Défense - Département de l'Armée de Terre (Vin- } \\
\text { cennes) }\end{array}$ \\
\hline SR & - & Samodzielny Referat \\
\hline SRI & - & Section de Renseignement \\
\hline TNA & - & The National Archives (Kew) \\
\hline
\end{tabular}





\section{Wstęp}

W nauce bywają niekiedy zagadnienia, które w powszechnym mniemaniu zbadane zostały gruntownie, a kolejne ich analizy mogłyby wydawać się zbędne. Autor, podejmując problematykę dotyczącą wydarzeń rozgrywających się w Europie w ostatnich miesiącach przed wybuchem II wojny światowej, zdawał sobie sprawę z tego, że wielokrotnie była już ona przedmiotem naukowej refleksji. Równocześnie jednak przekonany był, że wzięte przezeń na warsztat kwestie planów wojennej współpracy sił powietrznych kształtującej się właśnie antyhitlerowskiej koalicji, a szczególnie polskie aspekty tych planów, zbadane zostały w stopniu dalece niewystarczającym. Tymczasem, jak miał prawo sądzić na podstawie wcześniejszych prac, dogłębna analiza związanej z tą współpracą problematyki prowadzić mogła do interesujących wniosków, które nie ograniczałyby się jedynie do stosunkowo wąskiego kręgu zagadnień ściśle z nią związanych, ale byłyby też użyteczne do konstruowania ujęć szerszych, o bardziej ogólnym charakterze.

U progu II wojny światowej to właśnie lotnictwo wojskowe stanowiło bowiem jedną z nielicznych sfer, w których możliwa zdawała się współpraca coraz bardziej zagrożonej przez agresję Rzeszy Polski oraz Francji, z którą leciwy już alians nie bez trudu próbowano reanimować, i Wielkiej Brytanii, niespodziewanie skłonnej szukać związków z mało dotychczas znanym partnerem ze wschodu. Tym samym zagadnienia lotniczej kooperacji Warszawy, Paryża i Londynu stawały się jedną z kwestii rozważanych wówczas przez najważniejszych aktorów wydarzeń, a także swoistym probierzem ich rzeczywistych intencji. To właśnie analiza kolejno dochodzących w tej sferze do głosu koncepcji oraz towarzyszących im procesów decyzyjnych stała się głównym celem podjętych przez autora prac.

Koncepcje te i decyzje nie kształtowały się jednak oczywiście w politycznej, wojskowej czy finansowej próżni. Problematyka lotnicza stanowiła jedynie fragment, choć nie najmniej istotny, o wiele szerszej całości. Owo zróżnicowane, wielopłaszczyznowe tło także stało się przedmiotem źródłowych studiów autora. Rzecz jasna, przedstawienie pełnego jego obrazu nie było ani możliwe, ani niezbędne. W konstruowanej narracji uwzględnione zostały więc glównie te wątki, których przedstawienie 
zdawało się nieodzowne do zrozumienia głównej, dotyczącej zagadnień lotniczych części wywodu. Podkreślić przy tym trzeba, że w rzeczywistości w roku 1939 relacje zależności miały tu charakter dwustronny: bieg spraw dotyczących lotnictwa warunkowany był przez kwestie z zakresu ogólnej strategii wojskowo-politycznej, zarazem jednak w ramach owej strategii, jak już zauważyliśmy, problematyka lotnicza odgrywała niepoślednią rolę.

Opracowana przez autora analiza objęła stosunkowo krótki, ale obfitujący w wydarzenia okres od 15 marca do 31 sierpnia 1939 roku. Pierwsza z wymienionych cezur związana jest $z$ dokonaną przez Rzeszę ostateczną likwidacją niezależnej Czechosłowacji. Krok ten okazał się katalizatorem procesów, które w ciągu następnych kilku tygodni wywołały znaczące zmiany w europejskiej polityce, skłaniając m.in. Wielką Brytanię do udzielenia Polsce gwarancji suwerenności i przyczyniając się do ożywienia aliansu Paryża i Warszawy. Tym samym ukształtowane zostały podstawy militarno-politycznego układu, który stał się przedmiotem podjętych przez autora rozważań.

Cezura końcowa przedstawianego wywodu jest bardziej jeszcze czytelna. Wyznacza ją po prostu ostatni dzień pokoju, bezpośrednio poprzedzający wybuch kolejnej światowej zawieruchy. Oczywiście lotnicze aspekty wydarzeń, które we wrześniu 1939 roku rozgrywały się na niebie nad Polską oraz w stolicach jej zachodnich aliantów, w niemałej części stanowiły konsekwencję wcześniej podejmowanych decyzji. Równocześnie jednak należały już do innej, wojennej rzeczywistości. Autor nie zdecydował się więc na włączenie ich do prezentowanej obecnie analizy, wrześniową problematykę zamierzając omówić niebawem w odrębnej publikacji.

Całość prezentowanego tekstu uporządkowana została wedle klucza chronologiczno-problemowego $w$ ramach dziewięciu rozdziałów. Pierwszy $z$ nich ma charakter wstępny, stanowiąc zarys wojskowo-politycznych stosunków Paryża, Londynu i Warszawy w okresie od początku roku 1939 do czechosłowackiego kryzysu z połowy marca tego roku. Kolejne cztery zawierają analizę kształtowania się polskich odniesień $w$ wojennych planach mocarstw zachodnich. Została ona przedstawiona w porządku chronologicznym, w każdym zaś ze wspomnianych rozdziałów zaakcentowane zostało zagadnienie najbardziej na danym etapie aktualne: od wprowadzenia spraw polskich do brytyjsko-francuskiego dyskursu skutkiem udzielonych przez Brytyjczyków gwarancji, przez marginalną jedynie obecność tych spraw w początkowej fazie podjętych przez oba państwa rozmów wojskowych, po próby uzgodnienia ich kontrakcji w przypadku, w którym to Rzeczpospolita stałaby się pierwszą ofiarą zbrojnej agresji Rzeszy. Problematyka współpracy lotniczej z partnerem znad Wisły została w tej części pracy wpisana w znacznie bardziej od niej rozległe ramy ogólnej strategii wojskowej.

Rozdział szósty zawiera podsumowanie informacji i ocen, którymi na temat sił powietrznych Rzeczypospolitej dysponowano wiosną 1939 roku w stolicach mocarstw zachodnich, a także danych, którymi na temat lotniczego potencjału Francji i Wielkiej Brytanii rozporządzano wówczas w Warszawie. $W$ rozdziale tym przed- 
stawiono też w zarysie stan wiedzy wojskowych z Paryża i Londynu na temat sił powietrznych chętnie widzianego tam $w$ roli wojennego partnera ZSRR.

Dwa kolejne rozdziały są znacznie bardziej od poprzednich rozbudowane. W rozdziale siódmym przeanalizowano bezpośrednie kontakty wojskowe, do których doszło między Polską a jej partnerami z Zachodu w okresie od kwietnia do lipca 1939 roku, a także związane $\mathrm{z}$ tematyką pracy aspekty rozmów prowadzonych $\mathrm{w}$ drugiej połowie sierpnia w Moskwie przez wojskowych przedstawicieli Francji i Wielkiej Brytanii. W rozdziale ósmym przedstawione zostały polskie zabiegi o finansową i materiałową pomoc zachodnich sojuszników. W obu przypadkach zasadnicza część analizy skoncentrowana została wokół zagadnień dotyczących sił powietrznych.

Rozdział dziewiąty stanowi próbę syntetycznego przedstawienia stanu francusko-brytyjsko-polskiej lotniczej współpracy w ostatnich dniach sierpnia 1939 roku. Punktem wyjścia zaprezentowanych w tej części pracy rozważań stały się polityczno-wojskowe konsekwencje paktu Ribbentrop-Mołotow, który wedle sformułowanych na Zachodzie ocen ostatecznie zdezawuował wojskową użyteczność Polski jako partnera tamtejszych mocarstw. Oznaczało to także faktyczne przekreślenie nikłych już i uprzednio szans na realne wsparcie zaatakowanej przez Rzeszę Rzeczypospolitej przez francuskie czy brytyjskie siły powietrzne lub poważniejsze dostawy sprzętu lotniczego.

Przyjęty układ pracy stanowi wynik pewnego kompromisu. Stłoczenie w stosunkowo krótkim, kilkumiesięcznym okresie wydarzeń o różnorodnym charakterze uniemożliwiło w praktyce zastosowanie czysto chronologicznego układu treści. Próba takiego ich uporządkowania skutkować by musiała w najlepszym przypadku koniecznością licznych dygresji, w gorszym zaś, a prawdopodobnym - groźnym dla zrozumienia wywodu chaosem. $Z$ kolei ujęcie wyłącznie problemowe doprowadziłoby do sztucznego podziału rozważanych zagadnień na autonomiczne segmenty.

Autor zdaje sobie sprawę z tego, że rozwiązanie kompromisowe też nie jest wolne od wad. Najpoważniejszą z nich stanowi konieczność powrotu do już przedstawionych wydarzeń dla ukazania kolejnych, pominiętych uprzednio ich aspektów, a niekiedy też niezbędne dla zrozumienia wywodu powtórzenia podanych wcześniej informacji. Uwzględnienie kryterium problemowego skutkować też musiało pewną separacją niektórych treści. Wobec ograniczonej skali tego zabiegu ich powiązanie nie powinno jednak okazać się trudne.

Dwie jeszcze kwestie dotyczące oddawanego w ręce czytelnika tekstu autor czuje się w obowiązku wyjaśnić. Po pierwsze, zdecydował się na dość znaczne rozbudowanie przypisów. Nie zawierają one bynajmniej wszystkich możliwych odniesien jednak zarówno ich treść, jak i forma wykraczają nieco poza niezbędne minimum. Autor uznał jednak, że wyniki przeprowadzonej przezeń kwerendy mogą okazać się interesujące i dla innych badaczy - starał się więc w miarę możności dostarczyć im wskazówek. Ponadto zaś, świadom, że pierwszym odbiorcą jego tekstu stanie się polski czytelnik, nie zawsze zorientowany w niuansach organizacji francuskich czy brytyjskich wojskowo-politycznych struktur lub ich personalnej obsadzie, dążył do podawania odpowiednich informacji $w$ formie możliwie rozbudowanej. 
Po drugie, autor zdecydował się nagiąć reguły warsztatu, które nakazują unikać zbyt licznych cytatów, a odpowiednie treści zastępować syntetyzującym omówieniem. Był bowiem i nadal pozostaje przekonany, że w ramach podjętej tematyki oryginalne wypowiedzi czy charakterystyczne fragmenty dokumentów lepiej oddają myśli aktorów wydarzeń niż najlepiej choćby skomponowane streszczenia czy objaśnienia. Liczy, że to odstępstwo od zasad czytelnik zechce zrozumieć - i zaakceptować.

Nie lekceważąc dorobku poprzedników, autor zdecydował się oprzeć swą analizę głównie na źródłach pierwotnych, zgromadzonych w trakcie wieloletniej archiwalnej kwerendy. Przyczyny tej decyzji były stosunkowo proste: literatura przedmiotu okazała się niezwykle obfita, ale też relatywnie mało użyteczna w pracach nad zasadniczymi wątkami podjętej problematyki. Autorzy większości istniejących opracowań koncentrowali się bowiem głównie na zagadnieniach ze sfery politycznej, kwestie militarne uznając $w$ najlepszym wypadku za drugorzędne. $W$ tej sytuacji stanowiąca przedmiot naszych zainteresowań tematyka lotnicza była marginalizowana, często zaś pomijana całkowicie. Co więcej, niemała część wchodzących w grę opracowań powstała przed kilkudziesięciu laty, często w latach 60. i 70. minionego stulecia. Prace te, wobec ogromnego poszerzenia dostępnej obecnie bazy źródłowej, często uznać trzeba za przestarzałe - bez jakiejkolwiek winy ich autorów.

Nie znaczy to oczywiście, że w każdym aspekcie swych badań autor zamierza rościć sobie pretensje do roli pioniera. Przeciwnie, naukowy dług przyszło mu zaciągnąć u całkiem licznych badaczy. Kreśląc ogólny obraz międzysojuszniczej współpracy $w$ interesującym go okresie, mógł się odwołać do prac pierwszego ze swych mistrzów, Mariana Zgórniaka, czy Normana Henry’ego Gibbsa' ${ }^{1}$. Analizę wojskowych stosunków Rzeczypospolitej i Francji ułatwiła mu lektura tekstów Jana Ciałowicza, Henryka Bułhaka czy Pierre’a Le Goyeta ${ }^{2}$. Niezwykle cenne dla przedstawienia militarnych relacji Warszawy i Londynu po raz kolejny okazało się źródłowe opracowanie Anity Prazmowskiej, zaś w pewnych kwestiach szczegółowych także teksty Andrzeja Suchcitza ${ }^{3}$. Polsko-francuskie stosunki polityczne interesująco zaprezentowała Mał-

' N.H. Gibbs, Grand Strategy, vol. 1: Rearmament Policy, London 1976, History of Second World War. United Kingdom Military Series; M. Zgórniak, Europa w przededniu wojny. Sytuacja militarna w latach 1938-1939, Kraków 1993, Wydawnictwa „Księgarni Akademickiej”, 7; idem, Sojusz francusko-brytyjski i problemy jego realizacji $w$ planowaniu oraz praktycznej dzialalności wojskowej mocarstw zachodnich w 1939 roku, [w:] Z dziejów polityki i dyplomacji polskiej. Studia poświęcone pamięci Edwarda hr. Raczyńskiego Prezydenta Rzeczypospolitej Polskiej na wychodźstwie, Warszawa 1994, s. 364-380.

2 J. Ciałowicz, Polsko-francuski sojusz wojskowy 1921-1939, Warszawa 1970; H. Bulhak, Polska a Francja (październik 1938 - polowa kwietnia 1939 r.). Niektóre aspekty dyplomatyczne i wojskowe, [w:] Kampania polska 1939 r. Polityka, spoleczeństwo, kultura, t. 1: Strategia, red. M.P. Deszczyński, T. Pawłowski, Warszawa 2013; P. Le Goyet, France-Pologne 1919-1939. De l'amitié romantique à la méfiance réciproque, Paris 1991.

A. Prazmowska, Britain, Poland and the Eastern Front, 1939, Cambridge 2004, Soviet and East European Studies; A. Suchcitz, Wrażenia generala Ironside'a $z$ wizyt $w$ Polsce $w$ latach 1925 i 1939, „Mars” 1993, nr 1, s. 55nn.; ide m, Pplk Emilius Clayton: pierwszy brytyjski attaché wojskowy w Warszawie, [w:] Si vis pacem, para bellum. Bezpieczeństwo i polityka Polski. Ksiega ju- 
gorzata Gmurczyk-Wrońska ${ }^{4}$, niektóre aspekty takich stosunków polsko-brytyjskich prześledzić mógł autor $w$ ślad za Simonem Newmanem, Henrykiem Jackiewiczem, Marianem Nurkiem czy Jackiem Tebinką ${ }^{5}$. Wysoce użyteczne dla przedstawienia dylematów polskiej polityki zagranicznej objętego analizą okresu, a przy tym inspirujące intelektualnie stały się dla autora opracowania Anny Cienciały i Marka Kornata ${ }^{6}$.

Znacznie mniej liczne okazały się prace, w których szerzej uwzględniona została szczególnie nas interesująca tematyka lotniczej współpracy państw koalicji antyhitlerowskiej. I tu jednak autor wzmiankować winien co najmniej kilka tytułów. Znalazła się wśród nich m.in. wspomniana już wyżej książka Anity Prazmowskiej, ale też dwa opracowania Thierry'ego Viviera, który podjął w nich także kwestie kontaktów sił powietrznych Francji i Polski, czy dość obszerna praca Patricka Fridensona i Jeana Lecuira na temat lotniczej kooperacji francusko-brytyjskiej. Warte lektury okazały się też teksty Bartłomieja Belcarza?

Nie wszystkie też wykorzystane źródła musiał autor pozyskać bezpośrednio $\mathrm{z}$ archiwów. Niezwykle użyteczne okazały się obszerne edycje dyplomatycznych dokumentów brytyjskich ${ }^{8}$, francuskich ${ }^{9}$ i polskich ${ }^{10}$. Zdecydowanie przydatne, choć

bileuszowa ofiarowana profesorowi Tadeuszowi Dubickiemu, red. R. Majzner, Częstochowa 2013, s. 94 Inn., Zeszyty Historyczne Wyższej Szkoly Pedagogicznej w Częstochowie, 12.

- M. Gmurczyk-Wrońska, Polska - niepotrzebny aliant Francji? (Francja wobec Polski w latach 1938-1944), Warszawa 2003.

5 S. Newman, Gwarancje brytyjskie dla Polski. Marzec 1939, przel. J. Meysztowicz, T. Szafrański, Warszawa 1981; H. Jackiewicz, Brytyjskie gwarancje dla Polski w 1939 roku, Olsztyn 1980; M. Nurek, Polska w polityce Wielkiej Brytanii w latach 1936-1941, Warszawa 1983; J. Tebinka, Polityka brytyjska wobec problemu granicy polsko-radzieckiej, Warszawa 1998. Szereg dalszych istotnych informacji znaleźć można w szkicu: J. Tebinka, Przegląd brytyjskiej literatury naukowej na temat wydarzeń 1939 roku, „Dzieje Najnowsze” R. 41, 2009, nr 3, s. 89-100.

'A. Cienciała, Polska w polityce brytyjskiej i francuskiej w 1939 roku: wola walki czy próba uniknięcia wojny?, „Zeszyty Historyczne” (Paryż) 1985, z. 75, s. 152nn.; e a de m, Minister Józef Beck i ambasador Edward Raczyński a zbliżenie polsko-brytyjskie w okresie październik 1938 - styczeń 1939, [w:] Z dziejów polityki i dyplomacji polskiej..., s. 348nn.; M. Kor nat, Polska 1939 roku wobec paktu Ribbentrop-Molotow. Problem zbliżenia niemiecko-sowieckiego w polityce zagranicznej II Rzeczypospolitej, Warszawa 2002, Monografie PISM; ide m, Polityka zagraniczna Polski, 1938-1939. Cztery decyzje Józefa Becka, Gdańsk 2012.

P. Fridenson, J. Lecuir, La France et la Grande-Bretagne face aux problèmes aériens (1935 - mai 1940), Vincennes 1976; T. Vivier, L'aviation française en Pologne (janvier 1936 - septembre 1939), „Revue Historique des Armées” 1993, no. 4, s. 60nn.; ide m, La politique aéronautique militaire de la France (janvier 1933 - septembre 1939), Paris 1997; B. Belcarz, Morane-Saulnier M.S. 406 lotnictwa polskiego, „Militaria i Fakty” 2000, nr 2, s. 34n.; i de m, Polskie lotnictwo we Francji 1940, Sandomierz 2002.

" Documents on British Foreign Policy 1919-1939. Third Series [dalej: DBFP], ed. by E.L. Woodward, R. Butler, vol. 4: 1939, London 1951; vol. 5: 1939, London 1952.

` Documents diplomatiques français 1932-1939. 2me série: 1936-1939 [dalej: DDF], t. 13: 1er décembre 1938 - 31 janvier 1939, Paris 1979; t. 14: ler février - 15 mars 1939, Paris 1980; t. 15: 16 mars - 30 avril 1939, Paris 1981; t. 16: ler mai - 24 juin 1939, Paris 1983; t. 17: 25 juin - 12 août 1939, Paris 1984; t. 18: 13-25 aoùt 1939, Paris 1985.

11) Polskie dokumenty dyplomatyczne 1939 styczeń-sierpień [dalej: PDD 1939], red. S. Żerko, Warszawa 2005, Polskie Dokumenty Dyplomatyczne. 
często wymagające krytycznego osądu były także opublikowane po zakończeniu wojny świadectwa niektórych uczestników wydarzeń, jak Maurice Gamelin, Wacław Stachiewicz, Juliusz Łukasiewicz, John Slessor czy Edward Roland Sword"

Jednak zdecydowaną większość spośród wykorzystanych materiałów uzyskał autor podczas archiwalnej kwerendy, prowadzonej głównie w Polsce, Wielkiej Brytanii i Francji. Stan zachowania polskich materiałów z okresu bezpośrednio poprzedzającego wybuch wojny sprawił wszakże, iż użyteczność archiwów krajowych okazała się dość ograniczona - choć poszukiwania podjęte w zasobie Archiwum Akt Nowych oraz Centralnego Archiwum Wojskowego nie okazały się całkiem bezowocne. Znacznie jednak obfitszy plon przyniosła kwerenda przeprowadzona $w$ ulokowanym na krańcach Paryża zamku Vincennes, mieszczącym archiwa francuskiej armii lądowej (Service historique de la Défense - Departement de l'Armée de Terre) oraz sił powietrznych (Service historique de la Défense - Departement de l'Armée de l'Air). Szereg interesujących materiałów udało się także odnaleźć w zasobach Archives diplomatiques z podparyskiego La Courneuve, gdzie złożona została część akt Ministére des Affaires étrangères.

Nie mniej warte odwiedzin okazały się archiwa $z$ terenu Wysp Brytyjskich. Bardzo obfity materiał dotyczący zagadnień politycznych, wojskowych i ekonomicznych pozyskał autor w ulokowanych w Kew pod Londynem The National Archives. Niedostatki wyników kwerendy $w$ archiwach krajowych wypełnić pozwoliły zaś w znacznej mierze poszukiwania podjęte w londyńskim Archiwum Instytutu Polskiego i Muzeum im. gen. Władysława Sikorskiego.

Inne zagraniczne archiwa i biblioteki nie dostarczyły już materiałów o pierwszorzędnym dla podjętej analizy znaczeniu, choć niektóre odnalezione w nich dokumenty okazały się interesujące. Dalsze informacje na ten temat odnaleźć można w przypisach oraz umieszczonej na końcu pracy bibliografii.

Jest dobrym i miłym zwyczajem, że we wstępie umieszcza się także podziękowania. Autor, badania prowadząc wedle własnego planu i finansując je głównie z własnej, niezbyt bogatej szkatuły, tym większą wdzięczność odczuwa względem tych, którzy zechcieli podać mu pomocną dłoń. Podziękować chciałby więc dyrekcji Instytutu Studiów Międzykulturowych Uniwersytetu Jagiellońskiego, w tym nade wszystko Pani Dyrektor dr hab. Monice Banaś, której życzliwość, zrozumienie oraz skłonność do zaoferowania wszelkiej możliwej pomocy bardzo znacząco przyczyniły się do postępów jego prac. Słowa wdzięczności kieruje też pod adresem Fundacji z Brzezia Lanckorońskich. Przyznane przez nią stypendium, które umożliwiło na-

"M. Gamelin, Servir, t. 2: Le prologue du drame (1930 - août 1939), Paris 1946; t. 3: La guerre (septembre 1939 - 19 mai 1940), Paris 1947; W. St a chi ewicz, Wierności dochować żołnierskiej. Przygotowania wojenne w Polsce 1935-1939 oraz kampania 1939 w relacjach i rozwazaniach szefa Sztabu Glównego i szefa Sztabu Naczelnego Wodza, Warszawa 1998; J. Łuka sie wicz, Dyplomata w Paryżu, 1936-1939. Wspomnienia i dokumenty Juliusza Lukasiewicza, ambasadora Rzeczypospolitej Polskiej, oprac. J. Slessor, The Central Blue. Recollections and Reflections, London 1956; W. Jędrzejewicz, H. Bulhak, Londyn 1989; E.R. Sword, The Diary and Despatches of a Military Attaché in Warsaw, 1938-1939, ed. by E. Turnbull, A. Suchcitz, London 2001. 
ukowy wyjazd autora do Londynu, w pełni spożytkowane zostanie zapewne dopiero na dalszych etapach badań. Już teraz jednak umożliwia wprowadzenie do niemal ukończonego tekstu ostatnich korekt i uzupełnień.

Nigdy zapewne nie zdoła się autor odwdzięczyć za pomoc, której udzielił mu w Londynie dr Krzysztof Gebhardt. Jego wielką życzliwość zawsze mieć będzie w pamięci - i gorąco za nią dziękuje. Szczere podziękowania kieruje też autor pod adresem dr. hab. Piotra Bilińskiego, kierownika Zakładu Historii Kulturowej w Instytucie Studiów Międzykulturowych Uniwersytetu Jagiellońskiego i recenzenta pracy, za jego życzliwe zainteresowanie $w$ trakcie realizacji projektu i wnikliwe uwagi względem jego finalnej postaci. Wdzięczny niezwykle jest także panu Kamilowi Stepanowi, który zechciał przejrzeć maszynopis książki. Sformułowane przezeń przy tej okazji merytoryczne uwagi okazały się wielce pomocne w nadaniu tekstowi ostatecznej formy. Oczywiście za wszelkie niedoskonałości swej pracy sam autor ponosi wyłączną odpowiedzialność.

Podziękowania składa wreszcie autor także żonie Agnieszce - częstej towarzyszce naukowych wyjazdów, tłumaczce tekstów francuskich, pierwszej czytelniczce maszynopisów. Jakaś Jej cząstka tkwi i w tym tekście - reszta niech pozostanie milczeniem.

Kraków - Londyn, marzec 2017 r. 
Indicition sur les disjostiors qul serient éventielloisert prlses en cis de juerre. Le ċéveloppomeni c̀e i'.uróe llemende, la usse en service ravide de ses fortiflcctions a la frontièro occldentale et les cheifienents récents en Burope lientrile sort des factours dorit 11 fuut égelegept tenlr compte. Le France urait toutefols la posslbilité d'es.ectuer des oṕ́rationo ofícnsives à objectif linlté, dung le jut je jétourner les forces vilimandes du théatre orlental.

Une part1e de l'ietlon offensive se l'.éronautıque britennlque pourruit etre consicrée ù ilder l'-v1st1on frarçalso ì it taquer les objectifs suscetibles de contribuer ku succès des odérutions terrestres, sous réserve cu'll ne serit pas de notro 1ntéret de prendre l'inltiative d'sutaques pouvent oire interprètées cowle dirifées sontre la population civilo.

b) - vo.cluslons concernint le Tinéâtro d'ujératious su rooéen.-

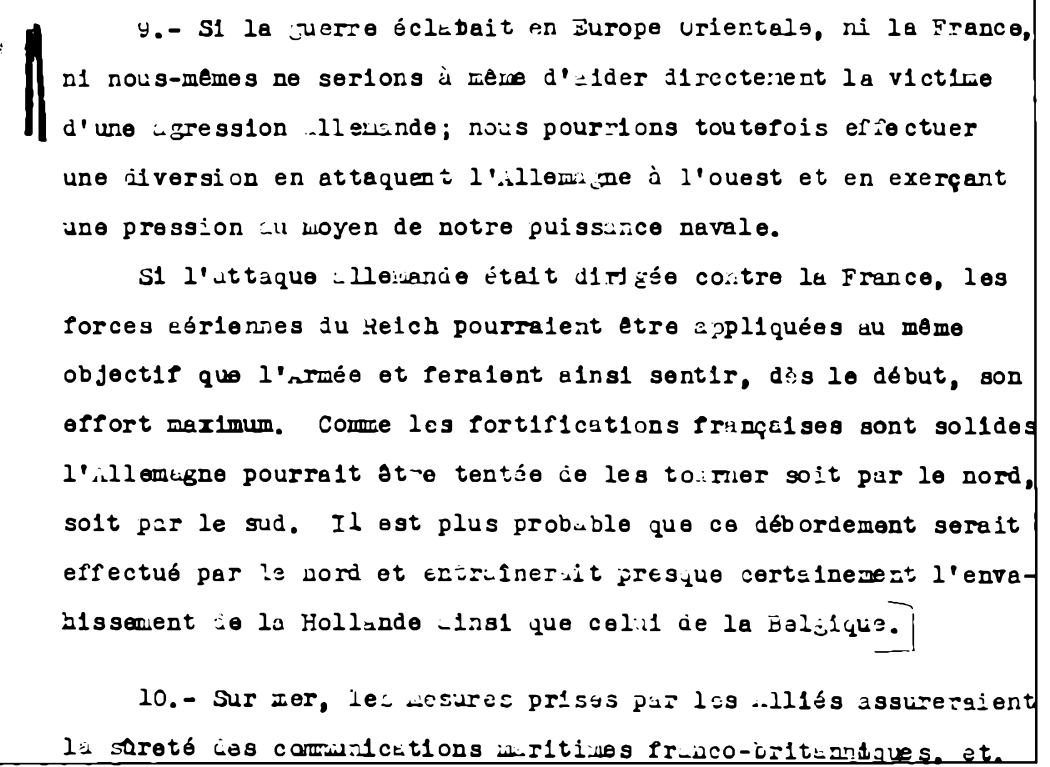

Fragment egzemplarza No 1 francuskiego kompletu dokumentów z pierwszej fazy brytyjsko-francuskich rozmów międzysztabowych (29 marca - 4 kwietnia 1939 roku). W obejmującym łącznie kilkaset stron maszynopisu tekście jako wyjątkowo ważny wyróżniono fragment "Jeśli wojna wybuchlaby w Europie Wschodniej ani Francja ani nawet my sami [Brytyjczycy] nie bylibyśmy w stanie udzielić bezpośredniej pomocy ofierze agresji niemieckiej; moglibyśmy jednak dokonać dywersji atakując Niemcy na zachodzie i wywierając presję z wykorzystaniem naszej potęgi morskiej" (Service historique de la Défense - Département de l'Armée de Terre, 7 NN 2/169). 


\section{Rozdzial 1}

\section{Uwertura \\ (styczeń - 15 marca 1939)}

W ostatniej dekadzie października 1938 roku II Rzeczpospolita musiała określić się wobec niemieckich żądań, które mogły przesądzić o dalszym jej losie. Ich zaaprobowanie oznaczało w perspektywie utratę suwerenności, odrzucenie - groziło wojną. Krąg osób zorientowanych w sytuacji był wąski, większość $z$ nich zaś, nie wyłączając ministra spraw zagranicznych Józefa Becka, liczyła, że w grę wchodzi jedynie osobista inicjatywa kierującego od niedawna Auswärtiges Amt ministra Joachima von Ribbentropa, co znacząco zmniejszać musiało skalę zagrożenia. Niewątpliwie jednak zasadne wydawało się dokonanie przeglądu posiadanych aktywów - w tym przymierzy, na których uruchomienie można by liczyć w razie ziszczenia się mniej szczęśliwych scenariuszy'.

Tu zaś sytuacja nie przedstawiała się optymistycznie. Od 1921 roku Polska związana była układem sojuszniczym z francuską III Republiką, ale wzajemne stosunki aliantów, od dłuższego czasu pozbawione głębszej treści, u schyłku roku 1938 bardzo powoli dopiero wychodziły z zapaści, w której znalazły się skutkiem odmiennych postaw zajętych przez oba państwa w trakcie wrześniowego kryzysu oraz dokonanej przez Polskę aneksji Zaolzia. Rozważane jeszcze niedawno w Paryżu koncepcje bardzo poważnego rozluźnienia czy wręcz zerwania aliansu z Warszawą coraz wyraźniej uznawano za niemożliwe do zaakceptowania - był to jednak dopiero początek drogi do nominalnej choćby odbudowy dawnej kooperacji². Nad Sekwaną zresztą polskiego partnera od dawna już traktowano w dużej mierze instrumentalnie - bacząc głównie na własny interes (czasem uznawany za interes wspólny), w nowej zaś sytu-

1 H. Batowski, Europa zmierza ku przepaści, wyd. 2, Poznań 1989, s. 105nn.; M. Kornat, Polityka zagraniczna Polski..., s. 242nn.

2 Problem ten był obszernie przedstawiany w literaturze. Zob.: M. Gmurczyk-Wrońska, op. cit., s. $41 \mathrm{nn}$. Krótkie podsumowanie podjętej w Paryżu dyskusji w oświetleniu jednego z jej inicjatorów, ambasadora Francji w Polsce Leona Noëla: The National Archives (Kew) [dalej: TNA], FO 371/21809, pismo No 388 (71/12/38) ambasadora Wielkiej Brytanii Howarda Williama Kennarda do ministra spraw zagranicznych lorda Halifaxa z 28 XI 1938 r. 
acji tendencje te uległy bodaj jeszcze nasileniu. Rafy i mielizny potencjalnej francusko-polskiej współpracy bez trudu dostrzegali rezydujący nad Sekwaną dyplomaci. Celnie charakteryzował sytuację także polski ambasador w Paryżu Juliusz Łukasiewicz. W datowanym 17 grudnia raporcie zwracał uwagę na brak w wypowiedziach przedstawicieli strony francuskiej oznak dążeń „do nadania sojuszowi z nami siły żywotnej, czy nawet potraktowania go [...] jako instrumentu polityki zagranicznej" oraz - dla odmiany - liczne powody do obaw, że "gdyby [...] wypadło Francji wykonać zobowiązania wypływające [...] z sojuszu z nami, wysiłek w kierunku wykręcenia się od tych zobowiązań byłby niewątpliwie większy niż akcja w kierunku ich dotrzymania”. „W stosunku do swoich zobowiązań [...] Francja jest zbyt słabą, aby z nami zerwać, i zbyt słabą również, aby przyznać się do nich z dostatecznym zdecydowaniem" - brzmiała niezbyt optymistyczna konkluzja?'.

Bardzo podobnie sytuację postrzegali Brytyjczycy, z którymi sojusz, jak przeświadczony był Łukasiewicz, uznawano w Paryżu za jedyny pozytywny walor francuskiej polityki zagranicznej. Dyrektor Departamentu Centralnego Foreign Office William Strang zauważał w tymże czasie, że względem Rzeczpospolitej Francuzi najwyraźniej oczekują na dalszy rozwój wypadków. Jeśli jednak w razie niemieckiego ataku na polskiego alianta interweniować nie zechcą - „prawdopodobnie znajdą środki [...] by uniknąć wywiązania się ze zobowiązań"4.

Głęboką wzajemną nieufność Paryża i Warszawy odnotowywał też ulokowany nad Sekwaną brytyjski attaché wojskowy płk William Fraser. Podsumowując nieoficjalne rozmowy z oficerami francuskiego Sztabu Generalnego, konstatował: „niewiele oczekuje się od Polski [...] w razie wojny $z$ Niemcami, i przeciwnie, jest mało prawdopodobne, by Francja zaangażowała się w wojnę, aby zachować polski Korytarz lub uratować Polskę od utraty ziem na rzecz niepodległej Republiki Ukraińskiej"ঙ. Niespełna zaś dwa tygodnie później tenże oficer dopełnił swoją wypowiedź w tonie

${ }^{3}$ Polskie dokumenty dyplomatyczne 1938 [dalej: PDD 1938], red. M. Kornat, Warszawa 2007, dok. 451, s. 843nn., Polskie Dokumenty Dyplomatyczne. Por.: J. Łukasiewicz, op. cit., s. $185 \mathrm{nn}$.

4 TNA, FO 371/21809, notatka Stranga z 12 XII 1939 r. w aktach reg. C/14878//2688/55. Możliwe jest jednak, że Niemcy uwikłają się w konflikt nie tylko z Polską, ale i ZSRR. Francja uznać to może za ostatnią szansę na wymierzenie Rzeszy ciosu, „w takim przypadku oni [Francuzi] powołaliby się na traktatowe zobowiązania dla usprawiedliwienia swej interwencji" - przewidywał Strang.

TNA, CAB 21/555, pismo No 1249 Secret płk. Frasera do ambasadora Wielkiej Brytanii w Paryżu Erica Phippsa z 22 XII 1938 r. „Wydaje się, że francuski Sztab Generalny nie uważa, iż Francja byłaby $z$ pewnością zaangażowana $w$ wojnę polsko-niemiecką, $w$ każdym razie we wczesnym jej stadium", komentował Phipps, przesyłając 28 grudnia raport Frasera do Halifaxa pismem No 1538 (ibidem). W skierowanym tegoż dnia do podsekretarza stanu w FO Orméa Sargenta piśmie No 189/34/38 Phipps swoją osobistą ocenę formułował bardziej dosadnie: „jeśli oni [Francuzi] rzeczywiście zdecydują się walczyć, będzie to efektem założenia, że mają bardzo dużą szansę na zwycięstwo, nie zaś staromodnej idei honorowania podpisów" [podkr. oryg. - W.M.] (TNA, FO 371/21809). Wzmiankowana przez Frasera "niepodległa Ukraina” powszechnie uznawana była za potencjalny twór niemiecki. W tejże kwestii: J.J. Bruski, In Munich's Shadow: The Ukrainian 
bliskim ocenom Stranga: pakt wiążący Paryż z Warszawą jest na tyle elastyczny, że może być interpretowany na różne sposoby, stąd racjonalna jest teza, że akcja francuska „będzie określana bardziej przez możliwości militarne niż zobowiązania jakiegoś traktatu"6.

Z perspektywy czasu wszystkie powyższe opinie na temat francuskich zamysłów względem sojusznika znad Wisły uznać trzeba za wyjątkowo wręcz celne. Równocześnie jednak podkreślić wypada, że z punktu widzenia gospodarzy paryskich sztabowych czy ministerialnych gabinetów sprawa nie przedstawiała się bynajmniej tak prosto, a formułowane wnioski wcale nie były jednoznaczne. Tendencja do ambiwalentnych ocen szczególnie wyraźnie rysowała się w analizach czynników wojskowych. Francuscy sztabowcy z jednej strony coraz wyraźniej dochodzili do przekonania, że najbliższym celem Niemiec, którego realizację Rzesza podjąć może już wiosną, będzie dezintegracja Polski i pozbawienie jej możliwości wystąpienia w roli czynnika militarnego o antyniemieckim charakterze. Zaangażowanie Paryża oznaczać musiałoby w takim przypadku zwiększone niebezpieczeństwo rychłego wciągnięcia Francji w spodziewany konflikt - ze wszystkimi tego faktu konsekwencjami. Zarazem jednak równie wyraźnie dostrzegali, że w pomonachijskiej Europie polski aliant jest im potrzebny bardziej niż kiedykolwiek wcześniej, przede wszystkim jako niezbędny ze względu na położenie i potencjał wojskowy element wschodniego frontu. Skonstruowanie takiego frontu zdawało się zaś konieczne - już samo jego istnienie oznaczało bowiem radykalne zmniejszenie szans powodzenia ewentualnej akcji wojsk Rzeszy w zachodniej części kontynentu?.

Ten ostatni pogląd przyjęty został bez sprzeciwu do wiadomości także w kierowanym przez premiera Édouarda Daladiera Ministerstwie Obrony Narodowej i Wojny. Bardzo podobne sądy formułowano w kręgu wyższych urzędników Quai d'Orsay, nie zawsze w zgodzie ze stanowiskiem ministra Georges’a Bonneta, chwiejnym zresztą i często niejasno formułowanym ${ }^{8}$. Gdy jednak 4 stycznia 1939 roku szef Dyrekcji Spraw Politycznych i Handlowych MSZ Émile Charvériat poprosił Sztab Generalny o ocenę wojskowej wartości Polski, usłyszał od gen. Henri Dentza: „zniknięcie

Question in Polish Foreign Policy (October 1938 - March 1939), „New Ukraine. Nowa Ukraina” 2011, no. 11, s. 29nn.

6 TNA, CAB 21/555, kopia pisma W. Frasera do Phippsa z 4 I 1939 r.

' Service historique de la Défense - Département de l'Armée de Terre (Vincennes) [dalej: SHD-DAT], 1 N 43, kopia pisma No 5808/S Szefa Sztabu Generalnego Obrony Narodowej Mauricéa Gamelina do ministra obrony narodowej i wojny z 27 XII 1938 r.; 5 N 579, „Information de Président" Séction de la Défense Nationale z 22 XII 1938 r.; 7 N 3434, opracowanie "Considérations sur la constitution d'un Bloc Oriental" Szefa Oddziału II Sztabu Generalnego płk. Maurice'a-Henri Gauché z 28 XII 1938 r.; DDF, t. 13, doc. 178, s. 337nn.; W. Mazu r, Pod wiatr. Francja i lotnictwo wojskowe II Rzeczypospolitej, 1921-1938, Kraków 2015, s. 265nn., Societas, 89.

"DDF, t. 13, doc. 240, s. 436nn. (także: Archives diplomatiques (La Courneuve) [dalej: AD], Papiers 1940, Cabinet Georges Bonnet 10, kopia "Note sur les accords franco-polonais" z 28 XII 1938 r.; C. Barbier, Henri Hoppenot (25 octobre 1891 - 10 août 1977), diplomate, Paris 1999, s. 123, Diplomatie et Histoire; M. Gmurczyk-Wrońska, op. cit., s. 41 nn.; H. Bułhak, op. cit., s. 448 . 
lub neutralizacja polskiego potencjału militarnego pociągnęłaby za sobą Rumunię i umożliwiła Niemcom zwrot ku Zachodowi z siłami, którym Francja nie mogłaby stawić czoła inaczej, jak tylko za cenę dodatkowego znacznego wysiłku wojskowego"'. Obaj wymienieni zdawali sobie sprawę z tego, że zdolność do takiego wysiłku uznać trzeba za wielce problematyczną.

Oczywiste było przy tym, co zauważał choćby ambasador Łukasiewicz w przywołanej wyżej korespondencji z 17 grudnia, że poziom aktywności Paryża względem polskiego sojusznika zależeć będzie nade wszystko od postawy władz znad Tamizy. Te jednak wciąż nie były w stanie względnie jasno jej określić - choć bowiem gotowość francuskiego partnera do wypełniania traktatowych zobowiązań wobec Rzeczypospolitej oceniały nisko, to brakowało im informacji o rzeczywistych jego intencjach. Rzecz zaś z punktu widzenia Londynu nie była bynajmniej błaha. Jak przypuszczano bowiem w Foreign Office, Ribbentrop, który 6 grudnia podpisał w Paryżu francusko-niemiecką deklarację o gwarancjach wspólnej granicy, mógł opuścić to miasto z przekonaniem, że uzyskał dla Rzeszy wolną rękę w poczynaniach względem Europy Wschodniej.

Konsekwencje tego faktu, zauważali urzędnicy Foreign Office, byłyby z punktu widzenia interesów brytyjskich poważne. Gdyby bowiem istotnie Niemcy mogły osiągnąć swe cele we wschodniej części kontynentu bez francuskiego przeciwdziałania, szybki wzrost ich potęgi musiałby zagrozić bezpieczeństwu mocarstw Zachodu. Z drugiej zaś strony, jeśli Francja chciałaby pokrzyżować plany Rzeszy, interweniując na rzecz Polski i ZSRR, powtórzyłaby się sytuacja z okresu sudeckiego kryzysu - Brytyjczycy stanęliby wobec pespektywy zaangażowania na rzecz partnerów zza Kanału, których bezpieczeństwo byłoby zagrożone ${ }^{10}$. Żadna $\mathrm{z}$ tych perspektyw nie mogła być uznana za atrakcyjną. Co gorsza, klucz do rozwiązania najwyraźniej znajdował się w Paryżu. Wydaje się, konkludowano w Foreign Office, „że będziemy zmuszeni siedzieć i czekać”, licząc, że do starcia nie dojdzie zbyt wcześnie ${ }^{11}$. Ambasador Eric Phipps został jednak upoważniony do dyskretnego wybadania w rozmowie z Bonnetem rzeczywistych francuskich intencji oraz uprzedzenia go, że w razie zamiarów podjęcia akcji na rzecz Polski Brytyjczycy oczekują odpowiednio wczesnej informacji, dla przeprowadzenia przygotowań i uzgodnienia stanowiska obu mocarstw („[...] to ask us how far they could count on our support") ${ }^{12}$.

Samą Polskę w Londynie obserwowano dość beznamiętnie - „z dużą wstrzemięźliwością", jak oceniał to ambasador Edward Raczyński - całość regionu uznając za domenę wpływów francuskich. Także nad Tamizą powoli rozproszeniu ulegały na-

y SHD-DAT, 7 N 3018, niedatowana (I 1939 r.) „Nota” Oddziału II Sztabu Generalnego Armii $\mathrm{i}$ in. dok.

11 TNA, FO 371/21809, minuta pisma Sargenta do Phippsa z 22 XII 1938 r., reg. C 14878/ $2688 / 55$.

11 Ibidem.

12 Ibidem. „Czyniąc to, powinien Pan unikać sprawiania wrażenia, że życzymy sobie, by Francja odżegnała się od zobowiązań względem Polski" - ostrożnie, acz wieloznacznie dodawał Sargent. 
tomiast dość silne jeszcze niedawno pomonachijskie resentymenty. Ich miejsce zajmować zaczynała pesymistyczna ocena sytuacji, w której znalazła się Rzeczpospolita, zagrożona, jak uważano, zarówno przez apetyty sąsiada z zachodu, jak i podsycane przezeń wewnętrzne (głównie ukraińskie) niepokoje ${ }^{13}$. Zdaniem reprezentującego w Warszawie brytyjskie interesy ambasadora Howarda Kennarda nad Wisłą ten stan rzeczy odnotowywano z zaniepokojeniem, wręcz nerwowo. Polskie władze reagowały nań dążeniem do zbliżenia $\mathrm{z}$ Londynem, licząc, że życzliwość $\mathrm{i}$ wsparcie $\mathrm{z}$ jego strony okażą się przydatne „w przypadku jakichś przyszłych trudności z Niemcami”'14.

Polsko-niemieckie kontakty na najwyższym szczeblu, do których doszło w styczniu 1939 roku, uczyniły próbę oparcia stosunku mocarstw zachodnich wobec władz z Warszawy na racjonalnych podstawach sprawą bardziej jeszcze niż uprzednio zawikłaną. O przebiegu i wynikach przeprowadzonej przez ministra Becka 5 stycznia w Berchtesgaden rozmowy $z$ kanclerzem Hitlerem i odbytych $w$ dniu następnym dyskusjach $z$ Joachimem von Ribbentropem Paryż i Londyn informowano nader oszczędnie i ogólnikowo. W podsumowujących wydarzenia analizach specjaliści z Quai d'Orsay i Whitehall zmuszeni zostali więc do posiłkowania się głosami prasy oraz spekulacjami własnych i obcych dyplomatów, które - choć niekiedy nie pozbawione wartości, pogłębiały tylko ogólną dezorientację. Sam minister Beck nie kwapił się $\mathrm{z}$ rozwiewaniem narastających wątpliwości ${ }^{15}$. Dopiero 11 stycznia przyjął ambasadorów Noëla i Kennarda, o efektach wizyty w Niemczech informując ich, jak zauważył ten ostatni, pokrętnie, acz w tonie uspokajającym. Jednocześnie w dość niejasnym wywodzie zasugerował, by usunąć na bok wcześniejsze polsko-francuskie nieporozumienia i podjąć rozmowy na temat przyszłych stosunków obu państw. Rozwój wypadków sprawił, że nad Sekwaną sugestię tę uznano niebawem za wartą rozważenia ${ }^{16}$.

13 PDD 1938, dok. 448, s. 830nn.; dok. 450, s. 834nn. Szerzej o tych kwestiach: A. Cie n ciała, Minister Józef Beck i ambasador Edward Raczyński...

it TNA, FO 371/23129, pismo No 141/10/38 Kennarda do Sargenta z 23 XII 1938 r. Opinia sformułowana została na marginesie informacji o propozycjach zacieśnienia polsko-brytyjskiej współpracy w dziedzinie marynarki wojennej, przedstawionych w drugiej połowie grudnia $1938 \mathrm{r}$. przez ministra Becka.

15 SHD-DAT, 7 N 3002, „Rapport No 2/S du 12 Janvier 1939” gen. Musse i nast. dok.; 7 N 3015, „Renseignement Pologne” DEPAS No 28/ED Section de Renseignement [dalej - SRI] Oddziału II Sztabu Generalnego Armii z 20 I 1939 r. i in. dok.; TNA, FO 371/23143, telegram (en clair) No 25 Saving Phippsa do FO z 21 I 1939 r. i in. dok; S. Żerko, Stosunki polsko-niemieckie 1938-1939, Poznań 1998, s. 198nn., Studium Niemcoznawcze Instytutu Zachodniego, 75.

${ }^{16}$ AD, Papiers 1940, Papiers Rochat 31, telegram szyfrowy przychodzący No 67 Noëla do Ministère des Affaires étrangères [dalej - MAE] z 12 I 1939 r., godz. 5.20 (tam też inne francuskie doniesienia na temat wizyty Becka w Berchtesgaden - m.in. z placówek w Berlinie i Londynie; por. także: P. de Villelu me, De Munich d Dantzig. Journal (30 août 1938 - 18 août 1939), éd. annotée et commentée par S. Catros, Paris 2015, s. 139nn., Mondes Contemporains). Relacja Kennarda o rozmowie z 11 stycznia: TNA, FO 417/39, telegram No 4 do kanclerza skarbu Johna Simona z 11 I 1939 r. Teksty zawierające ciągły przekaz depesz Noëla na temat spotkania z Beckiem opublikowano w DDF, t. 13 (doc. 345, s. 622n.). Wykorzystany w edycji materiał najwyraźniej nie zawierał jednak kilku końcowych depesz tej serii. Stąd też mylne jest (choć przez autora niezawinione) twierdzenie H. Bułhaka, że Noël nie odnotowal przywołanej wyżej uwagi Becka (H. Bułhak, op, 
Kolejną turę polsko-niemieckich rozmów, do których doszło w ostatniej dekadzie miesiąca, gdy do Warszawy przybył Ribbentrop, Francuzi i Brytyjczycy obserwowali już w spokojniejszych nastrojach ${ }^{17}$. W stolicach mocarstw zachodnich wciąż jeszcze nie zdawano sobie sprawy z zakresu formułowanych przez Rzeszę żądań oraz siły wywieranego na Polskę nacisku. Górę brało jednak przekonanie, że Warszawa opierać się będzie próbom wasalizacji, a w razie konieczności dokonania wyboru nie w Berlinie szukać będzie patrona ${ }^{18}$. Ambasador Noël, odnotowując z początkiem lutego wyraźny korzystny dla Francji zwrot w polskich sentymentach, nie omieszkał podkreślić, że stanowi on widomy dowód skuteczności zalecanej przezeń po wrześniowym kryzysie $\mathrm{z}$ roku ubiegłego polityki dystansu $\mathrm{w}$ stosunku do partnera znad Wisły. Zdecydowanie cieplejsze nastawienie oficjalnej polskiej opinii wobec Paryża i Londynu dostrzegali też dyplomaci brytyjscy, a nawet niemieccy ${ }^{19}$.

$\mathrm{Na}$ Wilhelmstrasse nadchodzące wieści komentowano na razie bez zbytniego zaniepokojenia. Zmianę polskiego nastawienia uznawano za powierzchowną, jej oznaki wiążąc $\mathbf{z}$ mało $\mathbf{w}$ istocie znaczącymi gestami strony francuskiej lub też okolicznościami spoza kręgu polityki. Także zresztą w Londynie powątpiewano, czy Paryż i Warszawa rzeczywiście okażą się zdolne do rozpoczęcia nowej fazy współpracy mimo pokaźnego bagażu wzajemnych pretensji i resentymentów. W Foreign Office rozważano nawet podjęcie działań $\mathrm{w}$ celu ułatwienia ponownego zbliżenia tych stolic, wyrażając zresztą obawy, że to polski minister spraw zagranicznych okazać się

cit., s. 450, przyp. 20). Pierwsze pozytywne reakcje francuskie na sugestię Becka: DDF, t. 13, doc. 388, s. 694. Na szerszym tle francuskich stosunków wewnętrznych reakcje Paryża na "niemiecką" wizytę Becka umieszcza M. G murczyk-Wrońska, op. cit., s. 67nn.

17 AD, Papiers 1940, Papiers Rochat 31, telegram przychodzący No 147 Noëla do MAE z 30 I 1939 r., godz. 22.35 i nast. dok.; SHD-DAT, 7 N 3002, „Rapport No 7/S du 2 Février 1939” gen. Musse; 7 N 3015, „Renseignement Pologne” DEPAS No 47/EO SRI Oddziału II Sztabu Generalnego Armii z 1 II 1939 r. Oczywiście jednak to Londyn mógł sobie pozwolić w tym wypadku na bardziej beznamiętne komentarze. Hitler zwodzi pułkownika Becka pięknymi słówkami, oceniał $w$ przeprowadzonej 25 stycznia rozmowie $z$ francuskim attaché wojskowym szef brytyjskiego wywiadu wojskowego bryg. Frederick George Beaumont-Nesbitt. Jednak pewnego dnia, dodawał, ekspansja Rzeszy obejmie Gdańsk, Korytarz i Górny Śląsk (SHD-DAT, 7 N 2816, pismo 12/S attaché wojskowego Francji w Londynie gen. Alberta Lelonga do przewodniczącego Rady Ministrów i ministra obrony narodowej (II Oddziału Sztabu Generalnego) z 25 I 1939 r.).

is Londyn i Paryż nie zostały poinformowane o podjętej przez polskie kierownictwo tuż po powrocie Becka do kraju decyzji o obronie suwerenności i integralności terytorialnej Rzeczypospolitej wszelkimi dostępnymi środkami, włącznie z oporem zbrojnym. Noël odnotował jednak przeprowadzoną wówczas rozmowę Becka z prezydentem Ignacym Mościckim. Z kolei gen. Musse, analizując niełatwy wybór, przed którym stała Polska, podkreślał, że jej ewentualna ugoda z Niemcami oznaczać by musiała co najmniej obecność wojsk Rzeszy na polskim terytorium, to zaś „wszyscy myślą̧cy Polacy” postrzegają jako kres niepodległości. SHD-DAT, 7 N 3002, „Rapport No 4/S du 19 janvier 1939" gen. Musse; DDF, t. 13, doc. 345, s. 622.

19 AD, Papiers 1940, Papiers Rochat 31, telegram przychodzący (kurierem) No 160 Noëla do MAE z 31 I 1939 r.; TNA, FO 371/23130, list No 31/3/39 Kennarda do Sargenta z 22 II 1939 r. i in. dok.; FO 371/23143, pismo No 64/9/39 kancelarii ambasady brytyjskiej w Warszawie do Departamentu Centralnego FO z 22 II 1939 r.; S. Że rko, op. cit., s. 245n. 
może mniej chętnym adresatem podobnych zabiegów. Niebawem okazać się jednak miało, że przekonania o konieczności szybkiego wznowienia politycznej współpracy z polskim partnerem brak także na Quai d'Orsay, gdzie osobę i poczynania szefa polskiej dyplomacji traktowano wciąż podejrzliwie ${ }^{20}$.

Francuzi nie zamierzali jednak czekać na rozwój wypadków z założonymi rękami. Zaniepokojenie rozwojem sytuacji, a poniekąd też labilnością poczynań resortu spraw zagranicznych, który najwyraźniej nie był zdolny do klarownego sformułowania realnych celów wschodniej polityki Francji, przejawiali szczególnie przedstawiciele elit wojskowych. Znacznie mniej od ministra Bonneta i jego podwładnych skłonni $w$ tym czasie do zastępujących działanie dywagacji, zdanie swe formułowali jednoznacznie: „zarówno z politycznego, jak i militarnego punktu widzenia Francja ma interes, by utrzymać Polskę w swej grze"21. Niektórzy francuscy oficerowie możliwe scenariusze tej "gry" przedstawiali nawet dość dokładnie. Tak np. Szef Oddziału II (Informacyjnego) Sztabu Generalnego Armée de l'Air ppłk dypl. Alfred Antoine d'Arnaud de Vitrolles w przeprowadzonej 10 stycznia rozmowie z brytyjskim attaché lotniczym w Paryżu płk. Douglasem Colyerem przewidywał, że niebawem Niemcy podejmą próbę sięgnięcia po niezbędne im zasoby żywnościowe Ukrainy. To jednak spotka się z oporem Polski, a zapewne też i ZSRR, który nie będzie mógł biernie przyglądać się podobnym działaniom. Zapoczątkowana zostać może w ten sposób swoista reakcja łańcuchowa - do walki przeciw Rzeszy dołączy Rumunia, Czechosłowacja zaś też z pewnością nie opowie się po stronie Berlina. "Jeśli Francja i Anglia zajmą nieugięte stanowisko i odmówią ustępstw względem ambicji Niemiec na wschodzie, te byłyby zmuszone stawić czoła poważnej wojnie na dwóch frontach i zostałyby pobite" - konkludował d'Arnaud de Vitrolles, dla kontrastu przedstawiając też opłakane skutki ewentualnej bierności Zachodu w takim konflikcie. Szef wywiadu Armée de l’Air odrzucił też sugestię, że pierwsze uderzenie Hitlera skierowane zostać może w kierunku zachodnim, argumentując, że przywódcy Rzeszy niezbędne są, i to niezwłocznie, zasoby Europy Wschodniej, zaś wojna „ze względu na kolonie lub imperialną dumę" nie rozwiąże trapiących go problemów ${ }^{22}$.

211 TNA, FO 371/23143, nota na akcie C 2448/842/55 z 1 III 1939 r. i nast. dok.

¿SHD-DAT, 7 N 3018, nota „Pologne. Valeur actuelle de l'armée polonaise” z 5 I 1939 r., zał. do pisma No 31 2/EMA/SAE za ministra wojny i z jego upoważnienia zastępcy Szefa Sztabu Generalnego Armii gen. Dentza do Dyrekcji Spraw Politycznych i Handlowych (Poddyrekcja Europa) MAE z 6 I 1939 r.

22 TNA, AIR 9/93, kopia „Memorandum” 26/823.G/3/1938 płk. Colyera dla brytyjskiego ambasadora w Paryżu z 12 I 1939 r. „Byłoby interesujące wiedzieć, co o tym sądzi francuskie Ministerstwo Wojny", komentowano sarkastycznie przesłane informacje w Air Ministry, przypominając, że podczas wrześniowego kryzysu 1938 r. francuski partner zareagował lękiem na formalnie bardziej jeszcze dlań atrakcyjną koncepcję uwikłania Niemiec w wojnę nie na dwóch nawet, ale trzech frontach. Zob. też: P. Jackson, France and the Nazi Menace. Intelligence and Policy Making, 1933-1939, Oxford-New York 2000, s. 319, gdzie jednak rozmowę przeprowadzoną przez Colyera błędnie datowano na 13 stycznia. 
Niespełna miesiąc później to właśnie ppłk d’Arnaud de Vitrolles stanął na czele misji oficerów lotnictwa, których francuskie władze zdecydowały się wysłać do Polski. Wybór płaszczyzny kontaktu nie był przypadkowy. Współpraca w dziedzinie lotnictwa wojskowego niemal od początku polityczno-militarnego sojuszu Paryża i Warszawy stanowiła istotną płaszczyznę kooperacji obu stolic. W drugiej połowie lat 30. jeszcze zyskała na znaczeniu, prócz wymiany informacji wywiadowczych stanowiąc jedną $z$ nielicznych sfer, $w$ których sojusz ten wciąż funkcjonował $w$ praktyce $^{23}$. Francuska misja lotnicza miała udać się do Warszawy późną jesienią 1938 roku - odwołanie przez Quai d’Orsay planowanego wówczas spotkania stało się ostentacyjnym sygnałem niezadowolenia Paryża z postawy zajętej przez polskiego partnera w trudnych dniach sudeckiego kryzysu. Ponowne uruchomienie lotniczych kontaktów stanowiło dla zainteresowanych równie czytelny sygnał. Zadbano przy tym, by nie zostawić pola dla nadinterpretacji. Wysyłanym nad Wisłę oficerom nakazano sprawiać wrażenie, że niczego od gospodarzy nie oczekują, oraz uchylać się od ewentualnych $\mathrm{z}$ ich strony awansów ${ }^{24}$.

Misja nie była jednak tylko politycznym rekonesansem. Jej członkowie realizować mieli także, a może nawet przede wszystkim, dyrektywy wojskowego kierownictwa, wznawiając międzysztabowe rozmowy na temat technicznych aspektów lotniczej współpracy sojuszniczych sił powietrznych oraz wymianę informacji na temat lotniczego potencjału Rzeszy. Sztab Armée de l’Air zastrzegł przy tym, by z przyczyn politycznych szczególnie $w$ tej pierwszej sferze nie angażować się zbyt mocno. Podjęte $w$ Warszawie studia nakazano ograniczyć tylko do kwestii amunicji i łączności, z których korzystać będzie mogło stacjonujące ewentualnie na terytorium sojusznika lotnictwo wojskowe każdej ze stron ${ }^{25}$.

Francuzi do Warszawy dotarli przez Berlin, w stolicy Polski zjawiając się rankiem 7 lutego. Realizację oficjalnego programu wizyty rozpoczęto wieczorem tego samego dnia na lotnisku Okęcie od spotkania z Szefem Oddziału II Sztabu Głównego płk. dypl. Marianem Józefem Smoleńskim i grupą towarzyszących mu oficerów. Następne trzy dni przeznaczono na serię spotkań z przedstawicielami polskiego Sztabu Głównego i Dowództwa Lotnictwa, a przede wszystkim - cykl roboczych konferencji poświęconych zagadnieniom organizacyjno-technicznym oraz wywiadowczym. Bardzo szybko okazało się przy tym, że gospodarze dążą do nadania lotniczej współpracy $z$ partnerem $z$ zachodu znacznie szerszych ram niż planowali

23. Szersze przedstawienie tej problematyki: W. Mazur, op. cit., s. $191 \mathrm{nn}$.

24 SHD-DAT, 2 N 235, niedatowany i niesygnowany „Rapport de la mission daviation en Pologne"; 5 N 579, pismo No 561 DN.3 gen. Gamelina do przewodniczącego Rady Ministrów i ministra obrony narodowej i wojny z 27 III 1939 r. W skład misji weszła też trójka innych oficerów kapitanowie Cazenave (szef sekcji łączności Oddziału III (Operacyjnego) Sztabu Generalnego Armée de l'Air), Rochot i Georges Grimal (z Oddziału V (Uzbrojenia) Sztabu Generalnego Armée de l'Air). Wspomnienia tego ostatniego oficera o jego udziale w misji i wrażeniach $z$ niej: Service historique de la Défense - Département de l'Armée de l'Air (Vincennes) [dalej: SHD-DAA], 8 Z 497/1 (Archives orales).

${ }^{25}$ SHD-DAT, 2 N 235, „Rapport de la mission d'aviation en Pologne”. 
przybysze znad Sekwany. Polscy oficerowie, uznając, że ich własne siły powietrzne nie osiągnęły jeszcze poziomu rozwoju, który mógłby uzasadniać podjęcie przez nie operacji z lotnisk francuskich, koncentrowali się na uzgodnieniach związanych ze stacjonowaniem części francuskiego lotnictwa bombowego $\mathrm{w}$ bazach położonych na terytorium Rzeczypospolitej. Francuzi, których instrukcje jednoznacznie zabraniały dania stronie polskiej pewności lotniczej asysty Paryża, nie okazali się jednak skłonni do tak szerokiej dyskusji. Posłużyli się więc pretekstem obecności w składzie ich delegacji jedynie specjalistów z zakresu uzbrojenia i łączności, dowodząc, że w takiej sytuacji nie są wystarczająco kompetentni do podejmowania kwestii wykraczających poza te dziedziny. Zgodzili się natomiast, by polskie postulaty zawrzeć $\mathrm{w}$ podsumowującym rozmowy procès-verbal. Ten ostatni jednak, jak wiedzieli, zawierał tylko niewiążące propozycje, które w realizacji znaleźć się mogły dopiero po zaaprobowaniu przez Szefa Sztabu Generalnego Armée de l’Air oraz Szefa polskiego Sztabu Głównego ${ }^{26}$.

Ostatecznie więc konferencje o charakterze technicznym poświęcone zostały materiałowi uzbrojenia (bomby, celowniki bombowe, strzelecka broń pokładowa) oraz kwestiom łączności (szyfry i kody, informacje meteorologiczne i nawigacyjne, namiary radiogoniometryczne, procedury lądowania, sprzęt radiowy i elektryczny, unifikacja radiostacji pokładowych, zaopatrzenie w części zamienne). Obradujący specjaliści uznali, że większość bomb używanych przez lotnictwo francuskie może być bez poważniejszych trudności wykorzystana także przez samoloty polskie, choć w przypadku najnowocześniejszych polskich maszyn bombowych PZL.37 „Łoś” użycie stukilogramowych bomb francuskich znacząco (o 50\%) ograniczy zabierany ładunek. Gorszy rezultat natomiast mogła dać operacja odwrotna - większość polskich bomb nie mogła być wykorzystana w samolotach francuskich lub ich użycie wymagało znaczących niekiedy modyfikacji samych bomb bądź wyrzutników bombowych. Uczestnicy rozmów za konieczne uznali utworzenie na terytorium Polski składów bomb przeznaczonych dla lotnictwa francuskiego, zdecydowanie zalecając też unifikację tego materiału $w$ ramach sojuszniczych sił powietrznych. Wymieniono też informacje o prowadzonych $w$ tej dziedzinie studiach. Stronie polskiej przekazano rysunki opracowywanych we Francji bomb o wagomiarze 60 i 150 kilogramów, uzgodniono też wymianę zapalników bomb. Wedle poczynionych ustaleń także w przypadku amunicji strzeleckiej i części zamiennych do broni pokładowej zaopatrzenie kierowanych ewentualnie do Polski francuskich samolotów winno było zostać oparte na przygotowanych zawczasu składach. Wymienność wspomnianego materiału uznana została za "pożądaną", ale na razie przynajmniej niemożliwą do praktycznej realizacji ${ }^{27}$.

26 SHD-DAT, 2 N 235, kopia „Protocole des conversations techniques franco-polonaises” z 15 II 1939 r. Sygnowany egzemplarz strony polskiej: Archiwum Instytutu Polskiego i Muzeum im. gen. Władysława Sikorskiego w Londynie [dalej - IPMS], Lot. A.I. 2/9.

27 IPMS, Lot. A.I. 2/9, „Protocole des conversations techniques franco-polonaises” z 15 II 1939 r. wraz z aneksami I i II. 
Z kolei większość pierwszej części obrad poświęconych zagadnieniom łączności przeznaczona została na przestudiowanie udzielonych przez stronę polską odpowiedzi na kwestionariusz przygotowany przez Sztab Generalny Armée de l'Air. Dalsza wymiana poglądów dotyczyła głównie dwóch zasadniczych spraw, przelotu samolotów francuskich nad terytorium Rzeszy (uznano, że operacji nie sposób przeprowadzić w sekrecie, omówiono kwestie dotyczące łączności, które winny zapewnić jej powodzenie) oraz problemów zaopatrzenia i obsługi technicznej materiału francuskiego stacjonowanego na obszarze Rzeczypospolitej (m.in. utworzenie wcześniej składów tego materiału, wymiana informacji technicznych na temat sprzętu radiowego oraz egzemplarzy tego sprzętu). Trzecią omawianą sprawą stały się kwestie związane $z$ wymianą informacji meteorologicznych użytecznych podczas konfliktu. Uczestnicy konferencji zaproponowali, by dokładność prognozowania w tym zakresie oszacować zawczasu, a następnie, w razie pozytywnych rezultatów tych studiów, określić procedury kooperacji (kody, częstotliwości radiowe itp. $)^{28}$.

Niemal równocześnie z konferencjami części „technicznej” oficerowie misji ppłk. d'Arnaud de Vitrolles uczestniczyli w spotkaniach poświęconych wymianie informacji na temat sił powietrznych III Rzeszy. „Wywiadowczy” segment pobytu Francuzów był bardziej skondensowany w czasie, obejmując jedynie dwa dni (8 i 9 lutego). Prace realizowane były też $w$ znacznie węższym gronie. Armée de l'Air reprezentował w ich trakcie głównie kpt. pil. Rochot, podczas gdy ppłk d'Arnaud de Vitrolles uczestniczył tylko w niektórych rozmowach. Podobnie incydentalny charakter miała obecność Szefa funkcjonującego w ramach polskiego Sztabu Głównego Sztabu Lotniczego płk. dypl. obs. Stanisława Ujejskiego oraz Szefa Samodzielnego Referatu „Niemcy” Oddziału II mjr. dypl. Jana Leśniaka. W całości obrad po stronie polskiej uczestniczyli natomiast: wyznaczony na Szefa SR „Niemcy” O. II SG mjr dypl. Stanisław Bień, Szef Referatu Lotniczego w tymże SR mjr obs. Ferdynand Bobiński oraz mjr pil. Józef Kiecoń ze Sztabu Lotniczego SG ${ }^{29}$.

Proces wymiany informacji porządkowany był przez przygotowane przez obie strony kwestionariusze. W wyniku konferencji ustalono, że posiadane przez sojusz-

2k IPMS, Lot. A.I. 2/9, „Protocole des conversations techniques...” oraz aneks III; Lot. A.I. 2/11, referat „Krótkie streszczenie rozmów techn. francusko-polskich: L. 377/S.Lotn.tj. Szefa Sztabu Lotniczego Sztabu Głównego gen. bryg. obs. Stanisława Ujejskiego dla Szefa SG z 9 V 1939 r." Zob. też: T. Vivier, Laviation française en Pologne..., gdzie jednak jako termin wizyty misji ppłk. d'Arnaud de Vitrolles podano marzec $1939 \mathrm{r}$.

29 IPMS, A.II. 27/25, pismo L. 20975/II.N.tjn. mjr. Leśniaka do Szefa SG z 14 II 1939 r („Ogólne sprawozdanie $z$ lotniczej konf. międzysztabowej w dn. 8 i 9 II 39 r."). W sprawie ówczesnych funkcji wymienionych wyżej oficerów O. II SG i spraw przyporządkowanych im podczas konferencji zob.: IPMS, Lot. A.I. 2/9, „Protocole des conversations techniques...” (gdzie mjr Kiecoń błędnie uznany został za pracownika SR „N" O. II SG) oraz Ł. Ulat ow ski, Polski wywiad wojskowy w 1939 roku. Struktura organizacyjna, sklady osobowe, personel, budzet, mob., Warszawa 2013, s. 54, 81 n. Tylko jednozdaniową wzmiankę poświęcił konferencji P. Kołakowski w opracowaniu Czas próby. Polski wywiad wojskowy wobec groźby wybuchu wojny w 1939 roku, Warszawa 2012, s. 258 . 
ników dane na temat Ordre de Bataille niemieckich sił powietrznych są na ogół zgodne („posiadamy więcej i aktualnych informacji o jednostkach”, zauważył z satysfakcją mjr Leśniak), jednak w przypadku jednostek artylerii przeciwlotniczej rozbieżności są liczne, co w pewnym stopniu wynika z przeprowadzanej właśnie reorganizacji tej broni. Zgodne okazały się też polskie i francuskie dane na temat niemieckich rezerw personalnych i sprzętu lotniczego (choć $w$ tym ostatnim przypadku polskie oceny były zdaniem Francuzów wyraźnie zaniżone) oraz wyszkolenia ${ }^{30}$. $\mathrm{Z}$ uznaniem partnera spotkały się zaprezentowane przez gospodarzy informacje na temat infrastruktury lotniczej Rzeszy, w znacznej części oparte na zdobytych przez polski wywiad dokumentach. $Z$ kolei Francuzi, jak się okazało, dysponowali bogatym zestawem danych na temat niemieckiego przemysłu lotniczego. Zaprezentował je specjalista od tej tematyki, kpt. Rochot, który jednak, jak utyskiwać miał później mjr Leśniak, w przypadku innych działów nie zawsze okazywał się równie kompetentny. Liczne luki odnotowane zostały natomiast $w$ posiadanych przez obie strony informacjach na temat organizacji Luftwaffe, przede wszystkim zaś wyższych dowództw i pozostających na stopie pokojowej wielkich jednostek ${ }^{31}$.

W podsumowaniu konferencji ppłk d'Arnaud de Vitrolles dokonał ogólnej oceny posiadanych przez obie strony informacji, podkreślając, że „w najbliższym okresie należy zwrócić uwagę na elementy poza personelem i sprzętem, które mogą wskazać na możliwości manewrowania lotnictwa, jak lotniska, urządzenia terenu, organizacje zaopatrywania”, gdyż „Niemcy zajmują położenie centralne w Europie, co pozwala im na manewrowanie jednostkami lotnictwa i przerzucanie ich ze wschodu na zachód zależnie od potrzeby"32. Wyraził też przekonanie, że w nadchodzącej wojnie szczególną rolę odegra „lotnictwo bombardowania nurkowego”, które po uzbrojeniu

30 Potencjał liczebny Luftwaffe wedle stanu na 1 II 1939 r. oszacowany został na 3960 maszyn lądowych i 400 wodnosamolotów, tj. łącznie ok. 4400 samolotów znajdujących się w jednostkach liniowych i zapasie. Zdaniem strony polskiej do celów szkolnych, treningowych i doświadczalnych niemieckie lotnictwo wykorzystywało kolejne 4400 samolotów oraz 150 wodnosamolotów. W trakcie konferencji podkreślono, że niedobory kadrowe nie pozwalają na wykorzystanie wszystkich tych maszyn - „personel latający i techniczny wystarcza jedynie dla ok. 5.000 samolotów” (IPMS, A.II. 27/25, pismo L. 20975/II.N.tjn. mjr. Leśniaka...). Szczególne braki miały występować w obrębie kadry oficerskiej, choć tu dane z dokumentów obu stron były rozbieżne: w sprawozdaniu mjr. Leśniaka zapisano stan ok. 7000 oficerów; zapis francuski zawieral informację o stanie "teoretycznym" 6500 oficerów i „aktualnym" nie więcej niż 4800 oficerów oraz przewidywanie uzupełnienia braków w dwuletnim okresie 1939-1940 („jeśli nie zostaną utworzone nowe jednostki").

3 IPMS, A.II. 27/25, pismo L. 20975/II.N.tjn. mjr. Leśniaka...; SHD-DAT, 2 N 235, kopia "Protocole des conversations techniques..." (cz. II: „Échange de renseignements sur l'aviation allemande"). W tymże czasie wywiad brytyjskich sił powietrznych szacował liczbę posiadanych przez Luftwaffe samolotów pierwszej linii na mniej niż 3400, zaś maszyn zapasowych na nie więcej niż 1700. Dawało to łącznie 5100 samolotów, czyli więcej, niż szacowali Francuzi i Polacy. Jednak wedle Brytyjczyków większość maszyn z niemieckiej rezerwy byla przestarzała i wymagała wymiany, co w praktyce oznaczało względną porównywalność wszystkich wymienionych szacunków. TNA, AIR 75/21, opracowanie D.D.I.S. „German First Line Strenght and Reserves, December 1938 - February $1940 "$ z 30 I 1939 r.

32 IPMS, A.II. 27/25, pismo L. 20975/II.N.tjn. mjr. Leśniaka... 
w ciężkie bomby użyte zostanie do ataków na umocnienia i fortyfikacje. Tezę tę zanegował płk Ujejski, który wskazał na relatywną słabość takiego lotnictwa po stronie niemieckiej, podkreślając, że bombardowania z lotu nurkowego wykorzystane zostaną raczej do ataków na mosty i obiekty przemysłowe oraz inne cele wymagające dużej dokładności w bombardowaniu ${ }^{33}$.

Wieńcząca wywód szefa francuskiej delegacji ocena panującej w Europie sytuacji polityczno-militarnej powielała tok myślenia miesiąc wcześniej zaprezentowany brytyjskiemu attaché. „Niemcy przeżywają obecnie duże trudności ekonomiczne” stwierdził d’Arnaud de Vitrolles - „nie zdecydowali się jeszcze wyraźnie, co robić. Najbliższa przyszłość powinna przynieść rozwiązanie, czy należy liczyć się z ich dalszą ekspansją, i to w kierunku wschodnim, czy też tylko z akcją dyplomatyczną". Utrzymanie dotychczasowego tempa niemieckich zbrojeń stanowić będzie wskazówkę, „że zdecydowali się na marsz na wschód, by zapewnić sobie niezależność pod względem surowcowym i wyżywienia". Kolejnymi etapami takiego marszu miały stać się zdaniem francuskiego oficera „Kłajpeda, Litwa, Polska, wreszcie Ukraina”. Brak ostatecznej w tej kwestii decyzji w przekonaniu ppłk. d’Arnaud de Vitrolles wynikał jedynie $z$ obaw przed nieprzyjazną postawą mocarstw europejskiego Zachodu oraz Stanów Zjednoczonych ${ }^{34}$.

Kończąc spotkanie poświęcone wymianie informacji wywiadowczych, ppłk d’Arnaud de Vitrolles zaproponował jej rozszerzenie w niezbyt odległej przyszłości także na siły powietrzne ZSRR. Jak wyjaśniał następnie przełożonym, krok taki miałby pozwolić na określenie stosunku strony polskiej do lotniczego potencjału wschodniego sąsiada, a co za tym idzie - także ewentualnej z nim w tej dziedzinie współpracy, „która choć pożądana, nie wydaje się dopuszczana przez Polaków”"

Przedstawione wyżej konferencje nie wyczerpały bynajmniej programu pobytu nad Wisłą delegacji francuskich lotników. W dniach od 11 do 14 lutego goście odbyli serię podróży po Polsce, odwiedzając kolejno wytwórnie PZL (silników lotniczych i płatowców) na podwarszawskim Okęciu oraz stacjonujący tam 1 Pułk Lotniczy, zakłady metalurgiczne w Stalowej Woli, wytwórnie płatowców w Mielcu (PZL WP-2) oraz silników lotniczych w Rzeszowie (PZL WS-2), a także szkolę lotniczą w Dęblinie. Wszędzie witani byli serdecznie oraz informowani z ostentacyjną wręcz otwartością ${ }^{36}$. W Warszawie zjawili się ponownie 15 lutego, kończąc swą misję w Polsce podpisaniem oficjalnego protokołu oraz serią pożegnalnych wizyt. Do Paryża uda-

33 Ibidem.

34 Ibidem.

35 SHD-DAT, 2 N 235, „Protocole des conversations techniques...”

${ }^{36}$ Ibidem oraz: SHD-DAT, 7 N 3002, „Rapport No 10/S, du 10 Février 1939” gen. Musse i in. dok. W PZL WP-1 na Okęciu francuscy oficerowie mieli m.in. okazję do krótkiej wizyty w pilnie strzeżonym hangarze prototypów, gdzie jako pierwsi zagraniczni goście zetknęli się z otaczanym dotąd ścisłą tajemnicą prototypem najnowszego polskiego samolotu myśliwskiego PZL.50 „Jastrząb". Gest ten, z pewnością wcześniej zaplanowany, świadczył o tym, jak wielką wagę strona polska przywiązywała do lotniczej współpracy $z$ francuskim partnerem. 
li się rankiem 16 lutego, przystanek w Berlinie wykorzystując na robocze rozmowy $\mathrm{z}$ tamtejszym attaché de l'air ${ }^{37}$. Wrażenie, $\mathrm{z}$ jakim po wizycie u wschodniego sprzymierzeńca Francji ppłk d’Arnaud de Vitrolles i członkowie jego misji wracali nad Sekwanę, było bardzo dobre, nieledwie doskonałe.

Mimo to trudno uznać, że strona polska zdołała w pełni zrealizować związane z wizytą zamysły. Francuzów, mimo wysiłków, nie udało się skłonić do podjęcia rozmów na tematy, których uzgodnienie otwierało niemal automatycznie drogę do stacjonowania w razie konfliktu części francuskiego lotnictwa bombowego na terytorium Rzeczypospolitej lub też podjęcia przez to lotnictwo wahadłowych bombardowań Niemiec $\mathrm{z}$ wykorzystaniem polskich baz. Fakt ten oficerowie misji w złożonym sprawozdaniu podkreślali $z$ całą mocą, jednoznacznie wskazując, że ewentualna decyzja w sprawie przyjęcia polskich awansów należy do władz wyższych. Najwyraźniej wprowadzeni w polityczne niuanse zauważali też, że nawet jeśli ta decyzja okaże się pozytywna, w grę wchodzić może wzmocnienie polskich sił powietrznych przez „inne lotnictwo zagraniczne", a więc (czego już wprost w sprawozdaniu nie sformułowano) niekoniecznie przybyłe z zachodu.

Jednak, co warto podkreślić, podsumowujący wyniki misji raport nie kończył się bynajmniej, jak można się było spodziewać, neutralnymi dywagacjami o ambiwalentnym wydźwięku. Wręcz przeciwnie. „Można zatem stwierdzić - napisano w wieńczącej dokument konkluzji - że Polska, nie posiadając potęgi lotniczej porównywalnej $\mathrm{z}$ wielkimi europejskimi mocarstwami, stanowić może jednak w Europie Wschodniej czynnik oporu przeciwko ekspansji niemieckiej, co najmniej do momentu, w którym mocarstwa zachodnie przyjdą jej z pomocą" ${ }^{38}$. Nie rozstrzygało to dylematu, ale dla Szefa Sztabu Generalnego Obrony Narodowej i premiera francuskiego rządu stanowiło sugestię aż nadto wyraźną. A to do nich należeć teraz miało sformułowanie dyrektyw co do dalszej lotniczej współpracy z Warszawą.

Ostateczna decyzja w tej sprawie musiała mieć charakter polityczny, oczywiste więc było, że poprzedzić ją musi wyklarowanie francusko-polskich stosunków w tej sferze. To zaś wciąż pozostawało niepewne. Nad Sekwaną odnotowano zmianę tonu, jakim Warszawa posługiwała się wobec Paryża i jego przedstawicieli. Fakt jednak, że na czele polskiej dyplomacji pozostawał traktowany z neurasteniczną wręcz podejrzliwością minister Beck, niezwykle utrudniał Francuzom uznanie gestów partnera za coś więcej niż kolejny $z$ doraźnych politycznych manewrów ${ }^{39}$. Taką sceptyczną posta-

3 SHD-DAT, 2 N 235, „Protocole des conversations techniques...”. Wedle wspomnień kpt. Grimala krótki pobyt w Niemczech uświadomić miał francuskim oficerom, jak wielką przewagą liczebną i jakościową dysponuje Luftwaffe względem ich własnych sił. Zdaniem Grimala wywarło to na czlonkach delegacji "straszliwe wrażenie” (SHD-DAA, 8 Z 497/1).

3N Ibidem.

${ }^{3 y}$ Na przełomie lutego i marca nastawienie polskiego MSZ do Francji znów zresztą uleglo zauważalnemu ochłodzeniu w związku z podejrzeniami, że to francuska ambasada inspirowała podczas wizyty złożonej w Warszawie w ostatniej dekadzie lutego przez włoskiego ministra spraw zagranicznych, hrabiego Ciano, studenckie wystąpienia skierowane przeciw Niemcom i polityce 
wę, szczególnie mocno zakorzenioną na Quai d'Orsay, podzielali także przedstawiciele kręgów wojskowych, przy czym i jedni, i drudzy nie zamierzali jej wcale ukrywać. Wizyty Becka w Paryżu pozbawione są głębszego znaczenia, chodzi w nich głównie o to, „by po powrocie dodać mu prestiżu we własnym kraju”, wyjaśniał w początkach marca Émile Charvériat jednemu z brytyjskich dyplomatów, dodając, że perspektywa kolejnej takiej wizyty go "nie ekscytuje”40. „Pułkownik de Vitrolles odniósł wrażenie, że proniemiecka polityka Becka nie odzwierciedla poglądów większości Polaków" informował Londyn płk Colyer krótko po rozmowie z Szefem Oddziału II Armée de l'Air, który wyrazić miał zresztą przy tej okazji zdecydowaną opinię, że wyraźne ze strony przedstawicieli sił zbrojnych Rzeczypospolitej oznaki gotowości do współpracy z mocarstwami Zachodu wykorzystać należy bezzwłocznie do ponownego scementowania „realnej przyjaźni z Polską"41.

Trudna do jednoznacznego oszacowania była także pojmowana najdosłowniej rzeczywista siła partnera. Polskie lotnictwo wojskowe znajdowało się w trakcie forsownej modernizacji, której tempo w poważnym stopniu ograniczały jednak możliwości kadrowe, organizacyjne, a nade wszystko - finansowe. Jego potencjał w ujęciu liczbowym był stosunkowo spory, sięgając - jak informował w połowie stycznia paryskich przełożonych ambasador Noël - 900 przestarzałych maszyn. Miesiąc później, zapewne już po powrocie znad Wisły (i zapewne pod wrażeniem świeżych doświadczeń), ppłk d’Arnaud de Vitrolles wielkość tę określił na „ponad 1000 samolotów o osiągach bardzo zadowalających", dodając, że są one obsługiwane przez personel dobrze wyszkolony i o wysokim morale. W tymże czasie Oddział II francuskiego Sztabu Generalnego Armii szacował potencjał polskiego lotnictwa na 500 do 600 maszyn pierwszej linii42.

Nietrudno dostrzec, że walory zasobów sił powietrznych Rzeczypospolitej budziły kontrowersje. Jedną $\mathrm{z}$ najistotniejszych ich przyczyn stanowiły z pewnością poczynania modernizacyjne: polskie samoloty wojskowe uznawane być mogły za „przestarzałe" bądź „najzupełniej satysfakcjonujące” w zależności od tego, które z konstrukcji wzięte zostały pod uwagę. Jak się jednak wydaje, w tym wypadku bliższa prawdy

Becka. AD, Pologne 364, fotokopia telegramu No 252 Noëla do MAE z 27 II 1939 r. godz. 23.55 i in. dok.; TNA, FO 371/23148, pismo No 99/14/39 Kennarda do podsekretarza stanu w FO Alexandra Cadogana z 7 III 1939 r. Kilka tygodni wcześniej żywe niezadowolenie i protesty Warszawy wywołał opublikowany 19 stycznia na łamach dziennika „La France Militaire” nieżyczliwy Polsce artykuł francuskiego generała rezerwy Frédérica Culmanna na temat sprawy ukraińskiej. SHD-DAT, $7 \mathrm{~N}$ 3015, kopia raportu No 6/S gen. Musse z 26 I 1939 r. i in. dok.

40 TNA, FO 371/23143, pismo 270/5/39 Phippsa do Sargenta z 8 III 1939 r. Bardzo podobne wnioski formułowali w tymże czasie zupełnie niezależnie także niektórzy przynajmniej przedstawiciele Foreign Office. Zob.: S. New man, op. cit., s. 207.

41 TNA, FO 371/23144, kopia „Memorandum” No 246/965.F.l płk. Colyera dla Phippsa z 25 II 1939 r.

42 SHD-DAA, 11 Z 12941, opracowanie „Conférence sur l'URSS et les puissances secondaires de l'Europe Centrale” ppłk. d'Arnaud de Vitrolles z II 1939 r. i in. dok.; DDF, t. 13, doc. 343, s. 616n.; doc. 462, s. 632n.; W. Mazur, U progu wrześniowego sprawdzianu - polskie lotnictwo wojskowe w oczach sojuszników, „Lotnictwo” 2011, nr 9, s. 78n. 
była ocena Noëla, który ewolucję wyposażenia polskich sił powietrznych obserwował od dłuższego czasu. Teraz zwracał uwagę na fakty, które budzić mogły zaniepokojenie. Co prawda, zauważał nie bez uznania, późną jesienią 1938 roku Polska, jako jedno z nielicznych państw, wystawiła w Paryżu na Międzynarodowym Salonie Lotniczym „niemal kompletną serię aparatów niezbędnych dla nowoczesnego lotnictwa [wojskowego]", a prezentowane konstrukcje spotkały się z wielkim zainteresowaniem międzynarodowej prasy lotniczej. W istocie jednak były to w większości prototypy wciąż znajdujące się $\mathrm{w}$ trakcie prób, zaś ich odpowiedników próżno by szukać w eskadrach. Ponadto Noël uzupełniał opinię informacją bardziej jeszcze niepokojącą - „wedle obserwacji poczynionych przez naszego attaché lotniczego" nawet eksponowane w Paryżu najnowsze polskie maszyny ustępowały pod względem osiągów, „szczególnie z punktu widzenia prędkości”, analogicznym konstrukcjom niemieckim, włoskim, angielskim czy francuskim ${ }^{43}$.

Nieco mniej rozbieżne były francuskie opinie na temat polskiego przemysłu lotniczego. Bardzo wysokie oceny wystawił mu ppłk d’Arnaud de Vitrolles, który w trakcie swej misji miał okazję odwiedzić wszystkie funkcjonujące na obszarze Rzeczypospolitej ważniejsze jego wytwórnie i odbyć dłuższe rozmowy z przedstawicielami ich dyrekcji. Także Noël podkreślał znaczenie rozbudowy polskich mocy produkcyjnych w tej sferze, wyrażając przeświadczenie, że Polacy mogą niebawem być zdolni do wytwarzania nawet i 100 płatowców miesięcznie, co może pozwolić na dokonanie zapoczątkowanej wymiany sprzętu w ciągu roku ${ }^{\text {t4 }}$.

43 SHD-DAT, 2 N 235, "Rapport de la mission d'aviation en Pologne”; DDF, t. 13, doc. 343, s. 617. Kierowany przez ppłk. d'Arnaud de Vitrolles O. II Sztabu Generalnego Armée de l’Air przygotowywał obszerne zestawienia napływających do Paryża informacji na temat polskiego lotnictwa wojskowego. Niespodziewanie liczne w tym zbiorze nieścisłości czy sprzeczności wydają się świadczyć o biurokratycznej rutynie części zestawiających dane oficerów, nieskorych do głębszej analizy danych. Częste były np. przypadki uwzględniania w takich zestawieniach samolotów produkowanych w Polsce wyłącznie na eksport (samolot myśliwski PZL.24, samolot rozpoznawczo-bombowy PZL.43 - oba typy wyposażone były skądinąd w silniki importowane z Francji) albo maszyn, których seryjnej produkcji nigdy nie podjęto (wodnosamolot Lublin R.XX). Z dużą dowolnością traktowano też dane dotyczące osiągów poszczególnych konstrukcji czy też ich uzbrojenia. Podobne przekłamania były dość częste w przypadku służb informacyjnych innych państw - Francuzi dysponowali tu jednak wyjątkowymi możliwościami, które wykorzystywali w stosunkowo niewielkim stopniu, często poprzestając na informacjach czerpanych po prostu z prasy czy materiałów informacyjno-reklamowych producentów. Por.: SHD-DAA, 2 B 58, niedatowane [VI 1938?] „Notices sur les forces aériennes de diverses puissances étrangères en Europe" O. II Sztabu Generalnego Armée de l'Air; 2 B 59, niedatowane (po 1 IV 1939 r.) „Dossier de fiches d'avions en service dans les pays étrangers" O. II Sztabu Generalnego Armée de l'Air; SHD-DAT, 7 N 3016, dossier „Aviation 1937-38-39" Sekcji Armii Obcych 2eme Bureau Sztabu Generalnego.

${ }^{4} \mathrm{~W}$ końcu listopada 1938 r. łączna pokojowa zdolność wytwórcza polskich fabryk płatowców wojskowych szacowana była na 67 egzemplarzy samolotów bombowych, rozpoznawczo-bombowych i myśliwskich oraz 40 maszyn obserwacyjnych, szkolnych i łącznikowych. Szacunki te miały jednak charakter czysto teoretyczny, nigdy nie zostały praktycznie zweryfikowane. Zob.: IPMS, Lot. A.I. 24/1c. „Protokół przesłuchania [mjr. Kazimierza Kaliny] sporządzony dnia 25 IV 40 r. w Paryżu..., L. dz. 1330/Rej.40.T.j.; Wojna obronna Polski 1939. Wybór źródel, zebr. i oprac. 
I w tej jednak sferze pojawiały się obawy i wątpliwości. Oddział II francuskiego Sztabu Generalnego bieżące polskie zdolności wytwórcze, określane wedle stanu na koniec 1938 roku na maksymalnie 60-70 płatowców i 50 silników miesięcznie, uznawał za „bardzo słabe”. Zwracał też uwagę, że w razie wojny poważnym problemem stanie się zaopatrzenie wytwórni lotniczych w surowce ${ }^{45}$. Z kolei Noël dostrzegał tu inne poważne niebezpieczeństwo. Jak bowiem donosił, „koszt tych 1200 przewidywanych samolotów sięgnąłby 200 milionów złotych", podczas gdy w budżecie na rok 1938 przewidziano na ten cel jedynie $50 \mathrm{mln}$ zł. A choć w preliminarzu budżetowym na rok kolejny na zakup nowego materiału przeznaczono kwotę większą, bo $71 \mathrm{mln}$, to wciąż jest ona dalece niewystarczająca. Wywołuje to protesty przedstawicieli lotnictwa wojskowego, informował ambasador, dodając, że „echo ich skarg dociera także i do nas". To ostatnie świadczyć mogło o tym, że kierownictwo polskich sił powietrznych w walce o niezbędne fundusze próbowało się uciec do szukania poparcia ze strony francuskiej ambasady ${ }^{46}$.

Ostatecznie potencjał sił powietrznych sojusznika ze wschodu w Paryżu określać zaczęto wieloznaczną formułą "ograniczony, choć nie bez znaczenia"47. Wysoko oceniając walory lotniczego personelu, a do pewnego stopnia także wartość sprzętu, za najważniejsze z polskich aktywów uznawano jednak strategicznie położone bazy lotnicze, z których wymierzyć można było cios trudno osiągalnym z zachodu ośrodkom administracyjnym i przemysłowym na terytorium Rzeszy. Względna słabość wojskowego lotnictwa Rzeczypospolitej oraz niedostatek własnych sił sprawiały, że w roli głównego wykonawcy takiego uderzenia dowódcy i politycy znad Sekwany skłonni byli widzieć lotnictwo radzieckie. To ostatnie, operując $z$ baz na własnym terytorium, objąć mogło swym działaniem całość terytorium Prus Wschodnich oraz wschodnie rubieże Rzeszy - do wysokości Frankfurtu nad Odrą. Możliwość wykorzystania baz położonych na obszarze Polski umożliwić mogła siłom powietrznym ZSRR, jak przewidywali Francuzi, podjęcie przez ciężkie lotnictwo bombowe (samoloty TB-3 i TB-4) akcji nad całym terytorium Niemiec, zaś lżejszym siłom, wyposażonym w maszyny typu SB-2 i TSKB-26, aż po południk Frankfurtu nad Menem. Równo-

M. Cieplewicz et al., pod kier. E.J. Kozłowskiego, Warszawa 1968, s. 179, Wojna Wyzwoleńcza Narodu Polskiego.

45 SHD-DAT, 7 NN 2/392, niedatowane [VIII 1938?] „Étude sur le potentiel de guerre de la Pologne (à la fin de l'année 1938)".

${ }_{46}$ DDF, t. 13, doc. 343, s. 616n. Nie jest jasne, którą z wersji preliminarza budżetowego na rok 1938/39 miał na myśli Noël. W wersji zachowanej w Centralnym Archiwum Wojskowym w Warszawie-Rembertowie [dalej: CAW], Oddział I Sztabu Generalnego/Głównego [dalej: O. I SG], I.303.3.646 budżet rezerwy zaopatrzenia obejmujący kwoty przeznaczane na odnowę sprzętu Dowództwa Lotnictwa MSWojsk. w dziale „Płatowce” zawierał początkowo 60194000 zl, zaś po redukcji - $46594000 \mathrm{zł} \mathrm{(co} \mathrm{stanowiło} \mathrm{sumę} \mathrm{zbliżoną} \mathrm{do} \mathrm{podanej} \mathrm{przez} \mathrm{francuskiego} \mathrm{ambasadora),}$ natomiast w dziale „Silnikj” - 24449380 zł. Por.: CAW, O. I SG, I.303.3.640, „Proj. prelim. budz. Dow. Lotn. na r. 1938/39", L. dz. 2477/Tjn./37 z 3 VIII 1937 r., gdzie podane zostały kwoty wyższe od podanych uprzednio.

47 SHD-DAA, 2 B 97, niedatowane [wiosna 1939 r.] opracowanie „Pologne. Laviation militaire"; 11 Z 12941, opracowanie "Conférence sur l'URSS..." i in. dok. 
cześnie, wedle tychże przewidywań, lotnictwo radzieckie mogłoby podjąć „ochronę punktów wrażliwych na terytorium polskim". Rzecz jasna, jak podkreślano, ewentualną realizację takiego zamysłu poprzedzić by musiały wcześniejsze przygotowania, "zarówno z punktu widzenia dyplomatycznego, jak i technicznego i wojskowego" 48 . Możliwość osiągnięcia podobnego porozumienia, szczególnie w pierwszej z wymienionych sfer, zimą 1939 roku oceniano w Paryżu sceptycznie, choć nie odrzucano jej całkowicie. Nie bez zastrzeżeń, ale optymistycznie wypowiadał się w tej kwestii m.in. ppłk d'Arnaud de Vitrolles, wywodząc, że choć „Europa złożona jest z ludów całkowicie różnych", to wspólny instynkt skłania je do jednoczenia się przeciw próbom narzucania hegemonii ${ }^{49}$.

Oczywiście jednak nie tylko rozwiązania z zakresu strategii wojennej skłaniały Francuzów do rozważań na temat szans wykorzystania lotniczego potencjału sojuszników z Europy Środkowej i Wschodniej. Równie ważną przesłankę stanowiła tu świadomość słabości własnych sił powietrznych. Ich stan na pozór przedstawiał się całkiem imponująco: w połowie stycznia 1939 roku w dyspozycji Armée de l'Air znajdowało się lącznie 3317 samolotów. Jednak tylko 1720, a więc niewiele ponad połowa tych maszyn, określana była jako należąca do "typów nowoczesnych". Spośród nich jako zdatne do bieżącego wykorzystania na terenie metropolii wymieniano już tylko 1255 aparatów. To już zaś była liczba zdecydowanie zbyt niska - zarówno w stosunku do zadań, których realizację podjąć miało francuskie lotnictwo wojskowe w razie wojny, jak i sił, którymi rozporządzali potencjalni jego przeciwnicy. Wysiłki podejmowane na rzecz zmiany zarysowującej się dysproporcji nie dawały na razie istotniejszych efektów ${ }^{50}$.

4* SHD-DAA, 11 Z 12941, niedatowane (początek 1939 r.) „Etude sur l'aide que pourrait apporter l'U.R.S.S. en cas de conflit européen"; T. Vivier, La politique aéronautique..., s. 533. Samoloty TSKB-26 nie były użytkowane przez siły powietrzne ZSRR. Opatrzony takim oznaczeniem prototyp bombowca dalekiego zasięgu wzniósł się po raz pierwszy $w$ powietrze $w$ połowie 1935 r. Jednak dopracowana wersja tej konstrukcji (powstała wiosną 1936 r.) otrzymała oznaczenie TSKB-30, do produkcji trafiając następnie jako DB-3.

19 SHD-DAA, 11 Z 12941, opracowanie „Conférence sur l'URSS...”.

5) SHD-DAA, 11 Z 12935, zestawienie Dyrektora Lotniczego Materiału Wojskowego „Situation de commandement à la date du 15 Janvier 1939"; DDN, t. 13, doc. 177, s. 335nn.; P. Facon, L'Armée de l'air dans la tourmente. La bataille de France 1939-1940, 2e réimpression, Paris 2005, s. 86n., Campagnes \& Stratégies. Les Grandes Batailles, 22. Por.: SHD-DAA, 3 B 47, zestawienie Dyrektora Lotniczego Materiału Wojskowego „Situation des avions de guerre de l'Armée de l'Air à la date du ler Février 1939", gdzie w odmiennym układzie umieszczone zostały bardzo podobne wielkości (łącznie 3339 samolotów). Wobec niedostatecznej wydajności własnego przemysłu lotniczego Francuzi zdecydowali się na zakup sprzętu w USA, jednak w początkach 1939 r. poważniejsze jego dostawy nie zostały jeszcze rozpoczęte. Stan sprawy w tym okresie: SHD-DAA, $11 \mathrm{Z} 12940$, niesygnowana notatka „Achat d'avions en Amerique (État de la question au 30 Janvier 1939)". Zob. też: J.M. Ha ight, Jr, American Aid to France, 1938-1940, New York 1970. Interesujące zestawienie informacji, jakimi na temat francuskiego lotnictwa wojskowego Francji dysponowali w tym czasie Niemcy, którzy nieco zawyżali rozmiary sił potencjalnego przeciwnika, opublikował M. Zgórniak w pracy Europa w przededniu wojny..., s. 463. 
Stan zachowania źródeł nie pozwala na precyzyjne określenie, na ile trudności, z którymi borykał się francuski sprzymierzeniec, znane były stronie polskiej. Wiadomo, że oficerowie sił powietrznych, którzy jesienią 1938 roku mieli okazję odbywać staże we Francji, w sprawozdaniach informowali o niektórych słabościach lotnictwa gospodarzy, wymieniając wśród nich m.in. niedostatki systemu szkolenia. Z kolei ulokowany w Paryżu attachat lotniczy dość nisko oceniał walory bojowe posiadanego przez francuskie siły powietrzne sprzętu, podkreślając jednak, że rok 1938 „był rokiem poszukiwań i doświadczeń nowych prototypów", trudno więc osądzić, czy realizowany przez Francuzów plan modernizacji i rozbudowy lotnictwa zostanie wykonany. $\mathrm{Z}$ innych pochodzących $z$ tego źródła danych (czy może raczej od attaché wojskowego, płk. dypl. Wojciecha Fydy?) mogło jednak wynikać, że francuski przemysł lotniczy pracuje rytmicznie i stopniowo zwiększa produkcję ${ }^{5 !}$.

Rozważania na temat kondycji sojusznika znad Sekwany byłyby zresztą do pewnego stopnia jałowe. Warszawa w swej dążności do zacieśnienia lotniczych więzów z Paryżem znajdowała się bowiem w sytuacji poniekąd przymusowej. Oczywiste było, że polskie lotnictwo bombowe, wyposażane właśnie w nowoczesny sprzęt, ale liczebnie wciąż szczupłe, operując samodzielnie przeciw Rzeszy nie zdoła znacząco wpłynąć na bieg działań wojennych. Zmianę tej sytuacji mogła przynieść jedynie francuska pomoc. Miałaby ona też poważne znaczenie psychologiczne i moralne. Ponadto, co szczególnie istotne, kwestia lotniczej pomocy stanowiła $w$ coraz bardziej niepewnej sytuacji swoisty probierz faktycznych intencji Paryża. W razie wybuchu wojny obecność nad Wisłą francuskich samolotów bombowych stanowić miała rodzaj rękojmi, symbolizującej, a do pewnego stopnia też gwarantującej rzetelną sojuszniczą współpracę partnera znad Sekwany. Kierownictwo polskich sił zbrojnych nie mogło mieć wątpliwości, że bez tej aktywnej pomocy Rzeczpospolita w zbrojnym konflikcie z sąsiadem z zachodu prędzej czy później skazana będzie na przegraną.

sI CAW, O. II SG, I.303.4.4400, „Sprawozdanie ze stażu w centrum Lotniczym w Istres, odbytym w czasie od dnia 5 X - 13 X 1938 r." oficera Sztabu Komendy Szkół Lotniczych mjr. pil. Jerzego Bajana z 17 X 1938 r.; „Sprawozdanie z odbytego stażu [...] przez mjr. pil. inż. Gosiewskiego Antoniego, Komendanta Szkoły Podchorążych Lotnictwa grupa techn. i kpt. pil. Stankiewicza Henryka w czasie od dnia 18 X - 27 X 38 r. w Centrum Wyszkolenia Mechaników Lotniczych w Rochefort" z 3 XI 1938 r.; I.303.4.7605, niedatowane [początek 1939 r.] „Sprawozdanie za IV kwartał 1938” attaché lotniczego przy Ambasadzie RP w Paryżu [ppłk. pil. obs. Franciszka Xawerego Pinińskiego], zał. do pisma L. 21/Tjn.39.Lot.; IPMS, Lot. A.I. 2/11, niedatowana (II 1939 r.?) i niesygnowana notatka na temat produkcji silników lotniczych we Francji; G. Łowczowski, Przymierze wojskowe polsko-francuskie widziane $z$ attachatu paryskiego, „Bellona” (Londyn) R.33, 1951, z. 1-2, s. 49. „Eliminacja uczniów prowadzona jest bardzo pobłażliwie, to znaczy, że bardzo mały procent odpada w czasie szkolenia; na moje uwagi odnośnie eliminacji przyznawano mi na ogół rację, jednak tłómaczono się tym, że w tej chwili potrzeba dużej ilości pilotów. Program wyszkolenia pilota myśliwskiego obejmuje właściwie tylko naukę latania na samolocie typu myśliwskiego, nie przygotowuje natomiast ucznia do wykonywania pracy bojowej w eskadrach" - informował mjr Bajan [pisownia oryg.]. Jak się wydaje, ppłk Piniński miał dobry dostęp do francuskich danych liczbowych czy regulaminów, w raportach poprzestawał jednak na prostym zestawianiu informacji, nie zdobywając się na głębszą ich analizę. 
Zgoła inaczej - podkreślić należy - przedstawiały się sprawy z punktu widzenia Francuzów. Jak już wyżej wskazano: polski aliant postrzegany był w tym przypadku jako użyteczny, a nawet zdecydowanie pożądany, ale nie niezbędny. Front wschodni w ramach konstruowanej przez francuskie elity polityczno-wojskowe strategii wojennej jawił się oczywiście jako element nieodzowny dla zapewnienia ostatecznego zwycięstwa. Równie oczywiste było jednak, że zwycięstwo to możliwe będzie dzięki uprzedniemu zbudowaniu przez mocarstwa Zachodu solidnej zapory na ich wschodnich rubieżach, i to tam skoncentrować należy gros sił, ostrożnie traktując wszelkie projekty grożące ich rozproszeniem ${ }^{52}$.

Swiadomi swej względnej słabości Francuzi za najważniejszego sojusznika nie uważali więc, rzecz jasna, ani Warszawy, ani Moskwy. W roli tej jednoznacznie występował Londyn, a brak formalnego sojuszu nie hamował tendencji do wznowienia wojskowo-politycznej współpracy w ramach odżywającej entente cordiale. Od maja 1938 roku kontakty obu sztabów generalnych objęły także kwestie związane z przygotowaniem sił powietrznych do współpracy w okresie wojny. Początkowo strona brytyjska starała się je ograniczyć do zagadnień o charakterze technicznym, z dopuszczeniem jedynie ogólnych dyskusji o ewentualnej koordynacji działańn ${ }^{53}$. Foreign Office obawiało się bowiem, że podjęcie bardziej konkretnych uzgodnień na temat wojennych przygotowań wzmoże wrogość Niemiec i uniemożliwi sukces polityki appesaementu. Sudecki kryzys z września 1938 roku sprawił jednak, że postawę taką uznawać zaczęto nad Tamizą za zbyt wstrzemięźliwą. Jak zauważył bowiem zastępca Dyrektora Planowania Ministerstwa Lotnictwa płk John Slessor, wobec realnej możliwości, że w bliskiej przyszłości brytyjskie lotnictwo wystąpi w sojuszu z Francją przeciw Niemcom, „nie możemy dłużej bezpiecznie i rozsądnie zachowywać braku

52 Nie oznacza to negowania całości tez Talbota C. Imlaya, który podkreślał znaczenie, jakie w opracowywanej nad Sekwaną strategii zajmowały działania na frontach od Francji odległych (front wschodni, następnie Bliski Wschód i Skandynawia). Owa „strategia peryferyjna”, jak przyjdzie nam jeszcze dowieść, $w$ interesującym nas okresie nie była jednak rozwijana konsekwentnie, nie stanowiła też głównego motywu działań podejmowanych przez przedstawicieli Paryża. T.C. Imlay, Facing the Second World War. Strategy, Politics, and Economics in Britain and France, 1938-1940, Oxford 2003; idem, France and the Phoney War, 1939-1940, [w:] French Foreign and Defence Policy, 1918-1940. The Decline and Fall of a Great Power, ed. by R. Boyce, London-New York 2005, s. 260nn.; ide m, Preparing for Total War. The Conseil Supérieur de la Défense Nationale and France's Industrial and Economic Preparations for War after 1918, „War In History” 2008, vol. 15, no. 1, s. 43nn., [online] http://dx.doi.org/10.1177/0968344507083993. Na temat lotniczych aspektów wspomianej strategii zob.: F. Pernot, Larmée de l'air et les projets périphériques 19391940, „Revue Historique des Armées” 1999, no. 217, s. 77nn. Por. też: F. Guel to n, France, Levant et Balkans 1937 - mai 1940. Les illusions perdues d'une grande stratégie périphérique, „Revue Historique des Armées" 2001, no. 226, s. 107nn.

s3 SHD-DAA, 2 B 106, "Conversations d'État-Major. Communication initiale au Ministère de l'Air Français (4 mai 1938)" i nast. dok.; AD, Papiers 1940, Reconstitution Fouques-Duparc 34, "Les conversations franco-britanniques des 28 et 29 Avril 1938" i nast. dok; TNA, CAB 24/276, „Visit of French Ministers to London. Record of an Anglo-French Conversation, held [...] on April 28 and 29, 1938" z 29 IV 1938 r.; P. Fridenson, J. Lecuir, op. cit., s. 85nn. 
zainteresowania francuskimi planami strategicznymi, które mogą istotnie wpłynąć na nasze działania i bezpieczeństwo w razie wojny" ${ }^{54}$. A choć ostatecznie jesienią 1938 roku do wybuchu wojny nie doszło, to niebawem podjęte zostały znacznie bardziej niż uprzednio zaawansowane uzgodnienia w sprawie lotniczej kooperacji obu mocarstw. W początkach roku 1939 uznać je można było za porównywalne do tych, które zdołano osiągnąć w trakcie dwudziestoletniej lotniczej współpracy Paryża i jego sprzymierzeńców znad Wisły ${ }^{55}$. W pierwszych dniach lutego rozpoczęto zaś ustalenia w sprawie kolejnej fazy rozmów ${ }^{56}$.

Nie był to bynajmniej wynik szczególnego sentymentu. Demokracje Zachodu znalazły się w sytuacji przymusowej. Rozpocząwszy zbrojenia z wyraźnym opóźnieniem względem państw totalitarnych, mozolnie i bez większego sukcesu starały się odrobić stracony dystans. Do współpracy skłaniała je kalkulacja sił, które nawet potraktowane łącznie wciąż uznawano za wyraźnie słabsze od posiadanych przez Rzeszę, i to bez uwzględniania jej włoskiego sojusznika (zob. tab. 1 i tab. 2).

54 TNA, AIR 75/3, Referat Dyrekcji Planowania Air Ministry "Staff Conversations with the French" z 10 IX 1938 r. Według późniejszych wyjaśnień Slessora w roku 1937 i pierwszych miesiącach roku 1938 Szefowie Sztabów mieli też uważać, że nie posiadają środków, które mogłyby pozwolić na wywiązanie się $z$ ewentualnych zobowiązań względem francuskiego partnera, zaś rząd nie wykazuje woli, by takie środki zapewnić (J. Slessor, op. cit., s. 146n.). Inną przyczynę wstrzemięźliwości w lotniczych kontaktach z Paryżem stanowić miało przekonanie Szefów Sztabów, że „rolą sił zbrojnych jest w pierwszym rzędzie zapewnienie bezpieczeństwa Zjednoczonego Królestwa i brytyjskich terytoriów zamorskich” (TNA, WO 106/1680, „France and Low Countries. Planning and Operations, 1 st February 1939 - 18th June 1940. Report by M.O.1. (Records)").

55 SHD-DAA, 2 B 106, pismo No 1003/DN.3 gen. Gamelina do Szefa Sztabu Generalnego Armée de l'Air z 16 XI 1938 r. i in. dok.; 2 B 107, pismo No 2660 3-O-S/E.M.A.A. za ministra lotnictwa i z jego rozkazu Szefa Sztabu Generalnego Armée de l'Air (faktycznie - Generalnego Inspektora Obrony Powietrznej) gen. Réné Kellera do ministra obrony narodowej i wojny (III Oddziału Sztabu Generalnego Armii) z 23 XI 1938 r. i in. dok.; AD, Grande Bretagne 253, fotokopia niesygnowanego pisma No 991 (ambasadora Francji w Londynie Charles'a Corbina?) do Bonneta z 4 XI 1938 r. Szersze przedstawienie realizowanej w tym czasie francusko-brytyjskiej współpracy w zakresie lotnictwa: P. Fridenson, J. Lecuir, op. cit., s. $101 \mathrm{nn}$.; T. Vivier, La politique aéronautique..., s. 550nn.

56 AD, Papiers 1940, Papiers Hoppenot 3, kopia „Aide-Mémoire” No 167/G/5/39 ambasadora brytyjskiego w Paryżu z 3 II 1939 r. i in. dok.; TNA, CAB 53/44, raport C.O.S. 838 „Staff conversations with France and Belgium" z 6 II 1939 r.; P. Fridenson, J. Le cuir, op. cit., s. 117n. Zaaprobowana 1 II 1939 r. przez brytyjski Gabinet decyzja o podjęciu rozszerzonych rozmów międzysztabowych przyspieszona została przez informacje o niemieckich zamiarach dokonania w najbliższym czasie inwazji na Holandię. (TNA, CAB 21/547, opracowanie „War with Germany. Office Diary ol Events (16th December 1938 - 23rd August 1939)"). 
Tab. 1. Porównanie stanu sił powietrznych państw europejskich wedle stanu z 1 II 1939 r. dane francuskiego Ministerstwa Lotnictwa

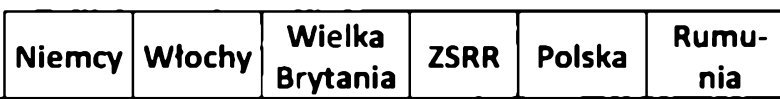

Samoloty myśliwskie

\begin{tabular}{|l|c|c|c|c|c|c|}
\hline $\begin{array}{l}\text { a) prędkość maksymalna powyżej } \\
400 \mathrm{~km} / \mathrm{h}\end{array}$ & 816 & 10 & 270 & 1085 & & \\
\hline $\begin{array}{l}\text { b) prędkość maksymalna poniżej } \\
400 \mathrm{~km} / \mathrm{h}\end{array}$ & 93 & 415 & 240 & 310 & 130 & 72 \\
\hline
\end{tabular}

Samoloty szturmowe i myśliwskie ciężkie

a) prędkość maksymalna powyżej $400 \mathrm{~km} / \mathrm{h}$

b) prędkość maksymalna poniżej $400 \mathrm{~km} / \mathrm{h}$

243

55

55

Lekkie samoloty bombowe i bombowce nurkowe (ponizej 7 ton)
a) prędkość maksymalna powyżej $400 \mathrm{~km} / \mathrm{h}$
b) prędkość maksymalna poniżej $400 \mathrm{~km} / \mathrm{h}$

324

Samoloty bombowe średnie i ciężkie (powyżej 7 ton)

a) prędkość maksymalna powyżej $400 \mathrm{~km} / \mathrm{h}$

b) prędkość maksymalna poniżej $400 \mathrm{~km} / \mathrm{h}$

\begin{tabular}{|l|c|c|c|}
\hline 399 & 360 & 30 & 650 \\
\hline 882 & 180 & 230 & 500 \\
\hline
\end{tabular}

640

90

$1508 \quad 180$

Samoloty rozpoznawcze

a) prędkość maksymalna powyże $350 \mathrm{~km} / \mathrm{h}$

b) prędkość maksymalna poniżej $350 \mathrm{~km} / \mathrm{h}$

Samoloty obserwacyjne

a) prędkość maksymalna powyże $260 \mathrm{~km} / \mathrm{h}$

b) prędkość maksymalna powyżej $260 \mathrm{~km} / \mathrm{h}$

402

Samoloty morskie - bombowe i rozpoznawcze

a) prędkość maksymalna powyżej $300 \mathrm{~km} / \mathrm{h}$

b) prędkość maksymalna poniżej $300 \mathrm{~km} / \mathrm{h}$

Samoloty lotnictwa zamorskiego i kolonialnego

Samoloty pokładowe

Samoloty transportowe

\begin{tabular}{|l|c|c|c|c|c|} 
& 63 & & & & \\
\hline 198 & 197 & & 398 & 32 & 21 \\
\hline & 380 & 400 & & & \\
\hline & 65 & 300 & & & \\
\hline
\end{tabular}




\begin{tabular}{|l|c|c|c|c|c|c|}
\cline { 2 - 6 } \multicolumn{1}{c|}{} & Niemcy & Włochy & $\begin{array}{c}\text { Wielka } \\
\text { Brytania }\end{array}$ & ZSRR & Polska & $\begin{array}{c}\text { Rumu- } \\
\text { nia }\end{array}$ \\
\hline $\begin{array}{l}\text { Ogółem samoloty w eskadrach, } \\
\text { z uwzględnieniem dowództw } \\
\text { dywizjonów i eskadr }\end{array}$ & 4170 & 2020 & 2540 & 5570 & 532 & 229 \\
\hline $\begin{array}{l}\text { Ogółem z uwzględnieniem ma- } \\
\text { szyn drugiej linii, szkolnych oraz } \\
\text { rezerwy parkowej i magazynowej }\end{array}$ & 7600 & 2320 & 2940 & 6570 & 1332 & 299 \\
\hline
\end{tabular}

Źródło: Opracowanie własne na podstawie SHD-DAA, 11 Z 12940, zestawienie „Tableau comparatif des Armées Aériennes des principales puissances européennes à la date du 1 Février 1939".

Nie oznaczało to bynajmniej, że interesy Paryża i Londynu były w tej sferze całkowicie zbieżne, a strony darzyły się pełnym zaufaniem. Francuzi zdawali sobie sprawę $z$ tego, że w razie wybuchu zbrojnego konfliktu zdecydowana większość sił myśliwskich brytyjskiego sojusznika zaangażowana zostanie do obrony jego własnych miast i ośrodków przemysłowych. Do operacji na korzyść Francji wykorzystane będzie mogło więc zostać przede wszystkim lotnictwo bombowe, które ze względu na ograniczony zasięg samolotów, winno zostać rozmieszczone w bazach po południowej stronie kanału La Manche. „W naszym interesie jest, by to ostatnie zostało maksymalnie rozwinięte", stwierdzano w Paryżu, dodając, że należy przeciwdziałać dominacji tendencji defensywnych w brytyjskich zbrojeniach lotniczych ${ }^{57}$.

Kondycję sił powietrznych sprzymierzeńca z północy oceniano z pewnym sceptycyzmem. Późną jesienią 1938 roku ich liczebność szacowano na 124 eskadry, dysponujące ogółem 1550 samolotami (z czego 430 stanowić miały myśliwce, a 820 bombowce), do których doliczyć należało $30 \%$ maszyn znajdujących się w bezpośredniej rezerwie eskadr. Jednak, zauważali francuscy analitycy, tylko mniejsza część tych jednostek posiada materiał nowoczesny i o wysokich osiągach, podczas gdy „reszta materiału ustępuje znajdującym się w służbie materiałom francuskim”. Poprawa tego stanu rzeczy przewidywana była na kwiecień 1939 roku, wraz z całkowitą wymianą sprzętu oraz stworzeniem jego rezerwy wojennej. W Paryżu najwyraźniej jednak powątpiewano $\mathrm{w}$ tak rychłą odmianę, a odpowiedni passus analizy opatrzony został przez jej adresata (ministra Daladiera?) umieszczonym na marginesie pytajnikiem. Dodać można, że Francuzi nie mieli też najlepszego zdania o brytyjskim personelu lotniczym, uznając, że jest on młody i nie ma „ani doświadczenia, ani wyszkolenia taktycznego kadr francuskiej l'Armée de l'Air"s8.

57 Archives Nationales (Pierrefitte-sur-Seine) [dalej: AN], 496 AP 11, „Information du Président. Conversations franco-britanniques" Gabinetu Wojskowego ministra obrony narodowej i wojny z 22 XI 1938 r. Por. też: AD, Europe 1930-1940, Grande Bretagne 253, fotokopia pisma No 1041 C. Corbina do MAE z 19 XI 1938 r. z załącznikiem.

5* AN, 496 AP 11, „Information du Président...” 222 XI 1938 r. oraz „Note sur l'Aviation Britannique" O. II Sztabu Generalnego AdA z listopada 1938 r. W datowanym 1 I 1939 r. opracowaniu 
Wątpliwości nie brakowało także nad Tamizą, tyle że tam dotyczyły one przede wszystkim Francuzów. Praktyczną stronę żywionych tam obaw ilustrował raport przygotowany w końcu stycznia wedle wskazówek brytyjskich Szefów Sztabów. Stwierdzano w nim, że w razie podjęcia przez Niemcy wiosną 1939 roku ataku na Francję Paryż dysponować mógłby flotą powietrzną złożoną z około 330 bombowców i 460 myśliwców, a także 467 samolotów rozpoznawczych i towarzyszących. W sukurs sojusznikom ruszyć by mogły, w części, a w razie konieczności nawet w całości, siły brytyjskie, obejmujące w pierwszej linii około 480 bombowców. Jednak nawet wówczas, przestrzegano, "Niemcy będą mieli ogromną przewagę w samolotach bombowych". I stan taki utrzymać się może przez dłuższy czas. Jak bowiem konkludowali autorzy dokumentu, w razie utrzymania przez państwa totalitarne dotychczasowego tempa rozwoju nawet wzmocniona w międzyczasie i wsparta przez Brytyjczyków Francja narażona jest na klęskę $w$ razie ataku Niemiec i Włoch, jeśli nastąpi on w ciągu najbliższego roku czy dwóch ${ }^{59}$.

W Londynie wyrażano przy tym przekonanie, że choć uderzeniowe siły powietrzne sprzymierzonych są nieporównanie słabsze od niemieckich i włoskich odpowiedników, to tempo wydobywania się z tej niebezpiecznej sytuacji jest zdecydowanie odmienne po obu stronach Kanału. Lotnictwo brytyjskie, podkreślali analitycy znad Tamizy, coraz szybciej nadrabia zapóźnienia. Tymczasem „pozycja Francji jest znacznie mniej satysfakcjonująca i niewielkie wydają się nadzieje, że wydajność jej wytwórni lotniczych osiągnie poziom satysfakcjonujący w mniej niż dwa lata"60.

Odmiennie niż czynili to Francuzi, Brytyjczycy w swej lotniczej polityce nie pokładali zbytnich nadziei $w$ aktywizacji sojuszy $z$ partnerami ze wschodniej części

"L'Armée de l'Air en Grande Bretagne" wartość brytyjskiego personelu lotniczego oceniano jeszcze surowiej: „kadry dowódcze o wartości bardzo umiarkowanej, podkomendni zbyt młodzi i bez wyszkolenia taktycznego; personel nawigacyjny - profesjonalne wyszkolenie techniczne na poziomie zadowalającym, braki doświadczenia i przygotowania do misji wojennych; personel specjalistyczny bardzo dobrej jakości". Brytyjskie siły lotnicze na terenie metropolii Francuzi szacowali w tym czasie na 490 samolotów myśliwskich (plus 150 w rezerwie bezpośredniej), 732 samoloty bombowe (plus $250 \mathrm{w}$ rezerwie) oraz 348 samolotów rozpoznawczych i współpracy (plus 100 maszyn w rezerwie) (SHD-DAA, 2 B 82). Francuskie oceny wcześniejsze o kilka tygodni, ale interesujące z punktu widzenia naszych analiz znaleźć można w: AD, Papiers 1940, Reconstitution Fouques-Duparc 35, „Étude sur les participation de l'Angleterre dans léventualité d'une action commune franco-britannique en cas de guerre" No 167/S gen. Lelonga z 8 XI 1938 r. Natychmiastowe brytyjskie wsparcie dla zaangażowanych $w$ działania wojenne Francuzów oszacowane zostało tam na 120 samolotów.

${ }_{5 y}$ TNA, CAB 53/44, opracowanie Podkomitetu Szefów Sztabów Komitetu Obrony Imperialnej "The strategic position of France in a European War. Draft report”, zat. do C.O.S. 827 (J.P.) z 25 I 1939 r. Brytyjczycy uznali, że w rozważanym przypadku opór francuski może być długi, chyba że skrócą go czynniki trudno przewidywalne, jak załamanie morale albo poważne straty materiałowe - „szczególnie wobec ciężkiego ataku lotniczego". W razie podjęcia przez siły Rzeszy ataku przez terytorium Holandii i Belgii przewidywany okres trwałości francuskiego frontu ulec mógł skróceniu do około sześciu tygodni.

61 TNA, CAB 53/44, opracowanie Podkomitetu Szefów Sztabów Komitetu Obrony Imperialnej „Draft European Appreciation, 1939-40”, zał. do C.O.S. 831 (J.P.) z 26 I 1939 r. 
kontynentu. Liczyli raczej na własne pokaźne rezerwy, które szczególnie w przypadku personelu, mogły być jeszcze uzupełnione przez posiłki z dominiów. Zapewnić im to miało korzyści szczególnie $w$ dalszych fazach spodziewanego konfliktu, gdy przeciwnik wyczerpie już swe ograniczone zasoby „załóg zdyscyplinowanych i o wysokim morale" 61 . Za atut w pierwszej, z założenia głównie obronnej fazie wojny uznawane było położenie Wysp, które były niełatwo osiągalne $\mathrm{z}$ terytorium potencjalnego agresora. Charakterystyczne, że sporządzane w Londynie zestawienia potencjału sił powietrznych mocarstw w przypadku samolotów bombowych za podstawę brały ich zasięg, podczas gdy w Paryżu uwagę zwracano głównie na tonaż przenoszonego ładunku.

Tab. 2. Maksymalny potencjał pierwszej linii wybranych sif powietrznych $w$ dniu 1 kwietnia 1939 roku wedle szacunków Podkomitetu Szefów Sztabów Komitetu Obrony Imperialnej

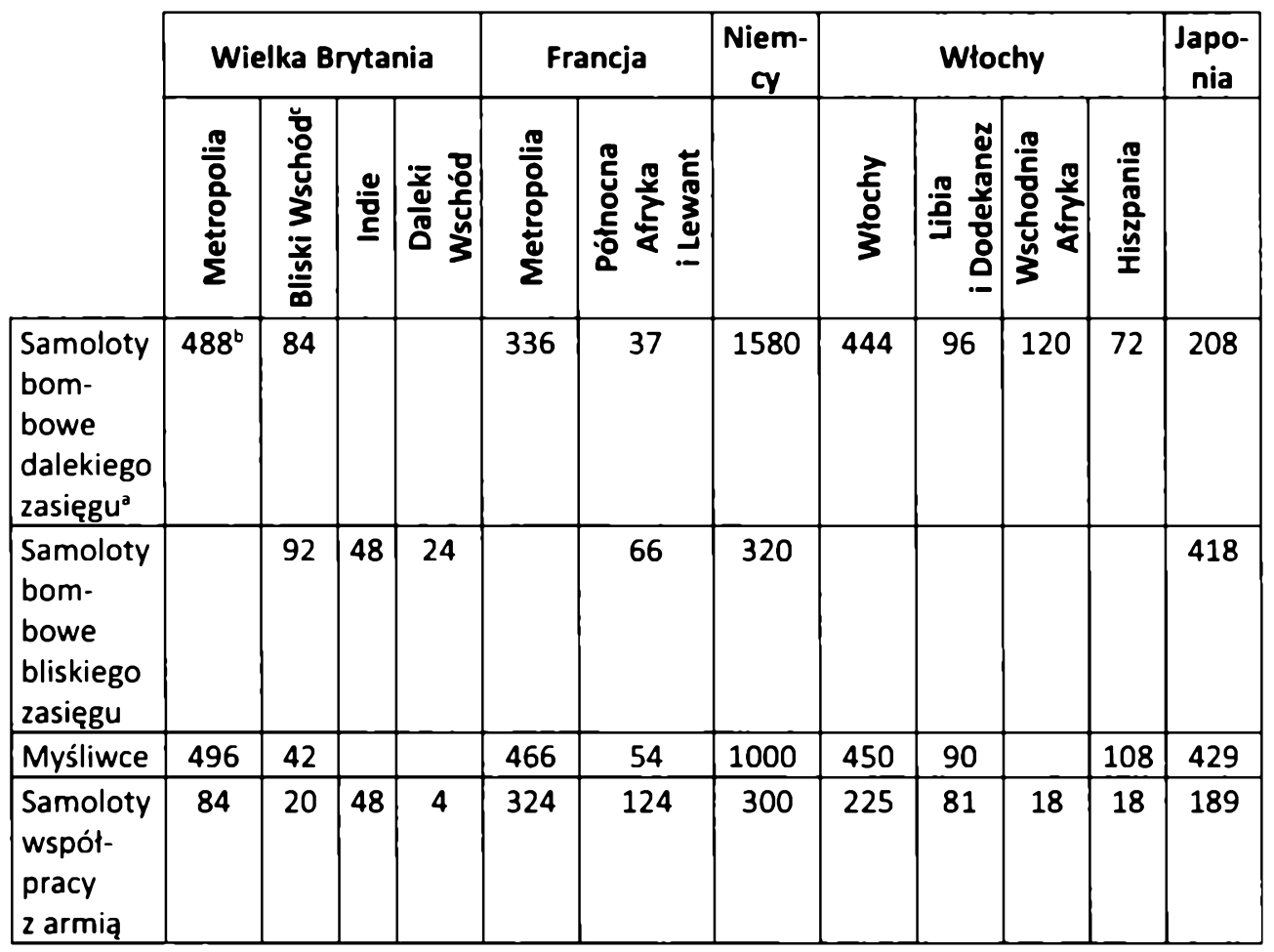




\begin{tabular}{|l|c|c|c|c|c|c|c|c|c|c|c|c|}
\hline $\begin{array}{l}\text { Samoloty } \\
\text { rozpo- } \\
\text { znawcze } \\
\text { i współ- } \\
\text { pracy } \\
\text { z mary- } \\
\text { narka }\end{array}$ & 222 & 8 & 10 & $324^{\circ}$ & 42 & 500 & 274 & 9 & & & 99 \\
\hline Razem & 1290 & 246 & 96 & 38 & 1450 & 323 & $3700^{\circ}$ & 1393 & 276 & 138 & 198 & $1343^{\prime}$ \\
\hline
\end{tabular}

Źródło: Opracowanie własne na podstawie TNA, CAB 53/44, opracowanie Podkomitetu Szefów Sztabów Komitetu Obrony Imperialnej „Draft European Appreciation, 1939-40”, zał. do C.O.S. 831 (J.P.) z 26 I 1939 r.

- Promień działania ponad 350 mil.

- Liczba ta dotyczy samolotów zdatnych do mobilizacji, tzn. pozostających w dyspozycji po utworzeniu półrocznych rezerw w efekcie rozwiązania niektórych dywizjonów.

' Wraz z Sudanem, Kenią, Adenem, Maltą i Irakiem.

' $W$ tym 143 lądowe samoloty rozpoznawcze możliwe do użycia jako bombowce: 13 dalekiego zasięgu, 130 bliskiego zasięgu.

e Możliwe braki członków załóg innych niż piloci.

' Japońskie lotnictwo jest zmobilizowane i można sądzić, ze pozostawać będzie $w$ tym stanie w kwietniu 1939 r.

W tym stanie rzeczy nie może dziwić, iż kontakty lotników brytyjskich i polskich nie były zbyt bliskie. Londyn od bardziej ścisłej lotniczej współpracy wręcz stronił. Świadczyły o tym m.in. doświadczenia polskiego attaché wojskowego, który w połowie roku 1938 próbował zainteresować wojskowych znad Tamizy wymianą informacji lotniczych (na temat Luftwaffe?). Po pierwszej fali zainteresowania, które szczególnie żywe miało być ze strony Air Ministry, propozycję skwitowano oficjalną informacją, że „przepisy angielskie nie pozwalają na tego rodzaju kontakty”. Wersja nieoficjalna, przekazana nieco wcześniej w rozmowie w cztery oczy, brzmiała zdecydowanie bardziej szczerze: „władze wyższe obawiają się, że takie rozmowy przekształcić by się mogły w wielkie rozmowy międzysztabowe, co w tej chwili nie wydaje się pożądane"62. Pewien dystans wobec przedstawicieli Albionu widoczny był zresztą

62 IPMS, Lot. A.V. 1/40j, „Notatka w sprawie rozmów z Anglikami na tematy ewent. wymiany wiadomości" L. 2052/38 ppłk. dypl. Bogdana J. Kwiecińskiego z 20 VI 1938 r.; pismo L. 2057/T.O. ppłk. Kwiecińskiego do Szefa O. II SG z 14 VII 1938 r. i in. dok. Jednak w późniejszym czasie ograniczona wymiana takich informacji została przeprowadzona. W sporządzonej w O. II SG wiosną 1939 r. niesygnowanej notatce „Materiały od Anglików. Siły powietrzne” zapisano: „W ostatnich trzech miesiącach nie otrzymaliśmy od Anglików materiałów z zakresu sił powietrznych. Otrzymaliśmy w końcu 1938 r. dobre zestawienie o niemieckim przemyśle lotniczym. [...] Otrzymaliśmy podziękowanie za powiadomienie o nowo rozpoznanym 252 pułku bombowym. [...] Przekazaliśmy charakterystyki niektórych niemieckich samolotów wojskowych. Nie mogliśmy z braku wiadomości dać odpowiedzi na zapytania o specjalnych bombach lotniczych" (CAW, O. II SG, I.303.4.7345). Na temat polsko-brytyjskiej współpracy wywiadowczej w tym okresie: A. Mi siuk, Slużby specjalne II Rzeczypospolitej, Warszawa 1998, s. 118n.; A. Pepłoński, A. Such citz, 
także ze strony Warszawy. Jeszcze w początkach roku 1937 brytyjski attaché z rozczarowaniem komentował brak zgody Oddziału II SG na przekazanie mu druku zawierającego budżet polskich sił zbrojnych na nadchodzący rok, choć w poprzednich latach podobne dane uzyskiwał bez problemu. $Z$ kolei w styczniu 1939 roku z odmową spotkała się prośba tegoż attachatu o informację na temat cudzoziemskich lotników odbywających staże w wojskowym lotnictwie nad Wisłą. Wyraźnie kontrastowało to $z$ ostentacyjną wręcz otwartością okazywaną przez Polaków ich francuskim sojusznikom, w sprawach zresztą często nieporównanie poważniejszych ${ }^{63}$.

$\mathrm{Z}$ wyjątkiem wizyt związanych $\mathrm{z}$ dokonywanymi przez stronę polską zakupami sprzętu lotniczego stosunkowo rzadkie były też inne formy kontaktów przedstawicieli sił powietrznych obu państ $w^{64}$. Ich niedostatek kompensowała do pewnego stopnia wielka aktywność sprawującego w londyńskiej Ambasadzie RP funkcję attaché wojskowego ppłk. dypl. obs. Bogdana J. Kwiecińskiego, oficera lotnictwa z wieloletnim i bardzo bogatym doświadczeniem ${ }^{65}$. Jego brytyjskim odpowiednikiem nad Wisłą był od 28 czerwca 1938 roku kawalerzysta ppłk Edward Roland Sword, podczas gdy akredytowany w Warszawie attaché lotniczy Zjednoczonego Królestwa, płk John Lyne

J. Tebinka, Wspólpraca wywiadowcza $w$ drugiej polowie lat trzydziestych XX w., [w:] Polsko-brytyjska wspólpraca wywiadowcza podczas II wojny światowej, t. 1: Ustalenia Polsko-Brytyjskiej Komisji Historycznej, red. T. Dubicki, D. Nałęcz, T. St irling, Warszawa 2004, s. 177nn.; P. Kołakowski, op. cit., s. $275 \mathrm{nn}$. We wspomnianych publikacjach wywiadowcza współpraca Londynu i Warszawy określana jest ogólnikowo jako „intensywna” (nieco odmienną ocenę formułuje P. Kolakowski), co jednak w świetle przywołanej tamże faktografii wydaje się dość wątpliwe. Stanowisko strony brytyjskiej w kwestii kooperacji „na odcinku” niemieckim dobrze ilustruje zapewne niedatowany (12 IX 1935 r??) dokument przeznaczony dla brytyjskiego attaché wojskowego w Warszawie: „nie mamy zbyt wielu informacji o wschodnich Niemczech, zwłaszcza Prusach Wschodnich i Śląsku. Bylibyśmy [...] bardzo zadowoleni, gdyby polski Sztab Generalny zapewnił jakąś informację o niemieckiej armii, kolejach i komunikacji drogowej we wschodnich Niemczech. $Z$ drugiej strony nie możemy zaangażować się w jakąkolwiek [...] wymianę informacji o Niemczech i attaché wojskowy nie powinien podnosić takiej kwestii, chyba że Polacy [sami] zaoferują informacje" (TNA, WL 190/349, rękopiśmienna notatka „Points to discussion with MA Warsaw”).

${ }^{63}$ Archiwum Akt Nowych w Warszawie [dalej: AAN], Sztab Główny, 617/56, koncepty pism Szefa O. II SG płk. dypl. Tadeusza Pełczyńskiego L. 14503/II Og. z 27 II 1937 r. oraz L. 29053/II Og. $z 18$ I 1939 r.

${ }^{64}$ Jednak późną jesienią 1938 r. stosunkowo długą wizytę złożyli w Wielkiej Brytanii kpt. dypl. Franciszek Kalinowski i kpt. pil. Zdzisław Królikowski, dość gruntownie zapoznając się z funkcjonowaniem Ministerstwa Lotnictwa, a przede wszystkim jednostek RAF i używanym przez nie sprzętem. CAW, Generalny Inspektorat Sił Zbrojnych [dalej: GISZ], Biuro Inspekcji, 1.302.4.2023, „Sprawozdanie kpt. dypl. Kalinowskiego i kpt. pil. Franciszka Królikowskiego z wizyty w Royal Air Force w czasie od 22 XI do 6 XII 38 r." z 21 XII [19]38 r.; F. Kalinowski, O lotnictwie polskim przed 1939 rokiem, „Bellona” (Londyn) R. 42, 1960, z. 4, s. 308.

6s Tematyka lotnicza $w$ raportach ppłk. Kwiecińskiego zajmowala istotne miejsce. 18 VIII 1938 r. przesłał on m.in. do Szefa O. II SG obszerne opracowanie "Angielskie lotnictwo wojskowe”, zapowiadając, że "w ciągu 203 miesięcy" dostarczy kolejne, "może znacznie szersze" opracowanie na ten temat. W trakcie kwerendy autor nie zdołał jednak odnaleźć tego ostatniego dokumentu. Być może rozwój sytuacji politycznej uniemożliwił jego przygotowanie (IPMS, Lot. A.V. 1/40j, zał. do pisma L. 2071/38 z 18 VIII 1939 r.; inny egzemplarz: AAN, SG 616/354). 
Vachell, większość czasu spędzał w przyporządkowanej mu równolegle, a znacznie ważniejszej z punktu widzenia jego przełożonych placówce berlińskiej.

W docierających nad Tamizę raportach tematyka lotnicza pojawiała się więc rzadziej niż w dokumentach zdążających w kierunku przeciwnym. Nie znaczy to jednak, że orientacja strony brytyjskiej w kwestiach dotyczących sił powietrznych Rzeczypospolitej była jedynie pobieżna. Wręcz przeciwnie, sporządzone jesienią 1937 roku przez służby informacyjne Air Ministry obszerne, liczące 76 stron opracowanie „The Polish Air Force" pod względem treści nie ustępowało francuskim odpowiednikom, od większości z nich było za to bardziej klarowne ${ }^{66}$. Przynajmniej niektóre aspekty funkcjonowania polskiego lotnictwa wojskowego kompetentni przedstawiciele Albionu nie tylko znali, ale wręcz mieli na ich temat osobiste poglądy. W kręgu tym wyraźne zaniepokojenie wywołały więc np. przekazane przez ppłk. d’Arnaud de Vitrolles po jego powrocie znad Wisły informacje o zamierzonym przez władze z Warszawy usunięciu ze stanowiska sprawującego funkcję Dowódcy Lotnictwa MSWojsk. gen. bryg. pil. inż. Ludomiła Rayskiego. „Znam bardzo dobrze generała Rayskiego jako wspaniałego organizatora i dobrego oficera. Istnienie efektywnych polskich sił powietrznych jest w większości jego zasługą" - raportował z Paryża płk Douglas Colyer. „Byłoby katastrofalne dla tych sił lotniczych, gdyby byli tak głupi, by usunąć człowieka z jego osobowością i zdolnościami" - nie próbując nawet tłumić emocji, komentował doniesienie wysoki urzędnik Departamentu Centralnego Foreign Office Richard Speaight. W tej ostatniej wypowiedzi wyraźnie przebijał paternalizm, podszyty charakterystycznym dla ówczesnych brytyjskich elit przekonaniem o własnej kulturowej, a co za tym idzie także intelektualnej wyższości. Przyznać jednak trzeba, że przedstawiciele Albionu nie po raz pierwszy sformułowali w sprawach dotyczących Polski bardzo celne opinie ${ }^{67}$.

Najbardziej intensywna współpraca miała natomiast miejsce $\mathrm{w}$ dziedzinie przemysłu lotniczego, a szczególnie produkcji silników lotniczych wielkiej mocy oraz ich oprzyrządowania, w której od dziesięciu bez mała lat strona polska opierała się na rozwiązaniach brytyjskich ${ }^{68}$. W tym czasie konstruktorzy znad Wisły poczynili

66 TNA, AIR 10/1423, opracowanie "The Polish Air Force. Issued by the Air Staff” z września 1937 r. Poprawne i przejrzyście zestawione były też brytyjskie dane na temat samolotów polskiego lotnictwa wojskowego: TNA, AIR 10/7368, „Performance tables of foreign service aircraft” Air Ministry ze stycznia 1939 r.

67 TNA, FO 371/23144, kopia „Memorandum” No 246/965.F.1 płk. Colyera dla brytyjskiego ambasadora w Paryżu z 25 II 1939 r.; kopia pisma C 2477/1110/55 Speaigha do II sekretarza ambasady brytyjskiej w Warszawie Roberta Maurice’a Alersa Hankeya z 15 III 1939 r. Przedstawiciele armii brytyjskiej wysokie oceny gen. Rayskiego formułowali od lat. Strona polska traktowala je podejrzliwie, autorów opinii posądzając wręcz o kpiny [sic!]. Zob.: AAN, Attachaty Wojskowe [dalej: AW], A II/101, niesygnowany raport „Attaché Wojskowy angielski o płk. Rayskim” 12334/II. Inf. dla Szefa O. II SG z 17 IX 1930 r. Tymczasem w opracowaniu „The Polish Air Force...” z roku 1937 stwierdzano wręcz: „Polska ma szczęście mieć jako dowódcę od roku 1926 oficera kalibru generała Rayskiego" (TNA, AIR 10/1423).

6* M.W. Majewski, Druga próba uruchomienia produkcji silników lotniczych. Polskie Zaklady Škody (1926-1935), „Annales Academiae Paedagogicae Cracoviensis. Studia Historica” 2005, 
bardzo znaczne postępy, a opracowywane przez nich nowoczesne płatowce bojowe nie bez racji cieszyć się zaczęły międzynarodową renomą. Jednak u schyłku lat 30. nadal żaden $z$ nich nie byłby $\mathbf{w}$ stanie wznieść się $\mathbf{w}$ powietrze bez uprzedniego sprowadzenia $z$ Wysp Brytyjskich elementów tak podstawowych, jak np. wytwarzane w firmie Ransome \& Marles Bearing Co. Ltd. z Newark-on-Trent łożyska kulkowe. Mniej lub bardziej niezbędne dla funkcjonowania polskiego przemysłu lotniczego (a pośrednio także i zaopatrywanych przezeń sił powietrznych) były także dostawy innych nabywanych w Wielkiej Brytanii materiałów i dokumentacji technicznej oraz zakupy licencji. Brytyjska pomoc wciąż okazywała się też konieczna dla utrzymania w eksploatacji sprzętu starszej nieco generacji ${ }^{69}$.

Przyspieszenie w roku 1938 prac nad modernizacją wyposażenia polskiego lotnictwa wojskowego wiązało się $\mathrm{z}$ nową serią dokonywanych za Kanałem zakupów. Władze kontrolujące kontrakty eksportowe do postulatów formułowanych przez partnera znad Wisły ustosunkowywały się na ogół życzliwie, choć nie bez pewnej dozy niepewności. W datowanym 22 lutego 1939 roku referacie Speaight zauważał z jednej strony, że wzmocnienie polskiej zdolności obronnej, ugruntowującej gotowość Warszawy do oparcia się niemieckiej presji, leży w brytyjskim interesie. Z drugiej - wyrażal obawę, że w ewentualnym europejskim kryzysie Rzeczpospolita pozostaje czynnikiem niepewnym, stąd w przyszłości "możemy ujrzeć jej samoloty skierowane przeciw nam". W rozpatrywanym przypadku na korzyść Warszawy dylemat pozwoliło rozstrzygnąć przeświadczenie, że w razie odmowy zamówienia mogą zostać ulokowane w Niemczech ${ }^{70}$.

Raz jeszcze podkreślić przy tym należy, że taka bardzo powściągliwa względem partnera znad Wisły postawa charakteryzowała politykę brytyjską już od dłuższego czasu. W niepewnej rzeczywistości przełomu roku 1938 i 1939 powściągliwość ta ulegała zaś dalszemu pogłębieniu. Kilka tygodni wcześniej, w początkach stycznia, Speaight swe zastrzezenia wobec polityki Warszawy wyrażał nawet ostrzej, twierdząc, że „przyszła rola Polski jest zbyt daleko niepewna”, by możliwa była bliższa współpra-

t. 4, Folia 28, s. 156nn; W. Mazu r, Zagraniczne zakupy silników lotniczych dla polskiego lotnictwa wojskowego (1926-1939), cz. 1, „Lotnictwo” 2007, nr 11, s. 6lnn. Za potencjalnie użyteczne wzorce uważano też $w$ Polsce zastosowane $w$ brytyjskim przemyśle lotniczym rozwiązania organizacyjne. Zob. np.: AAN, SG 616/354, pismo L. 2072/38 ppłk. Kwiecińskiego do Szefa O. II SG z 11 VIII $1939 \mathrm{r}$.

6y IPMS, Lot. A.V. 1/40j, pismo L. 247/38 tjn. Dowódcy Lotnictwa MSWojsk., wz. płk. inż. Henryka Abczyńskiego do attaché wojskowego i lotniczego RP w Londynie ppłk. dypl. Bogdana J. Kwiecińskiego z 2611938 r. i in. dok.; Lot. A.V. 1/40i XIII, niedatowane zestawienie "Licencyjne umowy zawarte przez K.[ierownictwo]Z.[aopatrzenia]L.[otnictwa] i państwowe zakłady"; Lot. A.V. 1/40i XIV, pismo L. 772-19/Zak. Kierownika Zaopatrzenia Lotnictwa płk. obs. inż. Czesława Filipowicza do attaché wojskowego RP w Londynie z 7 V 1938 r. i in. dok.; CAW, O. II SG, I.303.4.4600, odpis pisma L. 772-19/Zak. płk. Filipowicza do attaché wojskowego RP w Londynie z 22 II 1938 r.

71 TNA, FO 371/23144, referat Speaighta z 22 II 1939 r. do reg. no. C 1975/1110/55. Dodatkowo zgoda na zamierzone zakupy mogła pozwolić na poprawę niekorzystnego dla Brytyjczyków bilansu handlowego. 
ca Zjednoczonego Królestwa z którąkolwiek częścią sił zbrojnych Rzeczypospolitej ${ }^{j 1}$. Co bardziej zapewne istotne, podobnego zdania byli w tym czasie także brytyjscy Szefowie Sztabów, którzy myśl, by ufać w jakąkolwiek pomoc ze strony Polski, określili po prostu jako „nierozsądną". I nie była to incydentalnie użyta figura retoryczna: $\mathrm{w}$ następnych tygodniach fraza ta pojawiać się miała $\mathrm{w}$ dokumentach redagowanych przez przedstawicieli londyńskich kręgów wojskowych wielokrotnie, także podczas prac nad materiałami do rozmów $z$ francuskim sprzymierzeńcem ${ }^{i 2}$.

Tak więc siły powietrzne Rzeczypospolitej postrzegane były w Londynie w najlepszym razie jako odległy i niepewny „sojusznik naszych sojuszników”, którego istnienie należało odnotować - bardziej jako problem niż szansę - całość związanych z tym faktem spraw pozostawiając do rozwikływania Francuzom. To ci ostatni pozostawali jedynym branym w rachubę aliantem Brytyjczyków w coraz bardziej prawdopodobnym zbrojnym konflikcie.

Nad Sekwaną tymczasem wciąż nie potrafiono podjąć decyzji w sprawie wyraźnie artykułowanych przez Warszawę oczekiwań pogłębienia lotniczej współpracy. Tym razem, wbrew wszelkim zasadom prakseologii, taktyka "gry na zwłokę" okazała się nadspodziewanie skuteczna. Decyzję... podjęli Niemcy, w dniach 14 i 15 marca dokonując likwidacji resztek niezależnej Czechosłowacji. Nie przekreślało to bynajmniej francuskiego dylematu, ale umieszczało go w zupełnie nowym kontekście. Nadchodził czas radykalnych rozwiązań. A w każdym razie - tak mogło się wydawać.

`TNA, FO 371/23129, referat Speaighta z 4 I 1939 r do reg. no. C 27/27/55; A. Prazmow ska, op. cit., s. 30 .

72 TNA, CAB 53/44, „Draft European Appreciation, 1939-40”, zal. do C.O.S. 831 (J.P.) z 26 I 1939 r.; CAB 53/46, „Anglo-French Staff Conversations 1939. United Kingdom Delegation. British Strategical Memerandum" A.F.C. 1220 III 1939 r. Na temat politycznych stosunków obu państw w tym czasie zob.: A. Cien ciała, Minister Józef Beck i ambasador Edward Raczyński... 



\section{Rozdział 2}

\section{Gwarancje: politycy i żołnierze}

Dla większości obserwatorów europejskiej sceny politycznej wydarzenia z połowy marca 1939 roku nie stanowiły zbytniego zaskoczenia. Kryzys nabrzmiewał od wielu dni, a kolejne jego etapy sukcesywnie odnotowywali w swych raportach zarówno dyplomaci, jak i wojskowi analitycy. Trafne domysły formułowali Francuzi, celnie przewidywał rozwój wypadków wywiad Rzeczypospolitej. Wyraźnie mniej przenikliwe oceny dominowały bodaj jedynie w Londynie, gdzie jeszcze w początkach drugiej dekady miesiąca $\mathrm{w}$ związku $\mathrm{z}$ rozwojem sytuacji wzrastać miała, jak donosił francuski attaché wojskowy, nieuzasadniona fala optymizmu'.

Choć spodziewany, czechosłowacki dramat nie mógł zostać przyjęty spokojnie. Wręcz przeciwnie, już w pierwszych formułowanych ex post analizach miejsce dotychczasowego zaniepokojenia zaczęła zajmować panika. Tak stało się przede wszystkim w Paryżu, który już od kilkunastu miesięcy zwykł w ten sposób reagować na ziszczenie się kolejnego z systematycznie dewastujących jego strategiczne bezpieczeństwo scenariuszy. „We wrześniu 1938 roku Niemcy zapewniły sobie na planie strategicznym neutralizację czterdziestu dywizji czechosłowackich; obecnie pełna okupacja Czechosłowacji i rozbrojenie jej armii daje Rzeszy bezprecedensowe

' SHD-DAT, 7 N 2524, „Note pour le Comandement sur la situation en Europe Centrale” Sekcji Armii Obcych Sztabu Generalnego Armii z 9 III 1939 r.; 7 N 2816, raport No 253 gen. Lelonga z 16 III 1939 r. (opublikowany w: DDF, t. 15, doc. 17, s. 19nn.); P. Kołakowski, Polski wywiad wojskowy wobec wydarzeń z marca 1939 r., [w:] Wywiad wojskowy II Rzeczypospolitej. Materialy, red. idem, A. Pepłoński, Kraków 2011, s. 346n.; W. Murray, The Change in the European Balance of Power, 1938-1939. The Path to Ruin, Princeton 1984, s. 286; P. Jackson, op. cit., s. 313n.; P. de Vill elu me, op. cit., s. 194nn. Wedle ustaleń P. Kołakowskiego Francuzi mieli poinformować zawczasu polski O. II SG o przygotowywanej przez Niemców operacji, podając nawet dokładną datę jej przeprowadzenia (idem, Czas próby..., s. 264). Francuzi istotnie już 6 marca posiadali takie informacje, uzyskując ich potwierdzenie pięć dni później (SHD-DAT, 1 N 44, „Compte Rendu de la réunion des Chefs d'États-Majors” z 22 III 1939 r.). Por. też: R. Majzner, Polski wywiad wojskowy wobec polityki III Rzeszy, 1933-1939. Militarne aspekty polityki III Rzeszy w świetle analiz Oddziału II Sztabu Glównego Wojska Polskiego, Toruń 2006, s. 182nn. Wedle tego ostatniego autora francuskie informacje, przekazane 7 marca, nie zawierały jednak dokładnej daty spodziewanej niemieckiej akcji, sytuując ją „w najbliższym czasie”. 
korzyści materiałowe" - stwierdzał już 17 marca w przedłożonej Daladierowi analizie gen. Gamelin, informację doprawiając hiobową wieścią, że od czasów monachijskiej kapitulacji mocarstw Zachodu Berlin zwiększył swą nad nimi przewagę „o równowartość 80 dywizji"’. Dzień później francuski Szef Sztabu uzupełnił swą kalkulację o kolejną porcję danych. Siły militarne Francji, wyjaśniał w budzącym grozę wywodzie, na obszarze Europy w okresie pokoju liczą 503700 ludzi, zaś brytyjski sojusznik wesprzeć je może w skali ledwie symbolicznej, oferując (co Gamelin odnotował tylko pour mémoire) "początkowo 2 dywizje”. Armia niemiecka ma zaś do natychmiastowej dyspozycji milion ludzi, do których należy doliczyć 700000 ludzi, którymi dysponują Włosi - nawet jeśli ci ostatni na ich pełne wcielenie do szeregów potrzebować będą dwóch lub trzech miesięcy. W razie wojny łączny potencjał obu zachodnich demokracji wyrażać by się więc miał przeto liczbą 87 dywizji piechoty, podczas gdy połączone siły niemiecko-włoskie, złożone ze 190 dywizji (w tym zgodnie ze "stanem obecnym" 130 dywizji niemieckich) dysponowałyby miażdżącą przewagą ${ }^{3}$.

Dla jej zrównoważenia siły sojuszników z Europy Wschodniej nie będą wystarczające, oceniał Gamelin. Czechosłowacja znikła, a materiałowe zasoby jej armii przejęli Niemcy, wywodził. Rosja „w stanie obecnym" może być jedynie rodzajem rezerwy materiałowej i zabezpieczeniem zaplecza dla innych państw, które mogłyby się opowiedzieć po stronie Francji. Ich siły obejmują 50 dywizji w przypadku Polski oraz 25 dywizji rumuńskich i 20 jugosłowiańskich. Są to jednak jednostki o wartości wyraźnie mniejszej od niemieckich, nie byłyby więc w stanie sprostać żadnej poważnej ofensywie wojsk Rzeszy. W dodatku Bukareszt, a po części także i Belgrad sparaliżowane zostaną $\mathrm{w}$ razie konfliktu przez sympatyzujące $\mathrm{z}$ państwami Osi Węgry.

Ostatecznie więc, oceniał francuski głównodowodzący, w takim przypadku Niemcy i Włochy na wschodzie kontynentu pozostawią nie więcej niż 70 dywizji, pozostałe 120 jednostek kierując przeciw 87 dywizjom anglo-francuskim. Francja przeto trwać będzie musiała w obronie do czasu, gdy zmobilizowany wreszcie sojusznik zza Kanału okaże się zdolny do udzielenia jej poważniejszej pomocy - brzmiała konkluzja ${ }^{4}$.

2 SHD-DAT, 7 N 2293, „Analyse sur les conséquences militaires de la disparition de la Tchéco-Slovaquie et les nouvelles mesures de la sécurite à prendre pour la France". Wedle przedstawionych danych najświeższa niemiecka zdobycz objąć miała m.in. „około 600 samolotów”. W przygotowywanych równolegle opracowaniach Deuxième Bureau zwracano też uwagę na poprawę sytuacji strategicznej Rzeszy wobec zagrożenia ze wschodu oraz zwiększone możliwości wywierania przez Niemcy „presji szybkiej i decydującej w kierunku Morza Czarnego”, która zapewnić by im miała dostęp do produktów niezbędnych do prowadzenia wojny przez czas dłuższy, niż uprzednio zakładano. Dokument zawierał też ostrzeżenie przed możliwym podjęciem przez Rzeszę w najbliższym czasie nagłej akcji przeciw Holandii (AN, 496 AP 11, „Note sur la situation crée par la disparition de la Tchécoslovaquie" Sekcji Armii Obcych Sztabu Generalnego Armii z 16 III 1939 r. i nast. dok.). Dwa dni później wielkość wojskowych aktywów Włoch Gamelin obniżył do 641000 ludzi. Wobec zachowania pozostałych wartości na poprzednim poziomie nie stanowiło to jednak istotniejszej różnicy.

3 SHD-DAT, 2 N 224, kopia noty No 1.508/S Gamelina dla Daladiera z 18 III 1939 r.

+ Ibidem. 
Gamelin zaproponował środki, które jego zdaniem miałyby podnieść gotowość Francji do zmierzenia się z zarysowanym zagrożeniem. Oczywiste jednak było, że dalsza rozbudowa systemu fortyfikacji, przyspieszenie szkolenia rezerw czy lepsze przygotowanie kadr, które miały się stać jądrem jednostek formowanych $w$ trakcie mobilizacji, stanowiły półśrodki, jedynie w bardzo ograniczonym stopniu mogące się przyczynić do zniwelowania ogromnej przewagi liczebnej przeciwnika. Jak się jednak mogło wydawać, sam Paryż nie był w stanie uczynić wiele więcej. Tym istotniejsze znaczenie zyskiwała postawa jego sojuszników: Londynu, Moskwy, ale i Warszawy.

Rzecz jasna, najważniejsza była pierwsza z wymienionych stolic. Tymczasem na poczynania Berlina rząd Jego Królewskiej Mości zareagował początkowo miękko, wyraźnie sugerując, że realizowana przezeń dotychczas polityka appeasementu nie dozna poważniejszego uszczerbku. Ostrzejsze tony pojawiły się w wypowiedziach premiera Chamberlaina dopiero 17 marca - w reakcji na informacje rumuńskiego ambasadora Viorela Virgila Tilei o godzącym w suwerenność jego kraju (i kontrolę jego władz nad strategicznymi zasobami ropy naftowej) ultimatum Berlina oraz wieści o formalnym włączeniu ziem czeskich do Rzeszy pod nazwą Protektoratu Czech i Moraw. Jeszcze tego samego dnia Foreign Office rozesłało do placówek w Moskwie, Paryżu, Warszawie, Ankarze, Atenach i Belgradzie depeszę z poleceniem zbadania stanowiska rządów w sprawie udzielenia pomocy Rumunii, jeśli ta, poczuwszy się zagrożona, o taką pomoc by się zwróciła ${ }^{5}$.

Podjęta na rozpoczętym późnym popołudniem 18 marca posiedzeniu brytyjskiego gabinetu dyskusja nad niemieckim zagrożeniem względem Rumunii (któremu zresztą w międzyczasie rząd z Bukaresztu zdążył zaprzeczyć) bardzo szybko przerodziła się w rozważania na temat reakcji Londynu, w razie gdyby Rzesza istotnie zamierzała kontynuować ekspansję w kierunku wschodnim czy południowo-wschodnim. Punktem wyjścia stała się tu opinia lorda Halifaxa, który - wciąż formalnie odnosząc się do kwestii rumuńskiej - stwierdził, że w przypadku podjęcia przez Rzeszę otwartej agresji dla Wielkiej Brytanii byłoby bardzo trudne nie tylko nie podjąć wszelkich działań pozostających w jej mocy, aby „zmobilizować opór”, ale też i samej nie zaangażować się $\mathrm{w}$ działania przeciwko agresorowi ${ }^{6}$. Skoro bowiem - argumentował sekretarz stanu spraw zagranicznych - rzeczywistym celem Niemiec jest światowa dominacja, to sprzeciw wobec takiej polityki leży $w$ interesie wszystkich pozostałych państw. Tylko zaś Zjednoczone Królestwo jest w stanie taki opór zorganizować?. Stanowisko takie zaaprobowała zdecydowana większość zebranych, którzy nie kryli

H. Jackiewicz, op. cit., s. 84nn; S. Newman, op. cit., s. 125nn. (tu także szersza analiza przyczyn brytyjskiej apatii pocztowej oraz inicjatywy Tilei); M. Nurek, op. cit., s. 171nn.; Ch. Hill, Cabinet Decisions on Foreign Policy. The British Experience, October 1938 - June 1941, Cambridge 1991, s. 20. Równolegle odpowiednią informację przekazał do Warszawy ambasador E. Raczyński, zob.: PDD 1939, dok. 98, s. 162.

"TNA, CAB 23/98, "Conclusions of a Meeting of the Cabinet held [...] on Saturday, 18th March, 1939, at 5.0 p.m.".

7 Ibidem; A. Prazmowska, op. cit., s. 40. Dość dokładne streszczenie przebiegu dyskusji: M. Nurek, op. cit., s. 173nn.; Ch. Hill, op. cit., s. $24 n$. 
zresztą, że do akceptacji skłoniły ich nade wszystko nie tyle racje ogólnopolityczne czy moralne, ale wzgląd na interes Imperium. „Jeśli Rumunia zostałaby pokonana i Niemcy przesunęłyby się ku Morzu Śródziemnemu i Egejskiemu, znaleźlibyśmy się w niebezpieczeństwie zostania mocarstwem drugiego rzędu" - wyrażał obawę sekretarz stanu ds. dominiów Thomas Inskip. „Jeśli nie podjęlibyśmy tego wyzwania, moglibyśmy stracić wsparcie wszystkich tych narodów, których pomoc mogłaby nam być w późniejszym czasie potrzebna" - stwierdził chwilę później sekretarz stanu ds. kolonii Malcolm MacDonald ${ }^{8}$.

W wypowiedziach uczestników spotkania przewijały się postulaty budowy na wschodzie kontynentu „wielkiego frontu” z Polską i ZSRR w roli jego filarów. Perspektywa wojny na dwóch frontach, argumentowano, ostudzi wojenne zapędy Hitlera i uczyni bardziej prawdopodobnym zwycięstwo przeciwników Rzeszy, w razie gdyby wojna jednak wybuchła.

Jak jednak zauważył Chamberlain, nim Zjednoczone Królestwo publicznie ogłosi, że zamierza przeciwstawić się ,jakiemukolwiek dalszemu aktowi agresji ze strony Niemiec", co w jego przekonaniu miało powstrzymać ekspansywne poczynania tych ostatnich „przynajmniej na pewien czas", winno upewnić się, czy taki krok zyska akceptację ze strony innych zainteresowanych państw. W tym kontekście premier wymienił Polskę jako „najbardziej prawdopodobny klucz do sytuacji”, sugerując: „nasze kontakty z Polską powinny zapewne pójść nieco dalej niż kontakty $z$ innymi państwami". Kontynuując myśl, stwierdził, że brytyjski rząd nie powinien w takim razie poprzestać na pytaniu o polskie stanowisko, ale też przedstawić własne przewidywania co do rozwoju sytuacji, wskazując, że w jego przekonaniu „przyszedł czas dla tych, którzy są zagrożeni przez niemiecką agresję [...], by działać wspólnie". Wreszcie - wyjaśnił Chamberlain - należy zapytać, „jak daleko Polska gotowa jest posunąć się na tej drodze". Ewentualny udział w proponowanym projekcie najsilniejszego spośród wschodnich sąsiadów Niemiec wpłynąć miał na pozytywne decyzje pozostałych państw regionu?.

Na razie jednak trudno było mówić o pozytywnym przyjęciu brytyjskich sondaży. Wspomniana wyżej depesza, rozesłana przez Foreign Office do placówek w państwach, których opinię na temat zagrożenia Rumunii uznało za wartą poznania, nie zawierała bowiem żadnych informacji o zamierzonych działaniach Londynu. Efekty takiego postawienia sprawy (czy też raczej jej „nie-postawienia”) przewidzieć można było stosunkowo łatwo. Jak zapisał w swym dzienniku pod datą 19 marca Alexander Cadogan: „Dotychczas odpowiedzi nadeszły $z$ różnych stolic [...]. Wszystkie $\mathbf{w}$ odpowiedzi na nasze pytanie "Co zrobicie“, rzekły "A co wy? «"10.

" TNA, CAB 23/98, "Conclusions of a Meeting of the Cabinet held [...] on Saturday, 18th March, 1939...".

y Ibidem. Por. M. Nurek, op. cit., s. 175, gdzie zacytowane wyżej fragmenty przetlumaczone zostały nieco odmiennie.

11 A. Cadogan, The Diaries of Sir Alexander Cadogan, O.M., 1938-1945 [dalej: Cadogan Diaries], ed. by D. Dilks, New York 1972, s. 161. Zob. też: S. New ma n, op. cit., s. 158n. 
Było to zrozumiałe - także dla samego Chamberlaina. Bez zbytniego zdziwienia potraktowano więc $w$ Londynie informację, że ambasador Kennard, który z ministrem Beckiem rozmawiał rano 18 marca, spotkał się z odpowiedzią wymijającą. Zapewniając rozmówcę o swym żywym zainteresowaniu niepodległością Rumunii, szef polskiej dyplomacji podkreślił, że wedle posiadanych przezeń najzupełniej aktualnych informacji nic nie wskazuje na to, by była ona zagrożona przez Rzeszę ${ }^{11}$.

Znacznie bardziej dramatycznie sprawy przedstawiały się z perspektywy Paryża, który bardzo szybko włączony został do podjętej przez Brytyjczyków akcji. Quai d'Orsay pierwsze oznaki polskiej wstrzemięźliwości, najzupełniej w zaistniałej sytuacji racjonalnej, skłonne było uznać za dopełnienie rozgrywającej się już od wielu miesięcy tragedii, w której wkroczenie Niemców do Pragi stanowiłoby jedynie finał przedostatniego aktu, końcową zaś kulminację - ostateczny i nieodwołalny rozpad francuskiego systemu sojuszy na Wschodzie. Coup de grâce rozchwianej konstrukcji miałby zadać nieodmiennie osadzany nad Sekwaną w roli czarnego charakteru Beck, którego złą wolę raz jeszcze potwierdzały w mniemaniu Francuzów: milcząca akceptacja kolejnej niemieckiej aneksji, życzliwość wobec zajmujących Ruś Podkarpacką Węgrów, wreszcie - obojętna reakcja na alarmy Tilei. Ambasador Phipps, odbywszy rano 18 marca rozmowę z sekretarzem generalnym Quai d'Orsay Alexisem Légerem, tak sumował przedstawione przez tego ostatniego oceny i informacje:

Beck zdradził Rumunię lub jest $w$ trakcie dokonywania tego, z zamiarem odchylenia [drogi ekspansji] Niemiec na południowy wschód. Beck jest całkowicie cyniczny i fałszywy. Léger zastanawiał się czy rząd Jego Królewskiej Mości wie, co jest rzeczywistym celem podróży Becka do Londynu. On wie ze źródła bardzo tajnego, ale całkowicie pewnego i bardzo autorytatywnego, że planem polskiego ministra spraw zagranicznych jest poprosić Rząd Jego Królewskiej Mości o zawarcie sojuszu z Polską, który byłby trójstronnym sojuszem anglo-francusko-polskim, w którego ramach Wielka Brytania podjęłaby zobowiązanie przyjścia Polsce z pomocą, jeśli ta zostałaby zaatakowana. On [Beck] wie, że rząd Jego Królewskiej Mości nie mógłby podjąć zobowiązania większego, niż był w stanie uczynić w sojuszu z Francją. [Beck] wróciłby wtedy do Polski i przedstawil swą prośbę i odmowę Rządu Jego Królewskiej Mości, mówiąc, że były dwie alternatywy dla Polski, tj. skłonić się ku Wielkiej Brytanii lub Niemcom, a teraz jest jasne, że musi przechylić się na stronę Niemiec. Zapytany, co Beck chciałby przez to osiągnąć, Léger odpowiedzial, że to jest dziadowska polityka i że $w$ interesie kraju i własnym Beck chce po prostu pozbyć się bieżących trudności, nawet za cenę zostania wasalem (być może glównym wasalem) nowego Napoleona. Być może ma nadzieję, że w końcu wszystkie te sprawy obrócą się na dobre, ale jego glówną troską jest [...] teraźniejszośćc ${ }^{12}$.

Powyższa wypowiedź z pewnością warta była obszerniejszego przytoczenia - dobrze bowiem ilustruje panujące w tym czasie na Quai d'Orsay nastroje oraz sięgającą

1 DBFP, vol. 4, doc. 400, s. 370n.; H. Ja ckiewicz, op. cit., s. 269, przyp. 31.

12 TNA, FO 417/39, telegram No 114 (C 3455/3356/18) Phippsa do Halifaxa 218 III 1939 r. (publikacja: DBFP, vol. 4, doc. 405, s. 373). 
najwyższych szczebli hierarchii głęboką, podszytą paniką dezorientację ${ }^{13}$. Od emocji i resentymentów, które niewątpliwie znalazły się u podstaw budowanych przez Légera błędnych interpretacji, w bardzo interesujący sposób charakteryzujących ówczesne nastawienie francuskiej dyplomacji do polskiego sprzymierzeńca, ważniejsze wydają się jednak zawarte w przedstawionym wywodzie informacje. Wynika zaś z nich jednoznacznie, że koncepcja ministra Becka, by skłonić rząd Zjednoczonego Królestwa do zawarcia z Rzeczpospolitą dwustronnego układu sojuszniczego, dopełniającego ustanowiony przez nią jeszcze w roku 1921 alians z Francją oraz porozumienia francusko-brytyjskie, który powołać by miał do życia trójstronne porozumienie Londynu, Paryża i Warszawy, narodziła się już we wczesnej fazie zainicjowanej przez Chamberlaina akcji ${ }^{14}$. Za fakt istotny uznać wypada także, iż strona francuska nie tylko potrafiła dotrzeć do tak ważnej, dystrybuowanej w bardzo wąskim kręgu informacji, ale też zdecydowała się na jej przekazanie Brytyjczykom. To zaś, niezależnie od intencji Légera, stanowiło dla tych ostatnich z pewnością cenną wskazówkę, która - jak sugeruje analiza wydarzeń następnych dni - mogła wpłynąć na podejmowane wówczas $w$ Londynie decyzje $e^{15}$.

Kolejny etap rozwoju tych wydarzeń zapoczątkowała przygotowana 19 marca na spotkaniu tzw. „wydzielonego gabinetu” (i rozesłana wieczorem dnia następnego) deklaracja, w której rządy Wielkiej Brytanii, Francji, ZSRR i Polski miały obwieścić swą wolę podjęcia natychmiastowych konsultacji „w przypadku jakiejkolwiek akcji, która mogłaby stanowić zagrożenie dla [...] bezpieczeństwa i suwerenności" któregoś z państw europejskich ${ }^{16}$.

${ }_{13}$ Francuskie Ministerstwo Spraw Zagranicznych najwyraźniej okazało się też niezdolne do nadążania za biegiem błyskawicznie postępujących wydarzeń. Léger najpewniej nie formułowałby tak ostrych oskarżeń, gdyby zapoznał się z dostarczonym na Quai d’Orsay kilkanaście godzin wcześniej raportem Noëla, w którym ten informował, że także Warszawa zastanawia się nad kierunkiem dalszej niemieckiej akcji, skłaniając się ku hipotezie, że Hitler zwróci się na wschód a więc przeciw Polsce. AD, Pologne 364, telegram No 364 Noëla z 16 III 1939 r., otrzymany kurierem 17 III 1939 r. o godz. 12.20. Por.: M. Kornat, Polityka zagraniczna Polski..., s. 321.

14 Oczywiście, jak już wyżej wskazywano, tendencje Becka do szukania zbliżenia z Wielką Brytanią zauważano w Londynie i wcześniej. Informacje Légera oznaczały jednak bardzo istotne skonkretyzowanie dotychczasowych danych. Na temat krystalizowania się koncepcji Becka w marcu 1939 r. zob.: P. Starzeński, Trzy lata z Beckiem, Londyn 1972, s. 175.

15 Co najmniej od początku marca w Paryżu widziano także, iż odrzucone przez stronę polską niemieckie żądania obejmowały m.in. budowę autostrady przez pomorski Korytarz oraz przystąpienie Rzeczypospolitej do Paktu Antykominternowskiego. Wiedza ta obejmowała zapewne także żądanie przez Rzeszę aneksji Gdańska - niemiecka presja w tej sprawie nie była bowiem tajemnicą. SHD-DAT, 1 N 44, „Compte Rendu de la réunion des Chefs d'États-Majors (2 Mars 1939)”. O rozmowie Légera i Phippsa zob. też uwagi Anny Cienciały: Poland and the Western Powers, 1938-1939. A Study in the Interdependence of Eastern and Western Europe, London-Toronto 1968, s. 216, Studies in Political History. Por. tez: AD, Papiers 1940, Reconstitution Fouques-Duparc 54, kopie telegramów przychodzących (faktycznie - telefonogramów) No 1032-1935 Corbina do MAE z 4 IV 1939 r., godz. 21 i nast. dok.

16 TNA, CAB 24/284, „Draft telegram to Paris, Moscow, Warsaw”, zał. do pisma C.P. 75 (39) sekretarza Gabinetu Edwarda E. Bridgesa z 19 III 1939 r. W skład „wydzielonego gabinetu” wcho- 
W Warszawie i tę koncepcję przyjęto chłodno. Gdy 21 marca w południe Kennard przyjęty został przez wiceministra spraw zagranicznych Mirosława Arciszewskiego ${ }^{17}$, spotkał się (zgodnie w przypuszczeniami, jak komentował następnie w depeszy do Halifaxa) z obawą co do spodziewanej reakcji Niemiec $w$ razie przyłączenia się do brytyjskiej inicjatywy. Poinformowany następnie, że także perspektywa politycznej i wojskowej współpracy z ZSRR nie jest miła władzom z Warszawy, posłużył się argumentem, że „przyjazna Rosja” mogłaby być dla Polski źródłem ważnych z punktu widzenia militarnego surowców, a w razie wojny znakomicie ułatwić komunikację ze światem zewnętrznym ${ }^{18}$.

„Jest jasne, że nasze zaproszenie stawia rząd polski, i szczególnie Becka, wobec konieczności podjęcia kluczowej decyzji" - komentował sytuację Kennard w depeszy skierowanej tegoż dnia do Halifaxa. Polacy muszą osądzić, czy istniejące zagrożenie dla ich niepodległości uzasadnia prowokowanie Rzeszy, stwierdzał ambasador, nie wiedząc jeszcze o ponowionych tegoż samego dnia niemieckich żądaniach wobec Polski. Muszą też określić, dodawał, czy mogą liczyć na realne wsparcie innych sygnatariuszy deklaracji "nie tylko w ewentualnej wojnie, ale i w okresie chwiejnego pokoju", który pociągnąć za sobą może sygnowanie tego dokumentu ${ }^{19}$.

Dzień później równie celnie, choć bardziej lapidarnie i na własny tylko użytek tenże problem ujął wyższy urzędnik Foreign Office (Principal Private Secretary to the Foreign Secretary) Oliver Harvey. „Polacy mają dylemat - zapisał w swoim dzienniku - ponieważ boją się, że jakakolwiek publiczna deklaracja $z$ ich udziałem sprowadzi na nich tylko gniew Niemców"20.

dzili Chamberlain, Halifax, kanclerz skarbu John Simon oraz (nieobecny 15 marca z powodu choroby) sekretarz stanu spraw wewnętrznych Samuel Hoare. W spotkaniu uczestniczyli też A. Cadogan oraz sprawujący nadzór nad służbami specjalnymi Horace Wilson (Cadogan Diaries, s. 161). Wbrew informacjom M. Kornata 19 marca nie doszło do spotkania Gabinetu w pełnym skladzie. Decyzje, które ów autor łączy z tą datą, zapadły na posiedzeniu 18 marca (M. Kor nat, Polityka zagraniczna Polski..., s. 32ln.).

17 M. Arciszewski, który w maju 1938 r. odwołany został ze stanowiska posła RP w Bukareszcie, nie posiadał w centrali polskiego MSZ formalnego przydziału. Faktycznie jednak w kontaktach $z$ dyplomatami obcymi występowal często w zastępstwie podsekretarza stanu Jana Szembeka i w pochodzącej z roku 1939 korespondencji Kennarda określany był nieodmiennie jako wiceminister. Zob.: Historia dyplomacji polskiej (polowa X-XX w.), t. 4: 1918-1939, red. P. Łossowski, Warszawa 1995, s. 49n., przyp. 53.

18 DBFP, vol. 4, doc. 459, s. 428.

19 Ibidem, doc. 465, s. 431 n.; S. Ne w ma n, op. cit., s. 171. Wyliczając okoliczności, które Warszawa winna uwzględnić, Kennard wymienil długą i praktycznie niemożliwą do obrony granicę zachodnią, kwestie pomorskiego Korytarza i Gdańska, problemy związane z aktywnością mniejszości niemieckiej i ukraińskiej, bliskie kontakty handlowe z Rzeszą, nową granicę z Morawami i Słowacją, ,a nawet wspólną granicę z Węgrami”. Dwa dni później swoimi informacjami na temat polskiego stanowiska oraz związanymi z tym przemyśleniami Kennard podzielił się także z Noëlem (DDF, t. 15, doc. 132, s. 186n.).

20 O. Harvey, The Diplomatic Diaries of Oliver Harvey, 1937-1940, ed. by J. Harvey, London 1970, s. 266 [dalej: Harvey Diaries]. 
Znacznie mniej empatyczny okazał się francuski sojusznik Rzeczypospolitej, tym bardziej że pod nieobecność w Paryżu ministra Bonneta, który towarzysząc prezydentowi Lebrunowi udał się do Londynu, główny ciężar rozmów spoczął na barkach uprzedzonego do polskich interlokutorów Légera. Gdy 21 marca ten ostatni spotkał się $\mathrm{z}$ ambasadorem Łukasiewiczem, rozmówcy, dążąc do realizacji przeciwstawnych celów (uzyskanie deklaracji o polskim akcesie do ewentualnej antyniemieckiej akcji w Europie Wschodniej - uniknięcie jakichkolwiek w tym względzie zobowiązań), bardzo szybko znaleźli się $\mathrm{w}$ klinczu, spotkanie kończąc $\mathrm{z}$ obustronnie ugruntowanym przekonaniem o „wyraźnej złej woli i tendencji do fałszywej interpretacji” drugiej strony ${ }^{21}$.

Sytuację komplikowało dodatkowo subiektywne, choć zasadniczo zgodne $\mathrm{z}$ faktami przedstawienie zwierzchnikom przez każdego z uczestników spotkania jego efektów. Napięcie rozładowali jednak Bonnet i Daladier. Ten pierwszy zaistniałą kontrowersję uznał za efekt nieporozumienia osobistego, zapewniając ambasadora Raczyńskiego, „że po powrocie do Paryża sprawę pomyślnie i bez reszty wyjaśni"'2. Drugi z kolei, jak wspominał kilka miesięcy później Łukasiewicz, w trakcie spotkania $z$ nim 23 marca „przyjął [...] do wiadomości ze zrozumieniem, że celem stanowiska zajętego przez nasz rząd nie jest bynajmniej przeciwdziałanie polityce francuskiej w stosunku do Rumunii, jak to było przedstawione przez amb. Leger, ale dbałość o usunięcie z ogólnej sytuacji środkowoeuropejskiej jednego z zapalnych czynników". Jednak poczyniona przez szefa francuskiego rządu uwaga, że przedłożony przez Brytyjczyków projekt deklaracji "jest bardzo dobry, a w razie realizacji będzie bardzo pożyteczny, a może i skuteczny" [podkr. - W.M.], brzmiała raczej anegdotycznie niż przekonująco. Polski ambasador skwitował ją trzeźwą uwagą, że wspomniany dokument nie zawiera żadnych konkretnych zobowiązań i wobec tego miast hamować ekspansję niemiecką, może raczej ośmielić Rzeszę do nowych agresywnych poczynań ${ }^{23}$.

Dodać trzeba, że w bardzo podobnym, sceptycznym tonie wypowiadali $w$ tym czasie także szefowie Sztabów Generalnych francuskich sił zbrojnych. Anglia, Francja i ZSRR nie uznały dokonanej przez Rzeszę aneksji, komentowali na spotkaniu

${ }_{21}$ Zacytowanym zwrotem skwitował rozmowę Łukasiewicz, ale odczucia drugiej strony były bardzo podobne. J. Łukasiewicz, op. cit., s. 220; DDF, t. 15, doc. 107, s. 146nn. Zob. też dalsze dywagacje Légera na temat zamysłów polskiego rządu, przedstawione chargé d’affaires brytyjskiej ambasady w Paryżu Ronaldowi I. Campbellowi po południu 22 marca: TNA, FO 417/39, depesza C 7489/3356/18 Campbella do Halifaxa z 22 III 1939 r. Z datowanej 23 marca depeszy Łukasiewicza do Becka wynika, że rozmowa odbyła się dzień wcześniej, tak też przyjęli na s. 220 redaktorzy Dyplomaty w Paryżu... Notatka Légera wyraźnie jednak datuje spotkanie na 21 marca - tę też datę potwierdzać się zdaje chronologia późniejszych wydarzeń.

22 PDD 1939, dok. 123, s. 194n.

${ }^{23}$ IPMS, A. 12.49/12a, „Rokowania i ważniejsze rozmowy za czas od marca do września 1939" J. Łukasiewicza, opracowane w okresie od listopada 1939 r. do marca 1940 r. Odmienna nieco redakcja tekstu Łukasiewicza na temat rozmowy z Daladierem: Dyplomata $w$ Paryzu..., s. 220n. Zdaniem S. Newmana Chamberlain zdawał sobie sprawę ze słabości swej propozycji, wciąż jednak nie był gotowy do podjęcia dalej idących zobowiązań (op. cit., s. 169n.). 
22 marca, Londyn zaś zareagował na nią wzrostem dyplomatycznej aktywności. Na razie jednak nie przyniosła ona rezultatu. Nadal bowiem, oceniali zebrani, ,jest mało prawdopodobne, że Anglia chce podjąć wiążące zobowiązania". W tej sytuacji zaś sądzić można, że państwa Europy Wschodniej pozostaną niechętne wezwaniom płynącym znad Tamizy - konkludowano ${ }^{24}$.

W tym czasie stawała się jednak powoli aktualna koncepcja, którą wedle informacji przekazanych 18 marca Phippsowi przez Légera minister Beck hołubił już od pewnego czasu. Podsekretarz stanu w polskim MSZ Jan Szembek, który 22 marca wrócił z dłuższej wizyty w Watykanie, dzień później zanotował usłyszaną z ust zastępującego go podczas nieobecności Mirosława Arciszewskiego informację, że przedstawiona przez Brytyjczyków propozycja „[...] ma pewne strony atrakcyjne, ale Minister bardzo się nad nią zastanawia, gdyż przystąpienie do takiego związku mogłoby wywołać natychmiastowe uderzenie ze strony niemieckiej. Minister przychyla się natomiast do koncepcji układu bilateralnego z Anglią przy wyeliminowaniu Francji i Sowietów w celu niestwarzania pozorów jakiegoś szerokiego planu okrążenia Niemiec"2s.

Istotnie, Beck, spotkawszy się z Kennardem wieczorem 21 marca na przyjęciu $w$ brytyjskiej ambasadzie, $w$ trakcie wymiany zdań na temat czterostronnej deklaracji usłyszał z jego ust wzmiankę ,co do ewentualności d'un accord secret $\mathrm{w}$ dotyczących kwestiach”. „Pan Minister wówczas nie wypowiedział się wyraźniej w tej mierze” komentował $\mathrm{w}$ informacji przesłanej ambasadorowi Raczyńskiemu wicedyrektor Departamentu Politycznego MSZ (zarazem Naczelnik Wydziału Zachodniego) Józef Potocki, dodając: „[...] wszakże wspominam Ci o tym, abyś wiedział, że myśl ta nie była Anglikom, przynajmniej tutejszym, całkiem obca"26. Instrukcja, kierowana równolegle do Ambasady RP w Londynie, nakazywała „[...] zapytać Halifaxa, czy [...] rząd brytyjski nie wziąłby pod uwagę zawarcia z nami bezzwłocznie bilateralnego tajnego porozumienia w duchu proponowanej deklaracji". Podkreślano w niej, że proponowany układ nie byłby sprzeczny z polityką jego sygnatariuszy wobec Francji,

¿4 SHD-DAT, 1 N 44, „Compte Rendu de la réunion des Chefs d'États-Majors” z 22 III 1939 r.

${ }_{25}$ J. Sze mbek, Diariusz i teki Jana Szembeka (1935-1945), t. 4: Diariusz i dokumentacja za rok 1938. Diariusz i dokumentacja za rok 1939, oprac. J. Zar a ński, Londyn 1972, s. 528, Źródla do Najnowszej Historii Polski. W poprzednich dniach Beck mial intensywnie konsultować się w trakcie narad na Zamku, w których oprócz grającego rolę gospodarza prezydenta Ignacego Mościckiego brali też udział premier Felicjan Sławoj-Składkowski i generalny inspektor sił zbrojnych Edward Śmigły-Rydz (P. St arzeński, op. cit., s. 176).

26 PDD 1939, dok. 126, s. 197n. Informacja Kennarda o rozmowie: DBFP, vol. 4, doc. 479, s. $453 \mathrm{n}$. Nie jest pewne, czy Kennard znał informacje przekazane do Londynu przez Phippsa 18 marca, po rozmowie z Légerem. Przywołana przez A. Cienciałę informacja, że w tymże czasie Halifax zaproponował $w$ rozmowach toczonych $z$ Bonnetem tajne porozumienie o pomocy dla Polski (Poland and the Western Powers..., s. 217) nie wyjaśnia genezy wzmianki Kennarda, właśnie dlatego, że wydarzenia $z$ Londynu i Warszawy rozgrywały się w zasadzie równolegle. Trudno w każdym razie zgodzić się z opinią J. Tebinki, że polska propozycja była dla Londynu „nieoczekiwana" (J. Tebinka, Polityka brytyjska..., s. 30). Zarówno podana w korespondencji Potockiego data rozmowy, jak i czas ekspedycji depeszy Kennarda (22 marca, godz. 1.54) jednoznacznie rozstrzygają wątpliwość H. Batowskiego, który skłonny był rozmowę datować (mylnie) na 22 marca. H. Batowski, op. cit., s. 319, przyp. 47. Por.: M. Nurek, op. cit., s. 188, przyp. 19. 
zapewniając, że „w odpowiedniej chwili rząd francuski byłby poufnie powiadomiony o ewentualnych postanowieniach naszych" ${ }^{27}$.

Zacytowana wyżej korespondencja do Londynu wyekspediowana została kurierem 23 marca, a jej treść ambasador Raczyński przedstawił Halifaxowi dopiero dzień później. Już jednak w dniu dotarcia nad Tamizę polska koncepcja była komentowana w kręgu wyższych urzędników Foreign Office. Harvey zanotował wówczas w swoim dzienniku: „słyszymy, że Beck zamierza teraz zaproponować tajne porozumienie o konsultacji z Wielką Brytanią"28.

Bieg politycznych wydarzeń następnych dni, w których trakcie stanowisko Londynu stopniowo skłaniało się ku realizacji polskiego postulatu, należy do zagadnień wyjątkowo często podejmowanych w historiografii okresu. Bardziej szczegółowa analiza tych wydarzeń nie wydaje się konieczna z punktu widzenia rozpatrywanej przez nas problematyki. Można zresztą wątpić, czy dostarczyć by mogła bardziej ważkich, a nieznanych dotąd ustaleń.

Warto natomiast podkreślić, że w ostatniej dekadzie marca $\mathrm{w}$ rozmowach toczonych i w Londynie, i Paryżu coraz wyraźniej doceniano rolę, jaka przypaść musi Polsce $w$ realizacji rozpatrywanych $w$ obu stolicach projektów. Zauważyć przy tym nale$\dot{z} y$, że przynajmniej początkowo nie było to równoznaczne z gotowością do szerszego uwzględniania formułowanego przez polską dyplomację stanowiska. W rozmowie przeprowadzonej z Halifaxem 21 marca Bonnet określił znaczenie udziału Warszawy we wszelkich działaniach projektowanych $\mathrm{z}$ udziałem państw wschodniej części kontynentu jako „absolutnie podstawowe”, zwracając uwagę na oczywisty skądinąd fakt, że ZSRR skuteczną pomoc ze swej strony będzie w stanie zaoferować jedynie w razie polskiej współpracy. Opornego partnera znad Wisły proponował potraktować przedmiotowo, sugerując wywarcie nań możliwie "najsilniejszej presji” czy nawet zastosowanie „argumentów na pograniczu groźby”. Halifax podzielił stanowisko francuskiego kolegi, w dalszej części rozmowy dodając jednak, że mocarstwa zachodnie winny przygotować się do przyjęcia w kwestii pomocy dla Rumunii „bardzo twardej linii, nawet bez początkowej pewności polskiego poparcia". Winno to skłonić Polaków do przyłączenia się do podjętej akcji, dodawał'29.

27 PDD 1939, dok. 125, s. 196. Zob. też: DBFP, vol. 4, doc. 485, s. 463n. Zarówno w instrukcji, jak i załączonych do niej listach J. Potockiego oraz dyrektora Gabinetu Ministra Spraw Zagranicznych Michała Łubieńskiego podkreślano też poprawność stosunków Warszawy i Moskwy. M. Łubieński, przytaczając, jak twierdził, niemal in extenso wypowiedzi Becka, wyjaśniał natomiast: „[...] animozje istniejące dzisiaj między Berlinem a Moskwą są tego rodzaju, że mieszanie Sowietów do układu może w sposób gwałtowny [...] spowodować wybuch generalnego konfliktu" (PDD 1939, dok. 127, s. 199). Przekazanie władzom francuskim informacji dotyczącej polskich zastrzeżeń co do czterostronnej deklaracji oraz podjęciu dwustronnych rozmów $\mathbf{z}$ rządem brytyjskim Beck polecił amb. Łukasiewiczowi 27 marca (ibidem, dok. 140, s. $221 \mathrm{n}$.).

2* Harvey Diaries, s. 267; PDD 1939, dok. 132, s. 206. Zob. też: E. Raczyński, The British-Polish Alliance: Its Origin and Meaning, London 1948, s. 14, Publications of the General Sikorski Historical Institute in London.

${ }^{24}$ DBFP, vol. 4, doc. 458, s. 422nn. Wedle S. Newmana (op. cit., s. 173, przyp. 34) fraza o „argumentach bliskich groźby" pojawiła się jedynie w wersji brulionowej protokołu, w wersji finalnej 
Dzień później, gdy obaj szefowie dyplomacji wznowili rozmowy (tym razem $z$ udziałem m.in. Chamberlaina), Bonnet przypomniał swe stanowisko, raz jeszcze kładąc nacisk na znaczenie udziału Polski w każdej akcji podjętej na rzecz ewentualnie zaatakowanej przez Rzeszę Rumunii. Teraz jednak środki, które mogłyby zapewnić taki udział, kreślił szerzej i bardziej finezyjnie. Mocarstwa zachodnie winny zadeklarować pomoc dla Rumunii, jeśli ta stanie się ofiarą niemieckiej agresji - wywodzil - a równocześnie zapytać Polskę o jej postawę w takim przypadku. I dodawał: „jeśli sprawa zostanie postawiona w ten sposób, Polsce trudno będzie dać odpowiedź negatywną" ${ }^{30}$. „Aby przekonać Polskę do zaangażowania się we wsparcie [zaatakowanej] Rumunii, Wielka Brytania i Francja dałyby Polsce obietnicę, że [...] one zrobią to samo" - podsumowywał rezultaty dalszej wymiany zdań Halifax, wyrażając nadzieję, że w takiej sytuacji Polacy i Rumuni nie zgłaszaliby obiekcji wobec prób zapewnienia "zarówno w ich interesie, jak i naszym własnym" udziału w podjętych działaniach także ZSRR. Obaj rozmówcy zdawali sobie sprawę z tego, że zarówno Warszawa, jak i Bukareszt tę ostatnią perspektywę traktują z wielką niechęcią, stąd rolę Moskwy w ewentualnej partycypacji zamierzali ograniczyć do pomocy pośredniej, w postaci „materiału wojennego albo samolotów” ${ }^{31}$.

Co bardziej jednak dla rozważanej przez nas problematyki istotne, w myśl idei, która właśnie krystalizowała się w umysłach przedstawicieli Albionu ${ }^{32}$, także brytyjsko-francuska pomoc dla zaangażowanych w zbrojny konflikt państw Europy Wschodniej miałaby charakter wyłącznie pośredni, przybierając, jak ujął to Chamberlain, „formę presji na Niemcy ze strony zachodniego frontu”. Z kolei sformułowana tuż po zacytowanej wypowiedzi uwaga Halifaxa, że Polska z pewnością oczekiwać będzie od Wielkiej Brytanii, Francji i Rumunii gwarancji podobnych do tych, których sama miałaby udzielić tej ostatniej, stanowiła kolejny krok ku decyzji, którą szef gabinetu obwieścić miał w Izbie Gmin 31 marca $^{33}$.

Wydarzenia następnych dni, które przyniosły m.in. formalizację niemieckiej protekcji nad Słowacją oraz aneksję przez Rzeszę litewskiej Kłajpedy, wzmocniły nad Tamizą dążność do przeciwstawienia się poczynaniom Berlina, utwierdzając zarazem Chamberlaina i Halifaxa w przekonaniu o zasadniczym dla rozpatrywanych działań

zastąpić ją miał zaś zapis o „bardzo stanowczej postawie” wobec polskiego rządu. Jednak w tekście opublikowanym w DBFP nadal znajduje się zdanie: „It was desirable [...] to go to the utmost limit, even to the extent of threats, to bring Poland in" (s. 426). Tekst w tejże redakcji znaleźć można też np. w: TNA, CAB 284/20. Relacja Bonneta dla Daladiera: DDF, t. 15, doc. 113, s. 161nn.

31 DBFP, vol. 4, doc. 484, s. 457nn. Francuska wersja protokołu spotkania zachowała się jedynie fragmentarycznie, obejmując tylko ostatnią część konwersacji, poświęconą zagadnieniom współpracy lotniczej (DDF, t. 15, doc. 124, s. $171 \mathrm{n}$.).

$"$ DBFP, vol. 4, doc. 484, s. $457 \mathrm{nn}$.

${ }^{32}$ Oczywiście przynajmniej część omawianych w trakcie rozmów z Francuzami koncepcji była efektem wcześniejszych przemyśleń i analiz. Bardzo szybki bieg wydarzeń nie zawsze jednak pozostawiał dość czasu na te ostatnie. „You know how difficult it is in the middle of endless functions to find any time to think" - pisał Halifax do prominentnego polityka Partii Konserwatywnej lorda Salisbury 25 marca (TNA, FO 800/315).

3 DBFP, vol. 4, doc. 484 , s. 459. 
znaczeniu czynnika polskiego. Premier swemu stanowisku w tej kwestii dał wyraz 23 marca $w$ rozmowie z przedstawicielami Partii Pracy. Szef Foreign Office w podobnym tonie wypowiedział się dwa dni później, w trakcie konferencji z grupą bliskich współpracowników, dając wyraz przeświadczeniu, że „udział Polski jest kluczowy w każdym z efektywnych schematów powstrzymania Niemiec w razie agresji" ${ }^{34}$.

Równocześnie narastał sceptycyzm co do użyteczności pomocy ze strony Moskwy, której udział przekształcał każdy niemal z możliwych scenariuszy w swoistą kwadraturę koła, zaś realna siła budziła poważne wątpliwości. Oczywiście ani w Londynie, ani w Paryżu nie zamierzano bynajmniej całkowicie skreślać ZSRR z bieżącej agendy, w grę wchodziła jedynie korekta rozkładu akcentów. Z punktu widzenia Warszawy była to jednak istotna ewolucja. Nic więc dziwnego, że dotyczące jej informacje przekazywane rozmaitymi kanałami Polakom przyjmowane były przez nich nie bez satysfakcji ${ }^{35}$.

Nad Tamizą odrzucono natomiast („ze względu na nasze deklaracje genewskie i parlament", wyjaśniał Halifax) sugerowaną przez Becka koncepcję tajnego układu z Polską ${ }^{36}$. Zastąpić ją miało brytyjsko-francuskie zobowiązanie gwarancyjne. Wedle pierwotnych zamysłów Foreign Office Warszawa miałaby je odwzajemnić, godząc się na udzielenie pomocy Rumunii, a także Wielkiej Brytanii i Francji - w tym ostatnim przypadku nie tylko w razie bezpośredniego ataku Rzeszy na któregoś $\mathrm{z}$ zachodnich partnerów, ale i wojny dla stawienia oporu agresji niemieckiej w całej Europie Zachodniej lub Jugosławii. Już jednak 27 marca Chamberlain skłaniał się ku porzuceniu tych warunków, informując członków zwołanego naprędce Komitetu Polityki Zagranicznej, że Londyn w celu powstrzymania niemieckich wysiłków zmierzających do światowej hegemonii powinien być gotowy na udzielenie Polsce jednostronnej gwarancji „co do wschodniego frontu" ${ }^{3}$. Sformułowane w ten sposób stanowisko spotkało się z zaskakująco wręcz jednoznaczną akceptacją („ku mojemu zaskoczeniu, nie ma silnych zastrzeżeń - nawet ze strony [kanclerza skarbu] J[ohna] S[imona]", zanotował Cadogan), co pozwoliło na stosunkowo szybki postęp prac nad realizacją zamysłu ${ }^{38}$.

34 Harvey Diaries, s. 268; S. Newman, op. cit., s. 183 i 186n. „Im dłużej rozważa się sytuację, tym bardziej oczywiste się staje, jak kluczowe jest stanowisko Polski", stwierdzić miał Halifax $\mathrm{w}$ rozmowie $z$ ambasadorem Corbinem dzień później (DBFP, vol. 4, doc. 553, s. 533; także S. Newman, op. cit., s. 213).

35 IPMS, A.II. 49/WB/1, pismo ER/MR-No.49/WB/147 amb. E. Raczyńskiego do ministra spraw zagranicznych z 30 III 1939 r.; PDD 1939, dok. 146, s. 227; dok. 151, s. 240; S. Newman, op. cit., s. $184 \mathrm{nn}$. „Nie możemy umieścić Rosji na pierwszym planie, ale zarówno z przyczyn wewnętrznych, jak i ze względu na najwyższą wartość militarną, nawet jeśli tylko w roli arsenału, musimy utrzymać ją po naszej stronie", wyjaśniał Halifax współpracownikom 25 marca (Harvey Diaries, s. 268).

36 Harvey Diaries, s. 268; S. New ma n, op. cit., s. 186.

${ }^{37}$ H. Jackiewicz, op. cit., s. 107; S. Newman, op. cit., s. 192; A. Prazmowska, op. cit., s. $50 \mathrm{n}$.

3k Cadogan Diaries, s. 164. 
30 marca gabinet poddał dyskusji opracowany niewiele wcześniej pod kierunkiem Halifaxa projekt odpowiedniej deklaracji, na południowym posiedzeniu $w$ dniu następnym ostatecznie akceptując jej przedstawienie w Izbie Gmin. Kilka godzin później premier Chamberlain publicznie ogłosił, że w razie „jakichkolwiek działań wojennych mogących wyraźnie zagrozić niepodległości Polski", które Rzeczpospolita zdecyduje się odeprzeć przy użyciu swych sił zbrojnych, „rząd Jego Królewskiej Mości będzie się czuł zobowiązany do udzielenia rządowi polskiemu natychmiastowego poparcia będącego w jego mocy". Znaczenie oświadczenia wzmacniała dodatkowo umieszczona w jego końcowej części oficjalna informacja, że stanowisko rządu francuskiego „jest takie samo jak stanowisko rządu Jego Królewskiej Mości”39.

Udzielona Polakom gwarancja była bez wątpienia niezwykle istotnym aktem politycznym, i w tym charakterze winna być rozpatrywana. Zarazem jednak wiązała się z problematyką militarną na tyle ściśle, że wszelkie poświęcone jej rozważania, w których nie uwzględniono by tego ostatniego kontekstu, nieuchronnie niemal wieść muszą na manowce.

Przypomnieć tu wypada fakt skądinąd oczywisty: łańcuch wydarzeń, który swą kulminację znalazł 31 marca w popołudniowym wystąpieniu Chamberlaina, zapoczątkowany został dwa tygodnie wcześniej przez podjęcie przez Rzeszę akcji o charakterze militarnym, które w przekonaniu przywódców zachodnich demokracji nie mogły już zostać skontrowane przez wyłącznie dyplomatyczną reakcję. Stąd już 18 marca, tuż przed posiedzeniem Gabinetu kluczowym dla decyzji o formie, jaką przybrać winny tym razem działania Londynu, jego członkowie zdecydowali się zasięgnąć opinii skupiającego dowódców rodzajów sił zbrojnych (sił lądowych, lotnictwa i marynarki wojennej) Podkomitetu Szefów Sztabów Komitetu Obrony Imperialnej. Ciało to zebrało się w tym dniu dwukrotnie, próbując znaleźć odpowiedzi na pytania postawione przez ministra ds. koordynacji obrony lorda Chatfielda, a następnie podejmując rozważania nad możliwymi scenariuszami dalszych wydarzeń. Wstępne konkluzje nie były zbytnio pocieszające. Zaangażowanie Londynu na rzecz Rumunii doprowadzić może do wojny z udziałem Wielkiej Brytanii, wyłuszczali Szefowie Sztabów. W takim przypadku ta ostatnia nie zdoła, nawet $z$ ewentualnym francuskim udziałem, podjąć natychmiastowych działań, które pozwoliłyby skutecznie przeciwstawić się rozciągnięciu wpływów Rzeszy na południowy wschód Europy - ku wybrzeżom Morza Śódziemnego. Tymczasem jedynie zdecydowana zbrojna akcja na zachodzie i zmuszenie Niemiec do wojny na dwóch frontach może (choć nie musi) zakończyć się ich porażką. Dopiero sojusz Londynu, Paryża, Warszawy i Moskwy mógłby powściągnąć apetyt Berlina na rozciągnięcie kontroli nad Rumunią. Szefowie

14 TNA, CAB 23/98/6, „Conclusions of a Meeting of the Cabinet held on Thursday, 30 March, 1939, at 11.0 a.m." (tam też w załączniku projekt deklaracji); CAB 23/98/7, „Conclusions of a Meeting of the Cabinet held [...] on Friday, 31 March, 1939, at 11.0 noon”. Cyt. za: Dokumenty z dziejów polskiej polityki zagranicznej 1918-1939, t. 2: 1933-1939, red. nauk. T. Jędruszczak, M. Nowak-Kiełbikowa, Warszawa 1996, s. 316. Tekst oryginalny: DBFP, vol. 4, doc. 582, s. 552n. Zob. też: H. Jackiewicz, op. cit., s. $115 n n$.; S. Newman, op. cit., s. 236nn.; A. Prazmowska, op. cit., s. $53 n n$. 
Sztabów postulowali więc, co istotnie, jak wiemy, uczyniono, by podjąć dyplomatyczną akcję względem ZSRR i Polski, zapowiadając wstrzymanie się od formułowania dalszych ocen do czasu uzyskania informacji o rezultatach tych poczynań ${ }^{40}$.

Deklaracja ta niemal natychmiast została jednak w praktyce unieważniona. Wojskowi członkowie Podkomitetu podjęli bowiem rozważania nad możliwymi scenariuszami wydarzeń. Po dyskusji zdecydowali się odradzić rządowi podejmowanie kroków, które skutkować by mogły wojną, w której po stronie Londynu opowiedzą się rządy z Paryża, Aten i Ankary, zaś ZSRR i Polska pozostaną neutralne. Porzucenie neutralności przez tę ostatnią i podjęcie przez nią walki u boku Brytyjczyków wedle przedstawionych ocen nie zmieniłoby sytuacji w sposób istotny. Rzeczpospolita zapewne walczyć będzie dzielnie, ale trójstronnie otoczona przez terytoria Rzeszy i pozbawiona dogodnej komunikacji szybko zmuszona zostanie do obrony, nie będąc w stanie absorbować znaczniejszej części sił niemieckich. Lepiej oceniony został wariant odwrotny, w którym to Moskwa zyska status alianta, Warszawa zaś pozostanie neutralna. Nawet jednak i ten scenariusz Szefowie Sztabów podsumowali bez entuzjazmu, ostatecznie zalecając rządowi, by po prostu wstrzymał się od działań, które mogłyby uwikłać go w konflikt z Niemcami w związku z kwestią rumuńską ${ }^{41}$.

Bieg politycznych wydarzeń spowodował jednak, że zastosowanie się do tej rady nie okazało się w praktyce możliwe - zresztą dojrzewająca w gabinetach polityków znad Tamizy koncepcja coraz wyraźniej wykraczała poza pierwotne rumuńskie ramy. Brytyjscy wojskowi musieli więc poważniej zacząć brać pod uwagę możliwość, że wojna wybuchnie w niezbyt odległej przyszłości, zaś im samym przyjdzie stanąć do walki, w której towarzyszyć im będą w charakterze sojuszników także Polacy.

Wśród przedstawicieli wojskowych elit znad Tamizy budziło to uczucia mieszane. $Z$ jednej strony kolejne, podejmowane wbrew traktatowym ustaleniom agresywne poczynania Rzeszy rodziły przeświadczenie, że polityczne rozwiązanie coraz gwałtowniej narastającego konfliktu nie będzie zapewne możliwe. W razie zaś wojny polska armia, której bojowe kwalifikacje $z$ reguły oceniano wysoko, mogła okazać się aliantem, którego nie należało lekceważyć. Uskarżający się jeszcze niedawno na niechęć brytyjskich partnerów do bardziej ścisłej współpracy ppłk Kwieciński odnotowywał więc teraz wyraźny wzrost zainteresowania sprawami polskimi ze strony przedstawicieli War Office oraz nagłą ewolucję ich nastrojów, które „zmieniły się bardzo i są w chwili obecnej nadzwyczaj przychylne"42. Wyraźnym dowodem konstatowanej zmiany było zaopatrzenie polskiego attaché $w$ pochodzące $z$ brytyjskich źródeł wywiadowczych informacje o podjętych w związku z akcją względem Cze-

411 TNA, CAB 53/10, minuty z 282. i 283. posiedzenia Podkomitetu Szefów Sztabów (COS) Komitetu Obrony Imperialnej z 18 III 1939 r.

4) Ibidem; TNA, CAB 53/10, minuta z 283. posiedzenia Podkomitetu Szefów Sztabów z 18 III 1939 r.; S. New man, op. cit., s. 157n.

${ }^{42}$ IPMS, Lot. A.V. 1/40b, kopia pisma L. $142 / 39$ ppłk. Kwiecińskiego do Szefa O. II SG z 23 III 1939 r. Faksymile pierwszej strony tego dokumentu opublikowane zostało w wydawnictwie Spoleczeństwo $i$ Wojsko Polskie wobec zagrożenia wojennego 1939. Polska i jej armia 1935-1939, oprac. A. Wesolowski, K. Stepan, N. Bujniewicz, Warszawa 2009, s. 81, Pamiętamy. 
chosłowacji ruchach armii niemieckiej. Wartość tego gestu podnosił dodatkowo fakt, że - o czym zapewne ppłk Kwieciński nie wiedział - przekazany mu pakiet danych nie różnił się istotnie od analogicznych materiałów dostarczanych w tymże czasie Francuzom, nad Tamizą tradycyjnie notowanym zdecydowanie wyżej od Polaków. Zwrot był więc nie tylko radykalny, ale i głęboki ${ }^{+3}$.

Równocześnie jednak brytyjscy dowódcy dobrze zdawali sobie sprawę z tego, że polski partner, już wcześniej zagrożony przez Niemcy, po 15 marca znalazł się w sytuacji wyjątkowo wręcz trudnej. Dobrze charakteryzowały ją analizy kierującego pracą warszawskiego wojskowego attachatu ppłk. Sworda. Swe wstępne oceny położenia Rzeczpospolitej wspomniany oficer zawarł w raporcie przedłożonym 22 marca. Rzesza, wywodził, otacza obecnie Polskę z trzech stron, zagrażając bezpośrednio przemysłowym obszarom Śląska i wiodącej przez Pomorze łączności z wybrzeżem. Otwarte niziny na zachodzie wręcz zachęcają do inwazji, która dodatkowo może być wsparta flankującymi uderzeniami z Prus Wschodnich i Karpat. Luftwaffe zdolna jest, wedle woli, do zniszczenia każdego właściwie polskiego miasta - całkowicie niezależnie od jego użyteczności dla operacji o czysto wojskowym charakterze. Niewiele pomóc mogą ewentualnie zaatakowanej Rzeczypospolitej sąsiedzi: Rosja pozostaje enigmą, jednak jej armia znajduje się w stanie, który każe wątpić w zdolność do podjęcia działań o charakterze ofensywnym, a na pewno w sukces takich działań. Polscy dowódcy kategorycznie odmawiają zgody na udzielenie radzieckim oddziałom dostępu do polskiego terytorium, choć - spekulował Sword - może byliby gotowi dopuścić dostawy materiałowe. Te ostatnie, jak przypuszczał, „mogłyby nawet obejmować samoloty, a w razie skrajnego niebezpieczeństwa może i personel lotniczy"44. Iluzoryczne są natomiast polskie nadzieje na powstrzymanie Węgier przed przejściem do obozu Rzeszy, brak też realnych szans na udzielenie Rzeczypospolitej pomocy ze strony Rumunii czy państw bałtyckich. Wreszcie - trzeźwo zauważał attaché - w razie wojny z Niemcami Polska nie powinna się spodziewać poważniejszej francuskiej asysty. Ta ostatnia nie przekroczy bowiem poziomu "dywersji wobec sił niemieckich na francuskiej granicy, powiązanej z dostawami materiału wojennego" - oczywiście jeśli warunki komunikacyjne pozwolą na podjęcie tych ostatnich ${ }^{45}$.

Nieco niespodziewanie po serii wysoce sceptycznych ocen cząstkowych brytyjski attaché w konkluzji zaprezentował odmienne nastawienie. „Wydaje się - pisał - że wszelka pomoc brytyjska, która mogłaby zwiększyć siłę [...] Polski [...], mogłaby pomóc zahamować nieograniczony postęp niemieckiej agresji [...] i w ten sposób zyskać czas dla ukończenia naszego programu zbrojeniowego oraz służyć podtrzymaniu naszego prestiżu" 46 . Z tak sformułowaną końcową opinią zgodził się także

${ }^{13}$ IPMS, Lot. A.V. 1/40b, kopia pisma L. $142 / 39$ ppłk. Kwiecińskiego... (zał. „Informacje otrzymane $z$ angielskiego Ministerstwa Wojny") oraz SHD-DAT, 7 N 2816, pismo No 40/S gen. Lelonga do Oddziału II Sztabu Generalnego z 17 III 1939 r. i in. dok. Główne treści przekazanych przez Brytyjczyków informacji syntetycznie zestawił P. Kołakowski (Czas próby..., s. 275nn.).

4t DBFP, vol. 4, doc. 498, s. 477nn.

45 Ibidem, s. 479.

16 Ibidem, s. 480n. 
ambasador Kennard, wzmacniając ją jeszcze podkreśleniem, że Polacy, w odróżnieniu od sąsiadów z Czechosłowacji, będą zapewne walczyć o swą niepodległość oraz terytorialną integralność, nawet gdyby opór ten był „prawie beznadziejny"47.

Sztabowcy $z$ Londynu na tenże problem spoglądali jednak ze zdecydowanie większego dystansu, umieszczając go w znacznie szerszej, strategicznej perspektywie. Swemu stanowisku dali wyraz kilka dni później, gdy w politycznym kontredansie miejsce czterostronnej deklaracji państw oferujących pomoc zagrożonej $\mathrm{Ru}$ munii zająć zdążyła koncepcja gwarancji mocarstw Zachodu dla władz z Warszawy i Bukaresztu.

Opinia przedstawicieli najwyższych szczebli wojskowej hierarchii przedstawiona została 28 marca w szkicu raportu opatrzonego tytułem „Wojskowe implikacje anglo-francuskich gwarancji dla Polski i Rumunii", który członkowie Joint Planning Sub-Committee (JPC; Połączony Podkomitet Planowania) opracowali na życzenie ministra ds. koordynacji obrony „w formie szkicu raportu [Podkomitetu] Szefów Sztabów"48. Autorzy dokumentu w dość szczegółowym wywodzie poddali kolejno analizie morskie, lotnicze i lądowe aspekty ewentualnego konfliktu, przyjmując założenie, iż wojna - odmiennie niż przyjmowano we wcześniejszych studiach - może rozpocząć się atakiem Niemiec na wschodzie kontynentu, zaś Polska i Rumunia miast zachować neutralność, wystąpią $\mathrm{w}$ roli aliantów.

W przypadku działań morskich brytyjscy oficerowie uznali wschodnich sojuszników za całkowicie niemal nieużytecznych. Polski port w Gdyni, zauważyli, mógłby stanowić jedynie oparcie dla prób przecięcia niemieckiej komunikacji z Prusami Wschodnimi czy Skandynawią. Możliwość jego wykorzystania potrwałaby jednak krótko, Polacy bowiem nie byliby w stanie powstrzymać na tym obszarze ataku dysponujących bezwzględną przewagą sił Rzeszy. Z kolei klęska Rumunii pociągnąć by mogła za sobą obecność lekkich niemieckich sił nawodnych oraz okrętów podwodnych na Morzu Czarnym. Nawet jednak gdyby zdołały one przekroczyć Dardanele, newralgiczny rejon Morza Śódziemnego nie powinien zostać poważnie zagrożony.

Obszerniejsze, a przy tym zdecydowanie bardziej istotne dla tematyki naszej pracy fragmenty dokumentu poświęcone zostały zagadnieniom lotniczym, więcej też nieco wypada poświęcić im uwagi. Autorzy raportu stwierdzili, że nie sposób przewidzieć, czy w pierwszej fazie konfliktu Niemcy skierują główny wysiłek swych sił powietrznych przeciw Polsce i Rumunii, na froncie zachodnim pozostając w defensywie, czy też równocześnie podejmą powietrzną ofensywę przeciwko Francji i Wielkiej Brytanii. Jak podkreślali, ta ostatnia ewentualność byłaby oczywiście mniej korzystna z punktu widzenia Londynu i Paryża. Równocześnie jednak zaangażowani

4. Ibidem, s. 476.

44 TNA, CAB 53/47, „Military Implications of an Anglo-French Guarantee to Poland and Rumania", nota C.O.S. 870 sekretarza Podkomitetu Szefów Sztabów (oraz CID) płk. Lionela Hastingsa Ismaya z 28 III 1939 r. Tenże tekst też w: CAB 55/15 jako J.P. 387 sygnowany przez sekretarza Joint Planning Sub-Committee ppłk. Leslie Chasemore Hollisa. „Należy przyjąć, że ZSRR zachowa przyjazną neutralność do tego stopnia, że będzie gotów dostarczać materiał wojenny do Polski i Rumunii" - sprecyzowano w podyktowanych przez lorda Chatfielda założeniach wstępnych. 
na zachodzie Niemcy staliby się bardziej wrażliwi na uderzenia z terytorium Polski, wystawiając się także na możliwą w dalszych stadiach konfliktu akcję lotnictwa radzieckiego. Swiadomość takich zagrożeń powinna do pewnego stopnia ograniczać rozmiary niemieckich operacji lotniczych na Zachodzie.

Polskie siły bombowe, określone jako „dość wydajne”, oszacowano na 30 samolotów bombowych oraz 200 maszyn rozpoznawczo-bombowych, co stanowiło wielkości bardzo zbliżone do stanu faktycznego ${ }^{49}$. Wedle brytyjskich ocen $w$ zasięgu polskich działań znajdował się m.in. Berlin, Szczecin (oraz skoncentrowane $w$ jego rejonie bardzo znaczące zapasy paliw płynnych), a także niezwykle istotne dla bilansu energetycznego Rzeszy elektrownie ze wschodnich części kraju. Niestety - jak zauważali brytyjscy oficerowie - „ze względu na dysproporcje potencjału niemieckich i polskich sil powietrznych powietrzne zagrożenie [Rzeszy] ze strony Polski nie może być uważane za czynnik o pierwszorzędnym znaczeniu" 50 .

Jak przyjęli autorzy analizy, Niemcy dla zaradzenia "polskiemu niebezpieczeństwu" skłonni będą zapewne pozostawić na wschodzie około $20 \%$ swych sil myśliwskich. Podobną decyzję w odniesieniu do bombowców dalekiego zasięgu uznano za mało prawdopodobną, ze względu na rozmiary szacowanej na 320 maszyn niemieckiej floty bombowej krótkiego zasięgu.

„Nierozsądnie byłoby przypuszczać, że skala powietrznego ataku, któremu stawić będą musiały czoła Francja i Wielka Brytania, jeśli podejmą interwencję w razie niemieckiego ataku na Polskę i Rumunię, byłaby materialnie mniej intensywna niż w przypadku, w którym Polska i Rumunia będą neutralne. Wymuszone na Niemcach wielkie rozproszenie myśliwców i mobilnej obrony przeciwlotniczej skutkowałoby jednak pewnym zmniejszeniem strat ponoszonych przez brytyjskie i francuskie bombowce" - brzmiała zasadnicza część niezbyt zachęcającej do zaangażowania się w obronę państw Europy Wschodniej konkluzji lotniczej partii raportu ${ }^{51}$.

Scenariusz, w którym Niemcy w pierwszych fazach wojny mieliby się powstrzymać od ataków na Wyspy Brytyjskie, a być może także i Francję, do czasu całkowitego złamania oporu Polaków i Rumunów, uznano za możliwy, acz mało prawdopodobny. W tym przypadku inicjatywa rozpoczęcia działań powietrznych na zachodzie kontynentu zależna by była od decyzji podejmowanych w Londynie i Paryżu. W takiej sytuacji, stwierdzili sporządzający raport oficerowie, za nieopłacalne uznać by należało podjęcie akcji lotniczej przed rozmieszczeniem na pozycjach własnych środków aktywnej obrony przeciwlotniczej i lotniczych sił uderzeniowych, tj. przed upływem mniej więcej siedmiu dni. Ewentualnie podjęte po upływie tego terminu działania

ty W tekście dokumentu znalazła się zapowiedź przedstawienia w załączonym aneksie zestawienia potencjalu rozpatrywanych w raporcie sił powietrznych. Żaden jednak z odnalezionych przez autora egzemplarzy nie zawiera takiego dodatku. Być może w pośpiechu nie zdążono go opracować lub też posłużono się gotowymi danymi, które w naszym opracowaniu umieszczone zostały w tab. 2.

50 TNA, CAB 53/47, „Military implications of an Anglo-French Guarantee to Poland and Rumania. Draft Report", C.O.S. 871 (J.P.) Joint Planning Sub-Committee.

i) Ibidem. 
(samego faktu ich podjęcia bynajmniej bowiem nie przesądzano) zostałyby ograniczone do najściślej rozumianych obiektów wojskowych w najwęższym tego słowa znaczeniu, stąd ich efekt dla całości militarnego wysiłku Rzeszy byłby odpowiednio zredukowany.

Najszerszej wreszcie, wielowariantowej analizie poddane zostały spodziewane działania lądowe. I w tym jednak przypadku ewentualne pożytki $z$ udziału $w$ wojnie wschodnich sojuszników brytyjscy sztabowcy uznali za bardzo ograniczone. Jeśli Niemcy podejmą główną ofensywę na wschodzie, stwierdzali, „bez wątpienia zdołają okupować Rumunię i polski Korytarz". W razie zaś kontynuacji ofensywy przeciw Polsce zajęcie całości jej terytorium „będzie tylko kwestią czasu (zapewne jedynie miesięcy)" 52 . Pacyfikacja zdobytych ziem oraz ich zabezpieczenie przed możliwym atakiem ze strony ZSRR wymagać będą jednak sił porównywalnych z tymi, które użyte zostaną do podboju - wskazywali autorzy analizy, dając do zrozumienia, że jedynie te ostatnie okoliczności uznać można za potencjalną korzyść dla zaangażowanych w wojnę mocarstw Zachodu.

Ogólne wnioski $z$ tak przeprowadzonej analizy nie mogły być, rzecz jasna, pomyślne dla rzeczników zamierzonych gwarancji. W rozpatrywanym przypadku wojna wybuchnąć może, stwierdzano bowiem w owych konkluzjach, zanim brytyjski system obronny zostanie do niej odpowiednio przygotowany, sam zaś Londyn ma niewielki wpływ na stanowiącą potencjalne jej tło „niepewną kwestię" polskiego Korytarza. Udział w takim konflikcie sojuszników z Polski i Rumunii w niewielkim tylko stopniu będzie wpływał na rozpatrywany $z$ punktu widzenia Zachodu jego przebieg, tym bardziej że „Rumunia z pewnością zostałaby szybko pokonana”, zaś „podbój Polski mógłby być kwestią miesięcy". Z drugiej jednak strony ofiara złożona przez sojuszników ze wschodu nie byłaby całkiem daremna: zaangażowanie sił niemieckich $\mathrm{w}$ prowadzone na tym kierunku operacje, a następnie $\mathrm{w}$ zabezpieczenie zdobyczy spowodowałyby zapewne osłabienie ataku na Francję. „Niemcy zapewne nie miałyby dość jednostek, by przebić się przez Linię Maginota, choć Holandia i część Belgii mogłyby zostać zajęte" ${ }^{53}$.

Co istotne, zdaniem brytyjskich sztabowców w razie wybuchu wojny Wielka Brytania i Francja niewiele mogłyby uczynić dla sojuszników ze wschodu. Niemożliwe byłoby bowiem, stwierdzano w raporcie, udzielenie "bezpośredniego wsparcia na morzu, lądzie czy w powietrzu, aby pomóc im oprzeć się niemieckiej inwazji". Co więcej, przy „obecnym stanie” produkcji zbrojeniowej „ani Wielka Brytania, ani Francja nie byłyby w stanie dostarczać jakiegokolwiek uzbrojenia do Polski i Rumunii". Źródłem podobnych dostaw mógłby zostać jedynie ZSRR ${ }^{54}$.

52 Ibidem.

$\$ 3$ Ibidem. Glówne tezy dokumentu streścił (a częściowo zacytował, błędnie jednak wskazując źródło) J. Ciechanowski w szkicu: Przystapienie Anglii do wojny, [w:] idem, Wielka Brytania i Polska. Od Wersalu do Jalty. Wybór artykulów, dokumentów i recenzji, Pułtusk-Warszawa 2011 , s. $57 \mathrm{n}$.

st Ibidem. 
Jeszcze tego samego dnia powyższy dokument stał się przedmiotem obrad Podkomitetu Szefów Sztabów. Przedstawiony szkic raportu poddany został szczegółowej dyskusji, której skutkiem stało się wprowadzenie doń szeregu poprawek. Tak uzupełnioną wersję skierowano do dalszej dystrybucji, zastrzegając jednak dla Szefów Sztabów, którzy, jak wyjaśniano, nie mieli (z braku czasu?) „możliwości przestudiowania raportu w jego finalnej formie", prawo wprowadzenia do tekstu dalszych poprawek ${ }^{55}$. $\mathrm{Z}$ prawa tego istotnie skorzystali - znacząco zmieniony tekst dokumentu nosić miał ostatecznie datę 3 kwietnia ${ }^{56}$.

W tej ostatniej wersji nie mógł, rzecz jasna, wywrzeć wpływu na polityczne decyzje co do oferowanych Polakom gwarancji. Inaczej jednak przedstawiała się sprawa tekstu, który Szefowie Sztabów zaaprobowali 28 marca. Trafił on bowiem w ręce inicjatora opracowania raportu, lorda Chatfielda, który główne jego tezy, niekiedy $\mathrm{z}$ dodatkiem własnych interpretacji - nie zawsze zgodnych $\mathrm{z}$ intencjami autorów dokumentu - wykorzystał w trakcie kluczowej dyskusji na posiedzeniu Gabinetu w południe 30 marca. Położył przy tym nacisk przede wszystkim na te elementy sporządzonej przez wojskowych analizy, które skłonić mogły zebranych do zaaprobowania propozycji gwarancyjnej jako zgodnej z brytyjskim interesem, równocześnie wspierając się autorytetem Szefów Sztabów dla rozwiewania związanych z rozważaną decyzją obaw ${ }^{57}$.

W trakcie wspomnianych obrad minister ds. koordynacji obrony otrzymał dodatkowe memorandum, właśnie przygotowane przez Szefów Sztabów na kolejnym posiedzeniu ich Podkomitetu. Autorzy tego dokumentu, w porozumieniu z uczestniczącym w ich spotkaniu zastępcą dyrektora wywiadu wojskowego bryg. Frederickiem G. Beaumont-Nesbittem, przeczyli prawdziwości pogłosek o koncentracji na granicy śląskiej przygotowujących się jakoby do agresji na Polskę niemieckich oddziałów. Zwracali też uwagę, że w razie podjęcia przez Gabinet decyzji o udzieleniu Polsce gwarancji brytyjską zbrojną interwencję na rzecz tej ostatniej poprzedzić winno spełnienie trzech warunków: stwierdzenie agresji na polskie terytorium, stawienie przez Polaków oporu i wystosowanie do Brytyjczyków apelu o pomoc, wreszcie - zapewnienie pełnej zgodności działań Londynu i Paryża ${ }^{58}$.

5 TNA, CAB 53/10, minuty z 285. posiedzenia Podkomitetu Szefów Sztabów z 28 III 1939 r.

is TNA, CAB 53/47, „Military implications of Anglo-French Guarantee to Poland and Rumania", C.O.S. 872 Revise z 3 IV 1939 r. Nie wiadomo niestety, na ile wersja opracowana przez JPC i przyjęta przez Szefów Sztabów 28 marca różniła się od tekstu datowanego 3 kwietnia. Zawarta w minucie posiedzenia z 28 marca informacja o skierowaniu przyjętego przez COS raportu do dystrybucji zaopatrzona została jednak w dopisek: „Następnie rozesłany jako dokument No C.O.S. 872". Zarówno S. Newman (op. cit., s. 195n.), jak i A. Prazmowska (op. cit., s. 55n.) pomijają milczeniem wprowadzenie dokumentu do obiegu przed 31 marca, informując jedynie, że jego wersja ostateczna nosi datę 3 kwietnia. W tejże kwestii zob.: G.B. Strang, Once More unto the Breach: Britain's Guarantee to Poland, March 1939, „Journal of Contenporary History” 1996, vol. 31, no. 4, s. 740n., gdzie jednak cytowana jest także jedynie wersja z 3 kwietnia.

57 TNA, CAB 23/98/6, „Conclusions of a Meeting of the Cabinet held on Thursday, 30 March, 1939 , at 11.0 a.m.".

jк Ibidem, annex B; CAB 53/10, minuta z 286. posiedzenia Podkomitetu Szefów Sztabów w dniu 30 III 1939 r. W tym ostatnim dokumencie znalazła się adnotacja o przekazaniu uzgodnio- 
Politycy brytyjscy decyzję o udzieleniu Polsce gwarancji podjęli więc wbrew opinii Szefów Sztabów. Spośród sceptycznych, a w istocie jednoznacznie krytycznych ich ocen premier Chamberlain i jego polityczni adherenci wybrali te, które wspierały żywione przez nich przekonanie, że sukces $w$ nadchodzącym zbrojnym konflikcie odnieść można, tylko zmuszając Rzeszę do wojny na dwa fronty - nawet jeśli drugi okaże się w istocie bytem fantomatycznym ${ }^{54}$.

Jednak formułowanie na tej podstawie tezy, że taka właśnie wojna stanowiła cel Chamberlaina, zaś polski partner cynicznie wybrany został do roli ofiary, stanowiłoby wprowadzające $w$ błąd uproszczenie. Przygotowana przez wojskowych analiza dotyczyła militarnych aspektów zagadnienia i stąd próżno byłoby w niej szukać argumentów innej natury. $\mathrm{W}$ istocie jednak brytyjski premier i jego polityczni adherenci szukali rozwiązania zgoła przeciwnego, zamierzając zapobiec wybuchowi wojny, przynajmniej w krótkiej i średniej perspektywie, nie ryzykując przy tym drastycznego załamania mocarstwowej pozycji Londynu. Polskę traktowano tu, rzecz jasna, przedmiotowo, z czego dyplomacja Rzeczypospolitej dobrze zdawała sobie sprawę ${ }^{60}$. Warszawa świadomie decydowała się na przyjęcie oferty - alternatywę stanowiła bowiem faktyczna rezygnacja $z$ suwerenności, związana $z$ akceptacją formułowanych w ultymatywnym tonie niemieckich żądań. Londyn $\mathrm{z}$ kolei dysponował wystarczającym zasobem informacji na temat charakteru tych ostatnich, zaś tamtejsze wojskowo-polityczne elity przekonane były, że narastającej presji ze strony Rzeszy Polacy gotowi są przeciwstawić się zbrojnie, walkę podejmując choćby samotnie ${ }^{61}$. „Oni [...] niewątpliwie walczyliby o Korytarz", oceniali brytyjscy Szefowie Sztabów w memoriale z 31 marca $^{62}$. Obie wreszcie strony miały świadomość, że charakter i rozmiary

nego w' trakcie spotkania Szefów Sztabów raportu na temat sytuacji międzynarodowej uczestniczącemu w posiedzeniu Gabinetu lordowi Chatfieldowi około godziny 12.55 .

${ }^{5 y}$ Liczni historycy wskazują też, że jeden $z$ istotnych motywów podjętej przez Chambelaina decyzji stanowiła obawa przed niemiecko-polskim porozumieniem. Prędzej czy później groziło to znalezieniem się Warszawy w obozie satelitów Rzeszy, co perspektywę „drugiego frontu" rozwiać by musiało natychmiast.

61) Brak złudzeń co do postawy Londynu dobrze ilustrują datowane 29 marca korespondencje ambasadorów Łukasiewicza i E. Raczyńskiego. Zob.: PDD 1939, dok. 150, s. 233nn.; dok. 151, s. 236nn. Na tenże temat uwagi M. Korn at a, Polityka zagraniczna Polski..., s. 467n.

61 O wspomnianych przez polskiego attaché wojskowego $\mathrm{w}$ rozmowie $\mathrm{z}$ brytyjskim kolegą niemieckich żądaniach przystąpienia Polski do Paktu Antykominternowskiego donosił 25 marca z Berlina tamtejszy chargé d’affaires w Berlinie George Ogilvie-Forbes, wzmiankując też prawdopodobne zagrożenie statusu Gdańska i Korytarza. Dokładne informacje na tenże temat przekazał amb. Kennard w depeszy skierowanej do Londynu późnym wieczorem 29 marca. Jak dodał, indagowany wiceminister spraw zagranicznych starał się te informacje zdezawuować, czemu zresztą Kennard nie dał wiary. DBFP, vol. 4, doc. 520, s. 504; doc. 564, s. 543. Wiadomości o niemieckich żądaniach stanowiły już wówczas tajemnicę poliszynela - równolegle (31 marca) przekazywał je do Waszyngtonu wojskowy attaché USA mjr William H. Colbern (W.H. Colbern, Polska. Styczeń-sierpień 1939. Analizy i prognozy. Komentarze do wydarzeń attaché wojskowego ambasady USA w Warszawie, oprac. B. Grzeloński, Warszawa 1986, s. 45).

62 TNA, CAB 53/10, minuta 2 286. posiedzenia Podkomitetu Szefów Sztabów w dniu 30 III 1939 r. Por. też: TNA, PREM 1/331 A, opracowanie „Germany's intentions regarding Danzig - 30th March 1939" bryg. Beaumont-Nesbitta 230 III 1939 r. 
brytyjskich aktywów wojskowych $\mathrm{w}$ razie zbrojnego konfliktu w żaden sposób nie zdołają zapewnić efektywnej pomocy dla zaatakowanej przez Niemcy Rzeczypospolitej. W tym sensie udzielone gwarancje istotnie uznać było można za, jak to sformułowal przed laty Henryk Batowski, pozbawione pokrycia. Zarówno jednak nad Tamizą, jak i nad Wisłą sądzono, że zabezpieczenia wystawionego weksla nie stanowią bynajmniej armaty, a jego wykup nie okaże się w najbliższej przyszłości konieczny. Konflikt zbrojny postrzegany był tu jako scenariusz prawdopodobny, ale spośród możliwych zdecydowanie najgorszy ${ }^{63}$.

Wydaje się zresztą, że brytyjska droga ku gwarancjom nie miała wiele wspólnego z podążaniem z góry wytkniętym szlakiem. Stanowiła raczej serię niekonsekwentnych czy wręcz chaotycznych działań podejmowanych w wielkim pośpiechu dla wykreowania nowej politycznej rzeczywistości, skoro - jak niemal powszechnie uznano - polityka biernego reagowania na rzeczywistość okazała się prowadzić donikąd. Szukając wyjścia z matni, wybierano drogi, które doraźnie zdawały się możliwe do przebycia, gorączkowo dążąc do „zrobienia czegoś"64.

Przekonani, że wojnie można zapobiec lub przynajmniej poważnie odsunąć ją w czasie i/lub przestrzeni za pomocą politycznych rozwiązań, główni aktorzy marcowego dramatu sprowadzili wojskowych do roli doradców, traktując ich opinie instrumentalnie. Miało to mieć niebawem poważne konsekwencje. Wśród przedstawicieli wojskowej hierarchii wzmocnieniu uległy postawy sceptyczne względem znajdujących się u władzy cywilów, ugruntowując przekonanie, że - jak można by rzec, trawestując znane powiedzenie - „wojna jest sprawą zbyt poważną, by zostawiać ją politykom". Kilka miesięcy później, gdy do zbrojnego konfliktu wbrew usiłowaniom rządów z Londynu i Paryża jednak doszło, wojskowe elity Zachodu miały wyciągnąć nauki $z$ niedawnej przeszłości. Zachowując formalnie status doradców i wykonawców, francuscy i brytyjscy dowódcy spowodowali, że podjęta wówczas przez polityków kolejna próba „zrobienia czegoś” miała znacznie mniej poważne niż w marcu konsekwencje. W każdym razie - tak mogło się wydawać65.

${ }^{63}$ Charakterystyczna była tu rozmowa Becka i jego sekretarza Pawła Starzeńskiego, przeprowadzona tuż po odbytej przez ministra w początkach kwietnia podróży do Londynu: „Panie Pawle, czy oni będą się bili??" - zapytać miał Beck. „Bić się będą [...], bo granica ich własnego bezpieczeństwa została przekroczona, ale czym?” - brzmiała odpowiedź. Beck „uważał, że jeśli wojna nie wybuchnie przed sierpniem-wrześniem, to może uda się w ogóle jej uniknąć, a w każdym razie Anglia zyska na czasie i choć trochę odrobi zaniedbania w swoim uzbrojeniu", komentowal ową wymianę zdań jego sekretarz (P. St arzeń ski, op. cit., s. 204n.). Por. też: Cadogan Diaries, s. 167. $\mathrm{Na}$ temat występujących wśród polityków brytyjskich różnic w ocenach prawdopodobieństwa rychlego wybuchu wojny zob.: F. McDonough, Poland in the Political and Military Strategy of British Policy, March-September 1939, [w:] Kampania polska 1939 r. Polityka..., t. 1, s. 158n.

w Po latach przyznal to m.in. jeden z głównych aktorów wydarzeń z marca 1939 r., A. Cadogan (Cadogan Diaries, s. 166n.).

65 Postawa taka widoczna była już wiosną 1939 r., wówczas jednak reprezentowali ją głównie wojskowi francuscy. „Francuski Sztab nie ukrywa, że nie dowierza swoim politykom i mówi im tak mało, jak to tylko możliwe" - zauważał po spotkaniu z przybyłymi z Paryża oficerami zastępca Dyrektora Planowania Ministerstwa Lotnictwa płk John Slessor, po latach komentując, że choć 
postawa taka może dziwić kogoś, kto „nigdy nie był zmuszony nie wierzyć swym politycznym szefom”, to francuscy lotnicy „z pewnością mieli dobry powód”, by tak traktować niektórych spośród politycznych przywódców swego kraju. TNA, AIR 75/6, rękopiśmienny koncept raportu Slessora dla Szefa Sztabu Lotniczego z 31 III 1939 r.; J. Sle ssor, op. cit., s. 230. 


\section{Rozdzial 3}

\section{Sojusznik, którego nie było (29 marca -4 kwietnia 1939 roku)}

Charakter udzielanych Polsce gwarancji, stanowiących faktycznie rodzaj politycznego blefu, spowodował, że w prowadzonych nad Tamizą w ostatnich dniach marca kalkulacjach zaskakująco mało miejsca poświęcono elementowi, który powinien być uznany za kluczowy - a mianowicie Francji. Politycy zbagatelizowali go w pośpiechu, sądząc, że Paryż podąży po prostu za inicjatywą tak bardzo dlań istotnego partnera. Wojskowi, starając się określić wpływ, jaki na bezpieczeństwo Zachodu mógłby wywrzeć udział w zbrojnym konflikcie sojuszników z Europy Wschodniej, Francję potraktowali schematycznie, nie próbując nawet rozpatrywać jej w roli czynnika aktywnie kształtującego bieg wydarzen'!

Postawa taka, choć poniekąd zrozumiała (a w każdym razie - wytłumaczalna), winna była budzić zaniepokojenie - wojenny scenariusz nie został przecież definitywnie odesłany do lamusa, a to Francuzi mieli wziąć na siebie główny ciężar konstruowania zachodniego frontu. W praktyce jednak nawet wśród brytyjskiej elity wojskowej tylko bardzo nieliczni zdawali sobie sprawę z tego, jak bardzo hazardową grę podjęli, ignorując dokładniejsze zbadanie francuskich zamierzeń, autorzy gwarancyjnych decyzji, a w większym jeszcze stopniu decyzji tych adresaci. Bodaj zaś tylko jeden oficer zawarł swe wątpliwości w sformułowanym w ostrzegawczym tonie raporcie.

' Oczywiście jednak błędne jest twierdzenie M. Gmurczyk-Wrońskiej, że swoją deklarację "o wsparciu brytyjskim [dla Polski] w wypadku ataku niemieckiego" Chamberlain złożył, "nie informując Paryża" (op. cit., s. 85). Przeciwnie - w przeddzień wygłoszenia słynnej mowy Phipps powiadomił Bonneta o zamierzonych jej treściach, a rząd francuski zaaprobował powołanie się nań w odpowiednim fragmencie tego wystąpienia. Zob.: AD, Papiers 1940, Reconstitution Fouques-Duparc 58, „Aide-Mémoire” Ambasady Wielkiej Brytanii w Paryżu z 30 III 1939 r.; Ministère des Affaires étrangères, Documents diplomatiques 1939-1939. Pièces relatives aux événements et aux négociations qui ont précédé l'ouverture des hostilités entre l'Allemagne d'une part, la Pologne, la Grande-Bretagne et la France d'autre part, Paris 1939, doc. 88, s. 100. 
Już sam ten fakt $\mathrm{z}$ pewnością wart jest odnotowania. $\mathrm{Z}$ naszego punktu widzenia jednak równie istotne jest, że przed szereg wystąpił w ten sposób przedstawiciel sił powietrznych, Dyrektor Planowania Ministerstwa Lotnictwa płk John Slessor, sam zaś raport trafił na biurko innego lotnika - Szefa Sztabu Lotniczego Air Marshala Cyrila Newalla.

Zauważyć należy, iż krok Slessora, choć odosobniony czy wręcz - na ile wiemy wyjątkowy, sam w sobie nie był niczym niezwykłym. Uznał po prostu za właściwe poinformować Newalla o świeżo nabytej wiedzy o kwestiach bardzo istotnych dla podejmowanych właśnie przez polityków decyzji. Punktem wyjścia dla formułowanych uwag uczynił zaś scenariusz dość oczywisty, przyjmując po prostu, że dyplomatyczne wysiłki najpewniej nie dadzą pożądanego efektu i wojna w najbliższych miesiącach jednak wybuchnie. W takim przypadku, jak sądził, analizę należy rozpocząć od najsłabszego elementu rysującego się układu, to znaczy od izolowanej na wschodzie Europy Rzeczypospolitej, w razie zbrojnego konfliktu zależnej w wielkiej mierze od szybkości i charakteru działań podjętych przez sojuszników z przeciwnej strony kontynentu. To zaś oznaczało w praktyce - od Francuzów. Choć bowiem gabinet Chamberlaina wdrażał właśnie decyzje mające na celu znaczne zwiększenie rozmiarów brytyjskich sił zbrojnych i podniesienie ich bojowej efektywności, to na rychłe efekty podjętych wysiłków nie można było liczyć.

28 marca obradujący $z$ udziałem Slessora Joint Planning Sub-Committee, wypowiadając się na temat perspektyw francuskiej (i brytyjskiej) współpracy, jednoznacznie przekreślił możliwość udzielenia pomocy walczącej Polsce. Swego stanowiska jednak ani nie uargumentował, ani nie rozwinął samej tezy, co pozostawiało jednak pewien margines niepewności. Dzień później członkowie JPC stali się jądrem brytyjskiej delegacji, która zainaugurowała pierwszą, wstępną turę międzysztabowych rozmów z przedstawicielami Paryża. Slessor został w tym gronie reprezentantem Air Ministry. Stanowiło to dlań wyjątkową sposobność do zapoznania się z poglądami przybyłych do Londynu oficerów francuskiego Sztabu Generalnego i skonfrontowania ich $\mathrm{z}$ doskonale mu znanym stanowiskiem sztabowców brytyjskich².

To właśnie owa wyjątkowa wiedza pozwoliła inteligentnemu oficerowi lotnictwa na sformułowanie tezy, która ostatecznie przekreślała potencjalne wątpliwości co do ewentualnej postawy francuskiego sprzymierzeńca w razie wybuchu zbrojnego kon-

2 TNA, CAB 55/15, kopia telegramu szyfrowego Foreign Office do Phippsa z 22 II 1939 r., godz. $15.30 \mathrm{i}$ in. dok.; J. Sle ssor, op. cit., s. 228n. W skład brytyjskiej delegacji weszli czlonkowie Joint Planning Sub-Committee, $\mathrm{z}$ kmdr. Victorem H. Danckwertsem, Dyrektorem Planowania Admiralicji (i przewodniczącym JPC) w roli jej przewodniczącego oraz płk. Hughem Fraserem jako drugim obok Slessora przedstawicielem Air Ministry. Delegacji francuskiej przewodniczył gen. Lelong, francuskie siły powietrzne reprezentował w jej składzie mjr Paul Bailly - szef Sekcji Operacyjnej Oddziału III Sztabu Generalnego Armée de l'Air (po latach, od 22 III 1955 r. do 16 III 1958 r., mial pełnić funkcję Szefa Sztabu Generalnego Armée de l’Air). Slessor we wspomnieniach jako głównego przedstawiciela Armée de l'Air wymieniał płk. Marie Josepha Paula Rozoya, który jednak nie uczestniczył w I turze rozmów (AD, Papiers 1940, Papiers Hoppenot 3, pismo No 446/ DN.3 Gamelina do Dyrekcji Spraw Politycznych i Handlowych MAE z 8 III 1939 r.). 
fliktu o europejskim zasięgu. „Francuzi - pisał w raporcie - nie mają w ogóle zamiaru atakować we wstępnej fazie [wojny]. Stwierdzili, że ich strategią będzie stworzenie mocnego frontu defensywnego i zachowanie integralności własnego terytorium"

Wnioski były oczywiste - i Slessor nie cofał się przed ich sformułowaniem. Konstatując brak porozumienia między politykami i wojskowymi znad Sekwany, proponował, by zastanowić się, ,jak dalece francuskie Ministerstwo Spraw Zagranicznych zdaje sobie sprawę $z$ tego, w jakim stopniu Francja mogłaby faktycznie wesprzeć sprzymierzeńca we wschodniej Europie".

Postawiona kwestia miała przy tym charakter retoryczny, autor raportu wiedział, że jego adresat sam sobie będzie w stanie udzielić odpowiedzi na zawarte w niej pytanie. Stąd też niemal natychmiast przechodził do konkluzji: „Polacy powinni bazować na swoich własnych zasobach [...]; całość tego, co alianci mogliby [dla nich] zrobić, to zatrzymanie stosunkowo niewielu niemieckich dywizji na granicy francusko-niemieckiej, wprowadzenie blokady [Rzeszy] i bombardowanie Niemiec". Zdaniem Slessora (a najwyraźniej także jego francuskich rozmówców) to właśnie akcja lotnicza stanowić mogła jedyną możliwą formę aktywnej interwencji zachodnich sojuszników na rzecz zaatakowanej przez Rzeszę Polski.

Były to wnioski ważkie i nie miały przeminąć bez echa. Na razie jednak wojskowych $z$ Londynu i ich francuskich partnerów zaprzątały inne kwestie. Wątki polskie, choć jak widać, $w$ trakcie międzysztabowych rozmów obecne, pojawiły się tam niejako ad hoc, w związku z rozwojem wydarzeń. Dla zagadnień rozważanych w ramach przyjętego programu były jednak wciąż jeszcze bez większego znaczenia.

Same spotkania przedstawicieli Sztabów Generalnych z obu stron Kanału wiosną 1939 roku nie stanowiły, rzecz jasna, nowości. Zapoczątkowane jeszcze w roku 1936, w latach następnych odbywały się ze zmienną intensywnością. Ostatnia ich tura, skądinąd dotycząca właśnie współpracy lotniczej, przeprowadzona została całkiem niedawno, bo w listopadzie 1938 roku $^{5}$. Dotychczas jednak w trakcie takich kontaktów poprzestawano na dość ogólnych dywagacjach, omawianie bardziej kon-

${ }^{3}$ TNA, AIR 75/6, rękopiśmienny koncept raportu Slessora dla Szefa Sztabu Lotniczego z 31 III $1939 \mathrm{r}$.

- Ibidem. Główne tezy swego raportu Slessor przywołać mial po latach w swoich wspomnieniach (J. Slessor, op. cit., s. 230), cytując nawet niektóre frazy $z$ tego dokumentu, jednak bez informowania o ich pochodzeniu. Air Marshal Newall uwagi Slessora przyjął z aprobatą, ale i zaniepokojeniem. To ostatnie nie dotyczyło jednak kwestii polskich, ale tradycyjnie już, problemów, jakie pasywność Francuzów może przysporzyć Brytyjczykom. Newall wyraził obawę, że francuscy sojusznicy w razie wojny nie zamierzają „, robić czegokolwiek poza siedzeniem [...] w Linii Maginota", a w razie niemieckiej ofensywy główny ciężar walki spocznie na Brytyjskim Korpusie Ekspedycyjnym gen. Gorta (datowany 31 III 1939 r. odręczny komentarz Newalla na raporcie Slessora, ibidem).

"SHD-DAA, 2 B 106, „Note relative aux conversations ayant eu lieu à Londres les 16 et 17 Novembre 1939 entre les représentants des États-Majors de l'Air Britannique et Français" z 10 II 1939 r. Rozmowy przedstawicieli Sztabów Generalnych sił powietrznych obu państw miały też miejsce we francuskim Ministerstwie Lotnictwa 27 II 1939 r. - poświęcone były jednak dość szczegółowym kwestiom o charakterze technicznym. Wizyta delegacji francuskiej potrwała do 1 marca. 
kretnych aspektów kooperacji ograniczając, jak już wyżej wspomniano, głównie do kwestii o charakterze technicznym. Decydującą rolę odgrywały tu obawy Londynu przed drażnieniem potencjalnego przeciwnika i utrudnianiem realizacji polityki appeasementu'

Tendencje do zmiany tego nastawienia zaznaczyły się, jak już wyżej wspomniano, jeszcze jesienią 1938 roku. Jednak na wyraźniejsze odstępstwo od wcześniejszej asekuranckiej postawy zdecydowano się dopiero w pierwszych tygodniach roku następnego $^{\top}$. Nad Tamizą górę wzięły obawy przed rejteradą osłabionych po monachijskiej porażce Francuzów - i związaną z tym koniecznością samotnego stawiania czoła tryumfującej Rzeszy. W pierwszych tygodniach 1939 roku niepokój ten wzmocniły jeszcze, jak sądzi część historyków - nie bez francuskiej inspiracji - pogłoski o przygotowywanej jakoby przez Niemców inwazji na terytorium strategicznie ważnej dla Brytyjczyków Holandii ${ }^{8}$.

Wtedy to właśnie, 1 lutego 1939 roku, gabinet Chamberlaina uznał za konieczne rozpoczęcie kolejnej tury rozmów międzysztabowych z Francją (oraz Belgią), za ich podstawę przyjmując scenariusz wojny z Niemcami i Włochami oraz rozszerzając zakres dyskutowanych zagadnień do wszystkich prawdopodobnych obszarów operacji, ze szczególnym uwzględnieniem rejonu Morza Śródziemnego i Bliskiego Wschodu. Dzień później zaaprobowano też ramowy program rozbudowy sił zbrojnych, znaczące miejsce wyznaczając $w$ nim armii lądowej, która dotąd przy podobnych okazjach pozostawała w cieniu Królewskich Sił Powietrznych (RAF) oraz Royal

SHD-DAA, 2 B 107, „Procès-verbal des conversations ayant eu lieu entre les Représentants des Etats-Majors de l'Air Britannique et Français au Ministère de l'Air à Paris, le 27 Févier 1939".

" Obszerne streszczenie historii kontaktów międzysztabowych, począwszy od roku 1936: TNA, CAB 29/159, opracowanie A.F.C. 3 sekretarza delegacji brytyjskiej ppłk. L.C. Hollisa „Summarized History of Staff Conversations" 224 III 1939 r. Por. też uwagi na ten temat sformulowane przez Joint Planning Sub-Committee w: TNA, CAB 53/45, C.O.S. 850 (J.P.) z 28 II 1939 r. oraz: N.H. Gibbs, op. cit., s. $607 \mathrm{nn}$. Lotnicze aspekty kontaktów międzysztabowych z okresu po schyłek roku 1938 obszernie przedstawili P. Fridenson i J. Lecuir, op. cit., rozdz. 1-5; P. Facon, op. cit., s. $3 \mathrm{ln}$. Kontakty te $\mathrm{z}$ uwagą obserwowała st rona polska. Zob. np.: AAN, SG, 616/354, pismo 2033/38 ppłk. Kwiecińskiego do Szefa O. II SG z 4 V 1938 r. (na piśmie adnotacja o jego przedstawieniu 12 maja Szefowi Sztabu Głównego).

I wtedy jednak jeszcze zwrot nie był całkowity. Reliktem wcześniejszych obaw stała się m.in. decyzja o wyznaczeniu do prowadzenia negocjacji oficerów o stosunkowo niskiej (przynajmniej formalnie) pozycji w wojskowej hierarchii oraz rangach (J. Slessor, op. cit., s. 228n.).

* T.C. Imlay, The Making of the Anglo-French Alliance, 1938-39, [w:] Anglo-French Defence Relations between the Wars, ed. by M.S. A lexander, W.J. Philpott, Basingstoke 2002, s. 106nn., Studies in Military and Strategic History. Tam też informacje o innych przesłankach dokonanego przez Londyn zwrotu. Strona francuska już wcześniej przynaglała Londyn do zacieśnienia wojskowej współpracy, początkowo kładąc jednak nacisk na kooperację w koloniach i terytoriach zamorskich. Zasadność pogłębienia kontaktów międzysztabowych z Francją podkreślali też w tym czasie, wstrzymując się jednak od oficjalnego formulowania rekomendacji, brytyjscy Szefowie Sztabów. AD, Papiers 1940, Papiers Hoppenot 3, kopia pisma No 52/DM.3 Gamelina do Daladiera z 14 I 1939 r. i in. dok.; TNA, CAB 553/14, C.O.S. „Draft European Appreciation, 1939-40”, zał. do pisma J.P. 331 Joint Planning Sub-Committee z 26 I 1939 r. 
Navy ${ }^{9}$. Francuzów o propozycjach kontynuacji międzysztabowych kontaktów w nowej, poszerzonej formule poinformowano za pośrednictwem ambasadora Phippsa niemal natychmiast, 3 lutego ${ }^{10}$.

Następne tygodnie zajęły konsultacje i ustalenia, prowadzone zarówno pomiędzy Londynem i Paryżem, jak i po obu stronach Kanału z osobna. 25 lutego przekazane zostały stronie francuskiej brytyjskie propozycje co do ramowego składu delegacji, miejsca podjęcia rozmów (Londyn) oraz ich zakresu („wszystkie [...] teatry działań, na których wspólne akcje albo operacje Wielkiej Brytanii i Francji są możliwe") ${ }^{11}$. Równocześnie partnerom z Paryża zaproponowano podział całości planowanych negocjacji na trzy zasadnicze etapy. $W$ trakcie pierwszego $z$ nich rozważone miałyby być ogólne zagadnienia strategii wojennej konfliktu brytyjsko-francuskiego z połączonymi siłami Niemiec i Włoch. W fazie drugiej dyskusji poddane by zostały w ogólnych zarysach plany operacji na wybranych teatrach działań. Faza trzecia dotyczyć by miała przygotowania planów szczegółowych ${ }^{12}$.

Strona brytyjska punktem wyjścia do rozmów z Francuzami zamierzała uczynić przygotowywane już od początku listopada 1938 roku opracowanie „European Appreciation, 1939-1940", które ostatecznie po przykrojeniu do potrzeb międzysztabowych konferencji przybrało postać opatrzonego datą 20 marca 1939 roku trzyczęściowego „British Strategical Memorandum”"13. W'́ród aliantów oraz państw przyja-

y TNA, CAB 23/97/3, Cabinet 3 (39), „Conclusions of a Meeting of the Cabinet held [....] on Wednesday, 1st February, 1939, at 11.0 a.m."; CAB 23/97/5, „Conclusions of a Meeting of the Cabinet held on Thursday, 2nd February, 1939, at 11.0 a.m... Zob. też: TNA, CAB 53/44, nota C.O.S. 838 Ismaya $z 6$ II 1939 r. Por. rozdz. 1, przyp. 56.

11 AD, Papiers 1940, Papiers Hoppenot 3, Aide-Mémoire Phippsa 23 II 1939 r. Tam też przetłumaczona wersja francuska.

"Ibidem, Aide-Mémoire Phippsa No 167/14/G/39 z 25 II 1939 r. (tam też tłumaczenie na język francuski, opublikowane w: DDF, t. 14, doc. 212, s. 374nn.; odpis dokumentu dostępny także w: TNA, CAB 53/45 jako aneks I do raportu C.O.S. 853. Podkomitetu Szefów Sztabów z 6 III 1939 r.). W memorandum z 3 lutego nie przewidziano uwzględnienia w rozmowach rejonu Dalekiego Wschodu. O toku wewnętrznych ustaleń strony brytyjskiej: TNA, CAB 55/15, raport C.O.S. 838 Podkomitetu Szefów Sztabów z 13 III 1939 r.

12 Ibidem. Zob. też: SHD-DAT, 2 N 228, pismo 424/DN.3 Gamelina do Daladiera 26 III $1939 \mathrm{r}$.

13 TNA, CAB 53/46, A.F.C. 1 z 20 III 1939 r.; TNA, CAB 29/159, „Summarized history of the conversations", A.F.C. 30 sekretarza brytyjskiej delegacji Edwarda Iana Clauda Jacoba $z 14$ VII 1939 r.; P. Fridenson, J. Lecuir, op. cit., s. 121. Dokument formalnie stanowił opracowanie Podkomitetu Szefów Sztabów. 17 marca, po wprowadzeniu ostatnich poprawek i modyfikacji, został zaaprobowany przez Strategical Appreciation Sub-Committee jako „baza ustnych dyskusji dla naszych przedstawicieli w nadchodzących Rozmowach Sztabowych" - z zastrzeżeniem, że wbrew wcześniejszym założeniom nie zostanie przed ich rozpoczęciem przesłany do Paryża (ibidem, nota C.O.S. 856 Ismaya z 31 III 1939 r.). Ostatecznie ze względu na konieczność zachowania szczególnej tajemnicy stronie francuskiej przekazane zostały tylko fragmenty tego memorandum $w$ formie kilku oddzielnych dokumentów. W trakcie rozmów dystrybuowane były równolegle dwie serie dokumentów (w tym sprawozdań z kolejnych spotkań): oznaczenie A.F.C. przyporządkowane było materiałom przeznaczonym do wyłącznego użytku delegacji brytyjskiej, A.F.C. (J) oznaczało prze- 
znych z obszaru Europy i Bliskiego Wschodu w dokumencie tym wymienione zostały Portugalia, Egipt i Irak oraz Turcja, w której przypadku liczyć należało, zdaniem Brytyjczyków, „co najmniej na przyjazną neutralność, a być może aktywną interwencję po naszej stronie". Życzliwość wobec aliantów zachodnich zachować miały w razie konfliktu zbrojnego także Stany Zjednoczone. Na pozycji zdystansowanej wobec tego konfliktu analitycy z Londynu spodziewali się ujrzeć ZSRR, który wedle ich ocen byłby gotowy interweniować „tylko w razie bezpośredniego zagrożenia”. Z kolei Japonia i Hiszpania uznane zostały za potencjalnie wrogie, choć z ostateczną decyzją co do wyboru opcji wojennej skłonne zwlekać aż do wyklarowania się sytuacji. W przypadku Polski zachowano, mimo widocznych już przesłanek do zmiany oceny, powtarzaną co najmniej od początku roku w kolejnych wersjach dokumentu frazę, głoszącą, że "nierozsądnie by było polegać w istotnym stopniu na pomocy, aktywnej czy pasywnej", ze strony Warszawy ${ }^{14}$.

Ściśle wojskowe aktywa brytyjsko-francuskiego sojuszu gospodarze przygotowywanej serii spotkań oceniali sceptycznie, stwierdzając po prostu: „w roku 1939 stan naszej gotowości do wojny nie będzie porównywalny $[. .$.$] z osiągniętym przez pań-$ stwa, które uznajemy za wrogie”. W dodatku - brzmiała dalsza część diagnozy - „stan przygotowań Francji nie jest zapewne lepszy niż nasz", nawet jeśli jej armia lądowa wydaje się lepiej zorganizowana i wyszkolona, a fortyfikacje wzmocnić winny zdolności obronne Francuzów.

Stąd też założenia proponowanej na początkowy okres wojny strategii miały charakter nawet nie tyle defensywny, ile wręcz kunktatorski. Jak stwierdzali brytyjscy sztabowcy: "Militarna przewaga naszych przeciwników oddaje im inicjatywę na lądzie i w powietrzu, a naszym pierwszym zadaniem musi być powstrzymanie ich ataków. W międzyczasie nasza kontrola nad komunikacją morską powinna umożliwić nam [...] rozpoczęcie [...] ekonomicznej presji na naszych wrogów [...]. Od początku powinna też być organizowana ofensywa propagandowa". Nad kwestią ewentualnych sojuszników ze wschodu Brytyjczycy szerzej się nie rozwodzili, poświęcając im $w$ tej części memorandum jedynie dwuznaczne sformułowanie: „wydaje się nieprawdopodobne, by wielka część sił niemieckich i włoskich została zatrzymana przez operacje w Europie Wschodniej"15.

Do zagadnienia wojny na wschodzie kontynentu powrócono jednak w dalszych partiach opracowania. Prawdopodobieństwo poważnej akcji przeciwnika w tym rejonie brytyjscy sztabowcy ocenili jako umiarkowane, zwracając uwagę na to, że wobec takich poczynań ZSRR z pewnością nie mógłby pozostać obojętny, stąd apetyty potencjalnych agresorów powściągać będzie obawa przed rosyjską interwencją. Za

znaczenie dla obu delegacji. Zawierające fragmenty „British Strategical Appreciation” dokumenty tej ostatniej serii we francuskich tłumaczeniach: SHD-DAT, $2 \mathrm{~N} 228$ oraz $7 \mathrm{~N} 3441$. Obszerne omówienie tego memorandum: N.H. Gibbs, op. cit., s. $657 \mathrm{nn}$.

it Ibidem. Pozwala to na skorygowanie twierdzenia M. Kornata, że frazę tę brytyjscy wojskowi zarzucili już „,cztery dni" po użyciu jej w dokumencie datowanym 14 marca (Polityka zagraniczna Polski..., s. $32 \ln$.).

is TNA, CAB 53/46, A.F.C. 1 z 20 III 1939 r. 
całkiem nieprawdopodobną uznano natomiast równoczesną niemiecką ofensywę na wschodzie i zachodzie. Wyrażono też przekonanie, że nawet $w$ razie czasowego zwrotu w tym pierwszym kierunku trudno spodziewać się, że Niemcy, nie niepokojąc mocarstw zachodnich, pozwoliłyby na rozbudowę ich wojennego potencjału. Nawet więc $\mathrm{w}$ takim przypadku, zakładali autorzy memorandum, większa część niemieckiego lotnictwa dalekiego zasięgu użyta zostanie przeciw celom na Wyspach oraz utrzymywanym przez Albion morskim szlakom handlowym. Nawet więc w tym, formalnie poświęconym sprawom Europy Wschodniej, fragmencie opracowania uwaga brytyjskich autorów kierowała się, wcale zresztą nie metaforycznie, ku własnym brzegom. Krótkie w stosunku do całości dokumentu wywody dotyczące tego regionu podsumowane natomiast zostały fatalistyczną refleksją: „Nie moglibyśmy dostarczyć efektywnego wsparcia Polsce i Węgrom. W razie wrogości Włoch poza zasięgiem naszej pomocy znalazłaby się Jugosławia, a przy neutralnej Turcji nie moglibyśmy sięgnąć Rumunii"'16.

Jednak dwa akapity dalej myśl tę sformułowano nieco mniej kategorycznie: „Jeśli wojna wybuchnie w Europie Wschodniej, ani Francja, ani my nie moglibyśmy udzielić bezpośredniej pomocy ofierze niemieckiej agresji, choć moglibyśmy uczynić dywersję, atakując Niemcy na zachodzie i wywierając presję przez akcję na morzu"'خ.

Dodać należy, iż brytyjscy sztabowcy, podkreślając konieczność skupienia się w początkowej fazie wojny na obronie, nie wykluczali bynajmniej możliwości podjęcia już wówczas akcji o charakterze zaczepnym, szczególnie jeśli miałyby one służyć, choćby tylko pośrednio, wzmocnieniu pozycji defensywnych. Jako potencjalny cel działań tego typu wskazywano jednak przede wszystkim Włochy, wobec których mogłyby być one zdaniem Brytyjczyków łatwiejsze i bardziej efektywne. Podjęcie działań ofensywnych w szerszej skali zapowiadano dopiero w drugiej fazie wojny, po zmiękczeniu siły oporu wrogów za pomocą presji o charakterze ekonomicznym. Ten etap wojny brytyjscy sztabowcy kreślili jednak lakonicznie i ogólnikowo.

Zagadnieniom wojny powietrznej $\mathrm{w}$ omawianym memorandum poświęcono sporo miejsca. Za istotne uważała je większość przedstawicieli elit polityczno-wojskowych tego czasu, z brytyjskiego punktu widzenia ich waga była szczególna - to właśnie głównie z powietrza nadejść mogły ataki kierowane przeciw Wyspom Brytyjskim i wiodącym do nich morskim szlakom zaopatrzenia. Takim też zagrożeniom autorzy analizy poświęcili gros uwagi. Także w sferze działań lotniczych wojskowi z Londynu zamierzali skoncentrować się na działaniach obronnych, wykorzystując w nich przede wszystkim wciąż jeszcze zbyt skromne liczebnie (określone na 500 maszyn w pierwszej linii), ale nowocześnie wyposażone siły myśliwskie ${ }^{18}$. Strona brytyjska, przewidując, że Luftwaffe nie będzie się stosowała do określonych w międzynaro-

16 Ibidem.

17 Ibidem.

1" „Niemal wszystkie nasze myśliwce należeć będą do typów nowoczesnych" - stwierdzano $\mathrm{w}$ opracowaniu, dodając, że $\mathrm{w}$ razie konieczności tak wyposażone dywizjony w sektorach mniej wystawionych na atak mogłyby zostać uzupełnione przez „dywizjony innych klas”. 
dowych umowach reguł wojny powietrznej i podejmie zapewne także terrorystyczne ataki przeciw ludności cywilnej, przygotowywała się jednak do odpowiedzi ciosem na cios. „Moglibyśmy skierować nasze bombowce przeciwko temu, co uważamy za najbardziej żywotne punkty w Niemczech, w nadziei, że to zmusi Niemców do odstąpienia od atakowania nas" - pisano, dodając: „[...] albo też skierować je przeciw tym celom, których zniszczenie lub dezorganizacja zostały uznane za skutkujące redukcją potencjału niemieckich powietrznych sił uderzeniowych". Jako obszar szczególnie wrażliwy na uderzenia brytyjskiego lotnictwa wskazano Zagłębie Ruhry' ${ }^{19}$.

Jednocześnie jednak autorzy memorandum zauważali, że wiosną 1939 roku większą część (około dwóch trzecich) brytyjskich powietrznych sił uderzeniowych stanowić będą średnie bombowce, których ograniczony zasięg w przypadku operowania $\mathrm{z}$ lotnisk położonych na Wyspach nie pozwoli osiągnąć celów położonych $\mathrm{w}$ głębi Rzeszy, szczególnie jeśli zostaną zmuszone do omijania neutralnej Belgii i Holandii. Stąd też poważniejsze operacje będą mogły zostać podjęte dopiero po przebazowaniu tych maszyn na obszar północnej Francji, co oznaczać będzie znaczące opóźnienie planowanej kontrakcji.

Mniej uwagi poświęcono $\mathrm{w}$ memorandum kwestiom powietrznych działań na obszarach pozaeuropejskich, szkicując je głównie w odniesieniu do rejonu Morza Sródziemnego oraz Bliskiego i Dalekiego Wschodu. Problematykę lotniczej kooperacji z partnerami z Europy Wschodniej pominięto natomiast całkowitym milczeniem. Sił powietrznych tych ostatnich nie uwzględniono też $w$ umieszczonym $w$ tekście dokumentu tabelarycznym zestawieniu lotniczego potencjału ewentualnych uczestników konfliktu ${ }^{20}$.

Konstatowany brak zainteresowania stanowił naturalną konsekwencję pośledniej roli, jaką w nadchodzącej wojnie Szefowie Sztabów przypisywali państwom ze wschodniej części kontynentu. Obszar ten uważany był za domenę wpływów francuskich, Brytyjczyków nie wiązały z nimi poważniejsze interesy polityczne czy ekonomiczne, relatywnie nisko też oceniano wartość sił wojskowych państw regionu. Poważniejsze zaangażowanie na rzecz tego ostatniego wydawało się więc mało prawdopodobne.

Warto przy tym raz jeszcze podkreślić fakt dla naszych rozważań istotny: brytyjscy Szefowie Sztabów oraz oficerowie z najbliższego ich otoczenia w swych ocenach byli wyraźnie labilni, modyfikując niechętnie zasadnicze elementy przyjętych już założeń i wniosków. Choć więc $\mathrm{w}$ następnych miesiącach sytuacja międzynarodowa ewoluować miała $z$ coraz większą szybkością, zawarte $w$ memorandum oceny zmieniały się powoli i w stosunkowo niewielkim stopniu, aż do wybuchu wojny stanowiąc punkt odniesienia dla podejmowanych przez wojskowych z Londynu decyzji. Poszczególne fragmenty tego dokumentu niemal in extenso przeniesione miały zostać do materiałów wykorzystanych w trakcie rozmów ze stroną francuską, a stamtąd - do zamykających pierwszy etap owych rozmów konkluzji.

14 TNA, CAB 53/46, A.F.C. 1 z 20 III 1939 r.

21) Ilustrujące ów potencjał wartości liczbowe pozostały bez zmian względem wcześniejszych redakcji, tj. jak w tab. 2. 
Spójnym, logicznie skonstruowanym i obszernym treściom brytyjskiego memorandum Francuzi nie zdołali bowiem przeciwstawić równie szczegółowego opracowania. Przygotowania do konferencji z oczywistych przyczyn podjęli później od partnerów z Londynu, zaś biurokratyczny system znad Sekwany, nie mniej rozbudowany od funkcjonującego nad Tamizą, był jednak od tego ostatniego wyraźnie mniej sprawny. Niezbyt fortunnym rozwiązaniem okazało się też powierzenie funkcji koordynatora podjętych prac samemu gen. Gamelinowi - skądinąd na wniosek samego zainteresowanego. Obciążony wielością innych zadań Szef Sztabu Generalnego Obrony Narodowej nie mógł $w$ praktyce spełniać kolejnego $z$ nałożonych nań obowiązków, swą aktywność ograniczył więc głównie do ogólnego nadzoru i formalnych kontaktów z przedstawicielami strony brytyjskiej. Ta ostatnia utyskiwała jednak, że kierowana do "koordynatora" korespondencja nie dociera nawet do zaangażowanych w przygotowania Szefów Sztabów poszczególnych rodzajów sił zbrojnych. Ostatecznie więc Londyn zdecydował się na rozsyłanie im jej kopii we własnym zakresie ${ }^{21}$.

Opracowywanie dyrektyw dla kierowanej nad Tamizę delegacji Francuzi zakończyli dopiero w końcu pierwszej dekady marca, jako punkt wyjścia przyjmując informacje z przekazanej im 25 lutego noty brytyjskiej22. Przedstawione w niej stanowisko rządu Jego Królewskiej Mości starano się jednak skonfrontować z własną koncepcją strategiczną ${ }^{23}$.

Ta zaś sprowadzać się miała do próby zadania Niemcom pierwszego ciosu drogą pośrednią, przez uderzenie na znacznie od Rzeszy słabszego materialnie i moralnie jej włoskiego sojusznika. Francuzi zdawali sobie sprawę z tego, że podczas proponowanej ofensywy przeciw Włochom "kontynentalnym, wyspiarskim i kolonialnym” będą musieli zbudować bardzo silną osłonę na swej granicy wschodniej, skąd Berlin mógłby rzucić przeciw nim niemal całość swych sił, szczególnie gdyby nie zosta-

2 AD, Papiers 1940, Papiers Hoppenot 3, pismo No 180/D.N. Daladiera do Gamelina z 24 II 1939 r.; SHD-DAT, 2 N 228, pismo No 321 DN.3 Gamelina do Daladiera z 22 II 1939 r. i nast dok.; TNA, CAB 55/3, „Minutes of the meeting of the [Joint-Panning] Sub-Committee held on [...] 10th March, 1939..., J.P. 241 st Mtg.; DDF, t. 14, doc. 287, s. 518.

${ }^{22}$ Już jednak 28 II 1939 r. Szef Sztabu Generalnego Armée de l'Air gen. Joseph Vuillemin przedstawił notę na temat lotniczej współpracy obu mocarstw w basenie Morza Sródziemnego oraz na Bliskim i Dalekim Wschodzie. DDF, t. 14, doc. 234, s. 418nn.

23 SHD-DAT, $5 \mathrm{~N}$ 579, ,Note sur les accords d'États-Majors Franco-Anglais (directives pour la Délégation envoyées à Londres)" No. 443 DN.3 z 7 III 1939 r. Dokument opatrzony został aprobującą parafą Daladiera. P. Fridenson i J. Lecuir jako datę akceptacji dyrektyw przez Daladiera podają 9 marca (op. cit., s. 120), na wskazanym wyżej egzemplarzu widnieje jednak tylko odręczny dopisek "Approuvé" oraz parafa ministra; numer kancelaryjny dokumentu i datę wystawienia określono na podstawie kopii zachowanej w SHD-DAA pod sygnaturą 2 B 106. Publikacja: DDF, t. 14, doc. 275, s. 493nn. Por. też: SHD-DAT, 2 N 228, „Accords d'État-Major. Projet de directives rédigé par le colonel Aymé". Płk G. Aymé wchodził w skład personelu Sekretariatu Generalnego Najwyższej Rady Obrony Narodowej, w trakcie rozmów międzysztabowych, w których reprezentował Ministerstwo Kolonii, miał zostać zastępcą przewodniczącego francuskiej delegacji. Opracowany przezeń dokument 8 marca został parafowany przez Szefa Sztabu Generalnego Kolonii i członka Najwyższej Rady Wojennej gen. Jules’a Antoine’a Bührera. 
ły one uprzednio „poważnie zaangażowane przez naszych sojuszników w Europie Środkowej”24. Plany „włoskiej” ofensywy zniweczyć mogła także, jak zauważano, konieczność niesienia pomocy „tym państwom Europy Środkowej, które przyłączyłyby się do nas (Polsce i Rumunii)". To bowiem zdaniem autorów dyrektyw "mogłoby nas skłonić do podjęcia pewnych ofensyw (co najmniej lokalnych) o charakterze dywersyjnym"2s.

Główne założenia pierwszego etapu proponowanej przez Paryż strategii wojennej polegać więc miały na utrzymywaniu integralności terytoriów Wielkiej Brytanii i Francji oraz dążeniu do izolowania koalicji niemiecko-włoskiej jako całości oraz każdego z jej członków z osobna. Realizację tych ostatnich celów Francuzi zamierzali z kolei osiągnąć przez ustanowienie trwałego frontu na wszystkich lądowych granicach przeciwników i przerwanie wiodących ku ich terytoriom szlaków morskich. Ostateczna ofensywa przeciw Niemcom ruszyć miała dopiero po neutralizacji Włoch i zebraniu wystarczających dla takiego generalnego rozstrzygnięcia zasobów materiałowych ${ }^{26}$.

Dalsze uwzględnione w dyrektywach zagadnienia dotyczyły już kwestii bardziej szczegółowych. Stanowiły je kolejno: brytyjski korpus ekspedycyjny we Francji, ewentualny atak włoski na Korsykę, Tunezję i Egipt oraz takiż atak na położone nad Zatoką Adeńską Dżibuti, francusko-brytyjskie akcje w rejonie Pacyfiku, wreszcie powołanie przez obu zachodnich aliantów wspólnego dowództwa na czas wojny.

Do zawierającej dyrektywy noty załączona została tabela, w której zasadnicze treści przyporządkowane zostały poszczególnym departamentom Ministerstwa Obrony Narodowej i Wojny, a więc także „zespołom zagadnieniowym” przygotowywanych rozmów. Użyte $w$ tym zestawieniu sformułowania $z$ natury rzeczy miały charakter dość ogólny, żadne z nich nie odnosiło się wprost do ewentualnej współpracy z sojusznikami z Europy Srodkowo-Wschodniej. W przypadku sił powietrznych znaczenie dla tej kooperacji mogły jednak mieć takie spośród uwzględnionych $w$ tabeli zagadnień, jak szybkość przebazowania części brytyjskiego lotnictwa na obszar Francji, opracowanie wspólnego planu działań lotniczych przeciw Rzeszy czy też, uznany za kwestię opcjonalną, udział RAF-u w walkach lotniczych w północno-wschodniej części przyszłego zachodniego frontu ${ }^{27}$.

Niezwykle istotne wydają się jednak co najmniej dwie konstatacje dotyczące treści przygotowanych w Paryżu dokumentów. Po pierwsze, strona francuska konsekwentnie uznawała konieczność uczynienia nadchodzącego konfliktu wojną pro-

24 SHD-DAT, 5 N 579, „Note sur les accords...” z 7 III 1939 r.

25 Ibidem. Ta ostatnia ewentualność nie została uwzględniona w pierwotnej redakcji dyrektyw. Odpowiedni passus dopisany został odręcznie w maszynopisie przygotowanym przez płk. Aymé. Por. też: ibidem, analiza Sekcji Obrony Narodowej Ministerst wa Obrony Narodowej i Wojny z 8 III 1939 r. Wspomniany dokument, stanowiący faktycznie streszczenie dyrektyw przeznaczonych dla francuskiej delegacji, zawiera też wzmiankę o ich zaakceptowaniu przez gen. Gamelina.

26 SHD-DAT, 5 N 579, „Note sur les accords...” $z 7$ III 1939 r.

27 Ibidem, zestawienie „Questions pouvant faire l'objet d'accords d'États-Majors franco-anglais”, zal. do „Note sur les accords...” z 7 III 1939 r. Także: DDF, t. 14, doc. 275, s. 496nn. 
wadzoną przez Rzeszę na dwóch co najmniej frontach. Co więcej, twórcy dyrektyw zdawali się przekonani, że $\mathrm{w}$ roli filarów wschodniego frontu niezawodnie wystąpią Polska oraz sąsiadująca $z$ nią Rumunia. Najwyraźniej nie podzielali więc żywych w Londynie (a także, jak wiemy, w niektórych przynajmniej gabinetach z Quai d'Orsay) jeszcze dwa czy trzy tygodnie później obaw co do politycznego kursu, jaki obiorą władze z Warszawy. Po drugie zaś, założenia francuskiej strategii z pierwszej dekady marca 1939 roku przewidywały możliwość aktywnej, choć najpewniej ograniczonej interwencji na rzecz sojuszników ze wschodu. Można przy tym przypuszczać, że w tym czasie toczyły się w Paryżu jakieś poświęcone tej sprawie dyskusje. Pierwotna, przygotowana przez płk. Georges’a Aymé wersja dyrektyw nie zawierała bowiem fragmentu poświęconego wschodnim aliantom, jako strategiczne pryncypium wskazując jedynie oczywistą skądinąd konieczność budowy „solidnego frontu” na wszystkich dostępnych dla przeciwników granicach lądowych. Odpowiedni passus wprowadzony został, jako odręczny wtręt, dopiero $w$ trakcie prac nad finalną redakcją tekstu, a następnie powielony w późniejszych jego wersjach ${ }^{28}$. Zapoznanie się $\mathrm{z}$ treścią dyrektyw prowadzić też musi do wniosku, że francuscy rozmówcy płk. Slessora, zapewniając go o braku w Paryżu jakichkolwiek zamysłów aktywnej pomocy dla wschodnich aliantów, otrzymane dyspozycje potraktowali wybiórczo. Nie wyklucza to oczywiście możliwości, że swoistą „realną rzeczywistość" zaprezentowane przez nich stanowisko odzwierciedlało dokładniej niż zapisy dokumentu zaaprobowanego przez Gamelina i Daladiera.

Inaugurację międzysztabowych rozmów przewidywano początkowo na połowę marca. Termin ten jednak okazał się niemożliwy do dotrzymania. 11 marca ambasador Corbin powiadomił Bonneta o konieczności przesunięcia daty rozpoczęcia konferencji na późniejszy termin, po południu 14 marca oficjalne memorandum w tej sprawie wręczył Gamelinowi płk W. Fraser. Zwłokę motywowano koniecznością zakończenia prac nad przygotowywanym przez Brytyjczyków memoriałem dotyczącym strategii i ogólnej polityki prowadzenia wojny. Po jego przekazaniu stronie francuskiej, argumentowano, niezbędne będzie ustosunkowanie się doń przedstawicieli Paryża i sformułowanie przez nich własnego, uzupełniającego stanowiska, co też wymagać będzie czasu²9.

2* SHD-DAT, 2 N 228, „Accords d'État-Major. Projet de directives rédigé par le colonel Aymé".

${ }^{29}$ AD, Papiers 1940, Papiers Hoppenot 3, pismo No 93 Corbina do Bonneta z 11 III 1939 r. (opublikowane w: DDF, t. 14, doc. 307, s. 556n.); TNA, CAB 53/10, „Chiefs of Staff Sub-Committee. Minutes of the 278th Meeting, held on 2nd March 1939"; CAB 55/15, kopia pisma No 324 (167/G/25/39) do Halifaxa z 15 III 1939 r. wraz z tekstem załączonej noty (jej tłumaczenie na język francuski: SHD-DAA, 2 B 106) i kopią odpowiedzi Gamelina (No 494/DN.3 z 15 III 1939 r.). Ostatni z wymienionych dokumentów zawierał potwierdzenie zamiaru opracowania przez Francuzów własnego memorandum, które miało być następnie przekazane stronie brytyjskiej. Jednak przebadany bogaty materiał dotyczący podjętych rozmów nie zawierał takiego dokumentu ani jakichkolwiek wzmianek o jego przygotowaniu, zasadne wydaje się więc przypuszczenie, że do realizacji zapowiedzi nie doszlo. 
Trzy dni później Strategical Appreciation Sub-Committee, idąc za głosem Szefów Sztabów, wystąpił wręcz z koncepcją, by ze względu na konieczność dopracowania strategicznego memorandum oraz zmienioną przez "możliwość przyszłej niemieckiej agresji we wschodniej Europie" sytuację na kontynencie pierwsze spotkanie obu delegacji odłożyć na okres po przypadającej 9 kwietnia Wielkanocy. Ostatecznie jednak przeważyła argumentacja, że dłuższa zwłoka wywoła niezadowolenie Francuzów i spowoduje, iż tak istotne dla obu stron prace podjęte zostaną w złej od początku atmosferze. Wzgląd na zmienioną sytuację międzynarodową miał teraz posłużyć uzasadnieniu przyspieszenia spotkania - „dla uniknięcia dalszej straty czasu” ${ }^{30}$.

Zanim spotkali się przedstawiciele sił zbrojnych, o wojskowej kooperacji przyszło rozmawiać, zresztą nie po raz pierwszy w kontekście międzysztabowych kontaktów, brytyjskim i francuskim politykom. Właśnie do jednego z ostatnich spotkań o takim charakterze nawiązał Chamberlain po południu 22 marca, w końcowej fazie wspominanej już wyżej rozmowy z ministrem Bonnetem, podnosząc kwestię, jak z góry uprzedził, raczej delikatnej natury. Podczas wizyty złożonej przez brytyjskiego premiera w Paryżu w listopadzie 1938 roku szef francuskiego rządu zapowiedział mu, że lotniczy producenci znad Sekwany późną wiosną roku następnego będą w stanie zasilać miesięcznie siły powietrzne czterema setkami nowych samolotów. Przybysz znad Tamizy zareagował wówczas na tę zapowiedź zdumieniem. Teraz zaś uznał za stosowne ją przypomnieć, sugerując, że wszelkie dane wydają się wskazywać, iż jego ówczesna reakcja była w pełni zasadna.

Bonnet potwierdził obawy swego interlokutora, nie omieszkawszy zapewnić go uprzednio, że od początku wątpił w zasadność danych, które jesienią przekazano brytyjskiemu gościowi. Jak z ubolewaniem stwierdził, socjalne prawodawstwo z początków rządów Frontu Ludowego spowodowało radykalne obniżenie wydajności francuskiego przemysłu zbrojeniowego. Dokonane w tym zakresie korekty, wyjaśniał, zaczynają już przynosić rezultaty. Te jednak wciąż dalekie były od wcześniejszych założeń, wedle przedstawionych informacji w styczniu 1939 roku francuski przemysł lotniczy dostarczył tylko 100 maszyn, zaś dopiero „w lipcu lub sierpniu” powinno ich być „około 250 , albo 300 ”, co skądinąd nadal stanowiło poziom wyraźnie niższy od zapowiedzi Daladiera ${ }^{31}$. Bonnet wspomniał też o zapoczątkowanych przez Francuzów zakupach samolotów bojowych w Stanach Zjednoczonych. Nie zmniejszyło to wyraźnego rozczarowania Chamberlaina, który pod znakiem zapytania postawił walory nabywanych maszyn. Gość z Londynu mógł teraz dla kontrastu pochwalić się osiągnięciami własnych lotniczych producentów, którzy, jak stwierdzil, przezwyciężyli dotychczasowe trudności, osiągając zdolność produkcji „niemal 100 maszyn miesięcznie" ${ }^{32}$. Z kolei nieśmiałą sugestię Bonneta co do ewentualności dokonania

311 TNA, CAB 55/15, „Draft Conclusions of the 3rd Meeting of the Strategical Appreciation Sub-Committee" z 17 III 1939 r.; CAB 53/46, raport C.O.S. 861 (J.P.) z 22 III 1939 r.

3 DBFP, vol. 4, doc. 484, s. 462; DDF, t. 15, doc. 124, s. 171.

3 DBFP, vol. 4, doc. 484, s. 462; DDF, t. 15, doc. 124, s. 171. Dane Bonneta były nieco zawyżone, ale zasadniczo zgodne ze stanem faktycznym. Między l a 31 I 1939 r. francuskie zakłady 
przez francuskie siły powietrzne zakupów brytyjskich maszyn, premier rządu Jego Królewskiej Mości potraktował z dystansem, wyrażając wątpliwość co do istnienia możliwych do takiego zagospodarowania nadwyżek.

Ów wieńczący serię politycznych ustaleń lotniczy wątek spotkania przedstawicieli rządów obu zachodnich mocarstw, interesujący sam w sobie, stanowił, jak się wydaje, także swoistą ilustrację ich bardziej ogólnych relacji. Brytyjczycy okazywali się w nich zwykle lepiej przygotowani merytorycznie i bardziej pewni siebie, zręczniej też od swoich defensywnie nastawionych partnerów potrafili przejmować inicjatywę, wykorzystując zarówno własne atuty, jak i słabości drugiej strony. Niebawem, podczas międzysztabowych konferencji, okazać się miało, że podobne umiejętności nad Tamizą posiedli nie tylko politycy, ale i wojskowi. Dla wschodnioeuropejskich sojuszników Paryża nie była to dobra wiadomość.

W czasie gdy odbywała się przedstawiona wyżej wymiana zdań brytyjskiego premiera i francuskiego ministra spraw zagranicznych, przygotowania do rozmów przedstawicieli sił zbrojnych znajdowały się już w zaawansowanym stadium. Po południu 20 marca po raz kolejny stały się one przedmiotem obrad Joint Planning Sub-Committee. Rozważając kwestie merytoryczne, jego członkowie zwrócili m.in. uwagę, że zlecone im trzy dni wcześniej przez Strategical Appreciation Sub-Committee zadanie opracowania założeń planu brytyjsko-francuskiej akcji, która miałaby doprowadzić do wyeliminowania Włoch z wojny już w początkowej jej fazie, sformułowane zostało zapewne skutkiem nieporozumienia. Choć bowiem, zauważyli, założenia brytyjskiej strategii istotnie przewidują możliwość zadania Włochom nokautującego ciosu, to jednak nigdy nie postulowano uczynienia tego już w początkach konfliktu zbrojnego. Na morzu, lądzie czy w powietrzu nie są też w tym okresie przewidywane poważniejsze działania skierowane przeciw włoskim sprzymierzeńcom Rzeszy. Nie ma też wreszcie powodu przypuszczać, że takie działania byliby w stanie podjąć $w$ tej fazie wojny Francuzi. „Przeciwnie - konkludowali członkowie JPC - na ile możemy przewidywać, jest bardziej prawdopodobne, że francuskie wysiłki ograniczone by zostały do powstrzymywania Niemców oraz być może niewielkich ofensyw na froncie zachodnim"33.

lotnicze wyprodukowały 94 samoloty wojskowe, $z$ których dwa uległy wypadkom podczas prób odbiorczych. W tej ogólnej liczbie znalazły się jednak tylko 73 maszyny uznane za nowoczesne, a więc posiadające istotną wartość dla sił powietrznych. W sierpniu wykonać zdołano 232 samoloty, niemal spełniając przewidywania przekazane przez Bonneta Brytyjczykom (SHD-DAA,

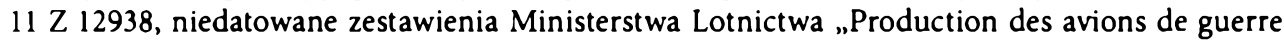
du 1 Janvier 1939 au 31 Janvier 1939 (inclus)”, „Production Août” i in. dok.). Por.: DDF, t. 15, doc. 223, s. 340. Na temat wzmiankowanej krytycznie przez Chamberlaina współpracy francuskich specjalistów przemysłu lotniczego z brytyjskimi kolegami: TNA, CAB 21/553, list ministra lotnictwa Howarda Kingsley-Wooda do lorda Chatfielda z 27 II 1939 r. Na temat francuskich zakupów w USA: J.M. Haight, Jr., op. cit.

13 TNA, CAB 55/3, „Minutes of the Meeting of the [Joint Planning] Sub-Committee held on 20th March, 1939...”; CAB 55/15, „Draft Conclusions of the 3rd Meeting of the Strategical Appreciation Sub-Committee" z 17 III $1939 \mathrm{r}$. 
W trakcie tegoż posiedzenia Podkomitet przyjął też wstępną wersję agendy zbliżających się rozmów ze stroną francuską. Zgodnie z wcześniejszymi uzgodnieniami obejmowała ona trzy etapy spotkań przedstawicieli obu sztabów. Pierwszy z nich, który rozpocząć się miał już niebawem, zamierzano poświęcić dyskusji na temat szeroko pojmowanej strategii, obejmując nią zagadnienia polityczne, ekonomiczne, porównanie sił, metody walki (jak np. zakres działań podwodnych i powietrznych czy użycie gazów bojowych), wreszcie opartą na przeprowadzonych analizach częściowych próbę generalnego podsumowania ${ }^{34}$. Przygotowany dokument miał charakter ramowy, a jego klarownie zestawiona treść znakomicie ułatwiała orientację w przyjętej przez brytyjskich sztabowców hierarchii strategicznych problemów. Kwestii związanych z Europą Wschodnią szukać należało w jego części II, dotyczącej operacji na poszczególnych teatrach działań przyszłego konfliktu. Wśród dziesięciu sekcji oraz licznych podpunktów region ów wspomniany został raz, w ostatnim, trzecim podpunkcie Sekcji VII („Teatr Europejski ogólnie”), zatytułowanym „Wojna we wschodniej Europie”. Nieporównanie szerzej potraktowano w "Agendzie” nie tylko przewidywania związane $z$ atakiem na macierzyste terytorium któregoś $z$ obu mocarstw, ale też kwestie działań w basenie Morza Sródziemnego, w Afryce Wschodniej czy na Bliskim i Dalekim Wschodzie. Powyższa uwaga jest o tyle istotna, że w treści "Agendy" nie wprowadzono już następnie żadnych istotnych korekt. Tym samym w następnych miesiącach to właśnie ona określać miała porządek dyskutowanych zagadnień, znacząco wpływając na cały przebieg rozmów ${ }^{35}$.

Partner z Paryża i tym razem postawiony został właściwie przed faktem dokonanym. Dopiero bowiem przed południem 27 marca brytyjska propozycja (teraz, w wersji francuskiej - „Ordre du Jour”) stała się przedmiotem obrad konferencji Szefów Sztabów, którym w trakcie spotkania towarzyszyli członkowie kierowanej nad Tamizę delegacji. Dość krótka, trwająca niewiele ponad godzinę dyskusja w zasadzie bez wyjątku dotyczyła jednak spraw basenu Morza Sródziemnego, Afryki Północnej oraz posiadłości zamorskich. Jedynie w ostatniej jej fazie gen. Gamelin zwrócił uwagę na konieczność obecności na kontynencie już od pierwszych dni ewentualnego konfliktu części brytyjskich eskadr myśliwskich. Miałyby one - wyjaśniał - podjąć zadanie osłony baz przerzucanych do Francji sił lądowych, umożliwiając równocześnie skierowanie części sił Armée de l'Air na południowy wschód, dla podjęcia operacji przeciw Włochom. Jednak gen. Lelong przedstawioną koncepcję uznał za bardzo

is TNA, CAB 55/3, „Minutes of the Meeting of the [Joint Planning] Sub-Committee held on 20th March, 1939....

3 Ibidem oraz: DDF, t. 15, doc. 274, s. 427, przyp. 1. Oczywiście problematyka Europy Wschodniej domyślnie uwzględniana być miała także na pierwszym etapie rozmów, w trakcie dyskusji na temat zagadnień politycznych (gdzie podstawę stanowić mial przypuszczalny podział na „państwa sojusznicze, przyjazne i inne") oraz przy okazji sporządzania bilansu sił. Jak już jednak wyżej wskazano, i w tych przypadkach Europie Wschodniej nie poświęcono wiele uwagi, samą Polskę traktując $z$ ostentacyjnym wręcz dystansem. W trakcie negocjacji poruszano także kilka kwestii $w$ agendzie nieuwzględnionych. Żadna $z$ nich jednak nie odnosiła się do spraw związanych z Europą Wschodnią. 
trudną do przeforsowania, zwracając uwagę, że strona brytyjska zamierza swe siły myśliwskie wykorzystać przede wszystkim do ochrony Londynu ${ }^{36}$.

Dopiero dzień później gen. Gamelin przetłumaczoną na język francuski „Agendę" („Ordre du Jour”) oficjalnie rozesłał Szefom Sztabów Generalnych. Do większości adresatów dokument trafił $w$ dniu następnym. Był to zarazem dzień inauguracji rozmów - przed ich zapoczątkowaniem żaden z odbiorców nie miał więc szansy uczynić zadość zawartemu w piśmie przewodnim życzeniu sformułowania uwag na temat treści otrzymanego materiału ${ }^{3 i}$.

Fakt ten uznać wypada za istotny dla analizy przebiegu rozpoczętych ostatecznie przed południem 29 marca w budynku War Office międzysztabowych rozmów ${ }^{38}$. Podkreślić bowiem warto raz jeszcze: pierwszy etap dyskusji zdominowany został przez zapisany w przygotowanej przez gospodarzy agendzie brytyjski punkt widzenia, a przybysze z Paryża mieli ograniczone możliwości zaproponowania tu własnych poprawek $-\mathrm{z}$ braku czasu na ich opracowanie. W zaistniałej sytuacji Francuzi zmuszeni zostali do postępowania o pół kroku za partnerami znad Tamizy. Gości z Paryża nie pozbawiało to, rzecz jasna, wpływu na przebieg rozmów, niewątpliwie jednak ograniczało ich inicjatywę - częściej zapewne w tych przypadkach, w których pozbawieni byli jednoznacznych dyrektyw lub też otrzymane dyrektywy uznali za wątpliwe ${ }^{39}$.

Sądzić można, że kwestie związane z udziałem w ewentualnej wojnie wschodnich sojuszników Francji zakwalifikowane zostały do którejś z tych ostatnich kategorii, a może nawet do obu równocześnie. Francuscy delegaci co prawda zastosowali się do otrzymanych dyrektyw i już w początkach obrad, po południu 29 marca zwrócili uwagę, że choć generalnie zgadzają się z przedstawioną przez stronę brytyjską analizą

36 SHD-DAT, 2 N 225, „Procès-verbal de la Réunion des Chefs d'État-Major Généraux de lundi 27 Mars 1939" z 29 III 1939 r. Na egzemplarzu znalazła się odręczna notatka gen. Jameta o zaaprobowaniu sprawozdania przez gen. Gamelina.

37 SHD-DAT, 2 N 228, „Note pour l'État-Major de l'Armée” No DN 572/D.N.3 z 28 III 1939 r. z załącznikiem. Egzemplarz przeznaczony dla Szefa Sztabu Generalnego Armée de l'Air: SHD-DAA, 2 B 106.

31 Przebieg rozmów, które potrwać miały do 4 kwietnia, znany jest stosunkowo dobrze strona francuska opublikowala dotyczący go raport mjr. Bailly'ego oraz sporządzone przez gen. Lelonga obszerne dossier konwersacji, problematyka ta była też niejednokrotnie podejmowana w literaturze. DDF, t. 15, doc. 254, s. 386; doc. 274 , s. $421 \mathrm{nn}$; N.H. Gibbs, op. cit., s. $667 \mathrm{nn}$.; M. Zgórniak, Europa w przededniu wojny..., s. 472nn. (niemal identyczna wersja także w: idem, Brytyjsko-francuskie kontakty sztabowe, próby opracowania wspólnej strategii $i$ utworzenia wspólnego dowództwa (1935-1939), [w:] W kręgu polityki, dyplomacji i historii XX wieku. Ksiega jubileuszowa profesora Waldemara Michowicza, red. B. Rakowski, A. Skrzypek, Łódź 2000, s. 215n.). Analizom poddawano też zarówno lotnicze aspekty ówczesnych brytyjsko-francuskich konferencji, jak i polski kontekst prowadzonych wich ramach dyskusji: P. Friden son, J. Lecuir, op. cit., s. $122 \mathrm{nn} ;$ A. Prazmowska, op. cit., s. 80nn.

39 "Francuski sztab, w opozycji do swoich polityków, całkowicie zgadzał się z nami co do faktu, że żadne z naszych państw nie może nic zrobić, by uratować Polskę" - komentował po latach Slessor (op. cit., s. 231). 
politycznego układu sił w spodziewanym konflikcie, to jednak Polska została w niej potraktowana zbyt surowo. Nastawienie tej ostatniej, podkreślili przedstawiciele Paryża, „może się zmienić”, w każdym zaś razie należy przyjąć, że będzie ona co najmniej dążyć do obrony swego terytorium ${ }^{40}$. Uwaga ta została odnotowana i przyjęta do wiadomości, nie wpływając jednak w żaden sposób na przebieg rozmów podczas kolejnych sesji, które toczyły się zgodnie z porządkiem zapisanym w „Agendzie”.

Do kwestii polskiej powrócono dopiero podczas piątej sesji, przed południem 31 marca, kilka godzin przed słynnym przemówieniem premiera Chamberlaina. W jej początkowej fazie przewodniczący delegacji brytyjskiej kmdr Danckwerts powrócił - zgodnie z porządkiem agendy - choć zapewne nieprzypadkowo, do sprawy podniesionej przez Francuzów dwa dni wcześniej, proponując, by ci ostatni przygotowali dokument, w którym przedstawiony byłby przypuszczalny efekt udziału w wojnie Polski jako sojusznika mocarstw zachodnich. Opracowanie takie wedle przedstawionego zamysłu mogłoby się stać podstawą dyskusji w kolejnej, drugiej fazie rozmów międzysztabowych. Generał Lelong niezwłocznie sugestię zaakceptował"'.

Ostatni dzień marca 1939 roku wyjątkowo zresztą obfitował w polskie akcenty o wojskowo-strategicznym charakterze. Tę datę nosi bowiem także przygotowany przez Sztab Generalny armii francuskiej komentarz do rozesłanego kilka dni wcześniej przez gen. Gamelina porządku obrad konferencji międzysztabowych. Dokument ten przybrał ostatecznie formę obszernej analizy, w której Francuzi, odmiennie niż Brytyjczycy, skupili się przede wszystkim na kwestiach związanych z Europą, rozważając polityczne, ekonomiczne i czysto wojskowe aspekty zaistniałej (a częściowo też - mogącej dopiero zaistnieć) sytuacji. W tym ostatnim przypadku powtórzone zostały znane już wyliczenia, wedle których w razie konfliktu stanowiące równowartość około 120 dywizji siły francusko-brytyjskie przeciwstawić by się musiały 250 dywizjom niemieckim i włoskim. Jedyny w zasadzie sposób, by choć w części zrównoważyć ten dramatyczny bilans, brzmiała również nienowa konkluzja, stanowiłoby włączenie do rachunku 110 dywizji polskich, rumuńskich i jugosłowiańskich. Stąd, stwierdzali autorzy analizy, na planie ogólnostrategicznym Francja i Anglia dążyć powinny:

40 TNA, AIR 9/112, "Comments and explanations on Part I of the Agenda (A.F.C. (J) 4-8)" A.F.C. (J) 18 z 29 III 1939 r.; wersja francuska: SHD-DAT, 2 N 228 i 7 N 3441 (opublikowany w: DDF, t. 15, doc. 374, s. 427nn., tekst protokołu z rozmów z 29 marca przywołany wyżej dokument wzmiankuje, nie zawiera jednak jego treści). Opatrzony tąż samą datą brytyjski dokument „European Theatre in general" (A.F.C. (J) 14) zawierał zapożyczoną z memorandum strategicznego tezę, że alianci nie mają możliwości, by pomóc zaatakowanym przez Rzeszę państwom Europy Wschodniej z wyjątkiem możliwej dywersji na lądzie i działań morskich (ibidem). Zapis ten został $w$ imieniu delegacji francuskiej zaakceptowany przez gen. Lelonga na czwartym posiedzeniu, wieczorem 30 marca - jak się wydaje bez wcześniejszej na ten temat dyskusji (SHD-DAT, 7 N 3441, „Procès-verbal...").

41 TNA, CAB 29/160, „Minutes of Fifth Meeting held in the War Office on March 31, 1939, at 10.45 hours". Wersja w języku francuskim: SHD-DAT, 7 N 3441 (publikacja: DDF, t. 15, doc. 274, s. 445). 
- do zmuszenia Niemiec [...] do prowadzenia wojny na dwóch frontach oraz określenia wspólnej polityki wobec państw wschodnich,

- do rozpatrywania konfliktu jako długotrwałego w sposób umożliwiający utworzenie koalicji,

- dla skutecznego wsparcia frontu wschodniego, do ustalenia z nim komunikacji lądowej i morskiej oraz likwidacji Włoch w razie konieczności [...].

I podkreślali, że „utrzymanie w Europie Wschodniej frontu tak aktywnego, jak to tylko możliwe, jest konieczne"42.

Przedstawione $\mathrm{w}$ tymże dokumencie założenia o charakterze czysto wojskowym przewidywały, że w pierwszej fazie nadchodzącego konfliktu utworzony zostanie w Europie Zachodniej solidny front, zapewniający możliwości strategicznego manewru o charakterze defensywnym - jako podstawa do dalszych operacji. Równocześnie w Europie Wschodniej miałaby powstać koalicja, która unieruchomiłaby część sił niemieckich i uniemożliwiła Rzeszy dostęp do strategicznie ważnych surowcowych zasobów regionu - ropy i pszenicy. W fazie drugiej koncentracja środków na zachodzie oraz utrwalenie przymierza państw wschodnich umożliwić by miały przejście aliantów do prób pobicia Włochów w Afryce i na kontynencie europejskim (co otworzyłoby drogę dla kierowanych na wschód dostaw broni i amunicji), a następnie ich zwrot ku Niemcom ${ }^{43}$.

$\mathrm{Na}$ bieg toczących się właśnie $\mathrm{w}$ Londynie rozmów tak sformułowane stanowisko nie wywarło jednak zapewne wpływu. Ich pierwszy etap z wolna zmierzał ku końcowi, zaś rozważania na temat Polski i wschodniego frontu jego uczestnicy zdecydowali się zawiesić do czasu przepracowania odpowiednich kwestii przez stronę francuską ${ }^{44}$.

Ten brak pośpiechu nie powinien był zaskakiwać. W stanowiącym punkt wyjścia prezentowanego przez gospodarzy stanowiska strategicznym memorandum Rzeczpospolitej nie przypisano, przypomnijmy raz jeszcze, żadnej istotnej roli, a wśród najbardziej pożądanych wschodnich partnerów Londynu wzmiankowano Ankarę, nie Warszawę. Włączenie Rzeczpospolitej do sporządzanych nad Tamizą kalkulacji, zresztą raczej w ich politycznym niż wojskowym wymiarze, było sprawą kilku ostatnich dni - do 31 marca pozbawioną jednoznacznego finału. Dyrektywy strony francuskiej przewidywały co prawda $\mathrm{w}$ razie zagrożenia wschodnich sojuszników

12 SHD-DAT, 2 N 228, „Avis de l'État-Major de l'Armée concernant l'Ordre du Jour transmis le 28 Mars 1939 sous No 572/D.N/3".

13 Ibidem. Powyższa koncepcja stanowiła rozwinięcie i uszczegółowienie zamysłu, który jeszcze w początkach marca sformułowano w "Note sur la collaboration franco-britannique" (z 2 III 1939 r., ibidem).

14 Do kwestii dotyczących „ewentualnego udziału w wojnie Polski i innych państw europejskich" nawiązano raz jeszcze 4 kwietnia, podczas ostatniej, ósmej sesji rozmów. I wtedy jednak ich uczestnicy uchylili się od prób podjęcia analizy tego zagadnienia. Kmdr Danckwerts zwrócił się tylko do delegacji francuskiej o przygotowanie dla potrzeb kolejnej, drugiej fazy konwersacji międzysztabowych studium wojskowych możliwości Polski i państw Europy Południowo-Wschodniej (DDF, t. 15, doc. 274, s. 461). 
(za których, podkreślić wypada, Paryż uważał głównie Polaków i Rumunów, a nie Turków) możliwość ograniczonych działań ofensywnych o dywersyjnym zasadniczo charakterze. Z tych koncepcji jednak partner brytyjski zdawał sobie już wcześniej sprawę, nie sygnalizując bynajmniej zamiaru własnego udziału $w$ ich realizacji. Zagadnieniom praktycznej wojskowej współpracy poświęcone miały być zresztą kolejne fazy rozmów - w ich pierwszym stadium Francuzi poprzestali przeto jedynie na zasygnalizowaniu, że w ogólnym strategicznym planie rolę Polski postrzegają nieco odmiennie od przedstawicieli Londynu ${ }^{45}$.

Choć jednak z punktu widzenia uczestników konferencji międzysztabowej wschodni front stanowił wciąż konstrukt bardziej wyimaginowany niż realny, to kilka rozważanych przez nich kwestii miało mieć na przyszłą kondycję tego frontu wpływ trudny do przecenienia. W grupie tej znalazły się m.in. zagadnienia dotyczące działań lotniczych. To one bowiem stanowiły jedyną w zasadzie dziedzinę, w której wspólny wysiłek Francuzów i Brytyjczyków wywrzeć mógł realny i stosunkowo szybki wpływ na wojskowe operacje podjęte przez Rzeszę we wschodniej części kontynentu.

By jednak tak się stało, podjęta akcja musiałaby być możliwie niezwłoczna i prowadzona energicznie. Tymczasem już u progu rozmów strona brytyjska uznała za konieczne zastrzec, że "nie jest częścią naszej narodowej polityki inicjowanie ataków powietrznych przeciw celom, które musiałyby pociągnąć za sobą ofiary wśród ludności cywilnej nieprzyjaciela"46. Oznaczało to poważne ograniczenie zakresu branych pod uwagę operacji - i nie mogło pozostać bez wpływu na ich efektywność.

Uznanie wspomnianej akcji za wartą rozważenia zależało zaś nade wszystko od przyjętych scenariuszy przyszłego konfliktu wojennego. Już jednak przed rozpoczęciem rozmów obie strony uznały, że główne (a może wręcz - jedyne) niemieckie uderzenie skierowane zostanie na zachód. W tej sytuacji podjęte rozważania na temat operacji lotniczych ograniczone zostały przede wszystkim do działań defensywnych, solidarnie realizowanych przez siły powietrzne obu mocarstw, bez jakichkolwiek odniesień do Europy Wschodniej ${ }^{47}$.

45 Delegacja francuska w myśl otrzymanych dyrektyw podkreśliła, że Rzesza prawdopodobnie będzie zdolna wykorzystać do operacji na Zachodzie całość swych sił, „jeśli nie zostaną one poważnie zaangażowane przez naszych sojuszników w Europie Środkowej". TNA, WO 193/197, "Allied reply to a German and Italian offensive against France", A.F.C. (J) 20 z 30 III 1939 r. Przywołany dokument stanowił tłumaczenie tekstu dostarczonego przez Francuzów w odpowiedzi na brytyjskie opracowanie A.F.C. (J) 11.

46 TNA, CAB 29/159, „Decisions governing the conduct of the conversations by the British delegation", A.F.C. 2 z 24 III 1939 r. Stronie francuskiej tezę tę przedstawiono w datowanym 30 marca dokumencie "Broad strategic policy for the conduct of the war” (A.F.C. (J) 19), dodając jednak, że "utrzymanie takiej sytuacji przez dłuższy czas jest mało prawdopodobne" (TNA, WO 193/197). Tegoż dnia na czwartym posiedzeniu przyjęto, iż sojusznicy nie podejmą jako pierwsi działań lotniczych przeciw obiektom, „które nie byłyby ściśle wojskowe w najwęższym sensie tego terminu", i wstrzymywać się będą od ataków mogących spowodować ofiary wśród ludności cywilnej (SHD-DAT, 7 N 3441).

47 Przeciwnie - Brytyjczycy podkreślali, że ich powietrzne siły uderzeniowe są „podstawowym komponentem obrony powietrznej naszego kraju i początkowo musiałyby być użyte głównie 
Na sugestie Francuzów, by zawczasu rozważyć także przejście do akcji o charakterze ofensywnym, Brytyjczycy odpowiedzieli koncepcją uderzenia $z$ powietrza na niemieckie zasoby paliw płynnych oraz wytwarzające te paliwa zakłady. Strona francuska z kolei, szczególnie zainteresowana możliwie wczesnym wyeliminowaniem $\mathbf{z}$ wojny Włoch, zaanonsowała zamiar podjęcia ofensywy powietrznej przeciw temu państwu i jego posiadłościom, niedwuznacznie dając do zrozumienia, że skala tej akcji zależeć będzie w dużej części od wielkości sił brytyjskich, szczególnie myśliwskich, które w północno-wschodniej części kraju zastąpić by mogły kierowane przeciw Italii jednostki Armée de l'Air. Wobec niechętnej postawy przedstawicieli gospodarzy 31 marca, na piątym posiedzeniu zdecydowano o przekazaniu szczegółów tego ostatniego problemu do dalszych studiów ${ }^{48}$.

W sferze lotniczej Brytyjczycy nie mieli zresztą zbytnich powodów do satysfakcji. $\mathrm{Z}$ jednej strony zasypani zostali trudnymi często do zaakceptowania apelami o pomoc, $z$ drugiej - mieli okazję przekonać się, że mimo zachowania ostrożności i tak przeszacowali realny potencjał Armée de l'Air. Jak bowiem wyjaśnili im już na początku londyńskich rozmów przybyli znad Sekwany oficerowie, choć zapisana w sporządzonych w Londynie dokumentach liczba 466 samolotów myśliwskich, którymi w metropolii rozporządzać miała strona francuska, zgodna była z rzeczywistością, to wśród owych maszyn jedynie 360 stanowiły myśliwce pierwszej linii. Pozostałe 106 samolotów należało do pomocniczych eskadr regionalnych (Escadrilles Régionales de Chasse), przeznaczonych do obrony lokalnej, a więc dla potrzeb przyszłego frontu właściwie nieużytecznych ${ }^{49}$.

Najistotniejsza jednak dla perspektyw wojskowej współpracy z państwami ze wschodniej części kontynentu okazała się przyjęta w trakcie londyńskich rozmów, a następnie zaaprobowana przez obie delegacje ogólna koncepcja wojennej strategii. Jak przekonywali delegaci brytyjscy, w razie wojny sojusznicy postawieni zostaną wobec przeciwników posiadających przewagę w powietrzu oraz na lądzie, ustępujących im jednak na morzu i pod względem potencjału ekonomicznego. W pierwszej fazie konfliktu muszą być przygotowani do odparcia skierowanej przeciw nim potężnej

w celu zmniejszenia skali ataków powietrznych nieprzyjaciela na nasz kraj i Francję". TNA, AIR 9/112, „Broad strategic policy..., A.F.C. (J) 19.

4" SHD-DAT, 7 N 3441, „Procès-verbal de la deuxième séance, 29 mars 1939 - 16 heures”, „Procès-verbal de la troisième séance, 30 Mars 1939 - 10 h. 30” (też: DDF, t. 15, doc. 274, s. 437) i nast. dok.; TNA, CAB 29/160, „Employment of British and French Air Forces (Reference Minutes od 2nd Meeting)", A.F.C. (J) 24 sekretarza delegacji brytyjskiej L.C. Hollisa z 31 III 1939 r.; AIR 9/112, "General appreciation of the problem of an offensive against Italy", A.F.C. (J) 23 z 31 III 1939 r. (tłumaczenie materiału dostarczonego przez delegację francuską); C. Webster, N. Fran kland, Strategiczna ofensywa powietrzna przeciwko Niemcom, t. 1: Przygotowania, Oświęcim 2015, s. 114n., $D W S, 16$. Na temat nastawienia strony brytyjskiej do francuskich postulatów zob. też: J. Slessor, op. cit., s. 231 n. oraz P. Fridenson, J. Lecuir, op. cit., s. 125nn.

19 TNA, AIR 9/112, „Comments and explanations on Part I of the Agenda..." z 29 III 1939 r. Ogólne rezultaty osiągnięte $w$ kwestiach poświęconych współpracy lotniczej streścił mjr Bailly: DDF, t. 15, doc. 224, s. 288nn. 
ofensywy. Konieczność skoncentrowania się na realizacji tego nadrzędnego zadania wymusić musi zastosowanie przez nich w tym okresie strategii defensywnej. Dopiero w następnych etapach, wciąż powstrzymując niemiecki nacisk, sprzymierzeni winni stopniowo przyjmować nastawienie bardziej ofensywne - decydującą ofensywę przeciw Rzeszy podejmując dopiero po pokonaniu jej włoskiego sojusznika i pełnej rozbudowie swych sił ${ }^{50}$.

Koncepcja przedstawiona przez Francuzów okazała się w ogólnych zarysach zbliżona. Ułatwiło to osiągnięcie generalnego porozumienia w tej kwestii, którego kolejne redakcje przedstawiano 3 i 4 kwietnia, wykorzystując w nich przede wszystkim zapisy dokumentów brytyjskich. We wszystkich wersjach końcowej konkluzji wyliczenie silnych i słabych stron bloków mocarstw, które miały być zaangażowane w wojenny konflikt, oraz podsumowująca je uwaga, że czas pracuje na rzecz koalicji brytyjsko-francuskiej, prowadziły do ogólnego wniosku o trudnym do przecenienia znaczeniu: „Anglo-francuska strategia powinna być więc przystosowana do długiej wojny, co pociąga za sobą:

(1) Defensywną strategię $w$ fazie początkowej, przynajmniej na kontynencie [...],

(2) Rozbudowę potencjału militarnego do punktu, w którym będziemy mogli przyjąć strategię ofensywną"51.

Podkreślić trzeba koniecznie, że przyjęta zasada nie stanowiła żadnej nowości: w początkach wojny Brytyjczycy działań ofensywnych na większą skalę prowadzić z braku sił nie mogli, Francuzi prowadzić ich nie zamierzali. Strategiczna defensywa nie przekreślała też automatycznie perspektywy francuskich uderzeń dywersyjnych, które odciążyć by miały znajdujących się w opresji sojuszników ze wschodu. Przewidywany na stosunkowo wczesnym etapie wojny zwrot zaczepny przeciw Włochom w razie powodzenia udrożnić mógł też wiodące ku owym sojusznikom szlaki komunikacyjne, choć $w$ taki sposób uzasadniać go tu akurat nie próbowano.

Udział $w$ rozpatrywanym konflikcie państw Europy Srodkowo-Wschodniej i Południowo-Wschodniej został zresztą w dokumencie całkowicie pominięty, choć przecież jedna $z$ układających się stron posiadała $w$ regionie wciąż formalnie aktywne alianse. Taka postawa Francuzów wzbudziła nawet, jak wiemy, pewne zdziwienie po stronie ich brytyjskich partnerów, konstatujących wyraźny rozdźwięk między wojskowym i politycznym segmentem poczynań Paryża. Równocześnie jednak, jak sądzić można, ułatwiło to osiągnięcie finalnego porozumienia.

Problem, zamieciony $w$ ten sposób pod dywan, istnieć jednak przecież bynajmniej nie przestał. Zdawali sobie $z$ tego sprawę, rzecz jasna, także uczestnicy za-

51) TNA, AIR 9/112, „Broad strategic policy..., A.F.C. (J) 19; WO 193/197, „Allied reply to a German and Italian offensive..., A.F.C. (J) 20 z 30 III 1939 r. Podobnie sformułowane obszerne stanowisko francuskie: TNA, AIR 9/112, „The strategical problem considered as a whole for the conduct of the war", A.F.C. (J) 27 z 31 III 1939 r.

51 TNA, AIR 9/112, "Conclusions on the Broad Strategic Policy for the conduct of war", A.F.C. (J) 27 z 3 IV 1939 r., A.F.C. (J) 28 oraz A.F.C. (J) 29 z 4 IV 1939 r. (także: DDF, t. 15, doc. 274 , s. 464 nn.). 
kończonych 4 kwietnia rozmów ${ }^{52}$. Datowany dzień później dokument zawierający sugerowaną agendę kolejnego ich etapu otwierała sekcja opatrzona tytułem „Nowe hipotezy" oraz umieszczona w pierwszym jej akapicie, wyróżniona kursywą fraza: Sojusz z Polską. Pytanie brzmiało: jak wpasować tę „nową hipotezę" we właśnie wzniesioną konstrukcję?53

${ }^{52} \mathrm{~W}$ datowanym 4 kwietnia piśmie A.F.C.6 Hollisa znalazła się informacja, że premier oraz szefowie resortów spraw zagranicznych i koordynacji obrony uzgodnili, iż delegaci brytyjscy „powinni przedyskutować z delegacją francuską możliwość, że Polska i Rumunia będą po naszej stronie". Za podstawę tej dyskusji służyć miała ukończona dzień wcześniej finalna wersja raportu Szefów Sztabów „Military implications of Anglo-French guarantee of Poland and Roumania” (TNA, CAB 29/159, C.O.S. 872 Revise). Właśnie to polecenie spowodowało zapewne wzmiankowaną już wyżej próbę podjęcia przez Brytyjczyków tej kwestii podczas ostatniej, ósmej sesji rozmów.

${ }_{53}$ TNA, CAB 29/159, „Suggested Agenda for further discussions”, A.F.C. (J) 30 Hollisa $z 5$ IV 1939 r. Wersja w języku francuskim: SHD-DAT, 7 N 3441. 



\section{Rozdział 4}

\section{„Nowa hipoteza”}

Decyzje, które zapadły w Londynie w ostatnich dniach marca, miały charakter polityczny, zaś ich autorzy przedstawione im oceny wojskowych doradców po prostu zlekceważyli, w zaistniałej sytuacji uznając je za relatywnie mało istotne. Teraz jednak to szefowie sił zbrojnych musieli powstały w ten sposób nowy stan rzeczy przeanalizować i ująć go w ramy planów przygotowywanych na wypadek, gdyby cywile popełnili jednak błąd $w$ swych rachunkach. Jak wskazano w poprzednim rozdziale, sztabowcy nie od razu objęli tworzoną koncepcją całość właśnie krystalizującej się sytuacji, perspektywę uwzględnienia niektórych jej elementów traktując z wyraźną niechęcią. Jednak pochylenia się nad „nową hipotezą" polskiego sojusznika uniknąć nie było sposobu.

Pierwsze próby tej analizy podjęto niejako „z marszu”, kontynuując projekty zapoczątkowane w minionej jeszcze rzeczywistości, przed 31 marca 1939 roku. Tak uczyniono w Londynie, gdzie Szefowie Sztabów wciąż prowadzili prace nad raportem zatytułowanym „Military Implications of Anglo-French Guarantee to Poland and Rumania", którego przygotowanie zlecił im lord Chatfield.

Jak wiadomo, wstępna redakcja tego dokumentu ukończona została 28 marca, a dwa dni później zleceniodawca wykorzystał niektóre z zawartych $\mathrm{w}$ niej tez $\mathrm{w}$ dyskusji na posiedzeniu Gabinetu, przyczyniając się do decyzji o udzieleniu Rzeczypospolitej brytyjskich gwarancji. Wersja finalna pojawiła się jednak dopiero 3 kwietnia, jako raport C.O.S. 872 Revise. Wydarzenia, które miały miejsce w międzyczasie, spowodowały istotne zmiany w treści tego materiału, wpływając także na silniejsze zaakcentowanie obaw już wcześniej wyrażanych przez autorów dokumentu. Teraz stwierdzali oni wprost, w tonie wręcz alarmującym: „uzależniamy kwestię pokoju czy wojny z Niemcami od działań rządów, nad którymi nie mamy kontroli, i to w czasie, w którym nasz program obrony jest daleki od ukończenia"'.

1 TNA, CAB 53/47, „Military Implications of an Anglo-French Guarantee to Poland and Rumania" z 3 IV 1939 r. Odpowiedni fragment wcześniejszej redakcji cytuje S. Newman (op. cit., s. 195), opatrując go jednak błędnie datą i numerem kancelaryjnym wersji finalnej. Zob. też: A. Prazmowska, op. cit., s. 81 n. 
Zaprezentowana następnie analiza sił Polski i Rumunii jako filarów ewentualnego wschodniego frontu ${ }^{2}$ powtarzała $w$ znacznej mierze informacje i wnioski cząstkowe zawarte we wcześniejszej redakcji. Pojawiło się jednak kilka bardzo istotnych różnic. Tak np. sformułowana uprzednio teza o przewidywanej wobec dysproporcji sił krótkotrwałości polskiego lotniczego zagrożenia dla wschodnich obszarów Rzeszy w wersji $z$ początków uzupełniona została teraz znamiennym dodatkiem: „[...] chyba że ZSRR byłby gotów wesprzeć Polaków samolotami i pilotami, tak jak uczynił to z byłym rządem hiszpańskim"3.

W nowy sposób kreślono też teraz zależności między spodziewanymi działaniami na wschodzie i zachodzie kontynentu. Skoro ewentualna wojna na dwa fronty wymagać będzie od Niemiec wyjątkowego natężenia sił, stwierdzali Szefowie Sztabów, to $w$ razie skierowania głównego uderzenia przeciw Polsce i Rumunii alianci zachodni „winni wywrzeć na Niemcy wszelką możliwą presję, na morzu, lądzie i w powietrzu". W takiej sytuacji trudno co prawda spodziewać się spektakularnego sukcesu w działaniach przeciw Linii Zygfryda, ale dzięki „wewnętrznej sytuacji Niemiec, rozproszeniu ich wysiłków i nadwyrężeniu programu zbrojeń" w dłuższej nieco perspektywie liczyć można na efektywność podjętych akcji i ostateczny sukces.

Gdyby natomiast na Wschodzie Niemcy przyjęli strategię defensywną, to wobec konieczności pozostawienia tam pewnej liczby jednostek ich siły okażą się zapewne zbyt wątłe dla sforsowania Linii Maginota - powtarzano wcześniej już przedstawioną tezę. W takim przypadku - tu w rozważaniach znów pojawiały się nowe elementy - Rumuni nie byliby zapewne w stanie zrobić czegokolwiek, oprócz pozbawienia Rzeszy dostępu do swych surowców i ściągnięcia na siebie kilku niemieckich czy węgierskich dywizji. Natomiast Polska mogłaby podjąć ofensywę w niemieckiej części Śląska, na Słowacji lub może w Prusach Wschodnich, łagodząc tym samym nieco nacisk na Francję i Wielką Brytanię̧4.

Wnioski końcowe dokumentu trudno określić jako spójne. $Z$ jednej strony jego autorzy raz jeszcze zwracali uwagę, że ani Wielka Brytania, ani Francja nie będą w stanie udzielić Polsce i Rumunii jakiejkolwiek bezpośredniej pomocy ani nawet „w obecnym stanie" swej produkcji zbrojeniowej zapewnić wschodnim sprzymierzeńcom dostaw uzbrojenia. To uwydatnia, podkreślano, znaczenie pomocy ze strony ZSRR. Równocześnie jednak, jak już wyżej zauważono, zachodni sojusznicy na niemiecki atak na wschód i bierność Rzeszy na zachodzie zareagować mieli „wszelką możliwą presją", obejmującą także - jak pośrednio, ale dość wyraźnie wynikało

${ }^{2} \mathrm{~W}$ obu redakcjach zwrócono jednak uwagę (za drugim razem $\mathrm{z}$ większym jeszcze nawet naciskiem), że w wyjściowych założeniach zleconego przez lorda Chatfielda zadania pominięta została Turcja, mimo jej „wielkiego znaczenia jako alianta w razie wojny z Niemcami i Włochami”.

3 TNA, CAB 53/47, „Military Implications..." z 3 IV 1939 r.

4 Ibidem. Jak podkreślali autorzy analizy, ofensywa w Prusach Wschodnich byłaby bardzo trudna i kosztowna dla nacierających ze względu na fortyfikacje i warunki terenu. Polska armia, oceniano, nie jest wyposażona wystarczająco dla pomyślnej realizacji podobnego przedsięwzięcia. $\mathrm{Za}$ bardziej prawdopodobne uważano więc ograniczone działania ofensywne na uprzemysłowionych obszarach Sląska i Moraw. 
z przedstawionego wywodu - próby sforsowania Linii Zygfryda. Wreszcie, deklarując „niemożność" pomocy dla Polski i Rumunii, Szefowie Sztabów proponowali... podjęcie rozmów w celu koordynacji wojennych planów członków powstającej właśnie koalicji, zadaniem tym zresztą proponując obciążyć głównie "posiadających znaczące doświadczenia" w kontaktach ze wspomnianymi narodami Francuzów

Trudno przeceniać znaczenie przedstawionej wyżej analizy. Już 4 kwietnia jej treści oficjalnie uznane zostały bowiem za podstawę dyskusji, którą na temat możliwego udziału w wojnie po stronie aliantów Polski i Rumunii przeprowadzić miała z francuskimi partnerami brytyjska delegacja na rozmowy międzysztabowe ${ }^{6}$.

Niewiele wiemy o szczegółach toczonych na temat tych treści dyskusji. Jedyny odnaleziony przez autora komentarz dotyczył jednak kwestii ściśle związanych $z$ tematyką naszej analizy: scenariusza, w którym pierwszy impet niemieckiego uderzenia skierowany by został ku Polsce i brytyjskiej akcji lotniczej.

Pułkownik Slessor - bo to on był autorem wspomnianego dokumentu - rozważania rozpoczął od przypomnienia najważniejszej jego zdaniem z poczynionych przez Szefów Sztabów konkluzji o niemożności udzielenia wschodnim sojusznikom bezpośredniej pomocy "na morzu, lądzie i w powietrzu" w razie niemieckiej agresji. Na lądzie Szefowie Sztabów nie spodziewają się szybkiego i spektakularnego sukcesu ataku na Linię Zygfryda, stwierdził, zaś „ostatnie rozmowy z Francuzami w pełni potwierdzity ten pogląd". Ci ostatni wyrażali w nich zdanie, iż front zachodni zatrzyma jednak około 30-35 niemieckich dywizji.

Presję wywieraną na morzu Slessor uznał za oczywiście skuteczną, zapowiadając natychmiastowe jej zapoczątkowanie. Jasne było jednak, że nawet $w$ takim przypadku do odczuwalnego drenażu niemieckich zasobów przyczyniać się będzie ona jedynie stopniowo?.

Jak już jednak wspomniano, zdecydowanie najobszerniejsza część opracowania Slessora poświęcona została działaniom powietrznym. W tym przypadku, zauważał jego autor, Brytyjczycy mogą podjąć ofensywę natychmiast. Jednak zakres ich operacji w początkowej fazie wojny może być skromny, szczególnie jeśli Niemcy nie podejmą w Polsce nieograniczonej wojny powietrznej. Co więcej, sojusznicy zachodni zdążyli właśnie ustalić, że swe ataki lotnicze ograniczą do obiektów czysto wojskowych - i to w najściślejszym tego słowa znaczeniu, zaś trudno spodziewać się, że tak zakrojone działania wywrą większe wrażenie na Niemcach. Mogą jedynie

Ibidem.

6 TNA, CAB 29/159, pismo A.F.C. 6 sekretarza delegacji brytyjskiej L.C. Hollisa.

"TNA, AIR 75/6, niedatowany maszynopisowy brulion opracowania „Action to assist Poland if Germany attacks in the East and holds in the West. Explanatory note". Do innego egzemplarza tego dokumentu (TNA, AIR 20/203) załączona została odręczna notka Slessora z informacją, że odnosi się on do spraw dyskutowanych z Szefem Sztabu Lotnictwa „ostatniej nocy”. Notki nie datowano, jednak dopiski kolejnych jej czytelników nosiły daty 18 i 22 V 1939 r. Wydaje się więc, że stanowisko Slessora sformułowane zostało $w$ związku z podjętymi przezeń wówczas zabiegami na rzecz wykorzystania terytorium Polski dla brytyjskich operacji bombowych przeciw celom we wschodnich Niemczech. To ostatnie zagadnienie przedstawione zostanie w dalszej części książki. 
spowodować rozproszenie ich obrony przeciwlotniczej, zaś ich nieuchronna kontrakcja na Zachodzie zmniejszy nieco nacisk na Polskę. Oczywiście, kontynuował Slessor, zapewne $\mathrm{z}$ czasem zakres ataków Luftwaffe ulegnie poszerzeniu. Wtedy lotnictwo brytyjskie zaatakuje nowe kategorie celów - jak przemysł w Zagłębiu Ruhry, zbiorniki paliw płynnych czy zakłady niemieckiego przemysłu lotniczego. Jednak i te akcje, bardziej efektywne i dla Niemców bardziej już bolesne, zapewne nie będą miały „żadnego natychmiastowego materialnego efektu redukującego nacisk na Polskę". Slessor wyraził zresztą przekonanie, że wobec faktu, że brytyjskie lotnicze siły uderzeniowe oraz obrona przeciwlotnicza są słabsze od niemieckich odpowiedników, „oni mogą wywrzeć na nas bardziej efektywną presję, niż my możemy na nich"в.

Co istotne jednak, autor opracowania nie zalecał bynajmniej w tej sytuacji biernej, wyczekującej postawy. Wręcz przeciwnie, przyznawał, że brytyjskie kierownictwo może stanąć wobec "niemiłej decyzji” podjęcia wojny powietrznej na Zachodzie mimo "moralnej pewności” natychmiastowego odwetu i bombardowania Londynu „oraz innych centrów ludności”. Niemniej jednak, podkreślał, „gdy znajdziemy się w wojnie, nie możemy mieć nadziei, że Anglia nie będzie bombardowana". W dodatku pewność niemieckich bombardowań niechybnie zwiększy się, ,jeśli pozwolimy na upadek Polski, nie podejmując akcji na drugim z niemieckich dwóch frontów, a potem znajdziemy się w obliczu ataku pozbawieni trwającego na Wschodzie alianta".

Jak stwierdzał Slessor w podsumowaniu, ze względu na światową opinię Brytyjczycy nie mogą odstąpić od zasady ograniczenia powietrznych uderzeń wyłącznie do obiektów wojskowych. Wyklucza to ${ }_{2}$ w początkowej fazie” [podkr. oryg. - W.M.] ataki na cele najważniejsze z punktu widzenia wojennego wysiłku Rzeszy, jak Ruhra czy przemysł lotniczy. Stopniowo jednak zakres powietrznych działań powinien być rozszerzany, obejmując właśnie zakłady lotnicze, bazy morskie, a także „armie niemieckie trzymające Linię Zygfryda". Do realizacji takiego scenariusza należy się z góry przygotować - nie tylko w sferze czysto wojskowej. Także propaganda brytyjska powinna być zdolna do natychmiastowego wyjaśnienia opinii przyczyn podjęcia kontrataku na Niemcy ${ }^{10}$.

W przedstawionej analizie bardzo wyraźnie przebijała więc niezwykle charakterystyczna dla ówczesnej postawy wojskowych elit Zachodu ambiwalencja: uznanie właściwie a priori za fakt dowiedziony niemożności pomocy dla zaatakowanej Polski ścierało się z przekonaniem, że pozostawienie jej własnemu losowi byłoby nie tylko niemoralne, ale przede wszystkim nierozsądne z punktu widzenia własnych interesów.

Nie wiadomo niestety, gdzie trafiła ostatecznie nota Slessora i jakie wywołała reakcje. Główny nurt prowadzonych w tym czasie w Londynie prac dotyczył podsumowania pierwszej tury rozmów podjętych ze stroną francuską oraz przygotowań do planowanej niebawem tury następnej. Sprawy "nowej hipotezy” polskiego sojusznika

\footnotetext{
Ibidem.

ฯ Ibidem.

11) Ibidem.
} 
nie zajmowały w niej jednak wiele miejsca - zgodnie z ustaleniami Brytyjczycy sporządzenie odpowiednich analiz pozostawiali w gestii Francuzów. Szefowie Sztabów na posiedzeniu swego podkomitetu 12 kwietnia przeanalizowali, a następnie zaaprobowali przedłożony im raport delegacji brytyjskiej, powierzając jej sporządzenie krótkiego memorandum, w którym uwzględnione by zostały tezy ich raportu z 3 kwietnia (C.O.S. 372) oraz odpowiednie poglądy Foreign Office ${ }^{11} .17$ kwietnia Strategical Appreciation Sub-Committee rozpatrzył uzupełniony o komentarze Szefów Sztabów raport z I tury konwersacji międzysztabowych oraz przedłożoną mu notę Foreign Office, dążąc do sformułowania podstaw „nowych hipotez politycznych” dla kolejnej fazy tych rozmów. Na posiedzeniu zaaprobowano raport brytyjskiej delegacji oraz wspomniane wyżej nowe hipotezy'2.

18 kwietnia na posiedzeniu Joint Planning Sub-Committee przedyskutowano treści memorandum, które opracowane zostało w ramach realizacji polecenia Podkomitetu Szefów Sztabów z 12 kwietnia, przekazując je następnie zleceniodawcom ${ }^{13}$. W dokumencie tym, choć jego autorzy do listy sojuszników w spodziewanej wojnie dopisali Polskę i Turcję (dodając: „choć niekoniecznie we wszystkich okolicznościach" [podkr. oryg. - W.M.]), w praktyce uwzględniona została jedynie ta ostatnia. Polski nie wymieniono nawet przy okazji analizy postawy ZSRR (który uznano za przyjaźnie neutralny, nie wykluczając jego udziału w dalszych fazach wojny po stronie aliantów Zachodu), gdzie w charakterze beneficjenta ewentualnej pomocy wzmiankowana została tylko Rumunia. Jedynie w podsumowaniu członkowie JPC stwierdzili ogólnikowo: „W warunkach, w których Polska i Turcja byłyby naszymi sojusznikami $\mathbf{w}$ wojnie z Niemcami i Włochami, pozycja militarna aliantów zostalaby niewątpliwie wzmocniona. Fakt, że Niemcy byłyby wtedy zmuszone do wojny na dwóch frontach i że Dardanele byłyby zamknięte dla Włoch, miałby najwyższe strategiczne znaczenie" 14 .

W następnych dniach memorandum zaaprobowane zostało przez Szefów Sztabów i jako dokument A.F.C. 16 rozesłane do zainteresowanych 24 kwietnia $^{15}$. $\mathrm{W}$ ostatecznej redakcji tekst został nieco zmieniony i rozbudowany. Tylko jedna z wprowadzonych korekt odnosiła się wprost do Polski - warto ją jednak przywołać. Oceniając, z wyraźnym skądinąd sceptycyzmem, rolę, którą w przyszłym konflikcie

"TNA, CAB 53/11, „Minutes of the 289th Meeting, held od 12th April, 1939”, C.O.S./289th Meeting. Datowany 11 kwietnia raport delegacji: TNA, CAB 53/47, A.F.C. 7 (Revise). Tam też nieco obszerniejsze jego podsumowanie przez Szefów Sztabów, w przypadku „polskiej” hipotezy również zakończone wnioskiem o wypowiedź Foreign Office - raport C.O.S. 877 z 13 IV 1939 r.

12 TNA CAB 29/159, „Summarized history of the conversations” A.F.C. 30 sekretarza brytyjskiej delegacji E.L.C. Jacoba z 14 VII 1939 r.

13 TNA, CAB 55/3, „Minutes of the Meeting held [...] 18 April, 1939..., J.P. 248th Mtg.

14 TNA, CAB 55/15, wstępna wersja dokumentu dla Szefów Sztabów „Military implications of the new situation in Europe (Draft Memorandum for use during the Second phase of the Anglo-French Staff Conversations)", zał. do pisma J.P. 395 (także C.O.S. 881 (J.P.)) z 19 IV 1939 r.

15 TNA, CAB 53/48, pismo C.O.S. 890 z 24 IV 1939 r. z załącznikiem (A.F.C. 16 z 22 IV 1939 r.). 
odegrać może ZSRR, Szefowie Sztabów wspomnieli możliwość dostaw materiałowych, zauważając trzeźwo: „wydaje się, że mogłyby one najbardziej pomóc Rumunii, ale jeśli polskie fabryki wciąż będą pracować, dostawy surowców dla zastąpienia strat na Śląsku [...] byłyby nie do przecenienia" ${ }^{\prime 16}$.

Dodać warto, że do dokumentu załączona została w aneksie zwięzła analiza wartości sił zbrojnych niektórych państw europejskich. Dość obszerny jej fragment poświęcono siłom zbrojnym ZSRR - w tym także lotnictwu. Liczba posiadanych przez to ostatnie samolotów i wodnosamolotów określona została na 4487 - z tego 3361 rozmieszczonych miało być na zachód od jeziora Bajkał. Radzieckie bombowce analitycy $z$ Londynu uznali za w większości „przestarzałe i bardzo powolne”, zauważając jednak, że posiadają one spory zasięg i mogą być wykorzystane do nocnych bombardowań. Z kolei radzieckie samoloty myśliwskie określono jako „stosunkowo nowoczesne", choć wyraźnie ustępujące najnowszym standardom brytyjskim czy niemieckim ${ }^{17}$.

Całości opracowanej analizy i tym razem nie zdecydowano się udostępnić francuskim partnerom, delegaci z Paryża uzyskali możliwość zapoznania się jedynie z jej fragmentami. Pierwszy $\mathrm{z}$ nich, zawierający początkowe akapity "całościowej” wersji brytyjskiej, w których na nowo uporządkowano listy państw alianckich, neutralnych i wrogich, opatrzony został datą 24 kwietnia $^{18}$.

Po drugiej stronie Kanału w tym czasie także próbowano mierzyć się z zadaniem wpasowania polskiego sojusznika w krystalizujące się właśnie ramy przyszłej strategii wojennej. 10 kwietnia Szefom Sztabów Generalnych rodzajów sił zbrojnych zaprezentowany został "nowy problem strategiczny", wynikający z sojuszu Polski, Wielkiej Brytanii i Francji oraz istniejącej w tym czasie „ogólnej sytuacji politycznej”. Trzy dni później gen. Gamelin rozesłał do tychże adresatów dossier pierwszego etapu konferencji międzysztabowych, prosząc o niezwłoczne (do 17 kwietnia) sformułowanie wypowiedzi na temat powyższego problemu ${ }^{19}$.

If Ibidem, A.F.C. 16 z 22 IV 1939 r.

17 Ibidem, „Notes of Armed Forces of Yugoslavia, Bulgaria, Greece, Turkey and U.S.S.R... Na zachód od Bajkału bazować miało 990 radzieckich samolotów bombowych, 983 myśliwce, 1283 maszyny bombowo-rozpoznawcze i szturmowe oraz 105 lodzi latających. Wielkość dostępnej rezerwy obliczano na okolo $50 \%$ sił pierwszej linii.

In TNA, AIR 9/112, "Military implications of the new situation in Europe”, A.F.C. (J) 38 z 24 IV $1939 \mathrm{r}$.

19 SHD-DAT, 2 N 229, kopia pisma Gamelina $z 13$ IV 1939 r. No 693/DN.3 do Szefa Sztabu Armii oraz No 694/DN.3 do Szefa Sztabu Marynarki; SHD-DAA, 2 B 106, pismo No 695/DN.3 Gamelina do Szefa Sztabu Armée de l'Air z 13 IV 1939 r. Wśród innych zagadnień, na które Gamelin żądał równocześnie odpowiedzi od gen. Vuillemina, znalazły się także: ewentualne zaangażowanie Japonii po stronie Niemiec i Włoch oraz zasady wspólnych akcji lotniczych Francuzów i Brytyjczyków. Gamelin zwrócił również uwagę na znaczenie podjęcia przez brytyjskie lotnictwo myśliwskie innych działań: akcji przeciw „kolumnom niemieckim” na kontynencie (siłom zmotoryzowanym przemieszczającym się przez Holandię i Belgię), zapewnienia obrony powietrznej baz brytyjskich oraz skierowania jednostek do akcji w północno-wschodniej części frontu, co zwolnić by miało część sil Armée de l'Air do ofensywy przeciw Wlochom. 
Odpowiedzi skierowane zostały do Szefa Sztabu Generalnego Obrony Narodowej między 15 a 17 kwietnia. Szef Sztabu Generalnego Armii, gen. Louis-Antoine Colson, podtrzymał stanowisko przedstawione w podobnej kwestii już dwa tygodnie wcześniej, 31 marca. Przyjmując założenie, że w razie wojny główny wysiłek Rzeszy skierowany zostanie ku zachodowi, za najistotniejsze walory czynnego udziału w konflikcie polskiego sojusznika uznał zaabsorbowanie przezeń sił niemieckich, obliczanych na 25-30 dywizji piechoty, zapoczątkowanie powstawania frontu wschodniego, który uniemożliwiłby Niemcom wykorzystanie zasobów Europy Wschodniej, wreszcie - możliwość wykorzystania wojennego potencjału ZSRR, w postaci dostaw surowców, czołgów czy samolotów. W zaistniałej sytuacji pozbawione możliwości znaczącego zwiększenia swych sił Niemcy i Włochy szukać by musiały szybkich rozstrzygnięć. Mocarstwa Zachodu - przeciwnie, zdolne do stopniowej rozbudowy swego potencjału, dążyć winny do powstrzymania wysiłków nieprzyjaciół, wyczekując momentu, gdy ich własna ofensywa stanie się możliwa.

Stąd też, podsumowywał swe strategiczne sugestie Colson, w początkowej fazie konfliktu w Europie Zachodniej zaatakowane mocarstwa powinny stworzyć solidny front, zachowując możliwości strategicznego manewru defensywnego. W Europie Wschodniej celem powinno być zmuszenie Niemiec do prowadzenia wojny na dwóch frontach „poprzez stworzenie z Polską i ewentualnie Rumunią koalicji tak poważnej i aktywnej, jak to tylko możliwe dla unieruchomienia [w regionie] części sił Rzeszy i uniemożliwienia im dostępu do zasobów gospodarczych Europy Wschodniej (zboże - ropa)". Działania w basenie Morza Śródziemnego służyć by miały utrzymaniu linii komunikacyjnych łączących obie części kontynentu. W późniejszych fazach, po wzmocnieniu środków frontu zachodniego i maksymalnym wzmocnieniu koalicji wschodniej należałoby dążyć do pobicia Włochów w Afryce (jeśli już wcześniej tego by nie dokonano) oraz na kontynencie, a następnie skierować wysiłek ku Niemcom ${ }^{20}$.

$\mathrm{Z}$ kolei gen. Vuillemin przyjął w swojej analizie odmienny punkt wyjścia, nie przesądzając kierunku pierwszego uderzenia Rzeszy. Rozważając wariant, w którym celem takiej agresji byłaby Polska, uznał, że w takim przypadku Niemcy skierowaliby zapewne przeciwko niej znaczną część swych sił powietrznych, w tym przypuszczalnie od jednej trzeciej do połowy lotnictwa bombowego. Rzecz jasna, oznaczać by to musiało pewną ulgę dla aliantów zachodnich, choć byłaby ona najpewniej krótkotrwała - dość szybko pojawiłaby się bowiem możliwość przerzucenia wielu spośród tych maszyn na zachodni teatr działań.

$\mathrm{Z}$ kolei w razie gdyby impet niemieckiego uderzenia skierowany został przeciwko Wielkiej Brytanii i Francji, nieporównanie słabsze od Luftwaffe polskie lotnictwo zapewne nie zainicjowałoby działań ofensywnych przeciwko Rzeszy. Ta więc poprzestać by mogła na zabezpieczeniu wschodnich połaci swego terytorium za pomocą sił myśliwskich, całość sił bombowych kierując przeciw wybranym celom w obrębie granic

20 SHD-DAT, 7 N 3439, „Étude du problème stratégique à la date du 10 Avril 1939” 4/82 Sztabu Generalnego Armii z 15 IV 1939 r. (fotokopia nieco odmiennej redakcji: 7 N 2524). 
mocarstw zachodnich. Większe nieco usługi oddać by mogło natomiast sojusznikom polskie lotnictwo rozpoznawcze, przejmując zadania przewidziane uprzednio dla czechosłowackiego odpowiednika ${ }^{21}$. Polska aktywność w tej sferze pozwoliłaby nade wszystko na określenie, w którą stronę kieruje się główna masa wojsk niemieckich, co w Paryżu od dwudziestu bez mała lat uważano za kwestię o pierwszoplanowym znaczeniu. Ogólnie jednak, konkludował Vuillemin, „nie wydaje się prawdopodobne, by $z$ punktu widzenia lotnictwa polska interwencja mogła stanowić bardzo istotną pomoc dla zachodnich sojuszników"22.

Mniej istotny dla naszej analizy był pogląd sformułowany przez wiceadmirała Jeana François Darlana, Szefa Sztabu Generalnego Marynarki Wojennej. Wspomnieć jednak warto, że także i on na wartość sojuszu z Rzeczpospolitą patrzył bez entuzjazmu. Co prawda bowiem, wywodził, polski udział w wojnie zmusi Niemcy do utrzymywania „pewnej liczby okrętów” na Morzu Bałtyckim, jednak na całość morskich planów Rzeszy pozostanie to w zasadzie bez wpływu. Z kolei dostarczenie Polakom zaopatrzenia z zewnątrz byłoby trudne, jeśli w ogóle możliwe - droga przez Bałtyk będzie zupełnie nie do przebycia, trasa południowa - niepewna, podobnie jak dostawy $\mathrm{z}$ Rosji lub sąsiadujących państw neutralnych"?.

Koncepcje obu stron miały zostać skonfrontowane już niebawem - 24 kwietnia w budynku War Office rozpoczęła się bowiem druga tura rozmów międzysztabowych. W ciągu następnych dni odbyć się miało pięć sesji plenarnych obu delegacji i szereg spotkań w węższym gronie, poświęconych omawianiu zagadnień o bardziej szczegółowym charakterze. Obie strony, zdając sobie sprawę z coraz bardziej napiętej sytuacji międzynarodowej, zdecydowały się skumulować w tej fazie kwestie uprzednio przewidziane dla faz drugiej i trzeciej - $w$ trakcie rozmów podjęto więc prace nie tylko, jak zamierzano uprzednio, nad ogólnymi planami strategicznymi dla wybranych teatrów operacji, ale zajęto się też planowaniem bardziej szczegółowym, uzgadniając plany na poziomie poszczególnych broni.

Przygotowane przez Francuzów zgodnie z wcześniejszymi ustaleniami studium wpływu, jaki wywrzeć mógł alians z Polską na strategiczną pozycję mocarstw zachodnich, przedłożone zostało delegacji brytyjskiej w drugim dniu obrad, 25 kwiet-

${ }^{21}$ Już 20 marca szefowie Armée de l'Air alarmowali, że skutkiem zmian spowodowanych przez upadek Czechosłowacji możliwości francuskiego rozpoznania lotniczego ograniczone zostały jedynie do zachodniej części Rzeszy, sięgając linii Brema - Hanower - Kassel - Norymberga Augsburg. SHD-DAT, 7 NN 2/254, pismo No 681 3-O-S/E.M.A.A za ministra lotnictwa i z jego rozkazu gen. Vuillemina do ministra obrony narodowej i wojny (2e Bureau Sztabu Generalnego) z 20 III 1939 r.

22 SHD-DAT, 2 N 229, „Note établie par l'État-Major de l'Armée de l'Air”, zał. do pisma Vuillemina do Gamelina No 956-3 OS/EMAA z 17 IV 1939 r. Nota zawierała także krótką ocenę polskiego potencjału lotniczego: około 550 samolotów w linii, „ale tylko bardzo niewielka część nowoczesna", rozwinięty przemysł lotniczy, który skonstruował właśnie kilka prototypów porównywalnych z odpowiednikami zachodnimi, wytwórczość silników lotniczych nadal w dużym stopniu zależna od zagranicy.

23 Ibidem, pismo No 466 E.M.G.3 Darlana do Gamelina z 17 IV 1939 r. 
nia $^{24}$. Autorzy dokumentu bardzo wyraźnie inspirowali się wyrażonymi dziesięć dni wcześniej poglądami szefów sztabów armii lądowej oraz lotnictwa, co - wobec znaczącej między nimi różnicy - skutkować musiało niespójnością formułowanych tez.

Te ostatnie wyraźnie podzielić można było wedle źródła pochodzenia. Ogólna strategiczna wizja zaczerpnięta została $z$ opracowania sporządzonego pod nadzorem gen. Colsona. Podkreślano w niej więc, że sojusz z Polską zrujnuje realizowany przez Rzeszę plan zniszczenia w Europie Wschodniej wszelkich elementów potencjalnej przeciwniemieckiej bariery i sprowadzenia regionu do roli kontrolowanego z Berlina dostawcy żywności i surowców. Niemcy zmuszone zostaną do prowadzenia wojny na dwóch frontach, pozostawiając na wschodzie co najmniej 25-30 dywizji. Zmniejszy to nieco siły, które wykorzystać by mogły do operacji na froncie zachodnim. Jak zauważali francuscy sztabowcy, redukcja ta byłaby rzecz jasna jeszcze większa, gdyby to Polska została pierwszym celem działań Rzeszy - choć jak się wydaje, nie był to scenariusz uważany w Paryżu za najbardziej prawdopodobny.

Ponadto, jak zakładano w omawianym dokumencie, za polskim przykładem mogłyby pójść Rumunia oraz państwa bałkańskie. To zaś oznaczać by miało powstanie długiego frontu wschodniego, który zaabsorbować by musiał jeszcze większą część sił niemieckich - użytych być może w ramach ofensywy podjętej dla zagarnięcia zasobów tej części kontynentu. Gdyby takie przypuszczenia okazały się prawdziwe, spekulowali Francuzi, być może liczebna słabość Francji i Wielkiej Brytanii stałaby się mniej znacząca, a zachodni sojusznicy zyskaliby więcej swobody do przygotowania ofensywy, która zdemolować winna włoskiego sprzymierzeńca Rzeszy.

Jednak, jak podkreślali autorzy, utrzymanie przez dłuższy czas tych wielce dogodnych warunków zależne będzie, co oczywiste, od trwałości wschodniego frontu. Ta zaś, przyznawano, uznana być musi za problematyczną, przynajmniej do czasu pełnej drożności wiodących przez Morze Śródziemne na wschód szlaków komunikacyjnych, do tego bowiem czasu ulokowani w tej części kontynentu sojusznicy mocarstw Zachodu liczyć będą musieli na własne, niezbyt imponujące zasoby. Powstałą w ten sposób kwadraturę koła, w której dłuższa egzystencja wschodniego frontu otwierała możliwość przygotowania pobicia Włoch, ale trwanie tych ostatnich u boku Rzeszy radykalnie skrócić mogło okres istnienia tego frontu, francuscy sztabowcy proponowali usunąć $w$ tradycyjny już sposób: przez zachęcanie wschodnich aliantów Zachodu „do wykorzystania wszystkich możliwości zaopatrzenia, jakie Rosja może im dać"2s.

Wyodrębniona $w$ drugiej części dokumentu analiza poświęcona działaniom lotniczym zawierała, jak wyżej zauważono, znacząco odmienne przemyślenia. W tym wypadku autorzy studium za równie możliwe uznali oba kierunki przyszłej niemieckiej ofensywy, uderzenie na Polskę czyniąc wręcz pierwszą z rozważanych ewentualności.

24 SHD-DAT, 2 N 228, D.F. 15, „Etude des conditions découlant d'une alliance entre la Pologne, La Grande-Bretagne et la France", w wersji brytyjskiej: TNA, CAB 29/160, A.F.C. (J) 44 z 25 IV 1939 r.

.s Ibidem. 
W takim scenariuszu, zauważali w ślad za gen. Vuilleminem, Rzesza skierowałaby przeciw wschodniemu sąsiadowi od jednej trzeciej do połowy swoich bombowców. Ulga dla Zachodu byłaby jednak krótkotrwała, większość $\mathrm{z}$ tych maszyn bowiem i tak szybko zostałaby zwrócona przeciw niemu. $Z$ kolei w razie podjęcia przez Rzeszę decyzji o rozpoczęciu wojny atakiem na froncie zachodnim sukurs polskiego lotnictwa dla sojuszników byłby problematyczny, a z pewnością mało odczuwalny. Stąd - powtarzano w dokumencie niemal dosłownie sformułowanie użyte już wcześniej przez Szefa Sztabu Armée de l'Air - w przypadku działań lotniczych czynnik polski uznać trzeba za mało istotny.

Za mało oryginalne, powielone po raz kolejny uznać należało także dalsze zapożyczone od Vuillemina wnioski tej części dokumentu, dotyczące możliwości wykorzystania polskiego lotnictwa rozpoznawczego do określenia głównego kierunku niemieckich działań oraz ewentualnego użycia baz lotniczych Rzeczypospolitej dla podjęcia, „w razie konieczności”, „ataku na Berlin i cele na wschód od Berlina”26.

Jak przy tym zastrzegano, wykorzystanie tych ekspektatyw zależne jest od uprzedniego poczynienia przygotowań na ziemi, te zaś wciąż nie zostały podjęte. Ponadto, zwracali uwagę autorzy studium, najwyraźniej obawiając się, by sojusznik brytyjski (i polski?) nie zrozumiał opacznie przedstawionych zamysłów: „takie wykorzystanie jej baz lotniczych nie powinno być uznawane przez Polskę za bezpośrednią pomoc z naszej strony, ale [tylko] za zwiększenie zasięgu naszych samolotów". Wreszcie bodaj po raz pierwszy formułowano myśl od dawna podskórnie obecną we francuskich koncepcjach lotniczych - „Jeśli ZSRR zdecydowałby się interweniować po stronie aliantów, Polska powinna otworzyć swe lotniska dla rosyjskich sił powietrznych w celu umożliwienia im zaatakowania Niemiec" ${ }^{2 i}$.

Za niewątpliwie istotne uznać należało wnioski końcowe sporządzonej przez Francuzów analizy - choćby $z$ tej racji, że od tego czasu miały być one powtarzane w wielu innych powstających w Paryżu i Londynie dokumentach. Jak stwierdzano: „Wejście Polski do wojny po stronie Wielkiej Brytanii i Francji wykaże pełną wartość jedynie wtedy, gdy pociągnie za sobą powstanie na Wschodzie długiego, solidnego i trwałego frontu" [wyróżnienie w oryg. - W.M.]28.

Dokument wręczony został delegacji brytyjskiej już podczas pierwszego spotkania kolejnej tury rozmów międzysztabowych, tj. 9. ich sesji, po południu 24 kwietnia. W zamian Francuzi otrzymali syntetyczny materiał (A.F.C. (J) 38), zawierający skorygowane przyporządkowanie państw europejskich do kategorii sojuszników, neutralnych (życzliwych wobec aliantów i przyjaznych względem ich wrogów) oraz wrogich.

Kwestię zarysowanych w ten sposób "nowych politycznych hipotez" podjęto dwa dni później, na rozpoczętej w południe 26 kwietnia 12. sesji. Przedstawiciele strony brytyjskiej z góry przy tym oświadczyli, że zasadniczo zgadzają się z teza-

26 Ibidem.

${ }^{27}$ Ibidem.

2x Ibidem. Zob. też: N.H. Gibbs, op. cit., s. 704. 
mi przedstawionymi przez partnerów zza Kanału, wymiana zdań dotyczyła więc jedynie kilku kwestii szczegółowych. Reprezentujący gospodarzy zastępca Dyrektora Operacji Wojskowych War Office bryg. John N. Kennedy zakwestionowal m.in. podaną przez Francuzów liczbę 25-30 niemieckich dywizji, które w razie skierowania głównego uderzenia Rzeszy na zachód miałyby zostać użyte przeciw Polsce. Zdaniem War Office, jak stwierdził, francuskie obliczenia są zawyżone, w istocie w grę wchodzić mogłoby raczej 18 do 22 takich jednostek. Niebawem jednak strony zgodziły się, że ze względu na szacunkowy charakter podobnych wyliczeń dyskusja na ich temat byłaby zasadniczo bezprzedmiotowa. Nie podjęto też dłuższych rozważań nad sytuacją przeciwną, tj. wariantem, w którym to właśnie Polska miałaby stać się celem pierwszej niemieckiej ofensywy. Jak wyjaśnił Kennedy, powielając tezę już wcześniej sformułowaną w Londynie, określanie liczby dywizji, które w takim przypadku pozostawione by zostały na froncie zachodnim, jest zadaniem stosunkowo mało istotnym, gdyż wyeliminowanie Polski z wojny byłoby jedynie kwestią czasu. Jednocześnie przewodniczący delegacji brytyjskiej zasugerował, że nawet po zwycięstwie na wschodzie Niemcy, nieustannie zagrożeni możliwą interwencją ZSRR, będą zmuszeni utrzymywać tam siły porównywalne do zaangażowanych uprzednio $\mathrm{w}$ realizację podboju ${ }^{29}$.

Strona francuska podzieliła przedstawiony punkt widzenia, dodając jednak, że front wschodni zostanie zapewne przedłużony przez Rumunów, którzy do 50 wysoko ocenianych przez przedstawicieli Paryża polskich dywizji piechoty dodadzą kolejne 35. Francuzi podkreślili przy tym postępy, jakie pod względem uzbrojenia i wyszkolenia poczyniła w ciągu kilku poprzednich lat armia rumuńska. Pogląd ten został zanegowany przez Kennedy'ego, który w imieniu War Office przedstawił ocenę znacznie bardziej surową („armia wyjątkowo słaba [...], materiał ludzki marnej jakości, uzbrojenie złożone $\mathrm{z}$ typów bardzo różnorodnych"), zastrzegając, że osobiście uznaje ją za zbyt krytyczną. Ostatecznie kwestię odesłano do rozstrzygnięcia przez służby wywiadowcze ${ }^{30}$.

W podsumowaniu tej części dyskusji Brytyjczycy zaproponowali, by delegacja francuska zaaprobowała hipotezy zawarte w opracowanym w Londynie dokumencie

2y SHD-DAA, 2 B 106, „Procès-verbal de la douzième séance. 26 Avril 1939 - 12 heures”. We wszystkich kopiach francuskiej wersji protokołu (także w SHD-DAT, 2 N 228) podano błędne oznaczenie stanowiącego podstawę dyskusji dokumentu: A.F.C. (J) 47 zamiast właściwego A.F.C. (J) 44. Pierwszy $z$ wymienionych materiałów dotyczył $w$ istocie wymiany in formacji między przedstawicielami francuskich i brytyjskich władz kolonialnych, z kwestią polską nie miał więc nic wspólnego.

3) Ocena Kennedy'ego stanowiła dosłowne powtórzenie treści odpowiedniego fragmentu opracowania C.O.S. 872 Revise z 3 IV 1939 r. W sprawie przebiegu tej części negocjacji zob. też: N.H. Gibbs, op. cit., s. 675. Brytyjczycy ze swych wątpliwości co do walorów armii rumuńskiej nie czynili wówczas zbytniej tajemnicy. „Odniosłem wrażenie (również w rozmowie w Ministerst wie Lotnictwa), że Anglicy nie oceniają zbytnio wysoko wartości armii rumuńskiej” - raportował 19 maja do Warszawy ppłk Kwieciński (IPMS, Lot. A.I. 2/15, pismo L. 174/39 ppłk. Kwiecińskiego do Szefa O. II SG z 19 V 1939 r.). 
A.F.C. (J) 38. Delegaci francuscy uchylili się jednak od przyjęcia tej propozycji, wyjaśniając, że choć zgadzają się ogólnie z treściami zawartymi we wspomnianej nocie, to nie posiadają w tej kwestii szczegółowych instrukcji ${ }^{31}$.

Zdziwienie budzić może fakt, że w roli konkluzji użyty miałby zostać ogólnikowy dokument brytyjski, w którym skonstatowano jedynie stan faktyczny, nie formułując żadnych dalszych wniosków, a nie znacznie bardziej obszerny materiał francuski. Można przypuszczać, że przedstawiciele Paryża poczuli się skonsternowani sugestią przyjęcia tak ogólnej, niewiele do ustaleń wnoszącej formuły - wykonali więc unik, licząc, że w toku kolejnych spotkań zdołają dokonać jej sprecyzowania w duchu bardziej dla interesów Francji dogodnym.

$\mathrm{Na}$ tym jednak nie skończył się katalog spraw polskich rozpatrywanych podczas tego posiedzenia. Uczestnicy dyskusji powrócili do nich niebawem $w$ interesującym z punktu widzenia naszej analizy kontekście. Przyjąwszy bowiem $z$ aprobatą przedstawioną przez Brytyjczyków tezę o wielkiej wartości sojuszu z Turcją, szczególnie dla ewentualnych operacji we wschodniej części Morza Śódziemnego, podjęli próbę analizy roli, jaką w nadchodzącym konflikcie odegrać mógłby ZSRR. Delegaci brytyjscy, zaznaczając, że brak im tu dokładnych informacji, wyrazili wątpliwość, czy Moskwa byłaby w praktyce zdolna wywiązać się z przewidywanej w dokumencie francuskim roli dostawcy materiałów wojennych dla Polski i Rumunii, choćby ze względu na odmienność użytkowanego sprzętu. Przedstawili też tezę, że radzieckie siły zbrojne, osłabione w ostatnim czasie przez falę czystek oraz pozbawione dogodnej komunikacji, nie są w zasadzie zdatne do operacji poza obszarem państwowym.

W pierwszej z wymienionych kwestii delegaci francuscy zaprezentowali stanowisko bardziej od gospodarzy optymistyczne, wyjaśniając, że ZSRR mógłby dostarczać do Polski działa, amunicję i czołgi. Natomiast dyskusja na temat ogólnej wartości sił radzieckich oraz ich potencjalnego udziału w wojnie, która ogarnąć by mogła wschodnią część kontynentu, okazała się bardziej ożywiona. Fakt, że po obu stronach toczyli ją głównie przedstawiciele sił powietrznych i to problematyka lotnicza stała się osią podjętej wymiany zdań, stanowił kolejny dowód szczególnej roli, jaką przedstawiciele wojskowej hierarchii z obu stron Kanału wyznaczali tej sferze w zbliżającej się koalicyjnej wojnie. Dyskusja prowadzona w tej części posiedzenia dobrze też ilustrowała zarówno oceny, jak i szersze poglądy czy sam sposób myślenia zaangażowanych $\mathrm{w}$ nią oficerów lotnictwa. Te zaś niewątpliwie uznać trzeba za istotne dla naszej analizy, stąd też warto dokładniej nieco prześledzić zasadnicze wątki tego fragmentu rozmów.

W zaprezentowanych stanowiskach wyraźnie dostrzegalne były ślady wcześniejszych studiów prowadzonych przez każdą ze stron. Major Bailly, który w kolejnej turze konferencji międzysztabowych pozostał reprezentantem Armée de l'Air, zwrócił uwagę na problemy $z$ komunikacją lądową, stanowiące wielkie utrudnienie dla zaopatrzenia i obsługi technicznej ewentualnych radzieckich ekspedycyjnych sił

3) SHD-DAA, 2 B 106, „Procès-verbal de la douzième séance...”. 
lotniczych. Jak zauważył, dla podjęcia przez nie operacji niezbędne byłoby poczynienie odpowiednich przygotowań w pobliżu granicy polskiej, jak i w samej Polsce. Zarówno zaś te przygotowania, jak i sam ruch w kierunku zachodnim wymagać by musiały odpowiedniej ilości czasu. Była to myśl standardowo już wypowiadana przez francuskich sztabowców lotniczych. Zasadniczo słuszna, służyć miała także, jak się wydaje, uzasadnianiu niedostatku własnej aktywności w momentach krytycznych. Ta ostatnia przecież, sugerowano w podtekście, podjęta bez uprzednich gruntownych przygotowań przynieść mogła więcej szkody niż pożytku.

$\mathrm{Z}$ kolei oficerowie brytyjscy zdawali się nastawieni bardziej od swych francuskich kolegów ofensywnie. Wypowiadający się w ich imieniu płk Slessor swój wywód także oparł na treści przygotowanych w poprzednich tygodniach w Londynie dokumentów. Wyraziwszy więc dość konwencjonalną aprobatę dla zdania przedmówcy, skoncentrował się na pożytkach, jakie mimo wszelkich ograniczeń przynieść by mógł udział w wojnie radzieckiego lotnictwa. Rosjanie, stwierdził, posiadają znaczną liczbę ciężkich bombowców. Choć zaś te ostatnie należą do typów już przestarzałych, część z nich może być wykorzystana do transportu materiału dla dywizjonów średnich bombowców, które dysponując mniejszym zasięgiem, powinny zostać rozlokowane w Polsce. Pozostałe takie samoloty użyte mogłyby zostać do celów zaopatrzeniowych, redukując tym samym znacząco problemy komunikacyjne. Ogólnie, zgodził się Slessor, nie można wiązać zbyt wielkich nadziei z radziecką asystą lotniczą. Z drugiej strony nie byłaby ona też bezużyteczna. Prócz samolotów bombowych także radzieckie lotnictwo myśliwskie można by wykorzystać do podjętych we współpracy z siłami polskimi działań o charakterze defensywnym.

Major Bailly pozostał jednak przy swoim zdaniu - wypowiedź Szefa Dyrekcji Planowania Air Ministry opatrując komentarzem, że nawet gdyby istotnie miało dojść do takiej lotniczej interwencji Moskwy, to i tak niezbędne okazać by się musiały podjęte zawczasu, trwające co najmniej miesiąc przygotowania instalacji naziemnych.

Zarysowane różnice poglądów specjalistów lotniczych próbował tonować, ponownie sprowadzając dyskusję ku zagadnieniom o charakterze bardziej ogólnym, gen. Lelong. Zwrócił przy tym uwagę, że choć istotnie sieć komunikacyjna ZSRR jest bardzo słabo rozwinięta, to jej stan niewiele lepiej przedstawia się w Polsce. Oznacza to, twierdził, że na trudności napotkać by mogły zarówno siły radzieckie operujące poza swym państwowym terytorium, jak i przeciwnicy, którzy podjęliby próbę zaatakowania tych sił po ich rozlokowaniu w granicach Rzeczypospolitej. Opinie o niezdolności armii radzieckiej do operacji poza obszarem ojczyzny uznał zresztą Lelong za zdecydowanie przesadne, podkreślając, że zdanie na ten temat był $w$ stanie sformułować na podstawie osobistych obserwacji.

Następnie dyskusja na krótki czas raz jeszcze wróciła do spraw polskich. Brygadier Kennedy, nawiązując do sytuacji z roku 1920, starał się dowiedzieć, czy Francuzi i tym razem zamierzają skierować do Polski misję wojskowych doradców. Generał Lelong wyraził tu pewną wątpliwość, podkreślając, że sprawa należy do bardzo delikatnych, Paryż stara się traktować czułą na tym punkcie Warszawę na zasadach pełnej równości i nie zamierza ponownie wcielać się w rolę profesora. Ewentualna 
misja musiałaby więc nie tyle recenzować poczynania polskiego partnera, ile zająć się koordynacją działań obu stron ${ }^{32}$.

Dalsza część dyskusji nie miała już związku z Polską ${ }^{33}$. W przyjętej w końcowej fazie posiedzenia konkluzji Francuzom powierzono opracowanie noty podsumowującej uzgodnienia względem Europy Wschodniej w kontekście nowej sytuacji politycznej. Podstawą prac nad tym dokumentem miały się stać materiały przedłożone przez obie delegacje (tj. A.F.C. (J) 38 oraz A.F.C. (J) 44) oraz wypowiedzi sformułowane $w$ trakcie przeprowadzonej właśnie wymiany zdań. Powstałe $w$ ten sposób opracowanie miało następnie zostać zaaprobowane przez obie delegacje ${ }^{34}$.

Do rozważania spraw związanych z Europą Wschodnią, w tym z Polską, powrócono na trzynastej sesji, po południu 3 maja. Komandor Danckwerts przypomniał pozostawioną kilka dni wcześniej bez odpowiedzi kwestię potencjalnej reakcji Francuzów i Brytyjczyków w sytuacji, w której Niemcy, zachowując bierność na zachodzie, podjęliby atak na Polskę. W takim wariancie, zauważył, Rzesza mogłaby skłonić Włochy do zachowania neutralności, przynajmniej w początkowej fazie konfliktu. Choć zaś zagadnienie takie, jak stwierdził, wykracza poza ścisły program podjętych rozmów, to warto i względem niego poczynić pewne ustalenia, choćby $\mathbf{z}$ tej racji, że strona polska może zażyczyć sobie na ten temat informacji. Ten ostatni argument, wobec przygotowywania się przez obie strony do wojskowych rozmów z Warszawą (o czym zresztą bodaj żadna $\mathrm{z}$ nich nie powiadomiła partnera), nie był bez znaczenia ${ }^{35}$.

Generał Lelong, który o zamiarze brytyjskiego kolegi został przezeń uprzedzony listem datowanym dzień wcześniej, przestawiony problem uznał za „bardzo drażli-

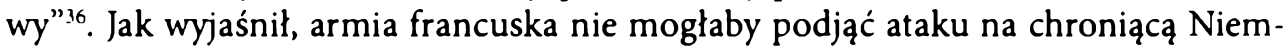
cy od zachodu ufortyfikowaną Linię Zygfryda bez długich przygotowań. Choć zaś ewentualny udział Włoch $\mathrm{w}$ wojnie doraźnie pogorszy sytuację sprzymierzonych, szczególnie na Morzu Śródziemnym, to stanowią one słaby punkt wrogiej koalicji. Ich pokonanie umożliwić może uderzenie na terytorium Rzeszy od strony odsłoniętej południowej flanki - przez nie w pełni jeszcze zasymilowane obszary Austrii i Czechosłowacji. Neutralność Włoch przekreśli tę koncepcję, zmuszając jednocześnie sojuszników do bezproduktywnego utrzymywania części sił na granicy Italii oraz włoskich posiadłości kolonialnych.

32 Ibidem.

33. Poruszono w niej natomiast kwestię zabezpieczenia przed przejęciem przez Niemców rumuńskich pól naftowych - $w$ razie konieczności poprzez zniszczenie odpowiednich instalacji.

34 SHD-DAA, 2 B 106, „Procès-verbal de la douzième séance...”.

${ }^{35}$ Inicjatywa Danckwertsa stanowiła efekt podjętych dwa dni wcześniej przez brytyjskich Szefów Sztabów rozważań na temat takich rozmów. Air Marhsal Newall uznał wówczas przedstawiony teraz przez Danckwertsa scenariusz za prawdopodobny, proponując skonsultowanie z Francuzami możliwej nań reakcji. Podkomitet Szefów Sztabów zgodził się z tym stanowiskiem i wydal odpowiednie dyspozycje. TNA, CAB 53/11, „Minutes of the 292nd Meeting, held on 1st May, 1939", C.O.S./292nd Mtg.

36 SHD-DAA, 2 B 106, „Procès-verbal de la 13ème séance. 3 Mai 1939 - 16 heures”; SHD-DAT, 7 N 3439, thumaczenie listu Danckwertsa do Lelonga z 2 V 1939 r. na język francuski. 
W tej sytuacji, kontynuował Lelong, liczyć można jedynie na powstanie w Europie Wschodniej solidnego frontu, podtrzymywanego przez siły zbrojne Grecji, Turcji, Rumunii, Polski, a może i ZSRR. Tylko $w$ takim bowiem przypadku nawet $w$ razie neutralności Włoch Francja może zyskać dość czasu na utworzenie rezerw, które następnie zostałyby wykorzystane do wzmocnienia tego frontu przez specjalistów czy dostawy materiałów ${ }^{37}$.

Z postawą Francuzów, podkreślających głównie trudności i niemożności, nie po raz pierwszy kontrastowała wypowiedź płk. Slessora, który szansę pewnej pomocy dla zaatakowanych przez siły Rzeszy Polaków dostrzegł w działaniach lotniczych. Jak stwierdził w uzasadnieniu tej opinii: „celem aliantów w tym przypadku byłoby narzucenie Niemcom wszystkich niedogodności, które niesie ze sobą prowadzenie wojny na dwóch frontach”. „Nie możemy mieć nadziei na osiągnięcie tego celu, jeśli nie zdecydujemy się zaangażować w pewne operacje na froncie zachodnim" - dodał ${ }^{38}$.

W przedmiotowej sprawie nie pojęto jednak żadnych ostatecznych ustaleń. Generał Lelong wyjaśnił bowiem, że nie posiada w tej kwestii instrukcji, a dotyczące jej sprawy nie były jeszcze w Paryżu referowane. Delegacje ustaliły więc jedynie, że po sformułowaniu odpowiedniego stanowiska przez francuski Sztab Generalny zostanie ono zakomunikowane stronie brytyjskiej.

W sporządzonym dzień później przez Brytyjczyków na ich własne potrzeby podsumowaniu tego zagadnienia odnotowano także „własne, osobiste i formułowane na bieżąco" poglądy członków delegacji francuskiej, które nie zostały umieszczone $\mathrm{w}$ oficjalnym protokole posiedzenia, podkreślając, że delegaci Zjednoczonego Królestwa zasadniczo zgadzają się z przedstawionym im wnioskowaniem. Francuzi, powtarzając opinię, że wszelki atak na Linię Zygfryda wymagać musi długotrwałych przygotowań, za jedyną możliwość podjęcia przez sprzymierzonych działań ofensywnych $w$ razie neutralności Włoch mieli uznać atak na Niemcy przez terytoria Belgii i Holandii. Był on jednak ich zdaniem możliwy jedynie po wyrażeniu przez te państwa zgody na udostępnienie terytoriów - i to tylko do czasu, gdy Niemcy nie ufortyfikują i tego pogranicza. W przeciwnym razie francuskie wsparcie dla wschodniego frontu przyjąć mogło postać „sił wyspecjalizowanych”, tj. „formacji zmechanizowanych i ciężkiej artylerii" 39 .

Co do akcji lotniczej delegacje nieoficjalnie ustaliły, że atak o celach ograniczonych nie mógłby przynieść Polsce dostrzegalnych korzyści. Gdyby więc front na wschodzie kontynentu okazał się wystarczająco silny, by przerzucone zostały nań jednostki wyspecjalizowane, można by - spekulowano - włączyć w ich skład także

3 SHD-DAA, 2 B 106, „Procès-verbal de la 13ème séance. 3 Mai 1939 - 16 heures”; TNA, CAB 55/16, „Extract from the Minutes of the 13th Meeting of the Anglo-French Staff Conversations held 3rd May, 1939".

3* SHD-DAA, 2 B 106, „Procès-verbal de la 13ème séance. 3 Mai 1939 - 16 heures”. Przebieg dyskusji podczas tego posiedzenia omawia krótko A. Prazmowska, op. cit., s. 83.

3y TNA, WO 193/197, opracowanie A.F.C. (J) 70 (draft) z 4 V 1939 r. Choć dokument należał do dystrybuowanej dla obu delegacji serii A.F.C. (J), pismo przewodnie opatrzone zostało zastrzeżeniem, że „na razie nie będzie wydany Francuzom". 
rzuty naziemne alianckich jednostek lotniczych, z zamysłem podjęcia przez nie następnie operacji na korzyść Polski z jej terytorium. Także i te kwestie delegaci francuscy zobowiązali się przekazać do rozważenia w Paryżu, zapowiadając powiadomienie brytyjskich partnerów o efektach przeprowadzonych tam analiz ${ }^{40}$.

Niemal równocześnie, wraz z przyjęciem przez obie delegacje dokumentu „Study of the conditons which would result from the intervention of other European powers", zakończone zostały natomiast studia nad "nową hipotezą" prawdopodobnego udziału Polski i Rumunii w wojnie po stronie aliantów. Francuzi, którzy 26 kwietnia wstrzymali się z aprobatą przedłożonego im materiału brytyjskiego, mogli teraz poczuć się usatysfakcjonowani: zapisy wersji finalnej nawiązywały $\mathrm{w}$ większości do tekstów, które nad Tamizę trafiły z Paryża.

Ponownie stwierdzono więc, że wejście Polski w porozumienie z Wielką Brytanią i Francją zniweczy niemiecki plan uniknięcia wojny na dwóch frontach i zapewnienia Rzeszy nieskrępowanego dostępu do ekonomicznych zasobów Europy Wschodniej. Postawi też Niemców wobec konieczności rozproszenia sił. $W$ razie podjęcia w pierwszej fazie wojny ataku na zachód Rzesza zmuszona będzie skierować na wschód około 25 dywizji ${ }^{41}$, w przypadku zaś wybrania przez nią przeciwnego kierunku uderzenia, Londyn i Paryż „będą mogły, co najmniej, zbudować silną pozycję na zachodzie i być może podjąć ofensywę"42. Ewentualne opowiedzenie się po stronie aliantów zachęconej polskim przykładem Rumunii i państw bałkańskich może zmusić Niemców do utrzymywania na wschodzie jeszcze poważniejszych sił, a nawet decyzji o skierowaniu głównego wysiłku właśnie w tym kierunku, dla zapewnienia sobie dostępu do zasobów niezbędnych do prowadzenia długiej, wyczerpującej wojny.

Takie zaangażowanie Niemiec mogłoby umożliwić aliantom decydującą rozprawę z Włochami. Warunkiem jednak pozostawać musi solidność frontu wschodniego. Pozbawionych poważniejszych materiałowych zapasów sojuszników z tej części kontynentu zdecydowanie należy więc zachęcać do wykorzystania wszelkich sposobności uzyskania zaopatrzenia z ZSRR. Spodziewana interwencja Turcji otworzyć by mogła inną jeszcze, alternatywną drogę dla kierowanych na wschód dostaw.

Odrębna, obszerna część analizy poświęcona została lotniczym aspektom polskiego udziału w spodziewanym konflikcie zbrojnym. Zawarte w niej wywody stanowiły jednak dosłowne powtórzenie tez gen. Vuillemina, które znalazły się w przedstawionym przez delegację francuską opracowaniu A.F.C. (J) 44 i stamtąd zostały teraz zaczerpnięte. Były one już wyżej przedstawiane, ponowne ich przywoływanie nie wydaje się więc konieczne.

411 Ibidem.

41 Najwyraźniej autorzy dokumentu postanowili znaleźć swoisty „złoty środek” pomiędzy wyższymi od ostatecznie przyjętych szacunkami Francuzów oraz wyraźnie niższymi przewidywaniami sztabowców brytyjskich.

42 TNA, WO 193/197, "Study of the conditions which would result from the intervention of other European powers" z 4 V 1939 r. Wersja francuska: SHD-DAT, 2 N 228. Zob. też: A. Pra zmowska, op. cit., s. 82 n. 
Na nowo natomiast sformułowano wywody poświęcone roli, jaką w nadchodzącej wojnie odegrać by mógł ZSRR, choć i w tym wypadku nie wchodziły w grę żadne nowe koncepcje. W razie gdyby Moskwa nie wzięła bezpośredniego udziału w wojnie jako sprzymierzeniec Zachodu, mogłaby, zakładano, zostać źródłem zaopatrzenia w materiał wojenny dla państw sąsiednich, dostarczając Polsce i Rumunii dział, amunicji i czołgów. Bez jej pomocy, zauważali raz jeszcze autorzy dokumentu, „konsolidacja długiego i trwałego frontu w Europie Wschodniej byłaby problematyczna". Dopóki zaś front taki nie zaistnieje, sojusz z Polską i Rumunią nie będzie miał z punktu widzenia Zachodu większej strategicznej wartości ${ }^{43}$.

Wartość radzieckich sił zbrojnych określona została jako relatywnie niska. Niezbyt wysoko oszacowano też wojenną użyteczność radzieckiego lotnictwa, zwracając uwagę na to, że w przypadku operacji poza ojczystym terytorium będzie ona dodatkowo ograniczana, szczególnie $w$ fazie początkowej, przez niewielką mobilność obsługi technicznej. Jednak, jak podkreślono, niezależnie od tego ewentualne wejście ZSRR do wojny znacząco zwiększyć by musiało niemieckie zaangażowanie w Europie Wschodniej.

Konkluzje końcowe znów stanowiły powielenie znanych już tez. Ponownie bowiem stwierdzono, że sojusz z Polską i Rumunią może mieć wartość jedynie wtedy, gdy pozwoli na utworzenie w Europie Wschodniej „długiego, solidnego i trwałego frontu". Ten z kolei mógłby być stabilizowany przez radzieckie dostawy materiałowe, a także $w$ razie zgody zainteresowanych państw - przez bezpośrednie zaangażowanie radzieckich sił zbrojnych. Jak jednak zauważano, „nawet jeśli Polska i Rumunia zostałyby pokonane, a Rosja przyłączyłaby się do aliantów, niemieckie zaangażowanie w Europie Wschodniej byłoby wciąż znaczące" ${ }^{44}$.

4 maja był zarazem ostatnim dniem drugiej tury rozmów międzysztabowych. $\mathrm{W}$ jej trakcie wiele uwagi poświęcono działaniom lotniczym. Na poczynienie $w$ tej kwestii możliwie szczegółowych ustaleń niemal od początku kwietnia gorączkowo nastawali zresztą Francuzi, coraz bardziej zaniepokojeni perspektywą możliwego niemieckiego ataku na zachodzie - najpewniej przez terytoria Belgii i Holandii, a przy

43 TNA, WO 193/197, „Study of the conditions..." z 4 V 1939 r.; SHD-DAT, 2 N 228; A. Pra zmowska, op. cit., s. 82n.

14 TNA, WO 193/197, "Study of the conditions..." z 4 V 1939 r.; SHD-DAT, 2 N 228. Stanowisko sformułowane $\mathrm{w}$ tym dokumencie strona brytyjska włączyła następnie jako aneks do sprawozdania $z$ rozmów. Gen. Lelong w swoim sprawozdaniu streścił je tylko w wielkim skrócie, referujący zagadnienia lotnicze mjr Bailly w podobnym opracowaniu napisał natomiast krótko: „polski sojusz nie byłby $w$ stanie przynieść nam znaczącej pomocy w walce, którą mielibyśmy podjąć przeciw lotnictwu niemieckiemu, z wyjątkiem jakiejś interwencji rosyjskiej z baz polskich; interwencji pożądanej, ale nierozsądnie byłoby liczyć na nią jako szybką i poważną". TNA, CAB 53/49, „Anglo-French Staff Conversations, 1939. United Kingdom Delegation. Report on Stage II" z 11 V 1939 r., Annex I; SHD-DAA, 2 B 106, pismo No 110 Lelonga do Gamelina 25 V 1939 r.; "Rapport du Commandant Bailly relatif à la 2ème Phase de Conversations d'États-Majors franco-britanniques (Londres, 24 Avril - 5 Mai 1939)". 
tym świadomi, że w takim przypadku jedyną wystarczająco szybką pomoc ze strony sojusznika zza Kanału stanowić by mogła seria uderzeń z powietrza ${ }^{45}$.

Przeprowadzone dyskusje $w$ żadnym $z$ przypadków nie odnosiły się jednak do spraw związanych z polskim sojusznikiem. Całość ustaleń odnośnie do kontynentu europejskiego dotyczyła zresztą działań o charakterze defensywnym, które podjęte być miały dla spowolnienia marszu atakujących państwa zachodnie niemieckich wojsk oraz osłabienia siły ich ofensywy. W'́ród rozpatrywanych operacji znalazły się jednak i takie, które mogłyby zostać wykonane z pożytkiem dla polskiego sprzymierzeńca, gdyby to on jednak stał się pierwszą ofiarą spodziewanej agresji. Do tej kategorii należały w szczególności akcje przeciwko niemieckiemu przemysłowi zbrojeniowemu, w tym głównie obiektom skupionym w Zagłębiu Ruhry, na czym zależało stronie francuskiej. Uzgodniono, że $w$ razie uruchomienia takich działań odpowiednie zadania zostaną rozdzielone proporcjonalnie do sił, którymi w danym okresie rozporządzać będzie dany sojusznik. Efektywność lotniczych uderzeń w każdym przypadku podlegałaby jednak zapewne swoistemu samoograniczeniu: alianci powtórnie bowiem stwierdzili, że nie zamierzają podejmować nieograniczonej wojny lotniczej, zastrzegając jednak, że w praktyce zastosowane rozwiązania zależne będą od sytuacji oraz osądzenia wszystkich istotnych okoliczności ${ }^{46}$.

${ }^{45}$ TNA, AIR 9/117, „Minutes of a discussion held between D. [irector] of Plans and commandant Bailly of the French Air Staff in room 22/II. Air Ministry on 5th April 1939" i in. dok.; WO 106/1756, S. 1132 Slessora do bryg. Kennedy'ego z 13 V 1939 r. i nast. dok.; J. Slessor, op. cit., s. 232; P. Fridenson, J. Lecuir, op. cit., s. 129nn. Brudnopisowe egzemplarze konkluzji ze spotkań przedstawicieli sztabów sil powietrznych obu delegacji $z$ dnia 27 i 28 kwietnia $z$ uwagami i poprawkami płk. Slessora: TNA, AIR 75/3.

46 TNA, AIR 9/112, "Joint plans for Franco-British Air Forces” A.F.C. (J) 72 z 5 V 1939 r. $i$ in. dok. (wersja francuska: SHD-DAT, 7 N 3441). Brytyjska analiza prawnych aspektów działań lotniczych: AIR 2/2884, „Note on the legal aspect of air bombardment” Dyrekcji Planowania Ministerstwa Lotnictwa z 25 IV 1939 r. i in. dok. Analizowany równolegle plan uderzenia na niemiecki system zaopatrzenia i zaplecze techniczne ( $w$ tym przemysl lotniczy) opatrzono jednoznacznym wyjaśnieniem: „w celu zredukowania skali ataku przeciw Francji i Wielkiej Brytanii albo przeciw” armii francuskiej wkraczającej do Belgii". Wśród scenariuszy uznanych za możliwe po ocenie relacji "między wojskową koniecznością a efektem politycznym" znalazło się m.in. bombardowanie belgijskich wiosek $w$ celu spowolnienia posuwania się Niemców. 


\section{Rozdział 5 \\ Jeśli Polska będzie pierwsza}

Zakończenie drugiej fazy rozmów międzysztabowych nie oznaczało bynajmniej rozstrzygnięcia wszystkich kwestii interesujących zaangażowane w nie strony. Brytyjczycy bez trudu dostrzegli m.in., że przyjęte 4 maja ustalenia na temat udziału w wojnie „innych europejskich państw” w żaden sposób nie odnoszą się do zagadnienia podniesionego przez nich ledwie dzień wcześniej, tj. postawy aliantów w przypadku skierowania głównego ataku Rzeszy na Polskę przy neutralności Włoch. Rozczarowani postawą Francuzów, którzy nie wydawali się zbytnio zainteresowani uzgodnieniem wspólnego stanowiska $w$ tej sprawie, członkowie Joint Planning Sub-Committee (i uczestnicy zakończonych właśnie rozmów) na posiedzeniu 5 maja zdecydowali się zrezygnować z prób formułowania tu wspólnej z partnerami z Paryża konkluzji, poprzestając na przedłożeniu Szefom Sztabów pisemnej informacji o punkcie widzenia Francuzów. $Z$ drugiej jednak strony, zauważyli, zapoznanie się $\mathbf{z}$ oficjalnym stanowiskiem tych ostatnich w przedmiotowej sprawie będzie w najbliższym czasie niezbędne, trudno bowiem bez jego znajomości podejmować zapowiedziane już rozmowy międzysztabowe ze stroną polską ${ }^{1}$.

To ostatnie zdanie podzielili Szefowie Sztabów, którzy zajęli się kwestią pięć dni później, 10 maja. W dyskusji, która się w związku z tym wywiązała, Air Marshal Cyril Newall przedstawił wniosek w kontekście analizowanej sytuacji oczywisty, ale dotychczas w Londynie ignorowany: „z poglądów wyrażonych przez Francuzów wydaje się wynikać, że żadna w ogóle akcja na Zachodzie nie była [przez nich] w rozpatrywanych warunkach rozważana". Gdyby francuski Sztab Generalny potwierdził ten fakt - kontynuował Szef Sztabu Lotnictwa - konsekwencje mogą okazać się bardzo poważne, „szczególnie w kontekście naszych zobowiązań wobec Europy Wschod-

' TNA, CAB 55/3, „Minutes of the Meeting held on [...] 5th May, 1939”, J.P. 250th Mtg. Szefom Sztabów przekazano po prostu wyciąg z protokołu 13. posiedzenia rozmów międzysztabowych z 3 V 1939 r. (TNA, CAB 53/48, C.O.S. 58 (J.P.) z 5 V 1939 r.). To właśnie zbliżające się rozmowy $z$ przedstawicielami wojskowych władz $z$ Warszawy staty się przyczyną podniesienia przez kmdr. Danckwertsa kwestii pomocy dla Polski jako pierwszej ofiary niemieckiej agresji podczas 13. sesji rozmów międzysztabowych $3 \mathrm{~V} 1939 \mathrm{r}$. 
niej”. Newall stwierdził więc, że o stanowisku Francuzów i dokonanej właśnie jego ocenie należy powiadomić Gabinet ${ }^{2}$.

Szefowie Sztabów uznali zasadność przedstawionego wnioskowania, postanawiając jednak działać wielotorowo. Do gen. Lelonga zwrócono się z ponagleniem, prosząc o możliwie niezwłoczne dostarczenie oficjalnej wykładni francuskich intencji. Z kolei sekretarza Podkomitetu obciążono zadaniem przygotowania memorandum, które po zaaprobowaniu przez członków tego gremium byłoby przedłożone ministrowi koordynacji obrony. Dokument ten, prócz streszczenia dotychczasowego rozwoju sprawy oraz stanowiska Szefów Sztabów, zawierać miał też ich krytyczne ustosunkowanie się do tezy, że „siły francusko-brytyjskie nie powinny czynić realnych wysiłków do zmuszenia Niemiec do walki na dwa fronty" ${ }^{3}$.

List do francuskiego attaché wystosowano już w następnym dniu. Joint Planning Sub-Committee, który zaaprobował treść tej korespondencji, na tymże posiedzeniu upoważnił też swego sekretarza do przedstawienia Szefom Sztabów raportu z drugiej fazy rozmów międzysztabowych.

Nad Tamizą nie zdawano sobie sprawy z tego, że dodatkowy nacisk na partnerów zza Kanału nie jest już konieczny. Francuzi co prawda swoje prace nad zagadnieniem wdrażali wolniej od Brytyjczyków, jednak już 10 maja gen. Gamelin wystosował serię pism do Szefów Sztabów Generalnych poszczególnych broni, prosząc ich m.in. o wyrażenie opinii na temat zagadnień poruszonych przez kmdr. Danckwertsa podczas 13. posiedzenia zakończonych właśnie w Londynie rozmów, tj. konsekwencji ewentualnej neutralności Włoch oraz współpracy wojskowej z Turcją 5 .

Nie znamy niestety wszystkich udzielonych odpowiedzi. Szczęśliwie zachowała się najbardziej spośród nich dla nas istotna, zawierająca stanowisko sformułowane przez gen. Vuillemina. Było ono, tradycyjnie już, zachowawcze i sceptyczne. Szef Sztabu Generalnego Armée de l’Air przyznawał co prawda, że w razie przyjęcia przez Włochów neutralnej postawy bilans sił lotniczych w początkowej fazie konfliktu okazałby się dla francuskiego lotnictwa nieco mniej niekorzystny niż w scenariuszu przeciwnym. Nie powinno to jednak, podkreślał, powodować większego zaangażowania znajdujących się w gestii Paryża sił powietrznych na rzecz Polski. Po pierwsze bowiem, tu Vuillemin posłużył się po raz kolejny standardowym argumentem, na terytorium wschodniego sojusznika nie ma niezbędnego dla eskadr Armée de l'Air

2 TNA, CAB 53/11, „Minutes of the 294th Meeting, held on May 10, 1939”, C.O.S./294th Mtg. Tam też w załączeniu tekst listu. Jego wersja przetłumaczona na język francuski: SHD-DAT, 7 N 2816; tam też pismo No 121/S skierowane w tej sprawie przez Lelonga do Gamelina 12 maja. Zob. też: A. Prazmowska, op. cit., s. 83.

3 TNA, CAB 53/11, „Minutes of the 294th Meeting...”; SHD-DAT, 7 N 2816.

4 TNA, CAB 55/3, „Minutes of the Meeting held on Thursday 11 th May, 1939...., J.P. 252nd Mtg. Podkomitet Szefów Sztabów zaakceptował to sprawozdanie na swym 299. posiedzeniu, 1 VI 1939 r. (TNA, CAB 55/11).

SHD-DAT, 7 N 3439, nota No 936/DN.3 Gamelina do Szefa Sztabu Generalnego Armii z 10 V 1939 r.; SHD-DAA, 2 B 106, nota No 938/DN.3 Gamelina do Szefa Sztabu Generalnego Armée de l'Air z $10 \mathrm{~V} 1939 \mathrm{r}$. 
wyposażenia i innych środków koniecznych do podjęcia walki. Po drugie zaś, gdyby nawet ta trudność została przezwyciężona, zdecydowanie korzystniejsze byłoby wykorzystywanie obszaru Rzeczypospolitej jedynie dla zaopatrzenia maszyn francuskich czy brytyjskich, które po przeprowadzeniu ataku na nieosiągalne $\mathrm{w}$ inny sposób obiekty we wschodnich Niemczech wracałyby następnie do macierzystych baz, wyposażonych w odpowiednią infrastrukturę i materiały.

Perspektywę udzielenia pomocy Polsce jako pierwszej ofierze ewentualnej agresji Vuillemin traktował poniekąd fatalistycznie. Jeśli władze podejmą taką decyzję, podkreślał (także dosłownie, w tekście), działania lotnicze należałoby podjąć szybko, by wymusić na Niemcach rozproszenie pomiędzy dwa fronty ich obrony oraz - co było charakterystycznym dodatkiem - riposty. Jednak - tu Vuillemin odwoływał się do stanowiska przedstawionego przed miesiącem - stan taki nie potrwa długo. Dysponująca na wschodzie przytłaczającą przewagą lotniczą Rzesza bardzo szybko rozprawi się z Polakami, kierując następnie całość swego potencjału przeciwko Francuzom i Brytyjczykom. Ziszczeniu się takiego scenariusza zapobiec może jedynie, co znów pokreślono graficznie w tekście, „wielce pożądana” interwencja po stronie Polski znaczącej części sił radzieckich ${ }^{6}$.

Gdy dziesięć dni później delegacja francuska przekazała wreszcie w Londynie oczekiwaną tam od tygodni odpowiedź, okazało się, że tekst Vuillemina włączony został do niej niemal in extenso, z zachowaniem charakterystycznej emocjonalnej retoryki, stając się po prostu poświęconą zagadnieniom lotniczym częścią tego dokumentu?

Poprzedzające ową część akapity, w których francuscy autorzy zaprezentowali analizę wpływu ewentualnej włoskiej neutralności na działania wojsk lądowych, stanowiły w dużej mierze konkretyzację informacji przedstawionych przez gen. Lelonga na 13. posiedzeniu rozmów międzysztabowych. Jak stwierdzano, gdyby w początkowej fazie wojny Rzym oraz Madryt zachowały postawę wyczekującą, nie podejmując działań, „uwolnione” do innych zadań mogłoby zostać około 15 sojuszniczych dywizji. W takim przypadku otwarta pozostałaby też zapewne droga przez Morze Śródziemne, umożliwiając Francuzom i Brytyjczykom przesyłanie bezpośredniej pomocy dla frontu wschodniego. Ta ostatnia przyjąć by mogła postać dostaw materiałów wojennych i zaopatrzenia, ale też kadr i wyspecjalizowanego personelu, wreszcie - w wyjątkowych wypadkach - ,jednostek bojowych dla uformowania rezerwy generalnej (czołgów i artylerii)"

Wedle autorów opracowania działania takie miałyby pozwolić na „zwiększenie potencjału naszych wschodnich sprzymierzeńców", zarówno w początkowej, defen-

6 SHD-DAT, 2 N 229, pismo No 1268 3-OS/EMAA Vuillemina do Gamelina z 15 V 1939 r. (też: DDF, t. 16, doc. 193, s. 370nn.).

"TNA, WO 193/197, „Note of the consequences of the possible neutrality of Italy", A.F.C. (J) 76 z 25 V 1939 r. Dokument stanowił tłumaczenie francuskiej noty D.F. 23.

"Ibidem. We francuskiej nomenklaturze wojskowej termin „rezerwa generalna” odnosił się do sił pozostających w strategicznym odwodzie naczelnego dowództwa i przeznaczonych do wykorzystania na decydujących kierunkach zgodnie $z$ jego decyzją. 
sywnej fazie działań wojennych, jak i w okresie późniejszym, gdy aktualna stanie się współpraca $w$ ofensywie przeciw Niemcom. Podkreślano więc, iż kwestią najwyższej wagi będzie uzyskanie swobodnego dostępu do baz zaopatrzeniowo-rozładunkowych położonych u ujścia Dunaju oraz w rejonie greckich Salonik 9 .

Wieńcząca całość przedstawionej w dokumencie analizy konkluzja sformułowana została co prawda ostrożnie, ale była to ostrożność zauważalnie odmienna od tej prezentowanej przez Vuillemina - graniczącej niemal z defetyzmem. Podkreślano bowiem, jako rzecz oczywistą, konieczność budowy na obu krańcach Europy, wschodnim i zachodnim, długich i solidnych frontów, zdolnych do oparcia się możliwie najliczniejszym siłom wroga. Równocześnie jednak zapowiadano podjęcie operacji ofensywnych przeciwko Niemcom, zastrzegając, że „zakres i data tych operacji nie mogą być określone a priori". Obawą mogła napawać asekuracyjna uwaga, że ograniczenie frontu ewentualnych działań do obszaru „pomiędzy Bazyleą a Luksemburgiem" postawi na drodze takiego ataku „podwójną przeszkodę" Renu i Czarnego Lasu albo niemiecki system fortyfikacyjny między Renem a Mozelą. Jednak, brzmiała wyrażona w ostatnim zdaniu dokumentu finalna opinia francuskich sztabowców, neutralność Włoch pozwoli zapewne zgromadzić rezerwy ludzkie i materiałowe konieczne do podjęcia takiej ofensywy ${ }^{10}$.

Jak niemal natychmiast zauważono w Londynie, przedstawiony przez Francuzów materiał w okrągłych zdaniach zawierał stosunkowo mało konkretnych treści. Z pewnością zaś nie dawał jednoznacznej, czytelnej odpowiedzi na postawione pytanie. Powstałą konsternację pogłębiały dodatkowo docierające z Paryża informacje, w których świetle francuskie stanowisko przedstawiało się bardziej klarownie, tyle że wyraźnie odmiennie od oficjalnej wykładni. W dodatku zaś źródło tych informacji trudno było posądzać o brak orientacji w zagadnieniu stanowiącym przedmiot zaistniałej w sojuszniczych stosunkach kontrowersji ${ }^{11}$.

Przekazany nad Tamizę szkic francuskich zamysłów pochodził bowiem wprost od szefa Gabinetu Specjalnego gen. Gamelina, płk. Jeana Louisa Paula Marie Petibona. Rankiem 18 maja w rozmowie z płk. W. Fraserem miał on wyjaśniać, że główna francuska ofensywa ruszy z pewnością „w rejonie Morza Śódziemnego, a nie przeciw Niemcom, zaś korzyść dla Polski z takiego kierunku jest taka, że sukces będzie umożliwiał jej zaopatrywanie przez Morze Sródziemne i Morze Czarne". W razie zaś gdyby główne ostrze niemieckiego uderzenia zwrócone zostało ku Polsce, wyłuszczał francuski oficer, Paryż przewiduje podjęcie akcji, która miałaby skłonić Rzeszę do utrzymywania na Zachodzie możliwie licznych sił. „Obejmowałoby to akcję na ziemi i w powietrzu, a Petibon sugerował, że w powietrzu moglibyśmy pomóc" -

${ }^{y}$ Ibidem.

${ }^{10}$ Ibidem; N.H. Gibbs, op. cit., s. 706.

$"$ TNA, CAB 53/49, memorandum "Anglo-French action in Support of Poland", C.O.S. 905 z 3 VI 1939 r. Wersja opatrzona tą datą stanowiła kolejną redakcję dokumentu. Wcześniejszych wersji nie udało się odnaleźć, informacje $z$ innych źródeł wskazują jednak, że powstały one przed dostarczeniem do Londynu francuskiej odpowiedzi na zadane w początkach maja pytanie. 
donosił Fraser. Dodał też, że jego rozmówca ostrożnie zaznaczył, iż takiej informacji nie przekazano przebywającej wówczas w Paryżu delegacji polskich władz wojskowych, zaś przewidywana akcja sił lądowych „obejmie ofensywy dobrze przygotowane i o ograniczonych celach"'?

W przekonaniu, że całość problemu ma "bezpośredni i natychmiastowy wpływ” na udzielone Polsce gwarancje, Air Marshal Newall opracował szkic stanowiska w tej sprawie, które sumując poglądy Szefów Sztabów i ich francuskich partnerów, miało być przedstawione brytyjskim ministrom. Jednak dyskusja podjęta nad tym dokumentem na posiedzeniu Podkomitetu Szefów Sztabów l czerwca ujawniła rozbieżność stanowisk członków tego gremium. Sformułowanym przez Newalla konkluzjom sprzeciwił się świeżo powołany na stanowisko zastępcy Szefa Sztabu Marynarki wiceadmirał Thomas Spencer Vaughan Phillips, kwestionując tezę, że Brytyjczycy, dążąc "do zrobienia czegoś" dla Polski, powinni w razie ataku na nią podjąć akcję lotniczą przeciw Niemcom. Jak zauważył, w takim przypadku strona brytyjska znalazłaby się wobec perspektywy potężnego niemieckiego odwetu, nie wywierając równocześnie poważnej presji na Rzeszę ani też nie osłabiając nacisku na Polskę. Przyznając, że alternatywna koncepcja "nierobienia niczego" jest równie mało satysfakcjonująca, Phillips postulował, by kwestię uznać za polityczną, pozostawiając decyzję członkom Gabinetu ${ }^{13}$.

Pozostali uczestnicy obrad zajęli $w$ tej sprawie mniej radykalne stanowisko w dyskusji podkreślano konieczność podjęcia działań na rzecz zaatakowanej Polski oraz fakt, że akcja lotnicza stanowi w istocie jedyną dostępną Brytyjczykom formę takich operacji. Choć zaś obradujący zgodzili się z tezą, że rozważany problem ma charakter polityczny, to jednak, jak wskazywali, decyzje Gabinetu oparte być winny na argumentacji przedstawionej uprzednio przez czynniki wojskowe. Ostatecznie więc zdecydowano, że przygotowana zostanie nowa wersja kontrowersyjnego dokumentu, z uwzględnieniem zarówno głosów z zakończonej właśnie dyskusji, jak i najnowszych informacji o stanowisku zajmowanym w tej sprawie przez Francuzów ${ }^{14}$.

Dokument przeredagowano w ciągu kilku dni - jego nowy wariant opatrzony został datą 3 czerwca oraz podpisami wszystkich już tym razem Szefów Sztabów. W dłuższym wywodzie przypomniano w nim podejmowane od początku kwietnia brytyjskie wysiłki na rzecz określenia wojskowych implikacji gwarancji, które udzie-

12 TNA, CAB 53/49, „Copy of a letter dated 18th May, 1939, from the Military Attache in Paris to major-general H.R. Pownall". Henry R. Pownall pełnił wówczas funkcję Dyrektora Operacji Wojskowych i Wywiadu w War Office. Nieco odmienną relację z tej rozmowy - krótszą, ale zawierającą dodatkowe szczegóły - Fraser przekazal do War Office w datowanym tegoż dnia raporcie No 706 (kopia: TNA, AIR 40/2032).

13 TAB, CAB 53/11, "Minutes of the 299th Meeting, held on 1st June, 1939", C.O.S./299th Mtg.

14 Ibidem; A. Prazmowska, op. cit., s. 84. Gen. Ismay zauważył, że Francuzi zasygnalizowali stronie brytyjskiej przy użyciu różnych kanałów aż trzy różne wersje odpowiedzi na postawione pytanie, formułowane kolejno przez francuską delegację na drugą turę rozmów międzysztabowych (nieoficjalnie), płk. Petibona oraz w stanowisku przedstawionym oficjalnie 25 maja. 
lone zostały Polsce i Rumunii, oraz próby poczynienia odpowiednich uzgodnień ze stroną francuską. Zwrócono też uwagę na dwie stale pojawiające się w ramach podjętych rozważań zasadniczo sprzeczne konstatacje: niemożność udzielenia Polsce i Rumunii pomocy bezpośredniej czy nawet pośredniej - przez „szybki i spektakularny sukces [ofensywy] przeciw Linii Zygfryda" z jednej strony oraz dążenie do zmuszenia Niemiec do walki na dwóch frontach i prowadzenia "wielkoskalowych i aktywnych operacji równocześnie na każdym froncie" $z$ drugiej strony ${ }^{15}$. Wreszcie - wyrażono opinię, że choć nie sposób przesądzić kierunku pierwszej niemieckiej ofensywy, to jednak najpewniej Rzesza zdecyduje się początkowo przyjąć defensywną postawę na Zachodzie i zaatakować na Wschodzie, ewentualnie podejmując równocześnie próbę podboju Holandii.

Jak podkreślili raz jeszcze autorzy memorandum, w początkowej fazie wojny siły brytyjskie niewiele będą mogły uczynić dla Polski na lądzie - znaczący wkład wnieść tu może jedynie lotnictwo oraz podejmująca blokadę morską Rzeszy Royal Navy. Jeśli więc Francuzi nie podejmą odciążającej wschodniego sojusznika ofensywy w bardzo wczesnym stadium konfliktu, pozbawiona pomocy Polska zostanie pokonana, zaś jej zachodni alianci staną osamotnieni wobec niezwykle groźnego wroga, „chyba że Rosja włączy się do wojny po naszej stronie".

Wątpiącym w ofensywnego ducha Francuzów Brytyjczykom pozostawało jedynie rozważenie możliwości podjęcia własnej akcji lotniczej. W tej części memorandum autorzy dokumentu nieświadomie powielili podejście niewiele wcześniej zastosowane w Paryżu, za wzór przyjmując analizy lotniczych sztabowców. Nad Tamizą te ostatnie wykorzystano jednak nieco bardziej twórczo - wzdragając się przed kopiowaniem całych akapitów tekstu, Szefowie Sztabów sięgnęli jedynie po argumenty płk. Slessora.

Innymi słowy, powtórzone zostały znane nam już wywody. Członkowie Podkomitetu $z$ ubolewaniem (oraz, dodać można, odrobiną hipokryzji) stwierdzili, że zasady lotniczych działań, już uzgodnione ze stroną francuską, przewidują ograniczenie operacji powietrznych do celów o charakterze ściśle wojskowym. Efekt ataku na takie obiekty, kontynuowali, nie byłby na tyle poważny, by zmusić Niemców do złagodzenia presji na Polskę. Spowodowałby natomiast najpewniej propagandową kontrakcję przeciwnika oskarżającego atakujących o przekroczenie zasad wojny powietrznej, a następnie natychmiastowy odwet i ciężkie straty w samej Wielkiej Brytanii.

Podobnie jednak jak uczynił to wcześniej płk Slessor, Szefowie Sztabów nie poprzestali na pełnych rezerwy zastrzeżeniach, decydując się przedstawić - w odróżnieniu od francuskich partnerów - i drugą stronę zagadnienia. Tu zaś motywem przewodnim stawała się mantra „musimy dać Polsce jakąś pomoc”. Raz jeszcze ją powtórzywszy, członkowie Podkomitetu uznali więc, że brytyjskie lotnictwo nie może bezczynnie przyglądać się miażdżeniu polskiego sojusznika, nawet jeśli w efekcie ich działań Luftwaffe podjąć by miała zmasowany kontratak. Zalecili jedynie, by po-

is TNA, CAB 53/49, memorandum „Anglo-French action in suport of Poland”, C.O.S. 905 
wstrzymać się od akcji ofensywnych przez kilka pierwszych dni dla ułatwienia mobilizacji i wojennej dyslokacji sił, a następnie tym skuteczniejszego podjęcia „akcji bardziej efektywnej niż przeciw celom o czysto wojskowym charakterze”. „Sądzimy, że te problemy są tak ważne, że naszym obowiązkiem jest przedstawienie ich do wiadomości Gabinetu" - stwierdzili autorzy dokumentu w podsumowaniu swej analizy ${ }^{16}$.

Niezależnie od zamykających dokument akcentów, bardziej zresztą fatalistycznych niż wojowniczych, odpowiedź na postawione miesiąc wcześniej pytanie nadal nie została udzielona. Co więcej, z biegiem czasu wyraźnie ulatniała się początkowa determinacja do podjęcia możliwie szybkich i radykalnych rozstrzygnięć. Oddanie tych ostatnich $w$ ręce polityków, dla których punktem wyjścia stać się teraz miały ogólnikowe i dość ambiwalentne wojskowe rekomendacje, prowadzić mogło do dalszego rozwadniania "polskiego dylematu", a może wręcz trwałego osadzenia go na mieliźnie spraw nierozstrzygniętych czy nierozstrzygalnych. Niejednoznaczna wciąż postawa Niemiec mogła zresztą wzmacniać nadzieje, że do wojny w najbliższej przyszłości jednak nie dojdzie.

22 czerwca kwestia anglo-francuskiej pomocy dla zaatakowanej ewentualnie przez Rzeszę Polski stała się przedmiotem obrad Komitetu Obrony Imperialnej, w których udział wziął także sam premier Chamberlain. W trakcie niedługiego posiedzenia (premier spieszył się na spotkanie ministrów) Air Marshal Newall przedstawił wyniki dotyczących tej kwestii kontaktów z Francuzami oraz ujęte w przygotowanym 3 czerwca memorandum (teraz oznaczonym jako D.P. (P.) 59) stanowisko Szefów Sztabów. Podkreślił przy tym, że ani Wielka Brytania, ani Francja nie będą w stanie udzielić zaatakowanej Polsce bezpośredniej pomocy. Z drugie strony - wskazał - niezaprzeczalny walor wojskowej współpracy z Warszawą (i Bukaresztem) stanowi możliwość powołania do życia drugiego frontu, którego istnienie oznaczać by musiało rozproszenie sił podejmującej działania wojenne Rzeszy. Niemcy jednak najpewniej podejmą w początkowej fazie konfliktu ofensywę we wschodniej części kontynentu, nieuchronna zaś klęska ulokowanych tam sojuszników Zachodu spowoduje, że całość sił niemieckich zwróci się niebawem ku Francji i Wielkiej Brytanii.

Co więcej - kontynuował Newall - próba uzgodnienia z Paryżem działań, które w razie wojny na Wschodzie mogłyby być podjęte na rzecz Polski, spotkała się z niechęcią Francuzów do precyzowania jakichkolwiek bardziej konkretnych zobowiązań. Skoro zaś brytyjska akcja na lądzie nie może z oczywistych powodów wchodzić w grę, a planowana blokada morska przynieść może efekty jedynie w długiej perspektywie, jedyną możliwą formę pomocy dla Polaków stanowić muszą operacje lotnicze.

Szef Sztabu Lotnictwa przedstawił następnie cztery ramowe scenariusze takich operacji, obejmujące warianty od całkowitej w praktyce bezczynności z wyjątkiem blokady morskiej, z pozostawieniem inicjatywy Niemcom i gotowaniem się do kontrakcji (wariant oznaczony następnie jako „A"), poprzez akcję ograniczoną do celów ściśle wojskowych, tj. jednostek armii w polu, floty wojennej (wariant „B”), rozszerzenie działań na obiekty związane ze sferą wojskową - w tym szczególnie zbiorniki 
ropy naftowej (wariant „C”), aż po porzucenie ograniczeń i „zainicjowanie akcji powietrznej drastycznej natury” (wariant „D”). Szef Sztabu Lotnictwa rekomendował przy tym wybór trzeciego z przedstawionych rozwiązań, jako skutkującego potencjalnie najpoważniejszą redukcją możliwości prowadzenia aktywnych działań przez siły zbrojne Rzeszy. Zastrzegł jednak, że efekt takich działań w szczytowym punkcie niemieckiego uderzenia na Polskę pozostanie bez większego wpływu na bieg wydarzeń, a ich konsekwencje ujawnią się w pełni dopiero, gdy Niemcy zwrócą się ku Zachodowi, sposobiąc się do ofensywy przeciw Francji i Wielkiej Brytanii ${ }^{17}$.

Powyższy wywód uzupełnił lord Chatfield, wyrażając opinię, że brytyjskie społeczeństwo nie zechce przyglądać się biernie miażdżeniu zaatakowanej Polski, lecz będzie oczekiwało „bardzo wczesnego" odwetu. Los wschodniego sojusznika dopełni się w dwa-trzy miesiące, przyznawał. W tym jednak czasie Brytyjczycy powinni wykorzystać sposobność i przezwyciężając swój brak przygotowania, podjąć próbę znaczącej redukcji potencjału wojennego Rzeszy - nim ten w całości zwróci się ku Zachodowi. W toku dalszej dyskusji sformułowany został pogląd, że w razie niemieckiego ataku na Wschodzie ,jakaś akcja na rzecz Polski [...] byłaby niezbędna"18.

Nim jednak podjęto rozważania, które tę ogólną opinię pozwoliłyby wypełnić treścią, minister spraw wewnętrznych Samuel Hoare skierował uwagę uczestników obrad na zupełnie odmienne tory. Jak stwierdził, najdogodniejsze rozwiązanie stanowić by mogło uderzenie w stanowiące najsłabszy punkt Osi Włochy. Odpowiednio wcześnie podjęta akcja tego typu zmusi bowiem Niemców do skierowania części sił na pomoc zagrożonym sojusznikom, to zaś automatycznie zmniejszy niemiecką presję na Polskę.

Uwaga Chamberlaina, że Włochy w początkowej fazie wojny wcale nie muszą wystąpić czynnie, wywołała ożywioną wymianę zdań. Uczestnicy obrad zastanawiali się w jej trakcie, czy początkową neutralność Rzymu uznać by należało za korzystną z punktu widzenia brytyjskich interesów, czy też - jak utrzymywał m.in. minister wojny Leslie Hore-Belisha - wręcz przeciwnie. Ostatecznie owo zagadnienie zdecydowano się przekazać do przestudiowania Szefom Sztabów - do kwestii polskiej już nie wracając ${ }^{19}$.

W sposób niejako naturalny nasuwać się może wyjaśnienie, że w tym przypadku część członków Komitetu dążyła po prostu do odsunięcia w czasie momentu podjęcia trudnej i w każdym przypadku niedogodnej politycznie decyzji. Jednak o kilka dni wcześniejsza notatka zastępcy sekretarza Komitetu Obrony Imperialnej C.N. Ryana dla płk. Hollisa skłania do przypuszczenia, że w grę wchodzić mogła inna, choć równie prozaiczna przyczyna: niezdolność części ministrów do osadzenia rozpatrywanych zagadnień we właściwym kontekście. Jak stwierdzał autor wspomnianego dokumentu, analizując fragment opracowania C.O.S. 905 poświęcony wywieraniu

17 TNA, CAB 2/8, ,Minutes of 360th Meeting, held on June 22, 1939”, C.I.D./360th Mtg. (D.P. (P.)).

in Ibidem.

${ }^{19}$ Ibidem. 
presji ekonomicznej na prowadzące wojnę Niemcy: „Ty i ja, i oczywiście Szefowie Sztabów aż nazbyt dobrze zdajemy sobie sprawę z tego, że presja ekonomiczna przez bardzo długi czas nie może być efektywna, przede wszystkim z powodu znacznej liczby państw neutralnych i zapasów zgromadzonych przez Niemcy, ale ośmielę się zasugerować, iż użyta tam [w dokumencie C.O.S. 905] fraza jest zbyt dwuznaczna dla wielu spośród ministrów Gabinetu, którzy mogą zakładać, iż nacisk odczuwalny będzie od początku"zo.

W każdym razie problem przedstawiony przez Newalla nie tylko nie doczekał się rozstrzygnięcia, ale wręcz, uwikłany $w$ kwestie poboczne, stracił dotychczasową klarowność. Szefowie Sztabów obciążeni zostali zaś dodatkowo przeprowadzeniem kolejnych analiz, które niewiele mogły wnieść do postawionego przez nich na forum Komitetu zagadnienia ${ }^{21}$.

Wspomniane analizy objąć miały kolejno: strategiczne konsekwencje neutralności Włoch w początkowym okresie wojny; środki, które mogłyby zmusić Rzym do zajęcia jednoznacznego stanowiska; efekt podjęcia natychmiastowej ofensywy przeciw pozostającym w sojuszu z Niemcami Włochom dla zmniejszenia niemieckiej presji na zaatakowaną przez Rzeszę Polskę, a także (co postulował lord Halifax) dla sytuacji na Dalekim Wschodzie. Konkluzje dotyczące każdego z tych zagadnień stanowić miały punkt wyjścia do przepracowania przez Szefów Sztabów ich wcześniejszego stanowiska i ponownego przedstawienia go członkom Komitetu22.

Wykonaniem tej serii zadań zajął się początkowo Joint Planning Sub-Committee, który efekty swej pracy zestawil 7 lipca w szkicu raportu „The attitude of Italy in war and the problem of Anglo-French support to Poland"'23. Autorzy dokumentu, rozpatrując neutralność Włoch z punktu widzenia strategicznego, ocenili ją jako korzystną dla aliantów (,jakkolwiek by nie była stronnicza”), uznając, że ograniczone w tej sytuacji możliwości wywierania presji na Niemcy skompensowane zostałyby $z$ naddatkiem przez możliwość redukcji niezbędnego w przypadku otwartej wrogości Rzymu wojskowego zaangażowania. Wobec tego - sugerowano - próbę skłonienia Włochów do opowiedzenia się po stronie Rzeszy trudno uznać za pożądaną, z kolei nacisk na ich akces do przeciwnego obozu byłby $\mathrm{z}$ uwagi na brak odpowiednich instrumentów nieskuteczny.

Gdyby jednak Włosi w nadchodzącej wojnie zostali sojusznikiem Berlina, stwierdzano, to z pewnością jedyną formą skierowanych przeciw nim działań, które mogłyby mieć wpływ na sytuację frontu wschodniego, byłoby podjęcie ofensywy

20 TNA, CAB 104/47, notatka „Economic Pressure” Ryana dla Hollisa z 17 VI 1939 r. Sprawa znaczenia neutralności Włoch dla ekonomicznej blokady Niemiec w dyskusji z 22 czerwca istotnie została podniesiona.

21 A. Prazmowska, op. cit., s. 85.

22 TNA, CAB 55/17, nota J.P. 443 sekretarza Joint Planning Sub-Committee mjr. A.T. Cornwall-Jonesa z 27 VI 1939 r. Członkowie Komitetu wyrazili obawę, że neutralność Włoch utrudni wywarcie presji ekonomicznej na Niemcy, sugerując, że być może lepszym rozwiązaniem byłoby zmuszenie Rzymu do porzucenia neutralnej postawy.

${ }^{23}$ Ibidem, J.P. 446 (takize C.O.S. 938 (J.P.)) z 7 VII 1939 r. 
skierowanej przeciw samej Italii (a nie jej kolonialnym posiadłościom) już w początkowej fazie wojny, nim Niemcy zdążą rozprawić się z polską obroną. Niestety, na lądzie taka akcja jest w praktyce niemożliwa, Francuzi byliby skłonni ją podjąć dopiero po spełnieniu szeregu wcześniejszych założeń, a przede wszystkim po przybyciu na kontynent większej liczby jednostek brytyjskich. To zaś, wobec niedostatku takich jednostek, nie może nastąpić szybko. Z kolei działania lotnicze przeciw włoskim zakładom przemysłowym dałyby zapewne efekt znaczący, po pierwsze jednak, byłyby sprzeczne z przyjętymi już zasadami wojny powietrznej, po drugie zaś, alianci jesienią 1939 roku nie będą posiadali wystarczających środków, by takie akcje przeprowadzić $w$ odpowiedniej skali. Ponadto ewentualne osłabienie przemysłowego potencjału Włoch i tak pozostałoby bez istotnego wpływu na wojenne możliwości Rzeszy.

Ogólnie więc, konkludowali członkowie Podkomitetu, w początkowej fazie wojny zdecydowanie lepiej byłoby działania skierować wprost przeciw Niemcom, nawet bowiem w ograniczonej formie najpewniej osłabią one presję na Polskę i zredukują szanse podjęcia przez Rzeszę ofensywy w kierunku zachodnim. W dodatku, argumentowano, pomoc dla Polski musi być natychmiastowa i efektywna, taki zaś charakter zapewnić jej może tylko bezpośrednia akcja przeciw Niemcom, a nie ich włoskim sprzymierzeńcom ${ }^{24}$.

W ten sposób „włoski wątek”, który zdominował sporą część 260. posiedzenia Komitetu Obrony Imperialnej, okazywał się wtrętem tyleż rozbudowanym, co nieużytecznym czy wręcz bezzasadnym. Przy okazji zaś zdezawuowane zostały roztaczane przez Francuzów jeszcze kilka tygodni wcześniej miraże pomocy dla Polski zapoczątkowanej przez alianckie uderzenie w miękkie „włoskie podbrzusze” sojuszu Berlina i Rzymu. Członkowie Joint Planning Sub-Committee podkreślali teraz z większym jeszcze niż uprzednio naciskiem: „z problemem, który przedstawiliśmy Komitetowi Obrony Imperialnej, [...] koniecznie trzeba się zmierzyć, a kwestia, jakie akcje musimy podjąć i kiedy, musi być wyczerpująco zbadana"2s.

Jak zastrzegli autorzy dokumentu, wciąż nie można było wykluczyć, że atak Rzeszy skierowany zostanie na Zachód, zaś Paryż i Londyn od początku zmuszone byłyby do walki o narodową egzystencję. Za wysoce jednak prawdopodobne uznali, że Hitler oportunistycznie wybierze atak na Wschód, gdzie akcja wojskowa o stosunkowo niewielkiej skali zapewniłaby mu natychmiastową realizację celów. Z kolei ewentualna reakcja Francji i Wielkiej Brytanii pozwoliłaby przypisać tym państwom miano "agresorów".

W dalszej części dokumentu ponownie podjęto analizę czterech scenariuszy możliwych działań na rzecz Polski (A-D), które przedstawiono już wcześniej w stanowiącym punkt wyjścia całości rozważań opracowaniu D.P. (P.) 59. Jak raz jeszcze warto chyba podkreślić, wszystkie cztery warianty dotyczyły wyłącznie podjęcia (lub zaniechania/ograniczenia) akcji brytyjskich sił powietrznych. 
Jak już wyżej wspomniano, pierwotna rekomendacja wskazywała jako najwłaściwsze $z$ wojskowego punktu widzenia „rozwiązanie C”, tj. lotniczy atak na możliwie szeroko zdefiniowane obiekty o charakterze militarnym. Wyrażano jednak wątpliwość, czy sugerowana koncepcja okaże się możliwa do przyjęcia w świetle niedawno uzgodnionych z francuskim sojusznikiem - skądinąd na wniosek samych Brytyjczyków i zgodnie z ich projektem - zasad polityki bombardowań. Rozpatrywana na posiedzeniu 7 lipca redakcja zawierała jedynie propozycję, by treść rozważań dotyczących bombardowań zakomunikować francuskiemu Sztabowi Generalnemu celem osiągnięcia ostatecznego $\mathrm{w}$ tej kwestii porozumienia. Wobec znanego w Londynie pasywistycznego nastawienia gen. Vuillemina tak sformułowana koncepcja stanowić mogła w istocie zawoalowaną próbę wycofania się z prób aplikacji bardziej radykalnych rozwiązań w zakresie lotniczej polityki - przy obciążeniu lwią częścią odpowiedzialności partnerów znad Sekwany²6.

Nad przedstawionym im tekstem Szefowie Sztabów dyskusję podjęli cztery dni później, na 306. posiedzeniu swego Podkomitetu. Z dość niejasnych przyczyn ponownie podjęto wówczas rozpatrywanie scenariusza, w którym Włochy zostać by miały zmuszone do wyboru strony konfliktu, analizując także środki, które mogły zostać wykorzystane w tym celu przez aliantów. W efekcie dyskusji sekretarz Podkomitetu, gen. Ismay, rozpoczął prace nad kolejną redakcją raportu. 12 lipca sprawą znów zajmował się Joint Planning Sub-Committee oraz Szefowie Sztabów. Skutkiem stała się seria kolejnych zmian tekstu ${ }^{2 i}$.

Wersja przedstawiona Szefom Sztabów na ich następnym spotkaniu, 18 lipca (C.O.S. 939 (Second Revised Draft)) wyraźnie różniła się od poprzednich, przede wszystkim w obrębie partii poświęconych aspektom polskim. Neutralność Włoch w przyszłej wojnie raz jeszcze, tym razem już ostatecznie, uznana została za korzystniejszą dla aliantów od otwartej wrogości, nawet gdyby Rzym w istocie wyraźnie sprzyjał Niemcom ${ }^{28}$. Jeśli jednak Włosi zdecydowaliby się na udział w konflikcie zbrojnym po stronie Rzeszy, podkreślali Szefowie Sztabów, żadna z możliwych do

26. Niepełne brzmienie wczesnych (choć niemożliwych do dokładniejszego datowania) wersji dokumentu zawiera, jak się wydaje, zachowana w spuściźnie J. Slessora redakcja jego Części II („In the event of Italy being allied to Germany against us what effect would an immediate offensive concentrated on Italy have in relieving pressure of a German attack on Poland in the circumstance visualized in C.I.D. Paper No. D.P. (P) 59”) oraz Części III ( „Re-examination of C.I.D. Paper No. D.P. (P) 59 in the light of the conclusions reached in Part I and II above"). Wersja rozpatrywana 7 VII 1939 r. (dokument bez numeru kancelaryjnego załączony do C.O.S. 938 (J.P.)): TNA, CAB 53/51; CAB 55/17.

27 TNA, CAB 53/11, „Minutes of the 306th Meeting held on 11 th July, 1939”, C.O.S./306th Mtg. i nast. dok.; CAB 53/52, "The attitude of Italy in war and the problem of Anglo-French Support to Poland. Note by Joint Planning Sub-Committee submitting a draft of paragraph 7 to Paper No. C.O.S. 939 (Revised Draft)", C.O.S. 942 (J.P.) z 12 VII 1939 r.; CAB 55/3, „Minutes of the Meeting held on [...] 12 July, 1939", J.P. 261 th Meeting.

2* Taką opinię Szefowie Sztabów powtarzać mieli konsekwentnie i z naciskiem aż do ostatnich dni pokoju. Zob.: TNA, CAB 53/11, „Minutes of the 312th Meetting, held on 24 August, 1939", C.O.S./312th Mtg. 
podjęcia przeciw nim akcji na morzu, lądzie czy w powietrzu nie mogłaby stanowić realnej ulgi dla zaatakowanej przez Niemcy Polski.

Po raz kolejny powtórzona została też teza, że jedyną możliwość brytyjskiej pomocy dla znajdujących się w takiej sytuacji Polaków stanowić mogą działania powietrzne. Zamiast jednak sformułować rekomendacje co do ich zakresu, Szefowie Sztabów zaproponowali kontynuację działań pozornych, za "najważniejsze” uznając rozpatrzenie alternatywnych scenariuszy takich akcji oraz ich potencjalnych efektów, tj. dokładnie to, co absorbowało ich od kilku już tygodni.

Wrażenie, że zwłoka w podjęciu decyzji stanowiła tu wstęp do wycofania się $\mathrm{z}$ bardziej radykalnych zaleceń, pogłębiała charakterystyczna fraza użyta $w$ następnym akapicie dokumentu. „Ogólnie chcielibyśmy podkreślić - stwierdzali jego autorzy - że los Polski zależy od ostatecznego rezultatu wojny, a ten z kolei zależy od doprowadzenia do ostatecznej klęski Niemiec, a nie od naszej możliwości zmniejszenia nacisku na Polskę w jej początkach"29. Uwaga ta, sama w sobie niewątpliwie słuszna, z braku innej, pozytywnej koncepcji stać się odtąd miała rodzajem zaklęcia służącego usprawiedliwianiu (oraz samousprawiedliwianiu) bierności zachodnich sojuszników Rzeczypospolitej.

Choć więc umieszczone w końcowej części tekstu rekomendacje brzmiały podobnie do zamykających wersję poprzednią, analizowaną przez Szefów Sztabów 7 lipca, zawierając sugestię przedstawienia treści brytyjskich rozważań francuskim aliantom dla podjęcia wspólnych decyzji w przedmiotowych kwestiach („jeśli to będzie niezbędne", dodawano w nowej redakcji), to sugerowany sens był już zdecydowanie odmienny. Miejsce uwag o konieczności „natychmiastowego" wsparcia dla Polski zajęło trącące sofizmatem podkreślenie związku przyszłych losów wschodniego sojusznika $z$ ostatecznym wynikiem nadchodzącego konfliktu zbrojnego ${ }^{30}$.

Jednoznaczne wskazanie przyczyn tej znamiennej, dokonanej przy tym w relatywnie krótkim czasie ewolucji poglądów nie wydaje się zadaniem łatwym, tym bardziej że żadnych właściwie wskazówek nie dostarcza tu lakoniczna minuta z posiedzenia Podkomitetu Szefów Sztabów ${ }^{31}$. Jak jednak sądzić można, główną rolę odegrała tu niejednoznaczna postawa polityków z kręgów rządowych. Wśród brytyjskich elit ugruntowywało się przekonanie, że kwestia pomocy dla Polski jako pierwszej ofiary niemieckiej agresji przestaje być zagadnieniem o charakterze teoretycznym, a podjęte decyzje mieć będą najzupełniej realne konsekwencje już w bliskiej przyszłości. Swiadomość, że Wielka Brytania nie jest przygotowana do zbrojnej konfrontacji z Rzeszą, nawet jeśli (czego bynajmniej nie uznawano za pewne) po stronie tej ostatniej nie opowiedzą się Włochy oraz coraz bardziej swą ekspansywną postawą

${ }^{24}$ TNA, CAB 53/51, C.O.S. 939 (Revise) z 18 VII 1939 r. Na wykorzystanie w tym dokumencie po raz pierwszy przywolanego wyżej argumentu zwróciła uwagę A. Prazmowska (op. cit., s. 86 i 167). P. Fridenson oraz J. Lecuir (op. cit., s. 157) błędnie datują pierwsze jego użycie na 7 VII $1939 \mathrm{r}$.

30 TNA, CAB 53/51, C.O.S. 939 (Revise) z 18 VII 1939 r.

3 TNA, CAB 53/11, „Minutes of the 308th Meeting, held on 18 July, 1939”, C.O.S./308th Mtg. 
absorbująca Londyn Japonia, w sposób naturalny sprzyjała szerzeniu się stanowisk o charakterze kunktatorskim. Szefowie Sztabów, którzy wobec perspektywy wojny w obronie Polski postawieni zostali wbrew swej woli, skłonni byli latem 1939 roku przedstawić najlepsze w swym mniemaniu koncepcje udziału Wielkiej Brytanii w takim konflikcie - z pewnością jednak nie zamierzali forsować radykalnych rozwiązań bez wyraźnej politycznej aprobaty.

$\mathrm{Na}$ ewolucję poglądów najwyższych dowódców brytyjskich sił zbrojnych wpłynąć mogły też opinie ich francuskich partnerów, przede wszystkim zaś gen. Gamelina, który w tym czasie gościł w Paryżu gen. Gorta wraz z grupą towarzyszących mu oficerów. Francuski głównodowodzący na kwestię zbrojnej pomocy dla zaatakowanej Polski zapatrywał się bowiem w sposób dość charakterystyczny czy też po prostu - cyniczny. W trakcie spotkania 13 lipca miał bowiem brytyjskim gościom oświadczyć wprost: „Mamy wszelki interes w tym, by wojna zaczęła się na wschodzie i rozwijała jedynie stopniowo. Mielibyśmy w ten sposób czas na postawienie na stopie wojennej całości sił francusko-brytyjskich". Zapewniając ogólnikowo, że Francuzi nie zamierzają bynajmniej pozostawiać Polski „od początku osamotnionej wobec Niemiec", Gamelin roztoczył wizję wykorzystania zyskanego dzięki jej ofierze czasu na opanowanie i umocnienie przedpola własnych pozycji, „na wypadek gdyby Niemcy zwróciły swe siły przeciwko nam". Trudno sądzić, by podobna postawa pozostała bez wpływu na podejmowane $w$ tym czasie w Londynie decyzje odnośnie do zaangażowania na rzecz i tak zdaniem tamtejszych wojskowych skazanego na zagładę partnera ze wschodniej części kontynentu ${ }^{32}$.

Zwieńczeniem trwającej nad Tamizą od tygodni dyskusji w kwestii, która początkowo dotyczyć miała brytyjsko-francuskiej pomocy dla zaatakowanej przez Rzeszę Polski, w razie gdyby ta pierwsza przyjęła na Zachodzie bierną postawę, a niebawem zdominowana została przez rozważania poświęcone przypuszczalnemu stanowisku Włoch, stało się odbyte 24 lipca posiedzenie Komitetu Obrony

"SHD-DAT, 7 N 3439, „Conversations militaires franco-britanniques. Résumé des conversations du 13 Juillet 1939". Zob. też: M.S. Alexander, The Republic in Danger. General Maurice Gamelin and the Politics of French Defence, 1933-1940, Cambridge 1992, s. 311 oraz DDF, t. 17, doc. 198, s. $341 \mathrm{nn}$. Ani w tej ostatniej edycji, ani w innych sporządzonych przez każdą ze stron zapisach przebiegu toczonych przez Gorta w Paryżu rozmów nie pojawiły się przywołane wyżej frazy. Zob. np.: SHD-DAT, 1 N 43, rękopismienna notatka "Séance du 13 Juillet 1939"; 2 N 229 , nota "Conversations franco-britanniques du 13 Juillet 1939” i in. dok; TNA, AIR 9/112, „Report on Anglo-French Conversations held in Paris on July 13. 1939”; WO 106/1687, „Notes for C.I.G.S. for Conversations with General Gamelin 13th-15th July, 1939" i in. dok. Stanowisko sformułowane 13 lipca Gamelin przedstawił w sposób uderzająco podobny kilka miesięcy póżniej - 12 września, podczas pierwszego posiedzenia Najwyższej Rady Sojuszniczej w Abbeville. Uznać je więc wypada za pogląd przemyślany i ugruntowany. Stosunek szefa francuskiego Sztabu Generalnego Obrony Narodowej do polskiego sojusznika znalazł zresztą odzwierciedlenie $w$ ówczesnych polskich ocenach. W sporządzonej w O. II SG pochodzącej z roku 1939 [?] syntetycznej charakterystyce Gamelina napisano: „Tęgi fachowiec, lecz słaba indywidualność. [...] Polska interesuje go tylko jako czynnik przeciwwagi niemieckiej. Sentymentu do niej nie miał i nie ma" (AAN, SG, 617/6, zał. do L. 2280/SO - 39). 
Imperialnej. Występujący ponownie w roli referenta stanowiska Szefów Sztabów Air Marshal Newall wyjaśnił, że w przekonaniu tych ostatnich neutralność Włoch w początkowej fazie wojny uznać należy za pożądaną, zaś ewentualna akcja przeciw zaangażowanej w działania zbrojne Italii nie zmniejszy niemieckiej presji na Polskę. Z kolei, klarował, przekonanie części członków Komitetu, że szybkie pokonanie Włoch umożliwi skierowanie uwolnionych w ten sposób sił aliantów do zadań na innych frontach, acz oparte na pewnych wcześniejszych analizach, w gruncie rzeczy stanowi nieporozumienie. $Z$ konsultacji ze stroną francuską wynikło bowiem jednoznacznie, że pierwsze działania wobec Włoch podjęte by zostały na terenie Trypolitanii, co z pewnością nie będzie skutkować szybkim zmuszeniem Rzymu do kapitulacji ${ }^{33}$.

Następnie Newall powrócił do przedstawionych już miesiąc wcześniej czterech scenariuszy działań lotniczych, wskazując, że wobec potrzeby poczynienia uzgodnień z Francuzami zajęcie przez Komitet stanowiska w tej kwestii byłoby wielce pożądane. Członkowie tego gremium, miast zająć się tak sformułowanym wnioskiem, ponownie pogrążyli się jednak w rozważaniach poświęconym Włochom, do kwestii przedstawionego przez Newalla wyboru powracając dopiero pod koniec posiedzenia. I wtedy zresztą nie przyjęto żadnej jasnej konkluzji, dość beztrosko stwierdzając, że problem lotniczej polityki aliantów rozwiążą sami Niemcy, którzy od dawna już dają do zrozumienia, iż w razie ataku na Polskę „bombardowaliby każdy istotny obiekt, niezależnie od możliwych strat wśród ludności cywilnej”. Kwestię wad i zalet możliwych scenariuszy działań lotniczych postanowiono natomiast przedyskutować z Francuzami i Polakami, za podstawę przyjmując przedłożone Komitetowi opracowanie Szefów Sztabów, w szczególności zaś jego Część III ${ }^{34}$.

$\mathrm{Z}$ naciskiem przy tym należy podkreślić, że wbrew spotykanym niekiedy w literaturze poglądom ani 18, ani 24 lipca nie przesądzono bynajmniej ostatecznie sprawy sojuszniczej czy choćby tylko brytyjskiej relacji do wschodniego frontu spodziewanej wojny ${ }^{35}$. Przeciwnie - 19 lipca obradujący pod przewodnictwem lorda Chatfielda Szefowie Sztabów, świadomi, że sami niewiele mogą tu zdziałać, zagadnienie to nadal wymieniali jako wymagające uzgodnień z Paryżem, dodając nie bez pewnej konster-

33 TNA, CAB 2/9, „Minutes of 368th Meeting, held on 24th July, 1939”, C.I.D./308th Mtg. (D.P. (P.)).

${ }^{34}$ Ibidem; TNA, CAB 66/1/1, „The attitude of Italy in war and the problem of Anglo-French support to Poland”, D.P. (P.) 65 (Revise) z 18 VII 1939 r., zał. do „Note by Secretary” W.P. (39) 1. E.E. Bridgesa z 3 IX 1939 r. Dla ścisłości dodać można, że wspomniana wersja dokumentu, uzupełniona o korekty stanowiące wynik obrad z 18 lipca, została przyjęta przez Szefów Sztabów dopiero 19 lipca, na kolejnym (309.) posiedzeniu, któremu w tym punkcie przewodniczył lord Chatfield. Wtedy też wprowadzono do niej na wniosek Newalla ostatnią już zapewne zmianę (TNA, CAB 53/11, "Minutes of the 309th Meeting, held on 19 July, 1939”, C.O.S./309th Mtg.). Przebieg dotychczasowych dyskusji na temat ofensywy przeciw Włochom podsumował 17 lipca płk Hollis w przesłanej Chatfieldowi nocie J.P. 473 oraz załączonym do niej „Summary of discussions and decisions as to offensive against Italy" (TNA, CAB 55/18).

35 A. Prazmowska, op. cit., s. 86. 
nacji, iż jest „możliwe, że Francuzi mogliby podjąć ograniczone ofensywy przeciwko Linii Zygfryda - ale sytuacja jest dalece niejasna"36.

Nie znaczy to oczywiście, że lipcowe debaty pozostały bez wpływu na dalsze poczynania brytyjskich władz, a szczególnie kierownictwa sił zbrojnych. W ich trakcie ostatecznie ugruntowane zostało bowiem krystalizujące się już od dłuższego czasu przekonanie, iż jedyną formę pomocy, której Zjednoczone Królestwo udzielić może zaatakowanej przez Rzeszę Polsce, stanowią działania lotnicze. W tym też niemal wyłącznie duchu kontynuowana była wymiana zdań z francuskim sojusznikiem, przy czym „kwestia polska” nie po raz pierwszy rozpatrywana być miała jako część szerszego zagadnienia o charakterze $\mathrm{w}$ dużej mierze teoretycznym, które od pewnego już czasu określano w Londynie mianem "polityki bombardowań" (bombardment policy).

Brytyjscy dowódcy, zaabsorbowani szeregiem innych spraw, sprawę podjęli ponownie dopiero 5 sierpnia. Wtedy to sekretarz Joint Planning Sub-Committee (a także brytyjskiej delegacji na rozmowy międzysztabowe) gen. A.T. Cornwall-Jones zaproponował, by decyzję Komitetu Obrony Imperialnej o podjęciu z Francuzami i Polakami dyskusji na podstawie przyjętego 24 lipca memorandum realizować stopniowo, pierwsze kroki kierując do Paryża. Sześć dni później stanowisko to poparli pozostali członkowie Podkomitetu. Na posiedzeniu przyjęto tekst listu, który w tej sprawie wystosowany miał zostać do gen. Lelonga, a także treść noty na temat polityki bombardowań, którą zamierzano dołączyć do tej korespondencji ${ }^{37}$. Jednocześnie wspomniana polityka stała się przedmiotem analiz specjalnie powołanego podkomitetu, który przestudiować miał przede wszystkim jej aspekty prawne. W tym przypadku efekty prac wykorzystać zamierzano głównie na użytek wewnętrzny (m.in. dla poinstruowania dowódców na obszarach zamorskich), jednak ich użyteczność dla podejmowanych $w$ tym czasie konsultacji z sojusznikami była najzupełniej oczywista ${ }^{38}$.

Pismo do Lelonga wystosowano bez zbędnej zwłoki, już 14 sierpnia. Cornwall-Jones potwierdził $w$ nim, jako fakt już uzgodniony w trakcie wcześniejszej wymiany poglądów, niemożność udzielenia polskiemu aliantowi w początkowym okresie wojny pomocy $w$ formie innej niż tylko akcja lotnicza. Następnie zaś poprosił o przedstawienie opinii francuskiego Sztabu Generalnego na temat analizowanych w załączonym memorandum strony brytyjskiej korzyści i mankamentów głównych

36 TNA, CAB 53/11, "Minutes of the 309th Meeting, held on 19 July, 1939", C.O.S./309th Mtg. Wskazywało to też wyraźnie, że kierownictwo brytyjskich sił zbrojnych w drugiej połowie lipca nie było świadome, nawet w ogólnych zarysach, treści dyrektyw wydanych w tej kwestii przez Gamelina niemal dwa miesiące wcześniej.

37 TNA, CAB 55/3, „Minutes of the Meeting held on [...] 11th August 1939..., J.P. 267th Meeting; CAB 55/19, noty J.P. 500 Cornwall-Jonesa z 5 VIII 1939 r. oraz J.P. 508 z 12 VIII 1939 r.

3* TNA, CAB 55/19, „Note by Secretary” J.P. 512 A.T. Cornwall-Jonesa z 9 VIII 1939 r. W skład powołanego gremium wszedł radca prawny Foreign Office William Malkin oraz trójka wyższych oficerów - członków Joint Planning Sub-Committee - z prawem ewentualnego doboru dalszych członków. Pierwsze spotkanie nowego podkomitetu miało miejsce 11 sierpnia. Zob. TNA, CAB 53/53, C.O.S.959 z 15 VIII 1939 r. 
możliwych wariantów takiej akcji. Zgodnie z wcześniejszymi zaleceniami Szefów Sztabów wyraził też przekonanie, że przyjęte $w$ ten sposób zasady „polityki bombardowań" winny koniecznie zaaprobować ex post także władze polskie, zaś wszelkie podejmowane w Warszawie decyzje o ewentualnych atakach lotniczych na Niemcy uzależnić należy od wcześniejszych konsultacji z Londynem i Paryżem ${ }^{39}$. Tym samym wyraźniej jeszcze niż uprzednio zarysowało się znamienne przesunięcie akcentów: dotychczas sednem problemu pozostawała kwestia możliwych form lotniczej pomocy dla zaatakowanego przez Rzeszę polskiego alianta - teraz istotne stawały się także działania na rzecz powstrzymania go od zbytniej samodzielności.

Zauważyć jednak trzeba, że obie sprawy, choć powiązane, należały do odmiennych nieco porządków, zaś troska o powstrzymywanie zbyt skorych do szarży Polaków (jak dość powszechnie oceniały ich brytyjskie i francuskie elity) nie oznaczała bynajmniej rezygnacji z dyskusji na temat lotniczej dla nich pomocy. Przygotowana w Londynie i przekazana następnie Francuzom analiza zysków i strat, które pociągać miałby za sobą każdy rozpatrywany wariant operacji powietrznych na rzecz Polski, uległa w ciągu kilkutygodniowych prac zauważalnym modyfikacjom, ale wciąż trudno byłoby się w niej doszukiwać zaleceń przyjęcia przez Zachód biernej postawy. Owszem, w międzyczasie z listy mankamentów najłagodniejszej z branych pod uwagę opcji „A", zakładającej poprzestanie na przygotowaniach do działań, jednak bez ich podejmowania, znikła np. uwaga, że utrudnić to może rozpoczęcie powietrznej ofensywy w przyszłości. Znacznemu skróceniu uległy też fragmenty, w których podkreślano znaczenie wschodniego frontu i zwracano uwagę, że w razie braku aktywności zachodnich sojuszników jego istnienie będzie wątpliwe lub okaże się zapewne krótkotrwałe ${ }^{40}$. Wreszcie, rozbudowano partie zawierające analizę niedogodności mogących wyniknąć z przyjęcia najbardziej radykalnego wariantu „D”, tj. ataku na cele najistotniejsze $z$ punktu widzenia redukcji wojennego potencjału przeciwnika, bez względu na ewentualne poważne straty wśród ludności cywilnej ${ }^{41}$.

Równocześnie jednak w memorandum przekazanym na ręce gen. Lelonga dość wyraźnie, choć nie wprost, rekomendowano jako najwłaściwszą opcję „C", zawierającą propozycję podjęcia działań przeciw obiektom o zasadniczo wojskowym charakterze, ważnym jednak dla całości podjętych przez nieprzyjaciela operacji, przede wszystkim zbiornikom paliw płynnych oraz odpowiednim instalacjom wytwórczym. Ograniczenie się do ataku na cele najściślej militarne (wariant „B”), zauważali Brytyjczycy,

3y TNA, WO 193/197, "Anglo-French action to support Poland. Letter from the Secretary, United Kingdom Delegation to General Lélong (dated August 14, 1939)"; kopia tego dokumentu w języku francuskim: SHD-DAA, 2 B 106 (takize: SHD-DAT, 7 N 2817).

41' W tym ostatnim przypadku we wczesnych wersjach dokumentu brano pod uwage nie tylko szybką klęskę Polski, ale też scenariusz, w którym Rzesza w krótkim czasie opanuje Gdańsk, Korytarz oraz inne „niemieckojęzyczne” części Rzeczypospolitej, a następnie wystąpi z propozycją zawarcia pokoju.

4) Wciąż jednak mowa była o atakach na cele o znaczeniu strategicznym, jak elektrownie czy wytwórnie łożysk kulkowych, a nie lotniczych rajdach kierowanych wprost przeciw ludności cywilnej. 
byłoby nieekonomiczne i w ogólnym bilansie nieefektywne - także z punktu widzenia redukcji niemieckiego nacisku na Polskę. Z kolei wariant „D”, choć najbardziej efektywny, zdaniem analityków z Londynu niewiele pod tym względem przewyższał nieco ograniczoną opcję „C". Korzyści z jego przyjęcia dodatkowo redukowały zaś uboczne konsekwencje natury politycznej (zrażenie opinii światowej, w tym amerykańskiej), prawnej (prawdopodobieństwo naruszenia zawartych w konwencji haskiej z 19 lutego 1923 r. reguł wojny powietrznej), moralnej i propagandowej (utrudnienie sukcesu skierowanej ku ludności niemieckiej propagandy antynazistowskiej) ${ }^{42}$.

W tej sytuacji szczególnego znaczenia nabierała reakcja francuskich adresatów wystosowanej przez Brytyjczyków korespondencji, którą gen. Lelong wyekspediował do Paryża 16 sierpnia ${ }^{43}$. W stolicy Francji dostarczony materiał trafił w krótkim czasie na biurko gen. Gamelina. Ten jednak, choć gorąca do niedawna sytuacja międzynarodowa wchodziła właśnie $\mathrm{w}$ fazę wrzenia, nie zdecydował się na zajęcie stanowiska przed zapoznaniem się ze zdaniem gen. Vuillemina, do którego kopia brytyjskiego memorandum została przesłana 23 sierpnia ${ }^{+4}$.

Adresat, do którego przesyłka dotarła dzień później, odpowiedział bezzwłocznie. Jak stwierdził, błędem byłoby dopuszczenie do skierowania na Polskę całej potęgi Luftwaffe. Konieczność zmuszenia Niemców do zatrzymania na froncie zachodnim możliwie znacznej części ich sił powietrznych skłonić powinna sojuszników Rzeczypospolitej do przyjęcia za najwłaściwszy, „z całą konieczną ostrożnością" w sferze procedur wykonawczych, wariantu „B” z brytyjskiej propozycji. Bardziej zdecydowane działania, argumentował Vuillemin, mogłyby być podejmowane w późniejszym czasie, stosownie do zakresu odpowiednich akcji lotnictwa przeciwnika. Oczywiście, zastrzegał Szef Sztabu Generalnego Armée de l’Air, podjęcie przewidywanych w wariancie "B" operacji musi być uzależnione od decyzji rządu, zaś ich data początkowa skorelowana $\mathrm{z}$ postępami koncentracji sił francusko-brytyjskich na Północno-Wschodnim Teatrze Operacji. Liczyć należy się bowiem z nieuchronną ripostą lotnictwa przeciwnika, która na płynność ruchów koncentrujących się wojsk nie pozostanie z pewnością bez wpływu. Co więcej, akcje lotnicze powinny poprzedzić

${ }^{12}$ TNA, WO 193/197, „Anglo-French action to support Poland. Letter from the Secretary, United Kingdom Delegation to General Lélong (dated August 14, 1939)".

${ }^{3}$ SHD-DAT, 7 N 2817, pismo No 306/S Lelonga do płk. Aymé z Sekretariatu Generalnego Obrony Narodowej z 16 VIII 1939 r. (inny sygnowany egzemplarz: SHD-DAA, 1 B 3). Kilka dni później Lelong przekazał do Paryża drobną korektę otrzymanego tekstu. SHD-DAT, 7 N 2817, pismo No 336 Lelonga do płk. Aymé z 24 VIII 1939 r.

4 SHD-DAA, 2 B 106, pismo No 1730/D.N.3 Gamelina do Vuillemina z 23 VIII 1939 r. (publikacja: DDF, t. 18, doc. 393, s. 466n.). Do zachowanej w SHD-DAT, 2 N 229 kopii tego pisma dołączona została jednak niesygnowana, datowana 21 VIII 1939 r. nota z lakonicznym streszczeniem brytyjskiej analizy oraz sugestią odpowiedzi, która sprowadzać by się miała do propozycji początkowego przyjęcia za obowiązujące zasad określonych w IV konwencji haskiej z 18 X $1907 \mathrm{r}$. (a szczególnie jej art. 25, zawierającego zakaz bombardowania przy użyciu jakichkolwiek środków miast, wsi, osiedli czy zabudowań, które nie byłyby bronione), w razie zaś gdyby Niemcy zlekceważyli zawarte w konwencji zapisy, postępować za ich przykładem. 
przewidywane rozpoczęcie przez armię lądową operacji zaczepnych na rzecz Polski. Jedynie wtedy ofensywa lotnicza okazać się może w pełni efektywna ${ }^{45}$.

Przedstawioną przez Vuillemina argumentację niewątpliwie należało uznać za zręczną. Dowódca francuskich sił powietrznych docenił zasadność proponowanej przez stronę brytyjską, a także - nie bez zastrzeżeń - Gamelina i Daladiera, lotniczej akcji na rzecz zaatakowanej Polski. Jednocześnie jednak jako najwłaściwszy wskazał najbardziej ograniczony $z$ możliwych $w$ tej sytuacji wariant działań, zaś uruchomienie lotniczych operacji obwarował szeregiem warunków, które jeśli miałyby zostać uwzględnione, znacząco opóźnić musiały podjęcie powietrznej ofensywy. Co więcej wreszcie, tę ostatnią proponował faktycznie uzależnić od zakrojonych na większą skalę ofensywnych poczynań wojsk lądowych. Miał zaś wszelkie powody przypuszczać, że perspektywę podjęcia przez nie takiej akcji uznać można za co najmniej wątpliwą.

Generał Gamelin przyjął stanowisko Vuillemina do aprobującej wiadomości argument o konieczności wstrzymania skierowanych przeciw Rzeszy działań bombowych zachodnich sojuszników do czasu zakończenia koncentracji wojsk francuskich miał zostać przezeń w następnych tygodniach wykorzystany wielokrotnie. Otrzymaną opinię nie po raz pierwszy przyjął za własną, powtarzając użyte przez Szefa Sztabu Armée de l'Air frazy w przesłanym 26 sierpnia piśmie do Daladiera. Zwrócił w nim uwagę na potrzebę podjęcia zawczasu odpowiednich decyzji o charakterze politycznym. Nie czekając na odpowiedź, wydał też polecenie przedyskutowania kwestii pomocy dla Polski na forum międzysojuszniczego Wojskowego Komitetu Studiów, który miał się zebrać w Londynie 28 sierpnia dla ponownego podjęcia zapoczątkowanych w końcu marca brytyjsko-francuskich rozmów międzysztabowych. Jak zapowiadał, opracowywane przez Comité des sections de Plan materiały do dyskusji na ten temat zostaną delegatom francuskim dostarczone, gdy tylko stanie się to możliwe ${ }^{46}$.

Równocześnie postępowały prace nad zagadnieniem, które jak już wskazano, przynajmniej nad Tamizą uważane były za nie mniej ważne od polskich aspektów przyszłych brytyjsko-francuskich działań lotniczych, tj. ogólnym kształtem „polityki bombardowań”. Ta skądinąd miała dwa powiązane ze sobą aspekty. Jeden z nich dotyczył przyjęcia rozwiązań na użytek głównie wewnętrzny, w formie instrukcji dla brytyjskich dowódców. Propozycja stanowiska w tej sprawie, opracowana w początkach drugiej dekady sierpnia przez podkomitet obradujący pod przewodnictwem Williama Malkina, uznana została za zbyt restrykcyjną. Przeciw zawartym w niej zapisom wypowiedział się m.in. lord Halifax, wyrażając opinię, że mogą one wywołać zaniepokojenie sojuszników i wywołać konsternację w szeregach własnych sił powietrz-

45 SHD-DAA, 1 B 3, pismo No 2190 3-O-S/EMAA za ministra lotnictwa i z jego rozkazu Vuillemina do Gamelina z 24 VIII 1939 r. (publikacja: DDF, t. 18, doc. 393, s. 466n.). Zob. też: P. Fri denson, J. Lecuir, op. cit., s. 158; M. Zgór niak, Europa w przededniu wojny. Sytuacja militarna w latach 1938-1939, Kraków 1993, s. 479, Wydawnictwa "Księgarni Akademickiej”, 7.

46 SHD-DAA, 2 B 106, pismo No 1754/D.N.3 Gamelina do Vuillemina z 25 VIII 1939 r. wraz z załącznikiem: „Principales questions à regler avec le Secrétariat du C.I.D.”; SHD-DAT, 2 N 229, kopia pisma No 1774/D.N.3 Gamelina do Daladiera z 26 VIII 1939 r. 
nych, niepewnych, czy wobec daleko posuniętych ograniczeń będą mogły właściwie wykonywać swe obowiązki. 17 sierpnia Joint Planning Sub-Committee uznał przeto za konieczne przeredagowanie tego dokumentu, a następnie przekazanie nowej jego wersji do aprobaty ministrowi koordynacji obrony. W późniejszym czasie, wskazano, pożądane byłoby zapoznanie z treścią instrukcji Sztabów Generalnych Polski, Turcji i ZSRR - „raczej za pośrednictwem kanałów wojskowych niż dyplomatycznych"47.

Drugi $\mathrm{z}$ aspektów „polityki bombardowań”, który mógłby zostać określony jako zewnętrzny, uczyniono na tymże posiedzeniu przedmiotem odrębnej dyskusji. W efekcie Joint Planning Sub-Committee przyjął szkic przeznaczonego dla Sztabów Generalnych Polski, Turcji i ZSRR memorandum w tej kwestii, decydując też o przekazaniu tego dokumentu francuskim sojusznikom za pośrednictwem gen. Lelonga ${ }^{48}$.

20 sierpnia w Ministerstwie Lotnictwa odbyło się nieformalne (ale protokołowane) spotkanie Podkomitetu Szefów Sztabów pod przewodnictwem Chatfielda. Potwierdzono na nim negatywne stanowisko Halifaxa względem efektów pracy międzyministerialnego podkomitetu opracowującego instrukcje dotyczące bombardowań lotniczych i morskich. Po dyskusji uzgodniono, że decyzję co do ich brzmienia podejmą Szefowie Sztabów' ${ }^{49}$.

Zebrali się oni ponownie nazajutrz, tym razem na oficjalnym, 311. posiedzeniu, debatując nad kolejną wersją instrukcji, przygotowaną przez utworzony ad hoc podkomitet $z$ udziałem przedstawicieli Foreign Office, Admiralicji oraz ministerstw wojny i lotnictwa. Perspektywę podjęcia przez stronę brytyjską w początkowej fazie wojny jakiejś „nieodpowiedzialnej akcji”, która powodując poważne straty wśród ludności cywilnej przeciwnika, dałaby Niemcom możliwość obciążenia aliantów winą za zainicjowanie podobnych działań, kompromitując tych pierwszych także w oczach opinii państw neutralnych, uczestnicy obrad uznali za niefortunną. Wyrazili przeto przekonanie, że podobnym bagażem zręczniej będzie obciążyć Rzeszę, tym bardziej że ta zapewne dość szybko podejmie ataki na cywilów, co z kolei umożliwi Brytyjczykom zdjęcie „jedwabnych rękawiczek” i adekwatną reakcję. Szefowie sił zbrojnych z pewnym żalem zauważyli, że przyjęcie w początkach wojny wstrzemięźliwej postawy i ograniczenie powietrznych ataków tylko do celów o najściślej

I7 TNA, CAB 55/3, „Minutes of the Meeting held on [...] 17th August, 1939..., J.P. 268th Mtg.

th Ibidem oraz TNA, CAB 54/11, Podkomitet Zastępców Szefów Sztabów [Deputy Chiefs of Staff Sub-Committee - DCOS], „Memorandum of bombardment policy for the Polish, Turkish, and Russian staffs", D.C.O.S. 181 (J.P.) z 17 VIII 1939 r. i nast. dok. Niejasności i przekłamania $w$ tekście protokołu z 268. posiedzenia Joint Planning Sub-Committee uniemożliwiaja jednoznaczne wyjaśnienie zależności między nową redakcją propozycji „Podkomitetu Malkina” a rozpatrywanym nieco później na tymże spotkaniu szkicem memorandum. Nie były to jednak dokumenty tożsame, dzień póżniej na posiedzeniu Podkomitetu Zastępców Szefów Sztabów także rozpatrywano je odrębnie (TNA, CAB 54/2, „Minutes of the 52nd Meeting held on 18th August, 1939", D.C.O.S./52nd Mtg.).

Iy TNA, CAB 53/53, "Minutes of the Informal Meeting held on [...] 20th August, 1939", C.O.S. 960 . 
wojskowym charakterze oznaczać może utratę możliwości ugodzenia Rzeszy w jej najbardziej wrażliwe punkty. Jednocześnie jednak stwierdzili, że pełne pogodzenie racji natury politycznej i militarnej nie jest w tym wypadku realne, i milcząco przyznali pierwszeństwo tym pierwszym - uznanym za użyteczne także w sferze moralno-propagandowej. Tekst opracowanej instrukcji postanowiono jeszcze przedstawić ministrom spraw zagranicznych i koordynacji obrony, a następnie w trybie pilnym przekazać brytyjskim dowódcom ulokowanym poza obszarem Wysp, w dalszej zaś kolejności - władzom dominiów i kolonii, a wreszcie - gwoli informacji - francuskim sojusznikom ${ }^{50}$.

Na odbytym bezpośrednio po zakończeniu obrad Szefów Sztabów spotkaniu Chatfielda i Halifaxa (z udziałem Ismaya i Cadogana) wprowadzono jeszcze do dokumentu drobną korektę (usuwając jedno z ograniczeń), po czym zarówno sam tekst, jak i decyzje odnośnie do jego rozesłania ostatecznie zaaprobowano. Brytyjska delegacja na rozmowy międzysztabowe $z$ Francuzami została upoważniona do wyjaśnienia tym ostatnim, że instrukcje sformułowano zgodnie z przyjętymi przez obie strony jeszcze wiosną ustaleniami oraz zasugerowania, iż analogiczny dokument winien być przyjęty także w Paryżu. Z kolei Foreign Office obciążono zadaniem przekazania odpowiedniej informacji oraz propozycji zastosowania się do brytyjskiego przykładu rządom Polski i Turcji ${ }^{51}$.

Sama instrukcja, opatrzona datą 22 sierpnia 1939 roku, stanowiła nawiązanie do konwencji haskiej z 19 lutego 1923 roku („Reguły wojny powietrznej”), a szczególnie jej art. 24, z zastosowaniem intencjonalnie restrykcyjnej jego interpretacji. Podstawową jej treścią Szefowie Sztabów uczynili zestawioną wedle kategorii listę „czysto wojskowych obiektów w najściślejszym sensie tego słowa", podkreślając, że tylko do nich ograniczone winno być "generalnie" bombardowanie $z$ morza i powietrza ${ }^{52}$. Wymowę tych daleko posuniętych ograniczeń osłabiało nieco kilka innych umieszczonych $w$ tekście stwierdzeń, jak zastrzeżenie, że adresaci instrukcji, tj. brytyjscy dowódcy, winni stosować się raczej do ducha niż litery nakreślonej w nim polityki, czy tchnąca realizmem, a nawet wręcz nadzieją uwaga, iż „jest co najmniej możliwe, że problem zostanie rozwiązany przez Niemców inicjujących nieograniczoną akcję lotniczą przeciw nam lub naszym aliantom" ${ }^{53}$.

51" TNA, CAB 53/11, „Minutes of the 311 th Meeting held on 21 st August, 1939”, C.O.S./311 Mtg.

s) Ibidem, „Notes of the interview between the Secretary of State for Foreign Affairs ant the Minister for Co-ordinatiom of Defence on Monday, 21 st August 1939, at 5 p.m...."

52 TNA, CAB 53/53, „Bombardment Policy at the outset of war. Instructions governing air and naval bombardment", C.O.S. 961 z 22 VIII 1939 r. Wśród wymienionych kategorii znalazły się siły morskie, w tym takíe doki, koszary itp.; jednostki wojskowe armii lądowej; jednostki lotnicze, lotniska, składy materiału lotniczego itp.; transporty wojskowe oraz wykorzystywane przez nie drogi komunikacyjne i instalacje; magazyny i składy sił zbrojnych (ale juz nie fabryki) oraz instalacje i polowe składy paliw usytuowane w obrębie obiektów wojskowych. Zob. też: TNA, AIR 8/283, kopia pisma S.46239/S.6 podsekretarza stanu w Ministerstwie Lotnictwa Artura Streeta do ? z 22 VIII 1939 r.

5) TNA, CAB 53/53, „Bombardment Policy at the outset of war...” z 22 VIII $1939 \mathrm{r}$. 
Na razie jednak w sposób oczywisty głównym efektem wydania tak sformułowanej instrukcji stać się musiało bardzo poważne ograniczenie możliwości podejmowania przez brytyjskie lotnictwo wszelkich niemal operacji bombowych. Oznaczało to także, że Szefowie Sztabów w swych długich dywagacjach na temat form lotniczej pomocy dla Polski (której rzecz jasna omawiana instrukcja formalnie nie dotyczyła w żaden sposób) zatoczyli koło. Dotychczas, rekomendując - wprost czy pośrednio relatywnie radykalne warianty lotniczej akcji przeciw Rzeszy (course C), wyrażali obawy, że mogą one okazać się sprzeczne z poczynionymi ze stroną francuską ustaleniami w kwestii polityki bombardowań. Teraz a priori ograniczali aktywność swych sił bombowych, w istocie redukując ją do poziomu scenariusza „B”, całkiem niedawno uznanego przez nich samych za nieefektywny.

Trudno sądzić, by Szefowie Sztabów nie wzięli pod uwagę tej istotnej i skądinąd oczywistej konsekwencji swych decyzji. Już jednak w ich najbliższym otoczeniu zaistniała $w$ ten sposób sytuacja wywołała poważną konsternację. Zależności między "teorią" polityki bombardowań i „praktyką" lotniczej interwencji na rzecz Polski kształtowały się bowiem w okresie dosłownie i w przenośni wyjątkowo gorącym, nerwowym i obfitującym w wydarzenia. Nigdy nie zostały jasno określone - gubili się w nich nawet współtwórcy, a wielość zaangażowanych w ustalenia gremiów, z krzyżującym się często członkostwem i nie zawsze precyzyjnie określonymi kompetencjami, dodatkowo utrudniała orientację $e^{j 4}$.

25 sierpnia Joint Planning Sub-Committee ponownie zajął się zagadnieniem formalnie właśnie rozstrzygniętym, tj. polityką bombardowań. W trakcie dyskusji nie bez konfuzji zwrócono uwagę na okoliczność wyżej przez nas wskazaną: zaaprobowany przez ministrów dokument C.O.S. 961 wprowadził w przedmiotowej materii restrykcyjne regulacje, które jednak miały się nijak do wciąż stanowiących przedmiot uzgodnień scenariuszy ewentualnej akcji bombowej przeciw Niemcom. Z wyjątkiem więc sytuacji, w której władze zdecydowałyby się na realizację wariantu „B”, wszelkie operacje Bomber Command zostały sparaliżowane, zaś jakakolwiek akcja przeciw Rzeszy mogłaby zostać zainicjowana dopiero po uzyskaniu odpowiednich dyrektyw Ministerstwa Lotnictwa.

Podjęta przez płk. Slessora karkołomna próba likwidacji tej sprzeczności za pomocą tezy, że problematykę obu dokumentów („teoretycznego" C.O.S. 961 oraz "praktycznego" A.F.C. (J) 92) należy uznać za całkowicie odrębną, brzmiała mało przekonująco. Instrukcja w sprawie bombardowań - dowodził szef Dyrekcji Planowania - zakreśliła pewne granice, stanowiąc interpretację uzgodnień poczynionych z Francuzami. Natomiast cztery ramowe scenariusze akcji bombowych, twierdził, odnoszą się do specyficznej sytuacji strategicznej, tj. lotniczych działań przeciw

54 Charakterystyczna jest tutaj uwaga umieszczona w dzienniku Cadogana pod datą 21 sierpnia - a więc dnia, w którym uczestniczył on w spotkaniu dotyczącym finalnej aprobaty dla instrukcji w kwestii bombardowań: „Frightful day, but don't rememeber [We.] all details” (straszny dzień, ale nie pamiętam (śr.[oda]) [tj. dwa dni później - dop. W.M.] wszystkich szczegółów) - Cadogan Diaries, s. 199. 
Niemcom, jeśli ci zaatakują Polskę, zachowując zarazem bierność na swych granicach zachodnich. Zdaniem Slessora ministrowie wciąż więc mieli możność podjęcia decyzji w tej konkretnej kwestii, a wobec zaistniałych niejasności decyzji tych należało się spodziewać niebawem ${ }^{55}$.

W dalszej części posiedzenia zwrócono uwagę na jeden jeszcze aspekt rozpatrywanej problematyki, tj. trudność spójnego przedstawienia nowej postaci „bombowej” problematyki Francuzom. Ostatecznie zdecydowano się na dokonanie syntezy treści obu wspomnianych wyżej dokumentów i opatrzenie treści tak powstałego opracowania jednolitym tytułem „Polityka bombardowań”. Brytyjscy delegaci na zbliżającą się kolejną turę rozmów międzysztabowych winni byli zapytać swych francuskich kolegów, czy ci uznają zgodność wydanych w Londynie instrukcji z przyjętymi uprzednio ustaleniami, następnie zaś przedyskutować $\mathrm{z}$ nimi scenariusze lotniczej akcji na rzecz Polski, odnosząc się do tychże instrukcji ${ }^{56}$.

Treść przeprowadzonej na forum Joint Planning Sub-Committee dyskusji zdaje się świadczyć o tym, że zamysł takiego postawienia sprawy wynikał z zaskakującej także członków tego gremium, zaistniałej ad hoc potrzeby, nie stanowiąc zawczasu przemyślanej pułapki ${ }^{57}$. Jednak proponowane rozwiązanie niewątpliwie było zręczne, faktycznie bowiem z góry zmuszało przedstawicieli Paryża do przyjęcia zasad podyktowanych przez Brytyjczyków. Trudno bowiem było przypuszczać, że Francuzi wycofają się z istotnie udzielonej już wcześniej akceptacji zasad ogólnych, zaś ich ostateczne zaaprobowanie pociągać za sobą musiało, jak już wyżej wskazano, przyjęcie w razie niemieckiego ataku na Polskę wariantu „B” zachodniej lotniczej odsieczy.

Członkowie Joint Planning Sub-Committee w swych pracach nad dostosowaniem koncepcji polityki bombardowań do nowych uregulowań posunęli się jednak jeszcze dalej, podejmując próbę pogodzenia tych uregulowań z planowaną akcją lotniczej pomocy dla zmuszonego do podjęcia działań obronnych przeciw niemieckiej agresji polskiego sojusznika. Zaznaczyć tu trzeba, że powstały w ten sposób dokument nigdy nie stał się przedmiotem oficjalnych obrad, nie został więc formalnie przyjęty. Co więcej, zachował się w co najmniej dwóch znacząco odmiennych redakcjach, to zaś utrudnia interpretację jego treści. Te ostatnie wydają się jednak istotne dla zrozumienia ówczesnego stosunku przedstawicieli najwyższych szczebli dowód-

ss TNA, CAB 55/3, „Minutes of the Meeting held on [...] 25th August, 1939..., J.P. 269th Mtg. Zob. też: A. Prazmowska, op. cit., s. 167.

56 TNA, CAB 55/3, „Minutes of the Meeting held on [...] 25th August, 1939..., J.P. 269th Mtg. Po przyjęciu tych ustaleń Slessor opuścił posiedzenie, zmierzając na spotkanie z Newallem, któremu zamierzał zreferować przyjęte postanowienia.

${ }^{57}$ Nie można natomiast wykluczyć, że całość prac nad zawartymi w dokumencie C.O.S. 961 instrukcjami stanowiła rodzaj intrygi, uknutej z udziałem niektórych członków Gabinetu czy może Szefów Sztabów. Jak bowiem wyżej podkreślono, wpływ tych instrukcji na możliwość podjęcia przez brytyjskie lotnictwo bombowe szerzej zakrojonych działan był dla zainteresowanych wystarczająco oczywisty. Niedostatek danych źródłowych uniemożliwia jednak na obecnym etapie badań dalszą konkretyzację tego przypuszczenia. 
czych brytyjskich sił zbrojnych do akcji na rzecz zaatakowanej Polski - warto więc poświęcić nieco miejsca ich analizie ${ }^{58}$.

Wspomniany raport, czy też raczej jego szkic - lub szkice, opatrzony został tytułem "Wykorzystanie Powietrznych Sił Uderzeniowych podczas wojny" (Employment of the Air Striking Force in War). Jego autorzy zwrócili uwagę, że wszelkie dotychczasowe brytyjskie plany zakładały niemiecki atak na Zachodzie. Znajdujące się w dyspozycji dowódców $z$ Londynu siły lotnicze miały być w takim przypadku wykorzystane do powstrzymywania atakujących wojsk przeciwnika albo przygotowania własnego kontrataku. $W$ takich warunkach dostosowanie zakresu własnej akcji lotniczej do poczynań sił powietrznych nieprzyjaciela zdawało się względnie proste, nietrudno też byłoby baczyć, by odpowiedzialność za podjęcie „nieograniczonej wojny powietrznej" nie została przypisana aliantom.

Zaistniała w "obecnych okolicznościach", stwierdzano upraszczająco, perspektywa skierowania pierwszego uderzenia Rzeszy na Polskę i zachowania przez Niemców biernej postawy na Zachodzie, mimo oczywistych dla Londynu korzyści, stawia jednocześnie brytyjskie władze w sytuacji „bardzo trudnej i delikatnej”, jeśli chodzi o wybór momentu podjęcia akcji lotniczej. Sprawę dodatkowo komplikują ostatnie instrukcje odnośnie do ogólnej polityki bombardowań. W dążeniu do wyklarowania sytuacji, stwierdzali członkowie Joint Planning Sub-Committee, przyjąć jednak można dwa założenia. Po pierwsze, że rząd Jego Królewskiej Mości zdecyduje się w początkowym okresie wojny skierować brytyjskie uderzenia lotnicze wyłącznie przeciw najściślej rozumianym obiektom wojskowym (tj. przyjąć wariant określony w dokumencie D.P. (P.) 65 jako „B”), po drugie, że celem brytyjskiej akcji lotniczej pozostanie złagodzenie niemieckiej presji na Polskę $e^{59}$.

Jednakże podjęta $w$ następnych akapitach dokumentu analiza realnych możliwości takiej akcji nie napawała optymizmem. Choć jego autorzy przyznawali, że brytyjskie siły lotnicze są już wyraźnie silniejsze niż podczas wrześniowego kryzysu sprzed roku, to jednak nadal cierpiały one ich zdaniem na poważny brak rezerw, zarówno sprzętu, jak i personelu, ocena zaś, na ile w warunkach ewentualnej wojny

54 TNA, AIR 20/22, szkic raportu „Employment of the Air Striking Force in War”, J.P. 526 z 25 [?] VIII 1939 r.; CAB 55/19, szkic raportu "Employment of the Air Striking Force in War” J.P. 526. Jak się wydaje, za wcześniej powstałą uznać należy pierwszą z wymienionych redakcji. Swiadczyć o tym mogą odręcznie naniesione poprawki w jej tekście, większa dosadność części sformułowań, które najwyraźniej następnie zostały „wygładzone”, oraz brak niektórych fragmentów, które znalazły się w zachowanej skądinąd w zbiorze minut i memorandów Joint Planning Sub-Committee wersji uznanej przez autora za późniejszą.

iy TNA, CAB 55/19, szkic raportu „Employment of the Air Striking Force...”. Podkreślić wypada, że w wersji uznanej za wcześniejszą odpowiedni fragment brzmial wyraźnie odmiennie. Nie bez żalu stwierdzano w nim, że wydane instrukcje sprawiły, iż "nasze najbardziej efektywne plany nie będą mogły być przyjęte na początku [wojny]", wskazując, że wobec tego konieczne stało się „sformułowanie planu improwizowanego, który jest wprawdzie niesatysfakcjonujący z wojskowego punktu widzenia, [...] przy założeniu, że rząd Jego Królewskiej Mości zdecyduje się pojąć akcję lotniczą przeciw Niemcom na zachodzie dla osłabienia presji na Polskę" (TNA, AIR 20/22, szkic raportu „Employment of the Air Striking Force..."). 
akcja przeciwnika pozwalać będzie na względnie szybkie uzupełnianie tych braków, nie wydawała się możliwa. Konstatacja ta prowadziła, nie po raz pierwszy, do zalecenia oszczędnego gospodarowania posiadanymi zasobami w początkowym okresie wojny oraz rozważnego doboru celów ataków - dla uzyskania możliwie najwyższej ich efektywności.

Uwzględnienie nakazu zachowania ekonomii sił oraz faktu, że bezpośredni cel podejmowanych działań stanowić by miała pomoc dla Polski, stwierdzali dość niespodziewanie brytyjscy sztabowcy, prowadzić musi do wniosku, że najbardziej obiecującym celem takiej akcji byłby atak na niemiecką flotę wojenną ( $w$ ramach tzw. Planu „K”) oraz system żeglugi śródlądowej Rzeszy - „jako pewne punkty kluczowe położone wystarczająco daleko od centrów zaludnienia"60. W dokumencie podkreślano, że powodzenie takich ataków, szczególnie $w$ pierwszym $z$ wymienionych przypadków, miałoby „bardzo znaczący” efekt moralny, dodając, że jest to plan, „który ze swej natury miałby największe szanse powodzenia $w$ razie zastosowania $w$ początkach wojny" ${ }^{\prime \prime}$ Z kolei zniszczenie systemu żeglugi śródlądowej, utrzymywali brytyjscy analitycy, wymusi na Niemcach dodatkowe obciążenie innych środków transportu, co spowoduje w szczególności „zakorkowanie” szlaków kolejowych. Jako zadania dodatkowe dla Powietrznych Sił Uderzeniowych wskazywano natomiast loty propagandowe dla rozrzucania ulotek nad niemieckimi centrami przemysłowymi (jako dodatkowy ich efekt wymieniając utrzymywanie w stanie ciągłego alarmu obrony przeciwlotniczej przeciwnika) oraz loty rozpoznawcze dla rozeznania niemieckiego systemu obrony $\mathrm{i}$ instalacji przemysłowych.

Ostatnie zdanie raportu, który jak wiele wskazuje, przygotowywany był w sporym pośpiechu, zawierało opinię, że „[...] konsekwencje pomyślnego ataku na [niemieckie] drogi wodne mogłyby być całkiem wyobrażalnym pośrednim wsparciem dla Polski", brzmiącą znacznie mniej pewnie niż wyrażane we wcześniejszych partiach tekstu przekonanie o znaczeniu dla polskiego sprzymierzeńca strat zadanych Kriegsmarine ${ }^{62}$. W obu jednak przypadkach $w$ grę wchodziły już nawet nie pobożne życzenia, ale próba stworzenia swoistej wersji „alternatywnej rzeczywistości”. Ataki na wskazane przez autorów dokumentu cele nie miałyby bowiem dla przebiegu ewentualnych walk w Polsce żadnego niemal znaczenia, wyjąwszy wspomniane przez

(1) TNA, CAB 55/19, szkic raportu „Employment of the Air Striking Force...”. W wersji zachowanej w TNA, AIR 20/22 stwierdzano jednoznacznie, że w grę wchodziło tu także dążenie do uniknięcia nadmiernych strat własnych w początkowej fazie wojny oraz konieczność uwzględnienia ograniczeń związanych z instrukcją Szefów Sztabów. Autorzy dokumentu zaznaczali: „te kierunki muszą zostać tak szybko, jak to tylko możliwe, uzupełnione przez akcję przeciw wrogim siłom powietrznym i lądowym [...]". Autorzy raportu z dużym dystansem oceniali przedstawiane w tym czasie przez Francuzów propozycje uderzenia na niemieckie lotniska, choć nie wykluczali całkowicie takiego kroku. Materiały na temat Planu „K” i zamiarów jego implementacji: TNA, AIR $9 / 83$.

61 TNA, CAB 55/19, szkic raportu „Employment of the Air Striking Force...”.

${ }^{62}$ Ibidem. We wcześniejszej redakcji zacytowany fragment sformułowano rzetelniej, była w nim bowiem mowa tylko o „pewnym niewielkim efekcie dla osłabienia presji na Polskę" (TNA, AIR 20/22, szkic raportu „Employment of the Air Striking Force...”). 
Brytyjczyków oddziaływanie moralne i propagandowe. Z czysto wojskowego punktu widzenia korzystne były głównie dla samych Brytyjczyków oraz ich francuskich aliantów. Udane uderzenie na okręty niemieckiej floty redukowało zagrożenie dla brytyjskich szlaków komunikacyjnych. $\mathrm{Z}$ kolei przeprowadzone z powodzeniem naloty na niemiecką żeglugę śródlądową w żaden sposób nie mogły zmniejszyć potencjału skoncentrowanych już przeciw Polsce (o czym w Londynie dobrze wiedziano) sił niemieckich ani utrudnić ich zaopatrywania z niemal nieosiągalnych dla brytyjskiego lotnictwa obszarów centralnych i wschodnich Rzeszy. Spowalniałyby natomiast potencjalnie przerzucenie zaangażowanych $w$ Polsce jednostek na front zachodni, tym samym wydłużając znacząco okres, w którym wojska francuskie i brytyjskie mogly względnie spokojnie czynić ostatnie przygotowania do nieuchronnie nadchodzącej kampanii wojennej. Innymi słowy, w ostatnich dniach pokoju coraz wyraźniej stawało się jasne, że wojskowym z Londynu znacznie bliższa jest (brytyjska) koszula niż (polska) suknia.

Nie jest jasne, czy i na ile stanowisko zajęte przez Brytyjczyków w sprawie polityki bombardowań wpłynęło na opinię w tej kwestii sformułowaną niemal równolegle przez gen. Vuillemina. Wiadomo, że projekt wydanej 22 sierpnia przez Szefów Sztabów instrukcji przesłany został do Paryża przez gen. Lelonga pismem opatrzonym tą samą datą. Dwa dni później ową korespondencję uzupełniła oficjalna brytyjska nota, zawierająca także informację, że ambasadorowie Jego Królewskiej Mości w Warszawie oraz Istambule zostali poinformowani o przyjętych $w$ porozumieniu $z$ władzami Francji zasadach polityki w kwestii bombardowań oraz oczekiwaniu Londynu, że wschodni sojusznicy przyjmą owe zasady za własne ${ }^{63}$. Tak też się stało. Treści odpowiedniej noty, złożonej przez ambasadora Kennarda 26 sierpnia, zostały dzień później w imieniu rządu Rzeczypospolitej zaakceptowane przez jej adresata, ministra Józefa Becka ${ }^{64}$.

Choć na Zachodzie zdawano się żywić uprzednio pewne wątpliwości, polska decyzja $w$ istocie nie mogła być inna. Uzasadniały ją względy moralno-polityczne, a nade wszystko świadomość słabości własnych sił powietrznych, która skłaniać musiała do unikania wszelkich kroków mogących sprowokować brutalną reakcję ze strony silniejszego przeciwnika.

Zgoda udzielona przez władze z Warszawy zdejmowała $z$ porządku dziennego jeden $z$ absorbujących dotychczas jej sojuszników problemów związanych z polskim kontekstem przyszłych działań lotniczych. Inne jednak, niewątpliwie ważniejsze, pozostawały aktualne - i formalnie przynajmniej nierozstrzygnięte. Kierunek, w którym od dłuższego czasu ewoluowały poglądy przedstawicieli najbardziej znaczących politycznych i wojskowych kręgów Paryża i Londynu, nie był dla Rzeczypospolitej korzystny. Pytaniem pozostawało, czy cokolwiek może się tu jeszcze zmienić.

63 SHD-DAT, 7 N 2817, pismo No 333/S gen. Lelonga do płk. Aymé z 22 VIII 1939 r.; 7 N 3439 , thumaczenie na język francuski brytyjskiej noty z 24 VIII 1939 r.

w IPMS, Lot. A.I.2/15, tłumaczenie na język polski noty $\mathrm{Nr} 86 / 240 / 2 / 39$ amb. Howarda W. Kennarda do ministra spraw zagranicznych RP z 26 VIII 1939 r.; odpis pisma No. P. II - 1/WB/27 J. Becka do Kennarda z 27 VIII 1939 r. 



\section{Rozdział 6}

\section{Rachunek sif}

Jednym z czynników, które szczególnie wyraziście określały pozycje Londynu, Paryża i Warszawy w łączącym te trzy stolice, ukształtowanym faktycznie wiosną 1939 roku sojuszniczym układzie, był znajdujący się $w$ ich dyspozycji wojskowy potencjał. Siły powietrzne w prowadzonych niemal na bieżąco kalkulacjach z oczywistych przyczyn stanowiły element o trudnej do przecenienia wartości. Informacje na ich temat były skrupulatnie zbierane, stając się następnie nierzadko przedmiotem rozbudowanych analiz i ocen.

W przypadku Polski dokładniejsza wiedza o jej potencjale bardziej, rzecz jasna, potrzebna była Brytyjczykom. W latach poprzednich, jak już przyszło nam wzmiankować, dane na temat sił zbrojnych Rzeczypospolitej nad Tamizą gromadzono skrupulatnie i z niezłym na ogół efektem. W zaistniałych okolicznościach trudno jednak było zebrany standardowy ich zestaw uznać za wystarczający, pojawiała się więc konieczność jego aktualizacji i uzupełnienia. Dodatkowy bodziec do pogłębienia dotychczasowych studiów stanowiła wizyta ministra Becka, który do Londynu zawitać miał już w pierwszych dniach kwietnia. Strona brytyjska wyrażała przypuszczenie, że przy okazji rozmów o pogłębieniu politycznej współpracy gość z Warszawy podejmie także kwestię pomocy finansowej, która posłużyć by miała zwiększeniu mocy produkcyjnych polskiego przemysłu zbrojeniowego. Orientacja w sprawach dotyczących obecnego stanu tego przemysłu oraz wyposażenia armii Rzeczypospolitej ułatwić mogła odniesienie się do podobnych życzeń'.

Trudno się dziwić, że wśród zagadnień, które teraz szczególnie interesowały wojskowych znad Tamizy, problematyka lotnicza zajmowała miejsce istotne. W Londynie zdawano sobie sprawę $z$ tego, że siły powietrzne w nadchodzącej wojnie odegrają bardzo poważną rolę. Zauważano też, że wiele kluczowych punktów na obszarze Rzeszy, nieosiągalnych z lotnisk położonych na Wyspach, z terytorium Polski zaatako-

1 TNA, BT 11/1069, pismo J.J. Willsa (Board of Trade) do Stranga 23 IV 1939 r. i in. dok.; AD, Relations commerciales 1918-1940, Pologne 13, telegram No 1077 Corbina do MAE z 6 IV 1939 r. Zapewne w związku z tymi oczekiwaniami ppłk Sword odnotował w swoich zapisach z 1 kwietnia informację o braku w Polsce szeregu strategicznych surowców. E.R. Sword, op. cit., s. 36. 
wać można bez większych trudności. Lotnictwo wreszcie stanowiło jedną z nielicznych sfer, w których praktyczna współpraca wojskowa Londynu i Warszawy zdawała się możliwa.

W celu zebrania odpowiednich danych oraz przeprowadzenia wstępnej ich analizy nad Wisłę przybył w pierwszych dniach kwietnia akredytowany w Polsce, choć rezydujący w Berlinie brytyjski attaché lotniczy płk John Lyne Vachell. Rezultaty krótkiej, wypełnionej intensywną pracą wizyty podsumowane zostały raportem o znamiennym tytule „Wartość Polskich Sił Powietrznych w czasie wojny”, który 5 kwietnia złożony został na ręce ambasadora Kennarda i niezwłocznie wyekspediowany przezeń do Londynu².

Autor raportu, jak zaznaczył na wstępie, starał się zaprezentować swój pogląd na sprawę, która w tym czasie absorbowała sztabowców z Londynu, starając się określić wpływ, jaki wywrzeć może polskie lotnictwo wojskowe na przebieg zbrojnego konfliktu, „w którym Polska jest atakowana przez Niemcy, a Francja i Wielka Brytania wypełniają swe złożone ostatnio obietnice i przychodzą Polsce z pomocą" ${ }^{3}$. Sformułowana $w$ dokumencie ogólna ocena polskich sił powietrznych była zdecydowanie pochlebna. Brytyjski oficer chwalił ich organizację, wyszkolenie i wyposażenie, podkreślając, że podobną opinię wyraża już nie po raz pierwszy. Niemal natychmiast jednak zaznaczał, że pochwały mają w tym wypadku wysoce relatywny charakter, a polskie osiągnięcia budzą niekłamane uznanie głównie w konfrontacji z rozmiarami finansowych ograniczeń. Te ostatnie, dodawał, „są przyczyną wielkiej liczby niesatysfakcjonujących rozwiązań", zaś świadomi tej sytuacji wyżsi oficerowie lotnictwa zmuszeni byli przyznawać $w$ rozmowach, że w innych uwarunkowaniach sporo elementów ich wojennych przygotowań „wyglądałoby zupełnie inaczej”. Co więcej, zauważał Vachell, samodzielność sił powietrznych Rzeczypospolitej jest poważnie ograniczona ich zadania sprowadzają się głównie do wspierania operacji armii lądowej, zaś stan ich wyposażenia $\mathrm{z}$ trudem jedynie umożliwić by mógł podjęcie operacji w szerszym zakresie $^{5}$. Wyposażenie to zresztą $z$ wyjątkiem nowoczesnych bombowców PZL.37 jest już wyraźnie przestarzałe - i od dłuższego czasu wymaga wymiany. Ta jednak

2 DBFP, vol. 5, doc. 12, s. 38n. i 43nn.; E.R. Sword, op. cit., s. 36. Wedle zapisków Sworda Vachell przebywał w Warszawie od 2 kwietnia. Raport sporządził 4 kwietnia i tegoż dnia opuścił stolicę Polski drogą przez Gdańsk. Kennardowi Sword przekazał raport wraz z przygotowanym równolegle własnym opracowaniem, zawierającym charakterystykę sił lądowych Rzeczypospolitej, stąd na obu dokumentach wpisana została data 5 kwietnia. Do przesyłanych do Londynu raportów obu oficerów dołączone zostało pismo II sekretarza ambasady brytyjskiej w Warszawie Roberta M.A. Hankeya do Speaighta zawierające prośbę o niezwłoczne zapoznanie się z ich treścią (TNA, FO 371/23144).

"DBFP, vol. 5, doc. 12, s. 43.

4 Ibidem.

5 W tym kontekście Vachell zwracał uwagę na właśnie wprowadzane do linii średnie bombowce PZL.37 „Łoś”, co jego zdaniem mogło sygnalizować pierwszy krok ku zmianie koncepcji wykorzystania polskiego lotnictwa. Jak jednak zauważał, maszyn tych jest obecnie nie więcej niż 50 , na razie zaś i one będą zapewne wykorzystywane do wspólpracy $z$ armią lądową. Brytyjski attaché przeszacował nieco liczbę użytkowanych przez Polaków „Łosi”, których w linii polskie lot- 
wyraźnie się opóźnia, jedynie w przypadku samolotu bliskiego rozpoznania produkcja jest już $\mathrm{w}$ trakcie realizacji, ale i $\mathrm{w}$ tym przypadku trudno przypuszczać, by do przezbrojenia jednostek doszło przed końcem roku'.

Sam przemysł lotniczy Vachell oceniał jednak bardzo wysoko, podkreślając jego szybki rozwój i wyrażając nadzieję, że rozpisana właśnie Pożyczka Obrony Przeciwlotniczej pozwoli przezwyciężyć widoczne i w tej sferze finansowe ograniczenia. Podsumowująca istniejący potencjał polskiego lotnictwa wojskowego oraz jego przemysłowego zaplecza konkluzja tchnęła więc ostrożnym optymizmem. „Jeśli Polska uzyska 12 miesięcy wytchnienia, a poprzednie ograniczenia finansowe znikną stwierdzał attaché - czuję, że może ona uczynić wielkie postępy, zaś jej siły powietrzne, choć wciąż zdecydowanie słabsze liczebnie od niemieckich, a w pewnym stopniu ustępujące im też pod względem jakości, odegrać mogą znacznie większą rolę, niż obecnie można by przypuszczać".

Na konkluzji tej Vachell jednak nie poprzestawał. Przywołując udzielone Rzeczypospolitej brytyjskie gwarancje, podjął w drugiej części raportu próbę określenia, „w jaki sposób Francja lub Wielka Brytania mogą obecnie najlepiej pomóc Polsce w powietrzu". Wyrażał w niej opinię, że wobec ogólnie niezadowalającego stanu wyposażenia polskich sił szybkie przezbrojenie jednostek lotniczych nie przyniosłoby istotnej zmiany: efektywność tych pierwszych i tak wyznaczana będzie przez dominujące, niepoddane modernizacji ich segmenty, zaś dla potrzeb współpracy $\mathrm{z}$ armią lądową liczba posiadanych przez Polaków samolotów jest zapewne wystarczająca. Do pewnego stopnia pożądane mogłyby być natomiast pewne drobniejsze dostawy z Zachodu, obejmujące np. bomby, karabiny maszynowe, amunicję czy paliwo. Materiał taki mógłby się okazać przydatny szczególnie $\mathrm{w}$ razie podjęcia decyzji o przebazowaniu na obszar Polski francuskich czy brytyjskich samolotów i wykorzystaniu ich podczas wojny do ataków na cele w Rzeszy. Vachell jednak, zastrzegając, że nie ma na temat takich zamysłów oraz ich osadzenia $w$ ramach ogólnego planu strategicznego ani dostatecznej wiedzy, ani też czasu na podjęcie ich analizy, opowiadal się przeciw podobnemu rozwiązaniu - głównie ze względu na trudności logistyczne?.

Podkreślając szczerość i otwartość polskich gospodarzy wizyty, attaché krytycznie wzmiankował o ich skłonności do tuszowania własnych braków i bagatelizowania słabości. Wyrażał nadzieję, że „w nowej sytuacji” zyskają oni czas na przemyślenie tej postawy i korektę dotychczasowej polityki.

nictwo wojskowe posiadało wówczas jedynie dwie eskadry (36 samolotów). Dalsze informacje: W. Mazur, U progu wrześniowego sprawdzianu..., s. $81 \mathrm{n}$.

${ }^{6}$ Takze w tym przypadku podane $w$ raporcie informacje były zbyt optymistyczne. Produkcja serii samolotów obserwacyjnych LWS-3 „Mewa”, wykonywanych przez Lubelską Wytwórnię Samolotów, znajdowała się dopiero w fazie przygotowań, a pełne jej uruchomienie uniemożliwiał m.in. brak zakupionych we Francji silników Gnome-Rhône GR 14M05, których pierwsza partia dotarła do Polski dopiero na przełomie kwietnia i maja. Zob.: W Ma zu r, Zagraniczne zakupy silników..., cz. 3, „Lotnictwo" 2008, nr 1, s. 93; ide m, Pod wiatr..., s. 241, przyp. 105.

7 DBFP, vol. 5, doc. 12, s. 44. 
By tę sposobność w najlepszy możliwy sposób wykorzystać, uważał Vachell, niezbędne będzie udostępnienie stronie polskiej nowoczesnych silników lotniczych. Dotychczas bowiem w polskich samolotach montowane były wykonywane na licencji konstrukcje brytyjskiej firmy Bristol, co wykluczało użycie najnowszych, niedostępnych w ramach licencji rozwiązań, skutkując osiągami niższymi niż w przypadku maszyn sąsiadujących mocarstw, w tym Niemiec. Attaché postulował więc, już po raz kolejny, by znieść wspomniane ograniczenie, dodając, że „w obecnych warunkach" kwestia ta staje się jeszcze pilniejsza.

Jak jednak podkreślał w końcowej części raportu, wszelkie jego uwagi odnosić się mogą jedynie do sytuacji, w której Niemcy dadzą Polsce jeszcze co najmniej rok na odpowiednie przygotowania. W krótszym okresie Warszawa nie będzie bowiem w stanie znacząco wzmocnić swych sił powietrznych i pozostanie słaba, posiadając nie więcej niż około 600 samolotów, w większości zdecydowanie ustępujących pod względem osiągów maszynom niemieckim. Lotnictwo wojskowe będzie musiało ograniczyć się do działań na rzecz wsparcia sił lądowych, te zaś, sądził Vachell, nieuchronnie zostaną zmuszone do odwrotu, a następnie oczekiwania na ulgę w postaci francuskiej i brytyjskiej ofensywy na Zachodzie lub bardziej jeszcze oddalonych w czasie efektów blokady morskiej ${ }^{8}$.

Pierwsze reakcje Foreign Office na treści raportu, który do Londynu dotarł dopiero po pięciu dniach, 10 kwietnia, pobrzmiewały głębokim rozczarowaniem, doprawionym być może nutką paniki. „To bardzo przygnębiający raport na temat polskich zdolności obronienia się przed niemieckim atakiem" - stwierdzał w sporządzonej 11 kwietnia notatce odpowiedzialny w Departamencie Centralnym za sprawy polskie Frank K. Roberts. „Siły powietrzne są nieużyteczne do czegokolwiek, $\mathbf{z}$ wyjątkiem współpracy $z$ armią lądową, przez co najmniej 12 miesięcy. Armia jest źle wyposażona. Marynarka wojenna może być wyłączona $z$ rachunku od początku. Żywotnie ważne obszary przemysłowe mogą zostać zapewne zajęte w pierwszym ataku, a strategiczna pozycja wydaje się możliwa do utrzymania jedynie dzięki wsparciu, albo przynajmniej dostawom, z ZSRR"'.

Jednak, co dla naszych rozważań istotne, za jedyną możliwość udzielenia przez rząd $\mathrm{z}$ Londynu natychmiastowej pomocy państwu, które niespełna dwa tygodnie wcześniej otrzymało $\mathrm{z}$ jego strony gwarancję ochrony niepodległości, uznany został materiał lotniczy, a szczególnie budowane na brytyjskiej licencji silniki. W tym też kierunku zmierzały już zresztą podjęte przez Brytyjczyków kroki. 30 marca, dzień

" Ibidem, s. 45.

y TNA, FO 371/23144, datowana 11 IV 1939 r. odręczna notatka Robertsa na akcie C 4898/1110/55. Komentarz odnosił się także do przesłanego do FO równolegle raportu ppłk. Sworda. Roberts podkreślał też, że niezdolność Polski do samodzielnego zaspokojenia potrzeb armii w zakresie zaopatrzenia w uzbrojenie i amunicję (wbrew optymistycznym deklaracjom złożonym właśnie przez Becka w Londynie) stanowi dodatkowe poważne uzasadnienie brytyjskich wysiłków zasypania przepaści między Warszawą a Moskwą. Dopisany 13 kwietnia komentarz Cadogana był bardziej lakoniczny i powściągliwy: „Z pewnością nie bardzo zachęcające”. Notatkę Robertsa wzmiankował J. Tebinka, Polityka brytyjska..., s. 42. 
przed „gwarancyjną" mową Chamberlaina, do Foreign Office dotarło pismo Ministerstwa Lotnictwa zawierające informację o udostępnieniu stronie polskiej danych oraz rysunków technicznych silników Bristol Hercules II (o co Polacy zabiegali od wielu tygodni), a także umieszczeniu tej konstrukcji na tzw. „open list”, co umożliwiało jej zakup przez zagranicznych, w tym polskich, nabywców ${ }^{10}$.

Przeprowadzona w Foreign Office analiza raportów Vachella i Sworda wywołała jeszcze co najmniej dwa efekty - uboczne, ale bardzo dla dalszego biegu wydarzeń istotne. Pierwszy z nich stanowiła zdecydowana i jednoznaczna akceptacja sformułowanej właśnie przez ambasadora Raczyńskiego (12 kwietnia, w rozmowie ze Strangiem) koncepcji podjęcia polsko-brytyjskich konsultacji międzysztabowych. Drugi uznanie konieczności bezzwłocznego podjęcia rozmów o współpracy z Rumunią i Turcją jako „jedynym kanałem komunikacji między Polską a światem zewnętrznym w razie wojny $z$ Niemcami" "I.

Francuski partner Londynu znajdował się, rzecz jasna, w odmiennej nieco od Brytyjczyków sytuacji. W Paryżu zasadniczo nie brakowało informacji na temat polskiego lotnictwa wojskowego. Nie wszystkie jednak były odpowiednio opracowane i uporządkowane, a ponadto część $\mathrm{z}$ nich wymagała weryfikacji lub aktualizacji. Tym bardziej że i nad Sekwaną potrzeba możliwie kompleksowej oceny polskich lotniczych zasobów stawała się sprawą pilną. Kryzys polityczny, który ogarnął Europę w połowie marca, stał się bowiem katalizatorem przez dłuższy czas odwlekanych decyzji. Na porządku dziennym stanął m.in. problem ustosunkowania się francuskich władz do przywiezionej przez ppłk. d’Arnaud de Vitrolles z Warszawy jeszcze w połowie lutego propozycji zacieśnienia współpracy lotniczej. 20 marca Szef Sztabu Generalnego Armée de l’Air gen. Joseph Vuillemin przesłał raport końcowy z tej misji do gen. Gamelina jako załącznik do pisma zawierającego ostrożnie sformułowaną sugestię akceptacji polskiej oferty. Jak dawał do zrozumienia Vuillemin, za krokiem takim przemawiają względy strategii polityczno-wojskowej: Polska (a w każdym

11) TNA, FO 371/23144, pismo 803753/38/S.8 Ministerstwa Lotnictwa do podsekretarza stanu w FO z 29 III 1939 r. i in. dok. Strona polska o powyższej zgodzie poinformowana została już wcześniej przez producenta silników. Złożone w firmie Bristol zamówienie No 853/39 na trzy silniki Hercules III nosiło datę 10 III 1939 r. 15 VII 1939 r. płk Kwieciński meldował, iż Ministerstwo Lotnictwa poinformowało go, że „sprawa otrzymania dokumentacji licencyjnej [...] silnika Hercules III jest załatwioną" (IPMS, Lot. A.V 1/40i XIV, pismo SM/CSC/EMW The Bristol Aeroplane Co. Ltd. do płk. Kwiecińskiego z 21 III 1939 r. i in. dok.).

"TNA, FO 371/23144, datowane 12 IV 1939 r. notatki Stranga oraz Sargenta na akcie C 4898/1110/55 i in. dok. Propozycja, którą 12 kwietnia przedstawil Raczyński w rozmowie ze Strangiem, miała na razie charakter nieformalny i przewidywała kontakty o charakterze wstępnym - realizowane za pośrednictwem attaché wojskowych. Sam Raczyński w serii datowanych tego dnia raportów nie wspomniał o swej inicjatywie. Rozmowy o współpracy z Turcją od dłuzszego już czasu znajdowały się w trakcie przygotowań. Zob.: TNA, CAB 53/47, Chiefs of Staff Sub-Committee, „Alliance with Turkey and Greece. Draft Report” z 31 III 1939 r.; B. Millman, The Ill-Made Alliance: Anglo-Turkish Relations, 1934-1940, Montreal-Kingston 1998, s. 162nn. Na temat brytyjsko-rumuńskich kontaktów wojskowych w tym okresie: M. Cîrstea, Din istoria relafiilor anglo-române (1936-1939), București 2011, s. 149nn. 
razie polskie lotnictwo) znajduje się $\mathrm{w}$ końcowym stadium przygotowań do przeciwstawienia się niemieckiej agresji w Europie Wschodniej - i odpowiednio wsparta może okazać się dla tej agresji poważną przeszkodą. Pozytywne potraktowanie polskich awansów uzasadniać mogły, zdaniem autora pisma, także względy czysto wojskowe, w tym możliwość osiągnięcia niedosiężnych $z$ terytorium Francji instalacji przemysłowych z rejonu Berlina oraz przywrócenie utraconych po upadku Czechosłowacji zdolności do prowadzenia rozpoznania obszarów na wschód od linii Brema - Hanower - Kassel - Norymberga - Augsburg, a tym samym szans na zyskanie orientacji co do kierunku strategicznego wysiłku Rzeszy (Wschód czy Zachód).

Vuillemin podkreślał przy tym, że cena, jaką trzeba by za lotnicze zbliżenie $\mathrm{z}$ Polską zapłacić, nie wydaje się zbyt wysoka. Składowane na terenie Rzeczypospolitej zapasy dla francuskich eskadr powstać będą mogły dopiero po całkowitym zaspokojeniu takich potrzeb na terytorium narodowym, zaś rozbudowana polska infrastruktura zawsze będzie zdatna do użycia jako punkt wyjścia do szybkiej, wzmacniającej lotnicze siły Polaków akcji „zagranicznych sił powietrznych”. Przypuszczać można, że to ostatnie określenie odnosić się miało głównie (a może nawet wyłącznie) do samolotów znaczonych czerwoną gwiazdą, choć sam autor pisma wstrzymał się przed takim sprecyzowaniem swej myśli $i^{12}$.

Tydzień później gen. Gamelin przesłał kopie korespondencji Vuillemina do Daladiera, o polskiej inicjatywie wypowiadając się $w$ duchu wielce przychylnym. Jako „bariera na drodze ambicji terytorialnych Niemiec” Polska ma „wielką wartość” podkreślał Szef Sztabu Generalnego Obrony Narodowej, rekomendując zmianę cechującego się dotąd rezerwą nastawienia do polskiego partnera i podjęcie rozmów międzysztabowych w atmosferze „wzajemnego zaufania”. Odbiorca dokumentu najwyraźniej podzielał przedstawione zdanie, na otrzymanym akcie wpisał bowiem odręcznie swoją aprobatę, zaznaczając, że $\mathrm{w}$ rozpatrywanym wypadku zbędne by było oczekiwanie na opinię Ministerstwa Spraw Zagranicznych ${ }^{13}$.

O decyzji premiera Gamelin poinformowany został z szybkością dla francuskiej biurokracji dotąd niemal nieosiągalną - pismo zostało doń wysłane bowiem już w dniu następnym. Daladier akceptował w nim przedstawioną przez Vuillemina propozycję podjęcia współpracy lotniczej z Polską oraz ewentualnego stacjonowania w Polsce części francuskiego lotnictwa bombowego, zastrzegając sobie prawo aprobowania sformułowanych w tym sensie dyrektyw. Na swej korespondencji umieścił dopisek: „pilne”. I rzeczywiście, projekt został sformułowany niemal bezzwłocznie wysłany do Daladiera 6 kwietnia do adresata dotarł jeszcze tego samego dnia ${ }^{14}$.

12 SHD-DAT, 2 N 235, pismo No 778 2./Cf/S./E.M.A.A Vuillemina do Gamelina 220 III $1939 \mathrm{r}$.

13 SHD-DAT, 5 N 579, kopia pisma No 561 DN.3 Gamelina do Daladiera z 27 III 1939 r. W tejże sprawie zob. też niedatowana (kwiecień 1939 r.) analiza Sekcji Obrony Narodowej (SHD-DAT, 2 N 236).

14 SHD-DAT, 5 N 579, pismo No 304 D.N. Szefa Gabinetu ministra obrony narodowej i wojny gen. Jules'a Decampa do Gamelina z 31 III 1939 r.; pismo 646/DN.3 Gamelina do Daladiera z 6 IV 1939 r. 
Niestety, tego ostatniego dokumentu nie udało się odnaleźć. Wiadomo jedynie, że przedłożony mu projekt Daladier istotnie zaakceptował, najpewniej $12 \mathrm{kwietnia}^{15}$. Dzień później Gamelin, wciąż najwyraźniej działając pod presją czasu, przesłał odpowiednie dyspozycje do Szefa Sztabu Armée de l'Air ${ }^{16}$.

Nie siląc się na nową argumentację, odwołał się przy tej okazji do fraz wykorzystanych już we wcześniejszej korespondencji. Podkreślił, że osobiście przywiązuje wielką wagę do podjęcia $\mathrm{w}$ razie ewentualnego konfliktu przez siły polskie interwencji na rzecz Francji, instruując Vuillemina, że rozmowy międzysztabowe ze stroną polską powinny być „ze względu na rozwój sytuacji międzynarodowej” podjęte $\mathrm{w}$ trybie pilnym i prowadzone $\mathrm{w}$ atmosferze zaufania.

Dokument uzupełniony został jednak także o dwie dyspozycje o charakterze bardziej szczegółowym. Po pierwsze, zgodnie z sugestią Vuillemina Gamelin nakazał szczegółowe przestudiowanie z przedstawicielami strony polskiej możliwości prowadzenia rozpoznania powietrznego nad całym terytorium Rzeszy, w celu ustalenia już w początkach konfliktu wojennego orientacji masy niemieckiego manewru. Ustalenia objąć też miały przyjęcie w Polsce „elementów lotnictwa francuskiego" dokonujących bombardowań celów położonych w głębi terytorium Niemiec i niezdolnych do natychmiastowego powrotu do macierzystych baz po przeprowadzeniu misji ${ }^{17}$.

Trudno nie zwrócić uwagi na to, że tak określone francuskie oczekiwania wobec polskiego partnera nierównomiernie rozkładały ewentualne korzyści. Lwia ich część przypaść miała Francuzom, podczas gdy stronę polską obciążałyby głównie koszty o materialnym i niematerialnym charakterze. Równocześnie jednak należy zauważyć, że przytoczone wyżej stanowisko Gamelina każe poddać korekcie zakorzenione $w$ literaturze, $w$ dużej mierze za sprawą powojennych wynurzeń samego zainteresowanego, przeświadczenie, że Szef Sztabu Generalnego Obrony Narodowej wiosną 1939 roku był zdecydowanie przeciwny podjęciu rozmów o współpracy wojskowej z Polską. Odtworzony na podstawie źródeł pierwotnych rzeczywisty obraz okazuje się bowiem nieco bardziej złożony, jeśli nie wręcz odmienny: w połowie kwietnia 1939 roku Gamelin był takich rozmów zdecydowanym rzecznikiem, licząc - podobnie jak Vuillemin - ze Francuzi zachowają w ich trakcie inicjatywę, narzucając słabszemu i znajdującemu się w wyjątkowo trudnej sytuacji partnerowi korzystne dla siebie zasady przyszłej wojennej kooperacji i płacąc za to zdawkową monetą, a może wręcz tylko dobrym słowem ${ }^{18}$.

15 Swiadczy o tym wpis gen. Decampa na zachowanej pod sygnaturą SHD-DAT, 5 N 579 koszulce odpowiednich akt (No 356 D.N. 212 IV 1939 r.).

16 SHD-DAT, 2 N 235, kopia pisma No 704/DN.3 Gamelina do Vuillemina z 13 IV 1939 r.

17 Ibidem.

${ }^{1 *}$ M. Gamelin, op. cit., t. 2, s. 415. Informacja Gamelina w polskiej literaturze niemal od początku traktowana była sceptycznie (J. Ciałowicz, op. cit., s. 265n.), równocześnie jednak nieodmiennie jest powtarzana - także przez autorów o ustalonej renomie (M. Zgórniak, Europa w przededniu wojny...., s. 435n.; M. Kornat, Polityka zagraniczna Polski..., s. 479n. - w tym drugim przypadku w tonie wręcz kategorycznym). 
Ze swej strony natomiast Szef Sztabu Generalnego Obrony Narodowej nie zamierzał w sojusz z Polską inwestować zbyt wiele. Pytany przez Daladiera o materiałową pomoc dla Polski 15 kwietnia odpowiedział odmownie, argumentując, że $w$ tej chwili całość wytwarzanego we Francji sprzętu wojskowego jest niezbędna dla należytego wyposażenia własnych sił lądowych i powietrznych. Równocześnie zapewnił, że w koncepcji zacieśnienia kontaktów między sztabem francuskim i polskim widzi „jedynie korzyści", proponując powierzenie mu, podobnie jak we wcześniejszym przypadku brytyjskim, koordynacji przyszłych rozmów, które miałyby zostać zapoczątkowane przez wejście w relację z marszałkiem Śmigłym-Rydzem. Słowa były najwyraźniej tym rodzajem oferty, po który francuski Szef Sztabu sięgał najłacniej ${ }^{19}$.

Wspomniana wyżej propozycja nadal nie oznaczała jednak bynajmniej korekty stanowiska Gamelina odnośnie do bardziej realnej pomocy dla Rzeczypospolitej. Przeciwnie - trzy dni później zwrócił on uwagę premiera, że Polacy, którzy domagają się pilnych dostaw silników lotniczych firmy Gnome-Rhône, równocześnie eksportują do Bułgarii samoloty wyposażone w napędy tegoż właśnie producenta ${ }^{20}$. Przyznając, że wedle informacji Departamentu Lotnictwa chodzi zapewne o materiał odmiennych typów, Szef Sztabu Generalnego Obrony Narodowej zasiał jednak ziarno niepewności co do rzeczywistych potrzeb polskiego alianta. Tego dnia Sekcja Obrony Narodowej Gabinetu ministra obrony narodowej i wojny w przedstawionej analizie uznała zasadność koncepcji formułowanej w ostatnich dniach przez Gamelina, sugerując uchylenie się od nowych dostaw sprzętu wojskowego dla Polski, przestudiowanie możliwości francusko-brytyjskiej pomocy finansowej dla władz z Warszawy oraz powierzenie Szefowi Sztabu Obrony Narodowej koordynacji przyszłych rozmów międzysztabowych z sojusznikiem ze wschodu. Reakcja nastąpiła już w dniu następnym: Gamelin otrzymał zadanie „centralizacji i koordynacji” rozmów, które być miały podjęte z przedstawicielami polskich sił zbrojnych w sferze „lądowej, powietrznej i ewentualnie morskiej", $z$ prawem delegowania w razie potrzeby uzyskanych kompetencji szefom Sztabów Generalnych Marynarki Wojennej i Lotnictwa ${ }^{21}$.

Debaty na temat francuskiego udziału $w$ wyposażaniu armii polskiej nad Sekwaną toczyły się właściwie bezustannie przez całe międzywojenne dwudziestolecie,

19 SHD-DAT, 5 N 579, pismo No 719/DN.3 Gamelina do Daladiera z 15 IV 1939 r. (też: DDF, t. 15, doc. 416, s. 672n.). Przywolana korespondencja stanowi jeden jeszcze argument za rewizją tezy o niechęci Gamelina do międzysztabowych kontaktów ze stroną polską.

20 Na ten temat: W. Mazur, Klient podwyższonego ryzyka. Eksport polskiego sprzętu wojennego do Bułgarii w okresie międzywojennym, „Studia z Dziejów Rosji i Europy Srodkowo-Wschodniej" 2006, t. 41, s. 96n.

21 SHD-DAT, 2 N 236, kopia pisma No 736/DN.3 Gamelina do Daladiera z 18 IV 1939 r., 5 N 579, analiza „Aide à la Pologne” Sekcji Obrony Narodowej z 18 IV 1939 r. (też: DDF, t. 15, doc. 438, s. 703); pismo No 392 D.N. Daladiera do Gamelina z 19 IV 1939 r. W tekście pisma z 19 kwietnia Daladier powielił (a częściowo po prostu skopiował) elementy stanowiska MAE, które zostały mu przesłane $z$ początkiem dekady $w$ korespondencji sygnowanej przez Légera. Ten ostatni $z$ kolei odwoływał się do koncepcji wyłuszczonych w korespondencji Noëla (SHD-DAT, 5 N 579, pismo No 1282 za ministra i z jego polecenia Légera do Daladiera z 10 IV 1939 r.). 
choć ze zmienną intensywnością. Wiosną 1939 roku właśnie dobiegał końca kolejny ich etap, związany $z$ rozdysponowaniem kwot przyznanych władzom Rzeczpospolitej jeszcze we wrześniu 1936 roku, w ramach zbrojeniowego kredytu z Rambouillet. Było już jednak oczywiste, że modernizacja możliwa dzięki dopiero uruchamianym dostawom francuskiego sprzętu będzie zbyt powierzchowna, by siły spod biało-czerwonych sztandarów mogły myśleć o sprostaniu czekającym je być może w nieodległej przyszłości egzaminom. Ich materiałowe potrzeby wciąż były liczne i palące. Jak oceniał w początkach kwietnia ambasador Noël: „Personel lotnictwa wydaje się doskonały, ale jego materiał musi zostać odnowiony prawie w całości. [...] Armii lądowej, której jakość i walory są niezaprzeczalne, brakuje jednakże ciężkiej artylerii i czołgów. Nie sposób uzyskać dokładnych informacji na temat zapasów amunicji i surowców (szczególnie ropy naftowej), te ostatnie są jednak bez żadnej wątpliwości bardzo niewystarczające i byłoby niezbędne uzupełnić je tak szybko, jak to tylko możliwe"22.

To właśnie ta datowana $6 \mathrm{kwietnia}$ depesza skłoniła ministra Bonneta, a następnie Daladiera do zainteresowania się sprawą dostaw materiałów koniecznych dla armii polskiej, a także równolegle sformułowaną przez Noëla propozycją podjęcia rozmów międzysztabowych z coraz wyraźniej zagrożoną Warszawą ${ }^{23}$. Choć jednak francuski ambasador sam bardzo dobrze orientował się w tych zagadnieniach, w poprzednich latach wielokrotnie czynnie uczestnicząc $w$ dotyczących ich rozmowach, to $w$ danym wypadku na podjętą przezeń inicjatywę decydujący wpływ wywarł impuls z zewnątrz. Konkretnie zaś - $z$ afiliowanych przy jego placówce wojskowych attachatów.

Kierujący działalnością tych ostatnich attaché gen. Félix Musse oraz płk Louis André Arbitre z Noëlem pozostawali rzecz jasna w stałym kontakcie, przekazując mu kopie sporządzanych raportów. Dwa z nich, datowane 30 marca, w szczytowym punkcie politycznego kryzysu, okazały się na tyle wymowne, że ambasador poczuł się zobligowany do natychmiastowego podjęcia działań.

Pierwszy $z$ tych dokumentów, autorstwa gen. Musse, zawierał głównie relacje ze spotkań z marszałkiem Smigłym-Rydzem (24 marca) oraz szefem polskiego Sztabu Głównego, gen. bryg. Wacławem Stachiewiczem. Rozmowa przeprowadzona $z$ Generalnym Inspektorem Sił Zbrojnych dotyczyła przede wszystkim zagadnień strategii polityczno-wojskowej oraz stanowiska Polski wobec krystalizujących się wówczas dopiero planów mocarstw Zachodu odnośnie do wschodniej części kontynentu. W drugiej $z$ wymienionych konwersacji padły m.in. postulaty „nowej umowy finansowej" $z$ Francją, która dostarczyć by miała środki na dalsze finasowanie polskich zbrojeń, w tym planowanego nad Sekwaną zakupu 200 lub 300 czolgów. Równocześnie polski Szef Sztabu nastawał na szybkie podjęcie przychylnej dla Warszawy decyzji w sprawie dostawy silników Gnome-Rhône „Mars” (GR 14M) dla

22 DDF, t. 15, doc. 279, s. 472n.

23. SHD-DAT, $5 \mathrm{~N}$ 579, pismo No 1282 za ministra spraw zagranicznych i $z$ jego delegacji Légera do Daladiera z 10 IV 1939 r.; nota No 357 D.N za ministra i z jego rozkazu gen. Decampa dla Gamelina 212 IV 1939 r.; DDF, t. 15, doc. 335, s. 540. 
konstruowanych właśnie 50 samolotów LWS-3 „Mewa”. To właśnie te postulaty przekazał do Paryża Noël, urgując o podjęcie odpowiednich kroków ze strony francuskiej24.

Polskie apele o kolejne dostawy sprzętu oraz zabiegi podejmowane w celu przyspieszenia lub odblokowania dostaw już uzgodnionych od dawna jednak stanowiły standardową wręcz treść korespondencji gen. Musse. Pewną nowość stanowiło tu jednoznaczne sformułowanie przez stronę polską oczekiwań względem nowego kredytu zbrojeniowego, choć i tego można się było spodziewać. Sytuacja międzynarodowa sprawiła, że Noël wszystkie te sprawy potraktował z pełną powagą, przekazując postulaty polskich wojskowych do Paryża, gdzie jak już wiemy, nie pozostały bez echa. Jednak to drugi $z$ wspomnianych raportów okazał się zapewne właściwym zapalnikiem podjętej akcji. Pułkownik Arbitre - bo to on był jego autorem - w szczegółowym wywodzie podsumował bowiem stan polskiego lotnictwa wojskowego, a następnie na tej podstawie przeprowadził diagnozę możliwości sił zbrojnych Rzeczypospolitej w konfrontacji z agresją Rzeszy, formułując wnioski, które trudno było potraktować obojętnie ${ }^{25}$.

Attaché za punkt wyjścia swej analizy przyjął coraz bardziej prawdopodobny scenariusz, zakładając, że skierowana na wschód ekspansja Rzeszy doprowadzi do konfliktu, w którym Polska zaangażowana zostanie po stronie Francji. Następnie zaś dążył do rozważenia trzech aspektów lotniczej części powstałego w ten sposób zagadnienia, starając się określić aktualny stan sił powietrznych i obrony przeciwlotniczej Rzeczypospolitej, a następnie przedstawić polskie możliwości „z punktu widzenia konstrukcji lotniczych" i wreszcie - wskazać ograniczenia, jakie napotyka rozwój lotnictwa znajdującego się w dyspozycji władz z Warszawy.

Całość należących do pierwszej linii zasobów polskich sił powietrznych Arbitre oszacował na 900 samolotów, zawyżając tym samym stany faktyczne o około $25 \%$, już po uwzględnieniu maszyn znajdujących się w zapasie ${ }^{26}$. Zawyżenia dotyczyły też liczby maszyn w każdej w zasadzie $z$ wymienionych kategorii. Bardziej istotna była tu jednak uwaga, że spośród wymienionych samolotów jedynie 50 bombowców "Łoś" ma wartość bojową porównywalną ze sprzętem używanym przez siły powietrzne wielkich mocarstw. Pozostałe maszyny, podkreślał attaché (czyniąc to zresztą w tek-

24 DDF, t. 15, doc. 214, s. 324nn. Polskie interwencje w sprawie dostaw silników (podejmowane uprzednio także przez marszałka Smigłego-Rydza) okazały się skuteczne, o czym Musse informował już w następnym raporcie (SHD-DAT, 7 N 3002, raport No 47/S z 5 IV 1939 r.). Silniki zostały wysłane z Francji w ciągu kilku następnych tygodni. Zob. wyżej przyp. 307.

25 SHD-DAT, 2 N 235, „Rapport sur l'aviation et la défense aérienne de la Pologne au ler Avril 1939" No 33/DS płk. Arbitre z 30 III 1939 r.

26 Nie dysponujemy ścisłymi danymi na temat liczby maszyn polskiego lotnictwa wojskowego w dniu I IV 1939 r. Miesiąc później odpowiednie stany obejmowały 383 samoloty w jednostkach pierwszej linii oraz dalsze 300 egzemplarzy w zapasie - łącznie więc 683 maszyny (IPMS, Lot. A.I. $2 / 15$, „Jednostki bojowe i samoloty. Stan rzeczywisty”, zał. do niedatowanego (początek maja 1939 r.) pisma L. 389/S.Lotn.Tj.39 Sztabu Lotniczego Sztabu Głównego). W obu dokumentach nie uwzględniono samolotów szkolnych. 
ście najzupełniej dosłownie), powinny zostać wymienione na nowocześniejsze w całości i bezzwłocznie ${ }^{27}$.

Tymczasem, jak donosił, nowe konstrukcje, już opracowane przez „bardzo aktywne" lotnicze biura studiów, wciąż znajdowały się w stadium prototypów lub w najlepszym razie (jak samolot obserwacyjny LWS-3 „Mewa”) w trakcie przygotowań do produkcji. Przeprowadzenie koniecznej odnowy materiału polskiego lotnictwa wojskowego spowalniały też, zdaniem attaché, dwa inne czynniki: możliwości produkcyjne przemysłu oraz kredyty na rozwój konstrukcji lotniczych.

W pierwszej z tych sfer wedle przedstawionych ocen sprawy rozwijały się względnie pomyślnie. Do trzech głównych zakładów lotniczych kraju, za które Arbitre uznał mieszczące się na Okęciu wytwórnie płatowców oraz silników Państwowych Zakładów Lotniczych (PZL WP1 i PZL WS1) oraz Lubelską Wytwórnię Samolotów, z początkiem roku dołączyły dwie nowe fabryki, umieszczone na terenie Centralnego Okręgu Przemysłowego ${ }^{28}$. Kompletowanie wyposażenia i załogi tych ostatnich znajduje się nadal w stadium realizacji, ale w ciągu roku 1939 ich wydajność osiągnąć winna 50 do $60 \%$ zakładanej mocy. Choć szczegółowych danych co do możliwej produkcji tak zarysowanego zespołu wytwórni Arbitre nie posiadał, to skłonny był uznać, że w czasie pokoju będą one w stanie dostarczać łącznie po około 100 samolotów miesięcznie. W tej sytuacji, jak stwierdził, w grę wchodzić by mogła nawet całkowita wymiana przestarzałego sprzętu polskiego lotnictwa wojskowego $\mathrm{w}$ ciągu roku budżetowego 1939/40, tj. do końca marca roku 1940.

Jednak przeprowadzenie podobnej operacji musiałoby być z pewnością bardzo kosztowne. Nawet po odliczeniu wartości 50 samolotów PZL.37, których wykonanie zamierzano pokryć z kredytów realizowanego już budżetu (1938/39), środki niezbędne do realizacji "programu 1200 samolotów” sięgnąć by musiały, wedle pobieżnych kalkulacji attaché, sumy około $140 \mathrm{mln}$ zł, dwukrotnie przewyższającej kwotę, którą wedle jego informacji strona polska zamierzała przeznaczyć na nowy materiał lotnictwa w ciągu nadchodzącego roku. Po uwzględnieniu niezbędnych zakupów wyposażenia i uzbrojenia niedobór szacowany być mógł zdaniem płk. Arbitre na około 100 $\mathrm{mln}$ zł, tj. ok. $700 \mathrm{ml}$ franków francuskich.

To właśnie względy finansowe, podsumowywał tę część swej analizy francuski attaché lotniczy, uniemożliwiają szybką modernizację polskiego lotnictwa. Jak pisał,

27 W zestawieniu figurowało 250 samolotów myśliwskich „P.11” (PZL.11), 300 samolotów obserwacyjnych Lublin R.XIII, 250 samolotów rozpoznawczo-bombowych PZL.23 „Karas”” (w dokumencie nie wymieniono ani ich oznaczenia, ani nazwy własnej), 25 samolotów bombowych Fokker [FVII] ( $w$ istocie odesłanych juz do rezerwy) oraz 25 samolotów bombowych "Lublin" (faktycznie - LWS-6 „Żubr”, których w rzeczywistości lotnictwo polskie posiadało 16 egzemplarzy; aktualna przez pewien czas latem roku 1936 koncepcja budowy 25 takich maszyn nigdy nie została zrealizowana), wreszcie - 50 samolotów bombowych „P.37” (PZL.37 „Łos”). Rzeczywiste stany - zob. tab. 3.

24 Arbitre miał tu na myśli ulokowaną w Mielcu fabrykę PZL Wytwórnia Płatowców nr 2 oraz uruchomioną w Rzeszowie PZL Wytwórnia Silników nr 2. Inne zakłady lotnicze: RWD (właściwie: Doświadczalne Warsztaty Samolotów), Podlaska Wytwórnia Samolotów oraz wytwarzająca silniki lotnicze firma Avia w raporcie wzmiankowane były tylko pour mémoire. 
w przypadku władz wojskowych „[...] brak pieniędzy jest lejtmotywem ich nieustannych gorzkich skarg, a Francja wydaje im sięjedynym krajem zdolnym ich wyciagnąć $z$ tych problemów poprzez przyznanie Polsce nowej pomocy finansowej" [podkr. oryg. - W.M. $]^{29}$.

Dalsze części analizy poświęcone były zagadnieniom związanym z polską obroną przeciwlotniczą. Całość zaś wieńczyła bardzo rozbudowana konkluzja, z której warto przytoczyć obszerne fragmenty, końcowa diagnoza była bowiem tyleż interesująca, co celna:

Ostatecznie, w chwili obecnej, ani polskie lotnictwo wojskowe, ani obrona przeciwlotnicza nie są dostatecznie rozwinięte dla efektywnego uczestniczenia w obronie Polski.

Jednakże dzięki [...] inicjatywom Rządu, który w mniej niż 2 lata stworzyl znakomite fabryki $[\ldots]$, przemysł polski jest $w$ stanie $[. .$.$] rozwinąć siły powietrzne i przeciwlotni-$ cze, pod warunkiem że się mu zapewni:

- pieniądze,

- pewne surowce (na przykład aluminium i duraluminium),

- pewne materiały (silniki lotnicze, [ciężkie] działo przeciwlotnicze kal. $90 \mathrm{~mm}$ )

i jeśli da mu się czas.

$\underline{Z}$ punktu widzenia lotnictwa słabym punktem jest kwestia silników, produkowanych $\mathrm{w}$ istocie na licencji, którymi są Bristol

- typu Mercury IV (500 KM) i VIII (700 KM)

- typu Pegasus VIII (700 KM) - XII i XX (8[00] - $900 \mathrm{KM})^{30}$.

Ona [Polska] zakupiła licencję na silniki Gnome-Rhône 14M o mocy $700 \mathrm{KM}$, ale fabryka Avia, która jest obarczona tą produkcją, będzie mogla naprawdę wypuścić pierwszy samolot [sic!] dopiero w przeciągu 10-12 miesięcy, jak twierdzą Polacy - ale rozsądniej byłoby przewidywać 16 miesięcy.

Przemysł lotniczy przez wiele jeszcze lat znajdować się będzie w niezdolności do:

1/ wykańczania odpowiedniej liczby silników,

2/ wytwarzania siników o mocy powyżej $900 \mathrm{KM}$.

Finał tego wywodu brzmiał jednoznacznie i niezwykle mocno:

W razie gdyby Polska zgodziła się teraz zaangażować po stronie Francji i Anglii w ewentualnej akcji przeciw Niemcom, demokracje zachodnie powinny rozpatrzyć w najkrótszym możliwym terminie dostarczenie Polsce:

- silników lotniczych,

- dział przeciwlotniczych kal. $90 \mathrm{~mm}$,

- pewnych surowców,

nie zapominając o pieniądzach. [...]

${ }^{24}$ SHD-DAT, 2 N 235, „Rapport sur l'aviation...” płk. Arbitre z 30 III 1939 r. Równocześnie Arbitre informował o rozpisaniu przez polskie władze Pożyczki Obrony Przeciwlotniczej, która mogła się stać alternatywnym źródłem finansowania planów modernizacji lotnictwa wojskowego.

${ }^{30}$ Faktyczna moc podanych typów silników dość znacznie odbiegała od informacji przekazanych $w$ raporcie. 
Bez tej pomocy Polska, mimo tego, co publikuje się w jej prasie, jest niezdolna do szybkiego [...] rozwoju lotnictwa i obrony przeciwlotniczej i ryzykuje, jakakolwiek nie bylaby brawura jej wojskowych, ze stawi Niemcom odpór jedynie efemeryczny [podkr. oryg. - W.M.|'s!

Obaj akredytowani w Warszawie francuscy wojskowi attaché $e^{32}$ zgadzali się przy tym, że pomoc dla Polski, aby była skuteczna, powinna uwzględniać także udział ZSRR. Generał Musse już 6 kwietnia przekazał do Paryża sugestie, by podjęto tam, na razie bez wciągania $w$ to polskiego Sztabu Głównego, studia nad ewentualnym wsparciem wojskowym, którego władzom z Warszawy udzielić by mogły radzieckie siły zbrojne. Niespełna dwa tygodnie później płk Arbitre posłał nad Sekwanę raport dotyczący możliwości „ewentualnego wzmocnienia lotnictwa polskiego przez siły francuskie, angielskie i rosyjskie"33.

Poczynania te były zgodne z kursem, który równolegle przyjęty został w Paryżu. Skądinąd określenie "przyjęty" nie jest w tym przypadku całkiem adekwatne. Brytyjska inicjatywa $z$ ostatnich dni marca usunęła bowiem $w$ cień jedynie chwilowo francuskie wysiłki na rzecz udziału ZSRR w "lamigłówce wschodniego frontu”, ale ich nie przerwała ani też - zdaniem Francuzów - w żaden sposób nie przekreśliła szans pomyślnej ich finalizacji. W tym też duchu już od pierwszych dni kwietnia Quai d’Orsay starało się przedstawiać zaistniałą sytuację w rozmowach z przedstawicielami Moskwy ${ }^{34}$. Na wewnętrzny zaś użytek podczas konferencji pod przewodnictwem Daladiera odbytej po południu 9 kwietnia w Ministerstwie Wojny Bonnet poinformował, że wobec polskiej odmowy podjęcia negocjacji z ZSRR zamierza się teraz odwołać do "nowej formuły”, prosząc Moskwę, by to ona określiła, co mogłaby

"SHD-DAT, 2 N 235, „Rapport sur l'aviation..." płk. Arbitre z 30 III 1939 r. Kilka tygodni później w Oddziale II Sztabu Generalnego Armée de l'Air powstało syntetyczne opracowanie dotyczące stanu polskiego lotnictwa wojskowego - chronologicznie ostatnie $z$ odnalezionych $w$ trakcie podjętej kwerendy. Wykorzystano w nim m.in. informacje przekazane w początkach kwietnia przez płk. Arbitre, niektóre $z$ nich uszczegóławiając (np. przez rozbicie liczby samolotów poszczególnych typów na maszyny znajdujące się w bieżącym użytku eskadr oraz zatrzymane w rezerwie I linii) lub poddając drobnym korektom (w zestawieniu figurowało np. już 70 samolotów typu PZL.37, z tego $40 \mathrm{w}$ rezerwie). Ogółem siły polskiego lotnictwa wojskowego określone zostały na 45 eskadr, 532 użytkowane w nich samoloty (oraz 420 w rezerwie I linii, łącznie więc w I linii 952 samoloty) i około 400 maszyn II linii. SHD-DAT, 7 NN 2/398, „Note sur l'Aéronautique militaire polonaise" z 27 IV $1939 \mathrm{r}$.

${ }_{32}$ Dla ścisłości przypomnieć trzeba, że akredytacją dysponował także wspomniany już wyżej płk Vachell oraz rezydujący stale w Berlinie brytyjski attaché morski, kmdr Thomas Hope Thoubridge. W Warszawie akredytowany był także francuski attaché morski. W roku 1939 funkcję tę pełnił kmdr ppor. Gruillot.

${ }^{33}$ SHD-DAT, 7 N 3002, raport No 59/S gen. Musse dla ministra obrony narodowej i wojny (Sekcji Armii Obcych Oddziału II Sztabu Generalnego) z 18 IV 1939 r.

${ }^{34}$ AD, Papiers 1940, Hoppenot 7, nota „Négociations franco-anglo-russes (15 mars 1939), (12 mai 1939)" JLR/39 Poddyrekcji Europa Dyrekcji Spraw Politycznych i Handlowych MAE z 12 V 1939 r.; M. Gmurczyk-Wrońska, op. cit., s. 85nn. 
uczynić dla Polski i Rumunii. Sformułowana w ten sposób propozycja zostać by miała następnie przekazana obu zainteresowanym państwom przez Francuzów ${ }^{35}$.

$\mathrm{Na}$ konieczność skłonienia Warszawy do zaakceptowania w razie wojny pomocy ZSRR nieodmiennie zwracali uwagę wszyscy zainteresowani (Noël, Leger, Bonnet, Gamelin), sam zaś premier, powierzając 19 kwietnia Szefowi Sztabu Generalnego Obrony Narodowej koordynację prac zmierzających do podjęcia rozmów międzysztabowych, podkreślił wagę „wzmożenia wysiłków naszej dyplomacji w celu doprowadzenia Polski do współpracy z ZSRR w czasie konfliktu, szczególnie w dziedzinie surowców, produktów żywnościowych oraz uzbrojenia" ${ }^{36}$. Zadanie to, choć niezwykle trudne, nie zdawało się wówczas Francuzom niewykonalne. Wpływ na to miały, jak się wydaje, głównie doniesienia Noëla, który perspektywy zamierzonej akcji przedstawiał z wyraźnym, choć ostrożnym, optymizmem. Uzasadniając taką ocenę, ambasador poinformował Paryż m.in. o rozmowie, w której „wysoki funkcjonariusz” polskiego MSZ wyraził przekonanie, że jedno z powiązanych z państwem polskich przedsiębiorstw importujących surowce $z$ pewnością byłoby skłonne podjąć studia nad możliwościami zaopatrywania się $w$ ZSRR. Z kolei niewymieniony $z$ nazwiska oficer polskiej marynarki miał $w$ trakcie spotkania ze współpracownikiem Noëla rozważać wykorzystanie w przypadku wojny przez polską flotę radzieckich portów ${ }^{37}$.

Ostrożniejszy w ocenach szans na zmianę polskiej postawy wobec radzieckiej pomocy był gen. Musse. I on jednak, raz jeszcze podkreślając w końcu kwietnia niewiarę polskiego kierownictwa w wartość podobnej asysty, zauważał, że ogólna atmosfera stosunków Rzeczypospolitej i jej wschodniego sąsiada uległa w ostatnim czasie poprawie. Wszystko to budzić mogło i istotnie budziło nadzieje nad Sekwaną ${ }^{38}$.

15 AN, 496 AP 11, „Procès-Verbal des décisions prises au cours de la conférence tenue au Ministère de la Guerre le 9 avril 1939" (też: DDF, t. 15, doc 316, s. 520nn.; M. Gamelin, op. cit., t. 2, s. 403nn.). Dokumentację pierwszego etapu rozmów z Moskwą (w tym kopie korespondencji) zawiera dossier "Les négociations anglo-franco-soviétiques - lère étape - Du 15 mars au 4 mai 1939" (AN, 496 AP 13).

36 SHD-DAT, 5 N 579, pismo No 392 D.N. Daladiera do Gamelina z 19 IV 1939 r.

37 AD, Papiers 1940, Rochat 31, telegram No 569 Noëla do MAE z 13 IV 1939 r. Wspomnianym przedsiębiorstwem była z pewnością "TISSA" Towarzystwo Importu Surowców S.A. o półpaństwowym istotnie charakterze, kierowane wówczas przez byłego attaché wojskowego RP w Moskwie oraz Bukareszcie, absolwenta paryskiej École Supérieure de Guerre ppłk. dypl. Jana Kowalewskiego. O możliwościach aktywizacji gospodarczych kontaktów z ZSRR, także w zakresie surowców, 12 kwietnia (a więc w dniu poprzedzającym ekspedycję raportu Noëla) rozmawiali Jan Szembek oraz przybyly w tym celu do Warszawy ambasador RP w Moskwie Waclaw Grzybowski (J. Szembek, op. cit., s. 554n.). Wspomnianym w korespondencji Noëla „współpracownikiem” był zapewne francuski attaché morski kmdr ppor. Gruillot, który w tym czasie w rozmowie z ppłk. Swordem wspomniał, rzecz komentując zresztą dość sceptycznie, o możliwości wykorzystania przez polskie okręty podwodne radzieckiego Kronsztadu w roli bazy zaopatrzeniowej. TNA, FO 417/39, raport M.165/P. Sworda dla Kennarda 217 IV 1939 r.

3* SHD-DAT, 7 N 3002, „Rapport No 61/S du 27 Avril 1939” gen. Musse. Kilka dni później, 1 maja, w analizie sporządzonej przez Oddział II francuskiego Sztabu Generalnego Armii stwierdzano, że korzystna ewolucja stosunków Polski i Litwy z ZSRR sprawia, iż trudności stojące dotychczas na przeszkodzie programowi współpracy tych państw (obejmującej też kooperację ra- 
W podejmowanych próbach przełożenia owych nadziei na rozwiązania o praktycznej użyteczności lotnictwo nie po raz pierwszy zajmowało miejsce szczególne. To bowiem operacje lotnicze zdawały się Francuzom najbardziej atrakcyjnym (a także najbardziej prawdopodobnym) aspektem radzieckiej partycypacji w spodziewanym europejskim konflikcie. Przesądzały o tym względy tak oczywiste, jak przewidywane znaczenie tych operacji dla przyszłych zmagań wojennych, dążność do objęcia akcją lotniczą nieosiągalnego w praktyce $z$ lotnisk we Francji obszaru wschodnich Niemiec, słabość lotnictwa polskiego sojusznika i faktyczna niemożność, wobec słabości Armée de l'Air, bazowania na jego terytorium poważniejszych sił francuskich, wreszcie - brak wspólnej granicy Rzeszy i ZSRR, który uniemożliwiał, a przynajmniej bardzo komplikowal bezpośrednie wykorzystanie $w$ starciu z Niemcami znajdujących się w dyspozycji Moskwy sił lądowych. Wydawało się ponadto możliwe, że władze z Warszawy, kategorycznie przeciwne obecności w granicach Rzeczypospolitej radzieckich sił lądowych, nie będą tak zdecydowane w kwestii udostępnienia przestrzeni powietrznej prowadzącym operacje przeciw Rzeszy radzieckim samolotom czy nawet przyznania im prawa do wylądowania, np. dla uzupełnienia paliwa.

W kwietniu 1939 roku w Paryżu dokonano kolejnej oceny potencjału radzieckich sił powietrznych. Całość radzieckich sił lotniczych pierwszej linii (włącznie z rezerwą pierwszej linii) po uwzględnieniu także lotnictwa morskiego oszacowano na 6000 samolotów i wodnosamolotów. Z tej liczby wedle autorów analizy 4000 maszyn znajdowało się w europejskiej części ZSRR, pozostałe zaś samoloty rozdzielone zostały po połowie między bazy z "Rosji azjatyckiej” i Syberii oraz Dalekiego Wschodu. Oznaczało to, że w przypadku konfliktu rozgrywającego się w Europie można było brać pod uwagę jedynie dwie trzecie ogólnej liczby samolotów z czerwoną gwiazdą, bazy maszyn rozlokowanych na Dalekim Wschodzie były bowiem zbyt odległe od zachodniego frontu, zaś $w$ części azjatyckiej ZSRR rozmieszczono samoloty stare, których udział w starciach wojennych nie mógł zmienić znacząco bilansu sił ${ }^{39}$.

Walory sprzętu posiadanego przez radzieckie lotnictwo określone zostały jako zróżnicowane. Część samolotów uznano za spełniające kryteria nowoczesności, wymieniając $w$ tej grupie myśliwce I- 16 oraz samoloty bombowe SB (SB-2) i „T.S.K.B.26”,

dzieckiego lotnictwa) przestają być niemożliwe do pokonania. Szczególnie optymistycznie oceniano szanse na radziecką interwencję wojskową w początkowym okresie wojny "na przykład po osi Moskwa - Smoleńsk - Kowno - Königsberg”. SHD-DAT, 7 N 3186, nota „Politique extérieure de I'U.R.S.S." z 1 V 1939 r.

${ }^{34}$ SHD-DAA, 11 Z 12941, niesygnowana "Note sur la puissance aérienne soviétique" $z$ kwietnia 1939 r. $Z$ ogólnej liczby samolotów $46 \%$ stanowić miały maszyny bombowe, $30 \%$ myśliwce, $24 \%$ samoloty rozpoznawcze, co francuscy analitycy uznali za rozkład analogiczny do występującego w przypadku innych mocarstw europejskich. W tym czasie analizowano także lotnicze aspekty radzieckiej doktryny wojennej. Plon tych prac zestawiony zostal w sporządzonym w kwietniu 1939 r. opracowaniu O. II Sztabu Generalnego Armée de l'Air „Les opérations aériennes et leur exécution d'après la doctrine officielle et la littérature militaire Soviétiques” (SHD-DAA, 2 B 100). Prawdopodobieństwo wykorzystania przeciw Niemcom maszyn bazowanych w azjatyckiej części ZSRR dodatkowo zmniejszało zagrożenie ze strony Japonii. 
inne, jak ciężkie bombowce TB-3 i TB-4, samoloty rozpoznawcze R-5 czy myśliwce I-15 - przyjęto za wyraźnie mniej już wartościowe. Stan taki, podkreślali autorzy analizy, sprawia, że realna wartość sił powietrznych ZSRR jest wyraźnie niższa, niż można by sądzić na podstawie budzących respekt danych liczbowych.

Także oceny radzieckiego przemysłu lotniczego formułowane były $z$ dużą ostrożnością. W analizie zwrócono uwagę na hamujące jego rozwój niedostatki, w tym brak odpowiedniej liczby inżynierów i techników, robotników wykwalifikowanych, niedostateczne kwalifikacje zatrudnionego personelu, rozbudowaną kontrolę polityczną oraz pedantyczną i pozbawioną elastyczności administrację. I tu jednak nie można było ignorować liczb. $\mathrm{Z}$ tych zaś wynikało, że mimo powyższych mankamentów rozbudowana infrastruktura przemysłowa, obejmująca 34 zakłady produkujące i remontujące płatowce, 7 wytwórni silników lotniczych oraz 15 wytwórni wyposażenia lotniczego, pozwolić mogła na osiągnięcie bardzo poważnej rocznej produkcji w wysokości około 5000 płatowców i 10000 silników rocznie - przy nieprzerwanej pracy na trzy zmiany. Możliwości dalszego zwiększenia tej produkcji w czasie wojny były wszakże niewielkie, całość dostępnych zasobów siły roboczej w przekonaniu francuskich analityków państwo radzieckie zmobilizowało już w okresie pokoju.

Ambiwalentnie oceniono także walory personelu radzieckich sił powietrznych. Jego ogólną wartość „z punktu widzenia realizacji misji bojowych” określono jako doskonałą. Już jednak jakość kadr podoficerskich uznano jedynie za wystarczającą, zaś wyższej kadry dowódczej i oficerów Sztabu Generalnego lotnictwa - za wręcz dalece niższą niż w przypadku zachodnich odpowiedników.

Część dokumentu poświęconą analizie potencjalnej użyteczności sił lotniczych ZSRR w konflikcie z Rzeszą rozpoczynała oczywista i wielokrotnie już wcześniej formułowana uwaga o braku wspólnej granicy $z$ tym ostatnim państwem, a co za tym idzie - konieczności wykorzystania przestrzeni powietrznej lub baz na terytorium Polski i/lub Rumunii. Dalsze ograniczenia stanowił charakter ewentualnej akcji, w której wziąć by miało udział jedynie średnie i ciężkie lotnictwo bombowe, zaś wykorzystanie lotnictwa rozpoznawczego oraz sił myśliwskich nie było przewidywane, oraz zasięg wykorzystanych samolotów bombowych. Ciężkie maszyny bombowe, powtarzano $\mathrm{w}$ ślad za analizami sprzed kilku miesięcy, operując $\mathrm{z}$ baz przy granicy ZSRR z Polską i Rumunią, dotrzeć mogą na wysokość Berlina, w zasięgu samolotów SB znaleźć by się mogły Prusy Wschodnie oraz stosunkowo wąski, obejmujący 50 $\mathrm{km}$ pas terytorium Rzeszy wzdłuż polskiej granicy. Ponownie też podkreślono, że umożliwienie działań powietrznych $z$ baz położonych $w$ Polsce, między Warszawą a Poznaniem, pozwoliłoby na objęcie operacjami ciężkiego lotnictwa bombowego całości terytorium Niemiec, zaś samolotom SB dotarcie w okolice Frankfurtu nad Odrą. Z kolei wykorzystanie baz rumuńskich (z rejonu siedmiogrodzkiego Cluj) oznaczać by miało możliwość podjęcia przez lotnictwo ciężkie bombardowań całego terytorium Austrii oraz obszaru Niemiec po linię Augsburg - Norymberga - Halle Berlin - Szczecin, w przypadku zaś samolotów SB - akcje sięgające rejonu austriackiego Salzburga oraz Śląska.

Przesunięcie obszarów bazowania przeznaczonych do interwencji przeciw Rzeszy sił ZSRR, choć niewątpliwie korzystne, uzależnione byłoby rzecz jasna od wcześ- 
niejszych ustaleń ona gruncie dyplomatycznym, a także przygotowań wojskowych oraz czysto technicznych. Jak stwierdzali autorzy dokumentu, we wrześniu 1938 roku, w związku z rozwijającym się kryzysem politycznym, przeprowadzono analizy możliwości podjęcia akcji lotnictwa radzieckiego z terytorium Polski i Rumunii. W tym okresie, jak uznano, pierwsze $z$ wymienionych państw mogłoby oddać do dyspozycji ZSRR jedynie pięć lotnisk o rozmiarach odpowiednich dla takich operacji (1000 na $1000 \mathrm{~m}$ ), co pozwalało na rozmieszczenie pięciu radzieckich dywizjonów. Drugie było w stanie udostępnić tylko trzy takie lotniska, jednak ich oddalenie od granicy o $160 \mathrm{~km}$ pozwalało, wedle Francuzów, na ulokowanie tam łącznie aż sześciu dywizjonów. „Obecnie sytuacja w Polsce uległa lekkiej poprawie”, komentowali analitycy z Paryża, konstatując zarazem, że w przypadku Rumunii górzysty charakter państwa poważnie ogranicza szansę na dalszą rozbudowę odpowiednich baz ${ }^{40}$.

$\mathrm{Z}$ większą bodaj powściągliwością do perspektyw lotniczej współpracy z ZSRR odnoszono się w Londynie. Brytyjscy sztabowcy zwracali uwagę na bardzo poważne osłabienie radzieckich sił zbrojnych skutkiem przeprowadzonej w poprzednich latach fali czystek oraz podwójny, polityczno-wojskowy system dowodzenia i kontroli. Silniej też jeszcze niż ich francuscy koledzy podkreślali, że "papierowy" potencjał armii ZSRR jest $w$ dużej mierze złudny, niemożliwe niemal do przezwyciężenia problemy z zakresu zaopatrzenia, brak rezerw czy trudności komunikacyjne uniemożliwią faktyczne jego wykorzystanie. Wreszcie przywoływali fakt oczywisty - wiele spośród państw, którym Moskwa mogłaby udzielić pomocy, bynajmniej takowej z jej strony sobie nie życzy, zaś "głęboka wrogość do komunizmu i vice versa może zniweczyć wiele korzyści wojskowych podnoszonych jako argumenty na rzecz rosyjskiej współpracy"41.

Sceptyczne były też brytyjskie oceny stanu samych radzieckich sił powietrznych. Sztabowcy z Londynu liczbę ich samolotów w jednostkach ulokowanych na zachód od jeziora Bajkał szacowali znacznie niżej od Francuzów - jedynie na 1000 bombowców i 900 myśliwców, uznając, że nie warto do tej kalkulacji włączać „wielkiej liczby" przestarzałych maszyn przeznaczonych wyłącznie do bezpośredniej współpracy z jednostkami armii lądowej i marynarki wojennej. Spośród bombowców, stwierdzano, połowę stanowią typy ciężkie, $w$ większości przestarzałe i niezdatne do akcji ofensywnych. Jednak druga połowa, na którą składają się średnie bombowce, dysponuje rozsądnymi parametrami - stąd może okazać się do pewnego stopnia użyteczna. Te ostatnie maszyny byłyby zdolne np., spekulowali Brytyjczycy, z okolic Warszawy sięgnąć ku linii Berlin - Lipsk - Praga, z Rumunii aż po Wiedeń i Fiume (Triest), pokrywając też całe terytorium Węgier, a z Turcji po Sofię i Dodekanez - oraz całe terytorium Bułgarii. Także osiągi radzieckich myśliwców uznano za relatywnie dobre. Jak jednak zaznaczono, zasięg tych maszyn jest mniejszy niż bombowców, stąd

10 SHD-DAA, 11 Z 12941, niesygnowana „Note sur la puissance..." z kwietnia 1939 r. Tam też poczynione na podstawie tego materiału odręczne notatki ministra Guy la Chambre.

"TNA, CAB 53/48, raport „Military value of Russia”, C.O.S. 887 z 24 IV 1939 r. Zob. też:

M. Kornat, Polityka zagraniczna Polski..., s. 323. 
użycie samolotów myśliwskich do roli eskorty odpowiednio zmniejszyłoby możliwości ataków bombowych na bardziej odległe obiekty. „Rosyjskie myśliwce mogą także utworzyć wartościowy dodatek do obrony przeciwlotniczej Polski" - nadmieniali autorzy raportu' ${ }^{42}$.

W dokumencie wyrażano też znaną nam już opinię, że zaopatrzenie radzieckich jednostek lotniczych ulokowanych w Polsce, Rumunii albo Turcji mogłyby zapewnić starsze, niezbyt bojowo użyteczne typy samolotów bombowych. Jak konkludowano, użyteczność sił powietrznych ZSRR w ewentualnym konflikcie zbrojnym sprowadzać by się mogła głównie do możliwości wykorzystania jako „ograniczonego zagrożenia” dla Rzeszy samolotów bazowanych w Polsce, Rumunii lub w Turcji, możliwości zmuszenia Niemców do ulokowania na granicy wschodniej ${ }^{43}$ większej liczby jednostek obrony przeciwlotniczej, niż uczyniliby to w innym przypadku, możliwości udziału w obronie przeciwlotniczej Polski ${ }^{44}$.

Tak więc i brytyjscy eksperci najwyraźniej uznawali pewną użyteczność lotniczej współpracy z ZSRR jako ewentualnym sojusznikiem mocarstw Zachodu. Również $\mathrm{w}$ ich kalkulacjach brano pod uwagę rozlokowanie jednostek radzieckich sił powietrznych na terytorium Polski. Scenariusz taki Brytyjczycy rozpatrywali jednak na razie, jak się wydaje, dość teoretycznie i beznamiętnie, nie podzielając emocji przebijających w niektórych francuskich analizach zagadnienia. Inicjatywę w kwestiach dotyczących Europy Środkowo-Wschodniej pozostawiali zresztą partnerom z Paryża. Sami, wierni swej tradycyjnej polityce, jeśli już kierowali wzrok na wschód, to raczej ku Ankarze niż Warszawie czy Moskwie ${ }^{45}$.

By kreślony w tej części naszych rozważań obraz uznać za możliwie kompletny, uwzględnić w nim trzeba jedną jeszcze, polską perspektywę. Choć bowiem zgodzić się przyjdzie $z$ dobrze już zadomowioną $w$ polskiej historiografii tezą o bardzo niewielkim polu politycznego manewru, którym dysponowała Rzeczpospolita wiosną-

42 TNA, CAB 53/48, raport „Military value of Russia”... Przytoczone dane warto porównać $\mathrm{z}$ informacjami $\mathrm{z}$ opracowanego niemal $\mathrm{w}$ tym samym czasie na potrzeby brytyjsko-francuskich rozmów międzysztabowych dokumentu A.F.C. 16 z 22 IV 1939 r., gdyż oba materiały do pewnego stopnia się uzupełniają.

4.3 W tekście raportu mowa była o "granicy zachodniej” - stanowiło to jednak błąd redakcji, którego uniknięto w zamykających całość analizy konkluzjach końcowych.

${ }_{44}$ TNA, CAB 53/48, raport "Military value of Russia”...

45 Tak np. spośród 31 punktów porządku dziennego sześciu posiedzeń Podkomitetu Szefów Sztabów, które odbyły się od 5 kwietnia do 8 maja 1939 r., do spraw tureckich wprost odnosiło się pięć, Polski - trzy, Rosji (ZSRR) - dwa. Jednak w przypadku Turcji rozpatrywano wyłącznie kwestie o charakterze, który określić by można jako podmiotowy (sojusz lub dwustronne rozmowy międzysztabowe), zaś zagadnienia "polskie” czy „radzieckie” miały często charakter odmienny, „przedmiotowy” (militarna wartość ZSRR; neutralność Włoch a możliwości pomocy dla Polski). Proporcje te miały ulec pewnej zmianie dopiero w następnych tygodniach z związku z zapoczątkowaniem z Warszawą i Moskwą rozmów międzysztabowych. Odmienność optyki zainteresowanych głównie współpracą z ZSRR Francuzów i nastających na pomoc dla Turcji Brytyjczyków odnotował we wspomnieniach m.in. J. Slessor (op. cit., s. 231), postawę przedstawicieli Londynu uznając zresztą $w$ tym przypadku ex post za błędną. 
-latem 1939 roku, ostatnio przekonująco uargumentowaną ponownie przez Marka Kornata, to wiedza o realnym potencjale sojuszników wydaje się istotna dla oceny decyzji podejmowanych wówczas przez sterników państwowej nawy. Tymczasem, co może dziwić, studiów na temat stanu ich poinformowania $w$ tych kwestiach dotychczas w zasadzie nie prowadzono ${ }^{46}$.

Nie byłyby one zresztą łatwe, odpowiednie materiały są bowiem dość nieliczne i rozproszone. Co więcej, lotnictwa dotyczy tylko niewielka ich cząstka. Niewiele więc konkretnego możemy powiedzieć o informacjach posiadanych w tym czasie przez polskie kierownictwo polityczno-wojskowe na temat sił powietrznych francuskiego sojusznika. Wiadomo jednak, że wiedza ta była dość szczegółowa, ich źródłem był zarówno ulokowany w Paryżu attachat lotniczy (którego raporty z końca roku 1938 były już wyżej przywoływane), jak i dość częste bezpośrednie kontakty oficerów obu państw. Przypomnieć trzeba, że właśnie w zakresie lotnictwa i wywiadu były one $w$ drugiej połowie lat 30 . szczególnie intensywne, a ostatni ich akt miał miejsce całkiem niedawno, w lutym 1939 roku, kiedy to w Polsce bawiła misja ppłk. d’Arnaud de Vitrolles ${ }^{47}$.

Jednak, jak przyszło już nam zwracać uwagę, wojskowe kontakty Rzeczpospolitej i Zjednoczonego Królestwa nie należały uprzednio do szczególnie bliskich. Choć więc pułkownicy Kwieciński i Sword bardzo dobrze wywiązywali się z zadań attachés militaires, to wiosną 1939 roku zasób posiadanych w Warszawie informacji na temat wojskowych możliwości nowo pozyskanego partnera znad Tamizy wymagał z pewnością pewnego odświeżenia i uzupełnienia.

Najpewniej z tego właśnie powodu ppłk Kwieciński wkrótce po udzieleniu Polsce brytyjskich gwarancji oraz londyńskiej wizycie Becka sporządził raport zawierający podsumowanie "lądowej i lotniczej siły zbrojnej Wielkiej Brytanii”, a następnie datowany 21 kwietnia dokument wręczył osobiście Szefowi Sztabu Głównego, gen. Waclawowi Stachiewiczowi ${ }^{48}$.

Sądzić wolno, że wspomniana notatka opracowana została na polecenie $\mathbf{z}$ kraju, domniemanie takie uzasadnia jej zwięzła, syntetyczna forma oraz specyficzne uporządkowanie treści, które zestawiono najpewniej wedle dostarczonego autorowi kwestionariusza. W pierwszej jej części omówiony został potencjał brytyjskiej armii

46 M. Kornat, Polityka zagraniczna Polski..., s. $387 \mathrm{nn}$. i in. Nieco paradoksalnie nawet w obszernych i wartościowych pracach $M$. Zgórniaka zaprezentowany został stan wiedzy raczej niemieckich niż polskich dowódców. Autor sięgnął bowiem dość szeroko do zasobu Bundesarchiv-Militärarchiv z Fryburga Bryzgowijskiego, w bardzo niewielkim stopniu uwzględniając trudniej dlań najwyraźniej dostępne polskie archiwalia emigracyjne. Zob.: M. Zgórniak, Europa $w$ przededniu wojny..., s. $451 \mathrm{nn}$.

17 Żadnych właściwie odniesień do spraw lotniczych z okresu przed wybuchem wojny nie zawiera niestety niedatowane „Sprawozdanie roczne b. Attaché Wojskowego w Paryżu [płk Fydy] za czas od 1.X.1938 r.-10.IX.1939" (IPMS, A.IV. 1.1b).

1" IPMS, Lot. A.V. 1/40b, „Notatka dla Pana Szefa Sztabu Głównego w sprawie lądowej i lotniczej siły zbrojnej Wielkiej Brytanii" L. $177 / 49$ ppłk. Kwiecińskiego z 21 IV 1939 r. Na dokumencie ppłk Kwieciński dopisał odręcznie: „Doręczone p. S.[zefowi] S.[ztabu] osobiście bez numeru”. 
lądowej. Osiągane w tym zakresie postępy ppłk Kwieciński oceniał z wyraźną aprobatą, szczególnie w przypadku zauważalnie gorzej dotychczas uzbrojonej i wyszkolonej „milicyjnej armii terytorialnej”. Zwracał jednak uwagę, że proces jej unowocześniania wymaga jeszcze czasu, zakończony być może najwcześniej w końcu roku. „W chwili obecnej - wyjaśniał - tylko jednostki armii regularnej mogłyby być użyte do akcji poza granicami kraju". Nawet jednak po zakończeniu wspomnianych prac całość przeznaczonego do działań na kontynencie brytyjskiego korpusu ekspedycyjnego składać się będzie z 19 dywizji (w tym trzech pancernych i trzech zmotoryzowanych). W czysto rachunkowym ujęciu nawet po doliczeniu wzmiankowanych przez polskiego attaché dwóch brygad kawalerii „i szeregu jednostek specjalnych" były to siły $\mathrm{z}$ górą dwakroć mniejsze, niż zamierzała wyprowadzić $\mathrm{w}$ pole zmobilizowana armia Rzeczypospolitej" ${ }^{49}$.

Zgodnie z przekazanymi w raporcie informacjami brytyjskie lotnictwo wojskowe wedle stanu z 1 marca 1939 roku liczyć miało ogółem 170 eskadr, w tym 73 eskadry bombowe (z tego $14 \mathrm{w}$ koloniach), 41 eskadr myśliwskich (z tego $6 \mathrm{w}$ koloniach), 14 eskadr współpracy (5 w koloniach), 20 eskadr rozpoznawczych (5 w koloniach), 16 eskadr "na użytek floty” oraz 6 eskadr „różnych”. „Ogółem samolotów pierwszej linii $w$ chwili obecnej c. 1750. Program rozbudowy przewiduje zdwojenie tej cyfry" donosił polski oficer ${ }^{50}$.

Osobny fragment notatki poświęcony został także brytyjskiemu przemysłowi lotniczemu. Jego bieżący potencjał produkcyjny attaché oszacował na 500-600 samolotów bojowych (nie licząc szkolnych), informując jednocześnie, że końca dobiega budowa kolejnych fabryk, stąd niebawem spodziewać się można dalszego wydatnego wzrostu możliwości w tym zakresie.

Właśnie przemysł wojenny ppłk Kwieciński uznał w podsumowaniu swojego wywodu za najpoważniejszą „siłę Anglii”, zaś tempo nadrabiania przez Brytyjczyków zbrojeniowych zapóźnień budziło jego niekłamany podziw. Słabość stanowić miały nade wszystko bardzo ograniczone rezerwy wyszkolonych rekrutów, stanowiące nieuchronną konsekwencję rezygnacji $z$ obowiązkowej służby wojskowej ${ }^{51}$.

$4 y$ Ibidem.

5" Ibidem. Źródłem przedstawionych informacji stała się m.in. debata nad budżetem zbrojeniowym (Defence Loans Bill) w Izbie Gmin 20 II 1939 r., którą wykorzystały w podobnym celu także ulokowane $w$ Londynie placówki francuskie. Porównanie danych $z$ raportu ppłk. Kwiecińskiego $\mathrm{z}$ informacjami samych Brytyjczyków (zob. tab. 2) wskazuje na dobre poinformowanie polskiego attaché - $w$ każdym razie na poziomie ogólnym. Część rozbieżności wynikać mogła $z$ różnic między stanem jednostek faktycznie istniejących i przeznaczonych do mobilizacji. Por. np.: TNA, AIR 16/116, zestawienie "Statement mobilizable squadrons in Fighter Command, with War Stations, and type of aircraft, as at 25th April, 1939" z 25 IV 1939 r., gdzie wymieniono 39 dywizjonów myśliwskich. Brytyjski termin squadron zwyczajowo w polskiej literaturze tłumaczony jest jako „dywizjon”, jednak faktycznie jednostki te stanowiły odpowiedniki polskich eskadr. Por. też: I.M. Philpott, The Royal Air Force 1930 to 1939. An Encyclopaedia of the Inter-War Years, vol. 2: Re-Armament 1930 to 1939, Barnsley 2008, Kindle edition.

5) IPMS, Lot. A.V. 1/40b, „Notatka dla Pana Szefa Sztabu Glównego...” z 21 IV 1939 r. 
Osobną, relatywnie obszerną część swej notatki polski attaché poświęcił analizie możliwości wojskowej współpracy Rzeczypospolitej i Wielkiej Brytanii. Jak zauważał, pośrednio raz jeszcze poświadczając wcześniejszy dystans Londynu, możliwości takie „obecnie istnieją”. Wśród wskazanych następnie sfer, w których rysujące się perspektywy mogłyby doczekać się praktycznej realizacji, znalazły się rozmowy międzysztabowe na temat brytyjskiej pomocy dla Polski w razie wojny (ta "mogłaby się w pierwszym rzędzie wyrazić przez przejęcie na siebie przez Anglię akcji ofensywnej lotnictwa" - podpowiadał attaché), zapoznanie się polskich specjalistów z brytyjskim przemysłem zbrojeniowym („głównie istniałyby możliwości w dziedzinie przemysłu lotniczego"), dostarczenie na dogodnych warunkach niezbędnego siłom zbrojnym Rzeczypospolitej sprzętu - "głównie lotniczego" ${ }^{2}$. Jak zaznaczał autor raportu, ziszczenie się współdziałania obu państw w dwóch pierwszych sferach zależy od sfinalizowania umowy politycznej, która w dotychczasowej formie, uzgodnionej podczas ostatniej wizyty w Londynie ministra Becka, ma charakter jedynie prowizoryczny ${ }^{53}$. $\mathrm{Z}$ kolei zakupy sprzętu wojskowego łączyć się muszą z podjęciem rozmów w sprawie brytyjskiego kredytu, te zaś, jak dotąd, nie zostały zapoczątkowane.

Także więc po stronie polskiej dostrzegano fakt skądinąd oczywisty: stosunkowo niewielkie siły zbrojne brytyjskiego partnera nie będą $\mathrm{w}$ najbliższym czasie $\mathrm{w}$ stanie udzielić zaatakowanej przez Niemcy Polsce żadnej niemal efektywnej pomocy. Jedyny wyjątek stanowić tu mogły działania lotnicze. Znajdujący się wciąż in statu nascendi sojusz z Londynem mógł być także wykorzystany do podniesienia zdolności obronnych samej Rzeczypospolitej. Tu również najwięcej zyskać mogły polskie siły powietrzne.

Teraz należało podjąć wysiłek, by sprawdzić realną wartość tak zarysowanych perspektyw. Droga do Londynu i Paryża wydawała się teraz krótsza niż kiedykolwiek w latach poprzednich. Pytanie brzmiało: czy tak jest w istocie? I czy wystarczy czasu, by ją przebyć?

52. Ibidem.

5. Na temat poczynionych podczas tej wizyty uzgodnień zob.: M. Kornat, Polityka zagraniczna Polski..., s. 345nn. Tam też dalsze wskazówki bibliograficzne. 



\section{Rozdział 7}

\section{Rozmowy międzysztabowe}

Przekonanie, że gwarancje dla polskiej suwerenności muszą za sobą pociągnąć podjęcie (w przypadku Londynu) lub faktyczną reaktywację (względem Paryża) wojskowej współpracy $z$ tym państwem, a możliwości owej współpracy i jej formułę określić należy w trakcie rozmów międzysztabowych, nad Tamizą i Sekwaną pojawiło się bardzo szybko. W istocie - moment udzielenia gwarancji wręcz poprzedzało. We Francji na szczytach wojskowo-politycznej hierarchii jako pierwszy sformułował je gen. Gamelin, w datowanym 27 marca piśmie do Daladiera, wówczas mając jednak na myśli głównie lotnicze aspekty współpracy z sojusznikiem ze wschodu'. W Londynie trzy dni później podobną myśl, osadzoną w szerszym już wszakże kontekście, wypowiedział lord Chatfield. Relacjonując 30 marca na posiedzeniu Gabinetu opinie Szefów Sztabów, wyraził przekonanie, że podjęte właśnie rozmowy o współpracy wojskowej z Francją powinny być rozszerzone tak, by objęły także Polskę. Jak dodał, drogę przetrzeć tu winni właśnie Francuzi, „którzy z Polakami mają już spore doświadczenia”.

$\mathrm{W}$ następnych dniach i tygodniach podobne wypowiedzi posypały się jak z rękawa. 3 kwietnia za podjęciem z Polską i Rumunią rozmów na temat koordynacji planów działań militarnych raz jeszcze wypowiedzieli się brytyjscy Szefowie Sztabów, ponownie sugerując powierzenie praktycznej realizacji tego zadania Francuzom³. Trzy dni później konieczność zapoczątkowania międzysztabowych rozmów ze stroną polską podkreślił w przesłanej do Bonneta depeszy Noël ${ }^{4} .12$ kwietnia podjęcie

1 SHD-DAT, 5 N 579, kopia pisma No 561 DN.3 Gamelina do Daladiera z 27 III 1939 r.

2 TNA, CAB 23/98, „Conclusions of a Meeting of the Cabinet held [..] on Thursday, 30 March 1939".

3 TNA, CAB 53/47, „Military implications of Anglo-French Guarantee to Poland and Rumania", C.O.S. 872 Revise z 3 IV 1939 r. W konkluzji tego dokumentu, co znamienne, mowa była już o koordynacji działań czterech stron - w tym ZSRR. Szefowie Sztabów proponowali też skierowanie $w$ momencie wybuchu wojny do Polski oraz Rumunii francuskich i brytyjskich misji wojskowych.

4 DDF, t. 15 , doc. 279, s. 473. Do swej propozycji francuski ambasador powracał w tym czasie jeszcze kilkakrotnie, na podjęcie rozmów międzysztabowych nalegając m.in. w depeszy z 13 kwietnia. Podobnie jak uczynił dzień wcześniej w Londynie E. Raczyński, Noël zasugero- 
takich rozmów zaproponował w Londynie ambasador Edward Raczyński, co jak już wiemy, spotkało się z jednoznaczną aprobatą wyższych urzędników Foreign Office, bezzwłocznie przekazaną czynnikom wojskowym ${ }^{5} .15$ kwietnia postulat „uporządkowania naszych stosunków sojuszniczych [z Francją] pod kątem politycznym i wojskowym" wysunął z kolei w korespondencji do Becka ambasador Łukasiewicz ${ }^{6}$. Wreszcie - cztery dni później pojawiły się w tej materii pierwsze konkrety: Gamelin otrzymał od premiera Daladiera zadanie „centralizacji i koordynacji” kontaktów z polskim Sztabem Głównym?.

Nie wydaje się, by w praktyce podjęto wówczas próbę realizacji koncepcji brytyjskich Szefów Sztabów, dążąc do poczynienia między Londynem i Paryżem odpowiednich uzgodnień. Wręcz przeciwnie, działania obu stolic zaskakiwały wręcz brakiem koordynacji. Niewątpliwie jednak ocena sztabowców znad Tamizy była słuszna, w rozmowach ze stroną polską Francuzi posiadali znacznie większe doświadczenie. Mieli też zdecydowanie lepszy punkt wyjścia - w niektórych sferach, jak lotnictwo, wywiad czy dostawy sprzętu wojskowego, ich współpraca z Warszawą realizowana była przecież na bieżąco. Wreszcie - przypomnieć wypada raz jeszcze - pierwsze analizy dotyczące zakresu ewentualnych międzysztabowych konwersacji i celów, którym mogłyby one służyć, w Paryżu podjęto wyraźnie wcześniej niż po drugiej stronie Kanału, bo już w drugiej połowie marca. Gdy więc po kilku tygodniach okazało się, że teoretyczne rozważania pilnie zastąpić muszą kroki bardziej konkretne, Francuzi mogli je podjąć bez większej zwłoki.

Decyzje $w$ tej kwestii przyspieszał nade wszystko bieg spraw politycznych. Tuż po zakończeniu londyńskiej wizyty ministra Becka ambasador Łukasiewicz uznał, że zaistniałą koniunkturę należy wykorzystać do aktywizacji wciąż jeszcze pogrążonego faktycznie w marazmie aliansu Warszawy i Paryża. Już więc 10 kwietnia podjął tę kwestię $\mathrm{w}$ rozmowie $\mathrm{z}$ ministrem Bonnetem, który życzliwie przyjął przedstawione mu stanowisko. Rezultatem spotkania stało się powierzenie polskiemu dyplomacie opracowania tekstu, który miałby służyć „interpretacji czy też uzupełnieniu” sojuszu obu państw oraz dostosowaniu go do treści polskich porozumień ze Zjednoczonym

wał, by rozmowy podjąć, przynajmniej na razie, na szczeblu attaché wojskowych, co służyć miało uniknięciu większego zainteresowania prasy. AN, Papiers 1940, Rochat 31, telegram przychodzący No 591 z 13 IV 1939 r., odebrany w MAE 14 IV 1939 r., godz. 16.15.

5 TNA, CAB 53/48, „Copy of letter dated 18th April 1939 from the Foreign Office to the Secretary, Committee of Imperial Defence". Autorem tej korespondencji był W. Strang.

6 PDD 1939, dok. 200, s. 336; J. Łukasiewicz, op. cit., s. 236n. (gdzie korespondencja datowana jest błędnie na 14 kwietnia). Na fotokopii pisma Łukasiewicza przechowywanej w zbiorach Biblioteki Polskiej w Paryżu (akc. 4610) znalazła się datowana 18 kwietnia adnotacja J. Szembeka: „Pan minister widział" (dokument opublikował M. Kornat w aneksie do opracowanej przez siebie publikacji: M. Łubieński, Refleksje i reminiscencje, Warszawa 2012, s. 181n., nie wzmiankując jednak powyższego dopisku). Zob. też inny egzemplarz dokumentu w zasobie AAN (Ambasada RP w Paryżu, 111A) oraz kopię z adnotacjami ambasady RP w Londynie (IPMS, A.11.49.F/4).

' SHD-DAT, 2 N 236, pismo No 392 D.N. Daladiera do Gamelina z 19 IV 1939 r. 
Królestwem. Przeprowadzona dwa dni później rozmowa polskiego dyplomaty z Daladierem przebiegła w podobnym duchu ${ }^{8}$.

Łukasiewicz był bardzo zadowolony $z$ rezultatów swych działań, przypisując sobie wpływ na zwiększone w następnych dniach i tygodniach zainteresowanie Polską ze strony najwyższych francuskich czynników. Nie zdawał sobie zapewne sprawy, że $w$ Paryżu zagadnienie polskiego aliansu rozważane było już od pewnego czasu, głównie $z$ inicjatywy Noëla, a pośrednio - przebywających nad Wisłą przedstawicieli francuskich sił zbrojnych, zaś polska akcja wpisała się w wyraźnie już rysujący się trend ${ }^{9}$.

Francuski ambasador $w$ Warszawie nie tylko zresztą nie zaniechał $w$ tym czasie podjętych wysiłków, ale wręcz je zwielokrotnił - prócz zwierzchników z Quai d’Orsay zwracając się także do ministra Becka. Z tym ostatnim spotkał się 12 kwietnia (a więc w dniu rozmowy Łukasiewicza i Daladiera), jednoznacznie proponując "rozmowy sztabowe polsko-francuskie". Co interesujące, spotkał się z dość powściągliwą reakcją. Polski minister zasugerował, by najpierw uzgodnić nową, klarowną interpretację politycznej części polsko-francuskiego sojuszu, wyjaśniając, że „accord polsko-angielski gra natychmiast, a natomiast [...] układ polsko-francuski nie jest jasny"10.

Wątpliwości Becka oraz podjęte przezeń konsultacje, zwieńczone dopiero późnym popołudniem 21 kwietnia naradą na warszawskim Zamku z prezydentem Ignacym Mościckim (oraz premierem i Generalnym Inspektorem Sił Zbrojnych?), sprawiły, że proces redagowania i ekspedycji instrukcji dla ambasadora Łukasiewicza uległ dość sporemu wydłużeniu. Spowodowało to oczywiście także przesunięcie w czasie działań o charakterze wykonawczym ${ }^{11}$. Te ostatnie $z$ kolei uległy dalszemu opóźnieniu ze względu na konieczność uzgodnienia poprawek, które do uzyskanego projektu tekstu wnieść proponowała paryska ambasada. W dodatku Łukasiewicz obiecał przekazać Bonnetowi (jak sądził - na podstawie instrukcji Becka) odpis tekstu tajnego protokołu, który po zakończeniu londyńskich rozmów z pierwszej dekady kwietnia parafowali Cadogan i Raczyński ${ }^{12}$. Gest taki byłby dowodem dobrych

" PDD 1939, dok. 193, s. 325n. oraz dok. 200, s. 335n.; J. Eukasiewicz, op. cit., s. 230; M. Kornat, Polityka zagraniczna Polski..., s. 477. Zob. też: AAN, Ambasada RP w Paryżu, 111 A, pismo L. Rz/6 Łukasiewicza do Becka z 15 IV 1939 r.

${ }^{y}$ J. Lukasi ewic z, op. cit., s. 237n. Zob. zachowana w papierach Henriego Hoppenota niedatowana notatka „Négociacions de la France et de la Grande Bretagne avec la Pologne, la Roumanie et la Grèce [12 mars - 12 mai 1939]" (AD, Papiers 1940, Reconstitution Fouques-Duparc 57).

10 AAN, Ambasada RP w Paryżu, 111 A, niesygnowana notatka „Rozmowa Pana Ministra Becka $z$ Amb. Francuskim w dn. 12 kwietnia 1939 r." Do ambasady RP w Paryżu dokument dotarł dopiero 19 kwietnia. Zob. fotokopia innego egzemplarza tego dokumentu w Bibliotece Polskiej w Paryżu (akc. 4610) z maszynowym dopiskiem: „wysł.[ano] z listem Dyrektora G[abinetu] M[inistra] 13.4.39".

"AAN, Ambasada RP w Paryżu, 111A, list Dyrektora Gabinetu ministra spraw zagranicznych Michała Łubieńskiego do Łukasiewicza z 21 IV 1939 r. i in. dok.; PDD 1939, dok. 212, s. 353 n.; dok. 220 , s. 366 n.

${ }_{12} \mathrm{O}$ istnieniu tego protokołu Łukasiewicz poinformował Bonneta już podczas rozmowy 10 kwietnia, o czym ten ostatni z kolei powiadomił Noëla jeszcze tego samego dnia po południu 
intencji strony polskiej, sam zaś dokument stanowić miał dla rokowań w sprawie interpretacji polsko-francuskiego sojuszu swoisty punkt odniesienia. Jednak odpowiedni materiał wciąż nie mógł trafić do paryskiej ambasady, stąd Łukasiewicz, coraz bardziej zaambarasowany, nie był w stanie spełnić oczekiwań dopytującego się o termin spełnienia obietnicy francuskiego ministra. Pisał więc do Warszawy z prośbą o pilne przekazanie oczekiwanego tekstu, tłumacząc w korespondencji, że jego brak „może zbudzić niepotrzebne podejrzenia i spowodować swary”, które utrudnią powodzenie podjętych właśnie negocjacji ${ }^{13}$.

Ostatecznie polski projekt protokołu interpretacyjnego do polsko-francuskich umów sojuszniczych przekazany został Bonnetowi dopiero 29 kwietnia ${ }^{14}$. Pierwsze reakcje odbiorcy zdawały się pozytywne i nic nie wskazywało, że pojawić się mogą jakieś poważniejsze trudności. Niebawem okazać się miało, że pierwsze wrażenie bywa niekiedy mylne.

Kwestia ożywienia wojskowych aspektów aliansu rozwijała się równolegle, nie bez oczywistych związków, $\mathrm{z}$ rozmowami o charakterze politycznym, ale $\mathrm{w}$ dużej mierze od nich niezależnie. Odmiennie niż w płaszczyźnie politycznej, strona polska nie wykazywała tu zrazu żadnej inicjatywy. Postawa taka budziła pewne zdziwienie Francuzów, którzy bierność wojskowych z Warszawy skłonni byli tłumaczyć obawą przed prowokowaniem Rzeszy lub też "manią" zachowywania tajemnicy, w tym także tajności planów operacyjnych, utrzymywanych w sekrecie również wobec aliantów znad Sekwany ${ }^{15}$.

(AD, Papiers 1940, Reconstitution Fouques-Duparc 39, odpis telegramu przychodzącego No 812 813 z 10 IX 1939 r., godz. 14.30).

13 Biblioteka Polska w Paryżu, akc. 4610, fotokopia listu Łukasiewicza do Łubieńskiego z $25 \mathrm{~V}$ 1939 r. i in. dok.; J. Łuka si ewicz, op. cit., s. 245 oraz s. 253, przyp. 2. Obawy Łukasiewicza, że brak obiecanej przesyłki jest spowodowany czymś więcej niż biurokratyczną inercją, nie były dalekie od prawdy. Przetłumaczony na język polski odpis protokołu zamierzano wysłać do Paryża jeszcze w końcu drugiej dekady kwietnia, zastrzegając jednak, że jego tekst może zostać Bonnetowi przekazany jedynie ustnie, bez fizycznego wręczenia. Ostatecznie 19 kwietnia projekt odpowiedniej korespondencji opatrzony został adnotacją "projekt nieprzyjęty" oraz parafą wicedyrektora Departamentu Politycznego MSZ Józefa Alfreda Potockiego (Biblioteka Polska w Paryżu, akc. 4610, fotokopia listu Łukasiewicza do Łubieńskiego z $25 \mathrm{~V} 1939$ r.).

14 Łukasiewicz oraz redaktorzy jego wspomnień podają datę 28 kwietnia (J. Łukasiewicz, op. cit., s. 245 i s. 233, przyp. 3). Jednak na zaopatrzonej w parafę Daladiera kopii zachowanej w: AD, Papiers 1940, Rochat 32 wpisana została data 29 kwietnia. Taka data też w: AD, Papiers 1940, Reconstitution Fouques-Duparc 57, notatka „Négociacions de la France et de la Grande Bretagne avec la Pologne, la Roumanie et la Grèce [12 mars - 12 mai 1939]". Redaktorzy DDF (t. 16), publikując na s. 49 ten dokument (doc. 23) po dokonanych w Paryżu zmianach, w przypisach datowali jego pierwotną polską wersję (za wspomnieniami Łukasiewicza) na 28 kwietnia. M. Kornat omówił tekst protokołu interpretacyjnego w kontekście wydarzeń z przełomu kwietnia i maja 1939 r., odnosząc się jednak do odmiennej od pierwotnej redakcji jego wersji finalnej, sygnowanej 4 września. Może to być źródłem nieporozumień (Polityka zagraniczna Polski..., s. 478n.).

15 SHD-DAT, 7 N 3002, raport No 59/S gen. Musse dla premiera i ministra obrony narodowej (Sekcji Armii Obcych O. II Sztabu Generalnego) z 18 IV 1939 r. 
Wobec formalnego przyłączenia się Francji do brytyjskich gwarancji dla Polski 13 kwietnia 1939 roku podjęcie formalnych kontaktów międzysztabowych stawało się jednak bardziej niż uprzednio pożądane. Proponował je już od jakiegoś czasu m.in. gen. Musse, w raporcie z 18 kwietnia po raz kolejny, z większym teraz naciskiem sugerując, że mogłyby się one odbywać na szczeblu attaché wojskowych, co zapewniałoby możliwość utrzymania rozmów we względnej dyskrecji, lub - co byłoby mniej dogodne - przy udziale wyłonionych przez sojusznicze sztaby delegacji ${ }^{16}$.

W Gabinecie ministra Daladiera, gdzie raport dotarł dwa dni później, wyraźnie preferowano tę pierwszą ewentualność: frazę o możliwości wysłania nad Wisłę „une délégation d'État-Major" w otrzymanym tekście podkreślono, wpisując następnie obok jednoznaczne „non”. Niebawem jednak sprawy potoczyły się w zgoła odmiennym kierunku.

Jeszcze 25 kwietnia Daladier przesłał do Bonneta informacje o zamiarze wysłania francuskiego przedstawiciela wojskowego na obszar Europy Wschodniej, który ze sztabami zainteresowanych państw regionu miałby omawiać zagadnienia wynikające $z$ rozwoju sytuacji polityczno-militarnej. Jako osoba właściwa do podjęcia takiej misji wskazany został były gen. Eugène Mittelhauser - w latach 1921-1926 Szef Sztabu Generalnego armii czechosłowackiej, następnie zaś, do niedawna, członek francuskiej Najwyższej Rady Wojennej, dysponujący wedle Daladiera odpowiednią osobowością, stosunkami oraz znajomością spraw wschodniej części kontynentu. Całość zadania miałaby być, przynajmniej początkowo, realizowana dyskretnie, pod pretekstem nawiązania kontaktu z siłami zbrojnymi państw, którym Francja właśnie udzieliła gwarancji (tj. Polski, Rumunii i Grecji), zaś za teren właściwy do zapoczątkowania tak zarysowanej pracy autor koncepcji uznał centralnie położoną względem innych francuskich aliantów Rumunię ${ }^{17}$.

Jednak dzień później gen. Gamelin wystąpił z inną jeszcze inicjatywą. Działając $w$ ramach przyznanych mu 19 kwietnia kompetencji „centralizacji i koordynacji” wojskowych rozmów ze stroną polską „w sferze lądowej, lotniczej oraz, ewentualnie, morskiej", poinformował o tym fakcie marszałka Edwarda Śmigłego-Rydza. Stanowito to wyraźną propozycję i tak też zostało odebrane $e^{18}$.

Podjęta przez Gamelina akcja, jak należy podkreślić, nie stanowiła konkurencji dla przedstawionego wyżej projektu Daladiera, który miał być w przyszłości realizowany. Wynikała jedynie z bieżącej, choć istotnej, potrzeby, stanowiąc wynik wcześniejszych uzgodnień. Wiedzieli o niej i ją zaaprobowali zarówno Daladier, jak i Bonnet. Ten ostatni wręcz na podobne działania naciskał, przywołując opinię Noëla, którego zdaniem zapoczątkowane właśnie negocjacje w sprawie protokołu interpretacyjnego stanowiły dogodną okazję dla podjęcia rozmów międzysztabowych.

${ }^{16}$ Ibidem. Przychylna wobec otrzymanych sugestii niedatowana analiza Oddziału II Sztabu Generalnego Armii francuskiej: SHD-DAT, 7 N 3006, niedatowane opracowanie „Collaboration militaire franco-polonaise".

17 SHD-DAT, 7 N 3015, kopia pisma No 1194 Daladiera do Bonneta z 25 IV 1939 r.

1* SHD-DAT, 7 N 3005, kopia listu Gamelina do Śmigłego-Rydza z 26 IV 1939 r. 
Minister spraw zagranicznych nalegał tylko na zachowanie najdalej posuniętej dyskrecji, podobnie jak dziesięć dni wcześniej gen. Musse, sugerując, że najlepszą formę kontaktu stanowić tu może pośrednictwo wojskowych attachél9.

$\mathrm{W}$ istocie jednak obu wojskowym przedstawicielom wystąpić przyszło głównie $\mathrm{w}$ roli oddawców krążącej między Paryżem i Warszawą korespondencji. Generał Musse pismo Gamelina przekazał marszałkowi Śmigłemu-Rydzowi 29 kwietnia, następnie zaś, wezwany do tego ostatniego w południe 5 maja, miał usłyszeć odeń odpowiedź zawierającą propozycję natychmiastowego podjęcia rozmów z udziałem wysłanego do Paryża ministra wojny gen. dyw. Tadeusza Kasprzyckiego, jako osobistego przedstawiciela Generalnego Inspektora, a nie szefa resortu. Dalszych informacji udzielił francuskiemu oficerowi gen. Stachiewicz, jako główny przedmiot planowanych rozmów wskazując najistotniejsze kwestie operacyjne oraz kolejną transzę francuskiej pomocy finansowej na cele zbrojeniowe, udzielonej na zasadach zbliżonych do uzyskanego przez Polskę we wrześniu 1936 roku kredytu z Rambouillet. Szef Sztabu Głównego wskazał jako drugiego z członków delegacji, która miałaby udać się nad Sekwanę, mianowanego niedawno jego II zastępcą płk. Józefa Jaklicza - który $z$ racji pełnionej uprzednio funkcji szefa III (Operacyjnego) Oddziału Sztabu był niewątpliwie jednym z najlepszym kandydatów do prowadzenia rozmów o podobnej tematyce. Nie chcąc pozbywać się na czas dłuższy niezwykle cennego w gorącym okresie wojennych przygotowań współpracownika, Stachiewicz zaproponował przeprowadzenie paryskich konwersacji w ciągu dwóch dni - jako najbardziej odpowiedni termin sugerując 15 i 16 maja $^{20}$.

Otrzymane $\mathrm{w}$ ten sposób informacje Musse natychmiast przekazał do Paryża. Decyzje o odpowiedzi podjęto kilka dni później. 10 maja nad Wisłę wysłana została depesza: gen. Gamelin, otrzymawszy w międzyczasie także osobisty list od polskiego marszałka, akceptował zarówno termin (ewentualnie proponując okres między 24 maja a 10 czerwca), jak i osobę wysłannika ${ }^{21}$. Tegoż dnia o ostatnich poczyna-

19 Ibidem, pismo No 1710 ministra spraw zagranicznych (wz. Pinetona de Chambrun?) do Daladiera z 28 IV 1939 r.; niesygnowana notatka rękopiśmienna Gabinetu ministra obrony narodowej i wojny z $1 \mathrm{~V} 1939 \mathrm{r}$. Noël przytoczonym przez Bonneta argumentem posłużyl się $\mathrm{w}$ depeszy No 622 z 18 IV 1939 r., która do Paryża dostarczona została kurierem dwa dni później (AD, Papiers 1940, Rochat 31). Myśl o wykorzystaniu do rozmów attaché wojskowych w korespondencji francuskiego ambasadora w Paryżu pojawiła się już 13 kwietnia, a więc kilka dni wcześniej niż w raporcie gen. Musse (ibidem, depesza No 591).

${ }^{20}$ SHD-DAT, 7 NN 2/382, „Rapport No 73/S du 11 Mai 1939” gen. Musse (też: DDF, t. 16, doc. 156, s. $320 \mathrm{nn}$.). Zdaniem autora raportu istotny wpływ na polską decyzję, która oznaczała porzucenie sygnalizowanej przezeń nie tak dawno wstrzemięźliwej postawy, wywarlo wypowiedzenie przez Hitlera 28 IV 1939 r. polsko-niemieckiego paktu o nieagresji. Przygotowania płk. Jaklicza do paryskiej misji znalazły odzwierciedlenie w jego zeszycie podręcznym. Faksymile odpowiednich stron tego zeszytu: To proste - będziemy się bić. Przygotowania obronne (marzec - sierpień 1939), Warszawa 2012, s. $321 \mathrm{n}$.

${ }^{21}$ Podana przez Gamelina w Servir (t. 2, s. 414) informacja, że przyjazd Kasprzyckiego stanowił dlań zaskoczenie, nie miała więc nic wspólnego z prawdą. 
niach Daladiera oraz Gamelina szczegółowo poinformowane zostało Quai d’Orsay, a więc także wyraźnie zainteresowany sprawą minister Bonnet ${ }^{22}$.

Generał Musse po raz kolejny miał okazję wystąpić w roli posłańca, telegraficzne zaproszenie Gamelina przekazując tuż po otrzymaniu na ręce szefa Gabinetu Generalnego Inspektora Sił Zbrojnych. W informacji przesłanej w dniu następnym do Paryża attaché przewidywał, że data wyjazdu kierowanej do Paryża delegacji zostanie ustalona $w$ najbliższym czasie. Sugerował też, posiłkując się zdaniem ambasadora Noëla, że sam również powinien zostać wezwany nad Sekwanę i wziąć udział w rozmowach ${ }^{23}$.

11 maja w Biurze Operacji Wojskowych i Szkolenia Ogólnego Sztabu Generalnego francuskiej armii lądowej opracowana została na potrzeby zbliżających się rozmów nota dotycząca głównych kierunków przyszłej strategii wojennej. Wstępne partie tego dokumentu zawierały informacje przedstawione już w poprzednich rozdziałach, dotyczące różnicy wyjściowego potencjału militarnego (znacznie większego po stronie koalicji niemiecko-włoskiej) oraz niezbędnych do dłuższego prowadzenia wojny zasobów („praktycznie nieograniczonych” w przypadku sojuszu francusko-brytyjskiego), relatywnej słabości Włoch oraz zamysłów pobicia ich w pierwszej kolejności, m.in. dla odtworzenia szlaków komunikacyjnych wiodących ku południowo-wschodniej części Europy ${ }^{24}$. Postawą, którą wskazywano Polsce w pierwszej fazie nadchodzącego konfliktu, było "utrzymywać się i trwać" (podkr. oryg. - W.M.), przy czym w razie skierowania głównego wysiłku adwersarzy na zachód miało być to trwanie możliwie aktywne, w przypadku przeciwnym - cierpliwie wyczekujące pierwszych efektów działań francuskich i brytyjskich aliantów. Sprzymierzeńcy, stwierdzano w dokumencie, będą się starać udzielić pomocy stanowiącej główny cel niemieckiej agresji Rzeczypospolitej przez zachowanie na froncie zachodnim defensywy "tak aktywnej, jak to tylko możliwe”, by unieruchomić tam istotną część sił

22 SHD-DAT, 7 N 3002, telegram szyfrowy No 67 gen. Musse, otrzymany w Paryżu $5 \mathrm{~V}$ 1939 r. o godz. 14 (na egzemplarzu pieczątka "widziane przez Ministra" oraz odręczna adnotacja „do wykonania bez zwłoki”) $i$ in. dok.; 7 N 3015, telegram szyfrowy No 1368-2/EMA-SAE za ministra wojny i z jego polecenia Gamelina do Musse z $10 \mathrm{~V} 1939$ r.; kopia pisma No 1369 Daladiera do ministra spraw zagranicznych (Poddyrekcja Europa MAE) z $10 \mathrm{~V} 1939$ r. Brak źródłowych dowodów na potwierdzenie przedstawionej bez dalszych wyjaśnień tezy M. Gmurczyk-Wrońskiej, że Daladier i Léger „uczynili z wizyty gen. Kasprzyckiego demonstrację wobec Londynu” (op. cit., s. 100).

${ }^{23}$ SHD-DAT, 7 N 3002, list gen. Musse do gen. Gamelina [?] z 11 V 1939 r. Do korespondencji załączone zostały notki biograficzne gen. Kasprzyckiego oraz płk. Jaklicza. Sugestie Noëla i gen. Musse spotkały się z aprobatą Quai d'Orsay, 13 maja występujący w imieniu tego ostatniego Hoppenot w piśmie do Daladiera podkreślił „poważny interes”, jaki przedstawiałaby obecność w Paryżu attaché z Warszawy podczas prowadzonych z Polakami rozmów (SHD-DAT, 7 N 3005, pismo No 2009 z 13 V 1939 r.)

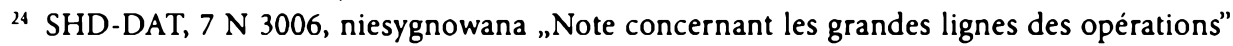
No 4/82 Biura Operacji Wojskowych i Szkolenia Ogólnego Sztabu Generalnego Armii z $11 \mathrm{~V}$ 1939 r. Dokument opatrzony został nagłówkiem "Conversations Franco-Polonaises". Zob. też: P. Le Goyet, op. cit., s. 220. 
przeciwnika; presję ekonomiczną wywieraną na Rzeszę poprzez blokadę morską i bombardowania lotnicze; wreszcie - wzmiankowane już wyżej udrożnienie wiodących przez Morze Śródziemne na wschód kontynentu szlaków komunikacyjnych ${ }^{25}$.

W obu przypadkach - stwierdzali autorzy noty - Polska powinna utworzyć solidny front, który pozwoli osłonić jej zasoby przemysłowe. Przyjęty przez nią plan działań, jak podkreślano, winien zostać skoordynowany z planem rumuńskim, także dlatego, że to właśnie przez Rumunię wieść będą główne linie polskiej komunikacji z Zachodem.

W końcowej części dokumentu wymienione zostały środki, które miałyby umożliwić realizację powyższych założeń. Były to:

„1/ Pomoc techniczna [z Zachodu] we wszystkich pożądanych dziedzinach, szczególnie w kwestii fortyfikacji,

2/ Nawiązanie ścisłej łączności z Rumunią,

3/ Pomoc materiałowa do zorganizowania obecnie przez siły francusko-angielskie i kontynuowania podczas operacji [wojennych] od momentu odtworzenia komunikacji z południowym wschodem Europy,

4/ Ewentualna pomoc Rosji"26.

Nie jest jasne, czy powyższa nota zawierała jedynie poglądy gen. Colsona i oficerów jego Sztabu, czy też zawarte w niej treści uzgodnione zostały z Gamelinem. Jednak podane $w$ dokumencie informacje na temat wojennej strategii Zachodu oraz roli wyznaczanej w niej Rzeczypospolitej mimo ogólnej formy z pewnością byłyby przydatne dla spodziewanych niebawem w Paryżu gości znad Wisły. Wiele zaś wskazuje, że zamierzano im je przekazać.

Strona polska rzecz jasna także przygotowywała się do negocjacji. Na bezpośrednio dotyczące ich prace miała nawet nieco więcej czasu niż francuscy partnerzy. Marszałek Śmigły-Rydz najwyraźniej bowiem analizę zadań, które pragnął powierzyć kierowanym nad Sekwanę delegatom, rozpoczął tuż po otrzymaniu listu gen. Gamelina, tj. w końcu kwietnia. Efektem podjętych przezeń prac stała się datowana 2 maja 1939 roku „Instrukcja dla rozmów z francuskim Sztabem Generalnym”2i.

Punkt wyjścia poświęconej zagadnieniom wojskowym części tego dokumentu stanowiła hipoteza, że pierwsze uderzenie Rzeszy skierowane zostanie przeciw Polsce, która początkowo zmuszona zostanie do obrony, prowadzonej z ogólnym zamysłem „nie dać się rozbić”. „Po zaangażowaniu się sprzymierzonych w sposób zdecy-

25 SHD-DAT, $7 \mathrm{~N} 3006$, niesygnowana „Note concernant les grandes lignes des opérations”...

${ }^{26}$ Ibidem.

${ }^{27}$ W. St achie wicz, op. cit., s. 723nn. Por. też: Protokóly polsko-francuskich rozmów sztabowych, odbytych w Paryzu, w maju 1939 r., „Bellona” (Londyn) R. 40, 1958, z. 2, dodatek „Relacja płk. Jaklicza z roku $1940 \mathrm{w}$ sprawie instrukcji otrzymanych przez delegację polską od Generalnego Inspektora Sił Zbrojnych”, s. 177nn. We wcześniejszej edycji („Zeszyty Historyczne” (Paryż) 1984, z. 84, s. 207nn.) dokument datowano na 25 IV 1939 r., co skorygował M. Zgórniak (Europa w przededniu wojny..., s. 436n.) na podstawie maszynopisu z Archiwum Generała Józefa Jaklicza (Józef Pilsudski Institute of America, Nowy Jork). Kopię tego dokumentu opublikowano w To proste - będziemy się bić..., s. 98n. 
dowany i poważny, gdy nacisk na froncie polskim osłabnie, będę działał zależnie od położenia" - stwierdzał Generalny Inspektor Sił Zbrojnych"28.

Wśród zagadnień, które polscy delegaci mieli wyjaśnić w Paryżu, znalazła się kwestia czasu niezbędnego do przeprowadzenia francuskiej mobilizacji oraz początkowych działań armii francuskiej, w tym zamysłów przekroczenia granicy Rzeszy, operacyjnych celów działań planowanych przeciw Niemcom i sił, które miałyby zostać w nich użyte, wreszcie - osłabienia akcji podjętej na tym kierunku przez ewentualny front włoski. Jak podkreślał marszałek, w polskim interesie było „jak najwcześniejsze i solidne działanie Francji", aby skrócić czas samotnego wykrwawiania się Rzeczypospolitej.

Tu zaś po raz kolejny uwidaczniała się szczególna rola lotnictwa jako broni ze swej istoty zdatnej do szybkiej interwencji na polu walki. Stąd, instruował Smighy-Rydz, wyłaniały się jako przedmiot przewidywanych rozmów kwestie następujące:

„a/ kiedy lotnictwo francuskie zacznie działać, pożądane działanie bezzwłocznie po pierwszym kroku niemieckim,

b/ ustalenia sposobów i celów działania lotnictwa francuskiego i naszego,

c/ kwestia współdziałania lotnictwa francuskiego z naszych baz i z naszego terenu":"9.

Dalsze części instrukcji poświęcone zostały sprawom francuskiej pomocy finansowej i materiałowej oraz możliwości działania floty francuskiej. W końcowych partiach stosunkowo zwięźle sformułowanego dokumentu Generalny Inspektor odniósł się także do perspektywy współpracy z partnerem brytyjskim (przyznając się, co może zaskakiwać, do braku wiedzy nie tylko o jego zamysłach, ale i możliwościach) oraz scharakteryzował swój stosunek do ZSRR. W tym ostatnim przypadku nie wykluczał, co uznać wypada za ważne, kooperacji w zakresie "materiałowym i surowcowym" (tu „decyzja z naszej strony nastąpi w przyszłości”), deklarując zarazem: „innych zamierzeń w tej chwili w stosunku do Rosji nie mam" ${ }^{30}$.

W tekście instrukcji, a także w jej podtekście marszałek dość jasno przedstawił nie tylko swoje zamiary, ale i obawy - głównie co do francuskiego alianta. Jak się miało okazać, te ostatnie nie były bynajmniej bezpodstawne. Jednak same dyspozycje dla kierowanej do Paryża delegacji sformułowane zostały lakonicznie i dość ogólnikowo, pozostawiając sporo domysłom i interpretacjom. Dokument zawierał raczej przemyślenia i zalecenia niż nakazy o bezwzględnym charakterze. W chwilach zwątpienia czy przesileń, których nadejścia w rozmowach stanowiących faktycznie „misję ostatniej szansy" można się było spodziewać, instrukcja marszałka nie mogła więc przeciąć ewentualnych wątpliwości ani zapewnić merytorycznego oparcia w autorytatywnie i jednoznacznie sformułowanej frazie ${ }^{31}$.

24. W. Stachiewicz, op. cit., s. $723 \mathrm{n}$.

29 Ibidem, s. 725.

3) Ibidem.

$3 \mathrm{Na}$ „zbytnią ogólnikowość i powierzchowność” instrukcji wiele lat temu zwracal uwagę J. Ciałowicz, op. cit., s. 268. W świetle znanych obecnie źródeł za całkowicie błędne uznać 
Ostateczny skład polskiej delegacji ustalony został najpewniej dopiero na początku drugiej dekady maja. Wtedy dopiero gen. Musse mógł przekazać do Paryża odpowiednią informację. Generał Kasprzycki, anonsował w raporcie datowanym 13 maja, opuści Warszawę pociągiem $w$ niedzielę 14. Towarzyszyć mu będzie płk Jaklicz, a także zastępca Szefa Sztabu Lotniczego Sztabu Głównego ppłk pil. Stanisław Karpiński oraz oficer ordynansowy ministra spraw wojskowych mjr Marian Dunin-Majewski. Korespondencja zawierała też drobny, ale być może istotny szczegół: dzień wcześniej żona szefa polskiej delegacji popełniła samobójstwo. Romans, który łączył ministra spraw wojskowych $\mathrm{z}$ warszawską aktorką Zofią Kajzerówną, od dawna stanowił tajemnicę poliszynela, zaś attaché uprzedzał: „wedle tego, co mi powiedziano dziś rano w Sztabie Głównym, unieważnienie małżeństwa zostało ostatnio ogłoszone przez Trybunał Rzymski i nie ma powodu składać Generałowi kondolencji". Można się jednak zastanawiać, czy tragedia w najbliższym otoczeniu nie wpłynęła aby na uprzednio wysoko ocenianą zdolność Kasprzyckiego do celnej analizy sytuacji, tym bardziej że płk Jaklicz nie miał w składzie wysyłanej do Paryża grupy ani odpowiednio silnej pozycji, ani ambicji ewentualnego przejęcia sterów, nawet $w$ tak wyjątkowej sytuacji ${ }^{32}$.

Korespondencja gen. Musse do Paryża dotarła dopiero 15 maja. Nie znaczy to oczywiście, że wcześniej nad Sekwaną nie znano zawartych w niej informacji. Od wieczora 12 maja francuski attaché szczegóły dotyczące wyjazdu gen. Kasprzyckiego i jego towarzyszy przesyłał sukcesywnie do paryskiego Ministerstwa Wojny w serii depesz. W dniu następnym podobne dane przekazał ustnie oficerom II Oddziału francuskiego Sztabu Generalnego Armii płk Fyda. Przy tej ostatniej okazji sprecyzowano raz jeszcze ramową tematykę planowanych rozmów. Miała ona objąć trzy podstawowe sfery: zagadnienia wojskowe (armii lądowej), lotnicze oraz kwestie materiałowe. Te ostatnie, jak można się było domyślać, po stronie polskiej omawiać miał m.in. mjr Dunin-Majewski, którego płk Fyda przedstawił jako specjalistę od takiej właśnie problematyki ${ }^{33}$.

natomiast trzeba spekulacje tego autora o rzekomej "niewiedzy” Bonneta na temat przyjazdu Kasprzyckiego do Paryża (ibidem, s. 265n.).

${ }_{32}$ SHD-DAT, 7 N 3002, raport No 80/S gen. Musse $213 \mathrm{~V} 1939$ r. Część instrukcji Smigły-Rydz przekazał Kasprzyckiemu w bezpośrednich rozmowach, w których płk Jaklicz nie brał udziału. W złożonej w roku 1940 relacji ten ostatni podkreślał swoją rolę wykonawcy. Zob.: Protokóly polsko-francuskich rozmów sztabowych..., s. 179. Tezę o możliwym wpływie ostatnich emocjonalnych doznań na percepcję wyjeżdżającego do Paryża Kasprzyckiego sformułował przed kilkunastu laty W. Rezmer (Tadeusz Kasprzycki - minister spraw wojskowych $20 \mathrm{~V} 1935$ - 30 IX 1939, [w:] Ministrowie spraw wojskowych 1918-1944. Z badań nad polityka wojskowa Polski, red. M. Jabłonowski, Pułtusk 2005, s. 231).

${ }^{33}$ SHD-DAT, 7 N 3002, depesze gen. Musse No 76, 77 i 78 z 12 i 13 V 1939 r.; 7 N 3015, „Note pour la Commandement. Renseignements communiqués verbalement au 2e Bureau le 13 Mai 1939 par le Colonel Fyda, Attaché Militaire de Pologne à Paris"; J. Lukasiewicz, op. cit., s. 255 oraz s. 267, przyp. 1 i 2 . Ubrani dla zachowania dyskrecji po cywilnemu członkowie misji gen. Kasprzyckiego do stolicy Francji przybyć mieli pociągiem Nord Express przed południem 15 maja (o 10.55). Na jednej z depesz gen. Musse odręcznie wpisano informację, że na dworcu (Paris Nord) 
15 maja, dzień po przybyciu misji gen. Kasprzyckiego do Paryża, gen. Gamelin skierował do Daladiera pismo dotyczące udziału Francji w zbrojeniach państw Europy Wschodniej uznawanych przez Paryż za przyjazne, tj. Polski, Rumunii, Turcji i Grecji. Zagadnienie to przyjdzie nam przedstawić w dalszej części analizy, już teraz odnotować jednak warto wyraźną zmianę w stosunku do stanowiska, które Szef Sztabu Generalnego Obrony Narodowej zaprezentował w podobnej kwestii ledwie kilka tygodni wcześniej. Wówczas w sprawie ewentualnych dostaw sprzętu wojskowego wypowiedział się jednoznacznie negatywnie, uzasadniając to szczupłością własnych zasobów. Teraz zaś stwierdzał: „konieczność zaistnienia solidnego frontu wschodniego, który zmusi Niemcy i Włochy do prowadzenia wojny na dwóch frontach, nie jest już przedmiotem dyskusji, ale w obecnym stanie swych zbrojeń lądowych i powietrznych nasi potencjalni sojusznicy mogą znaleźć się w sytuacji delikatnej wobec podjętej ofensywy w wielkim stylu mocarstw osi Berlin-Rzym" - dodając, że wobec tego pomoc materiałowa ze strony mocarstw zachodnich staje się nieodzowna ${ }^{34}$. Wynikające $z$ tej konstatacji obciążenia dla francuskiej armii oraz przemysłu zbrojeniowego Gamelin postulował dzielić $\mathrm{z}$ brytyjskim aliantem, sięgając w miarę możności także po dostawy ze Stanów Zjednoczonych i ZSRR, ale bardzo znacząca ewolucja jego poglądów pozostawała faktem. Dla polskich delegatów, którzy właśnie zawitali do Paryża, była to wiadomość zarazem dobra i zła. Francuski partner najwyraźniej życzliwiej gotów był teraz spojrzeć na ich postulaty, nie tylko dotyczące sfery materiałowej - głównie jednak z tej przyczyny, że wedle jego ocen pierwsze niemieckie uderzenie wymierzone miało zostać na wschód ${ }^{35}$.

Tegoż dnia o godzinie 10.00 rozpoczęła się oficjalna część polsko-francuskich rozmów wojskowych. Jej przebieg jest dobrze znany, posiadane przez stronę polską protokoły opublikowane zostały jeszcze w roku 1958, w latach późniejszych wielokrotnie je omawiano i analizowano ${ }^{36}$. Przedstawianie wszystkich poruszonych

gości witać będzie m.in. gen. Dentz. $Z$ informacji Łukasiewicza wynika, że w grupie powitalnej znalazł się także sam gen. Gamelin. W protokołach przeprowadzonych w Paryżu rozmów mjr Dunin-Majewski nie jest wymieniany, nie jest więc pewne, czy ostatecznie wziąl udział w wyjeździe.

is SHD-DAT, 5 N 2579, pismo No 1001/D.N.3 Gamelina do Daladiera z 15 V 1939 r. (publikacja w charakterze załącznika do pisma Daladiera do Bonneta z 19 V 1939 r.: DDF, t. 16, doc. 235 , s. 465n.). Zawierająca aprobatę przedstawionego stanowiska odpowiedź Daladiera: SHD-DAT, $2 \mathrm{~N}$ 236, pismo No 544 D.N. z 19 V 1939 r. (też: DDF, t. 16, doc. 236, s. 466).

${ }_{15}$ Podobne stanowisko - przychylność wobec polskich oczekiwań zbrojeniowych oraz wskazanie konieczności dzielenia związanych z nimi obciążeń z Wielką Brytanią i USA - Daladier zajął w rozmowie z Łukasiewiczem już nieco wcześniej, 13 maja (PDD 1939, dok. 284, s. 370).

${ }^{36}$ Protokóly polsko-francuskich rozmów sztabowych...; thumaczenie na język polski: Wojna obronna Polski 1939. Wybór źródel, dok. 63-67, s. 247nn. (nie obejmuje protokołu z pierwszej sesji plenarnej) oraz Polska w polityce międzynarodowej (1939-1945). Zbiór dokumentów, t. 1: 1939, oprac. W.T. Kowalski, Warszawa 1989, s. 242nn. Fotokopie protokołów strony polskiej: IPMS, A.II. 5/la. Protokoły strony francuskiej: SHD-DAT, $2 \mathrm{~N} 235$ (tu też sygnowany egzemplarz protokołu końcowego); 7 N 3006; publikacja: DDF, t. 16, doc. 207, s. 399nn., doc. 233, s. 461n. Pod podanymi wyżej sygnaturami SHD-DAT (oraz SHD-DAT, 7 NN 2/419) znajduje się też dokument "Conversations franco-polonaises du 17 Mai 1939. Résumé d'ensemble”, zawierający m.in. 
w trakcie konwersacji wątków nie wydaje się przeto niezbędne, tym bardziej że niemała ich część dotyczyła kwestii znacznie wykraczających poza tematykę naszej analizy. Nie sposób jednak uniknąć odniesienia się do wypowiedzi dotyczących zagadnień lotniczych oraz tych spośród przyjętych ustaleń, które precyzując na nowo zasady polsko-francuskiej współpracy wojskowej, wyznaczały niejako ramy dla aktywności lotnictwa.

Raz jeszcze przypomnieć bowiem trzeba, że problematyka współpracy sojuszniczych sił powietrznych już u progu rozmów uznana została, obok współdziałania armii lądowych oraz spraw materiałowych, za jedną z podstawowych dla przygotowywanego spotkania. Nic więc dziwnego, że odniesiono się do niej już w początkach obrad, podczas przedpołudniowej, plenarnej ich części. Poproszony przez Kasprzyckiego o wyrażenie opinii na ten temat Vuillemin przywołał poglądy, które sformułował już dwa miesiące wcześniej, rekomendując w korespondencji do Gamelina podjęcie ze stroną polską rozmów dotyczących problematyki lotniczej. Oczywiście jednak nie mógł wykorzystać całości użytej wówczas argumentacji, w której polski sojusznik potraktowany został czysto utylitarnie, wręcz nie bez szczypty cynizmu. Teraz w jego wypowiedzi pojawiły się jedynie elementy oczekiwane przez gości znad Wisły. Porozumienia Paryża i Warszawy w sprawie lotnictwa są dość zaawansowane, stwierdził Vuillemin. Francuskie siły powietrzne już na początku konfliktu mogłyby energicznie działać na rzecz odciążenia Polski. Problem stanowić tu może głównie organizacja baz i zaopatrzenie. Realne jednak wydaje się przezwyciężenie tych trudności i stworzenie warunków do podjęcia przez lotnictwo francuskie operacji z terytorium Polski ${ }^{37}$.

Przewodniczący polskiej delegacji podchwycił rysującą się możliwość, proponując przestudiowanie praktycznych aspektów poruszonej kwestii przez „oficera obecnego w Paryżu" (w domyśle - ppłk. Karpińskiego) oraz wezwanych telegraficznie specjalistów od spraw technicznych, na co Vuillemin odpowiedział aprobująco ${ }^{38}$. Wrażenie strony polskiej, że wreszcie ziszczają się nadzieje na uzyskanie bezpośredniej lotniczej asysty francuskiego alianta, próbował tonować Gamelin, oferując Kasprzyckiemu pośrednictwo w kontaktach z Brytyjczykami, którzy także mieliby podjąć lotnicze działania przeciw Rzeszy. Następnie zaś płynnie przeszedł do uwag

informacje nieuwzględnione w oficjalnych protokołach. Wiele dodatkowych wiadomości o przebiegu rozmów, w tym także ich nieprotokołowanej części, podał J. Łukasiewicz (op. cit., s. 255nn.). Całość paryskiej wizyty gen. Kasprzyckiego najobszerniej przeanalizowali J. Ciałowicz (op. cit., s. 266nn.) oraz M. Zgórniak (Europa w przededniu wojny..., s. 435nn.), w ostatnim zaś czasie, nieco bardziej zwięźle, M. Kornat (Polityka zagraniczna Polski..., s. 482nn.).

37 Protokóly polsko-francuskich rozmów sztabowych..., s. 168; M. Gamelin, op. cit., t. 2, s. 417; J. Ciałowicz, op. cit., s. 274n. Janusowe oblicze Vuillemina ujawni się w pełni, jeśli przypomnimy, że ledwie dzień wcześniej przesłał on do Gamelina analizę zawierającą odpowiedź na wątpliwości partnerów brytyjskich, stanowisko odnośnie do lotniczej współpracy z Polską formułując w sposób zgoła odmienny, a w gruncie rzeczy - przeciwny (SHD-DAT, 2 N 229, pismo No 1268 3-OS/EMAA z 15 V 1939 r; por. też przyp. 242).

3* Protokóly polsko-francuskich rozmów sztabowych..., s. 168. 
na temat znaczenia polskich kontaktów z Rumunią i Jugosławią. W tej części jego wypowiedzi pobrzmiewały echa niedawnych analiz gen. Colsona ${ }^{39}$.

Niebawem, tuż przed zamknięciem krótkiej sesji plenarnej, uczestnicy obrad przyjęli propozycję Gamelina, by dalsze rozmowy prowadzić w podkomisjach, osobno omawiając zagadnienia dotyczące sił lądowych, lotnictwa oraz problematyki materiałowej.

Zespół lotniczy podjął pracę jeszcze w tym samym dniu w gmachu Ministerstwa Lotnictwa. W obradach po stronie francuskiej wzięli udział gen. Vuillemin, ppłk d'Arnaud de Vitrolles oraz szef Oddziału III (Operacyjnego) Sztabu Generalnego Armée de l'Air płk Jean Bergeret. Stronę polską reprezentowali podpułkownicy Karpiński i Piniński.

Delegaci polscy wyjaśnili, że lotnicze zagrożenie z kierunku Prus Wschodnich zaabsorbuje niemal całość lotnictwa $z$ odwodu ogólnego Naczelnego Wodza. W takiej sytuacji, argumentowali, konieczne stanie się odciążenie sił powietrznych Rzeczypospolitej przez francuskie działania "na polsko-niemieckim zachodnim teatrze operacyjnym", podejmowane z baz na terytorium Francji i Polski. Przedstawiciele Paryża wskazali, że postulowana przez wschodniego sojusznika akcja byłaby trudna ze względu na przeprowadzaną właśnie reorganizację francuskich sił powietrznych oraz niedostatki sprzętu, szczególnie nowoczesnego, który do jednostek trafić ma dopiero jesienią i zimą. Jak więc stwierdzili, „w obecnych warunkach akcja francuskich sił powietrznych na korzyść Polski możliwa jest jedynie w wypadku decydujących działań lądowych lub $w$ razie kryzysu". W takich przypadkach lotnictwo francuskie mogłoby, zależnie od sytuacji na innych teatrach operacyjnych, podjąć działania na tyłach wojsk niemieckich lub ograniczone działania $z$ terytorium Polski. Francuzi proponowali przy tym jedynie czasowe bazowanie nad Wisłą własnych jednostek lotniczych, które, twierdzili, „można by w okresie kilku dni przerzucić na terytorium polskie [...], można przy tym przewidzieć głębszą akcję $\mathrm{w}$ trakcie przelotu nad terytorium niemieckim przy starcie z Francji i lądowaniu w Polsce i odwrotnie". Zgodnie $\mathrm{z}$ deklaracjami strony francuskiej $\mathrm{w}$ tej drugiej ewentualności $\mathrm{w}$ grę wchodzić by mogło nie więcej niż pięć dywizjonów liczących po 12 samolotów bombowych ${ }^{40}$

14 Odrzucić jednak trzeba formulowany w literaturze na podstawie powojennych wyjaśnień Gamelina pogląd, że w przedstawionej Polakom ofercie Vuillemin posunął się zbyt daleko, zaskakując tym Szefa Sztabu Generalnego Obrony Narodowej. W istocie bowiem, jak wyżej wskazano, szef francuskich sił powietrznych powtórzył, choć w odpowiednio przykrojonej formie, stanowisko Gamelinowi nie tylko znane, ale wręcz w korespondencji z marca i kwietnia przyjęte przezeń za wlasne. M. Gamelin, op. cit., t. 2, s. 417; J. Cialowicz, op. cit., s. 275. Bezkrytyczne odwoływanie się do powojennych wyjaśnień Gamelina w tej sprawie jest praktyką powszechną także w nowszej literaturze, zob. np.: M.S. A lexand er, op. cit., s. 308.

"I Francuski termin groupe na język polski tlumaczony jest (także w sporządzonych niebawem oficjalnych tłumaczeniach protokołu z 16 maja) jako dywizjon. W maju 1939 r. dywizjony polskiego lotnictwa bombowego liczyły etatowo po 18 samolotów (dwie eskadry po 9 maszyn), a więc o połowę więcej od francuskich odpowiedników. Pod tym względem francuskiemu groupe bombowemu blizej było do polskiej eskadry. 
(„prawdopodobnie AMIOT 143 M"), z których każdy, dysponując zasięgiem 1500 $\mathrm{km}$, zdolny byłby do przeniesienia ładunku $1500 \mathrm{~kg}$ bomb. Jak stwierdzono, większe i nowocześniejsze francuskie siły bombowe pojawić by się mogły w Polsce najwcześniej wiosną 1940 roku.

Jako linię rozgraniczenia działań polskiego i francuskiego lotnictwa bombowego gospodarze spotkania zaproponowali linię południka Rostock - Lipsk, „w przypadku potężnej akcji niemieckich sił powietrznych stacjonujących w Prusach Wschodnich", oferując jej przesunięcie w kierunku wschodnim, na linię Szczecin - Zgorzelec.

W trakcie rozmów lotniczej podkomisji poczyniono też wstępne uzgodnienia w sprawach organizacyjno-technicznych. Francuzi jako najdogodniejsze dla bazowania przybyłych znad Sekwany samolotów wskazali rejony oddalone od linii frontu o 180-250 km. Postulowali też, by przygotowaniem przeznaczonych dla tych maszyn zapasów bomb i materiałów pędnych zajęła się strona polska. Przedstawiciele lotnictwa polskiego zauważyli jednak, że nie posiadają niezbędnych dla jednostek francuskich ilości bomb, nie dysponują też zupełnie amunicją dla karabinów maszynowych typu francuskiego.

Ostatecznie w sprawach dotyczących zaopatrzenia uzgodniono podział ról. Polskim służbom miało $\mathrm{w}$ udziale przypaść przygotowanie baz wedle wytycznych dostarczonych z Francji, obsługa „we wszystkich specjalnościach", łączność naziemna, zapewnienie materiałów pędnych oraz ewentualnie oleju, dostarczenie naziemnych środków transportu, zakwaterowanie i zaopatrzenie w żywność przybyszów z Francji. Z kolei w gestii strony francuskiej znalazły się: zaopatrzenie składów w bomby i części zamienne, przygotowanie „dyplomowanych techników specjalistów wszystkich dziedzin”, wreszcie - „ewentualne zaopatrzenie w materiały pędne (przez zakupy w Rumunii i ich transport do Polski)" 41 .

Równolegle $z$ obradami poświęconymi lotnictwu odbywało się posiedzenie dotyczące sił lądowych, $z$ udziałem gen. Gamelina i grupy wyższych dowódców fran-

41 Protokóly polsko-francuskich rozmów sztabowych..., s. 173nn.; J. Cialowicz, op. cit., s. 282nn.; M. Zgórniak, Europa w przededniu wojny..., s. 439. Wszystkie cytaty z protokołów rozmów podkomisji lotniczej podano za: Wojna obronna Polski 1939. Wybór źródel, dok. 66, s. 253n. Tekst polski „poprawiony na podstawie uzgodnionego tekstu francuskiego w Sztabie Generalnym Ministerstwa Lotnictwa Francji": IPMS, LOT, U.1.2/12. Z czterech egzemplarzy protokołu rozmów tej podkomisji trzy przekazane zostały stronie polskiej. Egzemplarz francuski mial zostać przedłożony Gamelinowi ( $w$ tekście polskim pierwotnie figurował, następnie skreślony, zapis, że protokół „[...] będzie podpisany po zaaprobowaniu jego treści przez Generała Gamelin”), a następnie dolączony do protokołów misji gen. Kasprzyckiego. Brak go jednak w zachowanych aktach strony francuskiej (oraz oczywiście w ich edycji w ramach serii DDF), co więcej zaś, nie został wymieniony w sporządzonym zapewne bezpośrednio po zakończeniu rozmów zestawieniu tych akt (SHD-DAT, 7 N 235). O obradach podkomisji brak też wzmianki w podsumowującym polsko-francuską współpracę lotniczą z tego okresu chronologicznym „Résumé des conversations et des accords d'États-Majors franco-polonais en 1938-1939" (SHD-DAA, 2 B 104). Są one więc często pomijane w historiografii francuskiej. Por.: P. Le Goyet, Le mystère Gamelin, Paris 1975, s. 188nn.; idem, France-Pologne 1919-1939..., s. 220nn.; T. Vivie r, L'aviation française en Pologne..., s. 68; ide m, La politique aéronautique..., s. 525. Zob. też: B. Belcarz, Polskie lotnictwo..., s. 24nn. 
cuskich oraz trzonu polskiej delegacji, z gen. Kasprzyckim i płk. Jakliczem² ${ }^{42}$ Goście z Warszawy starali się wykonywać instrukcje marszałka Śmigłego-Rydza. Jednak ogólnikowa forma zawartych w nich pytań powodowała, że udzielane odpowiedzi były równie mało konkretne. I tak zapytanie płk. Jaklicza, czy Francuzi w razie ataku na Polskę przekroczą granice Niemiec i podejmą ofensywę, spotkało się z „zapewnieniami" Gamelina, że tak istotnie się stanie ${ }^{43}$. Obawy, że ewentualna francuska ofensywa przeciw Włochom może odbić się niekorzystnie na możliwościach działań wobec Rzeszy, skontrowane zostały opinią, że „ofensywa przeciw Włochom nie wymaga zbyt wielkiego wysiłku"44, zaś próba określenia sił, które Francuzi zamierzają rzucić do ataku na Niemcy, dała w efekcie dość mgliste wyjaśnienie Gamelina, że na kluczowym tu froncie północno-wschodnim znajdą się trzy czwarte sił francuskich, zaś połowa $z$ nich „może wziąć udział w ofensywie”. Jak kilka miesięcy później podał płk Jaklicz, „gen. Gamelin wymienił cyfrę 40 dyw.[izji]" - wielkość ta nie została jednak zapisana w żadnym z protokołów. Postawione nieco wcześniej przez Kasprzyckiego pytanie, czy francuskie działania zaczepne mogą nastąpić „przed upływem 15 dni”, spotkało się z ostrożnym i niezbyt zobowiązującym potwierdzeniem Szefa Sztabu Generalnego Obrony Narodowej („taki mniej więcej okres jest przewidywany”), uzupełnionym uwagą gen. Georges'a, że uderzenie na Linię Zygfryda w celu jej przełamania jego zdaniem „nie może rozpocząć się przed upływem 17 dni"45.

Całość posiedzenia złożonego z dwóch sesji (pierwsza między 11.15 i 12.00, druga od 17.00 do 18.00) trwała niespełna dwie godziny. Jest oczywiste, że w tak krótkim czasie dokonać można było jedynie pobieżnego przeglądu sytuacji oraz wymiany podstawowych danych. Obie strony skłonne były przy tym do operowania twierdzeniami o charakterze ogólnym, zarówno ze względu na tajemnicę wojskową, jak i brak czasu, który nie pozwalał podejmować bardziej szczegółowych dyskusji. W tej sytuacji za błąd strony polskiej uznać należy zarówno przyjęte zawczasu poważne ograniczenie czasu trwania wizyty, jak i nadmierną powściągliwość („wyjaśniłbym nasze projekty operacji generałowi Gamelinowi, gdyby on mnie o to poprosił",

12 W dokumentach dotyczących przebiegu tej części obrad występują różnice. We francuskim podsumowaniu („Conversations franco-polonaises du 17 Mai 1939...”) wymieniani są m.in. nieuwzględnieni w protokołach generałowie Louis-Antoine Colson oraz Gaston-Réné-Eugène Roton - Szef Sztabu gen. Alphonse’a Georges'a, członka Najwyższej Rady Wojennej, przewidywanego dowódcy Północno-Wschodniego Teatru Działań. W protokołach wymieniany jest też tylko jeden sekretarz - płk Aymé, w podsumowaniu w tej roli występuje także mjr Charles Noiret. Pośrednio obecność Rotona i Noireta potwierdza też P. de Villelume (op. cit., s. 291).

${ }^{43}$ Protokóly polsko-francuskich rozmów sztabowych..., s. 177. W "Conversations franco-polonaises du 17 Mai 1939..." zapisano, że zapewnień udzielili pospołu Gamelin i Georges.

${ }^{14}$ W "Conversations franco-polonaises du 17 Mai 1939..." znalazło się też nieobecne w protokole posiedzenia stwierdzenie, że ofensywa przeciw Włochom jest niezbędna z punktu widzenia koalicji i samej Polski - „szczególnie dla przywrócenia komunikacji przez Morze Śródziemne”.

15 Protokóly polsko-francuskich rozmów sztabowych..., s. 177. W odpowiednim fragmencie "Conversations franco-polonaises du 17 Mai 1939..." streszczono podkreślonym w tekście zapisem, że „właściwe operacje ofensywne rozpoczną się między 15 a 17 dniem”. 
tłumaczyl dwa miesiące później gen. Musse płk Jaklicz) ${ }^{46}$. Przywiezione z Warszawy ogólnikowe instrukcje okazały się bardziej zawadą niż pomocą. Polscy delegaci swe oczekiwania formułowali zaś w sposób zadziwiająco wręcz oględny i niezdecydowany, wyraźnie nie najlepiej czując się w roli kołaczących o pomoc petentów ${ }^{4}$. Odnalezienia się w tej sytuacji nie ułatwiał im zresztą bodaj i sam Gamelin, posuwający się do zgryźliwych (i nie całkiem zgodnych z prawdą) uwag, że Francuzom o wiele łatwiej byłoby podjąć interwencję przeciw Rzeszy w trakcie wrześniowego kryzysu z ubiegłego roku. Jeśli przyjmiemy, że - jak zdaje się wynikać z francuskiego „Résumé d'ensemble" - goście z Warszawy zgodzili się z powyższą uwagą, to ich konfuzja uwidoczni się w całej pełni ${ }^{48}$.

Główna „lądowa” część paryskich rozmów w niewielkim stopniu przypominała nie tylko polsko-francuskie konferencje międzysztabowe z pierwszej połowy poprzedniej dekady, ale też niedawne spotkania przedstawicieli Sztabów Generalnych Wielkiej Brytanii i Francji. Znaczenie wykraczające poza ramy przedsięwzięcia o charakterze informacyjno-manifestacyjnym nadać miały paryskiej wizycie gen. Kasprzyckiego decyzje zawarte w podsumowującym cykl obrad protokole końcowym. Ten ostatni dokument przygotowany został przez stronę polską, a następnie przekazany w ręce gen. Gamelina wieczorem 17 maja lub rano w dniu następnym ${ }^{49}$. Po wprowadzeniu doń kilku poprawek 19 maja dokument opatrzony został podpisami generałów Kasprzyckiego i Gamelina ${ }^{50}$.

4h SHD-DAT, 7 NN 2/412, raport No 109/S gen. Musse z 19 VII 1939 r. Kwestia podjęcia w trakcie paryskich rozmów uzgodnień w sprawie koordynacji planów operacyjnych obu armii stała się w późniejszym czasie przedmiotem wyjaśnień Gamelina oraz rozważań badaczy (J. Cia łowic z, op. cit., s. 289nn.). Informacja płk. Jaklicza wydaje się rozstrzygać zaistniałą kontrowersję. Gamelin nie był zbytnio zainteresowany szczegółami polskich planów, w możliwości efektywnej ofensywy ze wschodu nie wierzył, za wartość uznawal jedynie sam fakt istnienia ulokowanego w tej części Europy frontu. „Francuzi nie czynią sugestii co do celów [polskiej ofensywy], sugerują tylko, że oni [Polacy] nie powinni być zbyt ambitni i nie powinno być mowy o próbie osiągnięcia Berlina w jeden dzień", ironizowal w rozmowie $z$ plk. W. Fraserem streszczający mu główne wątki rozmów płk Petibon (TNA, CAB 53/49, „Copy of a letter dated 18th May, 1939, from the Military Attache in Paris to major-general H.R. Pownall").

${ }^{47} \mathrm{~W}$ polskiej literaturze wspomina się niekjedy o "naciskach" dążących do uzyskania konkretnych odpowiedzi polskich delegatów (zob. np.: L. Wyszczelski, Tajna gra mocarstw. Wiosna-lato 1939, Warszawa 2014, s. 98nn.). Jak się jednak wydaje, celniej przebieg obrad ocenił znacznie bardziej w tym wypadku krytyczny J. Ciałowicz (op. cit., s. 272).

4k Informacja o poczynieniu przez Gamelina takiej uwagi znalazła się w „Conversations franco-polonaises du 17 Mai 1939..., brak jej natomiast w tekście oficjalnych protokołów.

$4 y$ SHD-DAT 2 N 235, kopia (koncept?) pisma bez numeru kancelaryjnego Gamelina do Daladiera z 20 V 1939 r.; „Conversations franco-polonaises du 17 Mai 1939..."; J. Łukasiewicz, op. cit., s. 260. Same protokoły obrad zredagowane zostały natomiast przez stronę francuską, pod kierunkiem gen. Jameta.

50 J. Łukasiewicz podpisanie protokołu datował na 18 maja (op. cit., s. 261). Wobec opatrzenia zachowanych egzemplarzy dokumentu datą dnia następnego wydawać się to może oczywistym blędem i tak też potraktowane zostało przez redaktorów wspomnień polskiego ambasadora (przyp. 19, s. 267). Jednak w zachowanym w SHD-DAT, 7 NN 2/419 egzemplarzu „Conversations 
W ostatecznym brzmieniu protokół końcowy precyzował, że „w wypadku agresji niemieckiej przeciwko Polsce lub w wypadku zagrożenia żywotnych interesów Polski w Gdańsku, co wywołałoby zbrojną akcję Polski", automatycznie winna mieć miejsce następująca reakcja francuskiego sojusznika:

1. Francja podejmie natychmiast działania powietrzne zgodnie $z$ uprzednio ustalonym planem.

2. Gdy tylko część sił francuskich będzie gotowa (około trzeciego dnia po dniu początkowym powszechnej mobilizacji francuskiej), Francja przystąpi stopniowo do działań ofensywnych o ograniczonych celach.

3. Gdy tylko zaznaczy się główny wysiłek niemiecki przeciw Polsce, Francja głównymi siłami rozpocznie działania ofensywne przeciw Niemcom (poczynając od piętnastego dnia po dniu początkowym powszechnej mobilizacji francuskiej) $)^{51}$.

Francuzi uznawali też za konieczną „we wspólnym interesie" natychmiastową pomoc finansową i materiałową dla polskiego sprzymierzeńca.

I te zapisy omawiane $\mathrm{i}$ analizowane były wielokrotnie. W ślad za autorami wcześniejszych opracowań zwrócić możemy uwagę, że w sporządzonym w języku francuskim tekście protokołu posłużono się $w$ odniesieniu do sił, które na froncie zachodnim miałyby podjąć ofensywę przeciw Rzeszy, terminem "les gros" - siły główne, a nie "le gros" - siła główna. Choć zaś różnica zdawać się może niewielka, w terminologii wojskowej urastała do poważnych rozmiarów. Większość sił określano bowiem we Francji terminem le gros, podczas gdy les gros odnosiło się tylko do pewnych wyodrębnionych ich części (w tym przypadku - co wyjaśnić miał Gamelin Kasprzyckiemu - jednej trzeciej) ${ }^{52}$. Jak twierdził po latach szef francuskiego Sztabu, przyjęcie takiej formuły nastąpiło po wyjaśnieniach, które musiały być jasne dla polskiego ministra. Istotnie, ten ostatni był wysoko ocenianym absolwentem paryskiej École Supérieure de Guerre i biegle władał językiem francuskim, także w jego wojskowej odmianie ${ }^{53}$. Przeoczenie przezeń tak istotnego szczegółu wydaje się więc mało prawdopodobne. Wiadomo $w$ każdym razie, że już przed wprowadzeniem przez

franco-polonaises du 17 Mai 1939..." także wpisano odręcznie datę 18 maja (w innych egzemplarzach pozostawione $w$ tym celu miejsce nie zostało wypełnione).

si Protokóly polsko-francuskich rozmów sztabowych..., s. 176. Fragmenty oznaczone kursywą zostały opatrzone odnośnikiem prowadzącym do maszynowego dopisku w dolnej części karty (znajduje się on zarówno w egzemplarzach strony polskiej, jak i francuskiej).

$\$ 2$ M. Gamelin, op. cit., t. 2, s. 420n.; J. Ciałowicz, op. cit., s. 288n.; M. Zgórniak, Europa $w$ przededniu wojny..., s. 440n. W protokole pojawial się także zapis le gros, np. w punkcie dotyczącym ewentualnego ataku Rzeszy na Francję i polskiej nań reakcji mowa była o le gros sił niemieckich.

${ }_{33}$ Zob. przesłana przez gen. Musse w załączeniu do raportu No 73/S z $11 \mathrm{~V} 1939$ r. notka biograficzna generała zawierająca cytaty $z$ doskonalej opinii dyrektora ESG (a wcześniej m.in. Szefa Sztabu gen. Pétainèa) gen. Marie-Eugène Debeneya (SHD-DAT, 7 NN 2/382). Misja z maja 1939 r. nie była w przypadku Kasprzyckiego pierwszym takim wyjazdem. W prowadzonych w Paryżu rozmowach sztabowych uczestniczył on wcześniej m.in. w roku 1924 i 1929. 
Gamelina poprawek projekt protokołu końcowego zawierał owo tak dogodne dla strony francuskiej les gros ${ }^{i 4}$.

Znane są także inne fakty, $z$ których wnioskować można, iż kwestia francuskiej ofensywy na Linię Zygfryda przedstawiana była w trakcie rozmów w sposób mniej oczywisty, niż wynikało to z brzmiących jednoznacznie zapisów protokołu końcowego. Brytyjski attaché wojskowy, poinformowany w tym czasie przez najbliższego współpracownika Gamelina, płk. Petibona, o przebiegu wizyty gen. Kasprzyckiego, donosił o "pewnym niezadowoleniu” strony polskiej na wieść, że Francuzi nie zamierzają bynajmniej bezrozumnie rzucać się na Niemców, zaś główna ofensywa nastąpi na obszarze śródziemnomorskim ${ }^{55}$. Z kolei płk de Villelume zanotował 19 maja w swym dzienniku, że o ile gen. Roton bardzo optymistycznie zapatruje się na efekty prowadzonego "dzień i noc" ostrzału Linii Zygfryda przez francuską artylerię, to jego bezpośredni przełożony, gen. Georges, jest tu znaczne bardziej sceptyczny, wskazując na brak dostatecznej ilości amunicjii.

Można skądinąd zastanawiać się, czy gen. Kasprzycki oraz płk Jaklicz, jako absolwenci École Supérieure de Guerre, dobrze zorientowani w zasadach i praktyce działania armii francuskiej, istotnie uznali za realistyczne zapisane w protokole końcowym krótkie terminy podjęcia przez tę ostatnią zakrojonych na wielką skalę działań ofensywnych przeciw rozbudowanej linii stałych fortyfikacji. Kwestia ta nigdy, jak można sądzić, nie doczeka się jednoznacznej odpowiedzi. Istotną wskazówkę co do praktycznych wniosków wyciągniętych przez polskich sztabowców z majowej wizyty zawiera, jak się wydaje, opracowany na przełomie lipca i sierpnia na polecenie płk. Jaklicza przez szefa Oddziału III Sztabu Głównego płk. dypl. Stanisława Kopańskiego „Materiał dla opracowania dalszego planu wojny”. Wyjściową tezę, że „wojna musi być prowadzona w ten sposób, by zachować jak najdłużej zdolność do walki", uzasadniono tam w sposób następujący: „Główne uderzenie przeciwnika, skierowane na Polskę, nie może nas zniszczyć lub uczynić niezdolnymi do reakcji w chwili gdy państwa zachodu będą gotowe do działań decydujących, co może nastąpić po kilku miesiącach od początku konfliktu zbrojnego" [ortografia i interpunkcja oryginału, podkr. - W.M. $]^{57}$.

54 W SDH-DAT pod sygnaturą $2 \mathrm{~N} 235$ znajdują się dwie wersje maszynopisów projektu protokołu końcowego, liczne poprawki wprowadzone ręką Gamelina znaleźć można przynajmniej na jednym $z$ nich (późniejszym).

s5 TNA, CAB 53/49, „Copy of a letter dated 18th May, 1939, from the Military Attache in Paris to major-general H.R. Pownall". Oczywiście można założyć, że Fraser został rozmyślnie wprowadzony w błąd. Trudno byłoby jednak znaleźć oczywiste wytłumaczenie dla podobnej akcji, tym bardziej że przekazana do Londynu treść rozmowy, do pewnego stopnia sprzeczna z brytyjsko-francuskimi ustaleniami, wywołała natychmiastowe zaniepokojenie Szefów Sztabów (ibidem, "Staff conversations between France and Poland", C.O.S. 913 Ismaya z 24 V 1939 r.).

${ }_{56}$ P. de Villelume, op. cit., s. 291.

57 IPMS, A.II. 8/1, opracowanie niedatowane [przełom lipca i sierpnia 1939 r.]. Zob. też: IPMS, B.I. 7a, notatka płk. Kopańskiego „Fakty, uwagi i spostrzeżenia, dotyczące przygotowań wojennych" załączona do pisma do pomocnika ministra spraw wojskowych płk. dypl. Izydora Modelskiego z 13 XI 1939 r.; S. Kopański, Wspomnienia wojenne 1939-1946, wyd. 2, Londyn 1972, 
Oczywiście powyższe uwagi nie powinny przesłaniać konstatacji, która - jak raz jeszcze podkreślić trzeba $\mathrm{z}$ naciskiem, musi mieć $\mathrm{w}$ tym przypadku charakter nadrzędny: przyjęte w trakcie majowych rozmów uzgodnienia zapisane zostały w sygnowanym przez przedstawicieli obu stron protokole. I to ten dokument, mimo dość ogólnej i lakonicznej formy wystarczająco jednoznaczny, precyzował ich wzajemne zobowiązania ${ }^{58}$.

Sam fakt wejścia $w$ życie tych zobowiązań stał się jednak prawie natychmiast przedmiotem kontrowersji. Jedną z jej przyczyn była wprowadzona do pierwotnego brzmienia tekstu protokołu końcowego poprawka Gamelina. Francuski Szef Sztabu dodał w początkowej części dokumentu frazę precyzującą, że naczelne dowództwa działać będą „w ramach decyzji podjętych przez oba rządy”. Było to niewątpliwie posunięcie zręczne, zdejmowało zeń bowiem przynajmniej część odpowiedzialności, obciążając nią czynniki polityczne ${ }^{59}$.

Zaangażowanie owych czynników, w jakiejś formie nieuniknione, wyraziło się niemal natychmiast $w$ sposób, który miał $w$ wielkim stopniu zaważyć na losach zawartego właśnie porozumienia. Od początku było bowiem jasne, że zostanie ono powiązane $z$ uzgadnianym od kilku tygodni między Warszawą i Paryżem politycznym protokołem zawierającym interpretację łączącego obie stolice sojuszu. Jak już wyżej wzmiankowano, polski projekt tego ostatniego dokumentu wręczył 28 (29?) kwietnia Bonnetowi ambasador Łukasiewicz, spotykając się z życzliwą reakcją. Istotnie, tekst po wprowadzeniu stosunkowo niewielkich poprawek został dość szybko wstępnie zaaprobowany, a następnie 3 maja zwrócony polskiemu ambasadorowi. 11 maja protokół interpretacyjny przyjęła jednogłośnie francuska Rada Ministrów, zaś tydzień później Bonnet informował Daladiera o zamierzonym „w najbliższym czasie” jego podpisaniu $^{60}$.

s. 19n. Tekst Studium wraz z krótkim wyjaśnieniem okoliczności jego powstania opublikowany został z drobnymi zmianami w roku 1952 w z. 3 londyńskiej „Bellony” (id e m, Przyczynki do genezy polskiego planu operacyjnego do kampanii 1939 r. (cz. II), s. $53 \mathrm{nn}$.).

;* Jak się wydaje, istotną część problemu stanowil tu fakt, że jeden $z$ widniejących pod protokołem podpisów złożył człowiek, o którym już w roku 1935 ówczesny polski attaché wojskowy w Paryżu płk dypl. Jerzy Błeszyński napisał w ostatnim zdaniu dość obszernej charakterystyki: „We wszystkich posunięciach na zewnątrz cechuje go nieszczerość" (AAN, SG. 617/6, niedatowana [po roku 1936] notatka „Życiorys generała Gamelin Szefa Sztabu Generalnego Armji Francuskiej”).

5y SHD-DAT, $2 \mathrm{~N} 235$, poprawki w tekstach projektu protokołu końcowego rozmów; M. Gamelin, op. cit., t. 2, s. 420; J. Ciałowicz, op. cit., s. 287.

(n) SHD-DAT, 5 N 579, pismo No 2081 Bonneta do Daladiera z 18 V 1939 r. z załączonym tekstem protokołu (też: DDF, t. 16, doc. 222, s. 432n.). Przekazany dzień później za pośrednictwem Corbina do Londynu protokół wywarł na współpracownikach Halifaksa "dobre wrażenie" (ibidem, doc. 228, s. 452). W zachowanej w AD, Papiers 1940, Papiers Rochat 32 wersji protokołu interpretacyjnego oraz związanego z nim „Aide-mémoire” została już nawet wpisana (a następnie przekreślona ołówkiem) data przyjęcia: $20 \mathrm{~V} 1939$ r. Por.: IPMS, A.1 1.49.F/7, niesygnowana „Notatka o rozmowach Radcy [Feliksa] Frankowskiego z Dyrektorem Politycznym na Quai d'Orsay, Ministrem [Émile] Charveriat i zastępcą Dyrektora Politycznego, Ministrem [Charles] Rochat dnia 20 maja 1939 roku". W tejże kwestii zob. także: TNA, FO 371/23143, notatka Stranga z 18 V 1939 r. i in. dok. 
Już jednak w dniu następnym francuski minister rozpoczął grę na zwlokę, przesuwając moment złożenia swego podpisu na kolejne, choć wciąż niezbyt odległe terminy. Doraźnie wstrzymało to nawet sygnowanie protokołu końcowego rozmów międzysztabowych przez oczekującego finalizacji porozumienia politycznego Gamelina. Choć zaś ostatecznie zwłoka okazała się krótka, to francuski Szef Sztabu nadal $\mathrm{z}$ naciskiem podkreślał, że uzgodnienia wojskowych staną się aktualne dopiero w momencie wejścia w życie umowy pomiędzy rządami ${ }^{61}$.

To ostatnie zaś wciąż nie mogło się ziścić. Bonnet, główny sprawca przedłużającego się opóźnienia, wyjaśniał, że chodzi mu głównie o poczynienie uzgodnień ze stroną brytyjską, tak aby zobowiązania polityczne obu mocarstw względem Polski były możliwie równoważne. Wydaje się jednak, jak dość zgodnie przyjmują polscy historycy, że francuski minister chciał też zachować w dyspozycji Paryża istotny instrument wywierania nacisku na polskiego sojusznika - użyteczny choćby dla skłonienia go do większej życzliwości wobec ofert współpracy z ZSRR ${ }^{62}$. W efekcie jednak, mimo usilnych prób, podejmowanych, rzecz jasna, głównie przez stronę polską, nie udało się w następnych miesiącach osiągnąć porozumienia w kwestii finalizacji protokołu politycznego. Ów stan niemożności przerwany został dopiero wraz z wybuchem wojny - do podpisania negocjowanej tak długo umowy doszło w Paryżu 4 września 1939 roku. Wtedy też dopiero formalnie weszły w życie postanowienia protokołu sygnowanego 19 maja przez generałów Kasprzyckiego i Gamelina ${ }^{63}$.

Powojenne wyjaśnienia Gamelina, że wobec braku politycznej części umowy nastąpiło faktycznie zawieszenie wykonywania przyjętych uzgodnień natury wojskowej, brzmią jednak mało wiarygodnie. Także w świetle poczynań samego ich autora, który już 31 maja wydał „Directive pour le Général Commandant de Théâtre d'Opérations du Nord-Est en Vue des Opérations Initiales à Conduire Éventuelle entre Rhin et Moselle", przedstawiając w niej wstępne założenia działań, które winny

61 SHD-DAT, 5 N 579, kopia pisma bez numeru kancelaryjnego Gamelina do Kasprzyckiego z 20 V 1939 r. Na egzemplarzu pieczątka „widziane przez ministra”; DDF, t. 16, doc. 245, s. 489.

${ }_{62}$ M. Gmurczyk-Wrońska, op. cit., s. 100 nn.; M. Kornat, Polityka zagraniczna Polski..., s. 486nn. Pierwsza z wymienionej pary autorów przywołuje tu istotnie znaczące dla wspomnianej kwestii, przeznaczone dla Daladiera „Mémorandum au sujet de l'accord franco-polonais" Bonneta z 22 V 1939 r. (AN, 496 AP 11). Por. też obszerne materiały na tenże temat zgromadzone w: AD, Papiers 1940, Rochat 32. Szereg informacji i komentarzy na temat tej fazy rokowań o protokól interpretacyjny sojuszu podał J. Łukasiewicz, we wspomnieniach (op. cit., s. 260nn.) oraz raportach (np.: PDD 1939, dok. 302, s. 503 nn. - z podsumowaniem rozwoju problemu aż do 22 maja; dok. 312, s. 525nn.; dok. 315, s. 530nn.; dok. 325, s. 549n.). Dokumenty strony francuskiej dotyczące początków wspomnianej kontrowersji opublikowano w: DDF, t. 16, doc. 252, s. 500; doc. 253, s. 501 n.; doc. 255 , s. 505 n.; doc. 259 , s. 514 nn.; doc. 290 , s. 573 nn. i in.

${ }_{63}$ Tekst protokołu z 4 IX 1939 r. był wielokrotnie publikowany. Zob.: H. Batowski, Agonia pokoju i początek wojny, sierpień-wrzesień 1939, wyd. 4 popr. i uzup., Poznań 1984, s. 428n. Zob. też: M. Kornat, Polityka zagraniczna Polski..., s. 495. Ostatnią fazę negocjacji w sprawie protokołu politycznego z pozycji ich uczestnika przedstawił w niepublikowanych wspomnieniach Feliks Frankowski: IPMS, Kol. 26/17, „Sous le signe du grand conflit (Souvenirs et Pensées d'un Diplomate)". 
zostać podjęte w razie ziszczenia się hipotezy, że główny wysiłek Rzeszy w początkowej fazie wojny skierowany zostanie ku Polsce. Wtedy, jak wyjaśniał, siły francuskie mogą zostać zmuszone do podjęcia "najwcześniej, jak to tylko możliwe”, interwencji w celu zatrzymania lub ściągnięcia na front zachodni maksimum sił niemieckich. Zarysowane $\mathrm{w}$ tym dokumencie działania miały być jednak powolne i metodyczne, nie obejmując zresztą samego szturmu na niemiecką pozycję ufortyfikowaną. Sam ich szkic był zaś bardzo ogólnikowy, nie uwzględniono w nim np. w żaden sposób akcji sil powietrznych ${ }^{64}$.

Dyrektywa odwoływała się do wcześniejszych francuskich planów, przewidujących podjęcie ofensywy na Niemcy na obszarze położonej między Renem a Mozelą tzw. „bramy Saary”, przez którą armia francuska mogła wyprowadzić uderzenie w kierunku Moguncji i Koblencji ${ }^{65}$. Adresatem dokumentu był wyznaczony na dowódcę Północno-Wschodniego Teatru Operacji gen. Alphonse Georges. To pod jego kontrolą podjęte zostały w następnych tygodniach prace nad bardziej szczegółową wersją planu działań. Jej koncepcja zestawiona została 22 lipca 1939 roku w „Instrukcji nr l” gen. André-Gastona Prételata, dowódcy 2 Grupy Armii, której w ramach planowanej operacji przypaść miała kluczowa, ofensywna rola. Dwa dni później gen. Georges zatwierdzil przedstawiony mu dokument ${ }^{66}$. Przyjęty plan zakładał, że w przypadku przewidzianym w dyrektywie Szefa Sztabu Generalnego Obrony Narodowej armia francuska może podjąć działania w celu odciążenia walczącego na wschodzie sojusznika. Miałaby się na nie składać seria operacji, w trakcie których Francuzi planowali wejść w styczność $\mathrm{z}$ fortyfikacjami niemieckimi pomiędzy lasem Hochwald i zachodnim krańcem Wogezów, następnie podjąć ofensywę "o celach ściśle ograniczonych", a wreszcie, w razie jej powodzenia, przeprowadzić „atak na pozycję ufortyfikowaną na szerszym froncie na wschód od Sarrebruck" (Saarbrücken), gdzie Saara nie utrudniała nadmiernie dostępu do tej ostatniej. Choć niektóre z elementów tego planu zmodyfikowano $\mathrm{w}$ następnych tygodniach, to jego zasadnicze założenia pozostały w mocy aż do wybuchu wojny ${ }^{6 i}$.

Nie może być żadnych wątpliwości, że zakres zaplanowanych w ten sposób operacji nie odpowiadał temu, co strona polska skłonna byłaby uznać za wypełnienie

${ }^{64}$ M. Gamelin, op. cit., t. 2, s. 426n.; P. Le Goyet, France-Pologne 1919-1939..., s. 225. Gamelin tłumaczył, że wspomniane kroki podjął niejako w oczekiwaniu na sygnowanie politycznej części porozumienia, co jednak w świetle dalszych poczynań francuskich wojskowych nie brzmi przekonująco. S. 180 .

65 M. Gamelin, op. cit., t. 3, s. 26 i nast.; M. Zgórniak, Europa w przededniu wojny...,

th SHD-DAT, $1 \mathrm{~N} 48$, „Instruction No 1 pour les Généraux Commandant les III, IV et V Armées” No 1/3.S. gen. Prételata z 22 VII 1939 r.; „Instruction Personelle et Secrète pour le Commandant du Groupe d'Armées en vue des Opérations Initiales à Conduire Éventuellement entre Rhin et Moselle" No 7/78 gen. Georges'a z 24 VII 1939 r.

6i Ibidem, „Instruction Personelle et Secrète..." Georges'a z 24 VII 1939 r. Kształt tego planu w momencie przystąpienia Francji do wojny: ibidem, niesygnowana „Synthèse des instructions du G.A. et des III, II et V Armées pour l'opération Saare" z 4 IX 1939 r. 
zawartego w protokole z 19 maja zobowiązania Gamelina do podjęcia ofensywy większością sił, i to już w 15 dni od mobilizacji. Francuscy dowódcy przyszłe poczynania podporządkowanych im armii planowali bardzo ostrożnie, ich realnym efektem stać się miała raczej wspomniana wyżej ofensywa „o celach ściśle ograniczonych" (faktycznie - dywersyjnych) niż szerzej zakrojona akcja, której skutki mógłby w istocie odczuć polski sojusznik. Choć bowiem atak na Linię Zygfryda nie został nominalnie wykluczony, to wobec braku założeń co do wykorzystania ewentualnego powodzenia działań wstępnych taka perspektywa stawała się raczej figurą retoryczną, a nie realnie rozważanym zamiarem ${ }^{68}$.

Swe "wewnętrzne zadowolenie" $\mathrm{z}$ racji braku protokołu politycznego i wynikającej stąd „bezwartościowości” uzgodnień wojskowych Gamelin łączył, jak wyjaśniał po latach, szczególnie z przyjętymi podczas majowych rozmów z Kasprzyckim rozstrzygnięciami w sprawach francusko-polskiej współpracy lotniczej. Jak stwierdzał, gen. Vuillemin w swych propozycjach wyprzedził francuskie możliwości i tylko niechęć do dyskredytacji Szefa Sztabu Armée de l'Air wobec zagranicy sprawiła, że jego wypowiedzi nie zostały zanegowane ${ }^{69}$.

Należy jednak przypomnieć raz jeszcze, że Vuillemin działał w ramach dyrektyw otrzymanych od Gamelina (choć na swój własny wniosek) 13 kwietnia. Co więcej, jego wypowiedzi w trakcie obrad z 16 maja związane były $z$ inną jeszcze inicjatywą podjętą w ramach tych dyrektyw, o której Szef Sztabu Generalnego Obrony Narodowej został zresztą kilka dni wcześniej najzupełniej oficjalnie powiadomiony ${ }^{70}$.

Pismem z 9 maja Vuillemin upoważnił bowiem rezydującego w Warszawie płk. Arbitre do poczynienia z polskim Sztabem Głównym uzgodnień w sprawie rozmów na temat „ewentualnej współpracy lotnictwa francuskiego i polskiego". Miałyby one zostać podjęte $w$ Paryżu $w$ drugiej połowie maja i potrwać około tygodnia. Proponowany program zorganizowanego w tym czasie cyklu spotkań dotyczyć miałby, sugerował Vuillemin, kwestii taktycznych (rozpoznanie głównego kierunku manewru armii niemieckiej, stacjonowanie w Polsce francuskich sił bombowych oraz ich zaopatrzenie), technicznych (uzbrojenie, łączność) oraz wymiany informacji na temat niemieckich i radzieckich sił powietrznych. Innymi słowy, po trzech miesiącach stronie polskiej proponowano spełnienie jej postulatów zgłoszonych $w$ trakcie lutowej wizyty ppłk. d’Arnaud de Vitrolles. Rozmowy w sprawach technicznych, jak zaznaczano, miałyby zresztą stanowić wprost kontynuację podjętych wówczas ustaleñ ${ }^{\top 1}$.

6* Podobne oceny bywały formułowane dość często także w literaturze zachodniej. Zob. np.: P. Le Goyet, France-Pologne 1919-1939..., s. 225; M.S. Alexander, op. cit., s. 307; F. Dessberg, Poland in the Political and Military Strategy of France (September-October 1939), [w:] Kampania polska 1939 r. Polityka..., s. 127.

ny M. Gamelin, op. cit., t. 2, s. 423 i 428n.

7" SHD-DAT, 7 N 235, pismo No 1510 2/C-S/E.M.A.A. Szefa Sztabu Generalnego Armée de l'Air do Gamelina z 9 V 1939 r. Pismo sygnował za ministra [lotnictwa] i z jego rozkazu gen. Réné Keller.

"Ibidem, kopia "Note pour l'attaché de l'air à Varsovie” No 1509 2/C-S/E.M.A.A. z $9 \mathrm{~V}$ 1939 r., sygnowana za ministra [lotnictwa] i z jego rozkazu przez gen. Kellera. 
W Warszawie wciąż trwały prace nad spożytkowaniem materiałów stanowiących plon misji ppłk. d’Arnaud de Vitrolles. Streszczenie przeprowadzonych przy jej okazji rozmów gen. Ujejski przekazał Szefowi Sztabu Głównego właśnie 9 maja - propozycja francuska nadeszła więc, przynajmniej pod tym względem, we właściwym czasie ${ }^{72}$. Trudno też dziwić się, że została podchwycona niemal natychmiast. Organizację rozmów ułatwiał zresztą fakt, iż przewidziany na szefa polskiej delegacji ppłk Karpiński od 15 maja przebywal już w Paryżu, zaś wezwanie mających go wspierać $w$ trakcie rozmów lotniczych oficerów-specjalistów zostało wstępnie uzgodnione przed południem 16 maja, podczas międzysztabowej konferencji $z$ udziałem gen. Kasprzyckiego. Teraz, prócz skompletowania składu kierowanej nad Sekwanę grupy, pozostało przekazać tam dodatkowe wytyczne.

Szef Sztabu Lotniczego Sztabu Głównego uczynił to 22 maja. Jak wyjaśniał, w sprawach operacyjnych nie był w stanie się wypowiedzieć, nie znając zasad i choćby ogólnego planu użycia francuskiego lotnictwa. Utrudniało to na razie podjęcie dyskusji o sprawach, które we francuskiej propozycji z 9 maja określone zostały, niezbyt zresztą zręcznie, jako „kwestie taktyczne”. W sprawach o charakterze specjalistycznym ppłk Karpiński odwoływać się miał do pomocy kierowanych doń oficerów: mjr. obs. Ferdynanda Bobińskiego (sprawy informacyjno-wywiadowcze), mjr. pil. Henryka Gizaczyńskiego (sprawy techniczne samolotów i materiały pędne), mjr. pil. Roberta Hirszbandta (uzbrojenie), kpt. inż. Wiktora Majewskiego (łączność). W tym ostatnim przypadku wytyczne gen. Ujejskiego nakazywały wyjaśnienie i sprecyzowanie niektórych zagadnień podjętych już podczas lutowej tury rozmów. Zagadnienie lotnisk powierzone zostało osobistej pieczy ppłk. Karpińskiego. W wytycznych zapowiedziano też przesłanie odrębną pocztą zamówień, które miałyby być dokonane "W ramach dalszego 50-cio milionowego kredytu francuskiego"73.

Oficjalna część obrad polsko-francuskiej Komisji Lotniczej rozpoczęła się w paryskim Ministerstwie Lotnictwa 25 maja. Cykl posiedzeń potrwać miał dwa dni, zaś ich wyniki podsumowano obszernym, liczącym aż trzydzieści stron protokołem, podpisanym 27 maja przez stojących na czele delegacji - zastępcę Szefa Sztabu Generalnego Armée de l’Air gen. Jeana Achille Henri Mendigala oraz ppłk. Karpińskiego ${ }^{74}$.

i2 IPMS, Lot. A.I. 2/11, „Krótkie streszczenie rozmów techn. francusko-polskich”, L. 377/S. Lotn. z 9 V 1939 r. Na dokumencie notka gen. Ujejskiego z 9 maja o przekazaniu odpisu Szefowi Sztabu.

"I Ibidem, koncept pisma L. 423/S.Lotn.tjn. gen. Ujejskiego do ppłk. Karpińskiego z $22 \mathrm{~V}$ 1939 r. Do powyższego został załączony dokument „Wytyczne dla ppłk. Karpińskiego” zawierający wytyczne przekazane Karpińskiemu zapewne przed wyjazdem w składzie misji gen. Kasprzyckiego. Wymieniono tam następujące kwestie: „1. Wymiana danych, dotyczących zamierzeń ogólnych użycia lotnictwa, szczególnie lotnictwa bombowego. [...] 2. Sprecyzować, czy Francuzi decydują się użyć część lotnictwa bombowego z terytorium Polski. [...] 3. Omówić możliwości dyslokacji jednostek francuskich na terytorium Polski (obecnie lotniska zastępcze polowe, następnie zaś lotniska solidnie przygotowane). 4 . Stan liczebny naszego lotnictwa, w razie żądania tych danych, należy podać - jak w projekcie rozmów polsko-angielskich" [tj. dane odpowiednio zmodyfikowane - W.M].

it SHD-DAT, 2 B 104, „Procès-verbal des conversations tenues au Ministère de l'Air à Paris les 25 et 26 Mai 1939 entre les représentants de l'Aviation Polonaise et de l'Armée de l'Air Fran- 
Realizowany program obrad objął ostatecznie szeroką grupę zagadnień. Składały się na nie:

„1/ Plany początkowego wykorzystania lotnictwa polskiego i francuskiego; francusko-polska współpraca lotnicza,

2/ Ewentualna wysyłka francuskich dywizjonów bombowych do Polski,

3/ Zaopatrzenie, utrzymanie jednostek francuskich w Polsce,

4/ Łączność i materiał radiowy,

5/ Programy studiów nad uzbrojeniem,

6/ Rozpoznanie meteorologiczne,

7/ Szyfry"75.

Strona polska poinformowała Francuzów o rozpoznanym rozmieszczeniu wokół granic Rzeczypospolitej niemieckich dywizjonów bombowych, z których cztery miałyby podjąć atak z obszaru Prus Wschodnich, dziesięć znajdowało się na terenie Brandenburgii i Pomorza Przedniego, osiem zaś na Morawach i Sląsku. W początkowej fazie konfliktu, wyjaśniali Polacy, całość lotnictwa z odwodu Naczelnego Wodza wykorzystana zostanie do działań przeciwko stanowiącemu z przyczyn geograficznych szczególnie poważne zagrożenie nieprzyjacielskiemu zgrupowaniu z Prus Wschodnich. Jego szybkie zniszczenie pozwoli także, argumentowano, na odzyskanie swobody działań w północnej części frontu i skierowanie zwolnionych w ten sposób sił na kierunek zachodni.

Jednakże zamierzona skoncentrowana akcja uniemożliwi podjęcie w pierwszych dniach wojny efektywnych działań przeciwko pozostałym 18 niemieckim dywizjonom bombowym, a także zmotoryzowanym jednostkom niemieckiej armii lądowej. Stąd właśnie niezbędna staje się pomoc w postaci skierowania do Polski w tym czasie jednostek francuskiego lotnictwa bombowego - konkludowali polscy delegaci.

Przedstawione następnie założenia francuskich operacji lotniczych miały charakter znacznie bardziej ogólnikowy. Strona francuska wskazała jedynie trzy Teatry Działań, pomiędzy które zostaną rozdzielone znajdujące się w jej rozporządzeniu siły powietrzne (Północno-Wschodni, Południowo-Wschodni i Afryka Północna), a następnie omówiła podstawowe formy przewidzianych działań, tj. wsparcie operacji sił lądowych (tu wymieniono tytułem przykładu uderzenie na przemieszczające się

çaise" z 27 V 1939 r. Ze strony polskiej obok już wyżej wymienionych oficerów w rozmowach uczestniczył szef służby meteorologicznej lotnictwa mjr Kazimierz Zacharewicz oraz ppłk Piniński. W protokole nie został natomiast wymieniony zatrzymany ostatecznie w kraju mjr Bobiński. Delegacja francuska była wyjątkowo liczna. W jej skład wchodzili: płk Bergeret, mjr Bailly, mjr Lapon (Szef Sekcji Lotnisk O. IV EMA AdA), kpt. Ferio (Dyrekcja Wojskowych Materiałów Lotniczych), kpt. Lauzun (szef Sekcji Niemieckiej O. II EMA AdA), kpt. Cazenave, kpt. Meaux (O. IV EMA AdA), kpt. Grimal, kpt. Baudoin (O. II EMA AdA - szyfry), kpt. Le Blèvec (Narodowe Biuro Meteorologiczne).

${ }^{75}$ Ibidem. Jak widać, $z$ tematyki rozmów wyłączone zostały ostatecznie zagadnienia informacyjno-wywiadowcze, stąd też zapewne wynikło usunięcie ze składu polskiej delegacji mjr. Bobińskiego. 
przez terytoria Holandii i Belgii niemieckie kolumny zmotoryzowane), akcje podejmowane $\mathrm{w}$ powiązaniu $\mathrm{z}$ działaniami poszczególnych armii lądowych (np. atak na transporty kolejowe koncentrujących się wojsk przeciwnika) oraz działania niezależne (np. atak na przemysł lotniczy i zbrojeniowy Niemiec).

Dążąc następnie do określenia ram współpracy lotniczej, obie delegacje uszczegółowiły granice aktywności ich sił bombowych na terenie Rzeszy. I tak dla lotnictwa francuskiego linię taką miały odtąd wyznaczać Brema - Hanower - Erfurt - Norymberga - Augsburg, zaś dla lotnictwa polskiego Szczecin - Zgorzelec - Brno. „Nadzwyczajna” linia rozgraniczenia nakreślona została wzdłuż osi Rostok - Rathenow - Chemnitz - Linz. Uzgodniono także zasady współpracy w zakresie szczególnie interesujących Francuzów działań rozpoznania lotniczego. Każda ze stron prowadzić je miała w obrębie własnej strefy, w razie potrzeby - aż po „nadzwyczajną" linię rozgraniczenia, dokonując następnie $z$ partnerem wymiany informacji drogą radiową.

W ramach tejże współpracy Francuzi zgodzili się na podtrzymanie swej zapowiedzi z 16 maja. W razie gdyby Rzeczpospolita stała się obiektem zmasowanego ataku sił niemieckich, na żądanie polskiego Sztabu Głównego po ocenie sytuacji na innych Teatrach Działań oraz odpowiedniej decyzji rządu do Polski na kilka dni skierowane miałyby zostać francuskie jednostki lotnictwa bombowego. Rozmiary tej pomocy określone zostały na razie, „w roku 1939”, na pięć dywizjonów samolotów bombowych typu Amiot $143 \mathrm{M}$. Siły te, zgodnie z deklaracją strony polskiej, zostałyby wykorzystane do kontrataków przeciw lotnictwu niemieckiemu na polskiej granicy zachodniej lub ataków na stanowiące szczególne zagrożenie niemieckie siły lądowe (przede wszystkim zmotoryzowane).

Francuzi zwrócili uwagę stronie polskiej, że akcje podjęte przez ich lotnictwo bombowe $z$ baz na własnym terytorium także stanowić będą pomoc dla sojusznika ze wschodu, zmuszając $z$ czasem Niemców do przemieszczenia w kierunku zachodnim części ich sił bombowych. Z kolei Polacy, wybiegając myślą w przyszłość, podkreślili, że $w$ dalszych fazach konfliktu sojusznicze siły powietrzne powinny dla osiągnięcia pełnej efektywności podjąć skoordynowaną akcję przeciw celom wybranej kategorii, np. wytwórniom silników. Uzgodniona została wymiana informacji na temat obiektów, które mogłyby stanowić cel takich przedsięwzięć.

Dalsze rozważania poświęcono przelotom francuskich bombowców na terytorium Polski oraz ich bazowaniu. Po przybyciu nad Wisłę bombowce zachodniego alianta miały być skierowane do jednego $z$ trzech wstępnie wybranych rejonów lotnisk wysuniętych:

- Tomaszów Mazowiecki - Piotrków (kod: „Jean”),

- Gniezno - Września (kod: „Paul”),

- Inowrocław - Aleksandrów Łódzki (kod: „René”).

Węzły lotnisk podstawowych dla dywizjonów francuskich ulokowane miały zostać w głębi kraju: w rejonie Radom - Lublin planowano rozmieszczenie trzech dywizjonów, dwa inne miały zostać ulokowane opodal Międzyrzeca Podlaskiego (całość rejonu otrzymała kodowe oznaczenie „Leon”). Na siedzibę sztabu zgrupowania ( $z$ etatem jednego generała lub pułkownika, trzech oficerów i trzech podoficerów) 
przewidziano Radom bądź Lublin - zależnie od możliwości zapewnienia łączności $\mathrm{z}$ dowództwem polskiego lotnictwa bombowego.

Planowana operacja stanowiła skomplikowane zadanie. Już sam przelot wiązał się z koniecznością dostarczenia Francuzom szeregu danych, obejmujących m.in. informacje meteorologiczne, dane dotyczące celów do ewentualnego zbombardowania $w$ trakcie przelotu, informacje o znanych Polakom strefach niebezpiecznych na trasie przelotu, przyporządkowaniu konkretnych lotnisk każdemu $z$ francuskich dywizjonów, ewentualnej osłonie myśliwskiej podczas przekraczania przez francuskie samoloty linii frontu, trasach przelotu od frontu do poszczególnych lotnisk, kodach radiowych, funkcjonowaniu reflektorów szlakowych (znaki, kody itp.) czy węzłach lotnisk (opisy, szkice, fotografie, mapy). W samych bazach zapewnić należało pomieszczenia dla przybyłych z Francji lotników, personel obsługi (od pracowników fizycznych po tłumaczy) oraz obronę przeciwlotniczą.

Przybyłych do Polski Francuzów i ich maszyny trzeba było następnie, w okresie ich pobytu w Polsce, zaopatrywać w paliwo (zapewniając też przyrządy rozlewnicze), bomby (na pięć wypraw całego zgrupowania), zmagazynować dostarczoną z Francji amunicję, sprzęt naprawczy, zorganizować i utrzymywać w gotowości system łączności (także szyfrowej), dostarczać dane meteorologiczne. Dla tych ostatnich celów przygotowana miała zostać $w$ Warszawie lub Dęblinie specjalna stała radiostacja (oraz istniejące już stałe radiostacje w Warszawie, Poznaniu, Krakowie, Lwowie i Wilnie, uznane za zastępcze), zaś w rejonach węzłów lotnisk cztery radiostacje ruchome dla dwustronnej łączności z samolotami (tu wykonanie zależało od dostarczenia $\mathrm{z}$ Francji zamówionych radiostacji S.I.F. 10B).

Rzecz jasna uzgodnione podczas obrad zobowiązania nie mogły być jednostronne, polskie zaś miały stanowić efekt istotnej decyzji francuskiej, dotyczącej skierowania nad Wisłę zgrupowania bombowego oraz jego wykorzystania we wcześniej uzgodniony sposób. Sam przelot i jego wcześniejsza organizacja obciążały głównie Francuzów, ich partnerzy mieli służyć tu tylko niezbędną pomocą. Kierowane do Polski maszyny musiały być uprzednio przystosowane do odmiennych nieco niż nad Sekwaną warunków eksploatacji (m.in. poprzez dostosowanie ich silników do spalania paliwa 87-oktanowego, $z$ dodatkiem $15 \%$ alkoholu). Nad Wisłę należało też wysłać olej rycynowy (40000 dm $\mathrm{dm}^{3}$ na sześć wypraw bombowych całości zgrupowania), bomby francuskie (na jedną wyprawę całego zgrupowania), amunicję do broni pokładowej (600 000 naboi do lotniczych karabinów maszynowych kl. 7,5 mm), dokumentację techniczną samolotu Amiot $143 \mathrm{M}$, zapasowe silniki, części zamienne oraz narzędzia. Część prac, dotyczących m.in. łączności radiowej, kodów, szyfrów, zasad sygnalizacji, danych meteorologicznych czy wreszcie celów planowanych ataków, obciążać miała obie strony ${ }^{76}$.

it SHD-DAA, 2 B 104, „Procès-verbal des conversations...” z 27 V 1939 r.; IPMS, Lot. A.I. 2/11, referat L. 396/Mob./S.Lotn.39 Sztabu Lotniczego Sztabu Glównego z 13 VII 1939 r.; T. Vi vier, La politique aéronautique..., s. 525n.; W. Grabowski, Plany użycia lotnictwa francuskiego na froncie polskim w 1939 r., „Gapa. Lotniczy Magazyn Historyczny” 2013, nr 6, s. 39. 
Przemieszczenie do Polski pięciu francuskich dywizjonów bombowych nie mogło mieć, rzecz jasna, dla spodziewanego konfliktu decydującego znaczenia. Samoloty Amiot $143 \mathrm{M}$, które miały wziąć udział w planowanej operacji, nie stanowiły już konstrukcji w pełni nowoczesnej, a ich realne możliwości bojowe były dość ograniczone. Francuski sojusznik istotnie nie miał jednak do dyspozycji innego użytecznego sprzętu, zaś skierowanie na wschód pięciu wspomnianych dywizjonów i tak stanowiłoby dla jego stosunkowo szczupłych sił bombowych poważny wysiłek. Choć polskie średnie bombowce PZL.37 „Łoś” pod każdym niemal względem przewyższały francuskich kuzynów, to w momencie zawierania majowego porozumienia lotnictwo Rzeczypospolitej posiadało tylko jeden liczący 18 maszyn ich dywizjon, drugi zaś znajdował się w zaawansowanym stadium organizacji. Pomoc ze strony zachodniego alianta, acz niedostateczna, liczebnie znacząco przewyższałaby więc siły własne ${ }^{77}$.

Uzgodnione porozumienie trzeba było jednak jeszcze zrealizować. Tu zaś dość szybko pojawiły się trudności. W połowie lipca gen. Vuillemin poinformował stronę polską, że z sześciu radiostacji S.I.F. 10B, na których dostawę Polacy nastawali w maju (dowiedziawszy się wówczas, że 18 zamówionych uprzednio egzemplarzy nie zostanie dostarczonych przed lutym 1940 roku), lotnictwo francuskie zdoła przekazać tylko jeden. Ponadto nad Wisłę trafić miało sześć radiostacji w nowej, właśnie oddanej do produkcji wersji S.I.F. 10C, co polska delegacja wcześniej już zaakceptowała. W tej korespondencji anonsowano też rychłą wysyłkę do Polski amunicji, oleju rycynowego oraz części zamiennych do francuskich samolotów i silników ${ }^{78}$.

Tydzień później z Paryża nadeszła natomiast informacja o określeniu terminu wykonania innej $z$ uzgodnionych w maju operacji: testowy lot samolotu Amiot 143 M (z numerem podskrzydłowym E.358), który do Polski przybyć miał z pominięciem Niemiec, drogą przez Belgię, Holandię, Danię i Szwecję, wyznaczony został na 5 sierpnia $^{79}$. Realizacja tego projektu nastąpiła ostatecznie z pewnym opóźnieniem, przy czym dokładna data przybycia maszyny do Warszawy nie jest jasna: płk Arbitre meldował przełożonym, że miało to miejsce 7 sierpnia o godzinie 18.30 , gen. Ujejski podawał takąż godzinę - ale 8 sierpnia ${ }^{80}$.

77 Uzgodnione rozmiary tej pomocy nawet w okresie ścisłej polsko-francuskiej współpracy z pierwszej połowy lat 20. XX w. nigdy nie przewyższały wielkości przyjętych w maju 1939 r. Zob.: W. Mazur, Pod wiatr..., s. 66nn.

in IPMS, Lot. A.I. 2/11, odpis pisma No 1876-3.O.S./E.M.A.A. gen. Vuillemina do pplk. Pinińskiego z 17 VII $1939 \mathrm{r}$.

79 SHD-DAA, 2 B 104, telegram szyfrowy gen. Mendigala do płk. Arbitre z 24 VII 1939 r.; IPMS, Lot. A.I. 2/11, pismo L. 325/tj.lot.30 ppłk. Pinińskiego z 24 VII 1939 r. i in. dok. W skład załogi bombowca wejść mieli: por. Debrobant (dowódca), por. Bouchard (oficer-mechanik), sierż. Couzou (pilot), plut. Petit (radiooperator), sierż. Legrand (mechanik).

*1) SHD-DAA, 2 B 104, telegram szyfrowy No 147 płk. Arbitre odebrany w Paryżu 9 VIII 1939 r., o godz. 8.30; IPMS, Lot. A.I. 2/11, pismo L. 853/S.Lot.Tj. gen. Ujejskiego do Szefa O. II SG z 9 VIII 1939 r. Omyłkę popełnił najpewniej albo płk. Arbitre, albo osoba rozszyfrowująca jego telegram. Trudno bowiem sądzić, by francuski attaché zwlekał aż półtorej doby $z$ wysłaniem depeszy informującej o przylocie. 
Pobyt francuskiej maszyny w stolicy Polski ustalony został wstępnie na osiem dni, przy czym przewidywano możliwość jego przedłużenia w razie potrzeby. Przyjęcie samolotu i jego załogi powierzono mjr. Gizaczyńskiemu. On też miał zorganizować w Samodzielnym Dywizjonie Doświadczalnym Instytutu Technicznego Lotnictwa z Okęcia ośmiodniowy kurs obsługi francuskiego sprzętu, z udziałem sześciu oficerów technicznych - dowódców obsługi plutonów węzłów lotnisk, sześciu szefów mechaników tych plutonów, wywodzących się z ITL specjalistów fotografii lotniczej, uzbrojenia i łączności radiowej. Przewidywano także, iż w kursie udział weźmie oficer z Wydziału Studiów Dowództwa Lotnictwa Ministerstwa Spraw Wojskowych oraz „pewna ilość oficerów i inżynierów z K[ierownictwa].Z[aopatrzenia].L[otnictwa]". W roli instruktorów wystąpić mieli francuscy specjaliści z załogi samolotu. Sztab Lotniczy Sztabu Głównego wnioskował, by przy tej okazji przestudiować praktycznie szereg elementów dotyczących uzbrojenia, wyposażenia i eksploatacji francuskiego bombowca ${ }^{81}$.

Czas pobytu Amiota nad Wisłą na prośbę polskiego dowództ wa pragnącego zrealizować w pełni wszystkie zaplanowane prace istotnie uległ przedłużeniu. Ostatecznie opuścił on Warszawę rano (o godz. 8.40) 19 sierpnia, zmierzając do Kopenhagi. Jego powrót do Paryża miał potrwać trzy dni $\mathrm{i}^{82}$.

Nadal jednak nie dotarły do Polski transporty niezbędnego dla zaopatrzenia francuskich dywizjonów materiału ani też konieczne dla wymiany danych szyfry. Co prawda ppłk Piniński 21 sierpnia zapowiadał, że transport bomb opuści Francję „specjalnym okrętem holenderskim 23-go, lub 24-go wprost do Gdyni”, ale 30 sierpnia w Warszawie nadal brak było o realizacji tej zapowiedzi jakichkolwiek informacji, ponaglano więc paryski attachat lotniczy o ich pilne przekazanie ${ }^{83}$.

Po południu 24 sierpnia zjawił się natomiast w Warszawie drogą wiodącą przez Kopenhagę wyznaczony na dowódcę skierowanej do Warszawy francuskiej misji lotniczej gen. Paul Armengaud wraz z trzema oficerami. W następnych dniach dołączali doń pozostali członkowie misji, w której skład weszli ostatecznie obok Armengauda: płk de Clerck, kapitanowie Albert de Ponton d'Amecourt oraz Rochot, a takie porucznicy Panem i Kraskowski. Informacje przekazane w ostatniej chwili pułkownikowi Arbitre wyjaśniały, że francuscy lotnicy przybyli w ramach realizacji uzgodnień z 27 maja, co sugerowało, że sformować mają w przyszłości sztab zgrupowania bombowego. Na razie jednak ich obecność wprawiła gospodarzy w pewną konsternację, przybyły do Warszawy niewiele wcześniej szef francuskiej misji wojskowej gen. Louis

"1 Ibidem, koncept pisma L. 834.mob. Dowództwa Lotnictwa MSWojsk. z 4 VIII 1939 r. i nast. dok.

*2 SHD-DAA, 2 B 104, telegram szyfrowy No 108 płk. Arbitre odebrany w Paryżu 9 VIII 1939 r. o godz. $15.50 \mathrm{i}$ in. dok.

*3. IPMS, Lot. A.I. 2/11, depesza szyfrowa L. 3227 ppłk. Pinińskiego do Szefa Lotnictwa Sztabu Głównego z 21 VIII 1939 r. i in. dok. Późnym wieczorem 30 sierpnia ppłk Piniński informował: „Materiał ładuje się, ma odejść w sobotę [tj. 2 września - dop. W.M.] do Konstancy" (ibidem, depesza szyfrowa do Szefa Sztabu Lotniczego, otrzymana w Biurze Szyfrów O. II SG 30 VIII 1939 r. o godz. 22.00). 
Faury miał wręcz pewne trudności z wyjaśnieniem im sensu takiej podwójnej reprezentacji. Niebawem jednak sytuację zaakceptowano, zaś sam Faury uzgodnił zasady współpracy ze swym kolegą, powierzając mu po prostu prowadzenie spraw dotyczących lotnictwa ${ }^{84}$.

Wbrew informacjom gen. Stachiewicza, który już po zakończeniu wojny podawał, że „z naszej strony wszystkie przygotowania do przyjęcia eskadr francuskich zostały zakończone", także nad Wisłą nie zdążono do końca sierpnia zrealizować wszystkich zaplanowanych zadań ${ }^{85}$. Przygotowywanie lotnisk dla mających przybyć znad Sekwany maszyn zostało podjęte późno, a ich realna przydatność ex post oceniana była sceptycznie przez samych wykonawców ${ }^{86}$. Wraz $z$ datowanym 23 sierpnia pismem przekazane zostało ppłk. Pinińskiemu dossier polskich lotnisk tajnych, jednak dane dotyczące operacyjnych lotnisk jawnych, na których lądować miały przybywające do Polski francuskie bombowce, 31 sierpnia wciąż jeszcze znajdowały się w Warszawie, dopiero przygotowane do ekspedycji. W materiałach tych znajdowały się mapy dziewięciu lotnisk z węzłów „Paul”, „Réné”, „Jean” oraz „Leon" ${ }^{\circ}$. Uwzględnienie wśród tych ostatnich rejonów położonej na wschód od Kowla Mielnicy oraz znajdującej się na wschód od Włodzimierza Wołyńskiego miejscowości Oździutycze wskazywało na to, że polskie dowództwo ostatecznie zdecydowało się na przesunięcie podstawowych baz francuskich bombowców (węzeł „Leon”) dalej jeszcze w głąb kraju - na Wołyń. Najwyraźniej Lubelszczyzna uznana została za rejon w razie niemieckiej agresji nie dość oddalony od przewidywanej linii frontu.

W końcu sierpnia przygotowane były już zasady łączności radiowej, w rękach Francuzów znajdował się m.in. przewidziany do szyfrowania łączności operacyjnej szyfr „384”. Choć gotowa była też łączność między polskimi radiostacjami i samolotami francuskimi, to $w$ Warszawie nie posiadano jeszcze przewidzianych do jej pro-

x SHD-DAA, 2 B 104, telegram szyfrowy za ministra i z jego rozkazu gen. Mendigala do płk. Arbitre 24 VIII 1939 r.; SHD-DAT, 7 NN 2/384, „Rapport No 175/S du 30 Août 1939” gen. Musse; 7 NN 2/407, kopia pisma No 167/S gen. Faury do gen. Gamelina z 24 VIII 1939 r.; P. A rme n gaud, Batailles politiques et militaires sur l'Europe. Témoignages, 1932-1940, Paris 1948, s. 95nn.; K. Mazu rowa, Skazani na wojnę, Warszawa 1979, s. $111 \mathrm{nn}$.; T. Vivi e r, La politique aéronautique..., s. 526n. W opublikowanym przez K. Mazurową wywiadzie Armengaud przytoczył treść rozmowy, którą miał odbyć z Gamelinem przed wylotem do Polski. Jak wspominał: „Mówił do mnie językiem dość enigmatycznym. Nie mam potrzeby wyjaśniać panu, że nie mogę nic uczynić dla obrony Polski, poza wysłaniem dziesięciu przewidzianych eskadr lotniczych, które będą panu podległe. Nie będę w stanie nic zrobić aż do wiosny 1940 r." (s. 112).

"s. W. Stachiewicz, op. cit., s. 117.

* Polscy dowódcy byli przekonani, że w równinnym na ogół kraju improwizowane lotnisko zawsze będzie można przygotować bez trudu systemem polowym. „Mimo ogromu pracy włożonej wątpię, czy na wypadek kilkudniowego deszczu lotniska te nie stałyby się raczej pułapką dla tych ciężkich maszyn" - oceniał w relacji stan przygotowywanych dla Francuzów lotnisk węzła lubelskiego były szef Służby Portów Lotniczych Dowództwa Lotnictwa MSWojsk. ppłk obs. Karol Friser (Lot. A.I. 29/2, niedatowana relacja).

k7 Września, Ozorków, Łęczyca, Ciechocinek, Radziejów, Poznań, Kłodawa, Oździutycze, Mielnica. 
wadzenia specjalnych kodów ${ }^{88}$. Nie zostały też dostarczone z Francji cztery ruchome, umieszczone na samochodach Renault radiostacje S.I.F. 10, przeznaczone dla węzłów lotnisk ${ }^{89}$. Choć zaś strona polska opracowała dokument zawierający określenie celów, które miałyby zostać zbombardowane przez francuskie lotnictwo bombowe podczas przelotu na Niemcami, to i ten materiał wciąż jeszcze znajdował się w Polsce, dopiero przeznaczony do wysyłki.

Zawierająca pakiet wspomnianych wyżej bardzo istotnych dokumentów poczta do Francji miała zostać dostarczona za pośrednictwem płk. de Clercka, pełniącego funkcję kuriera francuskiej ambasady oficera misji gen. Armengauda. Jego odlot do Paryża przez Kopenhagę zaplanowany był jednak dopiero na ranek 1 września. Wszystko więc wskazuje na to, że owe materiały nad Sekwanę nie dotarły - z pewnością zaś nie przed wybuchem wojny ${ }^{90}$.

W letnich miesiącach 1939 roku istotną sferę polsko-francuskich kontaktów w dziedzinie lotnictwa stanowiła też współpraca informacyjno-wywiadowcza. Także ona realizowana była w ramach uzgodnień przyjętych protokołem z 27 maja. 24 lipca powołał się na te ostatnie w piśmie do Szefa O. II SG, płk. dypl. Józefa Smoleńskiego, płk Arbitre, przekazując w załączeniu projekt "planu poszukiwań informacji” opracowany w czasie pokoju w Oddziale II Sztabu Generalnego Armée de l'Air oraz propozycje środków, które zapewnić by miały „stałe i szybkie” przesyłanie danych o aktywności sił powietrznych Rzeszy ${ }^{91}$.

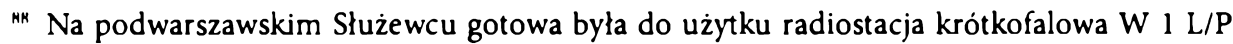
o mocy $1 \mathrm{~kW}$, przeznaczona do utrzymywania łączności między dowództwem lotnictwa polskiego i francuskiego. Rolę stacji zapasowej dla tej lączności odgrywać miała ulokowana na Okęciu radiostacja portowa 1 Pułku Lotniczego. IPMS, Lot. A.I. 29/2, niedatowane [1940 r.] „Sprawozdanie z działania radia w lotnictwie podczas wojny polsko-niemieckiej $1939 \mathrm{r}$." kpt. techn. Stanisława Bialowiejskiego. „Plan łączności dla korespondencji z Francją był opracowany niefachowo, między innymi w planie tym była surowo zakazana wszelka korespondencja próbna" - podawał autor sprawozdania.

ny Ich dostawa miała nastąpić do 1 października, zaś kolejnych dwóch egzemplarzy - do 1 listopada. W początkach sierpnia przewidywano, że jeszcze jedna radiostacja tego typu nadejdzie do Polski do 1 września i zostanie skierowana do dyslokowanego we Lwowie 6 Pułku Lotniczego w celu przeszkolenia personelu. IPMS, Lot. A.I. 2/10, „Protokół z konferencji odbytej w Dowództwie Lotnictwa - Wydział Zasobów w dniu 3.VIII.39 w sprawie współpracy lotnictwa francuskiego $z$ lotnictwem polskim". W niedatowanym [po 1 IX 1939 r.] zestawieniu materiału lotnictwa zamówionego we Francji (IPMS, Lot. A.I. 19/1) odnotowano, że jedna radiostacja S.I.F. 10B „na samochodzie z przyczepa" zostala wysłana do Polski 4 VII 1939 r. Ze sprawozdania kpt. Białowiejskiego (zob. poprzedni przypis) wynika, że istotnie "na krótko przed wojną" do Polski nadeszła radiostacja S.I.F. umieszczona na samochodzie ciężarowym $z$ francuskim numerem rejestracyjnym, z przyczepką (radiostacja posiadała własne niezależne źródło zasilania). Do wybuchu wojny znajdowała się ona w ITL.

91" IPMS, Lot. A.I. 2/11, koncept pisma L. 1054/Tjn.S.Lotn.39 Sztabu Lotniczego Sztabu Głównego do ppłk. Pinińskiego z 31 VIII 1939 r. Przygotowany do ekspedycji materiał obejmował też dokument precyzujący krótko zamierzony „sposób użycia lotnictwa polskiego".

${ }^{91}$ IPMS, Lot. A.I. 2/11, pismo No 85/S płk. Arbitre do płk. Smoleńskiego z 24 VII 1939 r. z załącznikiem. 
O ile sam plan przyjęty został bez zastrzeżeń, o tyle wątpliwości wzbudził proponowany system lączności, przewidujący bezpośrednią komunikację Sztabu Generalnego Armée de l'Air i Sztabu Lotniczego SG za pomocą skrótowych depesz szyfrowych, wędrujących linią łączącą polskie MSZ z Ambasadą RP w Paryżu. W zamian gen. Ujejski zaproponował wymianę wiadomości za pośrednictwem attachés lotniczych, co spotkało się z akceptacją strony francuskiej. Pułkownik Arbitre poprosił jedynie o przekazywanie codziennie na jego ręce informacji uzyskanych w dniu poprzednim, a raz na tydzień, w piątki - zbiorczych zestawień liczby jednostek lotniczych znajdujących się w poszczególnych podokręgach lotniczych Rzeszy. To z kolei zostało zaaprobowane przez jego polskiego partnera ${ }^{92}$.

Wykonywanie przedstawionych propozycji napotkało być może bliżej nieokreślone trudności, w depeszy wysłanej wieczorem 30 sierpnia ppłk Piniński zapytywał bowiem w imieniu francuskiego sztabu, „czy pułkownik Arbitre otrzymuje wiadomości o lotnictwie niemieckim ze wschodu, gdyż je nie przekazuje" ${ }^{\prime 93}$. Rzecz musiała jednak sprowadzać się do nieporozumienia, do dziś bowiem zachowały się $w$ archiwum w Vincennes zarówno przesyłane w tym okresie przez francuskiego attaché lotniczego codzienne raporty wywiadowcze, jak i tygodniowe syntezy otrzymywanych przezeń od Polaków danych ${ }^{94}$.

Brytyjski partner Francuzów, jeszcze w początkach kwietnia przeświadczony, że choć rozmowy międzysztabowe $z$ Warszawą są istotnie konieczne, to po stronie Zachodu powinni je prowadzić głównie bardziej doświadczeni przedstawiciele Paryża, już w połowie tego miesiąca zaczął zmieniać zdanie w tej kwestii. Przyczyniły się do tego przesłane nad Tamizę zawierające ocenę możliwości polskich sił zbrojnych raporty wojskowych attachés, towarzyszące tej korespondencji komentarze ambasadora Kennarda, wreszcie - sformułowana 12 kwietnia przez ambasadora Raczyńskiego propozycja strony polskiej95.

Polacy, pisał Strang w datowanym 18 kwietnia liście do Ismaya, przywiązują wielką wagę do świeżo nawiązanych stosunków ze Zjednoczonym Królestwem. Można się zastanawiać, czy są zadowoleni z pozostawienia wojskowych rozmów w gestii Francuzów, na pewno zaś, choćby ze względu na narodową dumę, oczekują bezpośrednich kontaktów z brytyjskim Sztabem Generalnym. Dodatkowy powód do podjęcia takich kontaktów stanowić może prawdopodobne oczekiwanie Warszawy na pomoc

${ }_{92}$ Ibidem, pismo L. 851/S.Lot.Tj. gen. Ujejskiego do płk. Smoleńskiego z 9 VIII 1939 r. i in. dok.

93 Ibidem, depesza szyfrowa do Szefa Sztabu Lotniczego, otrzymana w Biurze Szyfrów 30 VIII 1939 r. o godz. 22.00.

4 SHD-DAA, 2 B 97.

${ }^{45}$ Kennard sugestię podjęcia „sztabowych konsultacji” ze stroną polską przesłał do Londynu już 5 kwietnia, wtedy jednak mając na myśli głównie kwestie zbrojeniowe (TNA, FO 371/23144, pismo No 153/72/39 Kennarda do Sargenta z 5 IV 1939 r.). W sporządzonej 8 lipca w Foreign Office retrospektywnej notatce "The Question of Financial and Military Assistance for Poland" inicjatywę podjęcia rozmów międzysztabowych przypisano ministrowi Beckowi, który odpowiednią propozycję miał sformułować w rozmowie z Kennardem 14 kwietnia (TNA, FO 371/23145). 
w zakresie zbrojeń. Stąd też, stwierdzał Strang, szef Foreign Office jest generalnie przychylnie usposobiony do tej koncepcji - jeśli zostanie ona uznana za pożądaną, to odpowiednie kroki należałoby podjąć możliwie szybko, wykorzystując fakt pobytu w Londynie francuskich ekspertów ${ }^{46}$.

Wstępne decyzje najwyraźniej podjęto niezwłocznie. Jeszcze wieczorem tego samego dnia telegraficznie upoważniono Kennarda do poinformowania Becka, że Rząd Jego Królewskiej Mości rozważa kwestię rozmów międzysztabowych, zaś bardziej konkretny pogląd $w$ tej kwestii trafi nad Wisłę w czasie niezbyt odległym ${ }^{97}$.

Nazajutrz sprawa ewentualnych rozmów z polskim partnerem oraz stanowiska w tej sprawie Foreign Office stała się tematem obrad Podkomitetu Szefów Sztabów. Jego członkowie zwrócili uwagę na obciążenie Joint Planning Sub-Committee przez znajdujące się $\mathrm{w}$ toku lub przygotowywane rozmowy międzysztabowe. Uznając jednak za "niepraktyczne” powierzenie całości takich rozmów z polskim partnerem wyłącznie Francuzom, wystąpili z propozycją podjęcia ich za pomocą attaché wojskowych ${ }^{98}$.

Powyższa opinia trafiła znów do Foreign Office, gdzie jak się wydaje, przez krótki czas pozostawiono ją bez dalszego biegu. Ów okres zawieszenia przerwało 27 kwietnia przesłane do Stranga pismo płk. Hollisa z przypomnieniem stanowiska Szefów Sztabów i pytaniem, czy sprawa pozostaje aktualna. Odpowiedź, tym razem wystosowana bez większej zwłoki, okazała się twierdząca. Zagadnienie rozmów z Warszawą, wyjaśniał Strang, zostało przedyskutowane z szefem resortu, który podtrzymać miał uprzednio wyrażone zdanie. Zaakceptował też projekt podjęcia kontaktów międzysztabowych za pośrednictwem akredytowanych w Warszawie przedstawicieli wojskowych. Zauważył jedynie, że nie należy sprawiać wrażenia, iż Brytyjczycy zamierzają podjąć kontakty $z$ wykluczeniem równoległego podjęcia przez Francuzów takiej inicjatywy. Halifax stwierdził także, najwyraźniej odnosząc się do jakiejś wcześniej przedłożonej mu sugestii, że nie uważa za konieczne angażowania w powyższą inicjatywę autorytetu Gabinetu, choć sądzi, że lord Chatfield mógłby o niej poinformować premiera.

Równocześnie został przygotowany i przekazany do konsultacji czynnikom wojskowym szkic telegramu do ambasadora Kennarda - z poleceniem zakomunikowania powyższego stanowiska rządowi Rzeczypospolitej oraz zapowiedzią wezwania do Londynu attaché dla przekazania im odpowiednich instrukcji. Podkreślano przy tym konieczność zachowania zamierzonych rozmów w ścisłej tajemnicy ${ }^{94}$.

46 TNA, CAB 104/48, pismo C 4504l/G Stranga do Ismaya z 18 IV 1939 r. Kopie dokumentów z tej jednostki archiwalnej autor otrzymał od pana Tadeusza Zawadzkiego, któremu składa $z$ tej racji serdeczne podziękowania.

${ }^{7}$ Ibidem, telegram szyfrowy No 111 FO do Kennarda z 18 IV 1939 r., godz. 21.30.

9* TNA, CAB 53/11, „Minutes of the 290th Meeting, held on 19th April, 1939”, C.O.S./290th Mtg.

9y TNA, FO 471/23129, list Hollisa do Stranga z 27 IV 1939 r.; kopia pisma C 6157/G Stranga do Hollisa z 29 IV 1939 r. i in. dok.; CAB 53/49, nota C.O.S. 888 Ismaya z 28 IV 1939 r. Z wypowie- 
Zanim odbyło się zaplanowane na 1 maja posiedzenie Szefów Sztabów, którzy po raz kolejny mieli zająć się sprawą ewentualnych kontaktów międzysztabowych z Polską i podjąć $w$ tej kwestii decyzje, miało miejsce jeszcze jedno istotne dla tych decyzji wydarzenie. Jak informował 30 kwietnia Kennard w depeszy, która nad Tamizę dotarła przed wieczorem, dzień wcześniej w rozmowie z nim minister Beck wysunął propozycję bezzwłocznego podjęcia rozmów, najlepiej z udziałem przysłanej do Polski misji brytyjskich wojskowych ekspertów ${ }^{100}$.

1 maja Podkomitet Szefów Sztabów negatywnie odniósł się do sugestii Becka, za właściwe uznając - w wyraźnej w obawie, że ktoś może jednak ją podjąć - niezwłoczne rozpoczęcie przygotowań do rozmów prowadzonych za pośrednictwem attaché. Dalsza część dyskusji w tej kwestii miała przebieg niemalże anegdotyczny (za niepożądane uznano zaangażowanie $w$ realizację projektu oficerów reprezentujących w Warszawie marynarkę wojenną i siły powietrzne - obaj byli bowiem akredytowani także w Berlinie; koncepcja, by płk. Vachella zastąpił attaché lotniczy z Moskwy, po chwili uznana została także za chybioną), jednak sama idea kontaktów sztabowych ze stroną polską została zaaprobowana. Zebrani uznali, że należy wybrać odpowiednich oficerów lotnictwa i marynarki, a następnie skierować ich nad Wisłę, by wraz z ppłk. Swordem podjęli „konsultacje” z polskim sztabem. Wyniki tych ostatnich po powrocie delegatów miały być przedstawione Szefom Sztabów ${ }^{101}$.

Dzień później, na wniosek lorda Chatfielda, aprobatę dla stanowiska Szefów Sztabów wyraził Komitet Obrony Imperialnej, rzecz oddając jeszcze do akceptacji Halifaxa. Ten zgodę wyraził, nie po raz pierwszy zresztą, niemal natychmiast ${ }^{102}$.

Niebawem okazało się, że ppłk Sword jest obłożnie chory i jego osobisty udział w planowanych rozmowach w ciągu kilku najbliższych tygodni nie będzie zapewne możliwy. Stąd w telegramie do ambasadora Kennarda, który wysłany został ostatecznie dopiero po południu 5 maja, znalazła się informacja, że w skład wysyłanej do Warszawy wojskowej delegacji wejdą jedynie przysłani z Londynu oficerowie marynarki wojennej, sił lądowych oraz lotnictwa, zaś jeden z nich wyznaczony zostanie na szefa misji. Joint Planning Sub-Committee, który kilka godzin wcześniej zaaprobował treść szkicu depeszy przedstawionego przez Foreign Office, wyraził przy tej okazji opinię, że samych rozmów nie należy jednak podejmować przed uzyskaniem od Francuzów informacji o ich stanowisku co do zachowania zachodnich sojuszników

dzi Halifaxa wynika, że w końcu kwietnia 1939 r. Foreign Office nie posiadało informacji o podjętej już wówczas przez Francuzów inicjatywie wszczęcia ze stroną polską rozmów wojskowych.

1011 TNA, FO 471/23129, telegram szyfrowy No 133 Kennarda do FO z 30 IV 1939 r., godz. 14.29. "Jest to zgodne z naszymi własnymi propozycjami, z wyjątkiem tego, że my proponujemy, by rozmowy byly prowadzone przez naszych attaché wojskowych po ich wizycie w kraju dla odebrania instrukcji" - informowal Strang Cadogana 1 maja (ibidem, pismo C 6157/G).

101 TNA, CAB 53/11, „Minutes of the 292nd Meeting, held on Ist May, 1939”, C.O.S./292nd Mtg. Szefa delegacji - oficera posiadającego odpowiednią wiedzę strategiczną - miał zaproponować Joint Planning Sub-Committee, przedstawiając następnie kandydaturę do aprobaty Szefom Sztabów. Na tymże posiedzeniu zaakceptowano też zasady przygotowań do rozmów międzysztabowych $z$ Turcją, poświęcając im zresztą wyraźnie więcej uwagi.

1112 TNA, FO 471/23129, list Hollisa do Stranga z 3 V 1939 r. 
w razie przyjęcia przez Rzeszę defensywnej postawy na Zachodzie i skierowaniu jej ataku na Wschód. Kennard z powierzonego mu zadania wywiązał się niezwłocznie, jeśli wierzyć polskiej notatce z przeprowadzonej 6 maja rozmowy - wręcz z pewnym naddatkiem. Ambasador zaanonsować miał bowiem przyjazd delegacji "celem przeprowadzenia układów wojskowych $\mathrm{z}$ nami” już „w ciągu przyszłego tygodnia" (a więc do 14 maja). Być może jednak powyższe zapisy stanowiły raczej efekt swoistego życzeniowego myślenia niecierpliwie wyglądających gości z Londynu lokatorów pałacu Brühla ${ }^{103}$.

Niewątpliwie strona polska przyjęła zapowiedź przyjazdu brytyjskiej delegacji z zadowoleniem. Wkrótce zresztą poprosiła o możliwie szybkie przekazanie informacji o terminie jej przybycia. W Warszawie trwały przygotowania do rozmów $\mathbf{z}$ francuskim partnerem (o czym Brytyjczycy wciąż nie wiedzieli), a prawdopodobna równoczesność spotkań w Polsce i we Francji wymagała odpowiedniego dysponowania szczupłym gronem kompetentnych ich uczestników ${ }^{104}$.

Tymczasem przygotowania prowadzone $\mathrm{w}$ Londynie napotykały pewne przeszkody. Przede wszystkim nadal nieznane pozostawało oficjalne francuskie stanowisko w sprawie pomocy dla Polski jako ewentualnej pierwszej ofiary niemieckiej agresji. Nie mogąc oczekiwać na nie bez końca, wobec polskich nacisków zdecydowano się wstępnie określić termin wyjazdu delegatów na 19-20 maja. Informację tę natychmiast przesłano do ambasadora Kennarda, dodając, że trasa przejazdu w miarę możliwości zostanie wyznaczona z pominięciem terytorium Rzeszy ${ }^{105}$.

15 maja Joint Plannig Sub-Committee w obecności trójki oficerów wskazanych jako członkowie delegacji (Admiralicja: kmdr Henry Bernard Rawlings, Ministerstwo Wojny: ppłk Emilius H. Clayton, Ministerstwo Lotnictwa: ppłk Alexander Paul Davidson) przeprowadził dyskusję nad szkicem memorandum, które miało stanowić strategiczną podstawę rozmów ze stroną polską. Podkomitet, uznając, że planowane rozmowy dotyczyć będą głównie sił lądowych, w mniejszym stopniu lotnictwa, zaś marynarki wojennej tylko w ograniczonym zakresie, zaproponował objęcie przewodnictwa misji przez ppłk. Claytona, za dodatkowy jego atut uznając uprzedni kilkuletni pobyt $w$ Polsce $w$ charakterze attaché wojskowego oraz wyznaczenie go na szefa misji wojskowej w tym kraju w razie wojny ${ }^{106}$.

${ }^{1013}$ Ibidem, telegram szyfrowy No 140 Foreign Office do Kennarda z 5 V 1939 r., godz. 17.55; CAB 55/3, „Minutes of the Meeting held on [...] 5th May, 1939..., J.P. 259th Mtg.; CAB 104/48, pismo C 6524/G Stranga do Hollisa z 4 V 1939 r. i in. dok.; IPMS, A.11.49.WB/3, „Notatka z rozmowy Min. Arciszewskiego z Ambasadorem Brytyjskim w dniu 6 maja 1939". W powyższej notatce zapisano, że informacje Kennarda przekazane zostały gen. Stachiewiczowi.

104 TNA, FO 471/23129, kopia telegramu szyfrowego No 155 Kennarda do FO z 11 V 1939 r., godz. 14.26. Szefowie Sztabów wyrażali zadowolenie z faktu, że do rozmów dojdzie w Warszawie, a nie w Londynie. Jak informował Halifaxa Newall, niezbędne są głównie polskie informacje, zaś atmosfera nad Wisłą zdaje się bardziej sposobna do planowanej wymiany zdań. Zob.: ibidem, list Newalla do Halifaxa z 4 V 1939 r.

115 Ibidem, list Cornwall-Jonesa do Stranga z 12 V 1939 r. i in. dok.

116 Informacje o wcześniejszym pobycie Claytona nad Wisłą i jego stosunku do Polski zawiera szkic Andrzeja Suchcitza Pplk Emilius Clayton... 
Obawy Claytona budziła nieuchronna wręcz perspektywa skierowania doń przez gospodarzy pytania o postawę zachodnich sojuszników, w razie gdyby pierwsze uderzenie Rzeszy wymierzone zostało na wschód. Członkowie Podkomitetu mieli tu już jednak zawczasu przygotowaną odpowiedź: przewodniczący delegacji został poinformowany, że $w$ takim przypadku powinien wskazać Francuzów jako właściwych do udzielenia wyjaśnień, dodając uwagę, iż w Paryżu sprawa jest właśnie rozważana.

Wobec podniesionych przez ppłk. Claytona (i popartych przez kmdr. Rawlingsa) obaw co do polskiej "gadatliwości" (czy też, jak sformułowano to w memorandum "odmiennych od naszych standardów zachowywania tajemnicy"), za celowe uznano sporządzenie dodatkowej instrukcji, zawierającej wyjaśnienie, jak dalece gospodarze rozmów winni być informowani o brytyjskim potencjale wojskowym oraz planach jego rozbudowy. Zasugerowano wreszcie, by na czas trwania delegacji tymczasowo podwyższyć rangi wojskowe Claytona i Davidsona - odpowiednio do stopni brygadiera i pułkownika ${ }^{10 \tau}$.

W samym memorandum za główne założenie przyjęto, że wojna przeciw Niemcom we wschodniej części Europy prowadzona będzie wspólnymi siłami Polski i Rumunii. Jak podkreślono, z punktu widzenia Zachodu główną korzyść stanowić by tu miało zmuszenie Rzeszy do równoczesnych działań na dwóch frontach, przy czym użyteczność frontu wschodniego zależna jest przede wszystkim od jego trwałości.

W kolejnej części dokumentu omówiono aspekty sojuszniczej kooperacji w dziedzinie działań morskich, następnie zaś także lądowych i lotniczych. Pierwsza z wymienionych sfer nie jest w zasadzie istotna dla naszej analizy, nie została też za istotną uznana przez autorów brytyjskiego memorandum. Jak skonstatowano, polska flota wojenna, znacznie ustępująca niemieckiej pod względem wielkości, bardzo szybko pozbawiona zostanie baz, a tym samym choćby teoretycznych możliwości prowadzenia jakichkolwiek operacji w obrębie Morza Bałtyckiego. Zachodni sojusznicy nie będą w stanie udzielić jej na tym akwenie efektywnej pomocy, przynajmniej do czasu ewentualnego przystąpienia ZSRR do wojny po ich stronie.

Kwestia konfrontacji na lądzie i w powietrzu wymagała już jednak nieco szerszych wyjaśnień. Wedle brytyjskich sztabowców w pierwszych miesiącach wojny Francja zdolna byłaby do skierowania w metropolii do boju 86 dywizji, do których należałoby jeszcze doliczyć poważne siły rozmieszczone w Afryce Północnej. Potencjał brytyjski w tym czasie byłby wyraźnie mniejszy, sięgając w pierwszym półroczu konfliktu 6 dywizji regularnych oraz 10 terytorialnych, które do końca pierwszego roku wojny zasilone mogłyby zostać przez kolejnych 10 dywizji terytorialnych, przy czym powyższy program, jak zaznaczano, wciąż jeszcze znajduje się w stadium reali-

107 TNA, CAB 53/3, „Minutes of the Meeting held on [...] 15th May, 1939..., J.P. 253rd Mtg.; CAB 55/16, raport „Staff conversations with Poland” Joint Planning Sub-Committee J.P. 407 z 15 V $1939 \mathrm{r}$. W brytyjskim systemie stopni wojskowych ranga brygadiera umieszczona jest pomiędzy stopniami pułkownika i generała-majora. W systemie polskim nie ma bezpośredniej analogii, zwykle jednak uważana jest za odpowiednik stopnia generała brygady. Stąd w polskiej literaturze dotyczącej majowej misji Claytona $\mathrm{z}$ reguły występuje on jako generał. $\mathrm{W}$ sporządzonych $\mathrm{w}$ języku francuskim protokołach rozmów jego stopień określony został jako Le Brigadier Général. 
zacji. Polskie możliwości oszacowane zostały ze sporym naddatkiem - w 30 dniu po mobilizacji armia Rzeczypospolitej składać się miała wedle Brytyjczyków z 48 dywizji piechoty oraz 20 brygad kawalerii, a także 6-12 kolejnych dywizji zdatnych do zapewnienia państwu wewnętrznego bezpieczeństwa. W dodatku w walkę u boku Polaków miałaby zostać zaangażowana armia rumuńska, licząca po mobilizacji 22 dywizje piechoty, 3 dywizje kawalerii oraz 3 mieszane brygady górskie, a w następnych miesiącach zasilona prawdopodobnie przez kolejne jednostki, choć o mniejszej wartości bojowej ${ }^{108}$.

Możliwości Niemiec określono na 105-110 dywizji, z tego 77-80 najbardziej wartościowych dywizji pierwszej linii. Żadna z tych jednostek, zakładali Brytyjczycy, nie będzie musiała być wykorzystana do zapewnienia bezpieczeństwa wewnątrz Rzeszy, w tej roli wystąpią bowiem oddziały SS. Do kontroli obszarów Czech, Moraw i Słowacji Niemcy mogliby potrzebować około 10 dywizji, spekulowano, prosząc o skonfrontowanie wszystkich tych wyliczeń z danymi strony polskiej.

Konfrontacja danych zdawała się jeszcze bardziej pożądana w przypadku założeń co do podziału sił Rzeszy w momencie wybuchu konfliktu. W razie skierowania głównego uderzenia na Polskę, dość niepewnie spekulowali brytyjscy analitycy, na tym froncie Niemcy mogliby użyć około 40-45 dywizji, przeciw Rumunii kierując kolejne 15-17 jednostek, na froncie zachodnim zatrzymując 30-35, zaś w centralnej rezerwie 10-13.

Powielając znane już wcześniej stanowisko, w memorandum zaznaczono wyraźnie, że w razie skierowania niemieckiej ofensywy ku Polsce i Rumunii, które mogłyby zostać zaatakowane łącznymi siłami 60-65 dywizji, zachodni sojusznicy niemal na pewno nie będą w stanie pospieszyć ofiarom agresji z bezpośrednią pomocą. Wykorzystają jednak swe wojska lądowe i lotnict wo w celu zatrzymania na zachodzie części wrogich jednostek.

Jak jednak przyznawano, w przypadku ziszczenia się opisanego wyżej scenariusza, rokowania nie byłyby pomyślne. Armia niemiecka w stosunkowo krótkim czasie okupowałaby Rumunię, polską część Śląska, występ poznański oraz pomorski Korytarz. Dalsze jej postępy mogłyby być bardziej powolne, w miarę konsolidowania się polskiego oporu oraz wydłużania niemieckich linii komunikacyjnych. Niemniej jednak ze względu na ograniczone zasoby materiału wojennego ,jest problematyczne, czy Polacy i Rumuni będą w stanie zatrzymać pochód niemiecki i tym

IIK TNA, CAB 55/16, zał. „Draft memorandum” do raportu „Staff conversations with Poland” Joint Planning Sub-Committee J.P. 407 z 15 V 1939 r. Członkowie Joint Planning Sub-Committee zastanawiali się, czy mogą uwzględnić w swym memorandum dane uzyskane od Francuzów. Ostatecznie jednak uznali, że wszelkie podobne informacje i tak posiadaja już brytyjskie służby specjalne, nie zachodzi więc obawa nadużycia zaufania francuskiego sojusznika. Konstatowane przez Brytyjczyków atuty i słabości polskiej armii lądowej były już wyżej przedstawiane (dobre wyposażenie w nowoczesną broń, ale: słaba artyleria, nieodpowiednia obrona przeciwlotnicza, absolutna dominacja w transporcie ciągu konnego; „efektywność polskiej armii nie jest tak wysoka jak armii niemieckiej, ale oni [Polacy] biliby się dzielnie w obronie wlasnego terytorium"). 
samym stworzyć solidny front wschodni, chyba że w znacznej skali zostaną wsparci przez Rosję"109.

W razie skoncentrowania się wojennego wysiłku Rzeszy na wschodzie Europy, autorzy dokumentu nie przekreślali możliwości podjęcia po przeciwnej strony kontynentu aktywnych działań lądowych przeciw Niemcom. Nie dysponując tu jednak ani własnymi istotnymi możliwościami, ani nawet wciąż niedostępną wiedzą o zamysłach partnerów z drugiej strony Kanału, zauważali jedynie, zgodnie $\mathbf{z}$ instrukcją udzieloną Claytonowi w trakcie posiedzenia: „kwestia jest obecnie rozważana w Paryżu i Polacy mogliby zwrócić się w tej sprawie bezpośrednio do Francuzów". Co więcej, w dalszej części dokumentu wyjaśniano, że po zgromadzeniu odpowiednich zasobów pierwsza poważna ofensywa zachodnich aliantów skierowana zostanie przeciw Włochom - „prawdopodobnie w Libii"110.

Wobec separacji Polski i Wielkiej Brytanii, stwierdzano, koordynacja planów działan wojennych nie może być prosta. Planowane rozmowy służyć by miały w takim razie raczej ogólnemu poinformowaniu o celach obu stron oraz, w miarę możności, ustaleniu metod ścisłej ich łączności w czasie wojny. Omówienie systemu, który zapewnić by mógł sprawne i gwarantujące zachowanie tajemnicy przekazywanie informacji, brytyjscy sztabowcy uznali za jedno z głównych zadań wysyłanej do Polski delegacji. Dla ułatwienia porozumiewania się w czasie wojny Brytyjczycy proponowali wymianę misji wojskowych.

Ogólnym jednak zadaniem misji, jak instruowano jej uczestników, miałoby być podkreślenie, że w istniejącej sytuacji pomoc zachodnich sojuszników dla Polski i Rumunii mogłaby być jedynie pośrednia, co zresztą nie uczyni jej mniej wartościową. Jednak wojna wciąż nie jest nieuchronna: celem podejmowanych działań jest zapobieżenie wybuchowi konfliktu zbrojnego lub przynajmniej odroczenie tego wybuchu.

Strona polska $\mathrm{z}$ kolei miałaby wyłuszczyć swe własne problemy oraz oczekiwania odnośnie do zachodniej asysty. Sama delegacja nie miała jednak prawa zaciągania zobowiązań. Wszelkie kwestie wykraczające poza jej bardzo ograniczone kompetencje po powrocie miały być przedstawione w Londynie, dla rozważenia i sformułowania dalszych instrukcji.

Choć spora część przedstawionych powyżej zagadnień pośrednio odnosiła się także do lotniczych perspektyw współpracy, treści dotyczące wprost sił powietrznych zajmowały $\mathrm{w}$ dokumencie relatywnie niewiele miejsca. Jego autorzy podkreślali, zgodnie ze znaną nam już polityką, że choć ze strony przeciwnika spodziewać się można wykroczenia poza regulujące zasady wojny powietrznej traktatowe ograniczenia, to strona brytyjska nie zamierza inicjować jakiejkolwiek podobnej akcji. Jej własne oraz francuskie działania bombowe ograniczone więc zostaną do obiektów ściśle wojskowych, choć jeśli Niemcy rozpoczną nieograniczoną wojnę powietrzną, zachodnie rządy rozważą rewizję tej polityki.

I1y Ibidem.

1II) Ibidem. 
W tym kontekście zaniepokojenie Londynu budziła słabość polskiej obrony przeciwlotniczej. Polski partner miał w szczególności zostać zapytany, jak - wobec spodziewanych ciężkich ataków Luftwaffe na jego centra przemysłowe - wyobraża sobie organizację zaopatrzenia swych wojsk. Przy tej okazji (a także kilku innych) formułowano niedwuznaczną sugestię, że niezależnie od odrazy, jaką w polskim sztabie budzi perspektywa odwołania się do „rosyjskiej pomocy”, sojusznik ze wschodu powinien rozważyć potraktowanie ZSRR jako źródła materiału wojennego wszelkich kategorii ${ }^{11}$.

Rozmiary niemieckich sił bombowych, szacowanych na 1715 maszyn dalekiego zasięgu, brytyjscy analitycy podkreślili także przy okazji porównywania lotniczych zasobów obu stron spodziewanego konfliktu (zob. tab. 2). Członkom kierowanej nad Wisłę delegacji zwrócono przy tym uwagę, ponownie uwzględniając zastrzeżenia Claytona, na konieczność zachowania dyskrecji w odniesieniu do danych na temat strony brytyjskiej czy francuskiej, a także na fakt, że z kolei zbytnia w tej kwestii powściągliwość może być odebrana negatywnie, paraliżując rozmowy. W razie wątpliwości w tej kwestii należało więc zwracać się do Londynu po szczegółowe instrukcje.

Formalnym zakazem ujawnienia gospodarzom wizyty objęto natomiast szczegółowe informacje o programach rozbudowy brytyjskich sił powietrznych. Członkowie delegacji zostali jednak poinformowani, że w okresie do kwietnia 1941 roku przewidywane jest wyposażenie sił powietrznych metropolii w około 2500 samolotów wszystkich klas, z zapewnieniem pełnej zakładanej rezerwy. Natomiast do kwietnia 1940 roku możliwości mobilizacyjne miałyby objąć ponad 800 bombowców (ze znacznym udziałem ciężkich) oraz ponad 600 myśliwców - „z odpowiednią rezerwą"112.

W razie polskich nacisków uznano natomiast za możliwe przekazanie danych o bieżącej produkcji brytyjskiego przemysłu lotniczego, która - jak podano w tym dokumencie - wynosi miesięcznie około 500 maszyn i stale rośnie. Przy tej okazji autorzy zaznaczyli, że samoloty bombowe i myśliwskie stanowią tylko $50 \%$ podanej wielkości, zaś znacząca część nowych maszyn wykorzystywana jest do budowy rezerw, przezbrajania jednostek użytkujących dotychczas sprzęt przestarzały, pokrywania bieżących strat eksploatacyjnych czy szkolenia lotników.

Stosunkowo niewielkie lotnictwo wojskowe Rzeczypospolitej nie budziło zbytniego zainteresowania Brytyjczyków, tym bardziej że zdawali sobie oni sprawę z tego, iż zostanie ono użyte głównie do współpracy $z$ armią lądową. W memoriale dano jednak wyraz wyrażanej już od dłuższego czasu nad Tamizą nadziei na wykorzystanie

111 Ibidem. W innym fragmencie memoriału jego autorzy niechęć do zbliżenia z ZSRR wiązali m.in. z polityczną taktyką Warszawy, która - jak zakładali, podobnymi kontaktami nie chciałaby drażnić Niemców. Kierowanej nad Wisłę delegacji polecano więc wybadać stosunek polskiego sztabu do tego zagadnienia w sytuacji, w której Rzeczpospolita już znajdowałaby się w stanie wojny z Rzeszą.

112 Ibidem. 
polskich samolotów bombowych do ataków na pewne szczególnie ważne obiekty ze wschodniej części Niemiec, jak Berlin czy Szczecin.

W tym czasie przygotowania do planowanych rozmów prowadzono także nad Wisłą. Sporządzane $\mathrm{w}$ Warszawie analizy były przy tym co prawda (co dziwić nie powinno) znacznie mniej rozbudowane i tematycznie rozległe od powstających w Londynie, ale za to zdecydowanie bogatsze w konkrety. Opracowany w Sztabie Lotniczym Sztabu Głównego „Projekt rozmów polsko-angielskich w zakresie lotnictwa" zawierał m.in. wyszczególnienie informacji, które miałyby zostać przy tej okazji udostępnione przybyłym do Polski oficerom, oraz kwestii wartych omówienia $w$ trakcie oficjalnych $z$ nimi konwersacji. Wśród tych pierwszych znalazły się dane o lotnictwie polskim (stan liczebny ${ }^{113}$, położenie garnizonów i lotnisk jawnych, informacja o przygotowywaniu kolejnych lotnisk operacyjnych) oraz koncepcji jego wykorzystania w czasie wojny, a także informacje o lotnictwie niemieckim (i propozycja podjęcia stałej współpracy w zakresie wymiany takich wiadomości). Równocześnie wskazywano płaszczyzny, w których pożądana byłaby współpraca sił powietrznych obu partnerów. Podkreślano przy tym, że w razie skierowania przeciw Polsce głównego niemieckiego uderzenia „istotnym odciążeniem frontu polsko-niemieckiego może być tylko natychmiastowe działanie lotnictwa mocarstw zachodnich" [podkr. oryg. - W.M.], przy czym musi być ono szybkie, silne i sięgać możliwie daleko w głąb terytorium wroga, godząc w ważne elementy jego wojennego potencjału (lotnictwo, magazyny, przemysł wojenny). Dla podjęcia podobnych działań, szczególnie wobec celów nieosiągalnych z zachodu, strona polska oferowała bazy położone na jej własnym terytorium ${ }^{114}$.

Drugą $\mathrm{z}$ postulowanych sfer współpracy Warszawy i Londynu miałaby stać się współpraca materiałowa, a przede wszystkim zabiegi o sprzedaż przez Brytyjczyków samolotów myśliwskich i bombowych lekkich, „których zapas jest u nas niewystarczający"115.

113 Ostatecznie zaproponowano przedstawienie brytyjskiej delegacji danych zafałszowanych, zwiększając m.in. liczebny potencjał lotnictwa bombowego, zmniejszając zaś - liniowego i myśliwskiego. W tych ostatnich przypadkach chodzilo o uzasadnienie planowanego zakupu samolotów brytyjskich.

114 IPMS, Lot. A.I. 2/15, niedatowany [przed 13 V 1939 r.] referat L. 389/S.Lotn.tj. Sztabu Lotniczego SG.

115 Ibidem. 
Tab. 3. Jednostki bojowe i samoloty polskiego lotnictwa wojskowego w początkach maja 1939 roku, stan rzeczywisty

\begin{tabular}{|c|c|c|c|c|c|}
\hline \multirow{2}{*}{ Rodzaj lotnictwa } & \multirow{2}{*}{$\begin{array}{l}\text { Dy- } \\
\text { ony }\end{array}$} & \multirow{2}{*}{$\begin{array}{l}\text { Eska- } \\
\text { dry }\end{array}$} & \multicolumn{2}{|c|}{ Samoloty } & \multirow{2}{*}{ Uwagi } \\
\hline & & & I linii & Zapas & \\
\hline Bombowe „toś" & 1 & 2 & 18 & 48 & $\begin{array}{l}\text { Drugi dyon w trakcie organizacji. Trzeci } \\
\text { dyon powstanie do } 1 . I V .40 \text {. Ilość samo- } \\
\text { lotów do } 1 . \text { VII. } 39 \text { wyniesie/wzrośnie do } \\
110\end{array}$ \\
\hline Liniowe "Karaś" & 4 & 12 & 124 & 71 & $\begin{array}{l}5 \text { esk. zlikwidowano w grudniu } 38 \text {. Z za- } \\
\text { mówienia budż. } 39 / 40 \text { przybędzie } \\
100 \text { samol. „Sum” } \\
\end{array}$ \\
\hline Myśliwskie „F11" & 7 & 15 & 157 & 86 & W tym 64 samoloty P.7 małej wartości \\
\hline $\begin{array}{l}\text { Towarzyszące } \\
\text { „R.XIII" }\end{array}$ & - & 12 & 84 & 95 & $\begin{array}{l}6 \text { esk. zlikwidowano w grudniu } 38 . \\
6 \text { esk. w trakcie przezbrajania na "Cza- } \\
\text { ple”, których mamy } 64 \text { szt. Zamówiono } \\
2 \text { budż. } 39 / 40-150 \text { "Mew" }\end{array}$ \\
\hline Szkolne & - & - & - & 1160 & \\
\hline Razem & 12 & 41 & 383 & & \\
\hline
\end{tabular}

Tab. 4. Jednostki bojowe i samoloty polskiego lotnictwa wojskowego w początkach maja 1939 roku. Stan proponowany do informacji Anglików

\begin{tabular}{|l|c|c|c|c|l|}
\hline \multirow{2}{*}{ Rodzaj lotnictwa } & \multirow{2}{*}{ Dyony } & Eska- & \multicolumn{2}{|c|}{ Samoloty } & \multicolumn{1}{|c|}{ Uwagi } \\
\cline { 3 - 5 } & & dry & Ilinii & Zapas & \\
\hline Bombowe & 2 & 4 & 36 & $100 \%$ & $\begin{array}{l}\text { Pod względem ilości jedn. odpowiada } \\
\text { stanowi na 1.IV.1940. Pod względem } \\
\text { ilości samolotów z dn. 1.VII.1939 }\end{array}$ \\
\hline $\begin{array}{l}\text { Liniowe bombo- } \\
\text { we lekkie i rozpo- } \\
\text { znania dalekiego }\end{array}$ & 8 & 17 & 178 & $40 \%$ & $\begin{array}{l}\text { Pod względem ilości jedn. stan } \\
\text { zrudnia 38 r. Mały zapas motywuje } \\
\text { konieczność zakupu }\end{array}$ \\
\hline Myśliwskie & 7 & 15 & 157 & $40 \%$ & $\begin{array}{l}\text { Jak stan rzeczywisty. Mały zapas mo- } \\
\text { tywuje potrzebę zakupu }\end{array}$ \\
\hline Obserwacyjne & - & 18 & 126 & $100 \%$ & $\begin{array}{l}\text { Pod względem ilości jedn. odpowiada } \\
\text { stanowi z grudnia 38 }\end{array}$ \\
\hline Szkolne & & & & 1200 & $\begin{array}{l}\text { Nieznacznie zwiększy się stan rzeczy- } \\
\text { wisty }\end{array}$ \\
\hline Razem & $18[$ sic!] & 56 & 497 & & \\
\hline
\end{tabular}

Źródło: IPMS, Lot. A.I. 2/15, niedatowany [przed 13 V 1939 r.] referat L. 389/S.Lotn.tj. Sztabu Lotniczego SG. 
Tab. 5. Personel latający zawodowy polskiego lotnictwa wojskowego w początkach maja 1939 roku

\begin{tabular}{|l|c|c|l|c|c|}
\hline \multicolumn{3}{|c|}{ Stan rzeczywisty } & \multicolumn{3}{c|}{ Stan proponowany116 } \\
\hline Specjalnośc & $\begin{array}{c}\text { Ofice- } \\
\text { rowie }\end{array}$ & $\begin{array}{c}\text { Pod- } \\
\text { oficerowie }\end{array}$ & \multicolumn{1}{|c|}{ Specjalnośc } & $\begin{array}{c}\text { Ofice- } \\
\text { rowie }\end{array}$ & $\begin{array}{c}\text { Pod- } \\
\text { oficerowie }\end{array}$ \\
\hline Piloci & 408 & 567 & Piloci & 568 & 712 \\
\hline Obserwatorzy & 473 & - & Obserwatorzy & 492 & - \\
\hline $\begin{array}{l}\text { Strzel.[cy] samol. } \\
\text { [otowi] }\end{array}$ & - & 122 & $\begin{array}{l}\text { Strzel.[cy] samol. } \\
\text { [otowi] }\end{array}$ & - & 258 \\
\hline
\end{tabular}

Źródło: IPMS, Lot. A.I. 2/15, niedatowany [przed 13 V 1939 r.] referat L. 389/S.Lotn.tj. Sztabu Lotniczego SG.

Tymczasem 17 maja w Londynie, na 297. posiedzeniu swego Podkomitetu, Szefowie Sztabów zajęli się ponownie sprawą rozmów ze swoimi polskimi odpowiednikami. Na spotkaniu obecny był także ppłk. Clayton, jednak szczególną aktywność wykazywał Air Marshal Newall, najpierw wyrażając obawę, że jego zdaniem Polacy nie zawsze są skłonni zatrzymywać dla siebie powierzone im $w$ tajemnicy informacje, następnie zaś postulując, by płk W. Fraser zebrał w Paryżu informacje o rozmowach, jakie prowadzi tam gen. Kasprzycki. Dane te miałyby następnie być przekazane do wiadomości i ewentualnego użytku płk. Claytona, zapewne już w trakcie jego pobytu w Polsce.

Zebrani zgodzili się z tą ostatnią propozycją, zaś gen. Ismay niezwłocznie przekazał telefoniczne dyspozycje do stolicy Francji. Następnie zaś zajęto się analizą zaproponowanego przez Joint Planning Sub-Committee tekstu memorandum dla kierowanej nad Wisłę delegacji, wprowadzając doń poprawki, ostatecznie zaaprobowano skład misji oraz wyznaczoną na 18 maja datę opuszczenia przez nią Londynu, przyjęto wreszcie koncepcję czasowego podniesienia wojskowej rangi Claytona ${ }^{11 \overline{ }}$.

116 „Stan proponowany jest taki, jaki podano oficjalnie attaché francuskiemu. Odpowiada w przybliżeniu stanowi, jaki zostanie osiągnięty w ciągu bieżącego roku".

11: TNA, CAB 53/11, „Minutes of the 297th Meeting, held on 17th May, 1939”. Dzien później ambasador Phipps istotnie przesłał do Kennarda (a równocześnie z tym samym tekstem Fraser do Claytona) ogólną informację o przebiegu paryskich rozmów Kasprzyckiego. Niebawem przekazana została do War Office także przywoływana już wyżej kilkakroć korespondencja Frasera do Pownalla z tąż samą datą (TNA, CAB 104/48, kopia telegramu szyfrowego bez numeru Phippsa do Kennarda z 18 V 1939 r.). Szefowie Sztabów wydawali się wyraźnie zaskoczeni informacją o wizycie Kasprzyckiego, choć Foreign Office dysponował nią już od kilku dni, powiadomiony wysłaną jeszcze późnym wieczorem 11 maja depeszą Kennarda, któremu z kolei wiadomość tę przekazał w zaufaniu Noël (TNA, FO 371/23143, depesza szyfrowa Kennarda z 11 V 1939 r., godz. 19.50). Sami Brytyjczycy o wyjeździe delegacji Claytona do Warszawy zaproponowali oficjalnie poinformować Francuzów 16 maja. Trzy dni później do Londynu nadeszła "ogólna zgoda" konsultowanego w tej kwestii polskiego rządu (ibidem, kopia telegramu szyfrowego No 162 FO do Kennarda z 16 V 1939 r., godz. 16.30 i in. dok.). Jednak Noël o przyjeździe misji do Warszawy poinformował Paryż dopiero wieczorem 25 maja, podkreślając polskie dążenie do utrzymania tego faktu w tajemnicy (AD, Pologne 310, telegram przychodzący No 834 Noëla do MAE z 25 V 1939 r., godz. 20.50). 
Finalna wersja memorandum nie różniła się zasadniczo od formy nadanej mu dwa dni wcześniej przez Joint Planning Sub-Committee. Wprowadzone zmiany dotyczyły m.in. wojennych przygotowań brytyjskich sił lądowych, w których charakterystyce porzucono rozróżnienie na dywizje regularne i terytorialne, dodając też jednoznaczną informację, że pierwszych sześć jednostek zostanie przerzuconych do Francji „od razu” po wybuchu wojny. Z kolei w krótkiej analizie sił polskich opuszczono zdanie, w którym ich efektywność uznano za ustępującą armii niemieckiej, choć poważną w obronie własnego kraju. Nieco zubożona została wreszcie treść fragmentu dotyczącego planów rozbudowy brytyjskich sił powietrznych. Wszystkie te posunięcia oraz zastrzeżenia co do zachowania tajemnicy stanowiły jednak tylko dodatkowe środki ostrożności. Dokument opatrzony został bowiem umieszczoną na samym początku tekstu i bardzo wyraźnie podkreśloną informacją: „memorandum ma być wykorzystane przez Delegacje jako instrukcja i NIE powinno być przekazane Polakom"118.

Gdy gen. Ismay kierował wyżej wspomniany tekst do (bardzo skądinąd ograniczonej) dystrybucji, bryg. Clayton i towarzyszący mu oficerowie znajdowali się już zapewne w drodze do Warszawy. Zaokrętowani wieczorem 18 maja na SS „Baltrover”, do Gdyni dotrzeć mieli rano 22 maja, zaś do Warszawy - jeszcze tego samego dnia, pół godziny przed północą. Już w Polsce dopadła Claytona depesza gen. Ismaya z poleceniem natychmiastowego zniszczenia wręczonych mu do przestudiowania podczas podróży dwóch „wyjątkowo tajnych dokumentów” zawierających uzgodnioną ze stroną francuską strategię prowadzenia wojny. „On [Clayton] nie potrzebuje ich do prowadzenia rozmów sztabowych" - wyjaśniał Ismay sens tej dyspozycji Foreign Office. I dodawal - sensownie, acz w zaistniałych okolicznościach nielogicznie, najwyraźniej zdenerwowany możliwością, że polska "niedyskrecja” posunie się do przeszukania bagaży brytyjskich gości: „Dla tych konwersacji byłoby w istocie lepiej, gdyby on nie miał zbyt szczegółowej wiedzy o ich zawartości". W południe dnia następnego ambasador Kennard wysłał $w$ imieniu Claytona do Londynu depeszę $\mathbf{z}$ lakonicznym potwierdzeniem realizacji polecenia: action taken ${ }^{119}$.

W tym czasie trwało już rozpoczęte o godzinie 10.00 pierwsze $z$ oficjalnych posiedzeń rozmów międzysztabowych. Treść tych ostatnich, podobnie jak było to w przypadku wcześniejszych o kilka dni rozmów polsko-francuskich, w historiografii jest

114 TNA, CAB 53/49, "Memorandum for the guidance of the Unied Kingdom Delegation to the Anglio-Polish staff conversations, 1939", zal. do noty C.O.S. 909 Ismaya z 18 V 1939 r. Oprócz memorandum Claytonowi wręczono dokument Industrial Intelligence Centre zawierający analizę możliwości jak najdłuższego wykorzystania przez Polskę jej zasobów w wojnie z Niemcami, kopię aide-memoire ambasadora Raczyńskiego (z 12 maja, w sprawie kredytu zbrojeniowego dla Polski w wysokości $60 \mathrm{mln}$ funtów) oraz kopie dwóch dokumentów przyjętych podczas międzysztabowych rozmów brytyjsko-francuskich: A.F.C. (J) 19 - dotyczącego ogólnej strategii prowadzenia wojny i A.F.C. (J) 56 - zawierającego wspólne stanowisko Londynu i Paryża odnośnie do skutków udziału „innych europejskich państw” (w tym Polski) w spodziewanym konflikcie zbrojnym.

119 TNA, CAB 104/48, kopia listu Cornwall-Jonesa do Stranga z $18 \mathrm{~V} 1939$ r. i in. dok.; FO 371/23129, list Ismaya do Ivone Kirkpatricka [urzędnika Departamentu Centralnego FO] z 22 V $1939 \mathrm{r}$. 
znana w stopniu wystarczającym. I tym razem jednak przyjdzie nam się odnieść do niektórych kwestii podjętych w trakcie tej stosunkowo długiej, bo zakończonej dopiero 30 maja, serii konferencji ${ }^{120}$.

Najbardziej z oczywistych względów interesujące nas kwestie dotyczące lotnictwa pojawiły się już podczas pierwszego posiedzenia, zajmując sporą jego część. Generał Stachiewicz poprosił, by przedstawiciele strony brytyjskiej wyjaśnili, czy w razie wojny brytyjskie lotnictwo podejmie natychmiastową akcję przeciw Rzeszy. Z odpowiedzi Davidsona i Claytona wynikało, że przyjęta w takim wypadku przez Brytyjczyków postawa pozostanie defensywna, choć bynajmniej nie pasywna, w grę wchodzi bowiem zbombardowanie niemieckich baz lotniczych oraz zakładów produkcyjnych. Z drugiej jednak strony, wyjaśniali goście z Londynu, działania brytyjskie ograniczą się do ataków na cele ściśle militarne, z wykluczeniem możliwości powodowania przy tej okazji strat wśród ludności cywilnej. Gdy jednak gen. Stachiewicz spróbował dociec, jaka będzie reakcja dowódców znad Tamizy na podjęcie przez Rzeszę nieograniczonej wojny powietrznej, został zapewniony, że spotka się to ze zniesieniem wszelkich krępujących brytyjskie akcje ograniczeń oraz odpłatą tą samą monetą, nawet $w$ razie gdyby ofiarą niemieckiego barbarzyństwa paść mieli wyłącznie polscy cywile ${ }^{121}$.

Dalsze pytania Szefa Sztabu Głównego dotyczyły m.in. możliwego zasięgu brytyjskiego lotnictwa (odpowiedź Davidsona: $z$ baz we Francji pewna jego część mogłaby zapewne dotrzeć do granicy Polski), wielkości sił przeznaczonych do operowania z baz francuskich (Clayton: 6 dywizjonów po 16 samolotów), ogólnej liczby brytyjskich eskadr (Clayton: pełna liczba samolotów bombowych I linii wynosi 524), wykorzystania dyslokowanych we Francji brytyjskich maszyn przeciw Włochom (Clayton: nie jest to przewidywane), bieżącej brytyjskiej produkcji lotniczej (Clayton: przy produkcji na obecnym poziomie do 1941 roku liczba maszyn pierwszej linii sięgnie 2500 samolotów, przy rezerwach w wysokości 100-200\%).

Następnie gen. Stachiewicz sformułował propozycję wykorzystania do brytyjskich działań baz na terytorium Rzeczypospolitej - czy to dla zaopatrywania bombowców przeprowadzających wahadłowe ataki na cele w Rzeszy, czy też w celu dłuższego ich stacjonowania w Polsce i podejmowania $z$ jej obszaru operacji przecin obiektom we wschodniej części Niemiec. Ostrożna odpowiedź Claytona zawierała

120 Protokoły z rozmów w oryginalnej wersji francuskiej opublikowano w roku 1957 na la. mach londyńskiej "Bellony” (Protokóly polsko-brytyjskich rozmów sztabowych, odbytych w War. szawie w maju 1939, z. 3-4, s. 25nn.). Tłumaczenie polskiej części tych protokołów: Wojna obronnc Polski 1939. Wybór źródel, dok. 70-72, s. 264nn., dok. 74-75, s. 279nn. Zwięzłe omówienie przebie gu wspomnianych rozmów znaleźć można w: A. Prazmowska, op. cit., s. 94n. oraz M. Zgór niak, Europa w przededniu wojny..., s. 441. Interesującą ich analizę przeprowadził też ostatnic M. Kornat (Polityka zagraniczna Polski..., s. 498nn.). Syntetyczne streszczenie wątków poświęco nych lotnictwu: Polskie Sily Zbrojne w drugiej wojnie światowej, t. 1: Kampania wrześniowa 1939 cz. 1: Polityczne i wojskowe polożenie Polski przed wojna, Londyn 1951, s. 103nn.

121 Ten fragment obrad dość dokładnie przedstawili autorzy wymienionej w poprzednin przypisie części Polskich Sil Zbrojnych... (s. 104). Por. też: W. Stachiewicz, op. cit., s. $12 \ln$. 
uwagę, że podobne rozwiązanie wymagałoby dłuższych przygotowań, głównie technicznych i logistycznych. Stąd, stwierdził przewodniczący brytyjskiej delegacji, w początkowej fazie wojny podobne działania nie wydają się możliwe, nie można ich jednak wykluczyć w okresach późniejszych. Pomimo nalegań strony polskiej w dalszej części rozmowy Clayton pozostał sceptyczny, deklarując jedynie, że problem wart jest przestudiowania. Zgłaszane przezeń zastrzeżenia wsparł ostatecznie także milczący od dłuższego czasu Davidson, dowodząc, że w obecnej sytuacji podobna forma pomocy dla Polski nie jest możliwa, choćby $z$ tej racji, że tylko pewna część brytyjskich samolotów dysponuje odpowiednim zasięgiem. Niezrażony takim stanowiskiem gen. Stachiewicz zapowiedział powrót do tej sprawy w późniejszym czasie ${ }^{122}$.

W następnych dniach - 24 i 25 maja - problematyce lotniczej poświęcono dwa specjalne posiedzenia rozmów. Stronę brytyjską reprezentował w ich trakcie płk Davidson, delegacji polskiej przewodniczył gen. Ujejski, a towarzyszyli mu standardowo niemal uczestniczący w tym czasie w podobnych spotkaniach majorzy Bobiński i Kiecoń oraz przybyły $z$ Londynu ppłk Kwieciński. W trakcie pierwszego ze wspomnianych posiedzeń omówiono funkcjonowanie polskiego przemysłu lotniczego oraz zamiary Sztabu Głównego co do wykorzystania sił powietrznych w spodziewanej wojnie. Generał Ujejski wyjaśnił, że w trakcie konfliktu zbrojnego własne lotnictwo będzie używane oszczędnie, działając w związku z operacjami wojsk lądowych, zaś głębokie akcje bombowe nie są przewidywane ${ }^{123}$.

Szef Sztabu Lotniczego podkreślił też, że w razie skoncentrowanego ataku Niemiec na Polskę jedyną pomoc dla tej ostatniej ze strony aliantów zachodnich stanowić mogą jak najsilniejsze, sięgające możliwie daleko w głąb Rzeszy bombardowania lotnicze. $\mathrm{Z}$ protokołu obrad nie wynika jednak, by wypowiedź ta została $\mathrm{w}$ jakikolwiek sposób skomentowana przez płk. Davidsona, który przeszedł w tym czasie do omawiania ewentualnych polskich działań lotniczych w przypadku podjęcia przez Niemców ofensywy na froncie zachodnim. Usłyszawszy odpowiedź, że w takim scenariuszu polska akcja w powietrzu nie ulegałby istotniejszej zmianie, brytyjski oficer zaproponował dokonanie przez obie strony wymiany informacji o niemieckich obiektach - potencjalnych celach bombardowań.

Końcowa faza spotkania z 24 maja poświęcona została informacjom o własnych siłach partnerów (tu płk Davidson wykorzystał dane z brytyjskiego memorandum) oraz danym o lotnictwie niemieckim. W przypadku lotnictwa bombowego Rzeszy liczby przedstawione przez stronę brytyjską (1720 samolotów nowych typów i 320 starszych maszyn) okazały się wyraźnie wyższe od polskich (896 klasycznych samolotów bombowych oraz 210 bombowców nurkujących w eskadrach, dodatkowo w eskadrach rezerwa z 351 maszyn - łącznie 1467 samolotów). Nieco mniejsza różnica wystąpiła w kategorii samolotów myśliwskich, choć i tu obliczenia brytyjskie

122 Protokóly polsko-brytyjskich rozmów sztabowych..., s. 28nn. Clayton (Davidson?) zapisał tę kwestię jako jedną z postulowanych do dalszej dyskusji w swoich odręcznych notatkach (TNA, CAB 104/48, niedatowane [maj 1939 r.] „Questions by Polish General Staff”).

${ }^{123}$ Siły, które mogłyby wziąć udział w bombardowaniach, strona polska określiła na 4 eskadry bombowe i 60-70 samolotów liniowych (tj. lekkich bombowych). 
(1080 samolotów, włączając wodnopłatowce) zauważalnie przewyższały polskie (819 samolotów, z tego $630 \mathrm{w}$ bieżącym użyciu jednostek), oraz rozpoznawczych (łącznie 825 samolotów wedle Brytyjczyków - ogółem 632 zdaniem Polaków). Dane łączne okazały się jednak zbliżone: rachunek gości z Londynu sięgał 3940 samolotów wojskowych, gospodarzy - około 3500 (po włączeniu maszyn transportowych i morskich). Strony zgodziły się, że nie sposób ustalić wielkości niemieckich rezerw, wyrażając jedynie przypuszczenie, że miesięczna produkcja lotnicza Rzeszy wynosi 600-700 samolotów, choć znaczący w niej udział mają z pewnością nieużyteczne bojowo maszyny szkolne ${ }^{124}$.

Wymianę informacji o siłach lotniczych stron oczekiwanego konfliktu kontynuowano na posiedzeniu odbytym dzień później. Pułkownikowi Davidsonowi przekazane zostały m.in. posiadane przez polski wywiad wiadomości na temat wewnętrznej organizacji niemieckich jednostek lotniczych. On sam z kolei uzupełnił przedstawione uprzednio informacje o lotnictwie angielskim, charakteryzując eskadry samolotów Bristol Blenheim oraz Fairey Battle, które interesowały Polaków, jak można sądzić, $z$ racji planowanych na Wyspach zakupów.

Generał Ujejski podniósł kwestię zasięgu brytyjskich bombowców, zauważając, że maszyny o podanym w trakcie spotkania z 24 maja zasięgu $560 \mathrm{~km}$, startując z Anglii, nie będą mogły dotrzeć nad szereg okręgów istotnych dla systemu obronnego Rzeszy, np. nad Berlin. Zawoalowana sugestia, że samoloty bazowane w Polsce nie napotkałyby podobnych problemów, skontrowana została przez Davidsona wyjaśnieniem, że podany został zasięg minimalny, zaś niektóre typy, jak np. stanowiące wyposażenie siedmiu dywizjonów bombowce Wellington oraz używane w pięciu dywizjonach bombowce Hampden, mają zasięg znacznie większy ${ }^{125}$.

Podczas ostatniego z posiedzeń plenarnych, 30 maja, powrócono do zagadnień podjętych po raz pierwszy tydzień wcześniej. Polski Szef Sztabu starał się sprecyzować, jaką formę miałaby przybrać konsultacja aliantów poprzedzająca - w razie bombardowania przez Niemców obiektów cywilnych - adekwatną odpowiedź na takie działania. Brygadier Clayton podkreślił po raz kolejny, że byłoby wówczas absolutnie konieczne ustalenie, iż to Niemcy podjęli jako pierwsi takie akcje. Stwierdził przy tym, że odpowiednie porozumienie mogłoby zostać przeprowadzone telegraficznie. Strona polska upewniała się też co do planowanej przez Brytyjczyków wielkości ich rezerw lotniczych $w$ stosunku do liczby samolotów pierwszej linii, a także natychmiastowej gotowości do działań 524 brytyjskich samolotów bombowych pierwszej linii, które wspomniane zostały w trakcie posiedzenia z 23 maja. Pułkownik Davidson zapewnil, że owe maszyny mogą być gotowe do akcji najpóźniej w dwa dni po rozpoczęciu wojny.

${ }^{124}$ Protokóly polsko-brytyjskich rozmów sztabowych..., s. 37nn.; IPMS, Lot. A.V. 1/40b, „Protokół z Konferencji odbytej z przedstawicielem angielskiego ministerstwa lotnictwa w dn. $24 \mathrm{~V}$ b.r. w Sztabie Głównym w Warszawie".

${ }^{125}$ Protokóly polsko-brytyjskich rozmów sztabowych..., s. 48; IPMS, Lot. A.I. 2.15, „Protokół z Konferencji odbytej z przedstawicielem angielskiego ministerstwa lotnictwa w dn. $25 \mathrm{~V} 1939 \mathrm{r}$. w Sztabie Głównym w Warszawie". 
Poruszono wreszcie kwestię ewentualnych zakupów materiału lotniczego, które Polacy zamierzali przeprowadzić w Wielkiej Brytanii. Generał Stachiewicz przekazał gościom znad Tamizy informacje o zaaprobowanym już przez marszałka Śmigłego-Rydza zamiarze skierowania w tym celu do Londynu specjalnej misji, podkreślając, że dotychczasowe ustalenia ze stroną brytyjską dotyczyły nabycia 100 lekkich samolotów bombowych, ale „myśliwce są dla nas ważniejsze i potrzebujemy ich więcej”126.

Cykl polsko-brytyjskich spotkań tylko w ogólnych zarysach przypominał wcześniejsze rozmowy polsko-francuskie. Skierowanie do Warszawy misji brytyjskich oficerów miało nade wszystko charakter gestu politycznego, sam zaś ich pobyt nad Wisłą służyć miał głównie wymianie informacji, których żadna ze stron wciąż znajdującego się in statu nascendi sojuszu nie miała w nadmiarze. Niskie stopnie wojskowe członków brytyjskiej delegacji, ich mało znacząca pozycja w wojskowej hierarchii, wreszcie - brak kompetencji do czynienia jakichkolwiek wiążących ustaleń wprawiły

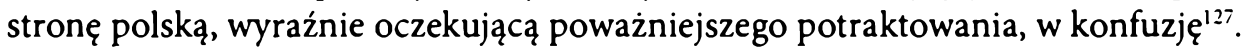

W zaistniałej sytuacji nie podjęto nawet próby podsumowania cyklu konferencji jakimś sumującym ich treści protokołem. Mimo wszystko jednak przekazane przez Brytyjczyków informacje brzmiały stosunkowo uspokajająco. Goście z Londynu, a przede wszystkim bryg. Clayton, dość wyraźnie wykroczyli bowiem poza udzielone im pisemne instrukcje. Indagowani na temat postawy sił powietrznych Zjednoczonego Królestwa w razie podjęcia przez Niemców nieograniczonej wojny powietrznej, w tym ataków na ludność cywilną, złożyli zapewnienie, że nawet gdyby podobne działania podjęte zostały jedynie wobec Polski, ich skutkiem będzie zniesienie wszelkich krępujących stronę brytyjską ograniczeń w tym zakresie. Tymczasem w Londynie kwestia ta była na razie jedynie przedmiotem rozważań, a choć często pojawiały się w nich głosy zbliżone do stanowiska przedstawionego przez Claytona, to formalne rozstrzygnięcia wciąż nie zostały przyjęte ${ }^{128}$.

${ }^{126}$ Protokóły polsko-brytyjskich rozmów sztabowych..., s. 54nn. Informację o zamiarze wysłania do Londynu polskiej misji zakupów Kennard przekazał nad Tamizę jeszcze tego samego dnia (tj. 30 maja) telegramem szybrowym No 181 (kopia: TNA, CAB 104/48).

${ }_{127} \mathrm{~W}$ Londynie zdawano sobie z tego sprawę. „Nie jestem zaskoczony, słysząc, że Polacy byli nieco rozczarowani, iż nie posłaliśmy do Warszawy bardziej imponującej misji" - stwierdzał Ismay w datowanym 9 czerwca liście do Sargenta, dodając natychmiast: ,jednak [...] nie sądzę, byśmy mieli powód do czynienia sobie wyrzutów". Jak zauważał bowiem, wobec wielkiego niedostatku posiadanych przez stronę brytyjską informacji o polskim partnerze misja miała mieć charakter głównie wyjaśniający, a jej członków dobrano pod kątem posiadanej już wiedzy o Polsce i znajomości języka. Powyższa korespondencja stanowiła odpowiedź na pismo No 153/382/39 Kennarda, w którym ten, pochlebnie wyrażając się o Claytonie, stwierdzał, że były attaché „niezupełnie nadaje się" do powierzonego mu zadania (TNA, CAB 104/48; zob. też: T. Skinder-Suchcitz, Rok 1939. Polsko-brytyjska polityka morska, Warszawa-Londyn 1997, s. 87; A. Su chcit z, Pplk Emilius Clayton..., s. 950).

128 Podczas ostatniego posiedzenia rozmów zapewnienie Claytona zostało obwarowane przytoczonym już wyżej zastrzeżeniem, że kontrakcja brytyjska będzie mogła nastąpić dopiero po porozumieniu sojuszniczych rządów. Podkreślił to $w$ swym powojennym opracowaniu także gen. Stachiewicz (op. cit., s. 122). 
Takie zapewnienia oraz liczenie na realizację francuskich zobowiązań do podjęcia ofensywy na froncie zachodnim już w pierwszych tygodniach wojny mogły ugruntować w najwyższych kręgach polskiej elity wojskowo-politycznej przekonanie o względnej niezawodności zachodniej asysty, przynajmniej w tak określonym zakresie. Choć zaś skądinąd wiadomo, że w Warszawie nie hołdowano tu bynajmniej skrajnie naiwnym złudzeniom, to owo przekonanie nie pozostało bez wpływu na podejmowane decyzje, także te nie najmniej istotne ${ }^{129}$.

Zaaprobowane przez obie strony protokoły polsko-brytyjskich rozmów zostały podpisane 1 czerwca. Stolicę Polski delegacja pod przewodnictwem bryg. Claytona opuściła dopiero rankiem 3 czerwca, zmierzając do Gdyni, a następnie Kopenhagi i Londynu ${ }^{130}$.

Jej sporządzonym po zakończeniu misji raportem Joint Planning Sub-Committee zajął się niespełna dwa tygodnie później, na posiedzeniu odbytym z udziałem przybyłych znad Wisły oficerów po południu 14 czerwca ${ }^{131}$. Uczestnicy rozmów podkreślili w tym dokumencie całkowitą szczerość gospodarzy, skłonnych do ujawniania partnerom swych wojskowych tajemnic. Wyrażali przy tym ubolewanie, że sami, nie dość dokładnie orientując się w planach strony brytyjskiej, nie mogli odpowiedzieć w podobny sposób, wyrażając zarazem opinię, że choć ich postawa została zapewne odnotowana, nie wpłynęło to znacząco na przebieg spotkań.

Jak stwierdzono, strona polska jest przekonana, że w początkowej fazie wojny zdecydowana większość sił niemieckich zostanie skierowana przeciw niej. Dla zaatakowanych oznaczać to będzie ciężkie straty, także terytorialne. Polacy jednak, informowali autorzy dokumentu, $z$ godną podziwu pewnością wyrażają przekonanie, że z czasem zdołają "gdzieś w Polsce" odbudować swój front, zaś ostateczną klęskę Rzeszy, niezdolnej do przetrwania długiej wojny z Wielką Brytanią i Francją, uważają za nieuchronną ${ }^{132}$.

Zdaniem Polaków, referowano, wojna rozpocznie się od gwałtownego ataku niemieckiego lotnictwa, którego celem staną się obiekty wojskowe, żywotne elementy linii komunikacyjnych oraz zakłady przemysłowe, szczególnie te, które uznane zostaną za użyteczne dla zaopatrywania sił zbrojnych. Atakujący kierować się będą przy tym niemal wyłącznie dążeniem do maksymalnej skuteczności działań, kwestia ewentualnych ofiar wśród ludności cywilnej nie zostanie uznana za istotną ${ }^{133}$.

${ }^{124} \mathrm{Na}$ ten temat warte uwagi konstatacje przedstawił ostatnio M. Kornat (Polityka zagraniczna Polski..., s. 466nn.).

1.10 TNA, CAB 104/48, niedatowany dokument [przełom maja i czerwca 1939 r.] „Staff conversations. Note on present position" i in. dok.; E.R. Sword, op. cit., s. 43 . W datowanym 7 czerwca raporcie No 343 dla Bonneta pobyt w Polsce Claytona i jego towarzyszy podsumował Noël, zwracając uwagę na polskie naciski w sprawie dostaw sprzętu wojskowego, która i jemu od dłuższego czasu leżała na sercu (kopia reportu: SHD-DAT, 7 N 3005).

1.11 TNA, CAB 55/3, „Minutes of the Meeting held on [...] 14th June, 1939..., J.P. 266th Mtg.

$1: 12$ TNA, CAB 53/50, „Anglo-Polish Staff Conversations. Report by United Kingdom Delegation. Note by Secretary", C.O.S. 927 H.L. Ismaya z 15 VI 1939 r. z załącznikami.

${ }^{133} \mathrm{~W}$ raporcie stwierdzano, że strona polska nie zamierza podejmować zawczasu próby oszacowania wielkości niemieckich sił powietrznych, które mogą zostać skierowane przeciw niej, 
Brytyjscy oficerowie, przedstawiając założenia polskich planów, sprowadzających się w ogólnym zarysie do strategicznej obrony, akceptacji przejściowego opuszczenia części obszarów kraju, a następnie kontruderzenia - w pierwszej kolejności wymierzonego przeciw Prusom Wschodnim, zwracali uwagę na słabości tej koncepcji. Warszawscy sztabowcy, konstatowano, nie doceniają armii niemieckiej. Jako argumenty podnoszą przy tym trapiący tę ostatnią niedostatek wyszkolonych kadr, niedostateczne wyszkolenie, braki w zakresie ciężkiej artylerii, nadmierny stopień zmotoryzowania, a wobec tego przywiązanie do dróg bitych, wreszcie - niską jakość pojazdów oraz stałe trudności w zaopatrzeniu w paliwo. Tymczasem część $\mathrm{z}$ tych słabości odnosi się też do armii polskiej, zaś mankamenty motoryzacji równoważone są przez jej niezaprzeczalne zalety ${ }^{134}$.

Za podstawową słabość polskiej armii uznano braki w uzbrojeniu i wyposażeniu, które ograniczały wielkość zmobilizowanych sił do 40 dywizji, mimo dysponowania znacznie większymi zasobami wyszkolonych rezerwistów. Choć członkowie misji nie bez nuty podziwu wyrażali się o dokonanej w ostatnich latach rozbudowie przemysłu zbrojeniowego kraju gospodarzy oraz funkcjonowaniu odwiedzonych w trakcie pobytu nad Wisłą zakładów, to możliwości większej ich produkcji w razie wojny oceniali sceptycznie. W grę wchodziły tu ich zdaniem ograniczenia finansowe państwa, ale też inne problemy, jak niedostatki wykwalifikowanej siły roboczej, narzędzi, surowców (oraz trudności $z$ ich importem; tu członkowie misji kładli nacisk na absolutną konieczność dostaw z ZSRR), a także wrażliwość na ataki lotnicze. Beztroskę wobec tego ostatniego zagrożenia oraz argument, że podczas zakończonej właśnie wojny domowej w Hiszpanii produkcja przemysłowa nigdy naprawdę nie została wstrzymana przez naloty lotnicze, brytyjscy sztabowcy komentowali ze zdziwieniem. „Nie wykonali maskowania ani nie zbudowali żadnych schronów dla personelu. Mają nieuzasadnioną wiarę w celność dział przeciwlotniczych" - utyskiwali autorzy raportu, dodając mimochodem, że działa te mają obsługiwać naprędce przeszkoleni robotnicy fabryczni ${ }^{135}$.

Przekazaną przez Polaków opinię, że Niemcy skierują przeciw nim 77 dywizji, w tym 61 dywizji aktywnych i rezerwowych oraz 17 mniej wartościowych dywi-

wyjaśniając, że bardzo rozbudowana infrastruktura Rzeszy umożliwia bardzo szybkie dokonywanie manewru, zaś dla podziału sił podstawowe znaczenie będzie miała intensywność działań podjętych na Zachodzie. Brytyjskim oficerom przedstawiono treść zdobytej przez polski wywiad tajnej niemieckiej publikacji pt. „Luftkriegshufrung”, z której wynikać miał przedstawiony podczas konferencji porządek ataków. W Londynie uzyskane informacje wzbudziły natychmiastowe zainteresowanie, jako użyteczne dla własnych analiz (TNA, AIR 20/2070, notatka Slessora dla Dyrektora Wywiadu z 14 VI 1939 r.).

${ }_{134} \mathrm{~W}$ tym ostatnim przypadku brytyjscy oficerowie mieli niewątpliwe kompetencje. W trakcie prowadzonych w Warszawie rozmów trudność sprawiło im zrozumienie używanego przez gospodarzy terminu „dywizja zmotoryzowana”. Jak bowiem wyjaśniali, w armii brytyjskiej zmotoryzowane są wszystkie dywizje.

135 TNA, CAB 53/50, „Anglo-Polish Staff Conversations. Report by United Kingdom Delegation...", Annex VI. 
zji Landwehry, Brytyjczycy zestawiali z informacją o liczących 40 dywizji (w tym 30 czynnych), 11 brygad kawalerii i jednej dywizji zmotoryzowanej (w oryginale armoured, tj. pancernej) siłach obrońców - całość pozostawiając bez komentarza. Ponownie zauważali jedynie, że te ostatnie oparte są niemal wyłącznie na transporcie konnym, zaś ich artyleria ciężka i bojowe pojazdy opancerzone są nieliczne. W raporcie potwierdzano też znaną już wcześniej w Londynie informację, że polskie siły lotnicze podczas wojny będą wykorzystywane niemal wyłącznie jako wsparcie armii lądowej. Lotnictwo gospodarzy niedawnej wizyty jej uczestnicy określili jako złożone głównie $\mathrm{z}$ bombowców średniego zasięgu, dodając, że myśliwce stanowią jedynie $30 \%$ jego całości, zaś ich jakość pozostawia sporo do życzenia.

Tab. 6. Potencjał polskiego lotnictwa wojskowego według raportu misji bryg. Claytona ${ }^{136}$

\begin{tabular}{|c|c|c|}
\hline Typ/klasa samolotu & Liczba & Uwagi \\
\hline \multicolumn{3}{|c|}{ I. Samoloty I linii } \\
\hline PZL.37 „Łos”" & 36 & $\begin{array}{l}\text { Ciężkie bombowce, tadunek bomb - } 2000 \mathrm{~kg} \text {, } \\
\text { promień akcji - } 500 \mathrm{~km}\end{array}$ \\
\hline PZL.23 „Karas'” & 170 & $\begin{array}{l}\text { Lekkie bombowce, ładunek bomb - } 600 \text { kg, pro- } \\
\text { mień akcji - 360-400 km }\end{array}$ \\
\hline PZL.11 & 150 & Myśliwce \\
\hline Fokker F.VIIm3 & 8 & $\begin{array}{l}\text { Samoloty transportowe; typ przestarzały, przy- } \\
\text { dzielony do dywizjonów bombowych }\end{array}$ \\
\hline Lublin R.XIII & 126 & Towarzyszące i rozpoznawcze; przestarzałe \\
\hline Łącznie & 490 & \\
\hline \multicolumn{3}{|c|}{ II. Samoloty rezerwowe (z pełnym wyposazieniem wojennym) } \\
\hline Bombowce ciężkie & ok. 36 & Włączając typy gorsze \\
\hline Bombowce lekkie & ok. 68 & jw. \\
\hline Myśliwce & ok. 60 & \\
\hline Towarzyszące i rozpoznawcze & ok. 126 & \\
\hline Łącznie & ok. 290 & \\
\hline
\end{tabular}

Źródło: Opracowanie własne na podstawie: TNA, CAB 53/50, „Anglo-Polish Staff Converstions. Report by United Kingdom Delegation. Note by Secretary", C.O.S. 927 H.L. Ismaya z 15 VI 1939 r., Annex VI.

Ogólna ocena szans polskiej obrony nie wypadała optymistycznie. Jeśli główne niemieckie uderzenie istotnie skierowane zostanie na wschód, oceniano $\mathrm{w}$ raporcie, przy zakładanej proporcji sił oraz intensywnej akcji lotniczej można się obawiać, że Polacy zostaną zepchnięci na wschodnie, bardziej dzikie obszary kraju, a zorgani-

${ }^{136}$ Dokument zawierał także informacje na temat personelu lotnictwa. Zostały one podane zgodnie z danymi strony polskiej (zob. tab. 5), z wyjątkiem liczby strzelców pokładowych, których w brytyjskim zestawieniu znalazło się (skutkiem omyłki?) 298. 
zowany opór może się załamać, „chyba że uratuje ich kolejny cud nad Wisłą". Sceptycznie przy tym komentowano potencjalne skutki tak bardzo oczekiwanej przez polskich uczestników rozmów pomocy z Zachodu. „Nie jest prawdopodobne, że intensywna akcja lotnicza $z$ naszej strony zdziała więcej niż odciągnięcie garści maszyn ze Wschodu, podczas gdy efekty lądowego ataku na Linię Zygfryda są poza zakresem wiedzy Delegacji" - stwierdzali członkowie tej ostatniej ${ }^{13 \%}$.

Nie znaczy to jednak, że $w$ ten sposób milcząco aprobowano wyrzeczenie się jakichkolwiek działań na rzecz polskiego sprzymierzeńca. Uczestnicy przeprowadzonych w Warszawie rozmów przekazali sztabowcom z Londynu informację o polskich oczekiwaniach co do czasowego lub nawet stałego bazowania na terytorium Rzeczypospolitej pewnej części brytyjskich sił powietrznych, uprzedzając, że sprawa ta niebawem może zostać ponownie przez Polaków podniesiona. Zwrócili też uwagę, że gospodarze niedawnej wizyty liczą, iż operujące nad Niemcami brytyjskie lotnictwo sięgnie w swej aktywności możliwie daleko na wschód, tak aby efekty jego poczynań odczuwalne były i w Polsce. Sami jednak członkowie misji nie rekomendowali realizacji któregoś $z$ tych scenariuszy, proponując raczej poprzestanie na akcjach bombowych $z$ baz w Wielkiej Brytanii i Francji. Takie operacje, łatwiejsze do przeprowadzenia oraz mniej ryzykowne, i tak skutkować winny ich zdaniem (sprzecznym zresztą w opinią wyrażoną w raporcie) „zatrzymaniem maksimum niemieckich sił lotniczych na Zachodzie” i „zmniejszeniem początkowej niemieckiej przewagi w powietrzu"138.

W raporcie podkreślono także, że znajdujące się w polskich rękach zapasy materiału wojennego obliczane są na 2-3 miesiące walki, zaś zgoła nieprawdopodobne jest, by krajowa produkcja przedłużyć mogła okres samowystarczalności do więcej niż 6 miesięcy. Autorzy dokumentu postulowali więc, by zachodni sojusznicy, we własnym skądinąd interesie, już teraz starali się dostarczyć Polakom odpowiednie zaopatrzenie w postaci gotowego materiału, surowców oraz środków finansowych, równocześnie opracowując system zaopatrywania na czas wojny.

Wśród materiału, który winien być w pierwszym rzędzie dostarczony nad Wisłę, wymienione zostały, prócz ciężkiej artylerii, przede wszystkim samoloty, szczególnie myśliwskie. Członkowie misji, deklarując, że zdają sobie sprawę z niedostatku myśliwców w samej Wielkiej Brytanii, argumentowali, że wobec doskonałego morale polskich lotników, jak i całego społeczeństwa przekazanie Polakom pewnej liczby takich maszyn mogłoby być korzystne. Przedłużenie oporu polskiego sojusznika oznaczałoby bowiem zmniejszenie w tym czasie niemieckiego nacisku na zachodzie kontynentu.

137 TNA, CAB 53/50, „Anglo-Polish Staff Conversations. Report by United Kingdom Delegation..." Bardziej szczegółowe omówienie treści tej części raportu: W. Mazur, Jeśli nie zdarzy się cud... Brytyjskie elity wojskowe wobec szans polskiej obrony (wiosna-lato 1939 roku), „Poligon” 2013, nr 1, s. 76nn.

134 TNA, CAB 53/50, „Anglo-Polish Staff Conversations. Report by United Kingdom Delegation..., Annex VII ( „Possible forms of air assistance to Poland”). 
Oczywiste było jednak, że $w$ trakcie działań wojennych dostarczanie do Polski materiału wojennego będzie znacznie trudniejsze. Możliwości uzyskania przez Polskę nowego sprzętu zależne byłyby wówczas w wielkim stopniu, podkreślali autorzy raportu, od nastawienia do ZSRR. Gdyby pomoc radziecka okazała się niemożliwa do zaakceptowania lub nieosiągalna, Polacy mogliby kontynuować tylko ograniczoną produkcję typów ustępujących niemieckim odpowiednikom, zaś większość ich potrzeb pokryć by musieli sojusznicy i państwa neutralne, wykorzystując zapewne okrężne drogi dowozu.

Nie widząc tu łatwych rozwiązań, członkowie misji Claytona posuwali się do sugerowania kroków dość karkołomnych, jak podjęcie w ZSRR produkcji samolotów typów polskich lub, alternatywnie, typów brytyjskich. W obu jednak przypadkach, przyznawano $w$ raporcie, nawet po przezwyciężeniu wszelkich trudności taka produkcja nie mogłaby przynieść efektów przed połową roku 1941. Wysunięta jako kompromisowa koncepcja skłonienia polskich fabryk lotniczych do produkcji samolotów brytyjskich pod względem organizacyjno-technicznym (a taki głównie rozpatrywano) nie wydawała się wiele prostsza $w$ realizacji, przynajmniej $w$ umiarkowanie odległym horyzoncie czasowym ${ }^{139}$.

Przedstawione wyżej stosunkowo obszernie informacje, oceny i komentarze wydają się istotne dla naszej analizy z co najmniej dwóch powodów. Po pierwsze, w raporcie misji Claytona zreferowany został dość dokładnie zarówno stan wiedzy, jak i koncepcje polskiego dowództwa $z$ okresu bezpośrednio poprzedzającego wybuch wojny. Po drugie, lektura tego dokumentu pozwala lepiej zrozumieć dylematy, przed jakimi stawali zaangażowani $\mathrm{w}$ kontakty z polskim partnerem przedstawiciele brytyjskiej wojskowej elity czy nawet szerzej - wojskowych elit Zachodu. Pamiętać trzeba jednak, że to nie w rękach autorów raportu znajdowały się ostateczne decyzje, oni sami zaś - doraźnie, $z$ braku alternatywy zaangażowani do roli ekspertów - nie posiadali wystarczającej wiedzy, by z zadania tego wywiązać się w pełni, czy to nad Wisłą, czy nad Tamizą.

Sam Połączony Podkomitet Planowania na wspomnianym wyżej posiedzeniu 14 czerwca przedłożony raport uznał za zbyt obszerny, zdaniem uczestników dyskusji część zawartych w nim treści interesować mogła raczej sekcje informacyjno-wywiadowcze odpowiednich ministerstw. Dalsze losy dokumentu i ewentualnej reakcji na zawarte w nim wnioski złożono w ręce Szefów Sztabów. Zarazem jednak zwrócono uwagę na to, że strona polska dąży do kontynuacji podjętych dyskusji, wskazując, że o ich dotychczasowych rezultatach koniecznie należy poinformować Francuzów, a dalsze rozmowy prowadzić być może w układzie trójkątnym - z udziałem przedstawicieli Londynu, Paryża i Warszawy ${ }^{140}$.

W następnych jednak tygodniach Szefowie Sztabów, zaabsorbowani głównie sprawami Dalekiego Wschodu, nie znaleźli czasu, by odnieść się do raportu Claytona. 7 lipca dokumentem oraz sporządzonymi w międzyczasie uwagami do jego treści

141 TNA, CAB 55/3, „Minutes of the Meeting held on [...] 14th June, 1939..." 
ponownie zajął się więc Połączony Podkomitet Planowania. Członkowie tego gremium przyznali, że teza gospodarzy niedawnej wizyty, iż w początkowej fazie wojny większość sił Rzeszy skierowana zostanie przeciwko nim, stanowi istotnie najbardziej prawdopodobny scenariusz. Zwrócili jednak uwagę, że za możliwe uznać należy co najmniej jeszcze dwie wersje niemieckiego gambitu, a mianowicie atak w kierunku zachodnim lub uderzenie na Rumunię. Współpraca Warszawy z Bukaresztem miałaby więc, podkreślili, podstawowe znaczenie dla ziszczenia koncepcji utworzenia w trakcie nadchodzącej wojny trwałego frontu w Europie Wschodniej.

W opinii Połączonego Podkomitetu Planowania przeprowadzone nad Wisłą rozmowy nie przyczyniły się $w$ materialnym sensie do poszerzenia posiadanej już w Londynie wiedzy o militarnym potencjale domniemanych uczestników nadchodzącego konfliktu. Nieco niższe od brytyjskich okazały się tylko polskie szacunki liczby możliwych do wystawienia przez Rzeszę dywizji rezerwy, niższe były też, co wyżej przyszło nam odnotować, posiadane w Warszawie dane o liczebności niemieckiego lotnictwa pierwszej linii. Ponownie wreszcie, tym razem przywołując także zdanie War Office, wyrażono opinię, że polski partner popełnia poważny błąd, jako uzasadnienie swych szans $\mathrm{w}$ walce $\mathrm{z}$ armią niemiecką podając niską bojową wartość tej ostatniej. „Ogólnie jesteśmy zdania, że Polacy mają tendencję do niedoceniania siły niemieckiej i przeceniania własnej [...]. Podzielamy pogląd naszej Delegacji, że Polacy są zapewne zbyt optymistyczni w kwestii swej zdolności oporu wobec niemieckiego natarcia" - komentowali brytyjscy sztabowcy ${ }^{141}$.

Blisko połowa wspomnianych komentarzy odnosiła się do zagadnień lotniczych. Ze zdziwieniem czy wręcz zgrozą odnotowano polskie odwołania do doświadczeń wojny w Hiszpanii. Siła i intensywność możliwych ataków lotniczych przeciw Polsce będzie raczej dziesięciokrotnie większa, oceniano, postulując, by skłonić władze z Warszawy do poważnej rozbudowy systemów biernej obrony przeciwlotniczej. Podkomitet podzielił natomiast pogląd członków misji Claytona o nikłym potencjalnie wpływie powietrznej ofensywy z Zachodu na rozwój wydarzeń w Polsce. Co praw-

141 TNA, CAB 55/18, „Anglo-Polish Staff Conversations. Report by United Kingdom Delegation. Commentary by the Joint Planning Sub-Committee", J.P. 462 z 7 VII 1939 r. Polacy szacowali, że $w$ razie skierowania przeciw nim pierwszego ataku Niemiec na Zachodzie pozostawione zostanie o 10 dywizji mniej, niż sądzili Brytyjczycy. Jednostki te, wedle przewidywań Warszawy, miałyby zostać użyte na froncie polskim. Brytyjscy komentatorzy nie bez zdziwienia odnotowywali, że zdaniem polskich sztabowców Niemcy, atakując na Wschodzie, mieliby na Zachodzie pozostawić 25-28 dywizji, podczas gdy w przypadku ataku w kierunku przeciwnym do osłony swej granicy z Polską potrzebowaliby znacznie więcej, bo aż 40 takich jednostek. Nie brali przy tym najwyraźniej pod uwagę długości granicy niemiecko-polskiej, zdecydowanie od niemiecko-francuskiej większej. Strona polska szacowała potencjał I linii niemieckiego lotnictwa na około 3500 samolotów, Brytyjczycy - na około 3700 samolotów. 31 VIII 1939 r. Luftwaffe miała posiadać w I linii 4033 samoloty, w tym 3646 w pełni sprawnych. Nieco bliższe rzeczywistości okazały się wiec szacunki brytyjskie, ale trafność przedstawionych danych uznać można za porównywalną. Zob.: F. A. Vajda, P. Dancey, German Aircraft Industry and Production, 1933-1945, Shrewsbury 1998, s. 49. Nieco odmienne, choć podobne liczby (4127 samolotów, w tym 3751 sprawnych) w: M. Zgórniak, Europa w przededniu wojny..., s. 386n. 
da, stwierdzano, uzyskane efekty zależeć będą w wielkim stopniu od obranych celów uderzeń, ale przynajmniej w początkowej fazie wojny zachodni sprzymierzeńcy nie powinni liczyć na zmniejszenie niemieckiej presji na Wschodzie. Stwierdzenie to pozostawiono w zasadzie bez jakichkolwiek dalszych komentarzy, niemal natychmiast proponując, by w razie ataku Rzeszy na Zachodzie polscy partnerzy podjęli działania bombowe w głębi Niemiec, choćby wobec zbiorników ropy w Szczecinie czy bazy morskiej w Królewcu. „Polacy powinni być namawiani do zaatakowania Szczecina, gdy tylko warunki na to pozwolą" - postulowano, bez jakiejkolwiek refleksji na temat skrajnej nieadekwatności własnej oferty i oczekiwań względem partnera ${ }^{142}$.

Podkomitet nie zanegował możliwości skierowania do Polski pewnej liczby brytyjskich samolotów bombowych, a następnie podjęcia przez nie operacji przeciwko celom na terenie wschodniej części Niemiec. Podobnie jednak jak czynili to w tymże czasie Francuzi, brytyjscy sztabowcy realizację zamysłu uzależniali od uprzedniego zmagazynowania nad Wisłą bomb, części zamiennych i innych materiałów niezbędnych do efektywnych działań skierowanych tam maszyn. Zastrzeżenie to było, rzecz jasna, zasadne. Probierz intencji stanowiły tu jednak realne kroki w celu utworzenia takich zapasów, tych zaś nad Tamizą wciąż nie podejmowano.

Komentatorzy przygotowanego przez misję Claytona raportu z naciskiem za to podkreślili, że znaczące dostawy materiału wojennego polski partner uzyskać może tylko z ZSRR. Za konieczne uznano jednoznaczne uprzytomnienie Warszawie tej oczywistości. Kwestię dostaw własnego sprzętu Podkomitet pozostawił za to do rozważenia przez odpowiednie gremia ${ }^{143}$.

12 lipca przeciążeni pracą Szefowie Sztabów sprawę brytyjsko-polskich rozmów międzysztabowych przekazali do rozważenia swym zastępcom. Skupiający tych ostatnich podkomitet zagadnieniem zajął się pięć dni później, uwagi Połączonego Podkomitetu Planowania przyjmując niemal bez zmian ${ }^{1+4}$.

142 Ibidem. Odnośnie do możliwości pomocy Polsce, w tym także przy użyciu sił powietrznych, Joint Planning Sub-Committee odwoływał się do opracowywanego równolegle, opatrzonego ostatecznie datą 7 lipca dokumentu C.O.S. 938 (J.P.). Polska akcja przeciw zbiornikom ropy w Szczecinie miałaby zdaniem Joint Planning Sub-Committee współgrać z wysiłkami podjętymi w tejże sferze przez lotnictwo brytyjskie na innych obszarach. Jak wiadomo jednak skądinąd, realizacja kreślonych w Londynie planów takiej akcji pozostawała wówczas co najmniej mocno niepewna.

14.3 Propozycja ta bardzo szybko spotkała się z bardzo mocnym wsparciem ze strony Foreign Office. Zob.: TNA, CAB 104/51, kopia pisma C/9510 G Sargenta do Ismaya z 17 VII 1939 r.

in TNA, CAB 53/11, „Minutes of the 307th Meeting, held on 12th July, 1939”, C.O.S./307th Mtg.; CAB 54/8, „Note by Secretary”, D.C.O.S. 126 (J.P.) L.C. Hollisa z 13 VII 1939 r. z zał.; CAB 54/9, „Anglo-Polish Staff Conversations. Report by United Kingdom Delegation. Commentary by the Deputy Chiefs of Staff", D.C.O.S. 127 z 17 VII 1939 r. Obciążenie Szefów Sztabów sprawami Dalekiego Wschodu zepchnęło w tym czasie sprawę rozmów międzysztabowych z Polską na drugi plan. Pośrednio spowodowało też perturbacje w obiegu tyczącej się tej kwestii dokumentów: tak np. przekazany Szefom Sztabów raport misji Claytona do Foreign Office dotarł dopiero trzy tygodnie później, w pierwszej dekadzie lipca (TNA, FO 371/23129, pismo Ismaya do Sargenta z 21 VII 1939 r.). 
24 lipca kontakty sztabowe $\mathrm{z}$ Warszawą stały się natomiast przedmiotem obrad Komitetu Obrony Imperialnej. W imieniu Podkomitetu Zastępców Szefów Sztabów zreferował ją gen. Ronald Adam, w swej wypowiedzi zwracając uwagę na polskie zamierzenia podjęcia $w$ początkowej fazie wojny odwrotu na pozycje dogodne do obrony oraz przekonanie brytyjskich sztabowców, że partnerzy znad Wisły dokonali błędnej oceny sił własnych i możliwości przeciwnika. Zwrócił także uwagę na konieczność uzgodnienia ze stroną polską zasad lotniczej polityki na czas wojny. Wreszcie jako sprawę do rozstrzygnięcia przedstawił koncepcję bazowania w Polsce "ograniczonej liczby" samolotów bombowych RAF-u, zauważając, że w razie zaaprobowania tej koncepcji należałoby upoważnić Ministerstwo Lotnictwa do wysyłki nad Wisłę bomb i innych niezbędnych materiałów.

Lord Chatfield przedstawił propozycję, by podjąć prace nad planami podjęcia przez brytyjskie lotnictwo bombowe operacji z terytorium Polski, jednocześnie uzgadniając owo zagadnienie ze stroną polską. Same jednak takie działania nie zostały definitywnie przesądzone, zebrani upoważnili jedynie Sztab Lotnictwa do przestudiowania praktycznych ich możliwości. Ewentualne skierowanie do Polski uzbrojenia i wyposażenia dla brytyjskich bombowców uzależnione zostało z kolei od wyniku tych studiów ${ }^{145}$.

Za pożądaną uznano także kontynuację kontaktów międzysztabowych z Warszawą. Wedle przyjętej przez Komitet konkluzji kolejna ich tura miałaby zostać przeprowadzona, zgodnie z polskimi postulatami, „na wysokim szczeblu”, sam zaś kontakt winien być realizowany $w$ porozumieniu $z$ Francuzami. $Z$ podjęciem dalej idących ustaleń postanowiono się jednak wstrzymać do czasu uzyskania informacji o wynikach dobiegającej właśnie końca misji Generalnego Inspektora Sił Zamorskich gen. Edmunda Ironside’a, który wyjechawszy do Polski tydzień wcześniej, miał tam poruszyć i tę tematykę.

Wspomniana misja stanowiła kolejną już w tym czasie oficjalną wizytę przedstawiciela armii brytyjskiej nad Wisłą. Wedle pierwotnych zamysłów służyć miała zatarciu mieszanych wrażeń, które uprzednio odniosła strona polska. W Londynie zdawano sobie bowiem sprawę z konsternacji, jaką wywołała w Warszawie relatywnie niska ranga skierowanych tam $w$ maju oficerów. Już więc 9 czerwca gen. Ismay na narzekania ambasadora Kennarda, wyrażającego nadzieję, że niebawem do Polski skierowany zostanie „wyższy brytyjski oficer, aby przedyskutować najważniejsze problemy w duchu pełnej współpracy", zareagował informacją, iż tak właśnie się stanie ${ }^{146}$.

Niebawem zamysł ten zyskał także wyraźnie szerszy kontekst. Nad Tamizą obawiano się bowiem, że udzielone Polsce gwarancje oznaczać mogą faktyczne oddanie tak istotnej dla Zjednoczonego Królestwa kwestii, jak decyzja o wojnie, w ręce czynnika zewnętrznego, który $\mathbf{w}$ dodatku miał nad Tamizą dość ambiwaletną repu-

145 TNA, CAB 2/9, „Minutes of the 268th Meeting, held on July 24, 1939”, C.I.D./368th Mtg. (D.P. (P.)).

146 TNA, FO 371/23129, pismo 153/382//39 Kennarda do Sargenta 230 V 1939 r.; CAB 104/48, list Ismaya do Sargenta z 9 VI 1939 r. Zob. też: A. Skinder-Suchcitz, op. cit., s. 87. 
tację. Niepokój ten podsycało narastające poczucie braku informacji o prawdziwych intencjach ministra Becka. W przekonaniu, że próba ich uzyskania u źródła stanowiłaby stratę czasu, brytyjskie kierownictwo uznało za wskazaną drogę dookolną, zamierzając nawiązać bezpośredni kontakt z drugą z osób uważanych za prawdziwych sterników polskiej państwowej nawy, tj. marszałkiem Śmigłym-Rydzem. Fakt, że Generalny Inspektor Sił Zbrojnych nie był łatwo dostępny dla cywilów, ograniczał przy tym grono osób, którym powierzona mogła być ta delikatna misja o quasi-dyplomatycznym charakterze, do wąskiego kręgu przedstawicieli najwyższych szczebli brytyjskiej wojskowej elity ${ }^{147}$.

Generał Ironside, wybrany do tego zadania w pierwszych dniach lipca, po konsultacjach $z$ ambasadorem Kennardem (który wówczas przebywał $w$ Londynie) był tu kandydatem zarazem odpowiednim, jak i nieodpowiednim. Jako jeden z nielicznych wchodzących w grę emisariuszy orientował się nieco w sprawach polskich. Nad Wisłą gościł kilkanaście lat wcześniej, po raz pierwszy w roku 1922, następnie zaś trzy lata później, jako przedstawiciel Londynu podczas wielkich manewrów zorganizowanych wówczas na Pomorzu. Początkowo niechętny wobec gospodarzy i ich kraju, miał wedle polskich ocen stopniowo zmienić ten stosunek, z czasem demonstrując szacunek i sympatię. W okresie późniejszym wiele lat spędził jednak poza metropolią, sprawując funkcje kwatermistrzowskie i dowódcze w Indiach. Następnie dowodził okręgiem wojskowym we wschodniej Anglii (Eastern Command), by jesienią 1938 roku ponownie opuścić Wyspy i objąć gubernatorstwo Gibraltaru. Stanowisko to sprawował do końca maja 1939 roku, kiedy to mianowany został Generalnym Inspektorem Sił Zamorskich, przez dłuższy czas pozostając jednak faktycznie w stanie swoistego zawieszenia - „bez biura, personelu, urzędników..."148. Teraz powierzono mu misję na poły reprezentacyjną, na poły polityczno-wojskową, dość ogólnikowo informując o jej założeniach.

Te zresztą, choć poświęcono im sporo uwagi na odbytym 4 lipca posiedzeniu Komitetu Polityki Zagranicznej, wciąż jeszcze były precyzowane. 6 lipca Halifax w przesłanej do warszawskiej ambasady informacji o zamierzonej wizycie stwierdzał nader ogólnikowo, że chodzi w niej głównie o „przedyskutowanie obecnej sytuacji

Hi TNA, CAB 27/625, „Conlusions of the Fifty-Fifth Meeting of the Committee [of Foreign Policy] held [...] on [...] 4th July, 1939...”; PREM 331 A, notatka Foreign Office „Visit of General Ironside to Warsaw" z 12 VII 1939 r. Koncepcja brytyjska stanowila więc do pewnego stopnia powielenie pomysłu Francuzów, którzy w sierpniu 1936 r. do Warszawy skierowali gen. Gamelina z misją podjęcia rozmów przede wszystkim ze Śmiglym-Rydzem, uważanym za przeciwwagę dla "proniemieckiego" i skłonnego do antyfrancuskich intryg Becka. Początkowo zresztą zamierzano wysłać do Warszawy mieszaną, brytyjsko-francuską misję generałów, odstępując od zamierzenia po informacji, że generał francuski (Louis Faury) zdążył już Polskę odwiedzić.

${ }_{1+1}$ [W.E. Ironside], The Ironside Diaries, 1937-1940, ed. by R. Macleod, D. Kelly, Constable-London 1962, s. 76n.; A. Such cit z, Wrażenia generala Ironside'a..., s. 55nn. Drugi z wymienionych autorów podał, że Ironside znal język polski (s. 60). W rzeczywistości władał on językiem niemieckim, duńskim, norweskim, niederlandzkim i francuskim. Podjęte w Warszawie rozmowy toczone były w tym ostatnim. 
militarnej z polskim Sztabem Generalnym" oraz ugruntowanie dobrych stosunków „z marszałkiem Śmigłym-Rydzem i innymi polskimi żołnierzami"149. Kilka dni później ministrowie Gabinetu premiera Chamberlaina byli jeszcze mniej konkretni. Na posiedzeniu 12 lipca stwierdzili jedynie, że w rozważanym przypadku „niemożliwe jest nakreślenie jasno zdefiniowanej linii między zagadnieniami politycznymi i wojskowymi”, za główne zadanie Ironside’a uznając próbę „uzyskania informacji lepszych niż dotychczas byliśmy w stanie uzyskać na temat kierunku, w którym zmierzają myśli Marszałka Smigłego-Rydza"150.

Jeszcze tego samego dnia w Foreign Office opracowana została instrukcja dla kierowanego do Warszawy wysłannika. Zawarte w niej dyspozycje ujęto wreszcie w sposób klarowny: Ironside miał dążyć do ustalenia, jakie konkretnie plany zamierzają wdrożyć polskie władze w kilku hipotetycznych, ale prawdopodobnych przypadkach, dotyczących przede wszystkim rozwoju sytuacji w Gdańsku. Otrzymał także zadanie zaszczepienia Śmigłemu-Rydzowi przekonania o konieczności konsultowania z Francuzami i Brytyjczykami wszelkich poczynań, które władze Rzeczypospolitej miałyby zamiar podjąć w związku z zagrożeniem jej bezpieczeństwa lub niepodległości. Zapytany, jakie kroki w razie takich zagrożeń podejmie Rząd Jego Królewskiej Mości, Ironside winien był wyjaśnić, że zgodnie ze stanowiskiem przekazanym już Beckowi reakcją będzie uruchomienie stopniowej mobilizacji brytyjskich sił zbrojnych, zaś w razie konieczności podjęcia przez stronę polską działań zbrojnych - natychmiastowa analogiczna akcja na lądzie, morzu i w powietrzu, podjęta w ścisłym porozumieniu ze stroną francuską. Instrukcja kładła przy tym nacisk, że należy podkreślić, być może nawet bez pytania - $\mathbf{z}$ własnej inicjatywy - iż choć Paryż i Londyn starają się prowadzić rozmowy w sprawie porozumienia z Moskwą, to pomoc zachodnich mocarstw dla Polski w żaden sposób nie będzie uzależniona od satysfakcjonującego efektu tych negocjacji ${ }^{151}$.

149 TNA, FO 417/40, telegram No 213 Halifaxa do chargé d'affaires w ambasadzie brytyjskiej w Warszawie Clifforda Nortona z 6 VII 1939 r.

150) TNA, CAB 23/100/5, „Conclusions of a Meeting of the Cabinet held [...] on [...] 12th July, 1939...”; A. Prazmowska, op. cit., s. 76. Większość uczestników posiedzenia Gabinetu wcześniej wzięła udział w obradach Komitetu Polityki Zagranicznej. Dzień przed posiedzeniem Gabinetu minister wojny Leslie Hore-Belisha podkreślał w liście do Halifaxa, że Ironside dopiero niedawno wrócił do kraju i koniecznie należy zaopatrzyć go przed wyjazdem w jasno sformułowane pisemne instrukcje, szczególnie odnośnie do polityki zagranicznej (TNA, CAB 104/49, kopia listu 211 VII 1939 r.). Zdaje się to przeczyć kreślonemu w tych dniach w dziennikach Ironsidéa obrazowi ministra całkowicie zagubionego w świecie powierzonych mu obowiązków. W Londynie powątpiewano zresztą (także?) w wojskowo-polityczne talenty samego Ironside’a, zaś gen. Pownall (Dyrektor Operacji Wojskowych War Office) wyrażał obawę, że nad Wisłą może on odegrać rolę "słonia w skladzie porcelany" (E.R. Sword, op. cit., s. 48).

151 TNA, PREM 331A, notatka FO „Visit of General Ironside to Warsaw” z 12 VII 1939 r. Do notatki załączono memorandum zawierające obszerniejsze przedstawienie brytyjsko-polskich stosunków politycznych w okresie od udzielenia gwarancji oraz obaw związanych $z$ kierunkiem i charakterem polskiej polityki w bliskiej przyszłości. 
Gospodarzy przygotowywanej wizyty o zamiarze jej zorganizowania powiadomiono późno. Dopiero 8 lipca Dyrektor Gabinetu ministra Becka Michał Łubieński mógł więc poinformować gen. Stachiewicza, że wedle informacji przekazanej mu przez brytyjskiego chargé d'affaires Clifforda Nortona Ironside przybywa do Warszawy „celem przeprowadzenia rozmów z naszym Sztabem Głównym”. Niezbyt zrozumiała w powyższym kontekście informacja o sprawowanej przez gościa funkcji stała się przy tej okazji przyczyną qui pro quo: w otrzymanej korespondencji podkreślono ją, opatrując umieszczonym na marginesie sporych rozmiarów znakiem zapytania ${ }^{152}$.

Powyższa zapowiedź zapoczątkowała krótką, acz intensywną wymianę korespondencji, w której trakcie strona polska usiłowała ustalić przynajmniej podstawowe fakty: „czy Generał przyjeżdża sam czy z delegacją”; „wizyta kurtuazyjna czy też przewidziane są rozmowy szersze wojskowe”; „dokładna data przyjazdu”. Jeszcze jednak 13 lipca treści odpowiedzi pozostawały dość mgliste: „generał Ironside przylatuje sobota 15.VII via Kopenhaga”; „[...] chce mówić z Panem Marszałkiem i Panem Szefem Sztabu Głównego na ogólne tematy wojskowe"'53. Dopiero dzień później ppłk Kwieciński w nieco obszerniejszej korespondencji przedstawił wyłuszczone ambasadorowi Raczyńskiemu cele przyjazdu brytyjskiego gościa i nakreślił krótko jego sylwetkę. Informacja, że choć formalnie stanowisko tego ostatniego sytuuje się w hierarchii poniżej Szefa Sztabu Imperialnego, to „faktyczne jego wpływy w armii są znacznie większe”, zaś "na wypadek wojny byłby on zapewne mianowany naczelnym wodzem sił angielskich", stanowiła wreszcie pewne wyjaśnienie wątpliwości sprzed kilku dni ${ }^{154}$.

Ostatecznie Ironside przyleciał do Gdyni po południu 17 lipca, do Warszawy docierając kolejnym samolotem niewiele później. Uroczyście powitany, oficjalny program wizyty zaczął realizować faktycznie dzień później, 18 i 19 lipca prowadząc

152 AAN, SG, 617/25, list Łubieńskiego do gen. Stachiewicza z 8 VII 1939 r.

153 Ibidem, koncept depeszy szyfrowej L. 50061/BSz. zastępcy Szefa O. II SG płk. dypl. Józefa Englichta do ppłk. Kwiecińskiego z 12 VII 1939 r.; depesza szyfrowa L. 70 ppłk. Kwiecińskiego do O. II SG z 13 VII 1939 r., godz. 14.12. i in. dok. Zob. też: IPMS, A.12.53/24, telegram szyfrowy amb. Raczyńskiego Nr 127 do MSZ (oraz Nr 16 do Amb. RP w Paryżu) z 11 VII 1939 r.; TNA, FO 417/40, telegram No 217 Nortona do Halifaxa z 11 VII 1939 r. W tymże czasie, 13 lipca, o przygotowywanej wizycie zawiadomiono także za pośrednictwem paryskiej ambasady Francuzów, informując ich, że Ironside będzie w Warszawie prowadził rozmowy z polskim Sztabem Głównym na temat aktualnej sytuacji militarnej oraz kroków, które Polacy zamierzają podjąć „w niektórych ewentualnościach" (SHD-DAT, 5 N 579, pismo No 2339 Hoppenota do Gabinetu ministra obrony narodowej i wojny z 13 VII 1939 r. oraz załączone aide-memoire brytyjskiej ambasady w Paryżu $z$ tegoż dnia).

1it IPMS, Lot. A.V. 1/40/b, kopia pisma L. 226/39 ppłk. Kwiecińskiego do Szefa O. II SG 214 VII 1939 r.; T. Skinder-Suchcitz, op. cit., s. 88. Do korespondencji załączona została datowana 14 lipca „Notatka 2 rozmowy Ambasadora Raczyńskiego $z$ generałem Ironside”, w której tej ostatni zadeklarował: „celem mojej podróży do Polski jest potwierdzenie, że nasza gwarancja nie jest tylko na papierze". Ostatnia z przekazanych przez ppłk. Kwiecińskiego informacji okazała si६̨ prawdziwa. W momencie przystąpienia Wielkiej Brytanii do wojny gen. Ironside został mianowany Szefem Sztabu Imperialnego. 
rozmowy głównie z przedstawicielami sił zbrojnych, w tym, zgodnie z zawczasu wyrażonym przez stronę brytyjską życzeniem, z marszałkiem Śmigłym-Rydzem oraz gen. Stachiewiczem, a także $z$ ministrem Beckiem. Wśród poruszanych $w$ trakcie spotkań zagadnień znalazły się przede wszystkim generalne kwestie polskiej strategii wojskowo-politycznej. Gospodarze z naciskiem podkreślali konieczność przełamania impasu w toczących się nad Tamizą rozmowach w sprawie zbrojeniowego kredytu dla Polski, co druga strona przyjmowała ze zrozumieniem, jak dziś wiemy, istotnie natychmiast podejmując wysiłki na rzecz spełnienia tych oczekiwań. Bardziej szczegółowych rozważań o charakterze wojskowym, dotyczących np. problematyki operacyjnej, podejmować nawet nie próbowano. Uniemożliwiał to zresztą brak u boku gościa $z$ Londynu sztabowców-specjalistów, a także nieobecność po stronie polskiej płk. Jaklicza. Przeprowadzone 20 lipca w Rembertowie pokazowe ćwiczenia batalionu piechoty stanowiły efektowną demonstrację polskiej determinacji (użyto ostrej amunicji), niewiele jednak wniosły do merytorycznych treści kolejnej fazy polsko-brytyjskich kontaktów.

Wizyta, zakończona rankiem 21 lipca odlotem uroczyście żegnanego Ironside’a do Kopenhagi, pozostawiła nad Wisłą dobre wrażenie. Generał okazał się gościem czarującym, niemal idealnie wypełniając reprezentacyjno-emocjonalną część powierzonej mu misji. Niewątpliwie dobrze, przynajmniej w doraźnym wymiarze, prezentowały się też jej efekty polityczne. Uśmierzeniu uległy trapiące dotychczas każdą ze stron lęki. Londyn uzyskał sporą dozę pewności, że „nieobliczalni” Polacy nie zamierzają bynajmniej wszczynać wojny z blahego powodu, np. w związku $\mathrm{z}$ jakąś prowokacją w kwestii gdańskiej ${ }^{155}$. Warszawa utwierdzona została w przekonaniu o niezawodności brytyjskiej asysty. Konstatacje te wedle ocen Nortona oddalały widmo rychłego wybuchu konfliktu zbrojnego. Przynajmniej nad Wisłą wizytę wykorzystano też propagandowo, jej przebieg obszernie relacjonując i komentując w środkach masowego przekazu, przede wszystkim w prasie ${ }^{156}$.

Nader zadowoleni $z$ odbytych spotkań i rozmów gospodarze w swych ocenach popełnili jednak jeden przynajmniej, ale istotny błąd. Obszerne wywody Ironside’a na temat forsowanej wówczas przez część londyńskich kręgów politycznych strategii śródziemnomorskiej przyjęli z wyraźnym zadowoleniem, uznając je za widomy do-

15: 14 lipca w rozmowie ze Swordem uzyskanie od Polaków gwarancji, że w pełni kontrolują sytuację i do wojny nie dojdzie z błahej przyczyny („kaprala wysadzającego w powietrze most”), Ironside przedstawił wręcz jako podstawowe $z$ powierzonych mu zadań (E.R. Sword, op. cit., s. 47).

156 DBFP, vol. 5, doc. 374, s. 415nn., doc. 445, s. 486n.; J. Sze mbek, op. cit., s. 672nn.; H. Ja ckiewicz, op. cit., s. 174nn; M. Zgórniak, Europa w przededniu wojny..., s. 442n.; A. Prazmow ska, op. cit., s. 76n.; E.R. Sword, op. cit., s. 48; E. Kwiatkow ski, Dziennik. Lipiec 1939 - sierpień 1940, oprac. M.M. Drozdowski, Rzeszów 2003, s. 32 ln; M. Kornat, Polityka zagraniczna Polski..., s. $500 \mathrm{nn}$. W świetle wyżej przytoczonych faktów i ocen nie można natomiast zgodzić się z opinią A. Prazmowskiej, że Polacy błędnie zinterpretowali wizytę Ironside’a, uznając ją za kontynuację rozmów międzysztabowych, a nie próbę zatarcia złego wrażenia wywołanego fiaskiem rozmów o finansach i współpracy wojskowej (op. cit., s. 98). 
wód zamiarów przyjścia Polsce z pomocą. Choć może się to wydawać zaskakujące, w Warszawie najwyraźniej nie potrafiono zdać sobie sprawy z oczywiście fatalnych dla Rzeczypospolitej, bez trudu dostrzeganych w tym czasie przez sztabowców znad Tamizy konsekwencji tych zamysłów, tj. skierowania wysiłku zachodnich aliantów ku zamorskim peryferiom Włoch, co losu zaatakowanych przez Rzeszę Polaków nie mogło poprawić w żadnym stopniu ${ }^{157}$.

Najbardziej nas interesujące lotnicze aspekty pobytu nad Wisłą brytyjskiego gościa były stosunkowo nieliczne, acz istotne. Sam Ironside zresztą, rozmawiając przez wyjazdem do Polski z ambasadorem Raczyńskim, jako jeden z celów swej wizyty deklarował konieczność opracowania ewentualnej pomocy lotniczej, jako zagadnienie szczególnie ważne wymieniając kwestię skierowania do Polski w razie wojny brytyjskich eskadr ${ }^{158}$. Nad Wisłą rzecz widziano podobnie. Wedle relacji sekretarza ministra Becka, Pawła Starzeńskiego, w toczonych z Ironsidem rozmowach przedstawiciele strony polskiej wprost wskazywali, że "najważniejsze jest, aby na wypadek wojny [Brytyjczycy] mogli nam pomóc intensywnie lotnictwem", najlepiej także bazowanym nad Wisłą. Sam Beck miał zaś na uboczu komentować: „liczę bardzo na ich pomoc lotniczą na Zachodzie, która będzie, zwłaszcza w początkach, jedyną, jakiej będą mogli nam udzielić". Strona brytyjska miała jednoznacznie potwierdzać zasadność tych rachub ${ }^{159}$. Wedle późniejszych informacji gen. Stachiewicza prowadzono też rozmowy na temat ewentualnego rozmieszczenia w Polsce $w$ razie wojny brytyjskich samolotów bombowych, zaś gen. Ironside obiecał przysłanie do Polski misji oficerów lotnictwa dla poczynienia odpowiednich uzgodnień. Wspomniane wyżej ćwiczenia w Rembertowie także odbyły się z udziałem lotnictwa. Nie doszło natomiast do planowanej pierwotnie na późne popołudnie tegoż dnia (20 lipca) wizyty Ironside’a w PZL. Zastąpił ją ostatecznie wyjazd do ulokowanego w Modlinie Centrum Wyszkolenia Saperów ${ }^{160}$.

157 P. Starzeński, op. cit., s. 235; M. Łubieński, op. cit., s. 150.

15x IPMS, Lot. A.V. 1/40b, „Notatka z rozmowy Ambasadora Raczyńskiego z generalem Ironside" z 14 VII 1939 r.

1:y Według Starzeńskiego deklarację taką złożył II sekretarz ambasady R.M.A. Hankey. Jednak także Ironside wobec gen. Musse $z$ wielkim naciskiem potwierdzał - w pełnej zgodzie z otrzymaną w Londynie instrukcją - całkowitą pewność brytyjskiej pomocy dla zaatakowanej Polski, jako podstawową jej formę wymieniając właśnie działania lotnicze oraz, być może, akcję okrętów podwodnych na Bałtyku (SHD-DAT, 7 NN 2/384, raport No 112/S gen. Musse z 19 VII 1939 r.; P. Starzeński, op. cit., s. 234n.). Ciekawie brzmi informacja Michała Łubieńskiego, zgodnie z którą Ironside „orzekł, że lotniska polskie nie nadają się do tego, aby RAF mogła z nich korzystać” (op. cit., s. 150). Rzecz jednak w tym, ze brytyjski gość nie odwiedził żadnej z wchodzących w tym przypadku w grę baz lotniczych.

I6i) AAN, SG 617/25, „Program pobytu gen. Ironside w Polsce” z 18 VII 1939 r.; SHD-DAT, 7 NN 2/384, raporty No 112/S gen. Musse z 19 VII 1939 r. oraz 138/S z 26 VII 1939 r.; W. Sta chiewicz, op. cit., s. 123. Zgodnie z informacjami przekazanymi przez wiceministra Szembeka podczas rozmów przyjęto też wstępnie koncepcję demonstracyjnego skierowania do Polski "awiomatki [lotniskowca], ewentualnie z oddziałem gwardii". Kwestia ta poruszona też została w datowanym 20 lipca telegramie szyfrowym Becka do ambasadora Raczyńskiego, w którym 
W złożonym tydzień po opuszczeniu Warszawy sprawozdaniu z pobytu w Polsce Ironside skupił się na zagadnieniach personalnych ( $\mathrm{z}$ aprobatą kreśląc sylwetkj gospodarzy niedawnej wizyty) oraz ogólnych uwagach na temat polskich zamysłów, które polecono mu uprzednio rozeznać. Raz jeszcze zaakcentował przy tym wykonanie najważniejszego z elementów powierzonej mu misji: jak osobiście zapewnił go marszałek Śmigły-Rydz, mimo niemieckich prowokacji władze z Warszawy nie zamierzały podejmować żadnych nierozważnych działań ${ }^{161}$. Co istotne dla naszej analizy, omawiając przedstawione mu polskie plany wojenne (skądinąd - ocenione pozytywnie), Ironside stwierdził jednoznacznie, że „Polacy jasno zdają sobie sprawę, że są geograficznie izolowani i będą musieli utrzymać się samodzielnie przez długi czas". Przytoczona wyżej refleksja ministra Becka wskazuje, że warszawskim rozmówcom generała konstatacja taka istotnie nie była obca. W praktyce jednak okazali się oni skłonni stosunkowo łatwo przechodzić nad nią do porządku dziennego ${ }^{162}$.

stwierdzono, że „przysłanie lotniskowca do Gdyni i wizyta samolotów byłyby szczególnie pożądane i zrobiłyby bardzo duże wrażenie u nas i w Niemczech" (IPMS, A.12.53.24, telegram szyfrowy Nr 182; J. Szembek, op. cit., s. 674). Brytyjska korespondencja w tejze sprawie z sierpnia 1939 r.: TNA, FO 371/23129, akta C/10906/27/55. O sugestii Becka dokonania przez brytyjską i francuską marynarkę wojenną demostracji na Bałtyku ambasador Noël donosił do MAE już wcześniej, bo 6 lipca (AD, Papiers 1940, Reconstitution Fouques-Duparc 58, kopia telegramu Noëla z 6 VII 1939 r., godz. 20.52).

161 Generał Musse uzyskał ze źródeł brytyjskich dość dokładną relację o przebiegu rozmów Ironside’a z Śmigłym-Rydzem i Beckiem. Wynika z niej, że gość z Londynu dokładnie, wręcz punkt po punkcie, realizował $w$ ich trakcie dyspozycje $z$ przekazanej mu instrukcji (SHD-DAT, 7 NN 2/384, raport No 138/S gen. Musse z 26 VII 1939 r.).

162 TNA, WO 106/1677, raport gen. Ironside’a z wizyty w Polsce, załączony do odręcznego listu do Szefa Sztabu Imperialnego z 28 VII 1939 r. Dokument ten streścił dość obszernie A. Suchcitz (Wrażenia generala Ironsidéa..., s. $61 \mathrm{nn}$.), czyniąc to jednak na podstawie kopii przekazanej do Foreign Office, która - jak wiadomo z dopisków na marginesach egzemplarza zachowanego w Sztabie Imperialnym - pozbawiona została fragmentu odnoszącego się do polskich planów wojennych. W podobny sposób okrojono wersję przesłaną do premiera Chamberlaina (ten egzemplarz: TNA, PREM 331 A). W odbytej 25 lipca rozmowie z ambasadorem Raczyńskim Ironside miał oświadczyć, że przedstawiony mu polski plan działań wojennych jest realny - „może jedynie ocena wartości armii niemieckiej jest zbyt niska". Podkreślał też, iż w Warszawie kładł nacisk na konieczność zapewnienia sobie przez Polaków przychylności ZSRR, czyniąc przy tym znamienną i ważną dla naszych rozważań uwagę: „w przeciwnym bowiem wypadku wszelka kalkulacja na stworzenie antyniemieckiego frontu wschodniego zawislaby do pewnego stopnia w powietrzu" (IPMS, Lot. A.V. 1/40/b, kopia pisma L. 248/39 ppłk. Kwiecińskiego do Szefa O. II SG z 25 VII 1939 r.). Kilka dni wcześniej wobec gen. Musse Ironside sformułowal bardzo podobne oceny, o pomocy radzieckiej wypowiadając się jednak sceptycznie i podkreślając bezsensowność wysiłków na rzecz jej zaakceptowania przez Polaków. Przebywający w tym czasie w Wielkiej Brytanii zastępca Dowódcy Lotnictwa MSWojsk. ppłk pil. inż. Wacław Makowski miał usłyszeć przekazaną z drugiej ręki inną wersję wniosków Ironside’a: „Wyszkolenie Polskich Sił Zbrojnych na poziomie, katastrofalne braki nowoczesnego sprzętu. Polska nie wytrzyma pierwszego uderzenia, może liczyć na kompensacje tylko po zwycięstwie aliantów", co jednak sprzeczne byloby z innymi ocenami generała (W. Ma kowski, Cywil w wojsku. Wspomnienia z życia i wojen. 1930-1945, cz. 3 i 4, Piekary Sląskie 2012, s. 210). Te ostatnie, a także treść złożonego w Londynie sprawozdania generała w żaden sposób nie 
Wbrew ustaleniom przyjętym 24 lipca przez Komitet Obrony Imperialnej oraz zapowiedzi samego Ironside’a jego wizyta nie zapoczątkowała kolejnej tury rozmów międzysztabowych. Zaabsorbowani innymi pracami londyńscy sztabowcy najwyraźniej nie znaleźli czasu na realizację podobnych działań lub też dostatecznych dla nich powodów. W następnych tygodniach wojskowe kontakty z Polską ograniczone więc zostały w praktyce, prócz kwestii dotyczących współpracy wywiadowczej oraz zakupów uzbrojenia, do spraw związanych z ewentualnym bazowaniem nad Wisłą brytyjskich bombowców ${ }^{163}$.

Problem ten, parokrotnie już przez nas uprzednio wzmiankowany, przedmiotem prowadzonych nad Tamizą studiów był wówczas już od kilku miesięcy. Jak się wydaje, wstępne nad nim rozważania podjęto jeszcze w połowie kwietnia, wkrótce po objęciu Polski brytyjską gwarancją. Raz jeszcze przypomnieć przyjdzie, że kręgi wojskowe Londynu ten ostatni krok przyjęły bez entuzjazmu, za jeden z pożytków udziału w wojnie Polski jako sojusznika Zachodu uznając zmuszenie Rzeszy do podjęcia walki na dwóch frontach oraz możliwość objęcia zasięgiem alianckich operacji bombowych także wschodnich obszarów Niemiec. W dokumencie opracowanym w kwietniu w Dyrekcji Planowania Ministerstwa Lotnictwa także zwrócono uwagę na rysujące się teraz nowe możliwości, wskazując jako cele ataków podjętych ewentualnie $\mathrm{z}$ wysuniętych lotnisk (advanced landing grounds) w Polsce obszar przemysłowy wokół Magdeburga, Berlin stanowiący centrum władzy politycznej, a także znajdujące się w jego okolicach skupisko wytwórni lotniczych, zbiorniki paliwa i rafinerie w Szczecinie, zakłady chemiczne $z$ okolic Lipska (w tym kombinat w położonej na zachód od tego miasta miejscowości Leuna) oraz elektrownie. Wszystkie te obiekty, zaznaczono, z trudem można by osiągnąć z terytorium Wielkiej Brytanii czy Francji,

uprawniają do wkładania w jego usta powtarzanych niekiedy w polskiej literaturze opinii, że "front wschodni właściwie nie istnieje”, zaś Polska „zostanie szybko pokonana” (M. Kornat, Polityka zagraniczna Polski..., s. 507). Przedstawiona z kolei w połowie sierpnia zastępcy polskiego attaché wojskowego w Paryżu mjr. dypl. Gustawowi Łowczowskiemu rzekoma opinia Ironside’a („Żolnierz dobrze wyszkolony. Slabe wyposażenie materiałowe. Wyżsi dowódcy nie doceniają wartości wojska i sprzętu niemieckiego") dość dokładnie streszcza pogląd przedstawiony nie przez tego ostatniego, ale misję Claytona (G. Łowczowski, op. cit., s. 50). Faktem jednak jest, że tekstem sprawozdania Ironsidéa Francuzi dysponowali już w końcu lipca, a więc niemal natychmiast po jego sporządzeniu (SHD-DAA, 2 B 104, depesza No 2465 - 2. C/S E.M.A.A. szefa EMAA do plk. Arbitre z 31 VII 1939 r.).

${ }^{163} \mathrm{~W}$ odbytej 19 lipca rozmowie $\mathrm{z}$ gen. Musse Ironside, bardzo zadowolony $\mathrm{z}$ dotychczasowego przebiegu swej misji, wyraźnie podkreślał, że stanowi ona zapowiedź dalszych kontaktów międzysztabowych (SHD-DAT, 7 NN 2/384, raport No 112/S gen. Musse z 19 VII 1939 r.). Tymczasem do postanowień CID w tej sprawie (z 24 lipca) w Londynie nawiązano dopiero kilka tygodni później, 24 sierpnia. Podjętą przez Podkomitet Zastępców Szefów Sztabów dyskusję zakończyła wówczas konkluzja, że do uzgodnienia ze sztabowcami z Warszawy pozostają jedynie dwie kwestie: polityka bombardowań, którą pilnie należało uzgodnić z Francuzami, a następnie ze stroną polską, oraz problem przerzucenia do Polski w razie wojny pewnej liczby brytyjskich samolotów bombowych (TNA, CAB 54/2, "Minute of the 53rd Meeting, held on 24th August, 1939", D.C.O.S./53rd Mtg.). 
omijając przestrzeń powietrzną państw neutralnych, a następnie na długim dystansie kontynuując lot nad terytorium przeciwnika, w stałym zagrożeniu ze strony jego obrony przeciwlotniczej, przy ograniczonej możliwości wykonywania manewrów, na które nie pozwalałby zapas paliwa. Zdolność do podjęcia ataku z obszaru Polski pozwoliłaby na usunięcie ogromnej części tych niedogodności. Wykorzystanie polskich lotnisk dałoby też możliwość podjęcia wahadłowych bombardowań obiektów na obszarze Rzeszy, a także akcji bombowych na cele w Czechach czy na Morawach lub wreszcie - lotów wykonywanych przynajmniej częściowo pod osłoną nocy, a więc bezpieczniejszych. Dwustronne zagrożenie lotnicze zmusiłoby przy tym Niemców do rozproszenia ich naziemnej obrony przeciwlotniczej oraz samolotów myśliwskich.

Wątpliwość autorów analizy budziła jedynie zdolność załóg Bomber Command do podjęcia podobnych zadań. Do dalszej dyskusji odsyłano też kwestie natury organizacyjnej i logistycznej, które w omawianym dokumencie nie zostały uwzględnione, dość optymistycznie oceniając jednak, że trudności w tym zakresie powinny być możliwe do przezwyciężenia. Podkreślono przy tym, że z podjęciem praktycznych przygotowań nie należy zwlekać, przeprowadzając je już w czasie pokoju: próba dostarczenia do Polski niezbędnego materiału w czasie wojny skończyć się może tym, że wybrane lądowiska zostaną wcześniej zajęte przez wojska przeciwnika.

Jako kwestie do przestudiowania w Londynie, a następnie rozmów ze stroną polską autorzy dokumentu wymieniali: dostępność odpowiednich baz i możliwość zagwarantowania ich bezpieczeństwa, wybór szlaków komunikacyjnych dla ewentualnych dostaw w razie wojny (projektowanych jako bardzo dookolne - przez Murmańsk i Leningrad, wokół Afryki przez Kanał Sueski do Odessy albo przez Basrę, Turcję i Odessę), system napraw i ewakuacji uszkodzonego sprzętu, zapewnienie odpowiedniego personelu i jego transport do Polski. Konieczność rozwiązania wszystkich tych problemów, zauważano, sprawia, że wykorzystania polskich lotnisk przez brytyjskie bombowce nie sposób rozpatrywać jako przedsięwzięcia, które zrealizowane zostanie $\mathrm{w}$ krótkim czasie ${ }^{164}$.

Powyższy zamiar w początkach maja został przekazany do konsultacji dowództwu Bomber Command oraz Dyrekcji Operacji Ministerstwa Lotnictwa. W obu przypadkach reakcje były zasadniczo niechętne. Najbardziej obrazowo i szczególnie krytycznie swoją opinię sformułował dowódca Bomber Command Air Chief Marshal Edgar Ludlow-Hewitt, który ewentualne lotnicze ataki na Magdeburg, Berlin czy Lipsk uznał za „w najlepszym razie bardziej niż wyjątkowo sporadyczne" - "głównie o naturze wyczynów". Podjęcie takich działań z terytorium Polski, precyzował swój

It TNA, AIR 14/116, opracowanie Dyrekcji Planowania „The operational advantages which would accrue from the use by Bomber Command of advanced landing grounds in Poland in two-front war against Germany" z 24 IV 1939 r. Wykorzystane jako załącznik do powyższego opracowanie "Facilities of R.A.F. units re-fuelling in Poland" datowane było 17 kwietnia, co sugeruje, że odpowiednie studia podjęto właśnie najpóźniej w połowie tego miesiąca. Zob. też: W. Mazu r, II Rzeczpospolita w planach koalicyjnych dzialań lotniczych przeciw Niemcom (1921-1939), „Przegląd Historyczno-Wojskowy" R. 17, 2016, nr 2-3, s. 216 n. 
pogląd, wyczyny te może nieco ułatwić, „ale to wciąż będą wyczyny"16ミ. Z drugiej jednak strony, zauważał, błędem byłoby zaniechanie "rozsądnych przygotowań" do wykonania przedstawionej przez Dyrekcję Planowania koncepcji - w stosownym czasie. Odpowiednie wzmocnienie obrony przeciwlotniczej mogłoby uczynić rozwiązaniem racjonalnym „wysłanie czterech albo pięciu dobrych dywizjonów bombowych, aby stacjonowały w Polsce, skąd mogłyby osiągnąć Berlin i inne cele na wschodzie stosunkowo łatwo". Skoro jednak na razie polska obrona przeciwlotnicza pozostaje słaba, podobny krok skutkować by musiał wyłącznie stratą tych dywizjonów w efekcie niemieckiego ataku. Całość przedstawionego wywodu sprowadzała się jednak dość wyraźnie do propozycji odłożenia kwestii ad Kalendas Graecas ${ }^{166}$.

Skierowana do Ministerstwa Lotnictwa odpowiedź stanowiła połączenie stanowiska Ludlow-Hewitta oraz własnych przemyśleń adresata jego korespondencji Air Commodore Normana Howarda Bottomleya. Sygnujący ów respons w imieniu swego dowódcy Bottomley zwrócił uwagę na nieuchronne w czasie wojny trudności z dostarczaniem zaopatrzenia dla bazowanych w Polsce samolotów oraz niedostatek w zachodniej części Polski lotnisk odpowiednich dla bombowców dalekiego zasięgu, tj. maszyn o sporej masie startowej, wymagających przeto długiego rozbiegu. Zauważył także, że bardzo ograniczona liczba brytyjskich samolotów bombowych nie jest wystarczająca nawet dla realizacji zadań na Zachodzie, zaś relokacja części sił do Polski oznaczałaby dalsze ich rozproszenie. Wśród kolejnych zgłoszonych wątpliwości znalazły się: słabość polskiej obrony przeciwlotniczej, nieprzystawalność rozważanej koncepcji do istniejących planów działań bombowych (,jedynym planem, który [...] przewiduje atak na cele $w$ Niemczech wschodnich, jest plan W.A.1, ale nawet $w$ tym przypadku owe cele stanowią niewielką część całości"), wreszcie - brak uwzględnienia $\mathrm{w}$ ramach przedstawionej koncepcji lotnictwa polskiego czy radzieckiego. $\mathrm{Ci}$ ostatni partnerzy, spekulował autor korespondencji, z pewnością mogliby zastąpić Bomber Command w atakach na wschodnie obszary Rzeszy.

Ostateczna konkluzja zawierała propozycję kontynuowania odpowiednich studiów i przygotowań. Jak bowiem przyznawali szefowie brytyjskich sił bombowych, działania takie nie pociągają za sobą żadnych zobowiązań, zaś zaskakujący, wykonany w odpowiednim czasie atak na wschodnie Niemcy mógłby istotnie mieć efekt polityczny nieproporcjonalny do jego czysto wojskowej wartości. Łudząco przypominało to opinie formułowane po drugiej stronie Kanału przez gen. Vuillemina ${ }^{167}$.

165 TNA, AIR 14/116, koncept pisma Ludlow-Hewitta do Air Commodore Normana Howarda Bottomleya. Stopień Air Commodore nie ma odpowiednika w polskim systemie, stanowi szczebel pośredni między pułkownikiem a generałem brygady. Bottomley od roku 1938 pełnił funkcję Starszego Oficera Sztabowego Bomber Command (Senior Air Staff Officer at Bomber Command).

166 Ibidem.

167 Ibidem, pismo No BC/S. 22017/Ops. Dowódcy Bomber Command wz. Air Commodore Bottomleya do podsekretarza stanu w Ministerstwie Lotnictwa z I VI 1939 r. Plan W.A.l dotyczył serii operacji powietrznych wymierzonych w niemiecki przemysł lotniczy. Bottomley nie byl pewien, czy siły radzieckie istotnie mogłyby być $w$ ten sposób wykorzystane, do sugestii ich użycia pchnęły go wzmianki na temat roli ZSRR jako pośrednika w komunikacji z Polską. 
Dyrekcja Planowania wciąż jednak obstawała przy swoim stanowisku. Nie jest prawdą, dowodzili jej oficerowie, że operacje podjęte $z$ terytorium Polski mogłyby zostać powiązane $z$ jednym tylko $z$ wojennych planów sił powietrznych. $W$ grę wchodzić może bowiem także inny plan - oznaczony jako W.A.5 (c) i dotyczący ataku na niemieckie zasoby ropy naftowej, w którego ramach także znalazły się cele ze wschodnich Niemiec. Ten ostatni obiekt powietrznych operacji, zauważano zgodnie $z$ dość powszechnym ówcześnie przekonaniem, w początkowej fazie wojny okazać się może wręcz ważniejszy od wszelkich pozostałych.

Jako błędne określone zostały również podnoszone przez opiniodawców argumenty o możliwości wykorzystania do planowanych działań bombowych samolotów polskich czy radzieckich. Polski sojusznik, zauważano, swe szczupłe siły zamierza wykorzystać do wsparcia sił lądowych, co potwierdzono w trakcie niedawnych rozmów międzysztabowych. W przypadku ZSRR za wcześnie zaś byłoby mówić o jakimkolwiek czynnym zaangażowaniu. Gdyby zaś nawet taka możliwość stała się faktem, to radzieckie siły powietrzne nie posiadają dość maszyn, które mogłyby sięgnąć dość daleko w głąb Rzeszy, zaś radziecka doktryna wojenna nie uwzględnia w dostatecznym stopniu ataków lotniczych na obiekty przemysłowe przeciwnika, w każdym razie $w$ początkowym stadium wojny.

Odrzucony został także argument o zbytnim rozproszeniu sił. Skoro bowiem najbardziej prawdopodobnym scenariuszem działań RAF-u w początkach wojny byłby atak na niemieckie zasoby ropy, to możliwość podjęcia takiego uderzenia z wykorzystaniem także polskich lotnisk czyni ową akcję bardziej wartościową od wszelkich alternatyw, z preferowaną w Bomber Command serią operacji przeciw Zagłębiu Ruhry włącznie $^{168}$.

Autorzy raportu pokusili się o uzupełnienie przestawionej w kwietniu koncepcji o szkic dotyczący praktycznych aspektów jej realizacji. Jak stwierdzili, w połowie lipca 1939 roku siły Bomber Command złożone będą z:

- 10 dywizjonów lekkich bombowców Fairey Battle,

- 10 dywizjonów lekkich bombowców Bristol Blenheim,

- 6 dywizjonów średnich bombowców Vickers Wellington,

- 6 dywizjonów średnich bombowców Armstrong Whitworth Whitley,

- 6 dywizjonów średnich bombowców Handley Page Hampden.

Spośród nich, stwierdzano, do operacji z terytorium Polski najlepiej nadawałyby się maszyny typu Wellington, które dysponując zasięgiem 1400 mil, mogłyby osiągnąć po starcie z Anglii bazy na wschód od Warszawy z odpowiednim marginesem bezpieczeństwa ${ }^{169}$. Lot byłby wykonany przez wszystkie maszyny każdej z jednostek

16* Ibidem, opracowanie Dyrekcji Planowania Ministerstwa Lotnictwa „Attack of objectives in Eastern Germany by British bombers operating from temporary advanced bases in Poland" z 6 VII 1939 r. Ostatni z przywołanych wyżej agumentów został w tekście podkreślony, zaś jeden z czytelników fragment ten opatrzył wyrażającym wątpliwość pytajnikiem.

169 W dokumencie samoloty Vickers Wellington określone zostały jako heavy bombers, tj. ciężkie bombowce. 
(tj. 12 samolotów, przy normalnej sile operacyjnej 9), które prócz swych pięcioosobowych załóg miałyby wziąć na pokłady 96-osobową grupę członków personelu naziemnego. Każdy dywizjon przetransportowałby w ten sposób 156 oficerów i żołnierzy, tj. większość swego personelu, liczącego wedle wojennego etatu 256 osób.

Zgodnie z przedstawioną propozycją do Polski przebazowane miałyby zostać dwa lub trzy z sześciu posiadanych dywizjonów samolotów typu Wellington. Jak zakładano, ich pobyty nad Wisłą byłyby stosunkowo krótkie, stąd wszelkie przeglądy i poważne naprawy miałyby być dokonywane w brytyjskich bazach macierzystych. Jako „ekonomiczną metodę" wykorzystania wspomnianych maszyn rekomendowano ich przelot do Polski $z$ dokonaniem po drodze ataku na cele $w$ Niemczech, dwa rajdy bombowe $\mathrm{z}$ baz ulokowanych na wschodzie, a następnie powrót do Anglii, z ponownym bombardowaniem Rzeszy w trakcie przelotu. Całość tak pomyślanej operacji, kalkulowano, mogłaby zostać przeprowadzona w ciągu siedmiu lub ośmiu dni.

Za konieczne dla realizacji projektu uznano przygotowanie w Polsce przynajmniej jednego lotniska oraz jednego lądowiska zapasowego, o odpowiedniej wielkości ( 1200 x 1200 jardów $\left.^{170}\right)$ i możliwościach rozproszenia oraz maskowania maszyn. Za konieczne przyjęto oszacowanie minimalnej liczebności personelu naziemnego niezbędnego do obsługi kierowanych nad Wisłę maszyn, a następnie przedyskutowanie ze stroną polską kwestii uzupełnienia stwierdzonego zapewne niedoboru.

Jak skrupulatnie oszacowali autorzy analizy, do całkowitego zniszczenia przez samoloty operujące z polskich lotnisk w ramach realizacji planów W.A.5(c) oraz W.A.1 celów we wschodnich Niemczech niezbędne byłoby 1185 ton bomb, 1470 ton paliwa lotniczego, 888 ton oleju oraz 4448780 sztuk amunicji ${ }^{171}$. Zagadnienie dostarczenia i składowania tych materiałów uznane zostało za kolejny problem do omówienia z Polakami. W dokumencie umieszczono też długą listę innych tematów, które powinny być poruszone w takiej dyskusji ${ }^{172}$.

Dyrekcja Planowania postulowała, by decyzje odnośnie do przygotowań natury administracyjnej oraz rozmów z polskim partnerem podjęte zostały bezzwłocznie, co umożliwić by miało skierowanie nad Wisłę transportów niezbędnego materiału

171 1200 jardów $=1097$ metrów.

171 Na liście zakładów, które miałyby zostać zaatakowane w ramach planu W.A.l, znalazło się 5 wytwórni płatowców, 2 wytwórnie aluminium, 1 wytwórnia łożysk kulkowych oraz 9 instalacji naftowych, lącznie 17 obiektów. Dla ich zniszczenia według przedstawionej kalkulacji miałoby być niezbędne wykonanie przez samoloty typu Vickers Wellington lub Handley Page Hampden lącznie 1225 samolotolotów. W innej (późniejszej? - choć opatrzonej tą samą datą) kalkulacji liczba uznanych za cele ataku wytwórni podniesiona została do 19 (na liście znalazło się 7, a nie 5 wytwórni płatowców). Pociągnęło to za sobą odpowiednie podwyższenie liczby niezbędnych samolotolotów (do 1335), wagomiaru bomb (do 1307 t), zużycia paliwa (do 1602 t) oraz amunicji (do 4739250 szt., przy czym wpisano tam następnie liczbę 6141000 szt., zakładając, że zamiast wcześniej uwzględnianych hampdenów do Polski skierowane zostaną wyłącznie silniej od nich uzbrojone wellingtony).

172 Zawierała ona zagadnienia zbliżone do ustalanych $w$ trakcie podobnych rozmów polsko-francuskich. Zostały one już wyżej przedstawione, stąd pominięto tu ponowne ich wyliczanie. 
w ciągu kilku miesięcy. Sugerowano przy tym, że rozmowy z Warszawą ułatwić by mogło zaangażowanie autorytetu rządu.

Po południu 14 lipca pod auspicjami zastępcy Szefa Sztabu Lotnictwa odbyła się konferencja zwołana w celu przedyskutowania całości powyższych zagadnień. Uczestnicy spotkania jednogłośnie uznali, że niezbędne jest poczynienie przygotowań, które miałyby zapewnić brytyjskim bombowcom możliwość operowania z terytorium Polski. Zastępca Dyrektora Operacji Wojennych Ministerstwa Lotnictwa został więc zobowiązany do zestawienia informacji na temat personelu i wyposażenia niezbędnego dla dwóch przerzuconych nad Wisłę dywizjonów samolotów bombowych Vickers Wellington. Zaproponowano, by ich bazy ulokowane zostały na południowy wschód od Warszawy, określając łączny wagomiar potrzebnych dla planowanych działań bomb na 1307 ton.

Dyrekcję Operacji Sztabu Lotnictwa obciążono też zadaniem ustalenia polskich standardów zapewniania zdolności operacyjnej maszyn bazowanych na otwartej przestrzeni w warunkach zimowych oraz zaproponowania odpowiednich rozwiązań dla samolotów brytyjskich. Miała ona też przestudiować problematykę nawigacyjną. Zdecydowano także o przedyskutowaniu $z$ polskim attaché lotniczym $w$ Londynie sprawy baz, w których mogłyby zostać rozmieszczone wspomniane wyżej dywizjony wellingtonów ${ }^{133}$.

Ta ostatnia inicjatywa, jak wiemy skądinąd, wychodziła naprzeciw oczekiwaniom, które w Warszawie formułowano co najmniej od początków maja, wyraźnie je artykułując m.in. podczas rozmów z oficerami misji bryg. Claytona. Wówczas nie zdołano doprowadzić w tej sprawie do żadnych konkretnych ustaleń. Ani w Warszawie, ani w Londynie sprawa nie została jednak odłożona ad acta.

Świadczyła o tym jedna jeszcze konferencja, która 14 lipca miała miejsce w Ministerstwie Lotnictwa. Wziął w nim udział przebywający wówczas nad Tamizą jako członek zbrojeniowej misji zastępca Dowódcy Lotnictwa MSWojsk. ppłk pil. inż. Wacław Makowski, zaproszony na spotkanie przez płk. Davidsona, któremu jak relacjonował następnie polski oficer, „polecone zostało wstępne przepracowanie zagadnienia lotów bojowych $\mathrm{z}$ alternatywnym lądowaniem w Polsce i w Anglji"174.

Wszystko wskazuje na to, że zbieżność w czasie obu konferencji nie była przypadkowa, zaś Brytyjczycy postanowili po prostu natychmiast podjąć realizację właśnie podjętych decyzji. Podpułkownikowi Makowskiemu przekazano bowiem wyniki dotychczasowych brytyjskich analiz, w tym m.in. oczekiwania dotyczące położenia lotnisk („w środkowej części Polski między Wisłą a Bugiem”), ich wielkości („ca. $1100 \mathrm{~m}$ do startu") oraz typu przewidywanych do wykorzystania samolotów (Wellington). Ze strony polskiej jako możliwe lokalizacje wzmiankowano Warszawę, Dęblin, Brześć

173 TNA, AIR 14/116, notatka Dyrekcji Planowania „Decisions of a conference held by D. [eputy]C.[hief of]A.[ir]S. [taff] on 14.7.39 to discuss the possibility and advisability of operation by Bomber Command from advanced bases in Poland in the event of war" z 19 VII $1939 \mathrm{r}$.

1/4 IPMS, Lot. A.I. 2/15, kopia pisma ppłk. Makowskiego do Dowództwa Lotnictwa z 14 VII 1939 r., zal. do pisma L. 231/39 ppłk. Kwiecińskiego do Szefa O. II SG z 14 VII 1939 r. 
nad Bugiem, a także - ewentualnie - Białystok i Świdnik. Podpułkownik Makowski zastrzegł przy tym, że są to propozycje wstępne, zaś „dokładne i miarodajne dane [Brytyjczycy] muszą otrzymać z Dowództwa". Zdaje się to wskazywać, co uznać można za konstatację nieco zaskakującą, że to w Londynie, a nie w Warszawie dokładniej zdołano przeanalizować całość „bombowej” problematyki.

Drugą z podjętych w trakcie spotkania kwestii stanowiły sprawy z zakresu łączności. Tu wyjaśnień ze strony polskiej udzielał inny członek misji zbrojeniowej, ppłk łączn. Stanisław Pociask, szef łączności Dowództwa Lotnictwa MSWojsk. Także on jednak nie dysponował zestawem niezbędnych informacji, zwracając się do przełożonych z Warszawy o przesłanie danych dotyczących uzgadniania łączności między stacjami naziemnymi obu państw oraz o stanie instalacji radiowych "na lotniskach w Polsce w ogóle, a na wybranych na ten specjalny cel w szczególności". W grę wchodziły tu przy tym nie tylko zagadnienia łączności, ale i radionawigacji.

Mniej problematyczna okazała się trzecia z dyskutowanych sfer, dotycząca obsługi brytyjskich samolotów, a w szczególności niezbędnych dla nich paliw i smarów. Napęd bombowców typu Wellington stanowiły bowiem silniki Bristol Pegasus XVIII, bardzo podobne do wytwarzanych w Polsce na brytyjskiej licencji. Jako sprawa do wyjaśnienia odnotowana została tylko kwestia szczegółów działania stosowanego w Polsce polowego podgrzewacza silników, przez Brytyjczyków poruszana także, jak już wiemy, na konferencji odbytej przez nich we własnym gronie. Za „osobne zagadnienie" uznano także problem amunicji i bomb. Ten $z$ kolei, wobec braku w Polsce odpowiednich materiałów, rozwiązywany musiał być nade wszystko w Londynie.

$\mathrm{W}$ rozmowie nie zostały na razie poruszone sprawy związane $\mathrm{z}$ logistyczną stroną planowanych przedsięwzięć, tj. personelem pomocniczym, magazynami, transportem, zakwaterowaniem itp. Podpułkownik Makowski sygnalizował jednak, że i one winny być w Warszawie przestudiowane, tym bardziej że całość zagadnień uznać należy za pilną, a Davidson „nalega bardzo, żeby możliwe do uzyskania dane mogły być dostarczone w ciągu paru dni"175.

W odpowiedzi, skierowanej do londyńskiego attachatu 25 lipca, gen. Ujejski zastrzegał, że zgodnie z decyzją Szefa Sztabu Głównego strona operacyjna polsko-brytyjskiej współpracy lotniczej należy do kompetencji tegoż sztabu i nie może być dyskutowana przez członków przebywającej w Londynie komisji technicznej Dowództwa Lotnictwa MSWojsk. Równocześnie nad Tamizę przesłana została mapka lotnisk, które mogłyby być wykorzystane przez brytyjskie samoloty bombowe. Autor pisma zapowiedział też, że $w$ razie akceptacji przedstawionej propozycji do Londynu dostarczone zostaną dodatkowe szkice i opisy tych lotnisk.

Dla potrzeb radionawigacji wykorzystane mogłyby zostać na razie jedynie radiostacje stałe, wykorzystywane przez PLL LOT - z Warszawy, Wilna, Lwowa, Poznania, Gdyni-Rumi oraz Krakowa (z nadajnikiem w Katowicach). W przyszłości dostępne miałyby się stać radiostacje krótkofalowe nadawczo-odbiorcze, instalowane w Warszawie, Krakowie, Dęblinie, Poznaniu, Lwowie, Toruniu, Lidzie, Brześciu nad 
Bugiem oraz Krośnie. Na razie jednak w grę wchodzić mogła jedynie stacja w porcie Warszawa-Okęcie, pozostałe uruchomione miałyby zostać dopiero w końcu roku. Ponadto, wyjaśniał gen. Ujejski, „poza stałymi urządzeniami lotnictwo polskie nie dysponuje żadnym sprzętem przewoźnym naziemnym, umożliwiającym stosowanie radionawigacji".

Ze względu na podobieństwo typów silników lotniczych nie powinna natomiast stanowić większego problemu obsługa przybyłych do Polski samolotów. Obsługa specjalistyczna musi jednak pozostać w rękach brytyjskich, zaś strona polska dostarczyć może jedynie pracowników pomocniczych i pewną ilość środków przewozowych. Z Wielkiej Brytanii należałoby też dostarczyć większość materiałów pędnych i bomb, gdyż Polacy mają tylko ograniczone ich zapasy. Według przedstawionej propozycji całość planowanej współpracy miałaby zostać przedyskutowana przez specjalną komisję. Skoro zaś działania prowadzone będą z obszaru Rzeczypospolitej, to Polska winna stać się miejscem tych prac ${ }^{176}$.

Nad Tamizą tymczasem sceptycy przedkładali kolejne argumenty przeciw realizacji projektu, przynajmniej w dotychczas rozpatrywanej formie. Zwracano uwagę, że w samej Wielkiej Brytanii występują braki części zamiennych do samolotów Vickers Wellington oraz ich silników, stąd wysyłka partii tych części poza granice Zjednoczonego Królestwa zdaje się zamierzeniem nader ryzykownym. Podobne braki sygnalizowano także w przypadku wyszkolonego personelu naziemnego, co czyniło wątpliwym możliwość zapewnienia odpowiedniej obsługi samolotom skierowanym do Polski. Formułowana w konsekwencji propozycja zmierzała ku znacznemu skróceniu czasu bazowania wellingtonów nad Wisłą i sprowadzenia operacji tylko do połączonych $\mathrm{z}$ bombardowaniem lotów wahadłowych nad terytorium Niemiec ${ }^{177}$.

Do tej właśnie koncepcji przychylił się 26 lipca zastępca Szefa Sztabu Lotnictwa Air Vice-Marshal Richard Edmund Charles Peirse, przesyłając do Szefa Sztabu opracowany pięć dni wcześniej dokument zawierający organizacyjne szczegóły operacji związanej z ewentualnym wykorzystaniem polskich lotnisk dla bombardowań obiektów ze wschodnich obszarów Niemiec. Peirse proponował jednak dopuścić pewien zakres samodzielności dowódców brytyjskich dywizjonów, pozwalając na podjęcie przez nich decyzji o przeprowadzeniu przed powrotem do Anglii ,jednego lub więcej" ataków bombowych z baz ulokowanych nad Wisłą. Realizacji takiej możliwości służyć miały m.in. odpowiednio skalkulowane wielkości zapasów dostarczonych do Polski bomb i paliwa ${ }^{178}$.

176 Ibidem, koncept pisma L. 759/S.Lotn. gen. Ujejskiego do ppłk. Kwiecińskiego z 25 VII 1939 r. Załączonej do korespondencji mapki nie udało się odnaleźć w trakcie kwerendy. Niemal identyczny zestaw informacji 21 lipca pismem L. 4376 tj. przesłał do ppłk. Kwiecińskiego gen. Kalkus.

17 TNA, AIR 14/116, kopia pisma bez liczby dziennika Dyrektora Organizacji Sztabu Lotnictwa Air Commodore Davida Grahame Donalda do zastępcy Szefa Sztabu Lotnictwa z 22 VII $1939 \mathrm{r}$.

174 Ibidem, kopia pisma S.54880 Peirse'a do Szefa Sztabu Lotnictwa z 26 VII 1939 r. z zał. ( „Administrative detail for the operation of two Wellington squadrons from advance bases in 
Wedle przedłożonej koncepcji polskie lotniska stać się miały czasową bazą dla dwóch odbywających wahadłowe loty nad Niemcami dywizjonów, tj. łącznie 32 samolotów bombowych Vickers Wellington ${ }^{179}$. W Polsce znaleźć się miała kwatera główna tego zgrupowania, złożona $z 6$ oficerów pod dowództwem pułkownika oraz 13 podoficerów i żołnierzy, a także zredukowany personel dywizjonów, liczący w przypadku każdego z nich 21 oficerów oraz 250 innych lotników i żołnierzy obsługi naziemnej. Wszyscy oni wedle przedstawionej koncepcji mieli trafić nad Wisłę na pokładach brytyjskich maszyn, przy czym ze względu na brak miejsca część z nich przetransportować zamierzano dopiero w drugim locie "lub w jakiś inny sposób". Od polskiego partnera oczekiwano m.in. przygotowania dwóch lotnisk (głównego i pomocniczego) o odpowiedniej wielkości, zapewnienia obrony przeciwlotniczej i bezpieczeństwa na ziemi, dostarczenia systemów łączności oraz ich obsługi, środków transportu wraz z obsługą, magazynów, podstawowego wyposażenia lotnisk (ambulans, wóz straży pożarnej, wózki do przewozu bomb), zakwaterowania i wyżywienia, tłumaczy, zapewnienia możliwości odbywania lotów nocnych (oświetlenie lotnisk itp.), udostępnienia wyposażenia i odzieży zimowej czy wreszcie informacji meteorologicznych ${ }^{180}$.

W pierwszych dniach sierpnia propozycje te przekazano ppłk. Kwiecińskiemu. Ten niezwłocznie przesłał je do Warszawy, podkreślając, że w Londynie sprawa uważana jest za bardzo istotną i pilną. Proponował przeto, by niezwłocznie zaakceptować zmodyfikowaną formułę koncepcji, bez wnikania w szczegóły. Te ostatnie mogłyby stać się przedmiotem rozmów skierowanej do Polski misji brytyjskiej. Raz jeszcze kładąc nacisk na konieczność podjęcia szybkiej decyzji, Kwieciński proponował, by $w$ razie zaakceptowania jego sugestii poinformować go o tym depeszą szyfrową "Zgoda na L. 282". Jak stwierdzał, „depeszę taką będę rozumiał, że jestem upoważniony zakomunikować [...] Ministerstwu Lotnictwa, że polskie władze zgadzają się na działanie lotnictwa bombardującego $z$ obszaru polski i na proponowany przez Anglików sposób upozorowania mającego być wysłanym materiału"181.

Do adresata powyższa korespondencja dotarła dopiero 16 sierpnia. Depesza z oczekiwanym przez Kwiecińskiego tekstem zaszyfrowana została błyskawicznie, bo

Poland in the event of War" zastępcy Dyrektora Organizacji Wojennej Ministerstwa Lotnictwa z 21 VII 1939 r.).

${ }_{17 y}$ Wbrew wcześniejszym propozycjom samoloty z bezpośredniej rezerwy tych dywizjonów (IR - Immediate Reserve) pozostać miały w bazie macierzystej.

Ix1 TNA, AIR 14/116, kopia pisma S.54880..., zał. „Administrative detail for the operation of two Wellington squadrons..." z 21 VII 1939 r.

1*1 TNA, FO 371/23147, kopia pisma mjr. Archibalda Roberta Boyle’a (łącznika Air Ministry $\mathrm{z}$ attaché wojskowymi) do ppłk. Kwiecińskiego z 3 VIII 1939 r. i in. dok.; IPMS, Lot. A.I. 2/15, pismo L. 282/39 ppłk. Kwiecińskiego do Szefa Sztabu Lotniczego Sztabu Głównego z 10 VIII 1939 r. Wzmianka o "upozorowaniu [...] materiału” dotyczyła brytyjskiej propozycji zakamuflowania dostawy do Polski materiałów niezbędnych do podjęcia z jej terytorium działań wellingtonów jako sprzętu nabytego przez polskie lotnictwo wojskowe (TNA, AIR 14/116, pismo No S.1224/ D.D.PLans (Op.) płk. Slessora do dowódcy Bomber Command $z 3$ VIII 1939 r.). 
jeszcze tegoż dnia o godzinie 18.30. Zegar bił już jednak wówczas zbyt szybko, by pośpiech ten mógł przynieść oczekiwany rezultat ${ }^{182}$.

W Wielkiej Brytanii wciąż jeszcze zresztą precyzowano założenia zamierzonego przedsięwzięcia. Jak np. informował 19 sierpnia Ludlow-Hewitt, przewidywana operacyjna siła dywizjonu bombowców wellington 16 maszyn wynosiła tylko teoretycznie. W praktyce braki personelu powodowały, że dywizjony tych maszyn były w stanie $w$ trakcie mobilizacji wystawić nie więcej niż 12 zdolnych do działań samolotów. Tyle też bombowców, wyjaśniał szef Bomber Command, mogłyby liczyć skierowane do Polski formacje dywizjonowe, ale w operacjach bojowych każda jednostka mogłaby operować średnio siłą 9 maszyn, jeśli nie mniejszą ${ }^{183}$.

Wątpliwości budziły także wielkie rozmiary niezbędnych do przeprowadzenia zakładanych działań zapasów. Wedle wyliczeń przedstawionych przez Ludlow-Hewitta pełna realizacja planów działań bombowych (do całkowitego zniszczenia celów) zająć by musiała co najmniej 7,5 miesiąca - i na taki właśnie okres należałoby zgromadzić zaopatrzenie. Przy czym w dotychczasowych kalkulacjach, jak zauważał, nie uwzględniono wielu kategorii materiału, jak np. pewnych niezbędnych elementów wyposażenia naziemnego, maszyn szyfrowych, zaopatrzenia medycznego, sprzętu ochrony przeciwgazowej, sprzętu niezbędnego do tankowania brytyjskich bombowców, taśm do amunicji lotniczej itp. ${ }^{184}$

Część przedstawionych zastrzeżeń dość wyraźnie stanowiła próbę „gry na zwłokę", inne jednak z pewnością warte były przemyślenia. Niewątpliwie stan przygotowań do realizacji projektowanego od kilku miesięcy przedsięwzięcia nadal pozostawiał wiele do życzenia. Fakt ten, a także wyraźne różnice zdań dzielące autorów koncepcji i jej potencjalnych wykonawców pod znakiem zapytania stawiały możliwość uruchomienia całości operacji w niezbyt odległej przyszłości. Jak się zresztą wydaje, strona brytyjska w ostatnich dniach sierpnia straciła już do niej serce. Na zadane przez polskie Dowództwo Lotnictwa pytanie płk Slessor wyjaśnił 29 sierpnia, że z powodu braku nad Wisłą odpowiednich bomb, paliwa i niezbędnego wyposażenia podjęcie akcji bombowych z obszaru Polski nie będzie możliwe. Jak więc stwierdził, jedynymi brytyjskimi maszynami, które w razie wojny pojawić się mogą na terytorium wschodniego alianta, miałyby więc być nieliczne bombowce operujące uprzednio nad wschodnimi Niemcami i zmuszone do lądowania w Polsce skutkiem uszkodzeń. Brakujące uzbrojenie i wyposażenie, dodawał Slessor, może zostać do

162 IPMS, Lot. A.I. 2/15, pismo L. 904/S.Lotn.Tj. gen. Ujejskiego do Szefa O. II SG z 16 VIII $1939 \mathrm{r}$.

1*3. Liczba 16 maszyn operacyjnych w dywizjonie wellingtonów w sierpniu 1939 r. stanowiła wciąz kwestię przyszłości. Kierowane do Polski maszyny należeć miały do 3 Grupy, w której w polowie sierpnia 1939 r. podniesienie stanów dywizjonów z 12 maszyn operacyjnych (IE) i 4 maszyn rezerwy (IR) do 16 maszyn IE oraz 5 samolotów IR znajdowało się dopiero na etapie decyzji (TNA, AIR 14/302, kopia pisma No 2097 płk. Edwarda Spencera Goodwina (Senior Staff Officer at Bomber Command) do Dowództwa 3 Grupy z 15 VIII 1939 r. i in. dok.).

1*4 TNA, AIR 14/116, kopia pisma Ludlow-Hewitta BC/S.22442/Org. do podsekretarza stanu w Ministerstwie Lotnictwa z 19 VIII $1939 \mathrm{r}$. 
Polski dostarczone później, po udrożnieniu drogi przez Morze Śródziemne. Była to już jednak tylko osłoda podanej właśnie gorzkiej pigułki ${ }^{185}$.

W tym czasie jedna jeszcze seria rozmów miała wpływ na perspektywy wojennej współpracy lotnictwa wojskowego Polski i jej zachodnich sojuszników. Tej jednak nie toczono ani w Londynie, ani w Paryżu, ani w Warszawie - ale w stolicy ZSRR. Delegacje wojskowe Wielkiej Brytanii i Francji przybyły tam przed południem 11 sierpnia, aby podjąć próbę osiągnięcia ostatecznego porozumienia $\mathrm{w}$ rozmowach, które $\mathrm{z}$ miernym skutkiem prowadzone były już od kwietnia, głównie na gruncie politycznym, choć nie bez bardzo stanowczych nacisków ze strony kręgów wojskowych Zachodu, przekonanych - jak już wielokrotnie wskazywaliśmy - że tylko współpraca $z$ ZSRR pozwoli na przekształcenie efemerydy wschodniego frontu w konstrukt "trwały i solidny", tak istotny dla kreślonych przez nie koncepcji ${ }^{186}$.

Przekonanie, że ewentualna umowa polityczna winna być uzupełniona przez określające praktyczne aspekty współpracy porozumienie militarne, w tle owych negocjacji obecne niemal od ich początku, jednoznacznie sformułowane zostało przez stronę radziecką w pierwszych dniach lipca. Generałowie Gamelin i Gort wstępne uzgodnienia w tej kwestii poczynili niemal natychmiast, bo już 13 lipca, w trakcie wizyty złożonej przez Szefa Sztabu Imperialnego nad Sekwaną ${ }^{187}$. Wśród kilku

185 W południe 29 sierpnia do Londynu nadeszła informacja płk. Sworda, że polskie Dowództwo Lotnictwa prosi o wiadomość, czy w razie wojny brytyjskie lotnict wo podejmie operacje $\mathrm{z}$ terenu Polski, a jeśli tak, to jaką liczbą samolotów oraz jakie przygotowania muszą być przeprowadzone dla ich przyjęcia (TNA, FO 371/23147, telegram szyfrowy No 350 Kennarda z 29 VIII 1939 r., deszyfrowany o godz. 12.20). Dzień wcześniej do ppłk. Kwiecińskiego Dowództwo Lotnictwa przesłało podobną serię pytań, znamionujących całkowitą dezorientację: „Kiedy i kto będzie omawiać z nami szczegóły użycia lotnictwa angielskiego z terenu Polski? Czy przybyły tu kapitan Donkin [skądinąd nieznany - dop. W.M.] jest do tego upoważniony i w jakim stopniu?" (IPMS, Lot. A.I. 2.11, pismo L. 1015/S.Lotn.tj. Dow. Lotnictwa MSWojsk. do Szefa O. II SG z 28 VIII 1939 r.). Odpowiedź Slessora: TNA, AIR 8/260, koncept pisma (depeszy?) z 29 VIII 1939 r.

${ }^{1 k 6}$ Polskie konteksty prowadzonych $w$ tym czasie rozmów z Moskwą w przypadku brytyjskim syntetycznie przedstawil J. Tebinka (Polityka brytyjska..., s. 37nn.), zaś dla strony francuskiej M. Gmurczyk-Wrońska (op. cit., s. 90nn., a nast. $106 \mathrm{nn}$.). Zob. też interesujące uwagi M. Kornata (Polityka zagraniczna Polski..., s. 356nn.) oraz sporządzone w Poddyrekcji Europa MAE tabelaryczne zestawienie przebiegu rozmów do początków czerwca (AD, Papiers 1940, Hoppenot 7 , „État de négociation au sujet du pacte d'assistance soviétique au 2 Juin 1939"). Rządy zachodnie, a przede wszystkim francuski, nie uważały w tym czasie za zasadne poszerzania negocjacji politycznych o rozmowy o tematyce wojskowej. Przebieg rokowań prowadzonych w okresie od kwietnia do lipca 1939 r. w oświetleniu brytyjskim: TNA, CAB 55/18, opracowanie Foreign Office "Course of the Anglo-French-Soviet Negotiations im Moscow" z 27 VII 1939 r.

187 Prace w Paryżu podjęte zostały już wcześniej, o czym świadczy datowana właśnie 13 lipca dość obszerna, opracowana w O. III Sztabu Generalnego Armii „Note relative au programme de la mission du Général Doumenc" (SHD-DAT, 7 N 3434). Wśród zagadnień, które miały zostać podjęte $w$ Moskwie, znalazła się m.in. pomoc materiałowa dla Polski (w tym dostawy materiału lotniczego i surowców) oraz akcja radzieckich sił powietrznych przeciw Niemcom, w tym także „we współpracy $z$ armią polską i rumuńską". W razie akcji niemieckiej przeciw państwom bałtyckim siły radzieckie miały zapewniać osłonę Polski od północy, a w razie pomyślnych okoliczności podjąć ofensywę przeciw Prusom Wschodnim wzdłuż osi Mińsk - Königsberg (Królewiec). W przy- 
zagadnień, które obaj rozmówcy uznali wówczas za najistotniejsze $w$ rozmowach ze stroną radziecką, znalazła się także kwestia przyszłego frontu wschodniego, który miałby być utworzony przez siły polskie i rumuńskie, zaś w części południowej przez potraktowanych odrębnie Turków. W obu przypadkach tematyka lotnicza stanowiła jedną z osi kreślonych zamierzeń. Zwrócono w nich uwagę na konieczność wykorzystania ZSRR dla zaopatrywania sojuszników Zachodu w materiał wojenny i surowce, a także możliwość bezpośredniego ich wsparcia przez siły powietrzne $\mathrm{z}$ czerwoną gwiazdą ${ }^{188}$.

W następnych dniach obaj Szefowie Sztabów zaprzęgli do pracy nad zarysowaną w ten sposób koncepcją podległe im struktury. Gamelin już 17 lipca „kwestię rosyjską" uczynił jednym z głównych tematów spotkania Szefów Sztabów Generalnych rodzajów sił zbrojnych. Obecni zostali poinformowani, że premier Daladier, przekonany przez Bonneta, iż Rosjanie nie zechcą zawrzeć porozumienia politycznego bez równoległej umowy wojskowej, nakazał przygotowanie misji, która miałaby się udać do Moskwy. Jej szefem miałby zostać gen. Joseph Doumenc (dotychczasowy dowódca 1 Okręgu Wojskowego w Lille), zaś członkami reprezentujący siły powietrzne gen. Martial Henri Valin oraz kmdr ppor. Jacques-Antoine Wuillaume jako przedstawiciel marynarki wojennej.

Celem misji, wyjaśnił Gamelin, byłoby ustalenie, jakiej pomocy strona radziecka mogłaby udzielić zaatakowanym Polakom oraz Rumunom, wykorzystując swe jednostki lotnicze i zmotoryzowane oraz podejmując działania na skrzydłach armii obu tych państw. Jak podkreślił, sprawę należało traktować ostrożnie, Polacy bowiem nie akceptują zasadniczo obecności wojsk radzieckich na swym terytorium. Nie zmienia to jednak faktu, dodał $z$ brutalną szczerością, że $w$ razie wojny zmuszeni będą ową obecność zaaprobować189.

padku niemieckiego uderzenia w kierunku Ukrainy siły radzieckie miałyby zapewniać lączność armii polskiej i rumuńskiej, a jeśli Rumunia pozostałaby neutralna - osłaniać Polskę od południa. 1** AD, Papiers 1940, Bonnet 11, kopia notatki Bonneta 213 VII 1939 r. „Négociations franco-anglo-russes (5 Juillet - 13 Juillet 1939)" z 13 VII 1939 r.; SHD-DAT, 2 N 225, niesygnowany dokument [Sekretariatu Generalnego Najwyższej Rady Obrony Narodowej?] "Questions Russes dont létude a été proposée au Gamelin des conversations franco-britannique du 13 Juillet 1939" z 15 VII 1939 r.; 7 NN 2/582, niedatowany i niesygnowany [gen. Doumenc] raport z misji w Moskwie; DDF, t. 17, doc. 196, s. 337; doc. 198, s. $341 \mathrm{nn}$. W końcu miesiąca stanowisko radzieckie stało się w tej kwestii jeszcze bardziej jednoznaczne: Rosjanie porozumienia polityczne i wojskowe uznają za nierozdzielne, stwierdzano w notatce sporządzonej na Quai d'Orsay 29 lipca (ibidem, doc. 364, s. 597).

149 SHD-DAT, 2 N 225, parafowany przez Gamelina „Procès-verbal de la Réunion des Chefs d'État-Major Généraux du 17 Juillet 1939". W opracowanym wkrótce po spotkaniu Szefów Sztabów koncepcie pisma do gen. Doumenca Gamelin nieco zniuansował tę ostatnią uwagę, przewidując, że w czasie wojny Polacy będą zmuszeni przyjąć na swym terytorium obecność radzieckiego lotnictwa, a być może także jednostek zmechanizowanych. Natomiast, dodawał, "otwarcie ich granic dla sił rosyjskich wszystkich kategorii pozostaje mało prawdopodobne" (pismo wysłane zostało 27 lipca jako No 1522/DN.3 - kopia: SHD-DAT, 7 N 3186). Takie opinie znajdowały uzasadnienie m.in. w ocenach 2e Bureau Sztabu Generalnego Armii, które informowało w tym 
W toku dość bezładnej dyskusji zwrócono m.in. uwagę na konieczność ostatecznego określenia wartości radzieckiej pomocy w gotowym materiale i surowcach, które dostarczone mogłyby być przez ZSRR do Polski, Rumunii i Turcji (gen. Louis Marie Jamet), oraz możliwość wykorzystania radzieckiej floty wojennej do przerwania niemieckich linii komunikacyjnych na Morzu Bałtyckim, a także obrony Gdyni (adm. Darlan). W końcowej fazie spotkania gen. Mendigal przedstawił informację o polskich siłach powietrznych, a także perspektywach ich wzmocnienia przez dostarczenie nad Wisłę nowoczesnych francuskich myśliwców, co jego zdaniem mogłoby nastąpić w październiku ${ }^{100}$.

W konkluzji obradujący sporządzili zestawienie zagadnień, które miałyby zostać poruszone przez delegację francuską podczas planowanych rozmów. Wśród siedmiu przyjętych punktów znalazła się m.in. radziecka akcja morska i lotnicza na Bałtyku (w tym pomoc w obronie Gdyni), wzmocnienie polskiego i rumuńskiego teatru operacji przez radzieckie lotnictwo, jednostki zmechanizowane oraz „ewentualnie oddziały lądowe", a także dostawy do trzech państw zagrożonych atakiem surowców, żywności, uzbrojenia, amunicji i oprzyrządowania. Całość przyjętych postanowień 24 lipca opatrzona została naniesioną na jednym z egzemplarzy procès-verbal aprobatą premiera Daladiera ${ }^{191}$.

W Londynie prace zainicjowano nieco później. Dopiero 26 lipca członkowie Połączonego Podkomitetu Planowania zostali poinformowani, że minister ds. koordynacji obrony polecił im podjęcie wstępnych studiów nad zagadnieniami podstawowymi dla planowanych rozmów: czego oczekujemy od Rosji na lądzie, morzu lub w powietrzu?, jaką pomoc materiałową można jej zaoferować?, a także - jak daleko można się posunąć, udzielając informacji o brytyjskich intencjach? Kwestię do rozważenia stanowił także skład brytyjskiej delegacji, która wedle sugestii Chatfielda składać by się miała $\mathrm{z}$ wysokiej rangi oficera armii lądowej, obdarzonego jeszcze wyższą rangą przedstawiciela sił powietrznych oraz reprezentanta marynarki wojennej ewentualnie o mniej znaczącej pozycji. Podkomitet miał się także zastanowić

czasie o „rosnącej sympatii” Polaków wobec rozmów francusko-brytyjsko-radzieckich. Podobne informacje przekazywał z Warszawy gen. Musse (SHD-DAT, 7 N 2524, opracowanie „Événements survenus pendant la période du 10 au 22 Juillet 1939 (Pologne - Roumanie - Turquie)"; 7 NN 2/384, „Rapport No 141/S du 2 Août 1939” gen. Musse). Z dokumentu Sztabu Generalnego Armii „Résumé des questions traitées à la Réunion des Chefs d'États-Majors Généraux du 11.7.39” zdaje się wynikać, że sprawa skierowania do Moskwy francuskiej misji wojskowej dyskutowana była już na poprzednim posiedzeniu Szefów Sztabów. Śladów podjęcia takiego tematu brak jednak w „Procès-verbal..." $z$ tego spotkania, dopisany w ostatniej chwili do jego porządku dziennego punkt dotyczący koordynacji działań wojskowych Rumunii i ZSRR w praktyce dotyczył spraw bałkańskich (SHD-DAT, 7 N 2293, „Résumé des questions traitées...”; 2 N 225, materiały posiedzenia Szefów Sztabów z 11 VII 1939 r.). Sam Doumenc o powierzonej mu misji dowiedział się 15 lipca.

${ }^{190}$ SHD-DAT, $2 \mathrm{~N} 225$, „Procès-verbal de la Réunion des Chefs d'État-Major Généraux du 17 Juillet 1939".

191 Ibidem, „Conclusions de la Réunion des Chefs d'État-Major Généraux du 17 Juillet 1939 au sujet de l'envoi d'une mission militaire en Russie" (na jednym z egzemplarzy poprawki i dopiski Gamelina oraz jego parafa). 
nad sposobami zapewnienia możliwie harmonijnej współpracy delegacji brytyjskiej i francuskiej ${ }^{192}$.

W trakcie przeprowadzonej dzień później dyskusji Połączony Podkomitet Planowania opowiedział się wstępnie za skierowaniem do Moskwy wspólnej delegacji obu mocarstw zachodnich (a nie dwóch odrębnych delegacji), proponując, by kierownictwo obrad powierzyć Francuzom, gdyż to oni musieliby odegrać główną rolę w ewentualnej ofensywie na froncie zachodnim. W razie niemożności scalenia $w$ jedną misji kierowanych do Moskwy z Londynu i Paryża sugerowano, że należałoby wysłać je jednocześnie i skorelować treści instrukcji, w które zostaną zaopatrzone. Podobne zdanie na ten temat wyraził niemal równolegle Podkomitet Zastępców Szefów Sztabów ${ }^{19}$.

Wstępna wersja brytyjskiej instrukcji dla delegatów opracowana została przez Połączony Podkomitet Planowania niemal natychmiast, bo 29 lipca. Wbrew zgłaszanym jeszcze dzień wcześniej propozycjom uznano, że brak czasu uniemożliwia podjęcie między Londynem i Paryżem uzgodnień o połączeniu obu delegacji w jeden zespół, a nawet skoordynowanie treści instrukcji brytyjskiej i francuskiej. W razie pojawienia się znaczących różnic pomiędzy dyspozycjami sformułowanymi nad Tamizą i nad Sekwaną delegaci brytyjscy konsultować się mieli z Szefami Sztabów. Podkreślano przy tym, że w trakcie podjętych w Moskwie rozmów obie zachodnie misje winny działać wspólnie, nie różniąc się niczym prócz nazwy.

Autorzy instrukcji akcentowali, że pierwszeństwo w negocjacjach nadal powinno mieć porozumienie polityczne. Stąd, jak wyjaśniali, rozmowy o charakterze militarnym muszą być początkowo prowadzone powoli - przynajmniej do czasu uzgodnienia umowy politycznej, przedwczesne ujawnienie poufnych informacji postawiłoby bowiem zachodnich negocjatorów w bardzo niedogodnej pozycji. Przyjmowano więc dość naiwne założenie, iż wojskowa część rozmów rozpocznie się od prób skłonienia gospodarzy do wyjaśnień, w jaki sposób oni sami mogliby pomóc "na przykład Polsce".

Radzieckiemu partnerowi z oczywistych przyczyn nie dowierzano, delegatów przestrzegając zarówno przed możliwością, że wszelkie ujawnione w Moskwie informacje trafić mogą do Berlina, jak i rozbudowanym w ZSRR systemem kontroli i inwigilacji, który z pewnością zostanie wykorzystany także przeciw nim. Rekomendowano więc, by w podróż na wschód zabierać jedynie dokumenty niebędne, o możliwie ogólnej treści, jak np. opracowania A.F.C. 7 i 25, w których nakreślone zostały pryncypia anglo-francuskiej strategii wojennej. Sama zaś dyskusja miałaby dotyczyć w miarę możności jedynie frontu wschodniego, Bałtyku i Morza Czarnego. $\mathrm{W}$ razie zaś konieczności wyjścia poza ten zakres tematyczny należało unikać wszelkich odniesień do technicznych szczegółów wyposażenia armii Zachodu, a proble-

192 TNA, CAB 55/18, nota J.P. 483 Cornwall-Jonesa z 26 VIl 1939 r.

19.3 Ibidem, opracowanie „Anglo-Franco-Russian staff conversations”, J.P. 485 z 27 VII 1939 r.; CAB 55/3, „Minutes of the Meeting held on [...] 28th July, 1939..., J.P. 265th Mtg. i in. dok.; CAB 54/10, raport „Staff conversations with Russia”, D.C.O.S. 147 z 28 VII 1939 r. 
my związane $\mathrm{z}$ ich wyszkoleniem taktycznym sprowadzać do stwierdzeń o charakterze ogólnym. Bardzo wyraźnie i z całą mocą podkreślano też, że w trakcie rozmów delegaci brytyjscy powinni zachowywać wielką ostrożność $w$ razie przedstawiania jakichkolwiek informacji o Polsce i polskich siłach zbrojnych, zachowując świadomość, że wieści na ten temat dotrzeć mogą także do uszu polskiego partnera, który część tych danych powierzył Brytyjczykom w zaufaniu. Stąd - formułowano rzecz jednoznacznie - „Rosjanie powinni być zachęcani do zasięgania wszelkich interesujących ich informacji wprost u Polaków"194.

Dobrze znany w Londynie problem niechęci władz Polski i Rumunii do jakiejkolwiek radzieckiej pomocy wojskowej brytyjska delegacja miała starać się rozwiązywać za pomocą następującej argumentacji: „Wielka Brytania, Francja i Rosja są wielkimi mocarstwami i mogą oceniać wielkie problemy strategiczne. Mniejsze państwa, jak Polska i Rumunia, są raczej skłonne do przeceniania swej siły i możliwości oporu. Jednak [...] inwazja Niemiec może szybko zmienić ich pogląd. Co więcej, byłoby wielką niedogodnością, gdyby Niemcy mogły zająć pozycję nad granicą rosyjską albo uzyskać dostęp do Morza Czarnego bez podjęcia poważnej próby ich zatrzymania. Stąd też $\mathrm{w}$ rosyjskim interesie jest mieć gotowe plany pomocy dla Polski i Rumunii, gdyby te państwa stały się obiektem inwazji"195.

Główną formą pomocy dla zaatakowanych miałyby być, wyjaśniano nie po raz pierwszy, dostawy amunicji i surowców. Delegacja brytyjska miała przy tym zachęcać radzieckiego partnera do nawiązania bezpośrednich negocjacji z oboma zagrożonymi sąsiadami. Także w Londynie najwyraźniej uważano, że może się to stać w najbliższej przyszłości możliwe, napomykając o widocznych już oznakach zmiany nieprzejednanego dotychczas stanowiska Polski w tej kwestii.

Dokładniejsze przedstawianie treści obszernej, liczącej ponad sto stron instrukcji nie byłoby celowe, także dlatego, że zawierała ona stosunkowo niewiele nowych, oryginalnych informacji i ocen. Do redagowanego pośpiesznie tekstu włączono bowiem po prostu obszerne fragmenty wcześniejszych analiz (nie usuwając $z$ nich nawet oczywistych omyłek), wielokrotnie już często przez nas przywoływanych. Z powstałych wcześniej opracowań zapożyczone zostały m.in. oceny wartości armii polskiej i rumuńskiej, informacje na temat potencjału wojennego pozostałych uczestników konfliktu (w tym radzieckich i niemieckich sił powietrznych), przypuszczalnego podziału sił Rzeszy pomiędzy dwa fronty rozpatrywanej wojny, domniemanych działań lotniczych, oceny szans polskiej obrony czy omówienie zagadnień związanych z ewentualnymi operacjami na zachodzie Europy.

194 TNA, CAB 55/18, „Memorandum for the guidance of the United Kingdom Delegation to Russia" z 29 VII 1939 r. Strona polska istotnie z góry już wyrażała zaniepokojenie możliwością ujawnienia podczas rozmów w Moskwie jej wojskowych tajemnic. Indagowani w tej sprawie Francuzi także zapewnili Warszawę, że nie przekażą stronie radzieckiej żadnych poufnych danych na temat Polski (SHD-DAT, 7 N 3002, kopia telegramu szyfrowego za ministra wojny i z jego rozkazu gen. Dentza do gen. Musse z 3 VIII 1939 r.).

195 TNA, CAB 55/18, „Memorandum for the guidance...”. 
$\mathrm{Z}$ natury rzeczy nieco szerzej niż $w$ innych dotychczasowych ujęciach potraktowano natomiast $w$ instrukcji wojskowy kontekst relacji Warszawy i Moskwy. Brytyjskich delegatów poinformowano, że podawana przez stronę polską oficjalna przyczyna niechęci względem bliżzzej współpracy $z$ tą ostatnią, tj. obawa przed drażnieniem Berlina, stanowi jedynie pretekst. Prawdziwym powodem, wyjaśniali autorzy instrukcji, jest lęk, że raz wprowadzonych do kraju oddziałów radzieckich nie można by się pozbyć, a ich pobyt skutkować by mógł „komunizacją” polskiego chłopstwa. Pewne jest w każdym razie - tu znów Brytyjczycy przedstawiali oceny bardzo podobne do formułowanych równolegle we Francji - ze „o ile Polacy mogliby być gotowi zaakceptować rosyjskie siły powietrzne i rosyjski materiał, to nie chcą rosyjskich żolnierzy na polskiej ziemi"196.

Jak zauważali autorzy instrukcji, brak w Polsce nowoczesnych myśliwców oraz słabość jej obrony przeciwlotniczej stanowiły bodaj najistotniejsze ze słabości tego państwa w ewentualnej wojennej konfrontacji z Rzeszą. Z kolei przedstawiciele ZSRR w toczonych ostatnio rozmowach przejawiali zainteresowanie możliwościami zapobieżenia niemieckiej penetracji w państwach bałtyckich. Stąd - formułowano tezę $w$ interesie obu państw jest podjęcie współpracy w zakresie obrony powietrznej na polsko-niemieckim froncie. Trwanie tego frontu utrzyma niemieckie bombowce w pewnej odległości od rosyjskiego terytorium, zapewniając też Polakom i Rosjanom krótszą linię obrony niż ta, której obronę musieliby podjąć ci ostatni w przypadku okupacji przez Rzeszę Polski i państw bałtyckich. Radzieckie myśliwce i obrona przeciwlotnicza miałyby zaś dla podtrzymania polskiej obrony znaczenie zasadnicze.

Kierowanym do Moskwy delegatom nie zalecano natomiast podejmowania we wstępnej fazie rozmów dyskusji na temat radzieckiego udziału w ofensywie bombowej przeciw Niemcom, uznając, że taka wstrzemięźliwość ma uzasadnienia zarówno polityczne, jak i czysto wojskowe. Radzieckim siłom powietrznym brak bowiem większej liczby nowoczesnych samolotów bombowych, które mogłyby wtargnąć w głąb niemieckiej obrony. Ponadto zaś, zauważano, trudno zachęcać Moskwę do podjęcia działań, których wobec obaw o spowodowanie ofiar wśród ludności cywilnej nie zamierzają podejmować jej zachodni partnerzy. W tym przypadku, sugerowano, należy raczej sprawiać wrażenie, że sami Brytyjczycy tworzą w Polsce składy bomb i paliwa lotniczego, mając zamiar podjęcia $\mathrm{w}$ razie wojny operacji $\mathrm{z}$ ulokowanych tam lotnisk wysuniętych ${ }^{197}$.

Ostateczna, znacząco przeredagowana wersja przeznaczonej dla brytyjskiej delegacji instrukcji przyjęta została przez zastępców Szefów Sztabów 31 lipca. Zasadnicze idee dokumentu, choć teraz wyrażone często w sposób bardziej klarowny, pozostały jednak bez większych zmian. W sferze lotniczej w razie niemieckiego uderzenia na Polskę strona radziecka, prócz pomocy materiałowej, miałaby udzielić wsparcia zaatakowanym, wykorzystując $w$ tym celu swoje myśliwce i bombowce. Autorzy instrukcji wyrażali nadzieję, że takie działania, podjęte ewentualnie także $z$ teryto-

${ }^{19 ;}$ ' Ibidem, annex II: „Estimate of the military value od Russian Forces”. 
rium Polski, nie musiałyby się wiązać z obecnością na tymże terytorium liczniejszych sił radzieckich, a więc mogłyby zostać przez Polaków zaakceptowane. W przypadku skierowania niemieckiej ofensywy na Zachód istotne stawałoby się odciągnięcie z tego kierunku możliwie dużej części niemieckiego lotnictwa. Delegacja brytyjska miała więc zachęcać gospodarzy rozmów, by w razie ziszczenia się takiego scenariusza rozważyli podjęcie, choćby $w$ formie improwizowanej, dywersyjnej akcji bombowej przeciw wschodnim obszarom Rzeszy ${ }^{198}$.

$\mathrm{O}$ rozpoczętych przygotowaniach partnerów z Paryża powiadomiono już we wstępnej ich fazie, wieczorem 28 lipca, proponując m.in. uzgodnienie treści posiadanych przez obie delegacje instrukcji, a następnie ich wspólną podróż do Moskwy. Brytyjczycy podali także wstępnie przyjęty skład swej misji. Na jej czele stanąć miał stanąć adm. Plunkett Ernle-Erle-Drax, zaś jako przedstawiciel sił powietrznych towarzyszyć mu miał Air Marshal Charles Burnett. Informacje na temat personaliów reprezentującego marynarkę wojenną trzeciego członka delegacji oraz sześciu wybranych do roli asysty oficerów sztabowych obiecano przekazać niebawem. Całość brytyjskiej grupy zebrać się miała w Londynie 31 lipca w celu przestudiowania instrukcji. Spotkanie $z$ francuskimi kolegami proponowano zorganizować 2 sierpnia w Londynie lub w Paryżu - wyjazd do Moskwy mógłby nastąpić natychmiast po przedyskutowaniu niezbędnych kwestii ${ }^{199}$.

Francuzi tymczasem wciąż jeszcze znajdowali się w trakcie przygotowań. 1 sierpnia ponownie zebrali się w Paryżu Szefowie Sztabów. W trakcie posiedzenia $\mathrm{z}$ udziałem gen. Doumenca oraz kierowanego z misją do Turcji gen. Charlesa Léona Huntzigera doszło do krótkiej dyskusji na temat zagadnień, o które mogłaby zostać uzupełniona tematyka planowanych w Moskwie rozmów. Wzmianka Doumenca na temat radzieckiej floty wojennej na Morzu Bałtyckim dopełniona została informacją gen. Vuillemina o prowadzonych w ZSRR pracach nad wykorzystaniem w obrębie tego akwenu także lotnictwa. Jak się jednak wydaje, wątku tego nie rozwijano. Dalsza wymiana zdań dotyczyła bowiem już innych zagadnień: aktywności radzieckich okrętów podwodnych oraz podniesionej przez Doumenca możliwości użycia radzieckiego lotnictwa przeciwko włoskim bazom na terenie Albanii. Ta ostatnia myśl spotkała się ze sceptycznym komentarzem Vuillemina, który zwrócił uwagę, że taka akcja wymagałaby użycia lotnisk tureckich, generalnie źle wyposażonych ${ }^{200}$.

Podjęte jeszcze w końcu lipca brytyjsko-francuskie konsultacje na temat ostatecznego wyboru terminu i miejsca spotkania obu delegacji, a także środka transportu, który miałby zapewnić nie tylko możliwie szybkie dotarcie do Moskwy, ale też zachowanie tajemnicy przewożonych dokumentów, ujawniły różnice zdań. Ostatecz-

19" Ibidem, nota D.C.O.S.154 (Revise) Podkomitetu Szefów Sztabów z 31 VII 1939 r. wraz z załączonym tekstem „Memorandum for the guidance...". Ten ostatni dokument zostal ostatecznie zaaprobowany przez Komitet Obrony Imperialnej na jego 372. posiedzeniu, 2 sierpnia.

${ }_{194}$ TNA, CAB 104/44, telegram szyfrowy No 248 Foreign Office do R.I. Campbella (z ambasady brytyjskiej w Paryżu) z 28 VII 1939 r., godz. 19.00.

2011 SHD-DAT, 2 N 225, „Procès-verbal de la Réunion de Chefs d'État-Major Généraux du Mardi ler août 1939". 
nie, wbrew propozycjom zgłaszanym przez Gamelina, to Francuzi udali się na drugą stronę Kanału, zaś do podróży wybrany został nie pociąg (jak chciał Doumenc) ani samolot (jak sugerował Ismay), ale wynajęty przez brytyjską Admiralicję pasażerski liniowiec "City of Exeter", na którego pokład delegacje zaokrętowane zostały 5 sierpnia ${ }^{201}$.

Tematyka podjętych w Moskwie rozmów zdecydowanie wykraczała poza ramy omawianej przez nas problematyki, sam ich przebieg był już zresztą wielokrotnie przedmiotem naukowych analiz, których podstawą stały się opublikowane przez każdą ze stron protokoły. Jak wiadomo, podjęte rokowania dość szybko utknęły w martwym punkcie. Ich postęp uniemożliwiały wysunięte przez stronę radziecką żądania odnośnie do tzw. agresji pośredniej (co dawałoby ZSRR praktycznie wolną rękę względem państw bałtyckich i Finlandii) oraz „korytarzy” na obszarze Wileńszczyny i Galicji oraz Rumunii, które Armia Czerwona miałaby wykorzystać w marszu ku niemieckim agresorom. Oczywiste było, że Polska na podobne żądania zgodzić się nie może, nawet gdyby - co nie miało miejsca - zostały one przez Moskwę względem niej sformułowane. Stanowisko Warszawy w tej sprawie, wielokrotnie uprzednio artykułowane, znano dobrze zarówno w Paryżu, jak i w Londynie. Wobec impasu w trójstronnych rozmowach i fiaska prób skłonienia strony radzieckiej do nawiązania bezpośredniego kontaktu ze stroną polską przedstawiciele mocarstw zachodnich zostali zmuszeni do podjęcia raz jeszcze wysiłku na rzecz przekonania sojusznika znad Wisły, by ten zajął bardziej elastyczne stanowisko. Starania te, prowadzone od 15 sierpnia, najpierw na gruncie paryskim, a następnie bezpośrednio w Warszawie, zakończyły się jednak niepowodzeniem. Co prawda minister Beck wyraził ostatecznie zgodę, by w trakcie prowadzonych w Moskwie negocjacji posłużono się formułą, że „w razie wspólnej akcji przeciw agresorom współpraca między ZSRR a Polską nie jest wykluczona", ale było już za późno, by krok taki pokrzyżował dojrzewające od dłuższego czasu plany porozumienia Stalina i Hitlera ${ }^{202}$. Można sądzić zresztą, iż

201 AN, 596 AP 13, kopia niedatowanego opracowania Sekcji Armii Obcych O. II Sztabu Generalnego Armii „Mission du Général Doumenc en U.R.S.S. du 10 au 28 Août 1939"; TNA, CAB 54/10, opracowanie D.C.O.S. 158 z 3 VIII 1939 r.; CAB 104/44, telegram (en clair) No 474 Saving Campbella do FO 229 VII 1939 r. i nast. dok.; SHD-DAT, 7 N 3186, niedatowane "Souvenirs de la mission en Russie. Août 1939" gen. Doumenca. Lotniczą część brytyjskiej delegacji utworzyli ostatecznie oprócz Air Marshala Burnetta płk Alfred Conrad Collier i mjr T.E. Rennington. Głównym przedstawicielem sil lądowych zostal gen. T.G.G. Heywood. W skład delegacji francuskiej jako drugi obok gen. Valina przedstawiciel Armée de l'Air wszedl kpt. pil. Pierre Soviche.

${ }^{202}$ AD, Papiers 1940, Reconstitution Fouques-Duparc 58, telegram szyfrowy ambasadora Francji w Moskwie Paula-Émile Naggiara do MAE z 15 VIII 1939 r., godz. 23.05 i in. dok.; AN, 496 AP 13, telegram (przekazany telefonicznie) No 2591 Cambona do MAE z 16 VIII 1939 r., godz. 19.40; telegramy szyfrowe No 586 i 588 Bonneta do Noëla z 16 VII 1939 r., godz. 21.45 i in. dok.; SHD-DAT, 7 NN 2/384, „Rapport No 163 du 24 Août 1939” gen. Musse (też: DDF, t. 18, doc. 396, s. 471); TNA, CAB 54/11, kopia telegramu szyfrowego No 197 brytyjskiego ambasadora w Moskwie Williama Seedsa do FO z 14 VIII 1939 r. (odszyfrowany 15 sierpnia, godz. 1.00); CAB 104/45, telegram szyfrowy No 268 Foreign Office do Kennarda z 16 VIII 1939 r., godz. $21.30 \mathrm{i}$ in. dok.; Polska w polityce międzynarodowej..., dok. 135, s. 420n. i nast. dok.; M. Kor nat , Polska 1939 
szanse na to nie istniały od początku moskiewskich rokowań, o czym świadczy też fiasko akcji Dumenca, który upoważniony przez Daladiera, wieczorem 22 sierpnia podjął próbę jednostronnego zaaprobowania radzieckich żądań w kwestii „korytarzy" wiodących przez terytorium Polski i Rumunii ${ }^{203}$.

Lotnicze treści toczonych w Moskwie rozmów, zważywszy na ich dramatyczny finał, nie miały poważniejszego znaczenia. Odnotować jednak należy, że związaną z nimi problematykę obszerniej poruszono po raz pierwszy na posiedzeniu z 16 sierpnia, kiedy to długie, choć dość ogólnikowe referaty wygłosili kolejno Air Marshal Burnett i gen. Valin, starając się w możliwie najlepszym świetle przedstawić wielkość i możliwości lotnictwa wojskowego własnych państw. Dzień później miało miejsce podobne wystąpienie dowódcy sił powietrznych ZSRR, komandarma II rangi Aleksandra Łoktionowa. Nie podjęto jednak żadnej dyskusji nad zarysowaną w ten sposób tematyką. Bez odpowiedzi pozostały też postawione 17 sierpnia pytania delegacji zachodnich dotyczące ewentualnej współpracy lotniczej ZSRR z jego zaatakowanymi przez Rzeszę sąsiadami. W zawieszeniu pozostały więc m.in. kwestie dotyczące okresu niezbędnego do mobilizacji radzieckich sił powietrznych na froncie wschodnim, zamysłów Moskwy odnośnie do działań z lotnisk na terytoriach Polski i Rumunii, udziału ZSRR w zaopatrywaniu tych państw w materiał lotniczy i surowce oraz możliwości działań lotnictwa ZSRR we wszystkich porach roku ${ }^{204}$.

Do zagadnień związanych z lotnictwem odwoływali się także biorący w tym czasie udział $\mathrm{w}$ próbach dyplomatycznych interwencji w Warszawie wojskowi przedstawiciele państw zachodnich. „Koenigsberg jest łatwo osiągalny dla radzieckich bombowców - podsuwał 19 sierpnia argumenty Kennardowi ppłk Sword - podczas gdy cele $w$ samych Niemczech mogą być z latwością dostępne, gdyby radzieckie

roku..., s. 330n.; W. St achiewicz, op. cit., s. 126nn.; M. Gmurczyk-Wrońska, op. cit., s. 116nn. (tam też informacje na temat dalszej literatury zagadnienia).

2013 AN, 496 AP 13, telegram szyfrowy do ambasad w Warszawie (No 624-627) i Moskwie (No 610-614) Bonneta z 20 VIII 1939 r., godz. 22.30 i in. dok.; TNA, CAB 104/45, „Record of a Conversation between Comrade Voroshilov and Général Doumenc. August 22, 1939" (tam też tekst w języku francuskim), zał. do końcowego raportu adm. Draxa dla Chatfielda z 28 VIII 1939 r. oraz list gen. Heywooda do gen. Pownalla z 23 VIII 1939 r.; SHD-DAT, 7 NN 2/582, telegram szyfrowy No 16-17 Doumenca do Sztabu Generalnego Armii z 23 VIII 1939, godz. 1.32 oraz niesygnowana notatka „Entretien Maréchal Voroshilov - Général Doumenc du 22 Août (soir)” z 24 VIII 1939 r. z załączonym tekstem protokołu spotkania w języku rosyjskim (rozmowa odbyła się bez obecności tłumacza, z udziałem jedynie stenografa strony radzieckiej); Polska w polityce międzynarodowej..., dok. 159, s. 456nn.; M. Gmu rczyk-Wrońska, op. cit., s. 118 (szczeg. przypis 140); M.J. Carley, 1939. The Alliance that Never Was and the Coming of World War II, Chicago 1999, s. 204nn. Dodac można, że gen. Ismay, któremu ze względu na późną porę przyszło w zastępstwie Szefów Sztabów i lorda Chatfielda odpowiedzieć na pytanie Foreign Office, czy brytyjskiej delegacji w Moskwie należy przekazać instrukcje podobne do otrzymanych przez gen. Doumenca, zajął w tej sprawie stanowisko negatywne, proponując poinformowanie delegatów, że Wielka Brytania „nie przyjmuje odpowiedzialności za dokładność informacji przekazanej przez Francuzów" (TNA, CAB 53/11, "Minutes of the 312th Meeting, held on 24th August, 1939", C.O.S./312th Mtg.).

${ }^{204}$ Międzynarodowe tlo agresji Rzeszy Niemieckiej na Polskę w 1939 roku. Wybór dokumentów, oprac. R. Nazarewicz, Warszawa 1986, dok. 44, s. 127nn. 
samoloty otrzymały zgodę na podjęcie operacji z terytorium Polski”. „Szczególnie ważną kwestią są radzieckie myśliwce, które mogłyby mieć wielką wartość na polskich lotniskach" - dodawał, wykazując przy okazji znajomość instrukcji przeznaczonej dla przebywającej w Moskwie brytyjskiej delegacji. Do możliwej współpracy lotniczej ze wschodnim sąsiadem oraz uznanych za wyjątkowo ważne dostaw materiału lotniczego $\mathrm{z}$ jego strony odwoływał się $\mathrm{w}$ trakcie odbytej tuż przed południem 18 sierpnia rozmowie $z$ gen. Stachiewiczem gen. Musse ${ }^{205}$.

Wspomnieć można jeszcze jeden polski aspekt moskiewskich negocjacji - istotny, a przy tym niepozbawiony lotniczych odniesień. Otóż, jak należy podkreślić, radzieckie stanowisko co do konieczności zapewnienia siłom zbrojnym ZSRR możliwości operowania $\mathrm{z}$ terenu Polski i Rumunii już w początkowej fazie wojny spotkało się wśród wojskowych elit Zachodu z powszechnym zrozumieniem, jako najzupełniej oczywiste. Jego zasadność bardzo mocno akcentowali brytyjscy Zastępcy Szefów Sztabów, którzy 16 sierpnia spotkali się na 51. posiedzeniu swego podkomitetu. „Jest doskonale jasne - stwierdzili w opracowanym wówczas dokumencie - że bez wczesnej i skutecznej pomocy rosyjskiej Polacy nie mogą mieć nadziei na powstrzymanie niemieckich ataków na lądzie i w powietrzu dłużej niż przez ograniczony czas. [...] Dostawy broni i materiału wojennego nie wystarczą. Jeśli Rosjanie mają współpracować w powstrzymaniu niemieckiej agresji [...] efektywnie mogą to uczynić jedynie $z$ terytorium Polski i Rumunii, [...] gdyby zgoda na to była wstrzymana aż do wybuchu wojny, to byłoby za późno". Natychmiastowa i efektywna rosyjska pomoc dla zaatakowanych, stwierdzali przy tym Zastępcy Szefów Sztabów, zaostrzając swe wcześniejsze oceny, konieczna byłaby przy tym nie tylko w powietrzu, ale i na lądzie. W innym przypadku, stwierdzali już bez ogródek, Polska i Rumunia utracą niepodległość i będą mogły jedynie mieć nadzieję na jej odzyskanie po długotrwałej wojnie, a i wtedy niekoniecznie „w formie przypominającej pierwotną" („in anything like their original form").

Tę gorzką prawdę zalecano „z absolutną szczerością” przedstawić zarówno Polakom, jak i Rumunom. Szczególnie zaś - podkreślali autorzy dokumentu - tym pierwszym, którym należy uprzytomnić, że „mają zobowiązania wobec nas, podobnie jak my względem nich", stąd „jest nierozumne $z$ ich strony oczekiwać od nas ślepego wywiązywania się $z$ danych im gwarancji, jeśli oni w tym samym czasie nie współpracują w działaniach podjętych dla wspólnego pożytku". Celem podjętych rokowań, zauważano $w$ raporcie, jest zapobieżenie wybuchowi wojny. W razie ich fiaska, proroczo przestrzegali Zastępcy Szefów Sztabów, w najgorszym razie dojść może do radziecko-niemieckiego zbliżenia, decyzji obu nowych partnerów o podziale łupów

2015 SHD-DAT, 7 NN 2/384, "Rapport No 163 du 24 Août 1939” gen. Musse; TNA, CAB 104/45, kopia pisma Sworda do Kennarda z 19 VIII 1939 r.; E.R. Sword, op. cit., s. 51 i 144n. Dwie kolejne rozmowy z Szefem Sztabu Głównego Musse i Sword odbyli tuż po południu 19 sierpnia i o podobnej porze dzień później. Początkowo do Polski dla uzyskania zgody na przemarsz wojsk rosyjskich skierowany miał być gen. Valin, który jako były członek Francuskiej Misji Wojskowej uchodził za znawcę stosunków panujących nad Wisłą. 
i parcelacji państw wschodniej części Europy. W scenariuszu niewiele lepszym ZSRR mógłby zachować w nadchodzącej wojnie neutralność, by następnie i tak uzyskać, co zechce, od wyczerpanych walką sąsiadów ${ }^{206}$.

Kilka dni później, 21 sierpnia, gdy było już jasne, że interwencje w Warszawie pozostały bezskuteczne, jeden z uczestników wspomnianego wyżej spotkania, płk Slessor, komentował sytuację w jeszcze ostrzejszym tonie. Jak stwierdził - strona polska, odmownie reagując na przedstawione jej stanowisko i wyjaśniając, że dopóki nie będzie przyparta do muru, nie zgodzi się na obecność na swym terytorium wojsk radzieckich, gdyż krok ten, „niemal samobójczy”, sprowokowałby niemiecką agresję, używa „starych argumentów”. Tymczasem, zauważał Slessor, „jest już za późno na formułowanie takiego stanowiska". Polska jest już przyparta do muru, zaś absolutne samobójstwo oznacza dla niej właśnie zerwanie anglo-radzieckich rozmów i eliminacja możliwości uzyskania radzieckiego wsparcia. Tymczasem „Polska musi dokonać wyboru między dwoma diabelskimi alternatywami - pewnością zostania podbitą przez Niemcy i możliwością niepożądanych rezultatów związanych z obecnością w Polsce wojsk radzieckich. Szczyt nierozumności Becka jest osiągnięty, gdy stwierdza on [...], że "sprzeciwia się przemarszowi wojsk rosyjskich przez Polskę tak samo jak i wojsk niemieckich «. Niemal niemożliwe jest spokojne komentowanie tego stanowiska. [...] To musi rodzić wątpliwości, czy Polska istotnie myśli o oporze wobec Niemców" ${ }^{207}$.

Jak komentował szef Dyrekcji Planowania Ministerstwa Lotnictwa, wzmacniając jeszcze ocenę sprzed kilku dni, Wielka Brytania została tym samym postawiona w skrajnie niedogodnej sytuacji, nie mogąc się wycofać z udzielonych Polakom obietnic pomocy, ale też nie mogąc ich wykonać, skoro niemal całkowicie uniemożliwiają to oni sami. Postulował, by w tej sytuacji wnioskowana niedawno „brutalna szczerość” względem Warszawy posunięta została jeszcze o krok dalej. „My oraz Francuzi powinniśmy powiedzieć teraz Polsce szczerze, że jest przyparta do muru i musi odbierać od nas rozkazy co do tego, jak te obietnice pomocy mają być urzeczywistniane. Bez nas oraz Francuzów nie ma ona nadziei uniknięcia losu Czechosłowacji i stąd nie może dłużej zachowywać się, jakby myślała, że jest suwerennym wielkim mocarstwem zdolnym do dbania o siebie" ${ }^{208}$.

Przypomnieć trzeba, że autor tych słów, choć daleki od szczególnych wobec Rzeczpospolitej sympatii, był dotychczas rzecznikiem podjęcia przez brytyjskie siły powietrzne aktywnej akcji na rzecz zaatakowanego przez Rzeszę sojusznika ze wschodu. Teraz wyraźnie zmienił swe nastawienie - i nie była to bynajmniej zmiana chwilowa. Wbrew pozorom, nie była też mało istotna. Już kilkanaście dni

2116 TNA, CAB 55/2, „Minutes of the 51 st Meeting held in 16th August, 1939”, D.C.O.S./51st Mtg.; CAB 55/11, raport „Russian Conversations: use of Polish and Roumanian territory by Russian Forces" Podkomitetu Zastępców Szefów Sztabów, D.C.O.S. 179 z 16 VIII 1939 r.

207 TNA, AIR 75/6, raport Slessora „Russian conversations - attitude of Poland to Russian request to operate on Polish soil" z 21 VIII 1939 r.

zon Ibidem. 
później głos Slessora miał sporo ważyć w podejmowanych nad Tamizą dysputach wojenno-lotniczych.

Skonstatowana wyżej ewolucja nie miała zresztą niestety charakteru jednostkowego. Polską postawę bardzo krytycznie przyjęto też w Paryżu, a o towarzyszących temu emocjach świadczą np. pełne pasji adnotacje sporządzane na marginesach nadchodzących w tym czasie telegramów przez premiera Daladiera. Próżne, a przy tym wykraczające już nie tylko poza zakres naszych rozważań, ale wręcz możliwości nauk historycznych byłyby próby rozważania, czy aby u źródeł owych reakcji nie leżało pragnienie obciążenia polskiego sojusznika bagażem własnych błędów i zaniechań z przeszłości i/lub ułatwienia sobie przyszłych decyzji (oraz takichże zaniechań). Same jednak reakcje oraz ich charakter uznać musimy z pewnością za fakt, pamiętając, że będą one miały niebawem niezwykle znaczące, fatalne dla Rzeczypospolitej konsekwencje $e^{209}$.

2114 AN, 496 AP 13, telegram (przekazany telefonicznie) No 1223 Noëla do MAE z 22 VIII 1939 r., godz. 5. Domysły M. Gmurczyk-Wrońskiej, wedle których reakcją Daladiera na polskie non possumus stało się m.in. zatrzymanie do francuskiej wiadomości docierających do Paryża informacji o dolączonym do radziecko-niemieckiego paktu o nieagresji tajnym protokole, muszą, rzecz jasna, pozostać bez rozstrzygnięcia (op. cit., s. 118). 


\section{Rozdzial 8}

\section{Pieniądze i samoloty}

U progu wiosny 1939 roku spełniły się przewidywania, które w Londynie i Paryżu budziły podszyte obawą zdziwienie: 19 marca gen. Ludomił Rayski, skutecznie tym razem złożywszy dymisję, po kilkunastu latach przestał sterować rozwojem sił powietrznych II Rzeczypospolitej'. W obu wymienionych stolicach jego odejście ze stanowiska przyjęto z żalem, nad Sekwaną określając je mianem „wielkiej straty dla polskiego lotnictwa". Istotnie, długoletnie doświadczenie zdymisjonowanego generała i jego spora wiedza techniczna były trudne do zastąpienia. Następca, gen. bryg. Władysław Kalkus, miał reputację energicznego dowódcy liniowego oraz dobrego pilota, ale jak zauważali analitycy Armée de l'Air, brakowało mu doświadczenia sztabowego i dyplomu wyższej uczelni wojskowej czy choćby tylko inżynierskiego. Niepokój wzmagać jeszcze mogło równoczesne odwołanie ze stanowiska I zastępcy Rayskiego, gen. bryg. obs. inż. Janusza de Beaurain, a następnie także innych jego najbliższych współpracowników ${ }^{2}$.

Tło wspomnianych zmian stanowily dążenia do przyspieszenia procesu modernizacji polskiego lotnictwa wojskowego oraz realizowanych $w$ jego ramach priorytetów. Generał Rayski uchodzil, nie bezzasadnie, za zwolennika rozbudowy sił bombowych. Jego krytycy, skupieni w Sztabie Lotniczym Sztabu Głównego oraz Inspektoracie Obrony Powietrznej Państwa, akcentowali konieczność unowocześnienia, a w miarę możności także liczebnej rozbudowy lotnictwa myśliwskiego. W tym ostatnim przypadku problem sprowadzał się nade wszystko do braku prototypu,

' Data 19 marca jest od dawna przyjęta w polskiej literaturze, zob. np.: S. Czmur, W. Wójcik, Generalowie w stalowych mundurach, Warszawa-Poznań 2003, s. 152. Jednak wedle datowanej 27 IV 1939 r. informacji No 129 (Aéronautique militaire - modifications dans le Haut Commandement) płk. Arbitre dla O. II EMAA „ostateczna dymisja” Rayskiego nastąpiła dopiero 27 marca, zaś 19 marca na stopień generalski promowany został jego przyszły następca, gen. Władysław Kalkus (SHD-DAT, 7 NN 2/398). Datę 27 marca podał też gen. Musse w „Rapport No 38/S du 30 Mars 1939" (SHD-DAT, 7 NN 2/385). Nie sprawdziły się natomiast przekazane w tym ostat nim dokumencie pogłoski o rychłym mianowaniu Rayskiego posłem RP w Sofii.

2 SHD-DAT, 7 NN 2/398, informacja No 129 dla O. II EMAA z 27 IV 1939 r. 
który odpowiednio dopracowany, mógłby stać się podstawą produkcji seryjnej. Oblatany w drugiej połowie lutego nowy polski samolot myśliwski PZL.50 „Jastrząb” jedynie w części spełnił pokładane w nim nadzieje - i można się było obawiać, że nawet po przezwyciężeniu „chorób wieku dziecięcego" nadal będzie poważnie ustępować konkurentom, $\mathrm{z}$ którymi mógłby się zetrzeć $\mathrm{w}$ powietrznym boju.

Szybko pogarszająca się sytuacja międzynarodowa sprawiła zresztą, że już w końcu marca oczekiwanie na rozstrzygnięcie powyższego dylematu uznano za niedopuszczalną stratę czasu. Zdecydowano więc, że w zaistniałej sytuacji odejść należy od obowiązującego dotychczas aksjomatu, zgodnie z którym użytkowany przez polskie siły powietrzne sprzęt lotniczy winien być produkowany w kraju. 28 marca działający $\mathbf{w}$ imieniu ministra spraw wojskowych zastępca II wiceministra gen. bryg. Mieczysław Maciejowski nakazał, by Dowództwo Lotnictwa MSWojsk. przystąpiło niezwłocznie do dokonywania za granicą zakupów surowców, samolotów myśliwskich i liniowych oraz niezbędnego sprzętu pomocniczego’.

Pierwsze próby takich zakupów podjęto niezwłocznie. W początkach kwietnia płk obs. inż. Czesław Filipowicz sondował nad Tamizą możliwości zakupu nowoczesnych samolotów myśliwskich, ale $z$ inicjatywy tej niewiele na razie wynikło. Niebawem okazało się zresztą, że Dowództwo Lotnictwa, w którym właśnie dokonano wymiany całości kierownictwa, nie jest w stanie szybko podjąć efektywnych działań dla realizacji przekazanego mu polecenia. Nowi szefowie dopiero nabywali orientację w sprawach, w których mieli podejmować decyzje, niejasne pozostawały kompetencje i zależności, dodatkowo komplikowane przez podjęte reorganizacje, a niektóre struktury dopiero oczekiwały na nowych przełożonych. Nadal też nie było wiadomo, gdzie konkretnie dokonane mają być zakupy, a przede wszystkim - za $\mathrm{co}^{4}$.

W przypadku sojusznika francuskiego, który od zarania niepodległości służył jako główne źródło zewnętrznego finansowania zbrojeniowych wydatków Rzeczypospolitej, bliskie wyczerpania były już przeznaczone na ten cel sumy ostatniego $\mathrm{z}$ udzielonych tzw. kredytu z Rambouillet. Ścieżki ku kiesie świeżo pozyskanego partnera znad Tamizy należało zaś dopiero wydeptać. Choć bowiem kontakty $z$ londyńskim City nie były dla polskich finansistów, także tych bliskich kręgów rządowych, nowym doświadczeniem, to jednak dotychczas nie podejmowano $\mathrm{w}$ ich ramach na większą skalę zagadnienia wojskowych zakupów 5 .

${ }^{3}$ CAW, O. I SG, I.303.3.779, pismo L. 579/mob.39 gen. bryg. M. Maciejowskiego wg rozdzielnika z 28 III 1939 r.

4 IPMS, Lot. A.V. 1.40b, pismo L. $174 / 39$ ppłk. Kwiecińskiego do Szefa O. II SG z 19 V 1939 r. Owczesną sytuację w Dowództwie Lotnictwa MSWojsk. przedstawiono w licznych składanych po klęsce wrześniowej relacjach. Emigracyjna, poklęskowa rzeczywistość skłaniała wówczas do łatwego formułowania oskarżeń wobec byłych przełożonych, ale obraz kreślony przez relantów jest zbyt spójny, by uznać go za fałszywy. Zob. np.: IPMS, A.20.5.6, protokól przesłuchania przed Komisją Powołaną w Związku z Wynikiem Kampanii Wojennej 1939 roku [dalej: KPZWKW] mjr. inż. pil. Franciszka Suchosa z 7 II 1942 r.; Lot. A.I. 29/3b, odpis protokołu przesłuchania przed KPZWKW ppłk. pil. inż. Romana Suryna z 25 IV 1945 r.

TNA, BT 11/1069, list wicedyrektora Departamentu Gwarancji Kredytów Eksportowych (Export Credit Guarantee Department) Ministerstwa Skarbu Herberta Sommerville-Smitha do 
Jak już wyżej wspomniano, strona brytyjska spodziewała się, że kwestia zbrojeniowego kredytu dla Polski zostanie podjęta w trakcie wizyty Becka, z początkiem kwietnia 1939 roku. Tak się jednak nie stało. Choć w trakcie pobytu ministra w Londynie ambasador Raczyński wspomniał o takiej potrzebie, Beck, obciążony mnogością innych spraw, na tę nie znalazł czasu. Brakło mu wówczas bodaj także chęci. Jak tłumaczyć miał Pawłowi Starzeńskiemu, zagadnienia zbrojeniowej pożyczki „nie chciał łączyć z "politicum " wizyty". Skądinąd wiadomo, że polski minister, już przed wyjazdem do Londynu proszony przez ekonomicznych doradców o poruszenie problematyki pomocy finansowej, miał zdecydowanie tym prośbom odmówić, proponowany temat rozmów uznając za niegodny gentlemanów ${ }^{6}$.

Taka wstrzemięźliwość wywołała jednak zdziwienie wśród brytyjskich gospodarzy wizyty, tym bardziej że zdecydowanie niedostateczny stan wyposażenia polskich sił zbrojnych unaoczniły im właśnie po raz kolejny wspominane już wyżej raporty wojskowych attaché. W następnych dniach ambasador Kennard kierował do Londynu dalsze raporty na ten temat, donosząc m.in., że oceny brytyjskich oficerów podzielają też francuscy eksperci, zaś ambasador Noël kładzie szczególny nacisk na konieczność dostarczenia Polakom pieniędzy na produkcję materiału wojennego oraz utworzenie zapasów surowców na czas wojny. Nad Tamizą zaczęto w efekcie rozważać wysuniętą w tym czasie przez kręgi biznesu koncepcję zakupu nadwyżek polskiej produkcji zbrojeniowej, co pośrednio służyć by miało wzmocnieniu ekonomicznej i finansowej pozycji partnera znad Wisły?

Niebawem jednak inicjatywę w swe ręce wzięli brytyjscy dyplomaci z Warszawy. 21 kwietnia do Radcy Ekonomicznego MSZ Jana Wszelakiego zgłosił się Clifford Norton, zapytując - jak zaznaczył, „bez instrukcji z Londynu, ale w porozumieniu ze swym Ambasadorem" - o sytuację finansową państwa oraz możliwości finansowania polskich zbrojeń, dodając, że Polska jest już jedynym państwem Europy Wschodniej,

zastępcy sekretarza skarbu Sigismunda D. Waleya z 2 III 1939 r. i in. dok.; A. Ko c, Wspomnienia, oprac. J. Mierzwa, Wroclaw 2005, s. 227nn. i 253; J. Mierzwa, Pulkownik Adam Koc. Biografia polityczna, Kraków 2006, s. 199n., Studia z Historii XX Wieku, 2. W pierwszej połowie marca Koc przebywał w Londynie, przecierając ścieżki dla przyszłych rozmów w sprawie kredytów.

6 DBFP, vol. 5, doc. 266, s. 283; P. Starzeń ski, op. cit., s. 204; H. Ja ckiewicz, op. cit., s. 180. Komentarz Stranga na ten temat: TNA, BT 11/1069, pismo C 4740/521/55 Stranga do Willsa z 13 IV 1939 r. Pogłoski o zamiarze sięgnięcia po brytyjską pomoc finansową krążyły wówczas także w Warszawie. Odnotowała je m.in. tamtejsza ambasada Włoch w informacji przekazanej do Rzymu 3 kwietnia (Archivio Storico Diplomatico (Rzym) [dalej: ASD], Affari Politici 1931-1945, Polonia 15, telegram przychodzący No 1657 R. ambasadora Włoch w Warszawie Pietra Arone di Valentino do MSZ z 3 IV 1939 r., godz. 20.41.

; TNA, CAB, FO 371/23144, pismo 153/84/39 Kennarda do Sargenta z 8 IV 1939 r.; "Note on the proposal by a certain Baron Gerard De Graffenried Villars regarding the disposal of the surplus output of certain Polish munitions factories" z 12 IV 1939 r. i in. dok. Propozycja zakupu wiązała się z zakończeniem zyskownej sprzedaży polskiego materiału wojennego do ogarniętej wojną domową Hiszpanii, wyraźnie była inspirowana przez kręgi trudniące się międzynarodowym handlem sprzętem wojskowym. Dotyczyła głównie karabinów oraz karabinów maszynowych i amunicji do nich. 
które jeszcze nie wystąpiło do Londynu z postulatami pomocy finansowej. W odpowiedzi na tak wyraźną sugestię Wszelaki potwierdził niewypowiedziane obawy Nortona, przyznając, że „stan finansowy Państwa jest naprężony”, co w dłuższej nieco perspektywie może doprowadzić do niepożądanych konsekwencji. Wskazał też, podkreślając, że wypowiada tu zdanie wyłącznie osobiste, że „ewentualna pomoc przyjaznej zagranicy” potrzebna byłaby głównie „w dziedzinie uzupełnienia stoków surowcowych i uchronienia Skarbu przed koniecznościami inflacyjnymi dla zaspokojenia wydatków wojskowych i gospodarczych"в.

Potwierdzało to niedawne opinie Kennarda i Noëla. Ten pierwszy uznał więc, że dla przerwania niezrozumiałej bierności polskiego kierownictwa potrzebna jest jego własna inicjatywa. 22 kwietnia o trudnej sytuacji polskiego budżetu, obciążonego rosnącymi wydatkami o charakterze militarnym, poinformował w obszernej korespondencji Cadogana. Dzień później zaś w trakcie rozmowy z ministrem Beckiem poruszył kwestię polskich wydatków obronnych, zauważając, że według posiadanych przezeń informacji „kosztuje to [...] miliony dziennie”. Beck sprawę starał się zbagatelizować, przyznał jednak, że polskie rezerwy wyszkolonych rezerwistów pozostają częściowo niewykorzystane ze względu na ograniczone możliwości sfinansowania ekwipunku dla nowych jednostek wojskowych, co więcej zaś, pełne wykorzystanie tych ostatnich wymaga "pomocniczej broni” (tj. np. artylerii). Do tego jednakże stwierdził - potrzebny jest czas i pieniądze. Ostatecznie więc w trakcie rozmowy przedstawione zostały polskie oczekiwania wobec brytyjskiego alianta, który miałby udzielić „pomocy w kierunku poszerzenia potencjału naszej armii w postaci kredytu gotówkowego oraz kredytu na zakup surowców"9.

Była to wciąż jeszcze sugestia udzielenia wsparcia finansowego, które miałoby zostać spożytkowane zapewne głównie, jeśli nie wyłącznie, przez przemysł krajowy, mimo coraz bardziej alarmującej sytuacji nadal posiadający nadwyżki mocy produkcyjnych. Pomoc materiałowa potraktowana została przez polskiego ministra jedynie marginalnie, $w$ trakcie rozmowy wspomniał on jedynie o dyskutowanych ze stroną brytyjską od pewnego czasu potrzebach marynarki wojennej. Beck podkreślił przy tym, niejako uzasadniając przy okazji swą dotychczasową powściągliwość, że „pomoc rządu angielskiego musiałaby mieć odpowiednio duże proporcje”, gdyż „mieszanie pieniędzy do polityki nie jest rzeczą przyjemną i może być dokonane tylko dla jakiegoś całkiem wyraźnego efektu"10.

W efekcie do Londynu powędrowały dwie korespondencje. W jednej z nich Kennard informował lorda Halifaxa o polskich oczekiwaniach co do kredytu na wydat-

* IPMS, A.11.49.WB.3, notatka J. Wszelakiego z 21 IV 1939 r.

y PDD 1939, dok. 225, s. 377 n.; DBFP, vol. 5, doc. 266, s. 283. Zob. też: IPMS, A.11.49. WB.3, „Sprawozdanie z ważnej rozmowy wczorajszej Pana Ministra z ambasadorem Kennardem” (odręczny dopisek: „Wyciąg z listu pana dyr. Potockiego do Amb. E. Raczyńskiego, z 24 kwietnia 1939”). W tym ostatnim dokumencie znalazła się też wzmianka, że „[...] rozmowę na ten temat [finansowy - dop. W.M] Minister faktycznie projektował na dzień następny. Tak się jednak stało, ze Kennard sam pierwszy zapytał [...]".

" PDD 1939, dok. 225, s. 378. 
ki wojskowe, inicjatywę w tej kwestii przypisując zresztą Beckowi. W drugiej Józef Potocki donosił ambasadorowi Raczyńskiemu o odbytej przez ministra rozmowie, dodając, że zdaniem MSZ w grę wchodzić winna suma rzędu 60 mln funtów. Zapytywał też o stanowisko w przedmiotowej sprawie oraz opinię, w jaki sposób i z kim należałoby teraz zainicjować negocjacje ${ }^{\mu !}$.

W Foreign Office nadesłane informacje wywołały ożywioną dyskusję, o czym świadczą andotacje na odpowiednich aktach. Pierwsze reakcje, choć dość ostrożne, były jednak pozytywne. Nim jednak zdążono podjąć pierwsze kroki praktyczne, Kennard ponownie, w telegramie z 30 kwietnia, doniósł o polskich oczekiwaniach kredytowych, potwierdzonych przez Becka w odbytej dzień wcześniej rozmowie oraz uzupełnionych o propozycję skierowania do Londynu misji polskich ekspertów dla omówienia niezbędnych szczegółów. Nowe informacje stanowiły dodatkowy bodziec dla brytyjskich urzędników, zarazem jednak zmusiły ich do przepracowania sformułowanego wcześniej stanowiska. Już jednak 1 maja Speaight zaproponował procedurę dalszych działań w powyższej sprawie, zaś cztery dni później Cadogan podjął jej realizację, rozsyłając serię pism skierowanych do wyższych urzędników Treasury oraz Board of Trade. Streszczając informacje Kennarda, zwracał w nich uwagę na ogólnikowość polskich sugestii. Jednocześnie wyrażał opinię, że stronie polskiej chodzi zapewne o sfinansowanie zakupów nie tylko w Wielkiej Brytanii, ale też w innych państwach, szczególnie w przypadku materiału wojennego, którego brytyjski przemysł nie wytwarza lub nie byłby w stanie dostarczyć w pożądanej ilości i terminie. Polska, argumentował, z brytyjskiego punktu widzenia jest ważniejsza od innych partnerów w Europie Wschodniej, włączając w to ZSRR, gdyż jako jedyna ma wolę i zdolności do przeciwstawienia się niemieckiej agresji. Stąd też Zjednoczone Królestwo w interesie swego własnego bezpieczeństwa powinno uczynić wszystko, co możliwe, dla wzmocnienia polskiej armii ${ }^{12}$.

Do korespondencji załączona została także datowana 2 maja relacja Kennarda $\mathbf{z}$ przeprowadzonej przezeń oraz radcę handlowego ambasady rozmowy $\mathrm{z}$ byłym podsekretarzem stanu w Ministerstwie Skarbu oraz prezesem Banku Polskiego płk. Adamem Kocem, pełniącym obecnie funkcję wiceprezesa Banku Handlowego. Koc, formalnie występując jako osoba prywatna, poinformował brytyjskich dyplomatów o powierzeniu mu przez rząd kierownictwa misji finansowej, która niebawem zostanie skierowana do Londynu. Przedstawił też charakter i skalę polskich potrzeb w tym zakresie oraz wyniki swych wstępnych prac nad koncepcją kredytu gotówkowego.

" IPMS, A.11.49.WB.3, „Sprawozdanie z ważnej rozmowy wczorajszej...”; DBFP, vol. 5, doc. 273, s. 289.

12 TNA, FO 371/23144, pismo C 6061/1110/55 Cadogana do podsekretarza w Ministerstwie Skarbu Fredericka Phillipsa oraz Williama Browna z Board of Trade $i$ in. dok. Kopie powyższej korespondencji trafity także do Gorta, Newalla oraz zastępcy Szefa Naval Staff wiceadm. Andrew C. Cunnighama, który w tym czasie przejął obowiązki chorego Pierwszego Lorda Morskiego Rogera Backhouse’a. W świetle powyższych faktów opinia $\mathrm{H}$. Jackiewicza, że „sugestia polska została pominięta milczeniem przez rząd brytyjski", musi być uznana za bardzo poważne uproszczenie (op. cit., s. 181). 
Przekazane do Londynu informacje wywołały tam zaniepokojenie. Potrzeba pomocy kredytowej dla Polski okazała się pilniejsza, niż można było przypuszczać - komentował je Cadogan - bez niej bowiem partner ze wschodu kontynentu nie będzie niebawem w stanie kontynuować swych wojskowych przygotowań ${ }^{13}$.

Odpowiedzi, choć wystosowane niemal natychmiast, były niezwykle rozczarowujące. Szczególnie oporne na przedstawione argumenty okazało się Ministerstwo Skarbu. Wyjaśniło ono, że "finansowanie polskiej mobilizacji” wywołać może negatywne reakcje Niemiec, polskie problemy nie stanowią bynajmniej wyjątku, z podobnymi boryka się też samo Zjednoczone Królestwo „i w istocie niemal każde państwo", zaś uwzględnienie kredytowych postulatów Warszawy skutkować by musiało zalewem podobnych próśb ze strony „Turcji, Grecji, Nowej Zelandii i innych krajów”. Treasury wyraziło więc jedynie gotowość zaoferowania Polsce gwarancji kredytowych na dostawy brytyjskiej amunicji lub innych produktów do sumy 5 mln funtów, $\mathrm{z}$ góry zresztą wyrażając wątpliwość, czy potencjalny odbiorca byłby taką ofertą zainteresowany.

Tab. 7. Ostatnie zagraniczne wnioski o pomoc finansową brytyjskiego Skarbu, według stanu 2 maja $1939 \mathrm{r}$.

\begin{tabular}{|l|c|}
\hline \multicolumn{1}{|c|}{ Wnioskodawca i efekt } & Suma w funtach brytyjskich \\
\hline Indie & $30 \mathrm{mln}$ \\
\hline Australia - odmowa & $10 \mathrm{~m} / \mathrm{n}$ \\
\hline Nowa Zelandia - odmowa & $5 \mathrm{~m} / \mathrm{n}$ \\
Wydaje się, że zechcą ekstra & $15 \mathrm{mln}$ \\
\hline Udzielone kredyty polityczne & $10 \mathrm{mln}$ \\
\hline Turcja otrzymała & $16 \mathrm{mln}$ \\
Prosi o ekstra & $8 \mathrm{mln}$ \\
\hline Belgia - odmowa & $10 \mathrm{mln}$ \\
\hline Rosja - kredyty & $10 \mathrm{mln}$ \\
\hline Chile - prawdopodobnie poproszą o około & $10 \mathrm{mln}$ \\
\hline Irak - prosił o & $5 \mathrm{mln}$ \\
\hline Chiny - prosiły o 30 mln i dostały & $10 \mathrm{mln}$ \\
\hline Rumunia - nadzwyczajny kredyt polityczny & $5 \mathrm{mln}$ \\
\hline Czecho-Stowacja dostała & $10 \mathrm{mln}$ \\
\hline Egipt - obiecane na fabrykę nawozów & $7 \mathrm{mln}$ \\
\hline Litwa - wnioskowała o & $3 \mathrm{mln}$ \\
\hline Polska - wnioskowała o & $60 \mathrm{mln}$ \\
\hline tacznie: & \\
\hline Udzielone & $68 \mathrm{mln}$ \\
\hline W trakcie rozważania i wnioskowane & $106 \mathrm{mln}$ \\
\hline
\end{tabular}

13 TNA, FO 371/23144, telegram (en clair) No 45 Saving Kennarda do FO z 2 V 1939 r. Cadogan w korespondencji przedstawił Koca jako prezesa Banku Polskiego, choć ten dymisję z tej funkcji złożył niemal równo trzy lata wcześniej - 8 V 1936 r. 


\begin{tabular}{|l|c|}
\hline \multicolumn{1}{|c|}{ Wnioskodawca i efekt } & Suma w funtach brytyjskich \\
\hline Prawdopodobne & $25 \mathrm{mln}$ \\
\hline Odmówione & $25 \mathrm{mln}$ \\
\hline
\end{tabular}

Źródło: Opracowanie własne na podstawie: TNA, PREM 1/357, załącznik do listu J. Simona do Chamberlaina z 15 V 1939 r.

Bardziej koncyliacyjne stanowisko zajęło Board of Trade. I ono jednak proponowało sfinansować dostawy materiału wojennego ze środków pochodzących $z$ okrojonych w tym celu budżetów własnych sił zbrojnych. Wysuwało też szereg zastrzeżeń wobec propozycji dostarczenia Polakom środków na zakupy w państwach trzecich, $\mathrm{z}$ góry zresztą odrzuconej przez Treasury. W dodatku, jak wyjaśniano, gdyby Polska miała zostać potraktowana na specjalnych zasadach, a w grę wchodziła bardzo znaczna suma, rządowy kredyt dla władz z Warszawy mógłby wymagać specjalnych regulacji legislacyjnych ${ }^{14}$.

Takie postawienie sprawy wywołało w Foreign Office niemałą konsternację. „Treasury wybrało traktowanie kwestii pod najściślej fiskalnym kątem” - gorzko zauważał Speaight w sporządzonej 6 maja notatce, dodając, że podane powody odrzucenia polskich próśb wydają się niezwykle miałkie. „Argument, że moglibyśmy urazić Niemcy, dając Polakom pomoc finansową, ujawnia [...] całkowite niezrozumienie polityki zagranicznej rządu Jego Królewskiej Mości. Argument, że mogłoby być wymagane specjalne ustawodawstwo, jest wyjątkowo marny, gdyż nie mogę sobie wyobrazić, by w obecnych warunkach Rząd mógł mieć wiele trudności w zapewnieniu wprowadzenia odpowiedniej legislacji"'15. Co więcej, zauważał brytyjski urzędnik, przebywający nad Tamizą Norton wyraził opinię, że Polacy z natury są drażliwi i dumni, stąd prośby nie zdecydują się ponowić, zaś jej odrzucenie załamie ich ufność w dobrą wolę Londynu i fatalnie odbije się na wzajemnych stosunkach ${ }^{16}$.

W następnych dniach pełną zgodę wobec tak sformułowanego stanowiska wyraziła spora grupa innych pracowników Foreign Office, w tym obaj podsekretarze stanu. Jednogłośnie postanowiono kontynuować niefortunnie zapoczątkowane wysiłki, ewentualnie dyskusję przenosząc na szczebel ministerialny. Pierwsze reakcje wskazywały jednak, że podjęta akcja jest tyleż pilna, co niełatwa do efektywnego przeprowadzenia ${ }^{1 i}$.

${ }^{14}$ Ibidem, listy Phillipsa i Browna do Cadogana z 5 V 1939 r.

15 Ibidem, notatka Speaighta z 6 V 1939 r. na akcie C 6860/1110/55.

${ }^{16}$ Norton udał się do Londynu $w$ celu przedstawienia tam informacji uzyskanych $w$ trakcie rozmowy z płk. Kocem. Aprobatę dla argumentacji Cadogana i sformulowanego przezeń stanowiska wyrazili także szefowie sił zbrojnych, choć Cunnigham podkreślił, że zarówno z brytyjskich analiz, jak i opinii wyrażanych właśnie na forum brytyjsko-francuskich rozmów międzysztabowych wynika, że „jeśli Polska zaatakowana zostanie przez Niemcy, będziemy mogli dostarczyć jej bardzo niewielkiej pomocy" (ibidem, list Cunnighama do Cadogana z 5 V 1939 r. i in. dok.).

17 Podsumowanie początkowej fazy zabiegów o kredyt zbrojeniowy dla Polski zawierała niesygnowana notatka FO "The Polish request for Financial Assistance for Military Purposes" z $9 \mathrm{~V}$ 
Strona polska 7 maja została poinformowana przez Nortona, który powrócił do Warszawy, że stanowisko Foreign Office w rozważanej sprawie jest pozytywne, lecz przeciążone pracą Treasury oraz Board of Trade nie zdążyły przedstawić swych opinii. Nie wstrzymało to rzecz jasna nabierających wreszcie tempa przygotowań do negocjacji kredytowych oraz wykorzystania uzyskanych $w$ ich efekcie środków ${ }^{18}$. Na przełomie kwietnia i maja ukończono projekt memorandum dla rządu brytyjskiego. Postulowano w nim udzielenie Polsce pomocy finansowej w trojakiej postaci, a mianowicie: kredytu gotówkowego, kredytu na zakup materiałów oraz "normalnych kredytów bankowych, niezbędnych do finansowania obrotów w wewnętrznym życiu gospodarczym Polski"'19. Bezpośrednie znaczenie dla polskich zdolności obronnych miały dwa pierwsze z przedstawionych punktów. W przypadku kredytu gotówkowego chodzić miało głównie o pokrycie zwiększonych wydatków związanych z koniecznością utrzymania sił zbrojnych $\mathrm{w}$ stanie pogotowia, zwiększenie zdolności wytwórczych przemysłu zbrojeniowego i zakup niezbędnych surowców, zarówno na użytek bieżący, jak i dla stworzenia niezbędnych rezerw na czas wojny, sfinansowanie prac publicznych o charakterze strategicznym, wystawienie i wyposażenie wielkich jednostek rezerwowych, wreszcie - te zakupy materiału wojennego, które musiałyby zostać poczynione za gotówkę. $Z$ kolei kredyt towarowy miałby zostać zużytkowany na zakupy maszyn i instalacji dla przemysłu zbrojeniowego oraz innych zakładów przemysłowych o znaczeniu wojskowym, półfabrykaty i ewentualnie pewne surowce, a także - być może - budowę w stoczniach brytyjskich statków handlowych ${ }^{20}$.

1939 r. - ibidem. W załączonej do jej kopii niesygnowanej i niedatowanej notatce Board of Trade wyliczono argumenty przeciw spełnieniu polskich postulatów. Po pierwsze, wyjaśniano, Polska chce kupić materiały, które już ma; udzielony jej kredyt szterlingowy zwiększy straty „złotej” waluty, które w poprzednich 12 miesiącach wyniosły $260 \mathrm{mln}$ funtów. Po drugie, „Polska jest niemal pewnym bankrutem" - pożyczone jej pieniądze nigdy zapewne nie zostaną odzyskane, zwiększając pulę straconych $w$ takim przypadku środków $z$ brytyjskich inwestycji, w większości pieniędzy rządowych. Po trzecie wreszcie, co najistotniejsze, plan kredytu dla Polski oznacza drenaż brytyjskiego kapitału. Tymczasem rząd już określił swoje potrzeby kredytowe na rok 1939 na sumę 407 mln funtów i niemal codziennie podwyższa ten poziom. Zgromadzenie środków niezbędnych do realizacji tego programu i zaspokojenia innych potrzeb państwa $w$ roku bieżącym stanowić będzie ekwilibrystykę, w której niezbędny okaże się łut szczęścia, a w roku 1940 liczyć trzeba już tylko na cud (TNA, T 160/878).

14 PDD 1939, dok. 265, s. 440. Norton rzecz jasna udzielił odpowiedzi niezupełnie zgodnej ze stanem faktycznym, najwyraźniej licząc na przełamanie oporu obu sceptycznych wobec kredytu dla Polski struktur. Jak zanotował jego rozmówca (J. Wszelaki), brytyjski chargé d’affaires był w tej części rozmowy wyraźnie zażenowany. Rezultaty rozmów odbytych przez Nortona w Londynie oczekiwane były przez stronę polską z niecierpliwością. Tym większe więc musiało być rozczarowanie. Zob.: IPMS, A.11.49.WB.3, „Notatka z rozmowy min. Arciszewskiego z Ambasadorem Brytyjskim, w dniu 6 maja 1939". 7 maja, zapewne już po zakończeniu spotkania Nortona i Wszelakiego, Kennard przesłał do FO dodatkowe argumenty za uwzględnieniem polskiej prośby (TNA, FO 371/23144, telegram No $142 \mathrm{z}$ godz. 17.40).

$1 y$ IPMS, A.I. 4/1/6, „Projekt memorandum dla Rządu Brytyjskiego w sprawie pomocy finansowej dla Polski" (redakcja pierwsza) z l V 1939 r.

20) Ibidem. 
8 maja doszło jednak do interwencji marszałka Śmigłego-Rydza, który za pośrednictwem zastępcy Szefa Sztabu Głównego, kierownika Sekretariatu Komitetu Obrony Rzeczypospolitej gen. bryg. Tadeusza Malinowskiego powiadomił radcę Wszelakiego, iż życzy sobie skreślenia postulatu dotyczącego kredytu bankowego oraz odstąpienia od zamysłu finansowania $z$ kredytu towarowego budowy statków. Jak uzasadnił to gen. Malinowski, „Pan Marszałek wychodzi [...] z założenia, że memoriał polski ma dotyczyć wyłącznie sprawy pomocy finansowej dla wojska". Za możliwe zostało natomiast uznane równoległe podniesienie kwestii kredytów bankowych jako niezależnej od zabiegów o pomoc na potrzeby wojskowe. Do decyzji ministra Becka oraz wicepremiera i ministra skarbu Eugeniusza Kwiatkowskiego oddano sprawę pozostawienia $w$ tekście memoriału informacji o zamiarze wykorzystania ewentualnie uzyskanych funduszy „na wzmożenie środków obrotowych państwa, wyczerpanych przez długotrwałe przesilenie", o co zabiegał ostatni z wymienionych"'.

W trakcie rozmowy podkreślono, że Generalny Inspektor Sił Zbrojnych życzy sobie, by memorandum zostało wysłane do Londynu możliwie szybko, bez oczekiwania na formalną odpowiedź brytyjską. Beck do tego życzenia zastosował się niezwłocznie, odpowiednie instrukcje przekazując ambasadorowi Raczyńskiemu już 10 maja. Ich adresatowi pozostawiono wybór osoby, do której miałby się zwrócić, oraz decyzję w sprawie ujawnienia już w pierwszej rozmowie postulowanej sumy kredytu. Memorandum oraz dodatkowe ustne instrukcje miał zawieźć do Londynu radca Wszelaki²2.

Wykonanie zadania przeprowadzono bez straty czasu. 12 maja Raczyński udał się do lorda Halifaxa, wręczając mu aide-mémoire w języku francuskim. W trakcie rozmowy przekazał także informację o wysokości oczekiwanej przez Polaków sumy, która miałaby wynieść mniej więcej $60 \mathrm{mln}$ funtów.

Halifax sprawę potraktował życzliwie, zapewniając, że podjął już odpowiednie działania. Następnie spróbował uzyskać od Raczyńskiego garść dodatkowych informacji na tematy związane $z$ kredytem. Ambasador nie był jednak w stanie udzielić precyzyjnych odpowiedzi, wyjaśniając, że kwestie bardziej szczegółowe omówić winni eksperci podczas właściwych negocjacji. Indagowany potwierdził jednak, że rozmowy w sprawie wsparcia finansowego podjęte zostały także ze stroną francuską, choć pomoc finansowa Londynu i Paryża (w tym ostatnim przypadku padła kwota około 20 mln funtów) winna być jego zdaniem traktowana osobno. W przesłanej następnie do Warszawy informacji o przebiegu rozmowy ambasador wyrażał ostrożny optymizm, przestrzegając jednak, że ze względu na własne poważne problemy finansowe strona brytyjska dążyć będzie do znacznej redukcji ostatecznie przyznanych Polakom kwot ${ }^{23}$.

2 IPMS, A.11.49.WB.3, notatka J. Wszelakiego z rozmowy z gen. Malinowskim z $8 \mathrm{~V} 1939$ r.

22 PDD 1939, dok. 271, s. 450.

29 Ibidem, dok. 279, s. 460nn.; DBFP, vol. 5, dok. 508, s. 539 (tam też tekst polskiego aide-mémoire); H. Jackiewicz, op. cit., s. 181. Kennarda o rozmowie powiadomiono także depeszą szyfrową No 161 z $13 \mathrm{~V} 1939$ r., godz. 22.00. Tekst aide-mémoire do ambasady w Warszawie przesłany został kilka dni później, telegramem szyfrowym No 166 z $20 \mathrm{~V} 1939$ r., godz. 17.00 (TNA, FO 371/23144). 
W Londynie tymczasem podjęto kolejne konsultacje. Kopie informacji o treści rozmowy z 12 maja niezwłocznie przesłano do Johna Simona oraz premiera Chamberlaina. Ten ostatni próbował skłonić kanclerza skarbu do zmiany stanowiska, spotkał się jednak ze zdecydowanym sprzeciwem. Zarówno zgoda na polskie zakupy w państwach trzecich, argumentował Simon, jak i finansowanie polskich wydatków wewnętrznych oznacza w praktyce wydatkowanie złota, które i tak wypływa już z Zjednoczonego Królestwa szerokim strumieniem. Dodatkowe obciążenia oznaczać zaś muszą - tu kanclerz skarbu uderzał w wysokie tony - „skrócenie czasu, przez który będziemy mogli wyżywić nasz naród w czasie wojny”. Jedyną więc pomoc finansową, którą Wielka Brytania może zaoferować Polsce - brzmiała konkluzja - stanowią kredyty eksportowe, w części przeznaczone na potrzeby zbrojeń. I one, rzecz jasna, mieć będą charakter „polityczny”, gdyż trudno sobie wyobrazić, by wypłacalność partnera uznana została za wystarczająco solidną. Punktem odniesienia mogłaby być w tym przypadku wysokość pomocy udzielonej innym szczególnie potraktowanym państwom, tj. 5 mln funtów przyznane Rumunii i 16 mln funtów, które uzyskała Turcja ${ }^{24}$.

Sceptyczne komentarze co do polskich postulatów formułowali jednak w tym czasie bynajmniej nie tylko obrońcy brytyjskiej wypłacalności spod znaku kanclerza skarbu. „Właśnie rozpoczynamy wyposażanie naszej własnej armii i musimy wydać na ten cel 134 miliony funtów w ciągu najbliższych osiemnastu miesięcy" - podnosił w korespondencji do Hallifaxa lord Chatfield, natychmiast zestawiając ową sumę z 63 mln polskiego zapotrzebowania. Tego samego dnia sekretarz Komitetu Obrony Imperialnej C.N. Ryan komentował obszerną analizę Industrial Intelligence Centre (Departament of Overseas Trade) „Poland. Armament supply in war" w sposób od Simona niezależny, a jednak wielce podobny ${ }^{25}$.

Do uzgodnień między premierem i kanclerzem skarbu doszło ostatecznie wieczorem 17 maja. Uznano, że Polacy nie powinni się spodziewać uzyskania w Londynie pomocy finansowej w postaci złota lub funtów szterlingów. Równocześnie

${ }^{24}$ TNA, PREM 1/357, załącznik do listu Johna Simona do Chamberlaina z $15 \mathrm{~V} 1939 \mathrm{r}$. W załączonym do korespondencji zestawieniu wrysokość kredytów udzielonych Turcji określona została na 16 mln funtów.

25. TNA, FO 371/23145, list Chatfielda do Halifaxa z 17 V 1939 r.; CAB 104/50, opracowanie "Supply Position in Poland" C.N. Ryana dla Ismaya z 17 V 1939 r. Polska może wystawić przy użyciu posiadanych zasobów 56 dywizji oraz lotnictwo liczące 500 samolotów („,choć rezerwy maszyn pierwszej linii liczą tylko 250 maszyn, a potem nie pozostanie już rezerw"), jednak nawet $w$ najbardziej sprzyjających warunkach jej przemysł $w$ razie wojny będzie $w$ stanie zaopatrywać tylko 10 dywizji, argumentował Ryan. Konieczne staną się dostawy z zewnątrz: z Francji (tylko ona posiada zdolność produkcji amunicji wzorów używanych w Polsce) albo z USA lub raczej ZSRR. Prócz kwestii technicznych i logistycznych problemem staną się pieniądze. „Polski eksport zostanie przerwany. Polska nie będzie $w$ stanie za nic zapłacić $\mathrm{i}$ będzie musiała być finansowana przez nas" - przestrzegał, dodając, że w grę wejdą głównie waluty obce, których Zjednoczonemu Królestwu brakować zaczyna nawet na własne potrzeby. Inne głosy sceptyczne względem pomocy dla Polski: TNA, FO 371/23143, list Arthura Mullinsa (Comptroller General of Department of Overseas Trade) do Stranga z 16 V 1939 r. i in. dok. 
zaakceptowano polską propozycję przysłania do Londynu misji w celu podjęcia odpowiednich negocjacji ${ }^{26}$.

Otrzymaną informację Foreign Office przekazało Raczyńskiemu 20 maja w formie memorandum. Równolegle treści dokumentu przesłano do Kennarda. Formalnie przyjmując polskie aide-mémoire, strona brytyjska zastrzegła, że ze względu na potrzeby związane $z$ realizacją własnego programu zbrojeniowego nie będzie $\mathbf{w}$ stanie udzielić pomocy Polsce w zaproponowanej skali, zaś sam kredyt dotyczyć może jedynie zakupów towarów i materiałów wyprodukowanych w Wielkiej Brytanii. Korespondencja zawierała też akceptację przyjęcia nad Tamizą polskiej misji, w terminie dogodnym dla rządu Rzeczypospolitej ${ }^{27}$.

Taka odpowiedź nie mogła rzecz jasna zadowolić Warszawy. Minister Beck stanowisko strony brytyjskiej określił jako „niezadowalające”, instruując ambasadora Raczyńskiego, by ten podjął bezzwłocznie interwencję u lorda Halifaxa, w celu skłonienia władz znad Tamizy do ponownego rozważenia sprawy. Wysiłek brytyjski, „jakkolwiek wielki i niewątpliwie konsekwentny”, argumentował, jest bowiem z polskim nieporównywalny, tymczasem obaj partnerzy dążyć winni właśnie „do wyrównywania wzajemnych ciężarów i świadczeń". Obu też stronom zależeć winno, by polski potencjał ludzki, a przede wszystkim możliwości produkcyjne polskiego przemysłu wojennego mogły zostać w pełni wykorzystane, czego nie uda się zrealizować bez poważnej pomocy finansowej ${ }^{28}$.

W korespondencji pominięte zostały wyjaśnienia przedstawiane nie tylko przez brytyjskich dyplomatów, ale i samego Raczyńskiego. Przedstawione mu stanowisko Beck uznał jedynie za wykręt, miast jednak próbować wykazać jego słabości lub dostarczyć ambasadorowi nowych argumentów, wolał nakazać mu wykonanie szarży z użyciem broni raz już bez powodzenia wykorzystanej - i doskonale znanej drugiej stronie.

Nad Wisłą w tym czasie prowadzone już były prace nad planem ewentualnych zakupów kredytowych. W pierwszej dekadzie maja Biuro Przemysłu Wojennego MSWojsk. zakończyło opracowywanie ramowych założeń rozdziału kwot, które zamierzano uzyskać $z$ Londynu. W czterech odrębnych wykazach zestawione zostały kolejno: I) surowce i półfabrykaty, materiały wybuchowe i paliwa; II) części (samochodowe, lotnicze, itp.), „różne maszyny i silniki”, chemikalia oraz inne „różne materiały"; III) maszyny i urządzenia dla sił zbrojnych oraz przemysłu; IV) gotowy sprzęt wojskowy. Ogólna, wyrażona w złotych wartość zapotrzebowania określona została na $777 \mathrm{mln}$, w tym wartość gotowego materiału na $283 \mathrm{mln}$. W tym ostatnim przypadku ogromną większość, bo aż 257,22 mln zł, stanowić miał materiał przeznaczony dla lotnictwa, obejmujący 150 samolotów myśliwskich i 100 lekkich samolotów bombowych (łączna wartość $150 \mathrm{mln} z \nmid)$ oraz wyposażenie lotnicze - w tym aparaty fotograficzne $(3,61 \mathrm{mln} \mathrm{z})$, radiostacje $(4,96 \mathrm{mln} \mathrm{z})$, samochody $(7,91 \mathrm{mln} \mathrm{zł})$,

if TNA, PREM /357, kopia notatki Szefa Służby Cywilnej i Głównego Doradcy Przemysłowego rządu Horacéa J. Wilsona dla drugiego Sekretarza Skarbu Richarda Hopkinsa z 17 V 1939 r.

$\because$ IPMS, A.11.49.WB.3, niesygnowane [E. Raczyński] „Uwagi na temat aide-mémoire brytyjskiego $z$ dn. 20 maja 1939 r."; DBFP, vol. 5, dok. 562, s. 604n.; H. Ja cki e wicz, op. cit., s. 181.

2* IPMS, A.11.49.WB.3, koncept pisma Becka do Raczyńskiego z 26 V 1939 r. 
uzbrojenie $(27,17 \mathrm{mln} \mathrm{zł})$ i inne materiały (6,35 mln zł). Zakupy, oprócz Wielkiej Brytanii, realizowane być miały także w USA, a w przypadku surowców, których nie byłyby w stanie dostarczyć wymienione państwa, także w innych krajach. Całość materiału lotniczego nabyć zamierzano jednak nad Tamizą ${ }^{29}$.

Niemal równocześnie powstawały zestawienia o charakterze bardziej szczegółowym, w których dokonywano niekjedy pewnych korekt wcześniej przyjętych wartości. W przypadku zakupów materiału lotniczego dane te $w$ ostatniej dekadzie maja przedstawiały się, jak zestawiono poniżej.

Tab. 8. Zestawienie ogólne do wykazu sprzętu lotniczego przeznaczonego do zakupu w Wielkiej Brytanii według stanu z maja 1939 r.

\begin{tabular}{|l|l|r|r|}
\hline A.I & 1. Gotowy sprzęt & 147351000 \\
\hline & 2. Osprzęt (wyposażenie) & & \\
\hline & a) radio & 4955000 & \\
\hline & b) foto & 1401250 & \\
\hline c) samochody & 6310000 & \\
\hline & d) uzbrojenie i amunicja & 27965000 & \\
\hline & e) sprzęt do remontów generalnych & 817700 & \\
\hline $\begin{array}{l}\text { f) różne nieprzewidziane: } \\
\text { sprzęt hangarowy, } \\
\text { małe ciągniki eskadrowe, pokrycia samolotów polowe, } \\
\text { piecyki do podgrzewania silników, płyn do chłodzenia } \\
\text { silników, ekwipunek lotniczy, aviofony }\end{array}$ & 2000000 & 43448950 \\
\hline B.II & 1. Sprzęt na bieżący użytek & & \\
\hline & a) radio & 3250000 & \\
\hline & b) foto & 6074250 & \\
\hline c) samochody & 12462500 & \\
\hline & d) przyrzady pokładowe & 800000 & \\
\hline & e) śmigła metalowe & 9970000 & 32511750 \\
\hline & 2. Obrabiarki dla fabryk państw. i jednostek & 10000000 \\
\hline 3. Dural (2000 ton) & & 10000000 \\
\hline & 4. Półfabrykaty & 6688300 \\
\hline & Razem & 250000000 \\
\hline
\end{tabular}

Źródło: IPMS, Lot. A.I. 19, niesygnowane i niedatowane [23 V 1939 r.?] zestawienie [Sztabu Lotniczego SG?].

${ }^{24}$ IPMS, Lot. A.V. 40i I, niedatowane [przed 9 V 1939 r.] „Zestawienie projektowanych zakupów" i in. dok. Materiały dla lotnictwa i przemysłu lotniczego znalazły się też w pozostałych wykazach. Tak np. w obejmującym części wykazie II umieszczono m.in. 3 wodnosamoloty ( 1917000 zł), śmigła (2 $156000 \mathrm{zł}$ ), przyrządy pokładowe (2 $271200 \mathrm{zł}$ ), półfabrykaty i przyrządy lotnicze (20000 $000 \mathrm{zl}$ ), prąadnice, turbozespoły i części (1 $946900 \mathrm{zl})$ ). Łącznie udział lotnictwa w zakupach działu I wynosić miał $8140000 \mathrm{mln}$ zł, działu II - $35270000 \mathrm{zl}$, działu III - $13810000 \mathrm{zl}$, działu IV - $200000000 \mathrm{zł}$. 
Tab. 9. Wykaz materiału lotniczego przeznaczonego do zakupu w Wielkiej Brytanii: płatowce, zapasowe silniki i osprzęt

\begin{tabular}{|c|c|c|c|c|c|}
\hline L.p. & Wyszczególnienie & Hość & \begin{tabular}{|c|} 
Orientacyjna \\
cena \\
jednostkowa
\end{tabular} & $\begin{array}{l}\text { Orientacyjna } \\
\text { suma ogólna }\end{array}$ & Uwagi \\
\hline 1 & Płatowce myśliwskie & 150 & $200000 \mathrm{zt}$ & $30000000 \mathrm{zt}$ & \\
\hline 2 & $\begin{array}{l}\text { Płatowce lekkiego } \\
\text { bomb. }\end{array}$ & 150 & $200000 \mathrm{zt}$ & $20000000 \mathrm{zt}$ & \\
\hline 3 & \begin{tabular}{|l|} 
Silniki do płatowców \\
myśliwskich
\end{tabular} & 300 & $150000 \mathrm{zt}$ & $45000000 \mathrm{zt}$ & \\
\hline 4 & $\begin{array}{l}\text { Silniki do płatowców } \\
\text { lekkiego bomb. }\end{array}$ & 200 & $150000 \mathrm{zt}$ & $30000000 \mathrm{zt}$ & \\
\hline 5 & $\begin{array}{l}\text { Części zamienne do } \\
\text { płat. myśl. }\end{array}$ & - & - & $45000002 t$ & $\begin{array}{l}\text { 15\% zakupu płatow- } \\
\text { ców } \\
\end{array}$ \\
\hline 6 & $\begin{array}{l}\text { Części zamienne do płat. } \\
\text { lekk. bomb. }\end{array}$ & - & - & $3000000 \mathrm{zt}$ & $\begin{array}{l}15 \% \text { zakupu płatow- } \\
\text { ców }\end{array}$ \\
\hline 7 & $\begin{array}{l}\text { Części zamienne do siln. } \\
\text { myśl. }\end{array}$ & - & - & $6750000 \mathrm{zt}$ & 15\% zakupu silników \\
\hline 8 & $\begin{array}{l}\text { Części zamienne do } \\
\text { silników lekk. bomb. }\end{array}$ & - & - & $45000002 t$ & 15\% zakupu silników \\
\hline 9 & $\begin{array}{l}\text { Sprzęt lotniskowy dla } \\
\text { esk. myśl. }\end{array}$ & 24 & $15000 \mathrm{zt}$ & $360000 \mathrm{zt}$ & $\begin{array}{l}\text { niezbędny dla uru- } \\
\text { chomienia esk. }\end{array}$ \\
\hline 10 & $\begin{array}{l}\text { Sprzęt lotniskowy dla } \\
\text { esk. lekk. bomb. }\end{array}$ & 20 & $15000 \mathrm{zt}$ & $3000002 t$ & $\begin{array}{l}\text { oraz potrzebne wóz- } \\
\text { ki do wożenia bomb. }\end{array}$ \\
\hline 11 & $\begin{array}{l}\text { Narzędzia bryg. obsługi } \\
\text { sam. myśl. }\end{array}$ & 100 & $5002 t$ & $500002 t$ & \\
\hline 12 & $\begin{array}{l}\text { Narzędzia esk. do sam. } \\
\text { myśl. }\end{array}$ & 20 & $3000 \mathrm{zt}$ & $60000 \mathrm{zt}$ & \\
\hline 13 & $\begin{array}{l}\text { Narzędzia bryg.[ady] } \\
\text { obst.[ugi] do sam. lekk. } \\
\text { bomb. }\end{array}$ & 70 & $500 \mathrm{zt}$ & $35000 \mathrm{zt}$ & \\
\hline 14 & $\begin{array}{l}\begin{array}{l}\text { Narzędzia esk. do sam. } \\
\text { lekk. bomb }\end{array} \\
\end{array}$ & 15 & $3000 \mathrm{zt}$ & $45000 \mathrm{zt}$ & \\
\hline 15 & $\begin{array}{l}\text { Zest. zapasowy przyrz. } \\
\text { pokład. oraz części dla } \\
\text { esk. myśl. }\end{array}$ & 10 & $7000 \mathrm{zt}$ & $70000 \mathrm{zt}$ & \\
\hline 16 & $\begin{array}{l}\begin{array}{l}\text { Dtto dla esk. lekk. } \\
\text { bomb. }\end{array} \\
\end{array}$ & 8 & $7000 \mathrm{zt}$ & $56000 \mathrm{zf}$ & \\
\hline 17 & $\begin{array}{l}\text { Piloty automatyczne do } \\
\text { płat. lekk. bomb. }\end{array}$ & 100 & $25000 \mathrm{zt}$ & $25000002 t$ & \\
\hline 18 & $\begin{array}{l}\text { Obrotomierze elektrycz- } \\
\text { ne (Smitha) }\end{array}$ & 100 & $500 \mathrm{zt}$ & $50000 \mathrm{zt}$ & dla esk. bomb. \\
\hline
\end{tabular}




\begin{tabular}{|l|c|c|c|c|c|}
\hline L.p. & Wyszczególnienie & Ilośćc & $\begin{array}{c}\text { Orientacyjna } \\
\text { cena } \\
\text { jednostkowa }\end{array}$ & $\begin{array}{c}\text { Orientacyjna } \\
\text { suma ogólna }\end{array}$ & Uwagi \\
\hline 19 & Termometry powietrzne & 500 & $150 \mathrm{zt}$ & $75000 \mathrm{zt}$ & $\begin{array}{l}\text { dla esk. bomb. i dla } \\
\text { płatowców „Sum” }\end{array}$ \\
\hline
\end{tabular}

Uwaga: Prócz tego materiału niezbędne jest zamówienie:

$1 /$ płyn do chłodzenia silników (Glicol)

$2 /$ płyn do amortyzatorów

3/ wszelki materiał pomocniczy niezbędny do normalnej obsługi, a nie ujęty powyższym wykazem

Źródło: IPMS, Lot. A.I. 19, niesygnowane zestawienie "Płatowce, zapasowe silniki i osprzęt" $223 \vee 1939 \mathrm{r}$.

Tab. 10. Wykaz materiału lotniczego przeznaczonego do zakupu w Wielkiej Brytanii: radiostacje

\begin{tabular}{|c|c|c|c|c|c|}
\hline L.p. & Wyszczególnienie & Ilość & $\begin{array}{l}\text { Cena jedn. } \\
\text { orientac. }\end{array}$ & $\begin{array}{c}\text { Suma } \\
\text { orientac. }\end{array}$ & Uwagi \\
\hline 1. & $\begin{array}{l}\text { Radiostacje pokładowe dla lotn. myśl. na } \\
\text { cały stan samolotów }\end{array}$ & 150 & 7500 & 1500000 & \\
\hline 2. & $\begin{array}{l}\text { Dyonowe naziemne radiost. na samocho- } \\
\text { dach dla łączn. } z \text { lotn. myśl. }\end{array}$ & 5 & 120000 & 600000 & \\
\hline 3. & $\begin{array}{l}\text { Zespoły spal. elektr. mocy } 600-800 \mathrm{~W} \text { do } \\
\text { tadow. akumulatorów }\end{array}$ & 10 & 2500 & 25000 & \\
\hline 4. & $\begin{array}{l}\text { Radiost. pokładowe dla lotn. liniow. na } \\
\text { cały stan samolotów }\end{array}$ & 100 & 13000 & 1300000 & \\
\hline 5. & $\begin{array}{l}\text { Radiost. eskadrowe naziemne na samo- } \\
\text { chodach dla łączn. } z \text { lotn. liniowym }\end{array}$ & 7 & 120000 & 840000 & \\
\hline 6. & Zespoły spalin. elektr. mocy ok. $2 \mathrm{~kW}$ & 10 & 4000 & 40000 & \\
\hline 7. & Części zamienne 15\% & - & - & 650000 & \\
\hline \multicolumn{4}{|c|}{ Razem } & 4955000 & \\
\hline
\end{tabular}

Źródło: IPMS, Lot. A.I. 19, niesygnowane zestawienie „Radiostacje” z 23 V 1939 r. 
Tab. 11. Wykaz materiału lotniczego przeznaczonego do zakupu w Wielkiej Brytanii: materiał fotograficzny

\begin{tabular}{|l|l|c|c|c|c|}
\hline \multicolumn{1}{|c|}{ Lyszczególnienie } & Ilośćc & $\begin{array}{c}\text { Cena jed- } \\
\text { nostkowa } \\
\text { orientacyjna }\end{array}$ & $\begin{array}{c}\text { Cena } \\
\text { ogólna } \\
\text { orientac. }\end{array}$ & Uwagi \\
\hline 1. & $\begin{array}{l}\text { Aparat foto wbudowany wym.18x18 F.25, } \\
\text { dostosowany do napięcia prądu 24V } \\
\text { kompletów - }\end{array}$ & 40 & 20000 & 800000 & \\
\hline & Części zapasowe 15\% & & & 120000 & \\
\hline 2. & $\begin{array}{l}\text { Samochodowe laboratoria fotograficzne / } \\
\text { typ lekki/ z całkowitym wyposażeniem do } \\
\text { wywotywania, suszenia i kopiowania zdjęć } \\
\text { lotniczych } \\
\text { kompletów - }\end{array}$ & 5 & 75000 & 375000 & \\
\hline & Czéści zapasowe 15\% & & & 56250 & \\
\hline 3. & $\begin{array}{l}\text { Błona fotograficzna do wymienionych powy- } \\
\text { zej aparatów }\end{array}$ & & 50000 & 1401250 & \\
\hline
\end{tabular}

Źródło: IPMS, Lot. A.I. 19, niesygnowane zestawienie "Foto" z 23 V 1939 r.

Tab. 12. Wykaz materiału lotniczego przeznaczonego do zakupu w Wielkiej Brytanii: samochody

\begin{tabular}{|l|l|r|c|c|c|}
\hline \multicolumn{1}{|c|}{ Wyszczególnienie } & Ilość & $\begin{array}{c}\text { Cena jed- } \\
\text { nostkowa } \\
\text { orientacyjnie }\end{array}$ & $\begin{array}{c}\text { Suma } \\
\text { orienta- } \\
\text { cyjna }\end{array}$ & Uwagi \\
\hline 1. & Samoch. cięż. 3 ton. & 126 & 35000 & 4410000 & \\
\hline 2. & Samoch. cysterna à 3000 litr. & 20 & 50000 & 1000000 & \\
\hline 3. & Części zamienne i narzędzia (15\%) & - & - & 900000 & \\
\hline \multicolumn{4}{|l|}{ Razem }
\end{tabular}

Źródło: IPMS, Lot. A.I. 19, niesygnowane zestawienie "Samochody” z 23 V 1939 r. 
Tab. 13. Wykaz materiału lotniczego przeznaczonego do zakupu w Wielkiej Brytanii: uzbrojenie i amunicja lotnicza

\begin{tabular}{|c|c|c|c|c|}
\hline $\begin{array}{c}\text { Wyszczegól- } \\
\text { nienie }\end{array}$ & Ilość sztuk & \begin{tabular}{|l|} 
Cena jed- \\
nostkowa \\
\end{tabular} & Suma & Uwagi \\
\hline $\begin{array}{l}\text { k.m. lotn. na } \\
150 \text { samolo- } \\
\text { tów myśliw- } \\
\text { skich i } 100 \\
\text { samolotów } \\
\text { liniowych }\end{array}$ & 1430 & 6000 & 8580000 & $\begin{array}{l}\text { W tym } 30 \text { szt. k.m. na zapas luźny. } \\
\text { Celowniki pilota powinny być na } \\
\text { samolocie. } \\
\text { Magazynki nabojowe i celowniki do } \\
\text { k.m. strzelca przewiduje się, że będą } \\
\text { przy k.m. strzelca/magazynków do } \\
\text { k.m. strzelca na } 700 \text { nabojów na } \\
\text { każdy k.m. }\end{array}$ \\
\hline $\begin{array}{l}\text { Celowniki } \\
\text { bombardier- } \\
\text { skie }\end{array}$ & 110 & 10000 & 1100000 & $\begin{array}{l}\text { Celowniki bombardierskie powinny } \\
\text { być kompletne, tj. posiadać podsta- } \\
\text { wę dla zabudowania ich na samolot, } \\
\text { wskaźnik bombardierskie dla pilota } \\
\text { i przewody do instalacji celownika }\end{array}$ \\
\hline $\begin{array}{l}\text { Części zamien- } \\
\text { ne do k.m. } \\
\text { lotniczych, } \\
\text { wyrzutników } \\
\text { oraz narzędzia } \\
\text { uzbrojenia } \\
\text { i przybory }\end{array}$ & \multicolumn{3}{|c|}{$\begin{array}{l}15 \% \text { sumy kosztów k.m. i celowni- } \\
\text { ków bomb. }\end{array}$} & $\begin{array}{l}\text { W przyborach przewiduje się sprzęt } \\
\text { pomocniczy, jak: ładowniki do ta- } \\
\text { śmowania ogniwek i nabijania nabo- } \\
\text { jów do magazynków k.m. strzelca. } \\
\text { W czéściach zamiennych przewi- } \\
\text { dziane są również uzgadniacze k.m. } \\
\text { pilota i przekaźniki ruchu (jeżeli k.m. } \\
\text { pilota uzgodnione są z silnikiem) }\end{array}$ \\
\hline $\begin{array}{l}\text { Naboje lotni- } \\
\text { cze zwykłe }\end{array}$ & 6000000 & 0,26 & 1560000 & $\begin{array}{l}\text { Jeżeli będzie możliwe przystoso- } \\
\text { wanie k.m. lotniczych na amunicję } \\
\text { polska, tj. kaliber } 7,5 \text {, wówczas zakup } \\
\text { nabojów odpada /byłoby latwiejsze } \\
\text { zaopatrywanie jednostek w naboje/ }\end{array}$ \\
\hline $\begin{array}{l}\text { Naboje lotni- } \\
\text { cze zapalające }\end{array}$ & 3000000 & 0,80 & 2400000 & Dtto \\
\hline $\begin{array}{l}\text { Ogniwka do } \\
\text { taśmowania } \\
\text { amunicji dla } \\
\text { k.m. pilota }\end{array}$ & 9000000 & $\begin{array}{l}100 \text { zł } \\
\text { za } 1000 \\
\text { sztuk }\end{array}$ & 900000 & $\begin{array}{l}\text { Dtto } \\
\text { Ponadto: jeżeli na samolotach znaj- } \\
\text { duje się urządzenie do zbierania } \\
\text { ogniwek po wystrzelonej amunicji, to } \\
\text { zakup ogniwek zmniejsza się o } 50 \%\end{array}$ \\
\hline $\begin{array}{l}\text { Bomby lotni- } \\
\text { cze }\end{array}$ & 2000 ton & $\begin{array}{l}6 z \nmid z a \\
\text { kilogram }\end{array}$ & 12000000 & $\begin{array}{l}\text { Sprzęt potrzebny do podwieszania } \\
\text { bomb na samolot przewidziany jest } \\
\text { w zestawieniu sprzętu lotniskowego }\end{array}$ \\
\hline \multicolumn{3}{|l|}{ Razem } & 27965000 & \\
\hline
\end{tabular}

Źródło: IPMS, Lot. A.I. 19, niesygnowane zestawienie „Uzbrojenie i amunicja lotnicza” z $23 \mathrm{~V}$ $1939 \mathrm{r}$. 
Tab. 14. Wykaz materiału lotniczego przeznaczonego do zakupu w Wielkiej Brytanii: sprzęt potrzebny do remontów generalnych

I. Samolotów 150 myśliwskich (Spitfire lub pod. [obne])

$\sim 100$ lekkich bomb. (Blenheim lub Battle)

II. Silników 500 silników (Rolls-Royce Merlin)

\begin{tabular}{|l|l|r|r|r|}
\hline L.p. & \multicolumn{1}{|c|}{ Nazwa materiału } & $\begin{array}{r}\text { Ilość } \\
\text { sztuk }\end{array}$ & $\begin{array}{r}\text { Cena jed- } \\
\text { nostkowa }\end{array}$ & $\begin{array}{r}\text { Cena } \\
\text { tączna }\end{array}$ \\
\hline 1 & $\begin{array}{l}\text { Komplet narzędzi i urządzeń specjalnych remontowych } \\
\text { do silników }\end{array}$ & 2 & 200000 & 400000 \\
\hline 2 & $\begin{array}{l}\text { Komplet przyrządów montażowych i narzędzi specjal- } \\
\text { nych do remontu płatowców myśliwskich }\end{array}$ & 2 & 70000 & 140000 \\
\hline 3 & $\begin{array}{l}\text { Komplet przyrządów montażowych i narzędzi specjal- } \\
\text { nych do remontu płatowców lekkiego bombardowania }\end{array}$ & 2 & 90000 & 180000 \\
\hline 4 & Instrukcja montażowa dla silników z tabelą kmów & 10 & 40 & 400 \\
\hline 5 & $\begin{array}{l}\text { Instrukcja montażowa dla płatowców myśliwskich } \\
2 \text { tabelą kmów }\end{array}$ & 10 & 40 & 400 \\
\hline 6 & $\begin{array}{l}\text { Instrukcja montażowa dla płatowców lekkiego bom- } \\
\text { bardowania z tabelą kmów }\end{array}$ & 10 & 40 & 400 \\
\hline 7 & $\begin{array}{l}\text { Młynki i urządzenia specjalne (dla danego typu) dla } \\
\text { hamowni silnikowej }\end{array}$ & 2 & 8000 & 16000 \\
\hline 8 & Komplet rysunków warsztatowych silników & 3 & 4000 & 12000 \\
\hline 9 & $\begin{array}{l}\text { Komplet rysunków warsztatowych płatowców myśliw- } \\
\text { skich }\end{array}$ & 3 & 4500 & 13500 \\
\hline 10 & $\begin{array}{l}\text { Komplet rysunków warsztatowych płatowców lekkiego } \\
\text { bombardowania }\end{array}$ & 3 & 5000 & 15000 \\
\hline 11 & $\begin{array}{l}\text { Komplet urzádzeń probierczych specjalnych dla gaźni- } \\
\text { ków, pomp itp. dla silników }\end{array}$ & 2 & 20000 & 40000 \\
\hline 12 & Razem & 817700 \\
\hline
\end{tabular}

Źródło: IPMS, Lot. A.I. 19, zestawienie "Sprzęt potrzebny do remontów generalnych" inż. pil. Antoniego Janowskiego z $13 \mathrm{~V} 1939 \mathrm{r}$.

Powyższe wyliczenia dobrze prezentowały się jednak głównie na papierze. Prawdopodobieństwo realizacji tak szeroko zakrojonych zakupów było bowiem niewielkie i malało dosłownie z każdym tygodniem. Problemy z uzyskaniem kredytu, który mógłby pozwolić na sfinansowanie planowanych transakcji, stanowiły tu przy tym tylko jedną, choć ważną, stronę zagadnienia. Istniała jednak i strona druga, nie mniej istotna - związana z dostępnością materiału, który zamierzano z Wielkiej Brytanii uzyskać.

Polscy nabywcy, co nie mogło dziwić, zamierzali skoncentrować swe zabiegi wokół sprzętu najbardziej nowoczesnego, zdając sobie sprawę z tego, że tylko przy jego pomocy choć częściowo będą mogli zrównoważyć nieuniknioną przewagę liczebną przeciwnika. Jednak taki materiał był zarazem najtrudniej dostępny. Czekały nań 
$\mathrm{z}$ utęsknieniem brytyjskie siły powietrzne, znajdujące się właśnie $\mathrm{w}$ trakcie przezbrajania swych dywizjonów, nadal jeszcze niekiedy wyposażonych w sprzęt nieledwie antyczny. O nowoczesne samoloty od dawna też już zabiegali w Londynie liczni zagraniczni kupcy, świadomi, że bez takiej „tarczy na niebie” armie państw nie na wiele się zdadzą w razie konfliktu zbrojnego. Polacy, jeszcze niedawno sami zdolni do zaopatrywania państw wschodniej części Europy w konstruowane nad Wisłą maszyny myśliwskie czy rozpoznawczo-bombowe i wiosną 1939 roku wciąż negocjujący kolejne transakcje, zbyt późno zorientowali się, jak bardzo im samym potrzebne są zagraniczne zakupy. Gdy wreszcie w początkach kwietnia podjęli pierwsze, dość nieśmiałe próby ich przeprowadzenia, do nielicznych dostawców stały już długie kolejki innych chętnych, a niektórzy $z$ nich zdołali już nawet uzyskać wstępne obietnice sprzedaży. W przypadku umieszczonych na pierwszym miejscu polskiej zakupowej listy samolotów myśliwskich Supermarine Spitfire sytuacja ta przedstawiała się jak w tab. 15.

Tab. 15. Zagraniczne zapytania w sprawie sprzedaży samolotów Supermarine Spitfire według stanu z 5 IV $1939 \mathrm{r}$.

\begin{tabular}{|c|c|c|c|c|}
\hline Państwo & $\begin{array}{l}\text { llość sa- } \\
\text { molotów }\end{array}$ & $\begin{array}{l}\text { Zapytanie do } \\
\text { Min. Lotnictwa }\end{array}$ & $\begin{array}{c}\text { Odpowiedź } \\
\text { Min. Lotnictwa }\end{array}$ & Obecny stan sprawy \\
\hline Belgia & $15-45$ & 25 XI 1938 & $\begin{array}{l}24 \text { I } 1939 \text { od- } \\
\text { roczono do } \\
\text { kwietnia }\end{array}$ & $\begin{array}{l}\text { Od tego czasu nadeszly pytania } \\
\text { o możliwości dostawy wypra- } \\
\text { sek, odlewów i przyrządów } \\
\text { montażowych. } 31 \text { III } 1939 \text { r. } \\
\text { dano zgodę na dostawę pew- } \\
\text { nych komponentów do } 40 \text { ma- } \\
\text { szyn, ale nie obejmowała ona } \\
\text { ww. elementów }\end{array}$ \\
\hline Bułgaria & 12 & 25 XI 1938 & jw. & $\begin{array}{l}\text { Kolejny wniosek dotarł do Min. } \\
\text { Lotnictwa } 24 \text { II } 1939 \text { r. - odpo- } \\
\text { wiedź oczekiwana }\end{array}$ \\
\hline Estonia & 12 & $25 X \mid 1938$ & $\begin{array}{l}19 \text { I } 1939 \text { zgo- } \\
\text { da na dostawę } \\
12 \text { maszyn } \\
\end{array}$ & $\begin{array}{l}\text { Projekt umowy otrzymany od } \\
\text { wladz Estonii } 2 \text { III } 1939 \text { r. }\end{array}$ \\
\hline Francja & 1 & 25 XI 1938 & $\begin{array}{l}\text { Zgoda na do- } \\
\text { stawę }\end{array}$ & $\begin{array}{l}\text { Negocjacje } z \text { władzami Francji } \\
\text { w trakcie }\end{array}$ \\
\hline Grecja & 12 & $25 \times 11938$ & $\begin{array}{l}19 \text { I } 1939 \text { zgo- } \\
\text { da na dostawe } \\
12 \text { maszyn } \\
\end{array}$ & $\begin{array}{l}\text { Projekt umowy otrzymany od } \\
\text { władz Grecji } 22 \text { III } 1939 \text { r. }\end{array}$ \\
\hline Holandia & $18 / 36$ & 25 XI 1938 & $\begin{array}{l}19 \mid 1939 \text { od- } \\
\text { roczono do } \\
\text { kwietnia }\end{array}$ & Bez dalszego ciaggu \\
\hline Iran & 24 & 25 XI 1938 & jw. & jw. \\
\hline Litwa & 12 & 21111939 & & $\begin{array}{l}\text { Oczekiwanie na decyzję Min. } \\
\text { Lotnictwa }\end{array}$ \\
\hline
\end{tabular}




\begin{tabular}{|c|c|c|c|c|}
\hline Państwo & \begin{tabular}{|l|} 
Ilość sa- \\
molotów \\
\end{tabular} & \begin{tabular}{|c|} 
Zapytanie do \\
Min. Lotnictwa \\
\end{tabular} & \begin{tabular}{|c|} 
Odpowiedź \\
Min. Lotnictwa \\
\end{tabular} & Obecny stan sprawy \\
\hline Portugalia & 15 & 23111939 & \begin{tabular}{|l|}
14 III 1939 zgo- \\
da na dostawę \\
12 maszyn
\end{tabular} & $\begin{array}{l}\text { Negocjacje z rządem Portugalii } \\
\text { w trakcie }\end{array}$ \\
\hline \begin{tabular}{|l|} 
Rumunia \\
\end{tabular} & 10 & $25 \times 11938$ & $\begin{array}{l}1911939 \text { od- } \\
\text { roczono do } \\
\text { kwietnia }\end{array}$ & Bez dalszego ciągu \\
\hline Szwajcaria & 15 & 25 XI 1938 & jw. & $\begin{array}{l}\text { Licencja produkcyjna w trakcie } \\
\text { rozważań, możliwa dostawa } \\
3 \text { Spitfire'ów }\end{array}$ \\
\hline Turcja & $\begin{array}{c}60 \\
\text { (początko- } \\
\text { wo 30) }\end{array}$ & 25 XI 1938 & jw. & $\begin{array}{l}\text { Rząd turecki oczekuje oferty } \\
\text { na } 15 \text { kompletnych samolotów } \\
\text { i } 45 \text { zestawów części. Sprawa } \\
\text { przekazana Min. Lotnictwa } \\
14 \text { II } 1939 \text { r. - oczekiwanie na } \\
\text { decyzję }\end{array}$ \\
\hline Jugosławia & 12 & $25 \times 11938$ & jw. & Bez dalszego ciaggu \\
\hline
\end{tabular}

Źródło: TNA, AIR 2/2037, zestawienie „Enquires for Spitfire aircraft” 25 IV 1939 r., zał. do pisma C 560B/0./19 Vickers-Armstrongs Ltd. do podsekretarza stanu w Ministerstwie Lotnictwa 25 IV $1939 \mathrm{r}$.

Polskie oczekiwania uznać więc trzeba za nierealistyczne, i to w dwójnasób. Niemożliwe w zasadzie było uzyskanie kredytu w żądanej wysokości - niewątpliwie adekwatnej do potrzeb, ale już niekoniecznie do możliwości strony brytyjskiej. Gdyby jednak kredytowe opory partnera znad Tamizy udało się w jakiś sposób przezwyciężyć, to i tak zgoła nieprawdopodobne było uzyskanie dostaw najbardziej niezbędnego Polakom sprzętu w ilościach choćby zbliżonych do postulowanych.

O tej ostatniej prawdzie przedstawicielom Warszawy przekonać się przyszło bardzo szybko. 15 maja ppłk Kwieciński, który właśnie powrócił z kraju, poinformowany został w Ministerstwie Lotnictwa, że Brytyjczycy nie są w stanie dostarczyć nad Wisłę nowoczesnych myśliwców, o których sprzedaż zapytywał ich kilka tygodni wcześniej płk Filipowicz. Niejako w zamian zaproponowano natomiast natychmiastową dostawę 150 lekkich bombowców Fairey Battle ${ }^{30}$. Te, jak wiadomo, także interesowały szefów polskiego lotnictwa wojskowego, zaś attaché zwrócono uwagę, że dodatkowym atutem mogą być ich chłodzone wodą silniki Rolls-Royce Merlin. W Air Ministry

31" Propozycja nie stanowiła dla strony brytyjskiej zbytniej ofiary. Według wyliczeń w okresie od września 1939 r. do marca 1940 r. wykonanych miało zostać co najmniej 350 takich maszyn ponad potrzeby. Jak obliczano, zewnętrznym odbiorcom można było natychmiast zaoferować 100 150 battli, a kolejne 50-100 ich egzemplarzy w okresie od września do grudnia. W drugiej połowie 1940 r. oferta mogła już przekraczać 500 samolotów Fairey Battle (TNA, AIR 8/260, niesygnowana notatka „Note on Battles for Poland” z 21 VI 1939 r.). 
uważano, że mogłyby one zostać z powodzeniem wykorzystane także w najnowszym myśliwskim prototypie PZL (tj. PZL.50 „Jastrząb”), w którym jak dotąd nie sprawdziły się gwiazdowe silniki chłodzone powietrzem. Jak spekulowano, skoro Polacy nie zdołają uzyskać brytyjskich myśliwców, to może zechcą nabyć na Wyspach silniki Rolls-Royce’a i uczynić je napędem swych własnych konstrukcji myśliwskich ${ }^{31}$.

Podpułkownik Kwieciński nie był w stanie udzielić wiążącej odpowiedzi na pytanie o akceptację takiej propozycji, na co nalegali Brytyjczycy. Jak stwierdził, władze z Warszawy ofertą najpewniej będą zainteresowane, stanowisko zajmą jednak przypuszczalnie dopiero po przeprowadzeniu rozmów z kierowaną właśnie do Warszawy misją brytyjską. Niebawem jednak okazało się, że sprawa istotnie musi być traktowana jako pilna, tym bardziej że - jak wyjaśniano polskim dyplomatom (zgodnie zresztą z prawdą) - „są inni reflektanci” na ten sprzęt. W tej sytuacji decyzja zapadła w tempie iście ekspresowym, 25 maja do londyńskiej Ambasady RP nadeszła krótka depesza: „na samoloty reflektujemy" ${ }^{32}$.

Wciąż jednak bardzo niepewne były finansowe podstawy zakupów. 31 maja i 1 czerwca krytyczne polskie stanowisko wobec przedstawionej kilka dni wcześniej brytyjskiej propozycji pomocy kredytowej kolejno zaprezentowali Halifaxowi Kennard i Raczyński, używając zresztą bardzo podobnych argumentów. W obu przypadkach wyrażone zostało przekonanie, że to ku Polsce najpewniej zwróci się pierwsze uderzenie Rzeszy, obaj dyplomaci zwrócili uwagę na konieczność wykorzystania zawczasu polskich zasobów ludzkich i możliwości produkcji przemysłowej, obaj wreszcie odwołali się do zapoczątkowanych już finansowych rokowań polsko-francuskich. Przy tej ostatniej okazji Raczyński wyraził obawę, że powściągliwość Londynu może być naśladowana przez Paryż, który nie będzie chciał zbytnio wysforować się przed partnera, czemu jego rozmówca żywo zaprzeczył. Polski ambasador wyraził z kolei

3 TNA, FO 371/23144, pismo F.H. Sandforda z Ministerstwa Lotnictwa do O. Harveya z Foreign Office z $19 \mathrm{~V} 1939 \mathrm{r}$. Jak wiadomo z korespondencji ppłk. Kwiecińskiego, strona brytyjska zaoferowała dostawę samolotów Battle z pełnym uzbrojeniem i wyposażeniem oraz partią zapasowych silników. Nie zajęła natomiast jednoznacznego stanowiska w sprawie ewentualnej dostawy jednego lub dwóch egzemplarzy dwumiejscowego samolotu myśliwskiego Boulton Paul Defiant, który interesował gen. Zająca, sygnalizując jedynie, że „prawdopodobnie byłoby to możliwe”, ale dopiero „około miesiąca sierpnia”. Wyraziła też wstępną zgodę na odbycie przez kilku polskich pilotów lotów testowych na nowoczesnych samolotach konstrukcji brytyjskiej. IPMS, Lot. A.V. 1.40b, pismo L. $174 / 39$ ppłk. Kwiecińskiego do Szefa O. II SG z 19 V 1939 r. 30 maja Ambasada RP w Londynie informowała, że taka zgoda została udzielona dla czterech lotników, zaś loty miałyby się odbyć w Central Flying School w Upavon w końcu czerwca. Z początkiem tego miesiąca do wyjazdu wyznaczeni zostali: ppłk pil. inż. Mieczysław Konarski (KZL), ppłk pil. Jerzy Bajan, kpt. pil. Andrzej Włodarkiewicz, ppor. pil. Roland Kalpas oraz Bolesław Orliński z PZL (IPMS, A.12.53.23, telegram szyfrowy No 97 Amb. RP w Londynie do MSZ z 30 V 1939 r.; Lot. A.I. 2.15, pismo L. 3264/39.tj. Dowódcy Lotnictwa MSWojsk. gen. Władysława Kalkusa do Szefa Sztabu Lotniczego SG 25 VI 1939 r.)

32 IPMS, A.12.53.23, telegram szyfrowy No 93 chargé d'affaires w Ambasadzie RP w Londynie Antoniego Jażdżewskiego do MSZ z 22 V 1939 r.; telegram szyfrowy No 131 Szembeka do Amb. RP w Londynie z 25 V 1938 r. 
pewne zrozumienie dla obaw kanclerza skarbu. Zaproponował jednak, by dyskusję ze skierowaną do Londynu misją podjąć bez jakichkolwiek wstępnych restrykcji, wyrażając przekonanie, że pozwoli to znaleźć rozwiązanie satysfakcjonujące obie strony ${ }^{33}$.

Lord Halifax zapewnił Raczyńskiego, że wesprze jego wysiłki, raz jeszcze zwracając się do premiera oraz kanclerza skarbu. Istotnie, osobisty list do Chamberlaina wystosował już nazajutrz, proponując spotkanie $z$ udziałem polskiego ambasadora, choć bez obecności Simona, który w takim przypadku znaleźć by się mógł w niezręcznej sytuacji.

Do proponowanej rozmowy istotnie doszło rano 6 czerwca. Ponowne przedstawienie polskich potrzeb i charakteru oczekiwanej pomocy skłoniło Chamberlaina jedynie do akceptacji przeznaczonych na zakup materiału wojennego kredytów eksportowych, z zastrzeżeniem, że wielkość tych ostatnich musi stać się jeszcze przedmiotem dyskusji. Nie było natomiast zgody na polskie postulaty dotyczące kredytu na zakupy surowców w państwach trzecich oraz na zwiększenie zdolności produkcyjnych polskiego przemysłu amunicyjnego. Jak bowiem stwierdził brytyjski premier, podtrzymując tu stanowisko Simona, w tych przypadkach konieczne byłoby zaangażowanie walut obcych, których „w obecnych warunkach" brakować zaczyna samym Brytyjczykom. Zwrócił także uwagę, że wedle jego wiedzy polskie władze wciąż kierują spore środki na roboty publiczne zamiast na produkcję amunicji, a w dodatku sprzeciwiają się dewaluacji przewartościowanych złotych, mimo że taki krok mógłby ułatwić zagraniczne zakupy surowców.

Replika Raczyńskiego, który wskazał, że przysłanie nad Tamizę misji jedynie w celu podjęcia negocjacji na temat kredytów eksportowych mija się z celem, spotkała się z sugestią, że planowany przyjazd powinien jednak dojść do skutku. Rozmowy, zaproponował Chamberlain, będą mogły objąć wszelkie zagadnienia, jednak z wyjątkiem kredytów eksportowych rząd brytyjski nie poczyni zadnych innych wstępnych zobowiązań. Ambasador, unikając zajęcia stanowiska w tej kwestii, zapowiedział skonsultowanie odpowiedzi z władzami z Warszawy ${ }^{34}$.

W Warszawie jednak, jak się wydaje, sprawa była już od pewnego czasu przesądzona. Decydowało o tym stanowisko marszałka Śmigłego-Rydza, który - przekonany do idei zakupów kredytowych nad Tamizą przez płk. Koca - musiał jeszcze tylko przełamać opór wicepremiera Kwiatkowskiego, który do osoby potencjalnego

3 DBFP, vol. 5, doc. 680, s. 734nn.; doc. 692, s. 747nn.; H. Jackiewic z, op. cit., s. $181 \mathrm{nn}$.

is TNA, PREM 1/357, list Halifaxa do Chamberlaina z 2 VI 1939 r.; notatka na temat rozmowy z Raczyńskim i Halifaxem, podyktowana przez Chamberlaina 6 VI 1939 r. i in. dok. - w tym bardzo interesująca notatka F. Phillipsa dla $\mathrm{H}$. Wilsona (który przekazał ją premierowi) z 3 czerwca, zawierająca some uncensored comments w kwestii pomocy dla Polski. Sprawozdanie Raczyńskiego z tej rozmowy, opublikowane w PDD 1939, dok 330, s. 560nn., pokrywa się w zasadniczych punktach z jej przedstawieniem przez Chamberlaina. Ambasador szerzej natomiast zrelacjonował część rozmowy poświęconą ewentualnemu przyjazdowi polskiej misji, wyjaśniając, że obawiał się, iż całość polskich zabiegów może zostać sprowadzona do technicznych rozmów ekspertów, podczas gdy "sytuacja wymaga daleko idących i szybkich decyzji, które "pobierać" może tylko Rząd przez swoje czynniki decydujące" (s. 562). 
emisariusza miał zastrzeżenia, związane $\mathrm{z}$ sięgającymi jeszcze połowy dekady różnicami poglądów na temat ekonomicznej polityki państwa. Generalny Inspektor był tu jednak konsekwentny, dążąc do tego, by negocjacje finansowe podjął w Londynie oficer $z$ wyższym wykształceniem wojskowym. Przygotowywany do wyjazdu Koc odbył szereg konferencji z najwyższymi czynnikami wojskowymi, w tym Szefem Administracji Armii gen. Aleksandrem Litwinowiczem oraz generałami Stachiewiczem i Maciejowskim. Dokonał także uzgodnień w Ministerstwie Skarbu, przyjmując na swego zastępcę (i poniekąd - kontrolera) wyznaczonego do tej roli przez szefa resortu dyrektora Departamentu Obrotu Pieniężnego Wiesława Domaniewskiego. W trakcie wspomnianych rozmów Koc skonstatował niebezpieczną jego zdaniem tendencję: Kwiatkowski wyraźnie dążył do tego, by znacząca część ewentualnego kredytu gotówkowego zużytkowana została nie wprost na cele obronne, ale dla zwiększenia bazy emisyjnej Banku Polskiego, a w konsekwencji „korzyści ogólnej dla ekonomiki kraju". Innymi słowy - komentował po latach szef kierowanej nad Tamizę misji minister skarbu próbował „rozwiązać kwadraturę koła”, chcąc zarazem „zjeść ciastko i mieć ciastko". Potwierdzało to skądinąd podejrzenia Brytyjczyków, dostrzegających wyraźną niespójność polskiej polityki w tym względzie i skłonnych przypuszczać, że za argumentami o konieczności wzmocnienia zdolności obronnych kryć się może inny, czysto już ekonomiczny interes ${ }^{35}$.

O takim dwoistym charakterze misji Koca świadczyła też wyraźnie przygotowana dlań w Ministerstwie Skarbu instrukcja, w której zestawione zostały potrzeby wszystkich resortów, sięgające w sumie ogromnej kwoty 7 mld zł. Spora część uwzględnionych w jej ramach pozycji nie miała bezpośrednich, a niekiedy wręcz jakichkolwiek związków z potrzebami sił zbrojnych. O ile dla tych ostatnich z pewnością przydatne byłyby inwestycje komunikacyjne (mosty, linie kolejowe, tabor, drogi bite - łącznie za $940 \mathrm{mln} z \nmid)$, wydatki na rolnictwo (elewatory, zapasy żywności - za $600 \mathrm{mln}$ zł), surowce i przemysł cywilny ( $477 \mathrm{mln} \mathrm{zł})$ czy niektóre elementy ujęte w ramach potrzeb Ministerstwa Spraw Wewnętrznych (schrony OPL, szpitale), o tyle finansowanie wydatków samorządów, a nade wszystko metra $\mathrm{w}$ Warszawie było $\mathrm{z}$ punktu widzenia armii całkowicie zbędne. Stąd też czynniki wojskowe bardzo krytycznie zapatrywały się na zamysły ministra Kwiatkowskiego, zaś zaalarmowany przez nie w początkach drugiej dekady czerwca marszałek Śmigły-Rydz osobiście przejrzał i opatrzył odręcznymi uwagami przygotowane przez gen. Malinowskiego „Zasady użycia kredytu angielskiego". Jako podstawowa przyjęta miała być odtąd naniesiona przezeń czerwonym ołówkiem zasada: „Kredyt na materiały nie związane z dozbrojeniem i wojną dopuszczalny jest tylko wtedy, jeśli zaangażowanie się w tych kierunkach kredytu angielskiego może wpłynąć na zwiększenie kredytu wojskowego". Powyższe dyspozycje zostały następnie przekazane płk. Kocowi ${ }^{36}$.

35 A. Koc, op. cit., s. 248nn.; J. Mierzwa, op. cit., s. 201 n. Obie publikacje zawierają też informację o pozostałych członkach misji.

36 IPMS, A.I. 4.1.20, niedatowana [12 VI 1939 r.] notatka „Zasady użycia kredytu angielskiego" $z$ odręczną adnotacją marszałka Smigłego-Rydza oraz (podyktowanymi przezeń?) popraw- 
Od samego początku mieli natomiast polscy wojskowi wpływ na drugą z wysyłanych w tym czasie nad Tamizę misji, która pracując pod przewodnictwem gen. Rayskiego, miała zorientować się w możliwościach dokonania w Wielkiej Brytanii zakupów sprzętu i materiału w ramach materiałowej części kredytu. Wysłanie takiej komisji ekspertów strona polska uzgodniła wstępnie z bryg. Claytonem, a po jego wyjeździe niezwłocznie przystąpiła do przekuwania tych uzgodnień w czyn. Pisma w sprawie przyjęcia wojskowej misji ppłk Kwieciński złożył w ministerstwach wojny oraz lotnictwa 5 czerwca, na dzień przed rozmową ambasadora Raczyńskiego z premierem Chamberlainem i ministrem Halifaxem, i już 9 czerwca mógł poinformować Warszawę o oficjalnej zgodzie na przedstawioną propozycję $e^{37}$.

Równolegle podjęto opracowywanie instrukcji dla wyjeżdżających do Londynu oficerów. W pierwotnej jej wersji łączna suma zamierzonych zakupów określona została na równowartość $863 \mathrm{mln} \mathrm{zł}, \mathrm{w}$ tym transakcji dla potrzeb lotnictwa - na $250 \mathrm{mln}$ zł. Siły powietrzne skorzystać miały częściowo także z kwot zarezerwowanych na zakupy surowców ( $350 \mathrm{mln} \mathrm{zł})$, materiału łączności ( $10 \mathrm{mln} \mathrm{zł})$, stałe pokrycie rocznego zapotrzebowania (64 mln $\mathrm{zł})$ oraz maszyny i urządzenia $(75 \mathrm{mln} \mathrm{z})^{38}$.

Po konsultacjach $z$ gen. Malinowskim $\mathrm{w}$ dokumencie wprowadzono korekty. Łączna wartość planowanych wydatków podniesiona została do $881 \mathrm{mln} \mathrm{zl}$, w ich zestawieniu wprowadzono zaś dodatkowe działy: sprzęt obrony przeciwlotniczej (40 mln zł) oraz artyleria ciężka, sprzęt pancerny, saperzy (55 $\mathrm{mln} z \nmid)$. Ofiarą nieuchronnych w tym przypadku cięć padło przede wszystkim lotnictwo, którego limit wydatków zmniejszony został do $200 \mathrm{mln}$ zł. Jak się jednak wydaje, w tym przypadku redukcja polegała po prostu na wyodrębnieniu z sum przeznaczonych dla lotnictwa części "przeciwlotniczej”, sama zaś wielkość zakupów materiału dla sił powietrznych pozostała bez istotnych zmian, obejmując (co teraz wpisano w instrukcji implicite) 150 samolotów myśliwskich oraz 150 lekkich samolotów bombowych. Właśnie zresztą "płatowce z całkowitym wyposażeniem" umieszczone zostały na najwyższym miejscu określonych w instrukcji „zakupowych priorytetów”. Przekazany wyjeżdżającym plan zakupów uznany został przy tym za "tymczasowy" i "orientacyjny". Jego

kami naniesionymi ręką gen. Malinowskiego. Czystopis dokumentu został następnie podpisany przez Generalnego Inspektora Sil Zbrojnych.

"7NA, CAB 104/50, kopia pisma L. $185 / 39$ ppłk. Kwiecińskiego do mjr. A.R. Boyléa z Min. Lotnictwa z 5 VI 1939 r.; IPMS, A.I. 4.1.10, pismo L. 186/39 ppłk. Kwiecińskiego do gen. Malinowskiego z 7 VI 1939 r.; telegram szyfrowy L. 34 Kwiecińskiego z 9 VI 1939 r., godz. 13.44. Tegoż dnia płk Sword rozmawiał z gen. Rayskim o planowanym wyjeździe (spotkanie odbyło się po telefonicznej rozmowie attaché z gen. Malinowskim), odnotowując następnie doskonałe wrażenie, jakie wywarł na nim były dowódca polskiego lotnictwa wojskowego (E.R. Sword, op. cit., s. 43n.). W sprawie polskiej propozycji przysłania do Londynu wojskowej misji zakupów: TNA, T 160/878, depesza No 181 Kennarda do FO z $30 \mathrm{~V} 1939$ r., godz. 18.15. Warte lektury jest syntetyzujące dotychczasowy stan brytyjsko-polskich kontaktów, datowane 8 czerwca memorandum C 82041110/55 Foreign Office "Financial and military assistance for Poland" (TNA, FO 371/23145).

st IPMS, A.I. 4.1.12, koncept pisma [gen. Litwinowicza] do gen. Rayskiego z ? VI 1939 r. Suma $114 \mathrm{mln}$ zł przypaść miała Marynarce Wojennej. 
ostateczne zdefiniowanie nastąpić miało dopiero po stwierdzeniu na miejscu brytyjskich „możliwości produkcyjnych i rynkowych"39.

Dodać należy, że równocześnie trwały przygotowania do wyjazdu podobnej misji nad Sekwanę. Stanowiły one efekt uzgodnień poczynionych w Paryżu podczas wizyty gen. Kasprzyckiego oraz zapoczątkowanych już negocjacji finansowych $z$ tamtejszym rządem. Przyjdzie nam jeszcze o tym napisać. Zaznaczyć jednak trzeba, że zabiegi podjęte względem Francji, choć ważne dla całości zbrojeniowej polityki Rzeczypospolitej, z punktu widzenia sił powietrznych zdawały się wówczas relatywnie mało istotne. Swiadczyły o tym właśnie wspomniane już wyżej „zakupowe priorytety” misji kierowanych do Londynu i Paryża. Te zaś określono następująco: „w Anglii najważniejszy sprzęt to lotnictwo, zwłaszcza myśliwskie; we Francji to 300 czołgów"40.

Generał Rayski znalazł się w Londynie już późnym wieczorem 11 czerwca, docierając tam drogą lotniczą przez Kopenhagę. Niemal natychmiast, w trakcie konferencji zorganizowanej w polskiej ambasadzie dzień później, zorientował się, że dostarczony mu plan zakupów jest „niezupełny i niewykonalny”, brak w nim bowiem informacji na temat ilości przeznaczonych do nabycia materiałów, zaś podaną $w$ instrukcji ich wartość, która mogłaby tu stanowić ogólną choćby wskazówkę, zabroniono mu podawać w trakcie negocjacji. Do Warszawy udać się więc musiał przydzielony Rayskiemu do pomocy zastępca ds. technicznych Dowódcy Lotnictwa MSWojsk. ppłk Wacław Makowski, który miał przywieźć niezbędne specyfikacje. Wizyta złożona 13 czerwca u lorda Chatfielda dała podstawy do żywienia umiarkowanych nadziei: Polakom obiecano przekazać "pewne materiały”, podkreślając zarazem ograniczone $\mathrm{w}$ tym względzie możliwości, zarówno $\mathrm{z}$ racji potrzeb własnych, jak i oczekiwań innych sojuszników. Z kolei w trakcie spotkania w Ministerstwie Wojny szef polskiej misji wypytywany był o „możliwości otrzymania materiału z Rosji lub drogą przez Rosję". Uprzedzono go też, że część brytyjskiej opinii sceptycznie odnosi się do materiałowej pomocy dla Polski, wyrażając obawę, iż ta ostatnia może nie wytrzymać niemieckiego uderzenia, a wtedy dostarczony jej sprzęt przepadnie ${ }^{41}$.

Misja płk. Koca nad Tamizę udała się niewiele później, opuszczając Warszawę koleją 13 czerwca. Właściwe jej prace zainaugurowane zostały dzień po przybyciu do celu podróży, 15 czerwca, spotkaniem z Johnem Simonem, a następnie posiedzeniem w brytyjskim Ministerstwie Skarbu, w którego trakcie delegacji gospodarzy przewod-

34 IPMS, A.I. 4.1.14, pismo L. 2057/Tj./39 gen. Litwinowicza do gen. Rayskiego z $10 \mathrm{VI}$ 1939 r. i in. dok. Instrukcja przygotowywana była w wyraźnym pośpiechu. Swiadczy o tym np. fakt, że choć w dokumencie mowa była o „przypuszczalnym podziale 800 mil. zł. kredytu angielskiego", to umieszczone bezpośrednio po tej frazie zestawienie działów, które miały partycypować w zawartych transakcjach, podsumowane zostało kwotą $881 \mathrm{mln} \mathrm{zl}$.

41) IPMS, A.I. 4.1.15, niesygnowana [data naniesiona ręką gen. Malinowskiego] „Notatka do odprawy komisji, jadących do Londynu i Paryża w sprawie wykorzystania kredytów materialowych" z 10 VI 1939 r.

41 IPMS, Lot. A.V. 1.40i I, notatki gen. Rayskiego z okresu 11 VI - 13 VI 1939 r.; odręczny list Rayskiego do II wiceministra spraw wojskowych [gen. Litwinowicza] z 13 VI 1939 r.; A.I. 4.1.25, pismo L. 195/39 ppłk. Kwiecińskiego do gen. Malinowskiego [?] z 14 VI 1939 r. 
niczył S.D. Waley ${ }^{\prime 2}$. Przedstawione przez stronę polską oczekiwania, nadal wyrażające się łącznie sumą 60,5-66,5 mln funtów, zrobiły złe wrażenie nawet na tych spośród przedstawicieli Londynu, którzy rozumieli istotę przedstawionych potrzeb ${ }^{+3}$. Na drugim posiedzeniu, 19 czerwca, płk Koc wysokość najpilniejszych polskich potrzeb gotówkowych określił już tylko na $600 \mathrm{mln} \mathrm{zł}$, tj. około $24 \mathrm{mln}$ funtów, postulując, by możliwie natychmiast wypłacona została nie mniej niż połowa tej sumy. Wysokość kredytu materiałowego oscylować miałaby na poziomie około $30 \mathrm{mln}$ funtów. I to jednak uznane zostało za zbyt wiele: nawet w zasadniczo przychylnym wobec Polaków Foreign Office myślano raczej o $15 \mathrm{mln}$ funtów. Co gorsza, nierealistyczna wysokość polskich żądań niebawem została wykorzystana przez konsekwentnie przeciwnego koncesjom na rzecz Warszawy kanclerza skarbu, który z „ogromnej i niepokojącej" kwoty 60 mln uczynił straszak, 21 czerwca na posiedzeniu Gabinetu epatując nim członków tego gremium. Stanowisko lorda Halifaxa, który próbował dowodzić potrzeby uznania kredytów dla niektórych państw za konieczność o charakterze polityczno-wojskowym, a nie zagadnienie rozpatrywane $z$ punktu widzenia komercyjnego, nie spotkało się z wyraźniejszym poparciem. W tej sytuacji „plac boju" pozostał w rękach Simona, zaś ministra spraw zagranicznych upoważniono jedynie do przedstawienia wysokości i adresatów politycznych kredytów, które miałyby być udzielone ponad ustalony wcześniej limit $10 \mathrm{mln}$ funtów ${ }^{\text {t4 }}$.

Skuteczność polskiej taktyki rozpoczęcia negocjacji z bardzo wysokiego pozio$\mathrm{mu}$, by po ewentualnych ustępstwach uzyskać kwotę mniejszą, ale wciąż znaczącą,

12 IPMS, A.12.53.24, telegram szyfrowy Nr 147 Becka do Ambasady RP w Londynie z 13 VI 1939 r.; A.11.49.WB.3, odpis telegramu szyfrowego gen. Malinowskiego do ppłk. Kwiecińskiego z 13 VI 1939 r. oraz list Wszelakiego do MSZ z 22 VI 1939 r.; TNA, CAB 104/50, list F.H. Nixona do Arthura Robinsona z Komitetu Obrony Imperialnej z 17 VI 1939 r. i in. dok.; T 169/878, depesza No 195 Kennarda do FO z 12 VI 1939 r., godz. 17.26 i in. dok. (w tym notatka z posiedzenia 15 czerwca oraz nota przedstawiona przez Koca w trakcie tego posiedzenia); A. Koc, op. cit., s. 254n. F.H. Nixon z Export Credits Guarantee Department Ministerstwa Skarbu był jednym z członków delegacji brytyjskiej. Foreign Office reprezentował w jej składzie Frank Ashton-Gwatkin. Jak stwierdził bowiem Halifax w notatce z 14 czerwca, resort spraw zagranicznych nie mógł pozwolić, by sprawa była rozstrzygnięta - w dodatku błędnie - za jego plecami (TNA, FO 371/23145).

43 Taka była m.in reakcja Gwatkina. Jeszcze 13 czerwca w memorandum dla Sargenta wyraził on swój krytycyzm wobec stanowiska Treasury i życzliwość względem polskich postulatów. 20 czerwca zaś komentował: „nie mogę uwierzyć, że nawet oni [Polacy] spodziewają się, iż dostarczymy tak wielką sumę" (TNA, FO 371/23145). Wedle niedatowanej notatki "Request of Polish Government for Credits (as communicated orally to the Export Credits Guarantee Department)" polskie postulaty obejmowały $18,5-24,5 \mathrm{mln}$ funtów na potrzeby przemysłowe (w tym $12-18 \mathrm{mln}$ na zakupy surowców), $18 \mathrm{mln}$ funtów na "materiał obronny" (z tego $15 \mathrm{mln}$ funtów na zakupy amunicji) oraz $24 \mathrm{mln}$ funtów w gotówce (z tego $12 \mathrm{mln}$ funtów od razu, kolejne $12 \mathrm{mln}$ po roku) - ibidem.

"I Ibidem, "Additional Statement made by Colonel Koc [...] at a meeting at the Treasury on Monday, June 19th, 1939"; CAB 23/100/1, „Conclusions of a Meeting of the Cabinet held [...] on Wednesday, 21 st June, 1939...”; IPMS, A.I. 4.1.28, „Notatka służbowa w sprawie rozmów o kredyt angielski" gen. Malinowskiego z 25 VI 1939 r.; A. Prazmowska, op. cit., s. 109. 
okazała się więc problematyczna. Co gorsza, przyjąwszy maksymalistyczne stanowisko, nie określono, jak się zdaje, minimalnego poziomu potrzeb. Z braku takiej "ostatniej linii oporu" prowadzone przez polską delegację pertraktacje pozbawione były punktu odniesienia, przekształcając się $\mathrm{w}$ pozbawioną finezji próbę uzyskania od brytyjskiego partnera "ile się da". Ostatecznie zaś - tu uprzedzimy bieg wypadków - zostały zerwane przez władze z Warszawy, które subiektywnie i arbitralnie uznały, że owo „ile się da” okazało się kwotą zbyt niską ${ }^{45}$.

Te decyzje w ostatniej dekadzie czerwca 1939 roku wciąż jednak stanowiły kwestię trudnej do przewidzenia przyszłości. Na razie polscy negocjatorzy starali się racjonalizować swe żądania. „Dyr. Potocki sądzi, że da się może uzyskać 10 milionów w gotówce, resztę w towarach, tak że ogólna suma wyniesie circa 20 milionów funtów" - zanotował wiceminister Szembek 28 czerwca po rozmowie z Józefem Potockim, któremu świeże wieści z Londynu dostarczył wchodzący w skład polskiej delegacji Wiesław Domaniewski ${ }^{46}$.

Problemy z kredytową materią mieli jednak także Brytyjczycy: spór reprezentujących w tym przypadku przeciwne poglądy Foreign Office oraz Treasury i Board of Trade zdawał się w miarę upływu czasu raczej tężeć, niż wygasać. Sam resort spraw zagranicznych zdawał sobie sprawę $\mathbf{z}$ tego, że „cokolwiek możemy zrobić dla Polski, będzie znacznie poniżej ich nadziei, a nawet ich potrzeb”, jednocześnie jednak poszukiwał realnych możliwości wyjścia naprzeciw postulatom delegatów $\mathbf{z}$ Warszawy. Jednym $z$ rozpatrywanych rozwiązań stała się propozycja byłego podsekretarza stanu resortu, Roberta Vansittarta, który w datowanym 16 czerwca memorandum zaproponował Halifaxowi wykonanie na rzecz Polaków jakiegoś gestu o psychologicznym znaczeniu, np. podarowania im pewnej partii samolotów. Krok taki miałby powściągnąć niezadowolenie zawiedzionej brakiem wyników rozmów kredytowych Warszawy, a zarazem stanowić sygnał dla Niemców, dowodząc brytyjskiej determinacji. „Potrzebujemy wywrzeć dramatyczne wrażenie, jeśli chcemy uniknąć wojny w ciągu miesiąca lub dwóch" - $\mathrm{z}$ naciskiem argumentował Vansittart ${ }^{4}$.

Przedstawiona sugestia miała zapoczątkować parutygodniowe konsultacje międzyresortowe $\mathrm{w}$ powyższej sprawie. Strona polska jednak, choć z rysujących się po stronie partnerów różnic zdawała sobie sprawę, to o szczegółach toczących się dyskusji wiedziała, jak się wydaje, niewiele. Stan jej wiedzy nieźle chyba ilustrowała in-

${ }_{45}$ Podane przez polskich negocjatorów ogólne sumy potrzeb finansowych $w$ poszczególnych działach nie znajdowały $w$ dodatku uzasadnienia $w$ załączonych do nich zestawieniach szczegółowych. $Z$ analiz Board of Trade wynikło m.in., że choć Polacy deklarują zamiar przeznaczenia 18 $24 \mathrm{mln}$ funtów na zakupy surowców, to surowce z przedłożonej specyfikacji warte są łącznie tylko ok. 8,7 mln funtów (TNA, FO 371/23145, memorandum „Poland: requests and reply” Gwatkina z 4 VII 1939 r.).

${ }^{4 h}$ J. Szembek, op. cit., s. 645.

4; TNA, T 160/880, list niezidentyfikowanego urzędnika FO do S.D. Waleya z 23 VI 1939 r.; FO 371/23145, memorandum Vansittarta dla Halifaxa z 16 VI 1939 r. i in. dok. W Niemczech rzeczywiście uważnie obserwowano podjęte przez Polaków rozmowy w sprawie kredytu. Zob. np.: TNA, GFM 33/783, gdzie znaleźć można liczne dokumenty na ten temat. 
formacja zapisana przez gen. Malinowskiego: „słyszano [...] rozmowę min. Halifaxa z Chamberlainem, że "Polacy nie dostaną tyle, ile żądają, ale musimy im dać więcej niż innym, na to musimy być przygotowani «" +8.

Tymczasem gospodarze negocjacji kredytowych wyjścia z rysującego się, także po ich własnej stronie, impasu próbowali szukać przez wprowadzanie rozwiązań o charakterze systemowym. 21 czerwca zainaugurował obrady Allied Demands Sub-Committee - powstały z inicjatywy Ministerstwa Skarbu dla koordynacji napływających z państw sojuszniczych wniosków o dostawy uzbrojenia. Polskie potrzeby staty się jedną z pierwszych rozpatrywanych przez to gremium zagadnień. Uczestnicy spotkania rozważali m.in. możliwość obciążenia większością dostaw dla polskiej armii lądowej Francuzów, sugerując, że niejako w zamian strona brytyjska mogłaby na większą skalę partycypować w zbrojeniach lotniczych partnera znad Wisły ${ }^{49}$.

Analiza dokumentów przedłożonych podkomitetowi przez ministerstwa spraw zagranicznych i skarbu, a także resorty wojskowe (wojny, lotnictwa oraz Admiralicję) doprowadziła do przyjęcia, że bez poważniejszego uszczerbku dla własnych potrzeb Polsce można by przekazać:

- dostawy materiału uzbrojenia o wartości 1875000 funtów (w tym 100 samolotów Fairey Battle i 6 samolotów myśliwskich Hawker Hurricane wartych łącznie 1418000 funtów);

- materiały surowcowe ze Zjednoczonego Królestwa o wartości miliona funtów,

- inne materiały zwykle gwarantowane przez Export Credit Guarantee Department o wartości miliona funtów,

- dostawy przemysłowe (głównie maszyny i urządzenia) o wartości 3500000 funtów,

- materiały surowcowe $\mathrm{z}$ Imperium Brytyjskiego ( $\mathrm{z}$ wyjątkiem Kanady) o wartości 5000000 funtów,

- kredyt gotówkowy w wysokości 5000000 funtów.

Finalna rekomendacja dotyczyła jednak tylko przyznania Polsce kwot z czterech pierwszych wymienionych pozycji, których łączną wartość zaokrąglono do 7,5 mln funtów. Przedstawiciele Foreign Office wyrazili wobec tego swoiste votum separatum, wyrażając opinię, że ogólna wartość finansowego wsparcia dla Polski wynieść winna 15 mln funtów, stąd suma proponowana przez Podkomitet powinna być podwojona - przez zwiększenie wielkości kredytu gotówkowego lub dostaw surowców ${ }^{50}$.

44 IPMS, A.I. 4.1.28, „Notatka służbowa w sprawie rozmów o kredyt angielski” gen. Malinowskiego z 25 VI 1939 r.

14 Francuzi w tym czasie mieli podobne zamysly, a powstanie Podkomitetu poprzedziły sugestie Paryża, by oba mocarstwa skoordynowały pomoc materiałową dla obecnych i potencjalnych sojuszników.

50 TNA, CAB 16/219, „Minutes of the First Meeting of the Sub-Committee held [...] on Wednesday, 21 st June, 1939..., A.D. 1st Meeting oraz memorandum „Export credits for Turkey and Poland", A.D. 12 z 28 VI 1939 r. W ostatniej dekadzie czerwca wspomniany Podkomitet do spraw pomocy finansowej i materiałowej dla Turcji oraz Polski powracał jeszcze 26 i 27 czerwca. 
Ostateczne decyzje należały jednak do Gabinetu. Ten na posiedzeniu 28 czerwca nie potrafił osiągnąć porozumienia w sprawie „politycznych" kredytów, których zestawiona przez Foreign Office suma sięgnęła ostatecznie $51 \mathrm{mln}$ funtów, a po uwzględnieniu zobowiązań długoterminowych $-80 \mathrm{mln}$. Sprawę przekazano więc do rozstrzygnięcia podczas spotkania w węższym kręgu, które miało się odbyć jeszcze tego samego dnia, $z$ udziałem ministrów bezpośrednio zainteresowanych resortów. Jego uczestnicy skupili się na kwestiach najbardziej istotnych - dotyczących Turcji (uznanej za szczególnie ważną przez Zastępców Szefów Sztabów ${ }^{51}$ ) i Polski (której adwokatem stało się Foreign Office). Pod nieobecność Halifaxa zastępujący go urzędnicy ponownie podjęli próbę przeforsowania kredytu gotówkowego dla Polski w wysokości 5 mln funtów, argumentując, że to właśnie Rzeczpospolita stanie się najpewniej pierwszą ofiarą niemieckiego ataku. Skoro zaś wszelkie oznaki słabości Polaków uczynią ten atak bardziej prawdopodobnym, należy wszelkimi środkami wzmacniać ich determinację.

Choć wywody te nie spotkały się z aprobatą pozostałych uczestników spotkania, ostatecznie zgodzili się oni na przedstawioną propozycję. Ustępstwo zostało jednak obwarowane warunkami: zaproszeniem Francuzów do udziału w pomocy finansowej, zaakceptowaniem przez stronę polską warunków wykorzystania dostarczanych jej sum (samych warunków nie sprecyzowano), wreszcie - na wniosek przewodniczącego Board of Trade - podjęciem przez Polaków korzystnych dla Brytyjczyków decyzji w sprawie porozumienia węglowego, które Warszawa jednostronnie wypowiedziała kilka miesięcy przed upływem terminu ${ }^{52}$.

Tak sformułowana oferta, którą nawet przeciwnicy argumentacji Foreign Office określili jako mającą "raczej naturę pozoru niż poważnego wkładu w polskie finansowe dylematy", nie mogła być rzecz jasna przyjęta przez reprezentujących Warszawę negocjatorów. $\mathrm{Z}$ drugiej strony przedstawiciele Treasury próbowali w następnych dniach wycofać się nawet $\mathrm{z}$ tak symbolicznych ustępstw, co z pasją komentowano w Foreign Office. Spotkanie z 28 czerwca nie przyniosło więc decydujących rozstrzy-

${ }^{51}$ W przypadku Polski i Rumunii stanowisko Zastępców Szefów Sztabów było jasne. Jak stwierdzili, w pełni uznając znaczenie obu tych państw dla budowy długiego i solidnego frontu wschodniego, nie mogą rekomendować w ich przypadku żadnych znaczących transferów uzbrojenia, gdyż sądzą, że „broń ta niemal na pewno ostatecznie wpadłaby w ręce niemieckie” (TNA, CAB $16 / 219$, "Relative strategic importance of countries requiring arms from the United Kingdom", D.C.O.S. 108 z 24 VI 1939 r.). Dalsze informacje na temat brytyjskiej hierarchii ważności państw odbiorców dostaw zbrojeniowych i stopniowego awansu Polski na najwyższą w jej ramach pozycję: G. Stone, The British Government and the Sale of Arm to the Lesser European Powers, 1936-1939, [w:] Power and Stability. British Foreign Policy, 1865-1965, ed. by E. Goldstein, B.J.C. McKercher, London-Portland 2005, s. 235nn.

52 TNA, CAB 23/100/2, "Conclusions of a Meeting of the Cabinet, held [...] on Wednesday, 28th June, 1939...”; FO 371/23145, notatka Johna Monro Troutbecka z FO „Polish currency loan” z 29 VI 1939 r. Komentujący bez entuzjazmu ustalenia z 28 czerwca Sargent stwierdzał, że oprócz 5 mln funtów kredytu gotówkowego Polska ma uzyskać na podstawie nowego Export Credit Bill kolejne $10 \mathrm{mln}$ funtów. Ogólna suma przyznana Warszawie sięgać więc miałaby $15 \mathrm{mln}$ funtów (TNA, FO 371/23145, minuta Sargenta na akcie C 9290/1110/55 z 29 VI 1939 r.). 
gnięć, a jedynie zapoczątkowało kolejną fazę rozmów z polską delegacją i towarzyszących im, nierzadko ostrych, wewnątrzbrytyjskich dyskusji ${ }^{53}$.

Odnotować jednak trzeba jeden przynajmniej istotny efekt poczynionych uzgodnień. Stało się nim odblokowanie drepczących dotychczas w miejscu pertraktacji o dostawy materiałowe. Misja gen. Rayskiego już bowiem w pierwszym tygodniu pobytu w Londynie przedstawiła przywiezione tam listy planowanych zakupów - i dalej posunąć się nie zdołała. Strona brytyjska, oficjalnie i nieoficjalnie demonstrując życzliwość, wyraźnie czekała na uzgodnienia w sprawach finansowych. Merytoryczne rozmowy zastępowano serią kurtuazyjnych wizyt u przedstawicieli władz (w tym ministra lotnictwa Howarda Kingsleya Wooda) oraz w wytwórniach i jednostkach lotniczych ${ }^{54}$.

Tę wyczekującą postawę gospodarze porzucili dopiero tuż przed końcem miesiąca. Wtedy to, po południu 30 czerwca, w Ministerstwie Lotnictwa odbyła się konferencja, w której trakcie Brytyjczycy - jak relacjonował to ppłk Kwieciński - „puścili nieco farby". Gościom znad Wisły zaproponowano dostawę 100 samolotów Fairey Battle oraz 14 myśliwców typu Hawker Hurricane. Po dyskusji polska delegacja wyraziła zgodę na propozycję. W trakcie dalszej wymiany zdań ustalono, że wspomniane wyżej maszyny zostaną dostarczone natychmiast. Wedle oświadczenia gen. Rayskiego samoloty Battle $\mathrm{w}$ Polsce miałyby być wykorzystane do wyposażenia eskadr o operacyjnym składzie po 10 maszyn oraz jednej eskadry szkolnej użytkującej maszyny wyposażone w podwójne sterowanie. Pozostałe 40 Battli stanowiłoby rezerwę, uzupełnioną w razie wojny przez samoloty szkolne. Zakup miałby obejmować także 50 zapasowych silników Rolls-Royce Merlin III. Potrzeba stworzenia tak dużej rezerwy (zdwojonej w stosunku do norm brytyjskich) została w tym przypadku uzasadniona niemożnością wytwarzania tych silników w Polsce oraz brakiem zarówno przeznaczonych dla nich części zamiennych, jak i możliwości uzupełniania ich stanu podczas wojny. $Z$ kolei w myśliwce Hurricane nad Wisłą uzbrojony miał zostać jeden złożony z 10 samolotów dywizjon, zaś pozostałe cztery maszyny zamierzano zatrzymać $w$ rezerwie.

Przekazywane Polakom samoloty miały być w pełni uzbrojone i wyposażone. Brytyjczycy zwrócili uwagę na fakt, że nie posiadają praw do sprzedaży za granicę wykonanych na licencji amerykańskiego Colta karabinów maszynowych Browning, które znalazły się w obu typach oferowanych Polakom samolotów. Uzgodniono jednak, że dla oszczędności czasu broń ta dostarczona zostanie z zapasów Ministerstwa

53 TNA, FO 371/23145, list Waleya do Troutbecka z 29 VI 1939 r. z załączonym projektem komunikatu dla Koca i in. dok. - w tym komentarze Troutbecka, Sargenta i Cadogana z 30 czerwca. Okazało się m.in., że brytyjska pomoc finansowa ma być niższa, niż jeszcze dzień wcześniej zakładano w Foreign Office, sprowadzając się do gwarancji kredytów eksportowych w wysokości $8 \mathrm{mln}$ funtów. Wszelką inną pomoc Treasury uzależniało od partycypacji Francuzów.

is IPMS, Lot. A.V. 1.40i I, kopia notatki służbowej ppłk. Makowskiego dla Dowódcy Lotnictwa z 21 VI 1939 r.; A.I. 4.1.26, kopia pisma gen. Rayskiego do gen. Litwinowicza z [23] VI 1939 r.; A.I. 4.1.28, „Notatka służbowa w sprawie rozmów o kredyt angielski” gen. Malinowskiego z 25 VI $1939 \mathrm{r}$. 
Lotnictwa, strona polska pokryje zaś ewentualne koszty związane z rozszerzeniem licencji. Gospodarze zastrzegli także, iż przekazane Polakom samoloty Battle nie będą posiadały zasobników na małe bomby, stąd niemożliwe będzie użycie w nich takich bomb oraz bomb zapalających. Generał Rayski przyjął to do wiadomości.

W toku dalszej dyskusji uzgodniono kolejno także inne szczegóły wyposażenia maszyn mających stanowić przedmiot dostawy oraz materiałów niezbędnych dla personelu obsługi naziemnej, jak rozruszniki elektryczne, narzędzia, wyposażenie warsztatów naprawczych, wózki do bomb, części zamienne, instrukcje użytkowania i naprawy itp. Za podstawę, dla uproszczenia pertraktacji, przyjęto tu normy brytyjskie, tj. dotację materiału na 12 miesięcy pokoju i 3 miesiące wojny.

Ekspedycja samolotów przewidziana została w transzach po 25 maszyn - drogą morską do Gdyni, gdzie sprzęt powinien docierać w skrzyniach, po uprzednim zastąpieniu brytyjskich znaków przynależności państwowej znakami polskimi. Samoloty ostatecznie złożone w całość miały być w Warszawie. Strona polska wnioskowała, by ta ostatnia operacja odbyła się pod nadzorem brytyjskich mechaników, skierowanych nad Wisłę przez producentów sprzętu. Ustalone priorytety dostaw przewidywały ich realizację w następującej kolejności:

1) bomby i amunicja;

2) 14 samolotów myśliwskich Hawker Hurricane wraz $z$ pełnym wyposażeniem i częściami zamiennymi; 11 samolotów Fairey Battle oraz odpowiednia dotacja wyposażenia i części;

3) partie po 25 samolotów Battle $z$ odpowiednią proporcją wyposażenia i części, aż do wyczerpania całości dostawy.

Przyjęty porządek miał zapewnić możliwość operacyjnego użycia dostarczonych do Polski samolotów, nawet $w$ razie gdyby całość transportów nie zdołała dotrzeć do miejsca przeznaczenia.

Polscy delegaci próbowali też uzyskać dostawę 6 pływakowych wodnosamolotów torpedowo-bombowych Fairey Swordfish, bez silników, ale z pełnym kompletem części zamiennych na 12 miesięcy pokoju i 3 miesiące wojny, a także 25 torped lotniczych i 5 głowic ćwiczebnych. Ostatecznie jednak 3 lipca udzielono im odpowiedzi odmownej. Sprzęt ten nie mógł zostać dostarczony - ani z zapasów Ministerstwa Lotnictwa lub Admiralicji, ani z bieżącej produkcji ${ }^{55}$.

Choć polscy uczestnicy konferencji po jej zakończeniu solidarnie demonstrowali rozczarowanie, to jednak $w$ komentarzach nieco inaczej rozkładali akcenty. „Ilość i jakość samolotów myśliwskich nie odpowiada zupełnie naszym żądaniom. Sądzę, że moja zamierzona interwencja w tej sprawie nie zmieni stanowiska angielskiego" stwierdzał gen. Rayski. „Lotnictwo myśliwskie. Tu sprawa przedstawia się dość źle. Anglicy chcą nam dać obecnie tylko 14 samolotów typu "Hurricane " - donosił do Warszawy ppłk Kwieciński. Zaraz jednak rzecz racjonalizował: „Ta mała cyfra wynika zdaniem moim z tego, że Anglicy sami są w trakcie przezbrajania swych eskadr, 
a z drugiej strony zapotrzebowanie na samoloty myśliwskie jest bardzo duże również ze strony szeregu innych państw. [...] Fakt, że [...] choć trochę chcą nam dać, jest raczej dobrym znakiem, oznacza bowiem, [...] że [...] liczą się z tym, iż w nieco dalszej przyszłości będą musieli nam dać więcej tego sprzętu, inaczej bowiem nie rozumiałbym dania nam tych 14 sztuk, które uważać należy tylko jako początek z przeznaczeniem dla celów treningowych [...]". Polski attaché zwracał przy tym uwagę na istotną techniczną trudność związaną z realizacją dostawy. Otóż, jak się okazało, wielkość skrzyń transportowych samolotów Battle była zbyt duża, by zmieściły się one pod mostami kolejowymi w trakcie przewozu z Gdyni do Warszawy. Podpułkownik Kwieciński, za problematyczną uznając alternatywę w postaci przeprowadzenia montażu samolotów w Gdyni, prosił przełożonych o rozważenie innych możliwych rozwiązań, np. wykorzystania transportu samochodowego ${ }^{56}$.

W następnych dniach potwierdziły się zarówno przypuszczenia Rayskiego (co do bezskuteczności zamierzonej interwencji), jak i Kwiecińskiego (dotyczące powodów ograniczenia dostawy myśliwców do tak niewielkiej ich partii ${ }^{57}$. Oficerowie polskiej misji, zmuszeni pogodzić się z tym, że przynajmniej w najbliższym czasie samolotów myśliwskich otrzymają niewiele, zaczęli się zastanawiać nad zaletami i mankamentami zaoferowanego im sprzętu. Jak wiadomo, pierwotne założenia Dowództwa Lotnictwa przewidywały nabycie w Wielkiej Brytanii najnowocześniejszych z dostępnych tam samolotów myśliwskich, tj. Supermarine Spitfire. W sytuacji, w której przedmiotem dostawy stać się miały nieco mniej technicznie zaawansowane maszyny typu Hurricane, polskie reakcje okazały się zróżnicowane. Podpułkownik Kwieciński, który jeszcze 1 lipca w dostawie hurricanów widział niebezpieczeństwo (gdyż „i w przyszłości Anglicy będą nam chcieli dostarczyć ten typ samolotu”, tymczasem "Spit-Fire" [...] jest lepszy od "Hurricana", a konstrukcją swą bardziej odpowiada naszym konstrukcjom krajowym”), teraz wyrażał opinię, że w sprawie tej „najmniejszym nieszczęściem jest to, że dostajemy ten typ, a nie Spitfire’y". Równocześnie przekazywał do Warszawy informację, że misja gen. Rayskiego podjęła starania w celu uzyskania choćby jednego samolotu Spitfire dla celów doświadczalnych, „ponieważ [...] nadaje się ewentualnie znacznie lepiej do budowy u nas w kraju", oraz jedne-

56 IPMS, Lot. A.I. 2.15, kopia pisma L. $203 / 39$ ppłk. Kwiecińskiego z 1 VII 1939 r.; Lot. A.V. I.40i I, list gen. Rayskiego do gen. Litwonowicza z 1 VII 1939 r. Zawód polskich delegatów musiał być tym większy, że jak wiemy, dostawa 100 samolotów Fairey Battle została wstępnie uzgodniona już kilka tygodni wcześniej, nie stanowiła więc żadnej nowej oferty. W późniejszych o kilka dni komentarzach ppłk Kwieciński podkreślał także znaczenie opinii publicznej, wobec której „Rząd nie chce się spotkać z zarzutem, że naraża życie własnych obywateli, oddając sprzęt innym państwom”. „W kraju o takiej mentalności jak Anglja sprawa ta odgrywa decydującą rolę”, dodawał attaché tytułem wyjaśnienia (ibidem, pismo L. 205/39 ppłk. Kwiecińskiego do gen. Malinowskiego z 4 VII 1939 r.).

57 Próbę uzyskania zgody na sprzedaż większej liczby myśliwców gen. Rayski podjął 4 lipca, w trakcie przeprowadzonej na jego wniosek rozmowy z Newallem. Przy okazji prosił też o dostawę unowocześnionej wersji samolotu Hurricane i egzemplarza myśliwca Spitfire (TNA, AIR 8/260, notatka mjr. Boyle’a z 4 VIII 1939 r.). 
go myśliwca Hurricane w wersji zmodyfikowanej (wyposażonej w metalowe, a nie płócienne pokrycie skrzydeł), która dopiero została skierowana do produkcji. Z kolei bardziej zainteresowany aspektami techniczno-przemysłowymi ppłk Makowski oceniał: „Hurricane - maszyna $z$ dużym doświadczeniem, łatwiejsza w obsłudze, wygodniejsza dla mechaników. Jeśli chodzi o natychmiastowy użytek, to poza mniejszą o $30 \mathrm{~km}$ szybkością jest lepsza. Nie będziemy z niej mieli dużo korzyści, jeżeli chodzi o wykorzystanie konstrukcyjne, dla naszych fabryk. Pozatem trzeba przewidzieć więcej na remonty półfabrykatów. [...] Spitfire - konstrukcja [...] moderna. [...] Byłoby bardzo pożyteczne wykorzystać te doświadczenie przy budowie naszych pościgówek [tj. samolotów pościgowych - dop. W.M.]. Osiągnięcie większej szybkości było możliwe, ścieśniając wymiary kadłuba i skrzydeł, z tego względu dostęp wszędzie jest znacznie gorszy i obsługa delikatniejsza. Pod względem pilotażu obie maszyny uważane są za bardzo łatwe, spodziewam się za parę dni mieć informacje od naszych pilotów"58.

Brytyjskie czynniki wojskowe, świadome sprawionego przybyszom z Warszawy zawodu, nadal w miarę możności starały się życzliwie traktować ich postulaty. Wyraziło się to m.in. w postaci udzielonej 7 lipca przez Ministerstwo Lotnictwa zgody na przygotowywanie przeznaczonego dla Polski sprzętu do ekspedycji, mimo braku będącego wciąż przedmiotem negocjacji porozumienia finansowego. Strona polska spodziewała się, że pierwszy transport wyruszy do Gdyni z końcem miesiąca. Na razie nad Wisłę wysyłane były stopniowo opisy techniczne oraz instrukcje. W Warszawie przygotowywano się do podjęcia prac nad ich tłumaczeniem - choć na większą skalę podjęto je chyba z pewnym opóźnieniem - być może dopiero w końcu sierpnia ${ }^{59}$.

W połowie lipca wciąż niejasna była kwestia transportu samolotów na terytorium Polski. Mimo upływu dwóch tygodni i rozpoczęcia pakowania pierwszej partii samolotów do Londynu wciąż nie dotarły informacje, w jaki sposób mają one zostać przetransportowane $z$ Gdyni do Warszawy ${ }^{60}$. Problem stanowiły też dalekie od finalizacji rokowania finansowe. Uzgodnione przez Brytyjczyków w końcu czerw-

${ }^{5 k}$ IPMS, pismo L. 205/39 ppłk. Kwiecińskiego z 4 VII 1939 r.; kopia pisma ppłk. Makowskiego do Dowództwa Lotnictwa z 4 VII 1939 r.

${ }^{59}$ IPMS, A.I. 4.1.41, pismo L. 225/39 ppłk. Kwiecińskiego do gen. Malinowskiego z 14 VII 1939 r. i in. dok. Informację o otrzymanym 29 sierpnia „wraz z z całą ekipą" (która właśnie wróciła z Wielkiej Brytanii) przydziale do Wydziału Użytkowego ITL „dla współpracy przy opracowywaniu instrukcji użytkowania samolotów Battle i Hurricane" wspomniał w złożonej w styczniu 1945 r. relacji były kierownik referatu płatowców w Wydziale Inspekcji Technicznej Dowództwa Lotnictwa MSWojsk. mjr (w roku 1939 - kapitan) Mikołaj Kaczanowski (IPMS, Lot. A.I. 3.1e, „Zestawienie rozdziałów i punktów do sprawozdania o organizacji i działalności jednostek tyłowych lotnictwa (szkół, baz, zakładów i innych formacyj) w czasie kampanii wrześniowej w Polsce w 1939 r.").

61) Decyzję w sprawie rozpoczęcia pakowania samolotów Ministerstwo Lotnictwa wydało 15 lipca. Nieco wcześniej Board of Trade uznało, że pierwsza ich partia zostanie wysłana do Polski między 1 a 8 sierpnia, a druga i trzecia odpowiednio dwa i cztery tygodnie później (TNA, AIR $8 / 260$, „Resume of situation relating to supply aircraft and equipment to Poland" Dyrekcji Planowania Ministerstwa Lotnictwa z 17 VII 1939 r.). 
ca stanowisko w tej sprawie przekazane zostało stronie polskiej 1 lipca. Ta jednak, skonsternowana jego treścią, nadal starała się uzyskać możliwie najkorzystniejsze dla siebie rozwiązania ${ }^{61}$. Rozbieżność formułowanych w londyńskich gabinetach opinii, Polakom wciąż znana tylko w ogólnych zarysach, znalazła odzwierciedlenie także na płaszczyźnie materiałowej. Popierani przez władze skarbowe producenci sprzętu lotniczego dążyli do narzucenia nabywcy możliwie wysokich, eksportowych cen, podczas gdy misja gen. Rayskiego przy wsparciu Foreign Office i Ministerstwa Lotnictwa obstawała przy cenach na poziomie ustalonym dla brytyjskich sił zbrojnych i produkcji wielkoseryjnej. Przedstawiciele Warszawy chcieli też formalnym nabywcą sprzętu uczynić władze brytyjskie, które następnie przekazałyby uzyskany materiał właściwemu odbiorcy. Takie rozwiązanie, stosowane uprzednio $w$ podobnych wypadkach we Francji, zapewnić miało nie tylko niższe ceny, ale i sprawne przeprowadzenie samej procedury odbioru, skutkując sporą oszczędnością czasu ${ }^{62}$.

Strona polska w ogóle natomiast zapewne nie zdawała sobie sprawy z tego, że nad Tamizą toczy się właśnie dyskusja na temat ewentualnego przekazania jej samolotów Battle jako daru - dowodu zainteresowania wzmocnieniem zdolności obronnych partnera znad Wisły. Zainicjował ją, przypomnijmy, Vasittart, jeszcze w połowie czerwca. Już po trzech dniach, 19 czerwca, Halifax przekazał propozycję na biurko ministra lotnictwa - Kinsgleya Wooda - dla informacji i ewentualnego poparcia jej u kanclerza skarbu. To wtedy właśnie, w odpowiedzi, adresat wspomnianej korespondencji wskazał setkę obiecanych już Polakom samolotów Battle jako ewentualny przedmiot darowizny, samemu uchylając się zresztą od zajęcia stanowiska i jako właściwych adresatów wskazując właśnie Simona lub też - alternatywnie - Gabinet jako całość $\mathbf{c}^{63}$.

Istotnie, $\mathrm{w}$ następnych dniach sprawa została przedłożona kanclerzowi skarbu. Jak można się było spodziewać, zgłosił on szereg wątpliwości, które podważały sens lub praktyczną możliwość przeprowadzenia rozważanej przez Foreign Office operacji. Niektóre z przedstawionych argumentów miały charakter poniekąd demagogiczny. Rząd polski - sugerował Simon - z racji narodowej dumy może nie życzyć sobie takiej darowizny, preferując raczej kredyt z odroczonym na trzy-cztery lata terminem

${ }^{61}$ IPMS, A.I. 4.1.30, thumaczenie na język polski brytyjskiego aide-mémoire z 1 VII 1939 r. Wersja oryginalna oraz dyskusja nad projektami tego dokumentu: TNA, FO 371/23145 (Foreign Office); T 160/879 (Treasury). Pierwsze polskie reakcje: IPMS, A.11.49.WN.3, list Wszelakiego do dyr. Potockiego [?] z 1 VII 1939 r. i in. dok. Zob. też: J. Mi e r zwa, op. cit., s. 203n.

62 IPMS, A.I. 4.1.41, pismo L. 225/39 ppłk. Kwiecińskiego z 14 VII 1939 r. Problem był dość złożony, faktem jednak pozostaje, że producenci lotniczy istotnie bardzo znacznie zawyżali podawane zagranicznym nabywcom (w tym i Polakom) ceny oferowanego im sprzętu. Tak np. każda maszyna Fairey Battle z pierwszej nabywanej przez Polskę ich transzy została wyceniona przez firmę Fairey na 25000 funtów. Po interwencji oficera łącznikowego Ministerstwa Lotnictwa cena ta uległa drastycznej obniżce - do 10000 funtów (TNA, T 161/1001, niedatowane [wrzesień 1939 r.] i niesygnowane zestawienie "Examples of excessive charges which the firms strenuously sought to impose").

63 TNA, T 160/880, kopia pisma Halifaxa do Kingsleya Wooda z 19 VI 1939 r. oraz kopia listu Kingsleya Wooda do Halifaxa z 22 VI 1939 r. 
płatności. Dar, kontynuował w tymże tonie szef brytyjskich finansów, mógłby zostać uznany przez Polaków, ale i przez Niemców, za gest bogatego państwa względem bankruta, nie zaś jednego $\mathrm{z}$ mocarstw względem innego. Jeśli jednak taki gest nie byłby niemiły Polakom - deklarował Simon - on sam chętnie rozważy ewentualną zgodę $^{\text {t- }}$. Zastanawia się jednak, jak można by podobny krok wytłumaczyć innym zabiegającym o pomoc (tu następowała długa lista państw), nie oferując im podobnej jej formy. Co więcej, przekazując $w$ darze samoloty w czasie pokoju, trudno będzie uniknąć takich darowizn względem aliantów w razie ewentualnej wojny. Wreszcie powracał Simon do myśli, którą już wcześniej formułował - lepszym rozwiązaniem byłoby wprowadzenie wspólnego, brytyjsko-francuskiego programu pomocy dla Polski, w którym Paryż uczestniczyłby na równi z Londynem. $Z$ pewnością zaś warto zaproponować Francuzom udział w takim programie ${ }^{65}$.

W Ministerstwie Finansów podjęto jednak prace nad ewentualnym urzeczywistnieniem darowizny. Prócz kwestii finansowych oraz obaw co do reakcji opinii, której trudno byłoby wyjaśnić, dlaczego równolegle z kolejnym podniesieniem poziomu własnych obciążeń zbrojeniowych przeprowadza się darowiznę sprzętu dla Polski, komplikacją okazały się uregulowania prawne. „Nie możemy po prostu spisać samolotów ze stanu Ministerstwa Lotnictwa i stwierdzić, że jedynym kosztem jest opakowanie i fracht" - zauważał 12 lipca podsekretarz stanu w Ministerstwie Skarbu w korespondencji do Waleya, sugerując, że to Foreign Office powinno przedłożyć parlamentowi wniosek o wydatkowanie 1,5 mln funtów, a następnie spowodować jego uchwalenie ${ }^{66}$.

W takiej sytuacji Halifax tracił z wolna początkowe zainteresowanie realizacją koncepcji. Jak 11 lipca informował Simona, postanowił nie spieszyć się z powiadomieniem o ewentualnej darowiźnie potencjalnych beneficjentów. Spotkawszy tego dnia ambasadora Raczyńskiego, dowiedział się odeń, że przywrócona właśnie nadzieja na przełamanie impasu w negocjacjach finansowych oraz zapowiedzi przyjazdu gen. Ironside’a polepszyły nastroje panujące w Warszawie. „Nic mu przeto nie powiedziałem o darmowych samolotach" - informował nie bez nuty zadowolenia kanclerza skarbu ${ }^{67}$.

Ta wstrzemięźliwość nie musiała jeszcze oznaczać fiaska rozważanej od kilku tygodni inicjatywy, ale tak właśnie się stało. 13 lipca Waley z ulgą umieścił na zacyto-

"4 Powyższa fraza zastąpiła wykreślone bardziej jednoznaczne sformulowanie: „nie odmówi swej zgody”. Jednak i tak skorygowana redakcja budziła obawy urzędników Treasury. „W obecnej krytycznej sytuacji [...] przygotowuje się do zrobienia tego, co Polacy zechcą" - brzmiał umieszczony na marginesie komentarz.

65 TNA, T 160/880, niedatowana [przed 26 VI 1939 r.] notatka (koncept pisma do Halifaxa?) Treasury. Na dokumencie liczne uwagi urzędników Treasury, dotyczące głównie pominiętego przez FO kosztu postulowanej akcji (F. Phillips: „myśliwce, jak rozumiem, są po około 15000 funtów, a bombowce, z wyjątkiem bardzo dużych, około 30000 funtów każdy").

or Ibidem, notatka Bernarda Williama Gilberta dla Waleya z 12 VII 1939 r.

6i Ibidem, list Halifaxa do Simona z 11 VII 1939 r. Krótka relacja E. Raczyńskiego ze wspomnianej rozmowy z Halifaxem: IPMS, A.12.53.24, telegram szyfrowy Nr 127 Raczyńskiego do MSZ z 11 VII 1939 r. 
wanej wyżej notatce Gilberta z dnia poprzedniego dopisek: „Na posiedzeniu Gabinetu [ 12 lipca - dop. W.M.] zadecydowano o porzuceniu tej paskudnej [hideous] idei"68. Oczywiście jednak sama dostawa nadal pozostawała w mocy. Już w pierwszej połowie lipca polskie Ministerstwo Spraw Wojskowych wyraziło zgodę na propozycję gen. Rayskiego, by odbioru jakościowego nabywanego materiału dokonały organy brytyjskie, polskie komisje przeprowadziły zaś tylko odbiór ilościowy. Nad Tamizę skierowano grupę oficerów i podoficerów lotnictwa, którzy po powrocie do kraju mieli zostać instruktorami obsługi i użytkowania zakupionego sprzętu ${ }^{69}$.

U schyłku drugiej dekady lipca zarówno Ministerstwo Finansów, jak i Ministerstwo Lotnictwa informowały stronę polską o gotowości uruchomienia procedur wysyłkowych. Warunkiem jednak miała się stać szybka akceptacja przez Warszawę płatności wynikających z dostawy, wyliczanych po uwzględnieniu kosztów opakowania, ubezpieczenia i frachtu na nie więcej niż 1,15 mln funtów. Jak wyjaśniano, szczegółowe kalkulacje nie były możliwe do sporządzenia w krótkim czasie, zaś negocjacje kredytowe, które dostarczyć miałyby środki na pokrycie należności, wciąż nie zostały sfinalizowane, stąd polska aprobata miałaby zostać dokonana a priori, a sama płatność zrealizowana ze środków przyznanych w ramach przyszłego kredytu.

W podobny sposób dzień później charakteryzował sytuację zastępca Dyrektora Wywiadu Ministerstwa Lotnictwa. Przekazując Dyrekcji Planowania resortu informację o stanie prac nad ekspedycją przeznaczonego dla zagranicznych odbiorców materiału lotniczego, wyjaśniał, że w przypadku Polski wstrzymuje ją brak umowy finansowej $z$ rządem brytyjskim oraz odmowa American Colt Co. udzielenia zgody na przekazanie Polakom (a także Rumunom i Turkom) karabinów maszynowych Browninga. Jednak ogólny postęp sprawy uznany został za „dość dobry”, co miało umożliwiać finalizację załadunku do 8 sierpnia $^{70}$.

64 Zob. też: TNA, T 160/880, przeznaczona dla głównego doradcy ekonomicznego rządu Fredericka Leith-Rossa notatka „Polish loan” podyktowana przez J. Simona po posiedzeniu Gabinetu 12 VII 1939 r. i in. dok. Konkluzje z tego posiedzenia Gabinetu zawierają informacje o dyskusji na temat kredytów dla Polski, brak w nich jednak odniesień do sprawy ewentualnej darowizny (TNA, CAB 23/100/5).

6y IPMS, Lot. A.V. 1.40i I, pismo L. 2274/tj. K.A. II wiceministra spraw wojskowych wz. gen. Maciejowskiego do gen. Rayskiego z [11?] VII 1939 r. i in. dok. (przy czym, jak wynika z adnotacji na odręcznej „Notatce z rozmowy z gen. Rayskim” gen. Malinowskiego z 25 VIII 1939 r., zgodę Szefa SG na powyższą procedurę uzyskano dopiero w tym dniu - IPMS, A.I. 4.1.47). W skład wysłanej do Wielkiej Brytanii grupy weszli: kpt. inż. Mikołaj Kaczanowski (Dowództwo Lotnictwa), kpt. pil. Mieczysław Sulerzycki (2 pułk lotniczy), por. pil. Michał Liniewski (1 pułk lotniczy), ppor. Józef Krasiński (Centrum Wyszkolenia Lotnictwa Nr 1), ppor. Narcyz Krupowicz (5 pułk lotniczy), chor. Józef Szakowski (instruktor płatowcowy ITL), chor. Franciszek Gerlicki (instruktor silnikowy ITL), chor. Wacław Cesarz (instruktor uzbrojenia ITL), chor. Feliks Swiątek (instruktor elektro- i radiotechniczny z l pułku lotniczego), sierż. Stanisław Jakisz (instruktor foto z CWL).

71) TNA, T 160/880, list Waleya do H. Sommerville-Smitha (Export Credits Guarantee Department) z 19 VII 1939 r.; kopia pisma S.54683 A.P. Davidsona do ppłk. Kwiecińskiego z 19 VII 1939 r. wraz z załączonym memorandum Air Ministry i in. dok.; AIR 9/118, notatka bez tytułu zastępcy Dyrektora Wywiadu z 20 VII 1939 r. 
Lista sprzętu, który Ministerstwo Lotnictwa proponowało dostarczyć do Polski $w$ pierwszej partii, po przetłumaczeniu na język polski przedstawiała się, jak następuje:

1. Samolot kompletnie wyposażony niezależnie od niżej wyszczególnionych pozycji:

14 Hurricane

36 Fairey Battle

2. Wyposażenie samolotu

Spadochrony - 60 pilotów, 90 obserwatorów

Podwójne stery - 8 kompletów Fairey Battle

Aparaty fotograficzne - F.24 - 10 sztuk

Zasłony do szkolenia w ślepym pilotażu - 10 sztuk

3. Zapasowe silniki

Merlin III - 32 sztuki

4. Przyziemne wyposażenie dla obsługi i utrzymania samolotu, odpowiednie dla każdego typu samolotu, szczegóły ustalone na konferencji w dniu 30.VI.39 r. dotyczące kompletu narzędzi do silników, śmigieł, K.M., kompletu uchwytów do napraw, wyekwipowania fotograficznego itp.

5. Przyziemne wyposażenie użytku ogólnego

Szczegóły uzgodnione $w$ dniu 30.VI.1939 r. dotyczące skrzynek narzędzi, kluczy, uchwytów, wózków startowych, wyposażenia do prób itp.

6. Zapas wyekwipowania

$\mathrm{Na} 12$ miesięcy pokoju i 3 miesiące wojny. Części zapasowe do platowców i silników, części wyekwipowania samolotu, materiały naprawkowe, glycol, specjalne smary.

7. Uzbrojenie i amunicja

Bomby, komplety z częściami przynależnymi 500 lbs. [funtów] G.P.

$250, \cdots$

40 , "

4860

$20, \mathrm{~F}$

9720

25 zapalające

2160

4 , "

16200

Bomby do szkolenia

4500

Amunicja do K.M

2800000

Ogniwa do taśmy K.M.

1400000

8. Samochody specjalne

Zespół 7 K.W na przyczepce 3

Samochód warsztatowy

Zespół 14 K.W. na przyczepce

Zespól 6 K.V.A. na przyczepce

Radiostacja GP na przyczepce

Ciągniki

Przyczepki cysternowe

7 IPMS, Lot. A.I. 2.15, tekst memorandum Ministerstwa Lotnictwa przetłumaczony na język polski, zał. do pisma L. 251/39 ppłk. Kwiecińskiego do Szefa Sztabu Lotnictwa SG z 23 VII 1939 r. 
Korespondencję Davidsona Kwieciński odebrał z opóźnieniem, w momencie jej wysyłki przebywał bowiem w Warszawie, towarzysząc tam gen. Ironside'owi. Po powrocie, wobec informacji, że ekspedycja transportu z początkiem sierpnia wymaga wynajęcia statku do 24 lipca, po konsultacjach z gen. Rayskim i ambasadorem Raczyńskim wyraził „zasadniczą zgodę” na zawarte w memorandum warunki ${ }^{72}$. Informując o tym 23 lipca gen. Malinowskiego, doniósł mu także o zgodzie Ministerstwa Lotnictwa na przekazanie Polakom jednego egzemplarza samolotu Spitfire z pełnym wyposażeniem wedle standardów brytyjskich, ale zredukowanym do niezbędnego minimum zapasem części zamiennych. Wspomniany resort przychylnie odniósł się też do polskiej prośby o dostawę kompletu zmodyfikowanych skrzydeł samolotu Hurricane (z aluminiowym, a nie płóciennym pokryciem), obiecując bądź sam materiał, bądź szczegółowe rysunki techniczne ${ }^{i 3}$. Uzgodnić też zdołano rychły wyjazd do Polski ekipy brytyjskich specjalistów, którzy mieliby przeprowadzić cykl szkoleń w zakresie obsługi i remontów nowego sprzętu. Jak zauważał ppłk Kwieciński, konieczne stawało się też porozumienie z producentami tego ostatniego $\mathrm{w}$ celu pozyskania specjalistów do nadzoru montażu przysłanych samolotów. Wysłana do Warszawy korespondencja zawierała także informację, że kontrowersja dotycząca karabinów maszynowych Browninga została przez Ministerstwo Lotnictwa „w zasadzie pomyślnie załatwiona". Uzupełniająca wzmianka, że strona polska będzie musiała porozumieć się z Amerykanami w sprawie opłat licencyjnych, skłania do wątpliwości, czy aby „załatwienie” nie polegało po prostu na przerzuceniu kosztów na odbiorcę znad Wisły ${ }^{i 4}$.

Tymczasem w decydującą fazę wkraczały toczone przez delegację pod wodzą płk. Koca negocjacje finansowe. Pełne przedstawienie ich biegu nie wydaje się tu niezbęd$n e, w$ istniejącej literaturze został on zresztą zarysowany wystarczająco klarownie ${ }^{75}$.

i2 Davidson termin możliwego wypłynięcia transportu określił na pierwszy tydzień sierpnia. Podpułkownik Kwieciński w swej korespondencji podał to jako „około 1 sierpnia”, dokonując drobnego "przyspieszającego" retuszu.

73 Zgodę na obie polskie prośby wyraził 12 lipca Air Marshal Newall, zastrzegając, że jeśli, jak sądzi, nie można by przekazać Polakom myśliwca Hurricane z metalowymi skrzydłami ze względu na brak takich maszyn $w$ dyspozycji sił powietrznych, strona polska otrzyma rysunki techniczne (TNA, AIR 8/260, koncept pisma Newalla do zastępcy Szefa Sztabu Lotnictwa).

${ }^{74}$ IPMS, Lot. A.I. 2.15, kopia pisma L. $250 / 39$ ppłk. Kwiecińskiego do gen. Malinowskiego z 23 VII 1939 r. Wywarcie na amerykańskiego licencjodawcę największej możliwej presji przy zaaprobowaniu z góry wszelkich należności i kar proponował jako możliwe rozwiązanie „browningowego" dylematu zastępca Dyrektora Wywiadu w notatce przywołanej w przypisie poprzednim. Kwestia przejęcia przez rząd polski wszelkich wynikających z dostawy browningów dodatkowych opłat licencyjnych została też uwzględniona w memorandum Ministerstwa Lotnictwa.

is Zob. w szczególności: H. Jackiewicz, op. cit., s. 183nn.; A. Koc, op. cit., s. 257; A. Prazmowska, op. cit., s. 120nn.; J. Mierzwa, Negocjacje kredytowe w 1939 r. Przyczynek do przygotowań wojennych Polski, „Studia Historyczne” 2005, t. 48, nr 3-4, s. 355nn.; id em, Pulkownik Adam Koc..., s. 202nn. Obszerną źródłową dokumentację finalnej fazy negocjacji zawiera: E. Kwiat kowski, Dziennik czynności Ministra Skarbu, oprac. J. Ra kowski, „Zeszyty Historyczne” (Paryż) 1991, z. 96, s. 19nn. 
Rozstrzygające decyzje zapadły po stronie polskiej 24-25 lipca. Mimo dramatycznych apeli Koca, który 24 lipca dawał „oficerskie słowo honoru, że transakcja jest dobra i że można ją podpisać”, deklarując zarazem, że w tym przypadku „bierze pełną odpow.[iedzialność] całk.[owitą] fakt.[yczną] i mor.[alną]”, a zarazem „stwierdza dobrą wolę najw. [yższych] ang.[ielskich] czynników tak wojsk.[owych], jak i zagranicznych", w Warszawie nie zechciano odstąpić od warunku zamiany części kredytu gotówkowego na złoto. Ostatecznie więc, krótko po południu 25 lipca dotarła tam informacja, że „sprawa pożyczki finansowej definitywnie upadła";6.

W tej sytuacji tym pilniejsza stawała się finalizacja rozmów na temat kredytu materiałowego, zwłaszcza że 3 sierpnia miało się odbyć ostatnie przed wakacyjną przerwą posiedzenie parlamentu, który rzecz winien był zaaprobowaćc ${ }^{77}$. Odpowiednie prace, w poprzednich tygodniach toczące się poniekąd w cieniu rokowań $w$ sprawie kredytu gotówkowego, były już zaawansowane. 31 lipca członkowie Allied Demands Sub-Commitee zostali poinformowani, że zarówno Ministerstwo Lotnictwa, jak i Admiralicja gotowe są do natychmiastowego podpisania odpowiednich umów, podobne deklaracje składa też Export Credits Guarantee Department, polscy delegaci nie chcą jednak sygnować porozumienia przed ustaleniem kompletnych list materiału nabywanego, dążąc do ustalenia zawczasu, „co mogłoby i co nie mogłoby zostać dostarczone". To zaś $\mathrm{z}$ różnych względów (jak procedury biurokratyczne, nie-

76 IPMS, A.I. 4.1.46, „Telefonogram płka d.[yplomowanego] Koca $z$ Londynu (brulion) 24/VII 1939" zapisany przez gen. Malinowskiego (na pierwszej stronie opatrzona parafą adnotacja: "Odpis przedstawiłem Panu Marszałkowi, 24/VII 1939"); E. Kwiat ko wski, Dziennik czynności..., s. 58nn. (tu też odniesienia do cytowanego telefonogramu); J. Mie rzwa , Pulkownik Adam Koc..., s. 206n. Jedną z najistotniejszych przyczyn zerwania negocjacji stały się względy polityczno-prestiżowe oraz, jak się wydaje, nadmierne oczekiwania wstępne. Charakterystyczna była tu zanotowana przez Kwiatkowskiego wypowiedź Smigłego-Rydza z 24 lipca: „Pan marszałek uważa obecne stanowisko za ostatnie ustępstwa. Dalej nie może pójść. I tak trzeba się zapytać, "gdzie jesteśmy z naszymi nadziejami, gdy mówiliśmy o 60 milionach funtów "' (Dziennik czynności..., s. 58). Podobne stanowisko Becka: ibidem, s. 75. Por.: TNA, FO 371/23146, pismo 190/71/39 C.J. Nortona do Sargenta z 29 VII 1939 r. Strona brytyjska, uznając słuszność pier wotnych zastrzeżeń zgłaszanych przez Polaków, ich ostateczne stanowisko (już po usunięciu lub zlagodzeniu kontrowersyjnych zapisów umowy) kładła na karb ekonomicznej ignorancji części polskich liderów. W procesach decyzyjnych, stwierdzano (bodaj nie bez racji), wiedzę zastępują oni poczuciem narodowej dumy (zob. np.: TNA, FO 371/23146, kopia pisma C 10501/1110.55 Sargenta do Nortona z 29 VII 1939 r. $i$ in. dok). Powyższe kwestie wymagają jednak z pewnością odrębnej, pogłębionej analizy. Merytoryczne przyczyny obstawania warszawskich nadzorców rokowań przy częściowej wypłacie środków $z$ kredytu w złocie, sprowadzające się do pragnienia zasilenia tym złotem Banku Polskiego dla poprawy finansowania krajowej produkcji wojennej, wyjaśnil b. dyrektor Departamentu Obrotu Pieniężnego Ministerstwa Skarbu (następca Domaniewskiego) Stanisław Kirkor w szkicu: Sprawy finansowe Polski w przededniu ostatnie wojny, „Zeszyty Historyczne” (Paryż) 1972, z. 21, s. 50n.

77 Beck, polecając 25 lipca ambasadorowi Raczyńskiemu oświadczenie władzom brytyjskim, że w zaistniałych warunkach „podpisanie układu nie wydaje się celowe”, nakazał mu również wyrażenie wobec partnerów nadziei, ,że rokowania o kredyt materjałowy nie będą nastręczały takich trudności i będą mogły być w niedługim czasie zakończone". W wersji pierwotnej tekstu (następnie wykreślonej) mowa była o niecelowości „dalszych negocjacji”, a nie „podpisania układu” (IPMS, A.12.53.24, telegram szyfrowy $\mathrm{Nr} 188$ ). 
kompletność danych na przedstawianych listach czy kontrowersje terminologiczne) wciąż nie zostało zakończone ${ }^{i 8}$.

Niepowodzeniem zakończyły się też podjęte przez przebywających wciąż w Londynie członków polskiej delegacji tuż po załamaniu się rozmów w sprawie kredytu gotówkowego próby zwiększenia kredytu materiałowego o $2 \mathrm{mln}$ funtów - do poziomu $10 \mathrm{mln}$. Wedle inicjatorów tej akcji miała ona zapewnić środki na pełne sfinansowanie polskich zakupów lotniczych, które ich zdaniem łatwo mogły przekroczyć przyznaną na ich realizację sumę $2 \mathrm{mln}$ funtów, ale nade wszystko stanowić dowód wciąż dobrej współpracy Londynu i Warszawy. Sprawę utrącili jednak pospołu, choć zupełnie od siebie niezależnie Waley oraz Kwiatkowski i Beck. Ten pierwszy uznał, że skoro Polacy prawie na pewno wrócą do stołu rokowań w sprawie kredytu gotówkowego, to zgoda na zwiększenie kredytu materiałowego byłaby błędem. Z kolei polskie MSZ przesłało delegacji dyspozycję, aby „jeżeli w jakikolwiek bądź sposób sprawa podwyższenia kredytu towarowego zahacza się o kredyt finansowy", negocjujący ją Domaniewski odmówił na ten temat rozmów. Na wszelki wypadek stanowisko to Beck przekazał równolegle do Londynu za pośrednictwem Kennarda ${ }^{79}$.

Już więc 30 lipca Domaniewski, informując o otrzymanej „nieoficjalnie” brytyjskiej sugestii, by $w$ razie zamiaru powrotu do negocjacji o kredyt gotówkowy nie starać się o podwyższenie kredytu towarowego, doradzał szybkie podpisanie umowy na warunkach dotychczas proponowanych, argumentując, że za takim rozwiązaniem przemawia „zwłaszcza konieczność natychmiastowego wysłania sprzętu lotniczego, którego nie załadują przed podpisaniem umowy"

Porozumienie $\mathrm{w}$ sprawie kredytu materiałowego zawarto istotnie niebawem, bo już 2 sierpnia. Strona polska uzyskała gwarancje kredytowe na sumę 8163300 funtów. Suma ta miała zostać zużytkowana w związku $z$ dokonanymi w terminie do 30 czerwca 1940 roku w Zjednoczonym Królestwie zakupami materiałów w części lub w całości wytworzonych na jego obszarze i dostarczonymi następnie do Polski na pokładzie brytyjskich statków. Umowa określała finansową stronę procedur zakupów oraz regulowania związanych $\mathrm{z}$ nimi płatności, oprocentowanie kredytu ustalając na $5 \%$ per annum ${ }^{81}$.

is TNA, CAB 16/219, „Minutes of the Third Meeting of the Sub-Committee held [...] on Monday 31 st July 1939..., A.D. 3rd Mtg.; CAB 104/51, pismo H. Sommerville Smitha do ppłk. W. Portera z CID z 28 VII 1939 r. i in. dok. Dążenie do możliwie szybkiego podpisania umowy o kredycie materiałowym miało też zdaniem strony polskiej służyć przerwaniu kampanii prasy niemieckiej, w której wyrażano satysfakcję z pogorszenia stosunków polsko-brytyjskich (IPMS, A.11.49.WB.3, notatka Wszelakiego z rozmowy z Nortonem z 29 VII 1939 r.).

is TNA, FO 371/23146, list Waleya do Sargenta z 28 VII 1939 r.; telegram szyfrowy No 240 Kennarda do FO z 31 VII 1939 r., godz. 22.00 i in. dok.; IPMS, A.11.49.WB.3, niesygnowana i niedatowana notatka MSZ; E. Kwiatkowski, Dziennik czynności..., s. 63, 72n., 84.

n10 IPMS, A.11.49.WB.3, „Szyfr z Londynu” otrzymany w MSZ 30 VII 1939 r. (opublikowany w: E. Kwiatkowski, Dziennik czynności..., s. 58).

"' Teksty umowy, przedstawionej 2 sierpnia parlamentowi przez przewodniczącego Board of Trade Roberta S. Hudsona, or az załączników: IPMS, A.I. 4.1; TNA, CAB 104/47. Krótkie streszczenie techniki realizacji kredytu zawiera niesygnowana i niedatowana notatka na ten temat: IPMS, 
Otwarta więc wreszcie została formalna możliwość przeprowadzania zakupów i kierowania do kraju transportów nabytego materiału. Generał Rayski utyskiwał, że na krótko przed podpisaniem umowy władze brytyjskie skreśliły z przedłożonych im list kilka istotnych pozycji, zastrzegając ponadto, że „i reszta [...] będzie dostarczana tylko w granicach ich możliwości, co [...] jest pojęciem bardzo rozciągliwym". Powyższe problemy nie odnosiły się jednak do materiału lotniczego, którego pierwszy transport, wedle kalkulacji szefa polskiej misji, mógł zostać wyekspediowany już 8 sierpnia. „Następny transport, który już się opakowuje, postaram się wysłać jak najszybciej" - dodawał generał ${ }^{82}$.

Podpułkownik Kwieciński był nastawiony nieco mniej optymistycznie - lub może po prostu był lepiej poinformowany. Meldując o podpisaniu umowy, datę wysłania pierwszego transportu określał na 14 lub 15 sierpnia. Sygnalizował przy okazji trudność, która mogła uniemożliwić szybkie postępy prac: Brytyjczycy nie ustalili jeszcze kwestii technicznych związanych z zawieraniem kontraktów, zaś wielość występujących po ich stronie podmiotów utrudnia poczynienie odpowiednich ustaleń. I te trudności do sprzętu lotniczego odnosiły się jednak w stosunkowo niewielkiej części, gdyż w tym przypadku większość materiału miała pochodzić z magazynów wojskowych, a nie bezpośrednio od producentów ${ }^{83}$.

W kraju podjęto ostatnie przygotowania do przyjęcia planowanych transportów. Zgodnie z przyjętymi ustaleniami materiał przeznaczony dla polskiego odbiorcy miał być dostarczony lotem do miejscowości Seeland, w której ulokowana była centrala dla sprzętu przeznaczonego na eksport. Stamtąd po odpowiednim opakowaniu przewożono go do portu w Liverpoolu, ładując na statki wynajęte przez polską ambasadę. Ta ostatnia też przezkazywała do KZL odpowiednie dokumenty, które posłużyć miały m.in. do uzyskania od Ministerstwa Skarbu zwolnień celnych.

Do przeładunku sprzętu do wagonów kolejowych wybrana została na życzenie władz wojskowych od dawna współpracująca z nimi firma „Viator”. Nadzór nad samym przewozem powierzony został Ministerstwu Komunikacji oraz Szefowi Komunikacji Sztabu Głównego. Konwój wojskowy zapewnić miało Biuro Przemysłu Wojennego MSWojsk., zaś bezpośredni nadzór techniczny transportu - PZL.

Jak się okazało, skrzynie zawierające samoloty Battle linią kolejową Gdynia - Toruń - Sierpc - Warszawa przewożone być mogły jedynie w pozycji poziomej, po od-

Lot. A.I. 2.15. Wkrótce po sygnowaniu umowy obie strony uzgodniły, że do transportu zakupionych materiałów mogą być wykorzystane także statki polskie. Na trasie Liverpool - Gdynia kursowało w tym czasie osiem sttaków polskich i dwa brytyjskie (od polskich jednak znacznie większe). W praktyce kwota kredytu wyniosła 8 mln funtów. „Nadmiarowe” 163000 funtów przeznaczano na opłaty stemplowe $\mathrm{i}$ inne koszty związane $\mathrm{z}$ jego uruchomieniem.

"2 IPMS, A.I. 4.1.49, kopia pisma Rayskiego do II wiceministra spraw wojskowych $z 2$ VIII 1939 r. Zagadnienia lotniczych zakupów w Wielkiej Brytanii oraz realizacji dostaw na podstawie źródeł strony polskiej przedstawił w skrócie J.B. Cynk w szkicu Kulisy niedoszlej dostawy, „Skrzydlata Polska" 2009, nr 8, s. 48nn.

n.3 IPMS, Lot. A.I. 2.15, depesza szyfrowa L. 100 ppłk. Kwiecińskiego z 2 VIII 1939 r., nadana o godz. 17.00; A.I. 4.1.56, pismo L. 271/39 Kwiecińskiego do gen. Malinowskiego z 3 VIII 1939 r. 
powiednim wzmocnieniu. Ponieważ pierwsze 11 samolotów przewieziono do Liverpoolu przed poczynieniem odpowiednich ustaleń, zawierające ich skrzydła skrzynie (22) miały zostać poddane przeróbkom w Gdyni. Pozostałe skrzynie wzmacniano już w Seeland.

Ładowanie pierwszego transportu podjęto najpewniej 14 sierpnia. Zakładano, że dostawy będzie można się spodziewać w Gdyni między 20 a 22 sierpnia. Przewidywania co do terminu ekspedycji potwierdzał też mjr A.R. Boyle, który 14 sierpnia wyrażał przekonanie, że statek opuści Liverpool pięć dni późnieje ${ }^{84}$.

Ostatecznie termin ten został przekroczony ledwie o trzy dni, ale to właśnie owo drobne w istocie opóźnienie przesądziło o losie dostawy ${ }^{85}$. Pierwszy transport samolotów i innego materiału lotniczego wypłynął z Liverpoolu (a właściwie z położonego opodal Ellesmere Port) do Gdyni 22 sierpnia na pokładzie SS „Lassell”. Jednak dzień później Admiralicja nakazała brytyjskim statkom powstrzymanie się od wpływania na Bałtyk i dostawa została zawrócona. Brytyjczycy planowali, że ponowne wyjście transportu w morze nastąpić może już 23 sierpnia wieczorem, przy czym ze względu na obawę, że Gdynia w najbliższym czasie nie będzie bezpiecznym portem docelowym, rejs miałby zostać wykonany do Rygi. W razie gdyby sytuacja uległa poprawie, statek w następnych dniach mógłby stamtąd pożeglować do Gdyni lub też po rozładunku w Rydze transport zostałby przewieziony do Polski koleją. Ze względu na fakt, że ewentualna strata ładunku stanowiłaby poważne obciążenie finansowe dla strony polskiej, oczekiwano jej decyzji w powyższej sprawie ${ }^{86}$.

"N4 IPMS, Lot. A.I. 2.15, koncept referatu L. 837/S.Lotn.tj. ppłk. Filipowicza dla I zastępcy Szefa Sztabu Głównego z 9 VIII 1939 r. i dopiski gen. Malinowskiego na koszulce aktu oraz depesza szyfrowa L. 113 ppłk. Kwiecińskiego z 12 VIII 1939 r., godz. 12.55 („Załadowanie pierwszego transportu Liwerpool rozpocznie się pojutrze. Odejście [...] około 18.VIII. Przybycie Gdynia około 24.VIII”); Lot. A.V. 1.40i I, „Notatka o stanie realizacji zakupu materiału lotniczego” ppłk. pil. inż. Mieczyslawa Konarskiego z 10 sierpnia oraz list gen. Rayskiego do II wiceministra spraw wojskowych z 11 VIII 1939 r.; TNA, CAB 105/51, list Boyle’a do ppłk. W. Portera z 14 VIII 1939 r. Generał Malinowski 12 sierpnia zanotował otrzymaną właśnie informację o rozpoczęciu załadunku. Jednak zarówno ppłk Konarski, który l sierpnia zastąpił w Londynie ppłk. Makowskiego, jak i gen. Rayski informowali, że załadunek pierwszego transportu rozpocznie się 14 sierpnia, a jego odejście do Gdyni planowane jest na 19. Tę ostatnią informację potwierdza korespondencja Boyle'a. Rejs do Gdyni wedle Konarskiego miał zająć 5-6 dni. Ogólne zasady transportu sprzętu ustalone zostały na konferencji w MSWojsk. 4 VIII 1939 r. (protokół: IPMS, Lot. A.V. 1.40i I).

ns Opóźnienie wynikało $z$ winy obu stron. W Wielkiej Brytanii nastał okres urlopowy, co spowolniło wszelkie prace urzędów. Te $z$ kolei, ku pewnemu zdziwieniu Polaków, przestrzegały formalności, podczas gdy strona polska ociągała się z podjęciem formalnie istotnych decyzji, jak ogłoszenie dekretu Prezydenta RP o pożyczce, wyznaczenie osoby uprawnionej do podpisywania umów i notyfikowanie jej nazwiska itp. Jak jednak meldował 11 sierpnia gen. Rayski: „w ciągu najbliższych 10 dni [...] lotnictwo będzie prawie całe załatwione" (IPMS, Lot. A.V. 1.40i I, list gen. Rayskiego do II wiceministra spraw wojskowych z 11 VIII 1939 r.).

46 TNA, FO 371/23147, minuta C 11838/1110/55 Franka K. Robertsa z rozmowy z ppłk. Victorem Goddardem z 23 VIII 1939 r. O decyzji Admiralicji informował Warszawę ambasador Raczyński telegramem szyfrowym z 23 VIII 1939 r., prosząc o instrukcje postępowania wobec polskich statków (IPMS, A.12.53.25, telegram Nr 171 Raczyńskiego z 23 VIII 1939 r.). 
Informacji na temat owych decyzji niestety nie udało się odnaleźćc $c^{8 i}$. Wiadomo natomiast na pewno, że stanu spraw nie znano wówczas w Warszawie, skąd 28 sierpnia wysłano do ppłk. Kwiecińskiego polecenie: „depeszować, co jest z transportami materiału lotniczego". Dwa dni później zaś, najwyraźniej nadal nie posiadając w tej sprawie żadnych informacji, naglono attaché o ich przekazanie ${ }^{88}$.

Wcześniej jednak odpowiednie dane nad Wisłę przekazało brytyjskie Ministerstwo Lotnictwa. Jak wyjaśniano: statek SS „Lassell” znajdował się w drodze, 29 sierpnia najprawdopodobniej żeglując na wodach Zatoki Biskajskiej. Jego dokładna pozycja nie była w Londynie znana, gdyż jednostki wiozące materiał wojenny otrzymały polecenie zachowywania ciszy radiowej. „Lassell” zaś, informowało ministerstwo, wiózł do rumuńskiej Konstancy m.in. 14 przeznaczonych dla Polski myśliwców Hurricane, 7 bombowców Battle, 500 ton bomb i $3 \mathrm{mln}$ sztuk lotniczej amunicji ${ }^{89}$. Datę dotarcia do celu podróży trudno było precyzyjnie określić, warunki rejsu przez potencjalnie niebezpieczne Morze Śródziemne nadal rozważane były przez Admiralicję. Jednak sygnujący korespondencję płk Slessor zakładał, że statek może osiągnąć Istambuł 8 września, a Konstancę 9 lub 10 września ${ }^{90}$. Informacje te 30 sierpnia znane były już także polskim władzom wojskowym. Opatrzone tą datą pismo Sekretariatu Obrony Rzeczypospolitej do ministra spraw wojskowych już w pierwszych zdaniach

א7 28 sierpnia konsul generalny RP w Londynie Zygmunt Merdinger informował o wyjściu przed dwoma dniami $z$ Londynu norweskiego statku „Ulv" $z$ ladunkiem surowców dla Polski. Statek zdążał formalnie do Helsinek i Rygi, jego kapitan mial jednak polecenie podjęcia próby przedostania się do Gdyni. Brytyjski pomysł był więc realizowany, choć w tym przypadku nie chodziło o interesujący nas transport (ibidem, telegram Nr 183 Merdingera z 28 VIII 1939 r.).

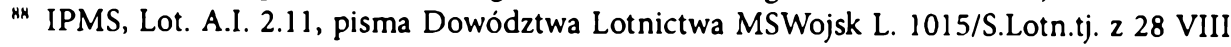
1939 r. oraz L. 1029/S.Lotn.tj. z 30 VIII 1939 r. do Szefa O. II SG; TNA, FO 371/23147, telegram szyfrowy No 350 Kennarda z 29 VIII 1939 r., deszyfrowany o godz. 12.20 .

" Pełna lista ładunku SS „Lassell” obejmowała: 14 samolotów Hurricane, 7 samolotów Battle, 8 ciągników Fordson, 1 pojazd ratownictwa technicznego Albion, 11 przyczep paliwowych, 1 przyczepę warsztatową, 4 przyczepy zasilania o mocy $7 \mathrm{~kW}, 1$ przyczepę zasilania o mocy $14 \mathrm{~kW}$, 3 egzemplarze $2 \mathrm{~W}$ Power Trailers, 16200 szt. czterofuntowych bomb zapalających, 1250 szt. practice bomb (ćwiczebnych) 115-funtowych (wypełnionych tytanem), 2000 practice bomb 115 -funtowych (oświetlających), 9720 bomb (F) 20 -funtowych, 2160 bomb zapalających 25 -funtowych, 4860 bomb 40 -funtowych, 2160 bomb 250 -funtowych, 540 bomb 500 -funtowych, ok. 2750000 szt. amunicji lotniczej, 60 spadochronów pilota i 90 spadochronów „C" obserwatora z uprzężami, 7 trójramiennych śmigieł V.P. do samolotów Battle, 14 trójramiennych śmigieł V.P. do samolotów Hurricane, 1 trójramienne śmigło V.P. do samolotu Spitfire, 2 skrzynie po 4 komplety kombinezonów, butów, gogli lotniczych, po 137 czapek lotniczych, nauszników itp., 112 lotniczych karabinów maszynowych Browning Mk. II, 2600 skrzyń innego wyposażenia (TNA, CAB 104/52, kopia zestawienia Ministerstwa Lotnictwa No S 54149/E.11 "Details of aircraft, engines, M.T., explosives etc., shipped to Gdynia, Poland, per s.s. "Lassell " from Ellesmere Port on 22/8/39" ppłk. F.H. Simsa z 22 VIII 1939 r.). Por. też: IPMS, Lot. A.I. 2/15, niedatowana notatka odręczna ppłk. Kwiecińskiego, zawierająca m.in. informację: „S.s. Lassell. 30.VIII Zatoka Biskajska (Hiszpanja) około 8.IX w Konstancy".

40 TNA, AIR 8/260, koncept depeszy Slessora z 29 VIII 1939 r. O ekspedycji tej depeszy do ppłk. Sworda informował 30 sierpnia Ivone Kirkpatricka mjr Boyle (TNA, FO 371/23147). 
wyjaśniało: „pierwszy transport z Anglii (statek Laselle) został skierowany do Gibraltaru jako pierwszego punktu przeznaczenia". Ranga odbiorcy korespondencji wyraźnie wskazywała, jak dużą wagę przywiązywano w Warszawie do tej kwestii ${ }^{91}$.

W sierpniu do finału zbliżały się już także przeprowadzane w Wielkiej Brytanii szkolenia grup specjalistów, którzy w Polsce mieli się zająć upowszechnieniem wiedzy o nabytym sprzęcie, jego obsłudze i naprawach. Już 10 sierpnia ppłk Kwieciński meldował, że szkolenie zakończyli stażyści skierowani do firm Fairey (płatowiec, silnik, uzbrojenie), Williamson (fotografia lotnicza) oraz Plessey (radiotechnika lotnicza). Trwały jeszcze staże podjęte w firmie Hawker, jednostkach liniowych lotnictwa i parkach lotniczych. Ostatnie prace w tym zakresie przewidywano zakończyć około 4 września ${ }^{92}$.

Coraz bardziej realna groźba rychłego wybuchu wojny skłaniała w końcu sierpnia polskie władze do wzmożenia wysiłków w celu uzyskania z Wielkiej Brytanii dodatkowych dostaw materiału wojennego oraz zwiększenia brytyjskiej finansowej pomocy. 23 sierpnia gen. Litwinowicz nakazał ppłk. Kwiecińskiemu zbadanie $\mathrm{w}$ Londynie możliwości zakupu z wciąż nie w pełni wykorzystanych kwot kredytu „50 samolotów Spitfeier lub Hurrican” oraz ich dostawy w terminie nie dłuższym niż cztery miesiące. W razie odpowiedzi odmownej attaché powinien był dążyć do nabycia innych materiałów użytecznych dla polskiego lotnictwa i przemysłu lotniczego, w tym m.in. łożysk kulkowych, wyposażenia silników lotniczych, 15 gotowych silników lotniczych Bristol Hercules, narzędzi do ich obsługi oraz oprzyrządowania produkcyjnego, a także licencji „płatowca Spitfeiera” - za łączną sumę $15 \mathrm{mln}$ funtów. Niemal równocześnie podejmowane były decyzje w sprawie wznowienia przerwanych w końcu lipca negocjacji w sprawie gotówkowej części kredytu ${ }^{93}$.

Gdy sprzedane Polakom brytyjskie samoloty wyruszały w ładowniach SS „Lassell" w rejs do Konstancy, nieco bardziej na południe, już na francuskim wybrzeżu rozpoczynał się załadunek innej, większej jeszcze partii samolotów, które niebawem podążyć miały podobną drogą. Co więcej, w tym przypadku trzon dostawy stanowiły nowoczesne myśliwce, najbardziej wówczas potrzebne polskiemu lotnictwu.

By wyjaśnić genezę wspomnianego transportu, musimy się jednak cofnąć w czasie o kilka miesięcy. Jak bowiem trzeba przypomnieć, przesyłane do Paryża już u progu wiosny raporty w sprawie niezbędnej Polsce pomocy materiałowej oraz dodatkowego wsparcia finansowego od początku kwietnia zaczęły napływać coraz szerszym strumieniem. Ich autorem był przede wszystkim ambasador Noël, choć wtórował mu, a poniekąd inspirował, gen. Musse. Nad Sekwaną owe apele zrazu traktowano

9I CAW, O. I SG, I.303.3.663, pismo L. 1072/Se.KOR./Tjn/39 z 30 VIII 1939 r. Zachowała się tylko pierwsza strona dokumentu, który jednak niemal na pewno sygnowany był przez gen. Malinowskiego, kierownika SeKOR. Reprodukcja dokumentu: To proste - będziemy się bić..., s. 334.

y2 IPMS, A.I. 4.1.59, odpis pisma L. $284 / 39$ ppłk. Kwiecińskiego do Dowódcy Lotnictwa 210 VIII $1939 \mathrm{r}$.

${ }^{43}$ IPMS, Lot. A.I. 2.15, pismo L. 3123/Tjn. Og. 39 gen. Litwinowicza do ppłk. Kwiecińskiego z 23 VIII 1939 r.; TNA, FO 371/23147, kopia pisma C 11229/1110/55 Stranga do Kennarda z 23 VIII 1939 r. i in. dok. 
niechętnie, gen. Gamelin zalecał odrzucanie zawartych w nich propozycji, a premier-minister Daladier nadawał tym opiniom swe placet. Radykalna zmiana nastąpiła w pierwszej dekadzie maja, zapewne w związku z wypowiedzeniem przez Hitlera 28 kwietnia polsko-niemieckiej deklaracji o niestosowaniu przemocy oraz zwiastującym kres polityki ustępstw wobec agresywnych poczynań Rzeszy przemówieniem ministra Becka z 5 maja. W Paryżu najwyraźniej ostatecznie uznano, że to Polska stanie się pierwszą ofiarą podjętej przez Rzeszę zbrojnej agresji. Jeśli jednak taki scenariusz miałby zapewnić Francji w początkowej fazie wojny nieco dłuższą chwilę oddechu, konieczne stawały się inwestycje w podwyższenie zdolności obronnych sojusznika znad Wisły.

Stąd, jak przyszło nam już wskazywać, krótko przed rozpoczęciem paryskiej wizyty gen. Kasprzyckiego w wypowiedziach przedstawicieli najwyższych szczebli francuskiej hierarchii wojskowej pojawiły się zasadniczo nowe tony, zdecydowanie życzliwsze przedkładanym teraz także przez samych Polaków wnioskom o finansową i materiałową pomoc. $W$ trakcie zaś owej wizyty negocjacje w sprawie takiej pomocy prowadzono równolegle do tych dotyczących zagadnień operacyjnych ${ }^{94}$.

Na dostarczonych do Paryża listach oczekiwanego przez stronę polską materiału nie było jednak samolotów. Fakt ten nie dziwił zresztą francuskich wojskowych. Zdawali sobie oni sprawę z tego, że Polacy od lat preferują raczej sprzęt brytyjski, zakładając, że ta tendencja zostanie utrzymana - czy to skutkiem oceny walorów technicznych, czy też po prostu ze względu na racje natury logistycznej. Jeszcze 16 czerwca na spotkaniu Szefów Sztabów gen. Vuillemin, podkreślając najwyższą wagę przywiązywaną do zbrojeń sojusznika ze wschodu, wypowiedział opinię, że w przypadku lotnictwa ten ostatni będzie zapewne zainteresowany głównie maszynami nabywanymi w Wielkiej Brytanii ${ }^{95}$.

Niezależnie jednak od tego już w drugiej połowie maja w Paryżu zainicjowano uzgodnione przez Gamelina i Daladiera prace nad oszacowaniem sprzętowych zasobów oraz zdolności produkcyjnych aliantów z Europy Wschodniej, a następnie

y4 U progu wizyty inspirowane przez Noëla Quai d'Orsay raz jeszcze przypomniało Daladierowi o pogarszającej się dramatycznie sytuacji finansowej Polski i potrzebie odpowiedniej pomocy. Właśnie z problematyką finansowania zbrojeń łączył podróż Kasprzyckiego informowany przez Noëla Kennard w pierwszych doniesieniach na temat planowanej wizyty (AD, Relations Commerciales, Pologne 13, telegram przychodzący (kurierem) No 762 Noëla do MAE z $11 \mathrm{~V} 1939$ r. i in. dok.; SHD-DAT, 7 N 3005, pismo No 1961 wz. ministra spraw zagranicznych zastępcy dyrektora Dyrekcji Spraw Politycznych i Handlowych MAE Roberta Renoma de la Baume z 11 V 1939 r.; 5 N 579, analiza „Fourniture d’armements à l'étranger" Sekcji Obrony Narodowej Gabinetu ministra obrony narodowej i wojny z 17 V 1939 r. i in. dok.; TNA, FO 371/23143, telegram szyfrowy No 153 Kennarda do FO z 11 V 1939 r., godz. 19.50; DDF, t. 16, doc. 144, s. 297).

95 SHD-DAT, 7 N 3006, zestawienie „Materiels d'armement pour l'Armée Polonaise” Sekcji Uzbrojenia i Studiów Technicznych Sztabu Generalnego Armii z 13 V 1939 r. i in. dok.; CAW, O. I SG, I.303.3.663, niesygnowana „Notatka służbowa w sprawie zwiększenia kredytu francuskiego" z 12 V 1939 r. i in. dok.; DDF, t. 16, doc. 457, s. 870. Dalsze szczegóły: W. Ma zu r, Broń ostatniej szansy. Zagraniczne zakupy sprzętu wojskowego dla armii II Rzeczypospolitej (wiosna-lato 1939 r.), „Annales Universitatis Paedagogicae Cracoviensis. Studia Historica” 2013, t. 14, s. 151. 
określeniem możliwości zaspokojenia ich potrzeb zbrojeniowych. Zebrane dane miały zostać następnie wykorzystane $\mathrm{w}$ rozmowach $\mathrm{z}$ partnerem brytyjskim, $\mathrm{z}$ którym zamierzano podjąć współpracę także $w$ zakresie materiałowego wzmacniania przyszłego frontu wschodniego ${ }^{96}$.

Na rozesłane w tej sprawie przez Gamelina dyspozycje do szefów sztabów poszczególnych broni gen. Vuillemin odpowiedział najpóźniej, bo dopiero 7 lipca. Wedle zebranych przezeń informacji rząd polski nie przejawiał zbytniego zainteresowania zakupami francuskiego sprzętu lotniczego. Wyjątkiem miałyby być myśliwskie wersje samolotu Potez 63 oraz samoloty szturmowe Breguet 690, przy czym w obu przypadkach chodzić miało o ewentualne podjęcie produkcji licencyjnej nad Wisłą. Polacy mieli też wyrażać zainteresowanie nabyciem lotniczych radiostacji pokładowych oraz naziemnych stacji radiowych. Zdaniem Vuillemina pewna liczba budzącego zainteresowanie Warszawy sprzętu łączności mogła być dostarczona do Polski przed końcem roku $1939^{97}$.

W momencie opuszczania przez wspomniane pismo biurka Szefa Sztabu Armée de l'Air zawarte $w$ nim dane były już jednak nieaktualne. Polskie zapatrywania na lotnicze zakupy nad Sekwaną uległy bowiem właśnie zmianie. Przyczynę stanowiły tu zarówno świeżo skonstatowane trudności z nabyciem w Wielkiej Brytanii większej partii samolotów myśliwskich, jak i przeciąganie się podjętych tam negocjacji w sprawie finansowania zbrojeniowych zakupów.

$\mathrm{Na}$ razie zresztą korekta programu zakupowego nie wyglądała radykalnie. Jak informował 5 lipca Noël, polski Sztab Główny zdecydował się wystosować do Paryża zapytanie o możliwość dostawy jednego, złożonego z 12-15 samolotów dywizjonu myśliwców Morane-Saulnier MS-406. Ambasador wyjaśniał z pewną dozą przesady, że polskie lotnictwo wojskowe właściwie nie posiada samolotów myśliwskich, zaś wysiłek podjęty w celu opracowania w kraju nowoczesnej maszyny tej klasy jak dotąd nie zakończył się powodzeniem. Sytuację wykorzystuje lotnictwo niemieckie, bez przeszkód i w sposób ostentacyjny przekraczając granice polskiego obszaru

${ }^{46}$ SHD-DAT, 2 N 236, pismo No 544 D.N. Daladiera do Gamelina z 19 V 1939 r. (też: DDF, t. 16, doc. 236, s. 466).

y: SHD-DAT, 2 N 236, pismo No 21952 T/S/E.M.A.A. Vuillemina do Gamelina z 7 VII 1939 r. i in. dok. Część wspomnianego w piśmie Vuillemina sprzętu strona polska już zamówiła lub zakupiła. Nowe zamówienia objąć miały 58 radiostacji pokładowych firmy Bronzavia (50 już zamówiono), 7 radiostacji portowych S.F.R. (10 już zakupiono), 6 radiostacji samochodowych Thomson-Houston (40 już zamówiono), 40 radiostacji samochodowych S.I.F. (12 już zamówiono), 10 radiostacji pokładowych UKF „Sadir”, 1 samochodową radiostację UKF „Sadir”, 1 goniometr samochodowy oraz 254 ciągniki nieustalonego na razie typu. Wraz z licencją planowano też zakupić 1-2 egzemplarze samolotów Potez 63 i Breguet 690. Zawierający te dane referat Sztabu Lotniczego SG, opatrzony 20 czer wca parafą gen. Ujejskiego, tegoż dnia gen. Malinowski uzupełnił decyzją: "Na razie nie wysyłajmy, aż się w M S Wojsk definitywnie ustali nasze zapotrzebowanie lotnicze", co wskazuje też, że w drugiej polowie czerwca, wobec załamywania się programu zakupów kredytowych w Wielkiej Brytanii, warszawscy wojskowi nie dysponowali rozwiązaniem alternatywnym. Wieczorem 20 czerwca ppłk Piniński depeszą szyfrową L. 2225 poinformował gen. Ujejskiego, że Francuzi wyrazili zgodę na wykonanie prób samolotu Breguet 690, prosząc o przysłanie załogi na 2 lipca (IPMS, Lot. A.I. 2/14). 
powietrznego, przede wszystkim nad Pomorzem. Uzyskanie nowoczesnych francuskich myśliwców zapewne pozwoliłoby na ukrócenie takich praktyk ${ }^{98}$.

Quai d'Orsay otrzymany wniosek uznało za wart realizacji. Wzmocnienie polskiego lotnictwa przez dostarczone z Francji samoloty myśliwskie nie tylko stanowiłoby przyjazny gest wobec sojusznika, ale też mogłoby przynieść obopólne korzyści w razie wojny, argumentowano. Przy okazji w korespondencji do Ministerstwa Lotnictwa przypomniano sformułowaną wcześniej propozycję, by w przypadku wojny oddać do dyspozycji polskiej armii kilka dywizjonów maszyn francuskich i angielskich. Korzyść z takiego kroku nie byłaby ograniczona jedynie do aspektów czysto militarnych, zauważali dyplomaci. Podobny fakt w oczach Polaków nadawać by mógł pożądanej w Paryżu (i obłożonej anatemą w Warszawie) kooperacji z ZSRR charakter współpracy międzysojuszniczej ${ }^{99}$.

Sztab Generalny Armée de l’Air, powiadomiony o polskiej prośbie także wysłaną 6 lipca depeszą płk. Arbitre, 17 lipca przekazał do Warszawy możliwie przychylne stanowisko w kwestii jej spełnienia. Władzom polskim zaoferowano natychmiastową dostawę 10 samolotów MS-406, jednak bez standardowo montowanego w nich działka lotniczego kal. $20 \mathrm{~mm}$, z uzbrojeniem w postaci jedynie dwóch karabinów maszynowych. Większa liczba myśliwców miała się stać dostępna dla zagranicznych odbiorców dopiero w październiku ${ }^{100}$.

Strona polska, rozważając różnorodne opcje zakupu nowoczesnych myśliwców, w tym szereg ofert firm amerykańskich, nie zareagowała natychmiastową decyzją. Co najmniej od przełomu czerwca i lipca starała się zresztą uzyskać od Francuzów informacje na temat przeprowadzonych przez nich testów maszyn zza Oceanu, w tym przede wszystkim samolotów Curtiss P-36 (w wersji przeznaczonej dla Francji: Curtiss Hawk 75A). W Paryżu wysiłki te traktowano ambiwalentnie, nie bardzo potrafiąc podjąć decyzję, czy ważniejszy jest interes krajowych producentów oraz tajemnica wojskowa (własna) i handlowa (amerykańska), czy też spełnienie życzeń polskiego alianta. To $\mathrm{z}$ kolei utrudniało rozwiązanie trapiących wojskowych $\mathrm{z}$ Warszawy dylematów ${ }^{101}$.

9* AD, Pologne 314, fotokopia pisma No 389 Noëla do Bonneta z 5 VII 1939 r. Równocześnie polski Sztab Lotniczy SG zdecydował się na skierowanie do Francji ekipy odbywającej dotychczas loty testowe na samolotach brytyjskich (kpt. pil. Andrzej Wlodarkiewicz, ppor. rez. pil. Roland Kalpas oraz ppłk dypl. pil. Olgierd Tuśkiewicz jako szef misji) celem przeprowadzenia prób samolotu Breguet 690, zaś po uzyskaniu informacji o rozszerzeniu francuskiej zgody - także Potez 63. Program prób obejmował wstępne zapoznanie się z charakterystyką samolotu, a następnie, w ciągu 5-10 godzin lotów, zbadanie sprawności w locie, własności akrobacyjnych, cech bojowych i działania uzbrojenia badanych maszyn (IPMS, Lot. A.I. 2.14, depesza szyfrowa L. 1463 ppłk. Pinińskiego do gen. Ujejskiego z 22 VI 1939 r., godz. 10.15 i in. dok.).

yy Ibidem, fotokopia (odpisu?) pisma poddyrekcji Europa MAE do ministra lotnictwa z 15 VII 1939 r.

1106 SHD-DAA, 2 B 104, depesza szyfrowa gen. Mendigala do płk. Arbitre z 17 VII 1939 r.; IPMS, Lot. A.I. 2.14, pismo No 80/DS. płk. Arbitre do gen. Kalkusa z 18 VII 1939 r.

101 IPMS, Lot. A.I. 2.14, depesza szyfrowa L. 1511 ppłk. Pinińskiego do gen. Ujejskiego z 26 VI 1939 r. i in. dok. Z informacji przekazanych przez płk. Arbitre wynikało, że 4 lipca przekazano 
Moment ich rozstrzygnięcia zbliżać się zaczął dopiero w ostatniej dekadzie lipca. Podpułkownik Filipowicz sporządził wówczas obszerną analizę, zestawiając w niej „własności wyczynowe i techniczne oraz uzbrojenia" jednomiejscowych samolotów myśliwskich (w dokumencie: pościgowych) z ofert amerykańskich (Seversky SP-1, Curtiss Hawk 75A) oraz brytyjskiego myśliwca Hawker Hurricane i francuskiego Morane Saulnier MS-406. Jak stwierdził: „Na pierwszym miejscu stoi angielski »The Hawker Hurricane», następnie trochę niżej prawie w tej samej klasie stoją amerykańskie "Seversky SP-1 " i "Curtiss Hawk 75A «, za nimi trochę dalej francuski "Morane Saulnier 406“. Różnice pomiędzy wymienionymi czterema typami w zasadzie nie są zbyt wielkie". Jednak, zaznaczył, amerykańskie oferty są zdecydowanie najdroższe, proponowane terminy dostaw dość odległe, problemów mogłyby nastręczać także płatności, zapewne o charakterze wyłącznie gotówkowym. Z kolei możliwości zakupu produktów Hawkera ograniczają się na razie do 14 wynegocjowanych już maszyn, kolejne zaś samoloty tego typu mogłyby być dostępne zapewne najwcześniej jesienią. Francuzi gotowi są natychmiast dostarczyć myśliwce $z$ ograniczonym do dwóch karabinów maszynowych uzbrojeniem, większą zaś liczbę począwszy od października, w cenie na razie nieznanej, ale bliskiej zapewne brytyjskiej. Podpułkownik Filipowicz postawił więc wniosek o natychmiastowy zakup myśliwców francuskich (oraz 14 brytyjskich Hurricane), oczekując tylko, „by przez specjalny nacisk na Ministerstwo Lotnictwa uzyskać działka do tych samolotów". Jako uzasadnienie dokonanego wyboru wskazal szybkość dostawy, umiarkowane ceny, względną latwość transportu, dobre uzbrojenie (w wersji z działkiem) oraz użycie paliwa 87-oktanowego (podczas gdy samoloty amerykańskie wymagały trudnego do uzyskania paliwa 100 -oktanowego) ${ }^{102}$.

Jeszcze tego samego dnia przedstawione wnioski zaakceptował gen. Ujejski, zaś dwa dni później gen. Zając. 29 lipca na koszulce aktu została naniesiona także najistotniejsza adnotacja: marszałek Śmigły-Rydz, „przyjął i zaaprobował” treści referatu ${ }^{103}$.

Proces realizacji decyzji zahamowany został dość niespodziewanie przez napływ nowych wieści. Późnym popołudniem 28 lipca do Warszawy dotarła bowiem informacja ppłk. Pinińskiego, że francuski minister lotnictwa, podtrzymując ofertę natychmiastowego przekazania Polakom 10 samolotów Morane, proponuje im podjęcie od października dostaw myśliwców Dewoitine 520, które wówczas zastąpią na liniach produkcyjnych gorsze pod względem osiągów morany ${ }^{104}$.

mu prośbę o alternatywną dostawę 10-15 samolotów MS-406 lub takiej liczby myśliwców Curtiss P.36, zapewne wydzielonych z partii maszyn, które Francuzi nabyli w USA.

1112 Ibidem, referat L. 798/S.Lotn.tj. ppłk. Filipowicza dla Szefa SG z 22 VII 1939 r. „Przewaga maksymalnej szybkości pościgowych samolotów amerykańskich nad francuskimi jest tak niewielka (od 14 do $20 \mathrm{~km} /$ godz.), że właściwie nie jest przewagą istotną, jeżeli się weźmie pod uwagę ich gorsze uzbrojenie oraz silnik o znacznie większej mocy (amerykański 1100 M.K., [...] francuski 860 M.K.), a więc o znacznie większym zużyciu bardzo bogatej, bo 100-oktanowej mieszanki" dodawał autor referatu.

1113 Ibidem - adnotacje na koszulce aktu.

104 Ibidem, depesza szyfrowa L. 2852 ppłk. Pinińskiego do Szefa Administracji Armii, Szefa Sztabu Lotnictwa i Dowódcy Lotnictwa z 28 VII 1939 r., godz. 18.00. Minister Guy La Chambre 
Nowe informacje wywołały zamęt po stronie polskiej. Mimo sugestii ambasadora Łukasiewicza, który uważał, że lepiej będzie nabyć samoloty dobrze już osadzone we francuskim programie zbrojeń, wyrażając też obawę, że droższe Dewoitine nie zmieszczą się w 430 mln franków negocjowanego właśnie kredytu, Generalny Inspektor Sił Zbrojnych nakazał podjęcie starań o zakup tych ostatnich maszyn. Równocześnie, „ze względu na ujemne strony wprowadzania do linii zbyt wielkiej różnorodności typów samolotów", polecił zrezygnować $z$ oferty natychmiastowej dostawy 10 myśliwców Morane ${ }^{105}$.

Powyższa decyzja została przekazana ppłk. Pinińskiemu depeszą wysłaną doń tuż przed północą 2 sierpnia, a kopię tej ostatniej otrzymał także dopytujący się o dokonany wybór płk Arbitre. Jednak niespełna dwa dni później, 4 sierpnia, nastąpił niespodziewany zwrot: gen. Ujejski poinformowal rezydującego w Paryżu attaché lotniczego, że „weźmiemy samoloty "Morane 406“, o ile Francuzi mogą nam dać 50 sztuk z całym wyposażeniem w ciągu sierpnia". Późniejsze, jesienne dostawy miałyby już dotyczyć maszyn Dewoitine (D.520). Gdyby jednak myśliwce Morane nie mogły być przekazane do końca sierpnia, Szef Sztabu Lotnictwa nakazywał rezygnację z ich zakupu i nabycie w zamian dewoitinów ${ }^{106}$.

Wciąż jeszcze nie był to koniec zamętu. Depesza gen. Ujejskiego minęła się bowiem w drodze z szyfrem znad Sekwany: Francuzi „definitywnie” oferowali 160 myśliwców Morane uzbrojonych w trzy karabiny maszynowe, w tym 10 „zaraz”, zaś następnych 50 sztuk $w$ dwóch równych partiach 15 września i 1 października. Jednocześnie informowali, że "sprawa Devoitine może być aktualna dopiero od 1 listopada w mniejszych seriach". Skutkowało to kolejną decyzją: gen. Ujejski akceptował ostatnią propozycję, zaznaczając, że samoloty miałyby być dostarczone "na warunkach kredytowych" z zapasem silników i części zamiennych oraz pełnym wyposażeniem, zaś polscy negocjatorzy dołożą starań, by przynajmniej $75 \%$ maszyn uzbrojonych zostało w działka lotnicze ${ }^{107}$.

Tym razem był to wybór rzeczywiście ostateczny. 9 sierpnia obradujący pod przewodnictwem gen. Vuillemina Komitet Materiałowy francuskiego Ministerstwa Lotnictwa zaaprobował dostawę do Polski 150 pochodzących z zasobów Armée de l'Air samolotów Morane w wyżej podanych terminach. Zaakceptowano także próby

w rozmowie $z$ ambasadorem Łukasiewiczem wyraził też zgodę na loty próbne polskich pilotów na samolotach Morane i Dewoitine oraz myśliwcu Bloch 151. Zasugerował też, by w razie odrzucenia ofert na francuskie myśliwce Polacy nabyli maszyny Curtissa, do których w razie wojny Francuzi mogliby dostarczyć posiadane w sporym zapasie części zamienne (ibidem, pismo L. 344/tj.Lot.39 ppłk. Pinińskiego do gen. Ujejskiego z 31 VII 1939 r.).

1115 IPMS, Lot. A.I. 2.14, koncept pisma L. 798/S.Lot.Tj. gen. Ujejskiego do Dowódcy Lotnictwa MSWojsk. 23 VIII 1939 r.

1116 Ibidem, pismo L. 817/S.Lot.Tj. gen. Ujejskiego do Szefa O. II SG z 4 VIII 1939 r.

${ }_{10 ;}$ Ibidem, depesza szyfrowa L. 2955 ppłk. Pinińskiego do gen. Ujejskiego z 4 VIII 1939 r., godz. 17.50; depesza szyfrowa L. 841/S.Lot.39 gen. Ujejskiego do Szefa O. II SG z 5 VIII 1939 r. (zaszyfrowa o godz. 15.30); B. B el ca r z, Morane-Saulnier..., s. 34n. Reprodukcje części przywołanych wyżej dokumentów opublikowano w: To proste - będziemy się bić..., s. 326n. 
w locie, którym polscy piloci mieliby poddać myśliwce MS-406 i Bloch 151, odmawiając takiej zgody (mimo wcześniejszej obietnicy ministra La Chambre) w przypadku maszyn D.520, ze względu na bardzo niewielką liczbę ich zdatnych do testów egzemplarzy ${ }^{108}$.

Decyzja w sprawie lotów testowych, mimo że w zaistniałych okolicznościach oczywista, okazała się fatalna w skutkach. Już bowiem dzień później około godziny 10.20 w trakcie lotu próbnego na samolocie MS-406 No 1014 w katastrofie lotniczej w okolicach położonej na południe od Paryża miejscowości Massy-Palaiseau zginął kpt. pil. Andrzej Włodarkiewicz. Polski oficer, który kwadrans wcześniej wystartował $\mathrm{z}$ bazy $\mathrm{w}$ Villacoublay, przeprowadzał test zachowania samolotu $\mathrm{w}$ locie $\mathrm{z}$ dużą szybkością. Podjąwszy przy dobrej pogodzie nurkowanie z wysokości około $6000 \mathrm{~m}$, nie zdołał wyprowadzić maszyny z lotu nurkowego i uderzywszy wraz z nią gwałtownie o ziemię pod kątem niemal $80^{\circ}$, poniósł śmierć. Przeprowadzone przez francuską komisję śledztwo wykazało, że przyczyną wypadku był zapewne wybuch butli ze sprężonym powietrzem systemu amortyzatora OLAER, który naruszył konstrukcję płatowca, uszkadzając też m.in. systemy sterowania i zasilania w paliwo. Pilot podjął próbę opuszczenia kabiny uszkodzonej maszyny, ale został wtłoczony do niej z powrotem przez pęd powietrza, a ten następnie spowodował zerwanie z uwięzi zbyt wcześnie otwartej czaszy spadochronu, co ostatecznie uniemożliwiło ratunek ${ }^{109}$.

Uroczysty pogrzeb kpt. Włodarkiewicza odbył się 12 sierpnia w Kościele Polskim w Paryżu. Tragedia nie zahamowała jednak działań podjętych dla finalizacji zamierzonego zakupu. Już 8 sierpnia ppłk Piniński w obszernym piśmie do Szefa Sztabu Lotniczego SG omówił całość tego zagadnienia, zgłaszając m.in. postulat, by po zawarciu umowy do Francji obok komisji odbiorczej przyjechała też ekipa techniczna, która miałaby się zapoznać $\mathrm{z}$ właściwościami i montażem nabywanego sprzętu.

I11 SHD-DAA, 2 B 6, protokół z posiedzenia Komitetu Materiałowego z 2 VIII 1939 r.; Z 12941, niedatowane [początek sierpnia 1939?] i niesygnowane „Mémorandum au sujet de la fourniture d'avions Morane 406 et d'autorisation de vol". Ten ostatni dokument zawierał też informację, że dostawa pierwszych 10 maszyn jest już „w trakcie”. Jak się więc wydaje, Polsce zamierzano przekazać łącznie 160 maszyn. Faktycznie loty testowe na MS-406 kpt. Włodarkiewicz i por. Kalpas rozpoczęli już dzień wcześniej, 8 sierpnia.

111y IPMS, Lot. A.I. 2.14, pismo L. 310-3111/39/L. ppłk. Pinińskiego do Szefa SG z 12 VIII 1939 r. i in. dok.; SHD-DAA, 2 B 140, „Rapport d'enquête sommaire du Commandant pilote Heurtier, de la base Aérienne de Villacoublay a/s d'un accident probablement imputable au matériel" z 11 VIII 1939 r. i in. dok.; Z 12938, „Raport sommaire sur l'accident survenu à Massy (Seine-\&-Marne) à un avion Morane 406 No 1014 de l'École Morane, le 10 Août 1939" No 1369 I.G.T.A./S Inspektora Technicznego Bezpieczeństwa Lotniczego z 12 VII 1939 r.; W. Grabowski, Katastrofa $z$ Moranem w roli glównej, "Gapa. Lotniczy Magazyn Historyczny” 2014, nr 10-11, s. 11nn. Był to trzeci z kolei lot kpt. Włodarkiewicza na samolocie Morane, lącznie zdążył on wylatać na tej maszynie zaledwie 56 minut. Finalne ustalenia Generalnej Inspekcji Technicznej Lotnictwa w sprawie przyczyn wypadku przedstawione zostały dopiero w końcu października 1939 r. Od jesieni 1939 r. strona polska prowadziła też z firmą Aéroplanes Morane-Saulnier dość obszerną korespondencję w sprawie odszkodowania za zniszczony 10 sierpnia samolot (IPMS, Lot. A.IV. 1.12e). 
W Warszawie koncepcję uznano za słuszną, dwa dni później Dowódca Lotnictwa MSWojsk. został poproszony o przygotowanie składu obydwu grup ${ }^{110}$.

Problemem jednak stawało się finansowanie planowanej transakcji. Raz jeszcze przypomnieć trzeba, że autorzy opracowywanych w Polsce późną wiosną list przeznaczonego do zakupu nad Sekwaną sprzętu założyli, że siły powietrzne będą w tych zakupach partycypować we względnie niewielkiej skali, nabywając głównie materiał łączności. Jeszcze w połowie lipca owa „łączność dla lotnictwa” ulokowana była na piątej pozycji siedmiopunktowej, hierarchicznie uporządkowanej listy, której szczyt zajmowały czołgi, artyleria ciężka i górska oraz ciągniki artyleryjskie. O ewentualny „kredyt na wzięcie kilku eskadr myśliwskich Moranów” koordynujący podjęte w $\mathrm{Pa}$ ryżu poczynania płk dypl. Fyda zapytany został dopiero po południu 26 lipca $^{111}$.

Niemal dwa tygodnie później attaché był już niemal pewny, że kwoty na zakup tych maszyn w obiecanym już Polakom nowym francuskim kredycie $w$ wysokości 430 mln franków zdołają się zmieścić, wątpił jednak, by w grę wchodzić mogło aż 160 maszyn. Wątpliwości tej dał wyraz w datowanym 8 sierpnia liście do Szefa O. I SG, płk. dypl. Józefa Wiatra. „Lotnictwo - pisał w tej korespondencji - Morany 406 - dają do 160 sztuk - ale zapewne nie starczy pieniędzy, i liczymy się z ilością jakich 100 samolotów - gdyż trzeba wziąć do nich części zapasowe”. Równocześnie zaś informował gen. Ujejskiego, że „zapotrzebowanie na [...] dostawę materiału dla lotnictwa myśliwskiego" obejmuje 120 samolotów Morane 406 z kompletnym uzbrojeniem w dwa działka lotnicze i $2 \mathrm{~km}$, radiostacją "Sadir”, przyrządami pokładowymi i aparatem tlenowym, 10 naziemnych radiostacji odbiorczych dla tych maszyn oraz części zapasowe wedle norm francuskich dla 3 dywizjonów liczących po 3 złożone z 10 samolotów eskadry ${ }^{112}$.

111 IPMS, Lot. A.I. 2.14, pismo L. 365/tj.Lot. ppłk. Pinińskiego do gen. Ujejskiego z 8 VIII 1939 r.; koncept pisma L. 882/S.Lotn.Tj. (gen Ujejskiego?) do gen. Kalkusa z 11 VIII 1939 r. i in. dok.

"11 CAW, O. I SG, I.303.3.663, pismo L. 2070/Tjn./39 II wiceministra spraw wojskowych gen. A. Litwinowicza do gen. bryg. Tadeusza Kossakowskiego (szefa kierowanej do Francji misji zakupów) z 17 VI 1939 r.; pismo L. 2575/tj.K.F.II gen. Maciejowskiego z 15 VII 1939 r. (reprodukcja: To proste - będziemy się bić..., s. 324) oraz koncept depeszy L. 2353.tj. Szefa O. I SG wz. płk. dypl. Romana Saloniego do płk. Fydy z 26 VII 1939 r. (zaszyfrowana tegoż dnia o godz. 15.30). W pierwszym z przywołanych dokumentów, dotyczącym powołania komisji gen. Kossakowskiego, określono też orientacyjny podział kwot $w$ ramach francuskiego kredytu, który według ówczesnych zalożeń miał wynieść miliard franków. Najwięcej, bo równowartość $70 \mathrm{mln} \mathrm{zl}$, przeznaczono na zakup czolgów, $30 \mathrm{mln}$ zł na przemysł wojenny, $24 \mathrm{mln}$ zł na potrzeby marynarki wojennej, $14 \mathrm{mln}$ na łączność itp. Nabywane dla sił powietrznych radiostacje Bronzavia znalazły się na ostatniej pod względem wartości pozycji tej listy, z przydzieloną wstępnie kwotą $1 \mathrm{mln}$ zł. Dalsze szczegóły ówczesnych planów zbrojeniowych zakupów we Francji: W. Mazu r, Broń ostatniej szansy..., s. 153nn.

112 CAW, O. I SG, I.303.3.663, list odręczny płk. Fydy do płk. Wiatra z 8 VIII 1939 r.; IPMS, Lot. A.I. 2.14, pismo L. 365/tj.ot. ppłk. Pinińskiego do gen. Ujejskiego z 8 VIII 1939 r. Zestawy części zapasowych miałyby obejmować: zapasowe silniki Hispano-Suiza 12Y-31 i części zapasowe do nich, zapasowe śmigła, części zapasowe do płatowców (podwozia, koła, dętki, skrzydła, usterzenie), części zapasowe do radiostacji pokładowych i naziemnych, części zapasowe uzbrojenia, amunicję do działek i km. 
Sześć dni później płk Fyda mógł już przesłać do Warszawy informację o parafowaniu 12 sierpnia porozumienia kredytowego, a także zamiarze niemal natychmiastowego (do 10 września) sporządzenia umów na dostawy sprzętu i równie szybkiej („od zaraz do 31 marca 1940 r. najpóźniej”) ich realizacji. Kwestia liczby nabywanych myśliwców Morane nadal jednak nie była wyjaśniona, ze względu na nieprzekazanie polskim nabywcom informacji o cenie kompletnie uzbrojonego i wyposażonego samolotu. Dopiero w Polsce, gdzie korespondencja ta dotarła 17 sierpnia, na marginesie dokumentu dopisano ołówkiem wyjaśniającą notkę: „120; zaraz 20+30”, uzupełnioną na końcu tekstu kolejną: „lotnictwo 206 milj. [franków]”113.

Dzień później, 18 sierpnia, minister Bonnet i ambasador Łukasiewicz sygnowali wreszcie negocjowaną od maja umowę kredytową ${ }^{114}$. Strona polska uzyskiwała dostęp do kwoty 430 mln franków, która miała być przeznaczona na sfinansowanie dokonywanych nad Sekwaną zakupów materiału wojennego. W ostatecznej wersji porozumienia zachowano terminy, które kilka dni wcześniej wzmiankował w korespondencji płk Fyda: 10 września jako data końcowa zawierania umów dotyczących cesji materiału i 31 marca 1940 roku jako kres realizacji dostaw. Całość oprocentowanego w skali 5\% per annum kredytu miała zostać przez rząd RP spłacona do 31 grudnia 1957 roku $^{115}$.

Polskie zakupy lotnicze we Francji uzyskały więc wreszcie finansowe podstawy. Ministerstwo Lotnictwa nie zamierzało ociągać się z realizacją uzgodnionych już dostaw. Na posiedzeniu Komitetu Materiałowego w dniu 23 sierpnia podano informację o decyzji w sprawie eksportu do Polski 40 samolotów myśliwskich Morane. Pierwsza ich partia miała zostać załadowana na statek już 28 sierpnia, druga - niewiele później. Jeszcze przed wieczorem tego dnia ppłk Piniński mógł wreszcie wysłać

${ }^{113}$ CAW, O. I SG, I.303.3.663, pismo L. 381/tj.39 płk. Fydy do Szefa SG i II wiceministra spraw wojskowych. Reprodukacja dokumentu: To proste - będziemy się bić..., s. 328. Dopiski naniesione zostały ręką płk. Wiatra, co pozwala datować je na 18 sierpnia (kiedy to pismo wpłynęło do O. I SG) lub któryś z dni krótko po tej dacie.

114 Pierwsze, wstępne wnioski w tej sprawie Łukasiewicz przedstawił nawet wcześniej, w połowie kwietnia. Zob.: Biblioteka Polska w Paryżu, akc. 4610, fotokopia pisma L. Rz/7 Łukasiewicza do Becka z 15 IV 1939 r. Datowane 11 maja polecenie podjęcia rozmów Łukasiewicz otrzymał dzień później, już 13 maja informując Becka o rezutatach pierwszych rozmów z Daladierem. Dokumentację przebiegu początkowej fazy negocjacji (maj i początek czerwca) zawiera przechowywane w IPMS pod sygnaturą A.11.47.F.6 dossier „Dodatkowy kredyt wojskowy”. Szereg dokumentów dotyczących rozmów w sprawie kredytu zostało opublikowanych zarówno przez stronę polską (np.: PDD 1939, dok. 325, s. 549nn; dok. 387, s. 671n.; dok. 389, s. 677n.; dok. 406, s. 699nn.), jak i francuską (liczne dokumenty w DDF, t. 16-18).

115 DDF, t. 18, doc. 131, s. 173nn. Po zakończeniu wojny, według stanu na 1 IX 1945 r., kwota należności z tytułu tej umowy wynosiła jedynie 10395669,98 fr. franc. (w tym odsetki: 2377 708,34 fr. franc.), co ilustruje bardzo niewielki stopień, w jakim zdążono ją wykorzystać (Centre des Archives Économiques et Financières, Savigny-le-Temple (dalej: CAEF), B65236, zestawienie "Situation au 1 Septembre 1945 des sommes dues par la Pologne au titre des avances faites par le Trésor Français"). Datowany 24 sierpnia dekret prezydenta Lebruna dotyczący wykonania umowy został opublikowany w „Journal Officiel” z 27 sierpnia (kopia: AD, Relations Commerciale, Pologne 13). 
do Warszawy depeszę z oczekiwanym tam niecierpliwie tekstem: „Dnia 29-30.VIII odchodzi do Gdyni 20 samolotów Morane z częściami zapasowymi, uzbrojeniem i amunicją. [...] Proszę potwierdzić odbiór" ${ }^{\prime 16}$.

116 SHD-DAA, 2 B 6, protokół z posiedzenia Komitetu Materiałowego z 23 VIII 1939 r.; IPMS, Lot. A.I. 2.14, depesza szyfrowa L. 3275 pplk. Pinińskiego do Szefa Lotnictwa SG (gen. Ujejskiego) i Dowódcy Lotnictwa (gen. Kalkusa) z 23 VIII 1939 r., godz. 18.00. W Warszawie depesza została odszyfrowana już 24 sierpnia, o godz 1.50. Sygnalizowany transport zawierał też inne materiały dla lotnictwa: 10 skrzyń z częściami zapasowymi dla radiostacji S.F.R., 53 skrzynie duraluminium, [20 +] 19 kolektorów do silników Gnome-Rhône 14M, 3 skrzynie z prądnicami, [30] 10 radiostacji SAR baterie M, 30 zespołów elektrycznych z częściami zapasowymi, 20 sztuk rur antenowych dla radiostacji. Liczby w nawiasach zostały dopisane ołówkiem, być może odnosiły się do sprzętu dostarczonego uprzednio. 


\section{Rozdział 9}

\section{Między błyskiem a gromem \\ (23-31 sierpnia 1939 roku)}

Sfinalizowane 23 sierpnia porozumienie Berlina i Moskwy, choć zarówno w Wielkiej Brytanii, jak i we Francji od pewnego czasu uważane za prawdopodobne, w stolicach obu państw wywołało wstrząs. Skrajnie zaniepokojeni byli nie tylko politycy, ale i wojskowi. Dla tych ostatnich bardziej bowiem niż dla cywilów oczywista była jedna z najistotniejszych konsekwencji podpisanego przez Ribbentropa i Mołotowa paktu: oto rozpadał się mozolnie od miesięcy konstruowany miraż wschodniego frontu. W Paryżu już wieczorem tego dnia, na zwołanym pod przewodnictwem premiera Daladiera posiedzeniu Komitetu Stałego Obrony Narodowej minister Bonnet zareagował na nową sytuację propozycją wycofania się ze zobowiązań wobec Polskj i kupieniu sobie jej kosztem dodatkowych miesięcy pokoju, niezbędnych dla wojennych przygotowań. W trakcie dyskusji przeważyło jednak przekonanie, że ewentualne zwycięstwo Niemiec na wschodzie pogłębi jeszcze militarną przewagę Rzeszy, Francja nie ma więc wyboru i musi wytrwać na dotychczasowym kursie politycznym. Generał Gamelin wyrażał przy tym nadzieję, że polski sojusznik zdoła związać poważne siły niemieckie na tyle długo, że ataku na zachodzie Rzesza nie zdoła podjąć przed wiosną przyszłego roku. A wtedy - dodawał - „Anglicy będą już po naszej stronie". O czynnych działaniach na rzecz Polski nie było na spotkaniu mowy, Gamelin i Darlan stwierdzili tylko w tonie uspokajającym, że ulgę dla alianta ze wschodu stanowić będzie już sama francuska mobilizacja, ściągająca na zachód Rzeszy pewną liczbę jednostek armii niemieckiej'.

W trakcie posiedzenia przeprowadzono także przegląd środków, które znajdowały się w dyspozycji Paryża. Minister Guy La Chambre stan sił powietrznych przedstawił w tonacji wyraźnie optymistycznej, podkreślając postęp w ich wzmocnieniu od września roku poprzedniego. W przypadku lotnictwa myśliwskiego, wy-

1 DDF, t. 18, doc. 324, s. 382nn. Szczegółowo przebieg tego posiedzenia przedstawił J. Cia lowicz, op. cit., s. 320nn. Zob. też: M. Zgórniak, Europa w przededniu wojny..., s. 478nn.; M. Gmurczyk-Wrońska, op. cit., s. 128. 
jaśniał, Francja dysponuje w większości nowoczesnymi samolotami wytwarzanymi w wielkich seriach, zaś połączone siły francusko-brytyjskie mniej więcej dorównują niemiecko-włoskim. Lotnictwo bombowe nie dysponuje jeszcze tak wielkim potencjałem - produkcja przeznaczonych dla jego potrzeb maszyn poważne rozmiary osiągnąć winna dopiero z początkiem roku 1939. Jednak i tu liczyć można na pomoc Brytyjczyków, którzy w razie wojny podejmą zmasowane bombardowania północnej części Niemiec. Obawa o rozwój sytuacji w powietrzu nie powinna więc ważyć na decyzjach rządu, jak miało to miejsce niespełna rok wcześniej, we wrześniu roku 1938 - zaznaczał 2 .

W przedstawionej ocenie bezdyskusyjnie prawdziwa była jednak tylko informacja o poczynionych w ostatnich miesiącach postępach. Stan wyposażenia Armée de l'Air istotnie ulegał poprawie w ciągu minionego roku, co wobec niskiego poziomu odniesienia, zwiększonych nakładów oraz wojennej groźby nikogo nie mogło zaskakiwać. Jednak osiągnięte do sierpnia 1939 roku efekty nie powinny były skłaniać ministra do nadmiernego optymizmu, a może nawet do optymizmu w ogóle. Istotnie, wyrażona $w$ liczbach francuska produkcja lotnicza stale rosła, na pozór wręcz imponująco. Jeszcze w styczniu 1939 roku zdołano wykonać zaledwie 24 egzemplarze stanowiących podstawowe myśliwce Armée de l'Air samolotów Morane-Saulnier MS-406, a w czerwcu ich produkcja sięgnęła 130 maszyn. Jednak łączna liczba 373 wykonanych w pierwszym półroczu roku 1939 samolotów w porównaniu z równoległymi osiągnięciami Niemców czy Brytyjczyków przedstawiała się blado. Było też oczywiste, że Morany zdecydowanie zbyt wolno zastępują w eskadrach znacznie od nich starsze, niezbyt już w powietrznym boju przydatne konstrukcje. Co gorsza zaś, ów nowy francuski sprzęt nadal wyraźnie ustępował bardziej technicznie zaawansowanym odpowiednikom ze wschodniej strony Renu.

Tymczasem prace nad prototypami, które przynajmniej pod względem walorów bojowych mogłyby równoważyć przewagę niemieckich messerschmittów, wyraźnie się przeciągały. O produkcji nowoczesnych bombowców nie sposób było wręcz mówić. Podana przez ministra informacja, że nie są one jeszcze wytwarzane w wielkich seriach, stanowiła daleko posunięty eufemizm: budzących spore nadzieje średnich samolotów bombowych Lioré et Olivier LeO 45 zdołano w pierwszym półroczu wykonać... sześć. Inne konstrukcje tej klasy wciąż znajdowały się w stadium prototypów3.

Wielce wątpliwa była też sformułowana przez La Chambre’a teza o względnej równorzędności sił powietrznych francusko-brytyjskiego przymierza oraz jego potencjalnych przeciwników. Najwyraźniej w każdym razie nie podzielał jej głównodowodzący Armée de l'Air gen. Vuillemin, który trzy dni później przesłał swemu cywilnemu przełożonemu obszerny raport na tenże temat. Wynikała zeń niezbicie przewaga wroga, który miał dysponować w pierwszej linii siłą 6500 maszyn, górując niemal dwukrotnie nad mającymi liczyć około 3800 maszyn siłami powietrznymi

2 DDF, t. 18, doc. 324, s. 383n.

3 SHD-DAA, 11 Z 12938, niedatowane zestawienie "Fabrication des avions de guerre du ler Janvier au ler Juillet 1939". 
trzech państw koalicji antyhitlerowskiej. Po uwzględnieniu zasobów drugiej linii wynikająca $\mathrm{z}$ rachunków Vuillemina dysproporcja stawała się wręcz przygniatająca: Paryż, Londyn i Warszawa miały łącznie posiadać 1900 maszyn tej kategorii, ich przeciwnicy $-6000^{4}$.

Przedstawione wnioski były więc znacznie bardziej ostrożne od zaprezentowanych przez ministra lotnictwa trzy dni wcześniej. Istotnie, potwierdzał Vuillemin, konstatowane przed rokiem wielkie zapóźnienie względem mocarstw totalitarnych zostało przez Francję w części odrobione, szczególnie w lotnictwie myśliwskim, a do pewnego stopnia także w przypadku lotnictwa rozpoznawczego. Brak jednak w jednostkach nowoczesnych samolotów bombowych powoduje, że francuskie siły powietrzne pozbawione są zasadniczo zdolności ofensywnych i stan taki utrzymywać się będzie jeszcze przez co najmniej 4-5 miesięcy. Pewną szansę poprawy tej sytuacji stanowi zapowiedź przebazowania na terytorium Francji w pierwszych tygodniach wojny części brytyjskiego lotnictwa bombowego. Mogłoby ono z lotnisk po południowej stronie Kanału podjąć bardziej intensywną akcję, do czego należy partnerów z Londynu zdecydowanie zachęcać. W lotnicze rachuby nie sposób natomiast włączać Polski, Rumunii, Turcji, a tym bardziej Grecji. Państwa te, stwierdzał dowódca Armée de l'Air, „nie posiadają prawdziwych sił powietrznych" - ich lotnictwo wojskowe znajduje się dopiero $w$ stadium modernizacji i rozbudowy, zaś lotnicza infrastruktura jest niedostateczna.

$\mathrm{Na}$ razie więc - podsumowywał Vuillemin - nie można mówić o równorzędnych możliwościach lotniczych obu stron zbliżającego się konfliktu. Taki stan mógłby dopiero zaistnieć $w$ perspektywie mniej więcej 6 miesięcy, pod warunkiem że odpowiednia produkcja zachodnich demokracji nie dozna większego uszczerbku skutkiem powietrznej ofensywy przeciwnika, a Berlina i Rzymu nie wesprze aktywnie Moskwa ${ }^{5}$.

W Londynie ukształtowaną 23 sierpnia sytuację przyjęto nieco spokojniej. Pierwsze jej oceny wojskowi z kręgu Komitetu Obrony Imperialnej spróbowali sformułować dopiero po południu 25 sierpnia. Obradujący wówczas Połączony Podkomitet Planowania uznał jednak, że sytuacja nadal pozostaje płynna i nie dość jasna, a niemożność uzyskania w krótkim czasie opinii Foreign Office jeszcze bardziej utrudnia czynienie jakichkolwiek komentarzy o wiążącym charakterze. Zamiast tych ostatnich

1 W rzeczywistości Armée de l’Air posiadała w tym czasie nominalnie aż 3959 samolotów wszystkich kategorii. Jednak tylko 1756 z nich można było wykorzystać niemal natychmiast (w ciągu czterech godzin), z tej zaś liczby tylko 497 stanowiły maszyny uznawane za w pełni nowoczesne. W dyspozycji brytyjskiego lotnictwa wojskowego znajdowały się wówczas 2753 maszyny na terenie metropolii oraz 677 samolotów na obszarach zamorskich (SHD-DAA, 3 B 47, zestawienie "Situation des Avions de Guerre de l'Armée de l'Air à la date 16 Août 1939"; TNA, AIR 8/218, zestawienia "Summary of Strenght of Metropolitan Force Squadrons as at 31 st August 1939, Compared with Existing Approved Establishments”, „Summary of Strenght of Overseas Squadrons as at 31 st August 1939, Compared with Existing Approved Establishments").

s SHD-DAA, 11 Z 12940, kopia pisma No 167/E.M.G.A.A/S Vuillemina do La Chambre'a 226 VIII 1939 r. 
wskazano więc tylko szereg kwestii do dalszego rozważenia, większość z nich kończąc znakami zapytania. Za zagadnienie ostatnie i najważniejsze z tej serii uznano możliwość zmuszenia Rzeszy do równoczesnego prowadzenia wojny na dwóch frontach. Tu jednak większych wątpliwości nie było. „Odpowiedź w tym momencie wydaje się brzmieć: Nie" - konkludowali członkowie podkomitetu'.

Stanowisko takie, współtworzone zresztą przez płk. Slessora, bardzo szybko znalazło odzwierciedlenie w analizach planów działań powietrznych. Jego lotnicze aspekty szef Dyrekcji Planowania najpełniej bodaj rozwinął w opracowanym 26 sierpnia dokumencie o znamiennym tytule "Air action in the West in support of Poland", przedstawiając propozycję ostatecznego rozstrzygnięcia kwestii wyboru akcji, która miałaby zostać podjęta, w razie gdyby Niemcy zaatakowali wschodniego alianta, zachowując na Zachodzie postawę defensywną. Jak wyjaśniał, zarówno rozwój sytuacji politycznej, jak i planowane na najbliższe dni wznowienie rozmów ze stroną francuską skłaniać tu winny do podjęcia decyzji.

Wcześniejsze ustalenia sprawiły, że wybór, który początkowo obejmował cztery warianty operacji powietrznych, zawężony został do dwóch najmniej spośród nich radykalnych, oznaczonych jako alternatywy A i B. Jak stwierdzał Slessor, przyjęcie pierwszej $z$ nich oznaczać będzie faktyczną rezygnację $z$ oddziaływania na rozwój wydarzeń wojennych $w$ Polsce, a także z prób zmuszenia Niemiec do prowadzenia wojny na dwóch frontach. Może być także sprzeczny - zauważał brytyjski oficer z przyjętymi zobowiązaniami udzielenia Polsce przez Londyn „wszelkiej możliwej pomocy" i wywołać niechętne reakcje państw neutralnych. Jednakże, stwierdzał, wybór opcji $B$ i tak nie zmieni znacząco sytuacji przynajmniej w dwóch pierwszych z wymienionych kwestii.

Co więcej, podkreślał Slessor, wnioski z wcześniejszych analiz w ogromnej części zdezaktualizował rozwój sytuacji. Teraz bowiem wydaje się oczywiste, że „nie możemy mieć nadziei na uchronienie Polski przed podbojem - wydaje się nawet możliwe, że może ona zostać podzielona między Niemcy i Rosję" . Żadne działania Zachodu nie zdołają zmienić nieuchronnego biegu wydarzeń. Stąd, konkludował Slessor, „naszym celem stać się musi odbudowa niepodległości Polski przez pokonanie Niemiec. [...] Nasza akcja winna być określana od początku nie przez rozważania, w jaki sposób moglibyśmy dostarczyć Polsce bezpośredniej pomocy, ale jak najlepiej możemy pokonać Niemcy w długiej perspektywie" [podkr. oryg. $]^{8}$.

Innymi słowy, przyjęcie wariantu B operacji powietrznych skutkować mogłoby jedynie udawaniem, że strona brytyjska próbuje coś zrobić dla Polski, nie przynosząc jednak żadnych realnych efektów. Jedynym odczuwalnym skutkiem byłaby w tym

6 TNA, CAB 55/3, „Minutes of the Meeting of the Sub-Committee held on [...] 25th August, 1939..., J.P. 269 Mtg.

TNA, AIR 9/445, „Air action in the West in support of Poland” J. Slessora z 28 VIII 1939 r. $\mathrm{W}$ ostatnim zdaniu początkowe ...it even seems likely zastąpiło ostatecznie mniej zdecydowane probably. Dokument powstał 26 sierpnia - pierwotną datę Slessor zmienił następnie odręcznie, dopisując do tekstu jeszcze jedno zdanie.

"Ibidem. 
przypadku bardzo poważna redukcja możliwości zadania Niemcom decydującego ciosu, gdy polityczne uwarunkowania uczyniłyby to możliwym. Przedwczesne zużycie wciąż bardzo szczupłych rezerw sprzętu i personelu byłoby błędem. Lepsze rozwiązanie stanowić będzie zachowanie ich $w$ stanie nietkniętym, do czasu gdy rzeczywiście będą w stanie odegrać decydującą rolę w wojnie, uderzając w najbardziej żywotne części niemieckiego systemu, jak zasoby ropy naftowej czy energetyka.

Slessor zastrzegał, że nie jest w stanie osądzić politycznych i dyplomatycznych aspektów rozpatrywanego zagadnienia, nie wie też, jakie reakcje ewentualna brytyjska bezczynność w powietrzu może wywołać w państwach neutralnych. Choć jednak jego analiza istotnie dotyczyła tylko kwestii natury wojskowej, było oczywiste, że zawarte w niej tezy nie są przeznaczone tylko dla wojskowych odbiorców.

Ci ostatni zresztą nieustannie w tym czasie podejmowali działania na styku sfery wojskowej i politycznej. Taki też $w$ gruncie rzeczy charakter miały rozmowy międzysztabowe ze stroną francuską, których kolejna tura miała się rozpocząć w Londynie 28 sierpnia. Porządek tego spotkania został wstępnie przyjęty przez Pokomitet Zastępców Szefów Sztabów 24 sierpnia, obejmując w kolejności: wojskowe konsekwencje nowej sytuacji w Europie, anglo-francuską akcję pomocy dla Polski i politykę bombardowań. Dalsze punkty odnosiły się głównie do spraw spoza obszaru Europy, mogą więc zostać w naszej analizie pominiętey.

Wydarzenia kilku poprzednich dni sprawiły, że aktualność straciła zarówno część przyjętych na poprzednim etapie rozmów uzgodnień, jak i niektóre zapisy pierwotnej wersji ich agendy. 25 sierpnia Połączony Podkomitet Planowania podjął więc próbę wprowadzenia tu uaktualnień, z góry zastrzegając, że ze względu na utrzymującą się płynność sytuacji i brak opinii Foreign Office jest w stanie sformułować raczej uwagi niż zalecenia.

W przypadku sytuacji w Europie Wschodniej uwagi te sprowadzały się do trzech zasadniczych kwestii, które należało przedyskutować z przedstawicielami Paryża, przedstawiając uprzednio własne stanowisko. Po pierwsze, wskazywali członkowie Połączonego Podkomitetu Planowania, choć w Londynie nigdy nie wiązano zbytnich nadziei $z$ bezpośrednią radziecką pomocą $w$ razie wojny, to sądzono, że potencjalne zagrożenie ze strony ZSRR zatrzyma na wschodzie pewną część sił niemieckich. Teraz, sugerowano, taki rozwój wydarzeń zdaje się wątpliwy. Po drugie, Rumunia, zmuszona obecnie do baczenia na trzy zagrożone granice, zachowa zapewne neutralność, jeśli tylko sama nie zostanie zaatakowana. Alianci liczyć jednak mogą, że będzie to neutralność dla nich przyjazna. Po trzecie wreszcie, „[...] możliwość zorganizowania "długiego, solidnego i trwałego « frontu na wschodzie obecnie znikła" ${ }^{\circ}$.

" TNA, CAB 54/2, „Agenda for conversations commencing Monday, 28th August, 1939” i in. dok.

11 TNA, CAB 53/3, „Minutes of the Meeting of the Sub-Committee held on [...] 25th August, 1939..."; CAB 55/19, „Brief for item I of agenda for French Conversations, commencing Monday, 28th August, 1939. Military Implications of new situation in Europe", zał. do pisma J.P. 529 (Revise) Joint-Planning Committee z 27 VIII 1939 r. Opinia Foreign Office na temat konsekwencji sytuacji, która ukształtowała się w Europie po 23 sierpnia, sformułowana została dopiero 27 sierpnia. Dra- 
Opracowany tegoż dnia i przekazany Francuzom projekt agendy rozmów nie zawierał już, co znamienne, punktu odnoszącego się do działań na rzecz Polski. Umieszczony w pierwotnej jej wersji zapis zastąpiony został nową formułą, dotyczącą bombardowań lotniczych. Strona francuska zmianę przyjęła nie bez zastrzeżeń: gen. Lelong po otrzymaniu dokumentu zaproponował, by to ostatnie zagadnienie powiązać jednak ze sprawami pomocy dla sprzymierzeńca ze wschodu ${ }^{11}$.

Niemal równocześnie nad Tamizą starano się zamknąć ostateczną konkluzją serię prowadzonych od dłuższego czasu analiz dotyczących działań, które w pierwszych dniach wojny miałyby zostać podjęte przez brytyjskie lotnictwo bombowe. Rolę spiritus movens odgrywał tutaj ponownie płk Slessor, i to jego właśnie przemyślenia wpływały w znacznym stopniu na treści opracowywanych dokumentów.

Wieczorem 26 sierpnia Szef Sztabu Lotnictwa przesłał ministrowi lotnictwa opracowanie „Immediate action by the Bomber Command of the Royal Air Force on the outbreak of war". Zawierało ono kolejne podsumowanie czterech możliwych wariantów działań lotniczych, uzupełnione uwagą, że wobec założenia, iż Niemcy nie podejmą początkowo nieograniczonej wojny powietrznej, a aktywność brytyjską hamować będzie instrukcja w sprawie bombardowań, w grę wchodzić mogą jedynie opcje A i B. Jednak, stwierdzano w raporcie, z punktu widzenia wojskowego wybór wariantu $B$ już uprzednio budził spore zastrzeżenia, a wydarzenia ostatnich dni znacząco jeszcze poszerzyły ich listę. W lipcu, gdy formułowany był zestaw czterech możliwych wariantów działań bombowych, można było zakładać, że polski opór wobec agresji Rzeszy potrwa dwa do trzech miesięcy. W tak relatywnie długim czasie „coś mogłoby się wydarzyć", poprawiając szanse zaatakowanych. W grę wchodziła także, przynajmniej w teorii, ewentualna radziecka interwencja na rzecz tych ostatnich. Teraz obie te szanse zostały przekreślone, Polska nie tylko straciła możliwość stawienia dłuższego oporu, ale „może nawet zostać zaatakowana od tyłu przez Rosję".

Dalsza część wywodu łudząco przypominała tezy zawarte w opracowanej równolegle, znanej nam już analizie płk. Slessora, wysoce prawdopodobne więc, że był on autorem i tego dokumentu. Końcowe partie analizy zaczerpnięto natomiast $\mathbf{z}$ innego opracowania, które w kręgu Dyrekcji Planowania powstało niewiele wcześniej, a mianowicie raportu „Employment of the Air Striking Force in War" J.P. 526. Autor lub autorzy omawianej noty, zauważając, że wybór wariantu A brytyjskich działań bombowych, choć w pełni uzasadniony militarnie, okazać się może niedogodny politycznie, proponowali bowiem podjęcie działań $w$ ramach opcji $B$, okrojonej jednak "do minimalnego zakresu, niezbędnego dla zaspokojenia wymagań politycznych". Praktyczna strona tej propozycji sprowadzała się zaś do dwóch przedstawionych już

matycznie pogorszoną pozycję Polski wzmiankowano tam jedynie we fragmencie poświęconym ZSRR, formułując ocenę zbieżną z poglądami przedstawicieli sił zbrojnych: „obecnie nie ma szans na wojnę na dwóch frontach w jakiejkolwiek perspektywie czasowej” (TNA, CAB 21/754, „Implications of New Situation in Europe and Far East" z 27 VIII 1939 r.).

" SHD-DAT, 2 N 229, „Projet d'ordre du jour pour les Conversations commençant le 28 Août 1939” z 25 VIII 1939 r. i in. dok.; TNA, CAB 29/160, „Suggested Agenda for the Conversations on Monday, 28th August, 1939", A.F.C. (J) 98 z 26 VIII 1939 r. 
przez nas uprzednio rozwiązań: uderzenia na niemiecką flotę w Wilhelmshaven lub też ataku na system śródlądowych dróg wodnych Rzeszy. Zawierający bardziej obszerne uzasadnienie takiego kroku raport J.P. 526 płk Slessor rozesłał zresztą równolegle gwoli uzupełnienia i konsultacji ${ }^{12}$.

Dwa dni później, 28 sierpnia, dokument „Immediate action by the Bomber Command of the Royal Air Force on the outbreak of war" Połączony Podkomitet Planowania przedłożył do rozważania Szefom Sztabów. Była to już kolejna jego redakcja, wzbogacona m.in. o uporządkowane konkluzje. Ich autorzy podkreślali z naciskiem konieczność podjęcia przez rząd Jego Królewskiej Mości decyzji co do postawy, jaką zająć miałaby Bomber Command w początkach spodziewanego konfliktu. Oni sami rekomendowali wybór wariantu $A$, proponując w pierwszych dniach działań nie podejmować żadnej akcji lotniczej z wyjątkiem operacji niezbędnych dla wsparcia francuskich sił lądowych. W wyraźnym dążeniu do powstrzymania polityków od przyjęcia bardziej agresywnego nastawienia zwracali także uwagę na to, że ewentualny, motywowany politycznie wybór opcji B sytuację zmieni w niewielkim stopniu, ze względu na bardzo nieliczne cele wchodzące $w$ tym przypadku w grę, zaś opcja C zastosowana zostanie automatycznie, gdy tylko Niemcy zainicjują nieograniczoną wojnę powietrzną. Podkreślali też, że przedstawiona analiza i wynikające $z$ niej propozycje odnoszą się jedynie do najwcześniejszego okresu wojny, wszelkie więc ewentualne decyzje miałyby charakter jedynie tymczasowy ${ }^{13}$.

Przyjęcie powyższej rekomendacji skutkować musiałoby nieuchronnie skreśleniem polskiego aspektu operacji lotniczych z porządku dziennego nie tylko $\mathbf{w}$ Londynie, ale najpewniej także w Paryżu. Tak się jednak nie stało. Ku pewnemu zaskoczeniu Brytyjczyków przeciwko koncepcji wstrzymania wszelkich działań powietrznych na rzecz polskiego sojusznika gwałtownie zaprotestowali bowiem Francuzi.

Krok ten, rzecz jasna, nie był bynajmniej związany z nagłym przypływem sentymentu do alianta znad Wisły. Tego ostatniego w Paryżu nadal postrzegano w zasadzie wyłącznie przez pryzmat własnego interesu. O ile jednak względnie bezpieczni za Kanałem Brytyjczycy mogli pozwolić sobie na konstatację, że w zaistniałej sytuacji los Polaków dopełni się szybko i brutalnie, Zachód zaś w żaden sposób nie zdoła temu zapobiec, o tyle w przypadku Francuzów poprzestanie na przyjęciu tej prawdy do wiadomości nie wchodziło w rachubę. W rozumieniu Gamelina i Vuillemina każdy tydzień polskiego oporu służyć miał bowiem dalszemu wzmacnianiu własnego systemu obrony, stąd też całkowite pozostawienie na łasce losu sprzymierzeńców z Warszawy byłoby krokiem nierozsądnym. Francuscy generałowie dobrze też zdawali sobie sprawę z tego, że milcząca aprobata porzucania przez Londyn sojuszników w ich akurat przypadku nie jest rozwiązaniem najlepszym $\mathrm{z}$ możliwych.

12 TNA, AIR 14/446, pismo 5321 Slessora do dowódcy Bomber Command Air Chief-Marshala Edgara Ludlow-Hewitta 226 VIII 1939 r. i nast. dok.

13 TNA, CAB 55/19, szkic raportu „Immediate action by the Bomber Command of the Royal Air Force on the outbreak of war" z 28 VIII 1939 r. 
Przygotowana agenda rozmów międzysztabowych przewidywała podjęcie sprawy działań bombowych zaraz na początku cyklu spotkań. W pierwszym ich dniu, 28 sierpnia, na wniosek gospodarzy uzgodniono przesunięcie tego punktu na dzień następny. Po południu 29 sierpnia, na 15. posiedzeniu plenarnym, zaniepokojeni przedstawiciele Paryża zaczęli naciskać na Brytyjczyków, by ci sprecyzowali zamierzone w początkach wojny akcje swych sił lotniczych, informując zarazem, iż nad Sekwaną zdecydowano się podjąć działania w ramach wariantu B. Otrzymawszy wreszcie odpowiedź, że choć Londyn nie podjął jeszcze formalnie ostatecznej decyzji, to zamierza ograniczyć się do opcji A, a w każdym razie działań „nieco poniżej" wariantu B, Francuzi zareagowali niezadowoleniem czy nawet - jak relacjonował na gorąco obradującym w tym czasie Szefom Sztabów Air Vice Marshal Evill - „wydawali się zszokowani”. Natychmiast też zaczęli nastawać na "bardziej żywą akcję" sił powietrznych brytyjskiego alianta, starając się go skłonić do podjęcia wespół z Armée de l’Air próby zniszczenia niemieckiej sieci komunikacji wojskowej ${ }^{14}$.

Przedstawiona propozycja spotkała się ze sprzeciwem Air Marshala Newalla, który $z$ wyraźną irytacją wyjaśnił, że ewentualne podjęcie podobnej akcji doprowadzi jedynie do ciężkich strat, w niczym zaś nie pomoże Polakom. Dodał też w oskarżycielskim tonie, że Francuzi próbują dysponować znacznie większym od ich własnych sił lotnictwem brytyjskim, zaprzągając je do wsparcia działań lądowych.

Z dalszej części dyskusji Szefów Sztabów wynikało zresztą, że strona brytyjska wciąż w istocie nie zna szczegółów francuskich zamierzeń ani nie jest pewna, czego sojusznik oczekuje od niej samej. Wywołało to zgryźliwe komentarze gen. Ismaya, który zauważył, iż sprawa lotniczej współpracy z Paryżem rozpatrywana jest od roku, stąd sytuacja wydaje się dziwna. Zasugerował więc, że obie delegacje powinny natychmiast przystąpić do uzgodnienia zadań, które $w$ początkach wojny zamierzają podjąć siły powietrzne każdego $z$ państw, i zakładanych efektów tych akcji. W razie braku takiego porozumienia, stwierdził, problem będzie musiał zostać rozwiązany przez gen. Gamelina i brytyjskich Szefów Sztabów. Zebrani przyjęli te propozycje ${ }^{15}$.

Do zawieszonej w ten sposób kwestii powrócono dzień później, w trakcie kolejnego posiedzenia. Tym razem obrady przebiegały $w$ mniej nerwowej atmosferze. Występujący w roli referenta zagadnienia płk Slessor przyznał, że Francuzi byli rozczarowani charakterem przedstawionych im poprzedniego dnia brytyjskich planów lotniczych na pierwsze dni wojny. Uznając, że Londyn zamierza tu „zrobić bardzo niewiele”, wypowiadali się „ze względu na osłabienie presji na Polskę" za przyjęciem

14 TNA, CAB 53/11, „Minutes of the 315th Meeting, held on 29th August, 1939”, C.O.S./315th Mtg.

15 Ibidem. Zapisy minuty z odbytego 29 sierpnia 15 . posiedzenia rozmów międzysztabowych, choć zasadniczo zgodne z relacją Evilla, brzmiały mniej dramatycznie. Zawierają natomiast informację o odbytej kilka godzin wcześniej wstępnej rozmowie Evilla $z$ reprezentantem francuskich sil powietrznych, płk. Rozoyem (TNA, CAB 29/160, „Minutes of Fifteenth Meeting [...] on Tuesday, 29th August, 1939", A.F.C. (J) 15th Meeting). Wersję francuską przebiegu 15. sesji rozmów zawiera pismo No 359/S przewodniczącego delegacji francuskiej wiceadm. J. Odend'hala do Gamelina 230 VIII 1939 r. (SHD-DAT, 2 N 229). 
wariantu B operacji powietrznych. Wyjaśniono im jednak, że zdaniem Air Staff na rzecz Polski uczynić można właśnie „bardzo niewiele”, potęga Luftwaffe przewyższa bowiem połączone siły zachodnich sojuszników, ci zaś pragną zachować swe zasoby na później, nie trwoniąc ich $w$ atakach, które nie wpłyną na wojenne możliwości Rzeszy. Francuzi, zapytani następnie wprost, co oni sami zamierzają uczynić, zaproponowali przyjęcie opcji B i atak na niemieckie lotniska na bezpośrednim zapleczu frontu zachodniego. Jak wyjaśnili brytyjskim partnerom, w tym przypadku celem nie byłoby zniszczenie rozmieszczonych na ziemi wrogich maszyn, ale uszkodzenie pól wzlotów, by uczynić je niezdatnymi do działań.

Zdaniem Slessora akcja taka byłaby jednak nieracjonalna i nieekonomiczna. Niemcy w rejonie nadgranicznym posiadali bardzo liczne lotniska i nie sposób było ustalić, które $z$ nich mają zostać wykorzystane w pierwszych dniach wojny. Z drugiej strony, zauważył Slessor, przedstawiony zamysł nie koliduje z planami Londynu, francuskim sojusznikom należałoby tylko uprzytomnić raz jeszcze konieczność oszczędzania sił. Powtórzone po raz kolejny przez delegatów Paryża argumenty o konieczności zmniejszenia nacisku na Polskę niewiele zdaniem Slessora wnosiły. Dyrektor Planowania odniósł zresztą wrażenie, że partnerzy sami nie mają tu klarownej koncepcji, zaś ich plany „nie zostały jasno przemyślane”16.

W dalszej części dyskusji kontynuowano rozważania na temat działań lotniczych, zaś jej uczestnicy formułowali rozbieżne opinie, zgadzając się jednak, że w najbliższym czasie praktyczne możliwości podjęcia efektywnych akcji bombowych są niewielkie. Ostatecznie znów przychylono się do propozycji gen. Ismaya, by opracować dwa warianty zamierzeń na początkowe dni wojny, z założeniem rozpoczęcia przez Niemcy nieograniczonej wojny powietrznej (co pociągałoby za sobą zastosowanie wariantów $\mathrm{C}$ i D) lub też zastosowania przez Rzeszę reguł tej wojny podobnych do przyjętych już po stronie brytyjskiej ${ }^{17}$.

Dokument taki powstał 31 sierpnia. Szefowie Sztabów informowali w nim o opracowania szeregu szczegółowych planów uderzeń na Rzeszę, a także rozkazów o charakterze wykonawczym. Sygnalizowali też gotowość jednostek Bomber Command do natychmiastowego podjęcia przewidzianych akcji. Proponowali, by w razie zainicjowania przez Rzeszę nieograniczonych działań w powietrzu, brytyjskie lotnictwo bombowe podjęło uderzenie na niemieckie zasoby paliw płynnych, niezbędne do prowadzenia wojny, ograniczone, a przy tym relatywnie wrażliwe na bombardowania lotnicze. W drugim, ograniczonym wariancie strona brytyjska miałaby poprzestać na uderzeniach na cele o ściśle militarnym charakterze, pamiętając przy tym, jak skrupulatnie przypomniano, że nie jest w stanie istotnie wpłynąć na los

16 TNA, CAB 53/11, „Minutes of the 316th Meeting, held on 30th August, 1939”, C.O.S./316th Mtg.

1" Ibidem. Wrażenie Slessora było, jak się wydaje, trafne - przynajmniej w części. Akcja francuska miała na celu oslabienie pierwszego impetu Luftwaffe, przy stosunkowo niewielkich stratach własnych. Podobne działania oczywiście nie miałyby wpływu na sytuację w Polsce, Francuzi nie po raz pierwszy użyli „karty polskiej” dla skłonienia Londynu do korzystnych dla siebie decyzji. Zauważyć można, że i druga strona niekiedy czyniła podobnie. 
równocześnie postrzegali Rzeczpospolitą jako nieodzowny element wschodniego frontu, bez którego niemożliwe okazać się mogło ostateczne zwycięstwo. To zaś nakazywać im winno podtrzymywanie jej egzystencji, także w razie konfliktu zbrojnego.

W obu państ wach podjęto próby zmierzenia się z powyższym problemem. A choć o szczegółach przeprowadzanych analiz drugiego partnera informowano skąpo i niezbyt chętnie, to wyniki tych studiów okazały się zbliżone. I w Paryżu, i w Londynie wskazano dwa możliwe rozwiązania, które byt polskiego trzonu frontu wschodniego mogły przedłużyć, być może nawet do ostatecznego zwycięstwa antyniemieckiej koalicji. Pierwsze, uznawane w zasadzie za nieodzowne, stanowiło oparcie tego frontu o materiałową, surowcową i żywnościową pomoc ZSRR, a najlepiej też jego aktywne wojskowe wsparcie przez Moskwę. Drugie, znacznie mniej perspektywiczne - zasilenie owego frontu zawczasu, jeszcze przed wybuchem konfliktu, sprzętem wojskowym, zaś w trakcie wojny pewną liczbą własnych jednostek. Niezależnie od tego zarówno we Francji, jak i w Wielkiej Brytanii rozważano podjęcie w razie agresji Rzeszy na Polskę ograniczonych działań wojskowych w celu złagodzenia niemieckiego nacisku na sprzymierzeńca ze wschodu.

Niemal w każdym z tych przypadków na plan pierwszy wysuwały się kwestie związane z lotnictwem wojskowym. Radzieckie dostawy materiałowe miałyby umożliwić dozbrojenie uważanych za stosunkowo słabe i przestarzałe polskich sił powietrznych oraz podtrzymać w czasie wojny funkcjonowanie polskiego przemysłu lotniczego. W ewentualnej antyniemieckiej interwencji Moskwy udział jednostek lotniczych uznawano za szczególnie pożądany, podobnie jak udostępnienie tym ostatnim baz i lądowisk na terytorium Rzeczypospolitej. Zarówno Francuzi, jak i Brytyjczycy podjęli u schyłku wiosny 1939 roku rozmowy z przedstawicielami Warszawy na temat możliwości wykorzystania polskich lotnisk do operacji swych sił bombowych przeciw obiektom na wschodnich terenach Rzeszy. W stolicach obu mocarstw zachodnich starano się w miarę możności życzliwie rozpatrywać polskie wnioski o finansowe wsparcie zbrojeń lotniczych oraz dostawy sprzętu lotniczego. Nad Sekwaną i nad Tamizą podjęto też analizy możliwości podjęcia działań lotniczych, które prowadzone z Zachodu, odciążyłyby polski front. W przypadku Brytyjczyków działania takie stanowiły zresztą jedyną wchodzącą w grę formę podobnej akcji.

Warszawa, choć liczyła, że ostateczny ratunek przyniesie jej uzgodniona w maju w Paryżu francuska ofensywa lądowa, dobrze zdawała sobie sprawę z tego, iż w pierwszych tygodniach wojny odsieczy spodziewać się będzie mogła niemal wyłącznie z powietrza. Choć więc zabiegi w celu zapewnienia sobie takiej odsieczy oraz dostaw sprzętu lotniczego Polacy podjęli późno, to latem 1939 roku nie ustawali w wysiłkach, by to początkowe opóźnienie nadrobić.

Większość podjętych na Zachodzie prac nad zagadnieniem wojskowej pomocy dla Polski prowadzona była niekonsekwentnie, w dużej mierze skutkiem różnic zdań między przedstawicielami sił zbrojnych a politykami $z$ kręgów rządowych, zaś $w$ brytyjskim przypadku także tarć międzyresortowych. W obu stolicach poważny wpływ na podejmowane decyzje wywierali Szefowie Sztabów sił powietrznych. Choć jednak zarówno w Londynie, jak i w Paryżu brano pod uwagę przede wszystkim włas- 


\section{Zakończenie}

U progu wiosny 1939 roku Rzeczpospolita, stojąc wobec groźby agresji ze strony Rzeszy, znajdowała się w całkowitym niemal osamotnieniu. Zawarty jeszcze w początkach poprzedniej dekady sojusz z Francją istniał bardziej nominalnie niż faktycznie i zarówno sami Polacy, jak i zewnętrzni obserwatorzy dość powszechnie wyrażali opinię, że w razie realnego zagrożenia Paryż nie zechce pośpieszyć z pomocą aliantom ze wschodu. Inni potencjalni obrońcy resztek wersalskiego ładu zachowywali względem Warszawy wyraźny dystans i trudno było przypuszczać, że w razie wzrostu napięcia zmieni się on w czynne na jej rzecz zaangażowanie.

Wojskowa współpraca polsko-francuska kontynuowana była niemal wyłącznie w zakresie wywiadu i lotnictwa wojskowego, i to właśnie w tej ostatniej sferze pojawiły się w lutym 1939 roku pierwsze jaskółki możliwych zmian nastawienia wojskowo-politycznych elit znad Sekwany wobec polskiego sprzymierzeńca.

W drugiej połowie marca 1939 roku wydarzenia związane z kryzysem czechosłowackim i dalszymi agresywnymi poczynaniami Hitlera zdynamizowały sytuację, dwa tygodnie później skutkując udzielonymi Polsce przez rząd z Londynu gwarancjami suwerenności. Równocześnie na większą aktywność względem sojusznika znad Wisły zdecydowała się także Francja, a decyzje o jej zaangażowaniu, początkowo ograniczone do współpracy sił powietrznych, bardzo szybko poszerzone zostały na inne dziedziny.

Szybki rozwój wydarzeń sprawił, że w podjętych u schyłku marca brytyjsko-francuskich rozmowach międzysztabowych kwestia stosunku do gwałtownie zyskującej strategiczne znaczenie Rzeczypospolitej pojawiła się stosunkowo późno. Spowodowało to, że rozważania na temat udzielenia Warszawie pomocy nieuchronnie znalazły się w konflikcie z dwoma wcześniej już przyjętymi pryncypiami strategii mocarstw zachodnich: zasadniczo defensywną ich postawą w początkowej fazie konfliktu oraz ograniczeniem bombardowań lotniczych wyłącznie do obiektów o najściślej militarnym charakterze. Co więcej, przedstawiciele Sztabów Generalnych obu mocarstw stanęli wobec trudnego do rozstrzygnięcia dylematu. Przekonani, że nie będą w stanie udzielić zaatakowanej Polsce efektywnej pomocy, stąd jest ona skazana na zagładę, 
równocześnie postrzegali Rzeczpospolitą jako nieodzowny element wschodniego frontu, bez którego niemożliwe okazać się mogło ostateczne zwycięstwo. To zaś nakazywać im winno podtrzymywanie jej egzystencji, także $w$ razie konfliktu zbrojnego.

W obu państwach podjęto próby zmierzenia się z powyższym problemem. A choć o szczegółach przeprowadzanych analiz drugiego partnera informowano skąpo i niezbyt chętnie, to wyniki tych studiów okazały się zbliżone. I w Paryżu, i w Londynie wskazano dwa możliwe rozwiązania, które byt polskiego trzonu frontu wschodniego mogły przedłużyć, być może nawet do ostatecznego zwycięstwa antyniemieckiej koalicji. Pierwsze, uznawane w zasadzie za nieodzowne, stanowiło oparcie tego frontu o materiałową, surowcową i żywnościową pomoc ZSRR, a najlepiej też jego aktywne wojskowe wsparcie przez Moskwę. Drugie, znacznie mniej perspektywiczne - zasilenie owego frontu zawczasu, jeszcze przed wybuchem konfliktu, sprzętem wojskowym, zaś w trakcie wojny pewną liczbą własnych jednostek. Niezależnie od tego zarówno we Francji, jak i w Wielkiej Brytanii rozważano podjęcie w razie agresji Rzeszy na Polskę ograniczonych działań wojskowych w celu złagodzenia niemieckiego nacisku na sprzymierzeńca ze wschodu.

Niemal w każdym z tych przypadków na plan pierwszy wysuwały się kwestie związane $z$ lotnictwem wojskowym. Radzieckie dostawy materiałowe miałyby umożliwić dozbrojenie uważanych za stosunkowo słabe i przestarzałe polskich sił powietrznych oraz podtrzymać w czasie wojny funkcjonowanie polskiego przemysłu lotniczego. W ewentualnej antyniemieckiej interwencji Moskwy udział jednostek lotniczych uznawano za szczególnie pożądany, podobnie jak udostępnienie tym ostatnim baz i lądowisk na terytorium Rzeczypospolitej. Zarówno Francuzi, jak i Brytyjczycy podjęli u schyłku wiosny 1939 roku rozmowy z przedstawicielami Warszawy na temat możliwości wykorzystania polskich lotnisk do operacji swych sił bombowych przeciw obiektom na wschodnich terenach Rzeszy. W stolicach obu mocarstw zachodnich starano się w miarę możności życzliwie rozpatrywać polskie wnioski o finansowe wsparcie zbrojeń lotniczych oraz dostawy sprzętu lotniczego. Nad Sekwaną i nad Tamizą podjęto też analizy możliwości podjęcia działań lotniczych, które prowadzone z Zachodu, odciążyłyby polski front. W przypadku Brytyjczyków działania takie stanowiły zresztą jedyną wchodzącą w grę formę podobnej akcji.

Warszawa, choć liczyła, że ostateczny ratunek przyniesie jej uzgodniona w maju w Paryżu francuska ofensywa lądowa, dobrze zdawała sobie sprawę z tego, iż w pierwszych tygodniach wojny odsieczy spodziewać się będzie mogła niemal wyłącznie $z$ powietrza. Choć więc zabiegi w celu zapewnienia sobie takiej odsieczy oraz dostaw sprzętu lotniczego Polacy podjęli późno, to latem 1939 roku nie ustawali w wysiłkach, by to początkowe opóźnienie nadrobić.

Większość podjętych na Zachodzie prac nad zagadnieniem wojskowej pomocy dla Polski prowadzona była niekonsekwentnie, w dużej mierze skutkiem różnic zdań między przedstawicielami sił zbrojnych a politykami z kręgów rządowych, zaś w brytyjskim przypadku także tarć międzyresortowych. W obu stolicach poważny wpływ na podejmowane decyzje wywierali Szefowie Sztabów sił powietrznych. Choć jednak zarówno w Londynie, jak i w Paryżu brano pod uwagę przede wszystkim włas- 
ny interes, to postawa Air Marshala Newalla i oficerów z jego otoczenia zdawała się w kwestii zaangażowania na rzecz Polski bardziej konsekwentna niż makiaweliczne poczynania gen. Vuillemina.

Deklarowana często w maju, czerwcu czy lipcu szczególna waga polskiego zagadnienia w miarę zwiększania się realnego niebezpieczeństwa wybuchu wojny oraz prawdopodobieństwa, że pierwszy niemiecki atak nastąpi na Wschodzie, coraz rzadziej miała jednak pokrycie w faktach. Polski opór wobec wszelkich form współpracy z ZSRR, z przyczyn, które na Zachodzie znano, uznając je wszakże za niewystarczające i w zaistniałej sytuacji nieracjonalne, stał się jednym $z$ dodatkowych uzasadnień nasilającej się biernej czy wręcz niechętnej wobec Warszawy postawy. Niemiecko-radzieckie porozumienie z 23 sierpnia dostarczyło tu ostatecznego argumentu: długi i trwały front wschodni nie mógł już powstać, polski partner, dwustronnie zagrożony, utracil przyznane mu w końcu marca zasadnicze strategiczne znaczenie. Pozostawało jedynie podjąć próbę przedłużenia jego skazanej z góry na klęskę walki. Ładownie brytyjskich i francuskich statków wypełniały kierowane nad Wisłę bojowe samoloty. Niemieckie maszyny rozgrzewały silniki. Zbliżał się świt 1 września. 



\section{Conclusion}

Before the arrival of spring in 1939 the Polish Republic, which was under threat by aggression of the Reich, was almost completely stranded. The alliance with France, concluded already at the beginning of the previous decade, was more a nominal than an actual affair, and both the Poles themselves and the external observers quite frequently expressed an opinion that in the case of a real threat Paris would not intend to help the allies in the east. Other potential defenders of the remnants of the order of Versailles maintained a clearly distanced attitude in reference to Warsaw, and it was difficult to assume that in the case of increasing tension it would change into active engagement.

The Polish-French military collaboration was continued almost exclusively in the field of intelligence and military aviation, and it was the latter sphere that saw the first auguries of possible change in the attitude of the military and political elites of France toward their Polish ally.

In the middle of March 1939 the events associated with the Czechoslovakian crisis and Hitler's further aggressive actions rendered the situation more dynamic, which two weeks later resulted in pledges to support to guarantee sovereignty granted to Poland by the government in London. At the same time also France decided to manifest greater activity in reference to the Polish ally, and the decision associated with its engagement, which initially was limited to collaboration of the air forces, was quickly extended to cover other areas.

The rapid development of events caused that in the inter-staff conversations which were held at the end of March the question of the attitude toward the Polish Republic which suddenly gained strategic significance appeared relatively late. This was the reason why the considerations devoted to providing assistance to Warsaw ineluctably clashed with two previously established principles of the strategy of Western powers: the basically defensive attitude in the initial phase of the conflict and the limiting of aerial bombing exclusively to purely military objectives. Moreover, the representatives of the General Staffs of both powers confronted a dilemma which was

difficult to solve. Convinced that they would not be able to help Poland effectively 
in case of an attack, hence the latter country was doomed to perish, at the same time they perceived Poland as a necessary element of the eastern front, without which eventual victory could prove impossible. This in turn was supposed to make them sustain its existence, also in the case of a military conflict.

In both countries attempts were made to confront the aforementioned problem. And even though the other partner was informed about the details of the analyses which were conducted in a reluctant and perfunctory manner, the results of these studies were similar. Both in Paris and in London two possible solutions were indicated, which could prolong the existence of the Polish bulk of the eastern front, perhaps even until the eventual victory of the anti-German coalition. The first solution, which was basically considered indispensable, had to do with focusing this front on the material, resource and food-provision assistance of the USSR, and best of all also the active military support of the front by Moscow. The second solution, which was considerably less future-oriented, had to do with the provision of advance support of this front with military equipment, even before the eruption of a conflict, and during the war itself - with a number of one's own units. Irrespective of this, both in France and in Great Britain the engagement of limited military activities in order to moderate the German pressure on the ally in the east in the case of an aggression of the Reich against Poland.

Almost in all of these cases the questions associated with military aviation came to the fore. The Soviet material provisions were supposed to facilitate the provision of additional military supplies to the Polish air force which was considered weak and obsolete, and to sustain the functioning of the Polish aviation industry during the war. In the case of a possible anti-German intervention of Moscow the participation of air units was considered especially desirable, similarly as rendering the bases and landing strips located in the Republic of Poland accessible to the latter. At the end of spring of 1939 both the French and the British were engaged in talks with the representatives of Warsaw about the possibility of using Polish airfields to conduct operations of their bombing forces against objectives located in the eastern parts of the Reich. In the capitals of both Western powers attempts were made to consider as favourably as they could the Polish requests for financial support of the air force and the supplies of aviation equipment. In Paris and in London analyses of the possibilities of engaging in air operation were also conducted - if such operations were carried out from the West, they would lessen the burden on the Polish front. In the case of the British such activities constituted the only possible form of action.

Warsaw, although it hoped that it would eventually be assisted by the French land offensive which was arranged in May in Paris, was aware that in the first weeks of the war it could hope to receive assistance almost exclusively from air units. Therefore even if attempts whose aim was to secure such assistance and the supplies of aviation equipment were made relatively late, in the summer of 1939 they did not cease to make efforts, to make up for their initial delays.

The majority of the work that was engaged in West in reference to the problem of providing military assistance to Poland was done so in an inconsistent manner, 
to a great extent due to the differences in the opinions of the representatives of the military and the government politicians, whereas in the case of the British it was also due to clashes between the particular departments. In both capitals a considerable influence upon the decisions which were made was exerted by the Chiefs of the Staffs of the air force. However, even though both in London and in Paris the interests of the respective countries were taken into consideration above all other concerns, the attitude of Air Marshal Newall and the officers of his milieu seemed to be more coherent in the question of engagement for the sake of Poland than the Machiavellian activities of General Vuillemin.

However, the significance of the Polish question, which was frequently declared in May, June and July as the real threat of the outbreak of the war increased, and the probability that the first German attack would occur in the East became less and less confirmable by facts. Polish resistance against all forms of collaboration with the USSR, the causes of which were known in the West but which were considered insufficient and, given the situation, irrational, became one of the additional instances of justification of the intensifying passive or even negative attitude toward Warsaw. In this context the German-Soviet agreement signed on 23 August provided the final argument: the long and permanent eastern front could no longer be established; the Polish partner, who was threatened from both sides, eventually lost the fundamental strategic significance which was accorded to him in late March. What remained was only to make an attempt to prolong his struggle which was doomed to fail. The cargo holds of the British and French ships were filled with combat aircraft directed to Poland. The German machines were warming up their engines. The dawn of 1 September was approaching. 



\section{Bibliografia}

I. Archiwa i muzea

1. Archiwum Akt Nowych (Warszawa)

Ambasada RP w Berlinie

Ambasada RP w Londynie

Ambasada RP w Paryżu

Attachaty Wojskowe

Ministerstwo Spraw Zagranicznych

Sztab Główny.

2. Centralne Archiwum Wojskowe (Warszawa-Rembertów)

Generalny Inspektorat Sił Zbrojnych, Biuro Inspekcji

Oddział I Sztabu Głównego

Oddział II Sztabu Glównego.

3. Archiwum Instytutu Polskiego i Muzeum im. gen. Władysława Sikorskiego (Londyn)

Lot. A.I, Lot. A.IV, Lot. A.V: Akta lotnicze

A.11: Ministerstwo Spraw Zagranicznych

A.12: Ambasada RP w Londynie

A.20: Ministerstwo Sprawiedliwości

A.I: Wojsko Polskie 1918-1939

A.II: Akta Kampanii Wrześniowej 1939 roku

A.IV: Akta Szefa Sztabu Armii Polskiej we Francji

B.I: Relacje z Kampanii Wrześniowej 1939 roku

Kolekcje

- Feliks Frankowski: Kol. 26.

- Jan Ciechanowski: Kol. 82.

4. The National Archives (Kew)

AIR (Air Ministry, the Royal Air Force)

- AIR 2: Air Ministry and Ministry of Defence: Registered Files

- AIR 8: Air Ministry and Ministry of Defence: Department of the Chief of the Air Staff: Registered Files)

- AIR 9: Air Ministry: Directorate of Operations and Intelligence and Directorate of Plans: Registered Files 
- AIR 10: Ministry of Defence and predecessors: Air Publications and Reports

- AIR 14: Air Ministry: Bomber Command: Registered Files

- AIR 16: Air Ministry: Fighter Command: Registered Files

- AIR 20: Air Ministry, and Ministry of Defence: Papers accumulated by the Air Historical Branch

- AIR 40: Air Ministry, Directorate of Intelligence and related bodies: Intelligence Reports and Papers

- AIR 75: Marshal Sir John Slessor: Papers

BT (Board of Trade)

- BT 11: Board of Trade and successors: Commercial Relations and Exports Department and predecessors: Registered Files and other records

$\mathrm{CAB}$ (Records of the Cabinet Office)

- CAB 2: Committee of Imperial Defence and Standing Defence Sub-committee: Minutes

- CAB 16: Committee of Imperial Defence, Ad Hoc Sub-Committees: Minutes, Memoranda and Reports

- CAB 21: Cabinet Office and predecessors: Registered Files (1916 to 1965)

- CAB 23: War Cabinet and Cabinet: Minutes

- CAB 24: War Cabinet and Cabinet: Memoranda (GT, CP and G War Series)

- CAB 27: War Cabinet and Cabinet: Miscellaneous Committees: Records (General Series)

- CAB 29: Cabinet Office: International Conferences: Minutes and Papers

- CAB 53: Committee of Imperial Defence: Chiefs of Staff Committee: Minutes and Memoranda

- CAB 54: Committee of Imperial Defence: Deputy Chiefs of Staff Committee: Minutes and Memoranda

- CAB 55: Committee of Imperial Defence: Joint Planning Committee: Minutes and Memoranda

- CAB 104: Cabinet Office and predecessors: Supplementary Registered Files (1923-1951)

FO (Foreign Office)

- FO 371 (Political Departments: General Correspondence from 1906-1966)

- FO 417 (Confidential Print Poland)

- FO 1103 (Registry: Day Books)

GFM (Copies of captured records of the German, Italian and Japanese Governments)

PREM (Prime Minister's Office)

- PREM 1: Correspondence and Papers, 1916-1940

$\mathrm{T}$ (Treasury)

- T 160: Registered Files: Finance Files (F Series)

- T 161: Supply Department: Registered Files (S Series)

WO (War Office)

- WO 106: Directorate of Military Operations and Military Intelligence, and prede-

cessors: Correspondence and Papers

- WO 193: Directorate of Military Operations and Plans, later Directorate of Military Operations: Files concerning Military Planning, Intelligence and Statistics (Collation Files). 
5. Service historique de la Défense - Departement de l'Armée de l'Air (Vincennes)

Série B: Aéronautique militaire entre les deux guerres jusqu'au 10 juillet 1940

- Sous-série 1B: Ministère de l'Air

- Sous-série 2B: État-major de l'Armée de l'Air

- Sous-série 3B: Directions et services - Service technique et industriel de l'Aéronautique

- Sous-série 8Z: Histoire orale

- Sous-série 11Z: Guy La Chambre (1898-1975).

6. Service historique de la Défense - Departement de l'Armée de Terre (Vincennes)

Série N: Troisième République

- Sous-série 1N: Conseil supérieur de la Guerre

- Sous-série 2N: Conseil supérieur de la Défense nationale

- Sous-série 5N: Cabinet du ministre

- Sous-série $6 \mathrm{~N}$ : Secrétariat général du ministère de la Défense nationale

- Sous-série 7N: État-major de l'Armée et attachés militaires

Série NN: Troisième République. Supplément. Archives rapatriées de Russie

- Sous-série 7 NN: Fonds SR-SCR

- Sous-série 7 NN 2: Attachés Militaires 1898-1942.

7. Service historique de la Défense - Archives Privées

- 1 K 224 - Fonds Gamelin

- 1 K 307 - Fonds Musse.

8. Ministère des Affaires étrangères, Archives diplomatiques (La Courneuve)

Correspondance Politique et Commerciale 1914-1940, Europe 1930-1940

- Pologne

- Grande Bretagne

Papiers d'agents

- Henri Hoppenot

Papiers 1940

- Papiers Cabinet Georges Bonnet

- Papiers Hoppenot

- Papiers Rochat

- Reconstitution Fouques-Duparc

Relations commerciales 1918-1940

- Pologne.

9. Biblioteka Polska w Paryżu

- Korespondencja dyplomatyczna 1937-1939 (fotokopie dokumentów z Biblioteki w Cardiff).

10. Centre des archives économiques et financières (Savigny-le-Temple)

Trésor - Dossiers pays: Europe orientale

- Pologne (1919-1939)

Direction de Finances Extérieures

- Pologne 1924-1943.

11. Archives nationales (Pierrefitte-sur-Seine)

- 496 AP: Papiers d'Edouard Daladier.

12. Archivio Storico Diplomatico - Ministero degli Affari Esteri (Rzym)

- Affari Politici 1931-1945, Polonia. 


\section{II. Źródła drukowane}

Documents diplomatiques français 1932-1939. $2^{\text {mt }}$ série: 1936-1939, t. 13: $1^{\text {er }}$ décembre 1938 31 janvier 1939, Paris 1979; t. 14: 1"r février - 15 mars 1939, Paris 1980; t. 15: 16 mars 30 avril 1939, Paris 1981; t. 16: $1^{\text {cr }}$ mai - 24 juin 1939, Paris 1983; t. 17: 25 juin - 12 août 1939, Paris 1984; t. 18: 13-25 août 1939, Paris 1985.

Documents on British Foreign Policy 1919-1939. Third Series, ed. by E.L. Woodward, R. Butler, vol. 4: 1939, London 1951; vol. 5: 1939, London 1952.

Dokumenty z dziejów polskiej polityki zagranicznej 1918-1939, t. 2: 1933-1939, red. nauk. T. Jędruszczak, M. Nowak-Kiełbikowa, Warszawa 1996.

Instrukcja marszałka E. Śmiglego-Rydza dla rozmów z francuskim sztabem generalnym, „Zeszyty Historyczne" (Paryż) 1988, z. 84, s. 207-210.

Międzynarodowe tlo agresji Rzeszy Niemieckiej na Polskę w 1939 roku. Wybór dokumentów, oprac. R. Nazarewicz, Warszawa 1986.

Ministère des Affaires étrangères, Documents diplomatiques 1939-1939. Pièces relatives aux événements et aux négociations qui ont précédé l'ouverture des hostilités entre l'Allemagne d'une part, la Pologne, la Grande-Bretagne et la France d'autre part, Paris 1939.

Morskie aspekty polskiej misji zakupów zbrojeniowych w Anglii $w 1939$ roku. Depesze kmdr. inż. Stanislawa Rymszewicza, oprac. T. Skinder-Suchcitz, Londyn 2011, Materialy Instytutu Polskiego i Muzeum im. gen. Sikorskiego, 17.

Polska w polityce międzynarodowej (1939-1945). Zbiór dokumentów, t. 1: 1939, oprac. W.T. Kowalski, Warszawa 1989.

Polskie dokumenty dyplomatyczne 1938, red. M. Kornat, Warszawa 2007, Polskie Dokumenty Dyplomatyczne.

Polskie dokumenty dyplomatyczne 1939 styczeń-sierpień, red. S. Żerko, Warszawa 2005, Polskie Dokumenty Dyplomatyczne.

Protokóty polsko-brytyjskich rozmów sztabowych, odbytych $w$ Warszawie w maju 1939, „Bellona" (Londyn) R. 39, 1957, z. 3-4, s. 25-57.

Protokóły polsko-francuskich rozmów sztabowych, odbytych w Paryżu, w maju 1939 r., „Bellona" (Londyn) R. 40, 1958, z. 2, s. 165-179.

Instrukcja Marszałka Polski Edwarda Śmiglego-Rydza dla rozmów z francuskim Sztabem Generalnym, „Zeszyty Historyczne” (Paryż) 1984, z. 84, s. 207-210.

Sprawa polska $w$ czasie drugiej wojny światowej na arenie międzynarodowej. Zbiór dokumentów, red. nauk. S. Stanisławska, Warszawa 1965.

Wojna obronna Polski 1939. Wybór źródel, zebr. i oprac. M. Cieplewicz et al., pod kier. E.J. Kozłowskiego, Warszawa 1968, Wojna Wyzwoleńcza Narodu Polskiego.

\section{Dzienniki, pamiętniki, wspomnienia}

Armengaud Paul, Batailles politiques et militaires sur l'Europe. Témoignages, 1932-1940, Paris 1948.

Biddle Anthony Joseph Drexel, Poland and the Coming of the Second World War. The Diplomatic Papers of A.J. Drexel Biddle, Jr., United States Ambassador to Poland, 1937-1939, ed. by P.V. Cannistraro, E.D. Wynot, Jr., T.P. Kovaleff, Columbus 1976. 
Bonnet Georges, Fin d'une Europe. De Munich à la guerre, Genève 1948, Bibliothèque du Cheval Ailé.

Cadogan Alexander, The Diaries of Sir Alexander Cadogan, O.M., 1938-1945, ed. by D. Dilks, New York 1972.

Colbern William Henry, Polska. Styczeń-sierpień 1939. Analizy i prognozy. Komentarze do wydarzeń attaché wojskowego ambasady USA w Warszawie, oprac. B. Grzeloński, Warszawa 1986.

Gamelin Maurice, Servir, t. 2: Le prologue du drame (1930 - août 1939), Paris 1946; t. 3: La guerre (septembre 1939 - 19 mai 1940), Paris 1947.

Gauché Général (Maurice-Henri), Le deuxième bureau au travail (1935-1940), Paris 1953, Archives d'Histoire Contemporaine.

Harvey Olivier, The Diplomatic Diaries of Oliver Harvey, 1937-1940, ed. by J. Harvey, London 1970.

[Ironside William Edmund], The Ironside Diaries, 1937-1940, ed. by R. Macleod, D. Kelly, Constable-London 1962.

[Ismay Hastings Lionel], The Memoirs of General Lord Ismay, New York 1960.

Kirkor Stanisław, Próby dozbrojenia Polski, „Zeszyty Historyczne” (Paryż) 1971, z. 20, s. 34-42.

Kirkor Stanisław, Sprawy finansowe Polski w przededniu ostatniej wojny, „Zeszyty Historyczne" (Paryż) 1972, z. 21, s. 43-62.

Koc Adam, Wspomnienia, oprac. J. Mierzwa, Wrocław 2005.

Kopański Stanisław, Wspomnienia wojenne 1939-1946, wyd. 2, Londyn 1972.

[Kożuchowski Jan], Sprawozdanie J. Kożuchowskiego - Wiceprezesa Banku Gospodarstwa Krajowego od listopada 1935 do listopada 1938 i Wiceministra Skarbu od listopada 1938 do października 1939 oraz Protokót z przestuchania z 12 lutego 1943 r., „Zeszyty Historyczne” (Paryż) 1986, z. 77, s. 207-238.

Kwiatkowski Eugeniusz, Dziennik czynności Ministra Skarbu, oprac. J. Rakowski, „Zeszyty Historyczne" (Paryż) 1991, z. 96, s. 3-156.

Kwiatkowski Eugeniusz, Dziennik. Lipiec 1939 - sierpień 1940, oprac. M.M. Drozdowski, Rzeszów 2003.

Lowczowski Gustaw, Przymierze wojskowe polsko-francuskie widziane z attachatu paryskiego, „Bellona” (Londyn) R. 33, 1951, z. 1-2, s. 44-54.

Łowczowski Gustaw, Wrzesień 1939 widziany z Paryża, „Więż” 1972, nr 9, s. 105-118.

Lubieński Michał, Refleksje i reminiscencje, oprac. M. Kornat, Warszawa 2012.

Łukasiewicz Juliusz, Dyplomata w Paryzu, 1936-1939. Wspomnienia i dokumenty Juliusza Łukasiewicza, ambasadora Rzeczypospolitej Polskiej, oprac. W. Jędrzejewicz, H. Bułhak, Londyn 1989.

Makowski Wacław, Cywil w wojsku. Wspomnienia z życia i wojen. 1930-1945, cz. 3 i 4, Piekary Śląskie 2012.

Malinowski Tadeusz, Kampania wrześniowa i nasze przygotowanie do wojny, „Zeszyty Historyczne" (Paryż) 1982, z. 62, s. 54-141.

Mazurowa Kazimiera, Skazani na wojne, Warszawa 1979.

Modelski Izydor, Wojskowe przyczyny klęski wrześniowej (próba syntezy), cz. 1, „Zeszyty Historyczne" (Paryż) 1990, z. 92, s. 111-181.

Morawski Kajetan, Wspomnienia z pracy w Ministerstwie Skarbu (od grudnia 1936 do października 1939), „Kultura” (Paryż) 1950, nr 2-3, s. 151-189.

Noël Leon, Polonia restituta. La Pologne entre deux mondes, Paris 1984.

Raczyński Edward, W sojuszniczym Londynie. Dziennik ambasadora Edwarda Raczyńskiego 1939-1945, Londyn s.d. 
Rayski Ludomil, Stowa prawdy o lotnictwie polskim 1919-1939, Londyn 1948.

Rivet Louis, Carnets du chef des services secrets, 1936-1944, éd. annotées et présentée par

O. Forcade, S. Laurent, Paris 2010, Le Grand Jeu.

Slessor John, The Central Blue. Recollections and Reflections, London 1956.

Stachiewicz Waclaw, Wierności dochować zolnierskiej. Przygotowania wojenne w Polsce 1935-

1939 oraz kampania 1939 w relacjach i rozważaniach szefa Sztabu Glównego i szefa Sztabu

Naczelnego Wodza, Warszawa 1998.

Starzeński Pawel, Trzy lata z Beckiem, Londyn 1972.

Sword Edward Roland, The Diary and Despatches of a Military Attaché in Warsaw, 1938-1939, ed. by E. Turnbull, A. Suchcitz, London 2001.

Szembek Jan, Diariusz i teki Jana Szembeka (1935-1945), t. 4: Diariusz i dokumentacja za rok 1938. Diariusz i dokumentacja za rok 1939, oprac. J. Zarański, Londyn 1972, Źródla do Najnowszej Historii Polski.

Villelume Paul de, De Munich à Dantzig. Journal (30 août 1938 - 18 août 1939), éd. annotée et commentée par S. Catros, Paris 2015, Mondes Contemporains.

Villelume Paul de, Journal d'une défaite (23 août 1939 - 16 juin 1940), Paris 1976.

Zając Józef, Dwie wojny. Mój udziat w wojnie o niepodleglość $i w$ obronie powietrznej Polski, Londyn 1964, Biblioteka Polska. Seria Czerwona, 63.

\section{Opracowania}

Alexander Martin S., The Republic in Danger. General Maurice Gamelin and the Politics of French Defence, 1933-1940, Cambridge 1992.

Anglo-French Defence Relations between the Wars, ed. by M.S. Alexander, W.J. Philpott, Basingstoke 2002, Studies in Military and Strategic History.

Barbier Colette, Henri Hoppenot (25 octobre 1891 - 10 août 1977), diplomate, Paris 1999, Diplomatie et Histoire.

Bartel Ryszard et al., Z historii polskiego lotnictwa wojskowego 1918-1939, red. nauk. I. Koliński, Warszawa 1978.

Batowski Henryk, Agonia pokoju i początek wojny, sierpień-wrzesień 1939, wyd. 4 popr. i uzup., Poznań 1984.

Batowski Henryk, Europa zmierza ku przepaści, wyd. 2, Poznań 1989.

Batowski Henryk, Polska w polityce Francji w przededniu II wojny światowej, „Dzieje Najnowsze" R. 23, 1991, nr 4, s. 39-51.

Belcarz Bartłomiej, Morane-Saulnier M.S. 406 lotnictwa polskiego, „Militaria i Fakty” 2000, nr 2, s. 34-35.

Belcarz Bartłomiej, Polskie lotnictwo we Francji 1940, Sandomierz 2002.

Bernád Denes et al., PZL.37 Łoś, Gdańsk 2006, Monografie Lotnicze, 100.

Berska Barbara, Kłopotliwy sojusznik. Wplyw dyplomacji brytyjskiej na stosunki polsko-sowieckie w latach 1939-1943, Kraków 2003.

Böhm Tadeusz, $Z$ dziejów naczelnych władz wojskowych II Rzeczypospolitej. Organizacja $i$ kompetencje Ministerstwa Spraw Wojskowych w latach 1918-1939, Warszawa 1994.

Boussard Dominique, Un problème de défense nationale. Laéronautique militaire au parlement (1928-1940), Vincennes 1983. 
The British General Staff. Reform and Innovation c. 1890-1939, ed. by D. French, B.H. Reid, London-Portland 2002, Cass Series - Military History and Policy, 10.

Bruski Jan Jacek, In Munich's Shadow: The Ukrainian Question in Polish Foreign Policy (October 1938 - March 1939), „New Ukraine. Nowa Ukraina” 2011, no. 11, s. 29-42.

Bułhak Henryk, Kontrowersja między generalem Gamelinem a marszalkiem Rydzem Śmiglym na tle kryzysu czechostowackiego w 1938 roku i jej antecedencje z 1936 roku, [w:] Europa Srodkowa $i$ Wschodnia w XX wieku. Studia ofiarowane Wieslawowi Balcerakowi $w$ siedemdziesiąta rocznicę urodzin, red. A. Koryn, P. Łossowski, Warszawa-Łowicz 2004, s. 235-254.

Bułhak Henryk, Polska a Francja (październik 1938 - polowa kwietnia 1939 r.). Niektóre aspekty dyplomatyczne $i$ wojskowe, [w:] Kampania polska 1939 r. Polityka, spoleczeństwo, kultura, t. 1: Strategia, red. M.P. Deszczyński, T. Pawłowski, Warszawa 2013, s. 445-466.

Cain Anthony Christopher, The Forgotten Air Force. French Air Doctrine in the 1930s, Washington 2002, Smithsonian History of Aviation Series.

Carley Michael Jabara, 1939. The Alliance that Never Was and the Coming of World War II, Chicago 1999.

Chadeau Emmanuel, De Blériot à Dassault. Histoire de l'industrie aéronautique en France (1900-1950), Paris 1987.

Ciałowicz Jan, Polsko-francuski sojusz wojskowy 1921-1939, Warszawa 1970.

Ciechanowski Jan, Wielka Brytania i Polska. Od Wersalu do Jałty. Wybór artykułów, dokumentów i recenzji, Pułtusk-Warszawa 2011.

Cienciała Anna, Minister Józef Beck i ambasador Edward Raczyński a zbliżenie polsko-brytyjskie w okresie październik 1938 - styczeń 1939, [w:] Z dziejów polityki i dyplomacji polskiej. Studia poświęcone pamięci Edwarda hr. Raczyńskiego Prezydenta Rzeczypospolitej Polskiej na wychodźstwie, Warszawa 1994, s. 348-363.

Cienciala Anna, Poland and the Western Powers, 1938-1939. A Study in the Interdependence of Eastern and Western Europe, London-Toronto 1968, Studies in Political History.

Cienciala Anna, Polska w polityce brytyjskiej i francuskiej w 1939 roku: wola walki czy próba uniknięcia wojny?, „Zeszyty Historyczne” (Paryż) 1985, z. 75, s. 152-183.

Cienciała Anna, Polska w polityce Wielkiej Brytanii w przededniu wybuchu II wojny światowej, „Kwartalnik Historyczny” R. 97, 1990, nr 1-2, s. 71-104.

Cîrstea Marusia, Din istoria relafiilor anglo-române (1936-1939), Bucureşti 2011.

Cynk Jerzy B., Kulisy niedoszlej dostawy, „Skrzydlata Polska” 2009, nr 8, s. 48-51.

Cynk Jerzy B., Polskie Sity Powietrzne w wojnie, t. 1: 1939-1943, przeł. W. Matusiak, Gdańsk 2001.

Cynk Jerzy B., Sily lotnicze Polski i Niemiec. Wrzesień 1939, Warszawa 1989, Biblioteczka Skrzydlatej Polski.

Czmur Stefan, Wójcik Waldemar, Generalowie w stalowych mundurach, Warszawa-Poznań 2003.

Ćwięk Henryk, W cieniu sojuszu polsko-francuskiego. Wspótpraca wywiadowcza między Warszawa a Paryzem w okresie międzywojennym, [w:] Studia nad wywiadem i kontrwywiadem Polski w XX wieku, t. 1, red. W. Skóra, P. Skubisz, Szczecin 2012, s. 237-250.

Davion Isabelle, Strategiczne stosunki francusko-polskie w latach 1918-1939, „Rocznik Instytutu Europy Środkowo-Wschodniej" R. 9, 2011, z. 1, s. 113-125.

Dessberg Frédéric, Poland in the Political and Military Strategy of France (September-October 1939), [w:] Kampania polska 1939 r. Polityka, spoleczeństwo, kultura, t. 1: Strategia, red. M.P. Deszczyński, T. Pawłowski, Warszawa 2013. 
Dessberg Frédéric, Stosunki francusko-polskie a Zwiazek Sowiecki od śmierci Marszalka Pilsudskiego do paktu Ribbentrop-Molotow (Perspektywa francuska), [w:] Polska bez Marszalka. Dylematy piłsudczyków po 1935 roku, red. M. Wołos, K. Kania, Toruń 2008, s. 31-49.

Deszczyński Marek Piotr, Mazur Wojciech, Na krawędzi ryzyka. Eksport polskiego sprzętu wojskowego w okresie międzywojennym, Warszawa 2004.

Dunin-Wilczyński Zbigniew, Od Belwederu do Pałacu Elizejskiego... Polska-Francja $w$ dwudziestoleciu międzywojennym, Warszawa 2012.

Duroselle Jean-Baptiste, La décadence 1932-1939, Paris 1979.

Facon Patrick, L'Armée de l'air dans la tourmente. La bataille de France 1939-1940, $2^{\circ}$ reimpression, Paris 2005, Campagnes \& Stratégies. Les Grandes Batailles, 22.

Facon Patrick, Histoire de l'armée de l'air, Paris 2009.

Forcade Olivier, La République secrète. Histoire des services spéciaux français de 1918 à 1939, Paris 2008.

French Foreign and Defence Policy, 1918-1940. The Decline and Fall of a Great Power, ed. by R. Boyce, London-New York 2005.

Fridenson Patrick, Lecuir Jean, La France et la Grande-Bretagne face aux problèmes aériens (1935 - mai 1940), Vincennes 1976.

Fridenson Patrick, Lecuir Jean, Vuillemin Joseph, Lorganisation de la coopération aérienne franco-britannique (1935-mai 1940), „Revue d'Histoire de la Deuxième Guerre Mondiale" 1969 , no. 73, s. 43-74.

Georgescu Maria, Midan Christophe, Un exemple de cooperation bilaterale. Les attachés militaires français en Roumanie et roumains en France (1860-1940), Bucarest 2003.

Gibbs Norman Henry, Grand Strategy, vol. 1: Rearmament Policy, London 1976, History of Second World War. United Kingdom Military Series.

Glass Andrzej, Polskie konstrukcje lotnicze do 1939 r., t. 1-3, Sandomierz 2004-2008.

Gmurczyk-Wrońska Małgorzata, Polska - niepotrzebny aliant Francji? (Francja wobec Polski w latach 1938-1944), Warszawa 2003.

Grabowski Waldemar, Katastrofa z Moranem w roli głównej, „Gapa. Lotniczy Magazyn Historyczny" 2014, nr 10-11, s. 11-17.

Grabowski Waldemar, Plany użycia lotnictwa francuskiego na froncie polskim w 1939 r., „Gapa. Lotniczy Magazyn Historyczny" 2013, nr 6, s. 34-39.

Guelton Frédéric, France, Levant et Balkans 1937 - mai 1940. Les illusions perdues d'une grande stratégie périphérique, „Revue Historique des Armées” 2001, no. 226, s. 107-116.

Haight John McVickar, Jr, American Aid to France, 1938-1940, New York 1970.

Higham Robin, Two Roads to War. The French and British Air Arms from Versailles to Dunkirk, Annapolis 2012.

Hill Christopher, Cabinet Decisions on Foreign Policy. The British Experience, October 1938 June 1941, Cambridge 1991.

Historia dyplomacji polskiej (polowa X-XX w.), t. 4: 1918-1939, red. P. Łossowski, Warszawa 1995.

Imlay Talbot C., Facing the Second World War. Strategy, Politics, and Economics in Britain and France, 1938-1940, Oxford 2003.

Imlay Talbot C., France and the Phoney War, 1939-1940, [w:] French Foreign and Defence Policy, 1918-1940. The Decline and Fall of a Great Power, ed. by R. Boyce, London-New York 2005, s. 260-281.

Imlay Talbot C., Preparing for Total War. The Conseil Superieur de la Defense Nationale and France's Industrial and Economic Preparations for War after 1918, "War in History" 2008, vol. 15, no. 1, s. 43-71, [online] http://dx.doi.org/10.1177/0968344507083993. 
Jackiewicz Henryk, Brytyjska pożyczka dla Polski w 1939 r., „Więż” 1974, nr 9, s. $101-111$. Jackiewicz Henryk, Brytyjskie gwarancje dla Polski w 1939 roku, Olsztyn 1980.

Jackson Peter, France and the Nazi Menace. Intelligence and Policy Making, 1933-1939, Oxford-New York 2000.

Jordan Nicole, The Popular Front and Central Europe. The Dilemmas of French Impotence, 1918-1940, Cambridge-New York 1992.

Kalinowski Franciszek, O lotnictwie polskim przed 1939 rokiem, „Bellona” (Londyn) R. 42, 1960, z. 4, s. 306-309.

Kania Krzysztof, Edward Bernard Raczyński 1891-1993. Dyplomata i polityk, Kraków 2014.

Kiesling Eugenia C., Arming Against Hitler. France and the Limits of Military Planning, Lawrence, Kan. 1996.

Kłobuch Klaudiusz, Geneza lotniczego września. Polska doktryna lotnicza i konstrukcje samolotów na tle wrogów i sojuszników, 1926-1939 r., Warszawa-Piekary Sląskie 2009.

Kmiecik Tadeusz, Polskie lotnictwo wojskowe w okresie międzywojennym, „Słupskie Studia Historyczne" 2009, t. 15, s. 203-211.

Kmiecik Tadeusz, Sztab Generalny (Glówny) Wojska Polskiego w latach 1918-1939, Słupsk 2005.

Kmiecik Tadeusz, Węzlowe problemy wykorzystania lotnictwa $w$ przyszlej wojnie $w$ polskiej myśli lotniczej lat 1919-1939, „Słupskie Studia Historyczne” 2003, t. 10, s. 129-148.

Kołakowski Piotr, Czas próby. Polski wywiad wojskowy wobec groźby wybuchu wojny w 1939 roku, Warszawa 2012.

Kołakowski Piotr, Działalność placówki wywiadowczej „Lecomte” Oddzialu II Sztabu Głównego WP w Paryż 1936-1939, „Dzieje Najnowsze” R. 44, 2012, nr 3, s. 61-70.

Kołakowski Piotr, Polski wywiad wojskowy wobec wydarzeń z marca 1939 r., [w:] Wywiad wojskowy II Rzeczypospolitej. Materialy, red. idem, A. Pepłoński, Kraków 2011.

Kopański Stanisław, Przyczynki do genezy polskiego planu operacyjnego do kampanii 1939 r. (cz. II), „Bellona” (Londyn) R. 34, 1952, z. 3, s. 53-60.

Koreś Daniel, Oddziat II Sztabu Głównego Wojska Polskiego pod kierownictwem plk. dypl. Tadeusza Pelczyńskiego w latach 1929-1932 i 1935-1939. Zarys wybranych problemów, [w:] Studia nad wywiadem i kontrwywiadem Polski $w$ XX wieku, t. 1, red. W. Skóra, P. Skubisz, Szczecin 2012, s. 167-235.

Kornat Marek, Choosing Not to Choose in 1939: Poland's Assessment of the Nazi-Soviet Pact, „The International History Review” 2009, vol. 31, no. 4, s. 771-797.

Kornat Marek, Polityka zagraniczna Polski, 1938-1939. Cztery decyzje Józefa Becka, Gdańsk 2012.

Kornat Marek, Polska 1939 roku wobec paktu Ribbentrop-Molotow. Problem zblizenia niemiecko-sowieckiego w polityce zagranicznej II Rzeczypospolitej, Warszawa 2002, Monografie PISM.

Kozłowski Eugeniusz, Wojsko Polskie 1936-1939. Próby modernizacji i rozbudowy, wyd. 2 , Warszawa 1974.

Krząstek Tadeusz, Związki lotnictwa wojskowego Francji i Polski w latach 1918-1940, [w:] Lotnictwo polskie w okresie międzywojennym (materialy z sesji popularnonaukowej), Warszawa-Suwałki 1991, s. 153-173.

Lacroix-Riz Annie, La Pologne dans la stratégie extérieure de la France (octobre 1938 - août 1939), [w:] Kampania polska 1939 r. Polityka, spoleczeństwo, kultura, t. 1: Strategia, red. M.P. Deszczyński, T. Pawłowski, Warszawa 2013, s. 111-123.

Laforest Christophe, La stratégie française et la Pologne (1919-1939). Aspects économiques et implications politiques, Lille 2001, Thèse à la Carte. 
Le Goyet Pierre, France-Pologne 1919-1939. De l'amitié romantique à la méfiance réciproque, Paris 1991.

Le Goyet Pierre, Le mystère Gamelin, Paris 1975.

Leczyk Marian, Polska i sasiedzi. Stosunki wojskowe 1921-1939, Warszawa 2004.

Levy James P., Appeasement and Rearmament. Britain 1936-1939, Lanham 2006.

Liste du Corps Diplomatique à Varsovie, nr 43: Juiin 1939, Warszawa 1939.

Laptos Józef, Dyplomaci II RP w świetle raportów Quai d'Orsay, Warszawa 1993.

Łaptos Józef, Majewski Mariusz W., Francuska pomoc w wyposażeniu armii polskiej (1917-

1939), „Annales Universitatis Paedagogicae Cracoviensis. Studia Historica” 2013, t. 14, s. $102-126$.

Lossowski Piotr, Dyplomacja polska 1918-1939, Warszawa 2001.

Majewski Mariusz Wojciech, Druga próba uruchomienia produkcji silników lotniczych. Polskie Zakłady Škody (1926-1935), „Annales Academiae Paedagogicae Cracoviensis. Studia Historica" 2005, t. 4, Folia 28, s. 148-164.

Majewski Mariusz Wojciech, Problemy z LWS-3 Mewa, „Do Broni” 2009, nr 1, s. 64-71.

Majewski Mariusz Wojciech, Przemyst lotniczy w Lublinie 1919-1939, Piekary Sląskie-Warszawa 2009.

Majewski Mariusz Wojciech, Rozbudowa i dyslokacja wytworni silników lotniczych $w$ Polsce (1935-1939), "Annales Academiae Paedagogicae Cracoviensis. Studia HIstorica” 2007, t. 6, Folia 43, s. 131-161.

Majewski Mariusz Wojciech, Samoloty i zaklady lotnicze II Rzeczypospolitej, Warszawa 2006. Majzner Robert, Attachaty wojskowe Drugiej Rzeczypospolitej 1919-1945. Strukturalno-organizacyjne aspekty funkcjonowania, Częstochowa 2011.

Majzner Robert, Polski wywiad wojskowy wobec polityki III Rzeszy 1933-1939. Militarne aspekty polityki III Rzeszy w świetle analiz Oddziału II Sztabu Glównego Wojska Polskiego, Toruń 2006.

Malak Edward, Administrowanie w lotnictwie polskim 1926-1939 mieniem państwowym w warunkach postępu technicznego, Toruń 2005.

Malak Edward, Dzieło generała Rayskiego, ks. 2: Technika i zarzązanie, Warszawa 2015.

Malak Edward, Prototypy samolotów bojowych i zaklady lotnicze. Polska 1930-1939, Warszawa 2011, Wojna, Technika, Historia.

Malak Edward, Prototypy samolotów bojowych. Polska 1936-1939, Wrocław 1990, Acta Universitatis Wratislaviensis, 1233.

Mazur Wojciech, Broń ostatniej szansy. Zagraniczne zakupy sprzętu wojskowego dla armii II Rzeczypospolitej (wiosna-lato 1939 r.), "Annales Universitatis Paedagogicae Cracoviensis. Studia Historica" 2013, t. 14, s. 143-164.

Mazur Wojciech, II Rzeczpospolita w planach koalicyjnych działań lotniczych przeciw Niemcom (1921-1939), „Przegląd Historyczno-Wojskowy” R. 17, 2016, nr 2-3, s. 201-220.

Mazur Wojciech, Jeśli nie zdarzy się cud... Brytyjskie elity wojskowe wobec szans polskiej obrony (wiosna-lato 1939 roku), „Poligon” 2013, nr 1, s. 74-80.

Mazur Wojciech, Klient podwyższonego ryzyka. Eksport polskiego sprzętu wojennego do Bulgarii w okresie międzywojennym, „Studia z Dziejów Rosji i Europy Srodkowo-Wschodniej” 2006, t. 41, s. 75-103.

Mazur Wojciech, Pod wiatr. Francja i lotnictwo wojskowe II Rzeczypospolitej, 1921-1938, Kraków 2015, Societas, 89.

Mazur Wojciech, Polscy attaché wojskowi jako realizatorzy polityki zbrojeniowej II Rzeczypospolitej. Lata 1921-1939, [w:] Studia nad wywiadem i kontrwywiadem Polski w XX wieku, t. 2, red. W. Skóra, P. Skubisz, Szczecin 2012, s. 121-141. 
Mazur Wojciech, U progu wrześniowego sprawdzianu - polskie lotnictwo wojskowe w oczach sojuszników, „Lotnictwo” 2011, nr 9, s. 78-84.

Mazur Wojciech, Zagraniczne zakupy silników lotniczych dla polskiego lotnictwa wojskowego (1926-1939), cz. 1, „Lotnictwo” 2007, nr 11, s. 58-63; cz. 2, „Lotnictwo” 2007, nr 11-12, s. 60-67; cz. 3, „Lotnictwo” 2008, nr 1, s. 90-96.

McDonough Frank, Poland in the Political and Military Strategy of British Policy, March-September 1939, [w:] Kampania polska 1939 r. Polityka, społeczeństwo, kultura, t. 1: Strategia, red. M.P. Deszczyński, T. Pawłowski, Warszawa 2013.

Mierzwa Janusz, Negocjacje kredytowe w 1939 r. Przyczynek do przygotowań wojennych Polski, „Studia Historyczne” 2005, t. 48, nr 3-4, s. 355-365.

Mierzwa Janusz, Pułkownik Adam Koc. Biografia polityczna, Kraków 2006, Studia z Historii XX Wieku, 2.

Military Planning and the Origins of the Second World War in Europe, ed. by B.J.C. McKercher, R. Legault, Westport 2001.

Millman Brock, The Ill-Made Alliance: Anglo-Turkish Relations, 1934-1940, Montreal-Kingston 1998.

Misiuk Andrzej, Stużby specjalne II Rzeczypospolitej, Warszawa 1998.

Moczulski Leszek, Wojna polska, Warszawa 2009.

Mordawski Hubert, Polskie lotnictwo wojskowe 1920-1939. Od tryumfu do tragedii, Wroclaw 2011.

Morgała Andrzej, Samoloty wojskowe w Polsce, 1924-1939, Warszawa 2003, Encyklopedia Broni $i$ Uzbrojenia.

Mousseau Jacques, Le siècle de Paul-Louis Weiller, 1893-1993. As de l'aviation de la Grande guerre, pionnier de l'industrie aéronautique, précurseur d'Air France, financier international, mécène des arts, [Paris] 1998.

Murray Williamson, The Change in the European Balance of Power, 1938-1939. The Path to Ruin, Princeton 1984.

Newman Simon, Gwarancje brytyjskie dla Polski. Marzec 1939, przeł. J. Meysztowicz, T. Szafrański, Warszawa 1981.

Nurek Mieczyslaw, Polska w polityce Wielkiej Brytanii w latach 1936-1941, Warszawa 1983.

Parker Robert Alexander Clarke, Chamberlain and Appeasement. British Policy and the Coming of the Second World War, New York 1993.

Pasztor Maria, Polska w oczach francuskich kól rządowych w latach 1924-1939, Warszawa 1999.

Pasztor Maria, Polski korpus oficerski w oczach Francuskiej Misji Wojskowej $i$ attachatu wojskowego Francji w Warszawie (1921-1939), „Mazowieckie Studia Humanistyczne” 1998, t. 4, nr l, s. 79-101.

Pawłowski Tymoteusz, Lotnictwo lat 30. XX wieku w Polsce i na świecie. Wybrane zagadnienia, Warszawa 2011.

Peden George C., British Rearmament and the Treasury, 1932-1939, Edinburgh 1979.

Pepłoński Andrzej, Wywiad a dyplomacja II Rzeczypospolitej, Toruń 2004.

Pepłoński Andrzej, Suchcitz Andrzej, Tebinka Jacek, Współpraca wywiadowcza w drugiej polowie lat trzydziestych XX w., [w:] Polsko-brytyjska wspótpraca wywiadowcza podczas II wojny światowej, t. 1: Ustalenia Polsko-Brytyjskiej Komisji Historycznej, red. T. Dubicki, D. Nałęcz, T. Stirling, Warszawa 2004.

Pernot François, Larmée de l'air et les projets périphériques 1939-1940, „Revue Historique des Armées"1999, no. 217, s. 77-88. 
Perrier Patrick, Relations aéronautiques franco-soviétiques (1933-1939), „Revue Historique des Armées" 1991, no. 4, s. 108-116.

Philpott Ian M., The Royal Air Force 1930 to 1939. An Encyclopaedia of the Inter-War Years, vol. 2: Re-Armament 1930 to 1939, Barnsley 2008, Kindle edition.

Piszczkowski Tadeusz, Anglia a Polska 1914-1939 w świetle dokumentów brytyjskich, Londyn 1975.

Płachciak Grzegorz, Zarys działalności informacyjnej $i$ wywiadowczej ataszatu wojskowego w Paryżu w latach 1921-1939, [w:] Polski wywiad wojskowy 1918-1945, red. P. Kołakowski, A. Pepłoński, Toruń 2006, s. 237-250.

Poland in the British Parliament 1939-1945, vol. 1: British Guarantees to Poland to the Atlantic Charter (March 1939 - August 1941), ed. by W. Jędrzejewicz, Trenton, N.J. 1946.

Polska technika lotnicza do roku 1939, t. 1: Źrodła osiagnięć, red. A. Glass, Warszawa 1992.

Polskie Sily Zbrojne w drugiej wojnie światowej, t. 1: Kampania wrześniowa 1939, cz. 1: Polityczne i wojskowe polozenie Polski przed wojna, Londyn 1951.

Prazmowska Anita, Britain, Poland and the Eastern Front, 1939, Cambridge 2004, Soviet and East European Studies.

Prévélakis Constantin, Fictions ou réalités méditerranéennes? Le „Théâtre d'opérations de la Méditerranée orientale" et les projets d'un nouveau front d'Orient (1938-1940), „Matériaux pour l'Histoire de Notre Temps" 2010, no. 3, s. 45-50.

Przedpełski Andrzej, Lotnictwo w myśli wojskowej II Rzeczypospolitej, Toruń 2001.

Raczyński Edward, The British-Polish Alliance: Its Origin and Meaning, London 1948, Publications of the General Sikorski Historical Institute in London.

Rezmer Waldemar, Sity zbrojne Wielkiej Brytanii, Francji i Rumunii oraz plany ich użycia na wypadek wojennego zagrożenia Polski, [w:] Polski wrzesień 1939 r. - wojna na dwa fronty. Pamiętnik konferencji. Materiały z Międzynarodowej Konferencji Naukowej, [Piotrków Trybunalski 9-10 IX 1999], red. A. Felchner, Piotrków Trybunalski 1999, s. 39-54.

Rezmer Waldemar, Tadeusz Kasprzycki - minister spraw wojskowych 20 V 1935 - 30 IX 1939, [w:] Ministrowie spraw wojskowych 1918-1944. Z badań nad polityka wojskowa Polski, red. M. Jabłonowski, Pułtusk 2005, s. 207-236.

Ritchie Sebastian, Industry and Air Power. The Expansion of British Aircraft Production, 193541, London-Portland 1997, Cass Series - Studies in Air Power, 4.

Rojek Wojciech, Pierwsze oceny $i$ komentarze dyplomatów brytyjskich na temat paktu Ribbentrop-Molotow, sierpień 1939 r., [w:] W kręgu polityki, dyplomacji i historii XX wieku. Ksiegga jubileuszowa profesora Waldemara Michowicza, red. B. Rakowski, A. Skrzypek, Łódź 2000, s. 223-237.

Rybka Ryszard, Stepan Kamil, Najlepsza broń. Plan mobilizacyjny „W" $i$ jego ewolucja, Warszawa 2010.

Sarmant Thierry, Les plans d'opération français en Europe centrale (1920-1939), „Revue Historique des Armées" 1999, no. 4, s. 13-22.

Shaw Louise Grace, The British Political Elite and the Soviet Union, 1937-1939, London-Portland 2003.

Skinder-Suchcitz Teresa, Rok 1939. Polsko-brytyjska polityka morska, Warszawa-Londyn 1997.

Soutou Georges-Henri, Polska a stosunki francusko-niemieckie w latach 1914-1990, [w:] Francja, Niemcy i Polska w Europie nowożytnej i najnowszej (XVI-XX w.). Dziesięć lat Trójkąta Weimarskiego. Konferencja międzynarodowa, Uniwersytet im. Adama Mickiewicza w Poznaniu, Poznań, 11-12.10.2001, red. M. Forycki, M. Serwański, Poznań 2003, Publikacje Instytutu Historii UAM, 56. 
Spoleczeństwo $i$ Wojsko Polskie wobec zagrożenia wojennego 1939. Polska $i$ jej armia 19351939, oprac. A. Wesołowski, K. Stepan, N. Bujniewicz, Warszawa 2009, Pamiętamy.

Stachula Adolf, Przygotowania lotnictwa i obrony powietrznej do wojny w 1939 roku w okresie od 24 marca do 31 sierpnia, Legnica 2014.

Stone Glyn, The British Government and the Sale of Arm to the Lesser European Powers, 19361939, [w:] Power and Stability. British Foreign Policy, 1865-1965, ed. by E. Goldstein, B.J.C. McKercher, London-Portland 2005, s. 227-258.

Strang G. Bruce, Once More unto the Breach: Britain's Guarantee to Poland, March 1939, „Journal of Contenporary History" 1996, vol. 31, no. 4, s. 721-751.

Suchcitz Andrzej, Ppłk Emilius Clayton: pierwszy brytyjski attaché wojskowy w Warszawie, [w:] Si vis pacem, para bellum. Bezpieczeństwo i polityka Polski. Księga jubileuszowa ofiarowana profesorowi Tadeuszowi Dubickiemu, red. R. Majzner, Częstochowa 2013, s. 941954, Zeszyty Historyczne Wyższej Szkoly Pedagogicznej w Częstochowie, 12.

Suchcitz Andrzej, Wrażenia generata Ironside'a z wizyt w Polsce w latach 1925 i 1939, „Mars” 1993, nr 1, s. 55-63.

Tebinka Jacek, Polityka brytyjska wobec problemu granicy polsko-radzieckiej, Warszawa 1998.

Tebinka Jacek, Przegląd brytyjskiej literatury naukowej na temat wydarzeń 1939 roku, „Dzieje Najnowsze" R. 41, 2009, nr 3, s. 89-100.

Tebinka Jacek, „Wielka Brytania dotrzyma lojalnie swojego stowa”. Winston S. Churchill a Polska, Warszawa 2013.

To proste - będziemy się bić. Przygotowania obronne (marzec - sierpień 1939), oprac. A. Wesolowski et al., Warszawa 2012.

Turlotte Michel, L'Alliance polonaise à travers les archives de létat-major de l'Armée, „Revue Historique des Armées" 1985, no. 4, s. 70-83.

Ulatowski Łukasz, Polski wywiad wojskowy w 1939 roku. Struktura organizacyjna, sklady osobowe, personel, budzet, mob., Warszawa 2013.

Vajda Ferenc A., Dancey Peter, German Aircraft Industry and Production, 1933-1945, Shrewsbury 1998.

Vivier Thierry, Laviation française en Pologne (janvier 1936 - septembre 1939), „Revue Historique des Armées" 1993, no. 4, s. 60-70.

Vivier Thierry, La politique aéronautique militaire de la France (janvier 1933 - septembre 1939), Paris 1997.

Watt Donald Cameron, How War Came. The Immediate Origins of the Second World War, 1938-1939, London 1989.

Webster Charles, Frankland Noble, Strategiczna ofensywa powietrzna przeciwko Niemcom, t. 1: Przygotowania, Oświęcim 2015, DWŚ, 16.

Wyszczelski Lech, Tajna gra mocarstw. Wiosna-lato 1939, Warszawa 2014.

Zając Józef, Nasze przygotowania do wojny, „Kultura” (Paryż) 1961, nr 1-2, s. 159-188.

Zapalec Anna, Druga strona sojuszu. Żolnierze brytyjscy w Polsce w okresie II wojny światowej, Gdańsk 2014.

Zgórniak Marian, Brytyjsko-francuskie kontakty sztabowe, próby opracowania wspólnej strategii i utworzenia wspólnego dowództwa (1935-1939), [w:] W kręgu polityki, dyplomacji i historii XX wieku. Ksiegga jubileuszowa profesora Waldemara Michowicza, red. B. Rakowski, A. Skrzypek, Łódź 2000, s. 223-238.

Zgórniak Marian, Europa w przededniu wojny. Sytuacja militarna w latach 1938-1939, Kraków 1993, Wydawnictwa „Ksiegarni Akademickiej”, 7.

Zgórniak Marian, Sojusz francusko-brytyjski i problemy jego realizacji w planowaniu oraz praktycznej działalności wojskowej mocarstw zachodnich w 1939 roku, [w:] Z dziejów poli- 
tyki i dyplomacji polskiej. Studia poświęcone pamięci Edwarda hr. Raczyńskiego Prezydenta Rzeczypospolitej Polskiej na wychodźstwie, Warszawa 1994, s. 364-380.

Żerko Stanisław, Stosunki polsko-niemieckie 1938-1939, Poznań 1998, Studium Niemcoznawcze Instytutu Zachodniego, 75.

Żukowski Przemysław Marcin, Na przelomie pokoju $i$ wojny. Francja w oczach polskiej opinii publicznej od wiosny 1938 roku do lata 1940 roku, Kraków 2012. 


\section{Indeks}

Abczyński Henryk 44

Adam Ronald, gen. 210

Alexander Martin S. 72, 121, 169, 178

Arbitre Louis André, płk 143-147, 178, 183 $187,217,239,284,286$

Arciszewski Mirosław 53, 55, 190, 246

Armengaud Paul, gen. 184-186

Ashton-Gwatkin Frank 263-264

Aymé Georges, płk 77-79, 125, 133, 171

Backhouse Roger 243

Bailly Paul, mjr 70, 83, 102-103, 107, 180

Bajan Jerzy, ppłk pil. 34, 258

Banaś Monika 14

Barbier Colette 19

Batowski Henryk 17, 55, 67, 176

Baudoin, kpt. 180

Baume Robert Renom de la 282

Beaumont-Nesbitt Frederick George, bryg. 22,65

Beaurain Janusz de, gen. bryg. obs. inż. 239

Beck Józef 17, 21-22, 29-30, 51-53, 55-56, 58, $67,133,135,138,153,158-159,187-189$, $211,213-216,234,237,241-243,247$, 249, 263, 276-277, 282, 289

Belcarz Bartłomiej 13, 170, 286

Bergeret Jean, płk 169

Białowiejski Stanisław, kpt. techn. 186

Bień Stanisław 26

Biliński Piotr 15
Błeszyński Jerzy, płk dypl. 175

Bobiński Ferdynand, mjr 26, 179-180, 200

Bonnet Georges 19-20, 23, 36, 54, 56-57, 69, 79-80, 143, 147-148, 157-163, 166-167, $175-176,228,234,289,291$

Bottomley Norman Howard, Air Commodore 219

Bouchard, por. 183

Boyce Robert 35

Boyle Archibald Robert, mjr 225, 261, 269 , 279-280

Bridges Edward E. 52, 122

Brown William 243, 245

Bruski Jan Jacek 18

Bührer Jules Antoine 77

Bujniewicz Natalia 60

Bułhak Henryk 12, 14, 19, 21

Burnett Charles, gen. dyw. 233

Butler Rohan 13

Cadogan Alexander 30, 50, 53, 58, 67, 128 $129,159,189,243-245,267$

Campbell Ronald I. 54, 233

Carley Michael Jabara 235

Catros S. 21

Cazenave, kpt. 24, 180

Cesarz Waclaw, chor. 273

Chamberlain Neville 49-54, 57-59, 66, 69, 72, 80-81, 84, 115-116, 139, 212, 245, 248, $259,261,265$ 
Charvériat Émile 19, 30, 175

Chatfield Ernle (Alfred Ernle Montacute Chatfield, 1. baron Chatfield) 59, 62, 65-66, 81, 91-92, 116, 122, 127-128, 157, $188-189,210,229,235,248,262$

Ciałowicz Jan 12, 141, 165, 168-170, 172-173, 175,291

Ciano Galeazzo 29

Ciechanowski Jan Mieczysław 64

Cienciała Anna 13, 21, 45, 55

Cieplewicz Mieczysław 32

Cîrstea Marusia 139

Clayton Emilius H., ppłk 190-191, 193-194, 197, 199-203, 205, 207-209, 217, 222, 261

Clerck de, płk 184, 186

Colbern William H., mjr 66

Collier Alfred Conrad, płk 234

Colson Louis-Antoine, gen. 97, 99, 164, 169, 171

Colyer Douglas, płk 23, 30, 43

Corbin Charles 36, 58, 79, 135, 175

Cornwall-Jones A.T., mjr 117, 123, 190, 198, 230

Couzou, sierż. 183

Culmann Frédéric, gen. 30

Cunnigham Andrew C., wiceadm. 243, 245

Cynk Jerzy B. 278

Czmur Stefan 239

d'Arnaud de Vitrolles Alfred Antoine, ppłk 23-24, 26-31, 33, 43, 139, 153, 169, 178-179

Daladier Édouard 19, 38, 48, 54, 57, 72-73, $77,79-80,126,140-143,147,157-159$, 161-163,167, 172, 175-176, 228-229, $235,238,282-283,291$

Dancey Peter 208

Danckwerts Victor H., kmdr 70, 84-85, 104, 109-110

Darlan Jean François, wiceadm. 98, 229, 291

Davidson Alexander Paul, ppłk 190-191, 199 201, 222-223, 273, 275

Debeney Marie-Eugène, gen. 173

Debrobant, por. 183

Decamp Jules, gen. 140-141, 143

Dentz Henri, gen. 19, 23, 167, 231

Dessberg Frédéric 178
Deszczyński Marek P. 12

Dilks David 50

Domaniewski Wiesław 260, 264, 276-277

Donald David Grahame, Air Commodore 224

Donkin, kpt. 227

Doumenc Joseph, gen. 227-228, 233-235

Drozdowski Marian Marek 214

Dubicki Tadeusz 42

Dunin-Majewski Marian, mjr 166-167

Englicht Józef, płk. dypl. 213

Ernle-Erle-Drax Plunkett, adm. 233

Evill Douglas, gen. bryg. 298

Facon Patrick 72

Faury Louis, gen. 184-185

Ferio, kpt. 180

Filipowicz Czesław, płk obs. inż. 44, 240, 257, 279,285

Frankland Noble 87

Frankowski Feliks 175-176

Fraser Hugh, płk 70

Fraser William, płk 18-19, 79, 112-113, 172, 174, 197

Fridenson Patrick 13, 35-36, 73, 77, 83, 87, $108,120,126$

Friser Karol, ppłk obs. 185

Fyda Wojciech, płk dypl. 34, 166, 288-289

Gamelin Maurice, gen. 14, 19, 24, 48-49, 70, $72-73,77-79,82-84,96,98,107,110-112$, $121,123,125-126,139-142,148,157-$ $158,161-164,167-178,185,211,227-$ $228,234,282-283,291,297-298$

Gauché Maurice-Henri, płk 19

Gebhardt Krzysztof 15

Georges Alphonse, gen. 171, 174, 177

Gerlicki Franciszek, chor. 273

Gibbs Norman Henry 12, 72, 74, 83, 101, 112

Gilbert Bernard William 272-273

Gizaczyński Henryk, mjr pil. 179, 184

Gmurczyk-Wrońska Małgorzata 12-13, 17, $19,22,69,147,163,176,227,235,238$, 291

Goddard Victor, ppłk. 279

Goldstein Erik 266 
Goodwin Edwin Spencer, płk 226

Gort John, gen. 71, 121, 227, 243

Gosiewski Antoni, mjr. pil. inż. 34

Goyet Pierre Le 12, 163, 170, 177-178

Grabowski Waldemar 182, 287

Graffenried-Villars Gerard de 241

Grimal Georges, kpt. 24, 29, 180

Gruillot, kmdr ppor. 147-148

Grzeloński Bogdan 66

Grzybowski Wacław 148

Guelton Frédéric 35

Haight John McVickar 33

Halifax Edward (Edward Frederick Lindley Wood, 1. hrabia Halifax) 17-18, 49, 51, $53,55-59,79,117,126-128,175,188$ 190, 211-213, 242, 247-249, 258-259, 261, 263-266, 272

Hankey Robert Maurice Alers 43, 136, 215 Harvey John 53

Harvey Oliver 53, 56, 258

Heywood T.G.G., gen. 234-235

Hill Christopher 49

Hirszbandt Robert, mjr pil. 179

Hitler Adolf 21-23, 50, 52, 118, 162, 234, 282, 301

Hoare Samuel 53, 116

Hollis Leslie Chasemore 62, 72, 87, 89, 93 , $116-117,122,188-190$

Hopkins Richard 249

Hoppenot Henri 36, 70, 72-73, 77, 79, 147, $159,163,213,227$

Hore-Belisha Leslie 116

Hudson Robert Spear 277

Huntziger Charles Léon, gen. 233

Imlay Talbot C. 35, 72

Inskip Thomas 50

Ironside Edmund, gen. 211-217, 272, 275

Ismay Hastings, gen. $62,73,113,119,128$, 174, 187-188, 197-198, 202-203, 205, 209-210, 234-235, 248, 299

Jabłonowski Marek 166

Jackiewicz Henryk 13, 49, 51, 58-59, 214, $241,243,249,259,275$

Jackson Peter 23
Jacob Edward Ian Claud, mjr 73, 95

Jakisz Stanisław, sierż. 273

Jaklicz Józef, płk dypl. 162-164, 166, 171-172, 174,214

Jamet Louis Marie, gen. 172, 229

Janowski Antoni, inż. pil. 255

Jażdżewski Antoni 258

Jędruszczak Tadeusz 59

Jędrzejewicz Wacław 14

Kaczanowski Mikołaj, kpt. 270, 273

Kajzerówna Zofia 166

Kalina Kazimierz 31

Kalinowski Franciszek 42

Kalkus Władysław, gen. bryg. 239, 258, 284, 288, 290

Kalpas Roland, ppor. pil. 258, 287

Karpiński Stanislaw, ppłk pil. 166, 168-169, 179

Kasprzycki Tadeusz, gen. dyw. 162-163, 166168, 170-174, 176, 178-179, 197, 262, 282

Keller René, gen. 36, 178

Kelly Denis 211

Kennard Howard William 17, 21-22, 30, 51, $53,55,62,66,133,136,148,187-190$, 197-198, 202, 210-211, 227, 234-236, 241-244, 246-247, 249, 258, 261, 277, 280-282

Kennedy John N., bryg. 101, 103

Kiecoń Józef, mjr pil. 26, 200

Kingsley-Wood Howard 81, 267, 271

Kirkor Stanisław 276

Kirkpatrick Ivon 198, 280

Koc Adam, płk 241, 243, 245, 259-260, 262 263, 275-276

Kołakowski Piotr 26, 42, 47, 61

Konarski Mieczysław, ppłk pil. inż. 259, 279

Kopański Stanisław, płk. dypl. 174

Kornat Marek 13, 17-18, 52-53, 66, 74, 141, $151,153,155,158-160,168,176,199$, $203,214,217,227,234$

Kossakowski Tadeusz, gen. bryg. 288

Kowalewski Jan, ppłk dypl. 148

Kowalski Włodzimierz Tadeusz 167

Kozłowski Eugeniusz J. 32

Krasiński Józef, ppor. 273

Kraskowski, por. 184 
Królikowski Zdzisław 42

Krupowicz Narcyz, ppor. 273

Kwiatkowski Eugeniusz 214, 247, 260, 275-277

Kwieciński Bogdan J., ppłk 41-42, 44, 60-61, $72,101,139,153-154,200,213,216,222$, 224-225, 227, 239, 257-258, 261-263, $267-271,273,275,278-281$

La Chambre Guy 151, 285, 287, 291-293

Lapon, mjr 180

Lauzun, kpt. 180

Le Blèvec, kpt. 180

Lebrun Albert 54, 289

Lecuir Jean 13, 35-36, 73, 77, 83, 87, 108, 120 , 126

Léger Alexis 51-52, 54-55, 142-143, 148, 163 Legrand, sierż. 183

Leith-Ross Frederick 273

Lelong Albert, gen. 22, 39, 47, 61, 70, 82-84, $103-105,107,110-111,123-125,127$, 133,296

Leśniak Jan, mjr. dypl. 26-27

Liniewski Michal, por. pil. 273

Litwinowicz Aleksander, gen. bryg. inż. 260$262,267,269,281,288$

Loktionow Aleksandr, gen. 235

Łossowski Piotr 53

Lowczowski Gustaw, mjr dypl. 34, 217

Łubieński Michal 56, 158-160, 213, 215

Ludlow-Hewitt Edgar, gen. Broni 218-219, 226, 297

Łukasiewicz Juliusz $14,18,20,54,56,66$, 158-160, 166-168, 172, 175-176, 286, 289

MacDonald Malcolm 50

Maciejowski Mieczysław, gen. bryg. 240, 260, 288

MacLeod Roderick 212

Majewski Mariusz 43

Majewski Wiktor, kpt. inż. 179

Majzner Robert 13, 47

Makowski Wacław, ppłk pil. 216, 222-223, 262, 267, 270, 279

Malinowski Tadeusz, gen. bryg. 247, 260 $263,265,267-268,270,273,275,278$ $279,281,283$
Malkin William 123, 126-127

Mazur Agnieszka 15

Mazur Wojciech 19, 24, 30, 44, 137, 142, 183, 206, 218, 282, 288

Mazurowa Kazimiera 185

McDonough Frank 67

McKercher Brian 266

Meaux, kpt. 180

Mendigal Jean Achille Henri, gen. 179, 183, $185,229,284$

Merdinger Zygmunt 280

Meysztowicz Jan 13

Mierzwa Janusz 241, 260, 271, 275-276

Millman Brock 139

Misiuk Andrzej 41

Mittelhauser Eugène, gen. 161

Modelski Izydor, płk dypl. 174

Molotow Wiaczesław 11, 291

Mościcki Ignacy 22, 55, 159

Mullins Arthur 248

Murray Williamson 47

Musse Félix, gen. 21-22, 28, 30, 143-144, 147 $148,160-163,166,172-173,185,215$ $217,229,231,234,236,239,281$

Naggiar Paul-Émile 234

Nałęcz Daria 43

Nazarewicz Ryszard 235

Newall Cyril, gen. dyw. 70-71, 104, 109-110, $113,115,117,122,130,190,197,243$, $269,275,298,303$

Newman Simon 12, 30, 49-50, 53-54, 58-60, 65,91

Nixon F.H. 263

Noël Leon 21-22, 31-32, 52, 142-144, 148, $157,159,162-163,197,203,216,234$, 238, 241-242, 281-283

Noiret Charles, mjr 171

Norton Clifford 212-214, 241-242, 245-246, 276-277

Nowak-Kiełbikowa Maria 59

Nurek Marian 13, 49-50, 55

Odend'hal Jean Hernest, wiceadm. 298

Ogilvie-Forbes George 66

Orliński Bolesław 258 
Panem, por. 184

Pawłowski Tymoteusz 12

Peirse Richard Edmund Charles, gen. bryg. 224

Pełczyński Tadeusz 42

Pepłoński Andrzej 41, 47

Pernot François 35

Pétain Philippe 173

Petibon Jean Louis Paul Marie, płk. 112, 172, 174

Petit, plut. 183

Phillips Frederick 243, 245, 259, 272

Phillips Thomas Spencer Vaughan, wiceadm. 113

Philpott Ian M. 155

Philpott William J. 72

Phipps Eric 18-21, 30, 51-52, 55, 69, 73, 197

Pineton de Chambrun Gilbert 162

Piniński Franciszek Xawery, ppłk pil. obs. 34, 169, 180, 183-187, 283-288, 290

Pociask Stanislaw, ppłk. 223

Ponton d'Amecourt Albert de, kpt. 184

Porter W., ppłk 277, 279

Potocki Józef 55, 160, 242-243, 264

Pownall Henry R., gen. 113, 172, 174, 197 . 212,235

Prazmowska Anita 12-13, 45, 49, 58-59, 65, $83,91,105-106,110,113,117,120,122$, $130,199,212,214,263,275$

Prételat André-Gaston, gen. 177

Raczyński Edward 20, 49, 54-56, 58, 66, 139 , 157-159, 187, 198, 213, 215-216, 241$243,247,249,258-259,261,272,275-$ 276, 279

Rakowski Boguslaw 83, 275

Rawlings Henry Bernard, kmdr 190-191

Rayski Ludomił, gen. bryg. pil. inż. 43, 239, 261-262, 267-269, 271, 273, 275, 278

Rennington T.E., mjr 234

Rezmer Waldemar 166

Ribbentrop Joachim von 11, 17, 20-22, 291

Roberts Frank K. 138, 279

Robinson Arthur 263

Rochat Charles 22, 148, 158, 160, 162, 175-176

Rochot, kpt. 24, 27, 184
Roton Gaston-Réné-Eugène, gen. 171, 174

Rozoy Marie Joseph Paul, płk 70

Ryan C.N. 116-117, 248

Salisbury James (James Edward Hubert Gascoyne-Cecil, 4. markiz Salisbury) 57

Saloni Roman, płk. dypl. 288

Sandford F.H. 258

Sargent Orme 18, 20-22, 30, 139, 187, 202, 209-210, 241, 263, 267, 275, 277

Seeds William 234

Simon John $21,53,58,245,248,259,262$ 263, 271-273

Sims F.H. ppłk. 280

Skinder-Suchcitz Teresa 202, 210, 213

Skrzypek Andrzej 83

Sławoj-Składkowski Felicjan, gen. dyw. 55

Slessor John, płk 14, 35-36, 67-68, 70-71, 79, 93-94, 103, 105, 108, 119, 129-130, 152, 204, 226, 237-238, 280, 294-299

Śmigły-Rydz Edward, marszałek Polski 55, 142-144, 161-162, 164-166, 171, 202, 211-212, 214, 216, 247, 259-260, 275, 285

Smoleński Marian Józef, płk. dypl. 24, 186-187

Sommerville-Smith Herbert 240, 273, 277

Soviche Pierre, kpt. pil. 234

Speaight Richard 43-45, 136, 243, 245

Stachiewicz Wactaw, gen. bryg. 14, 143, 153, $162,164-165,185,190,199-200,202$, 213-215, 235-236, 260

Stalin Józef 234

Stankiewicz Henryk 34

Starzeński Paweł 52, 55, 67, 215, 241

Stepan Kamil 15, 60

Stirling Tessa 42

Stone Glyn 266

Strang G. Bruce 65

Strang William 18-19, 135, 139, 158, 175, $187-190,198,241,281$

Street Artur 128

Suchcitz Andrzej 12, 14, 41, 190, 202, 211 , 216

Suchos Franciszek, mjr inż. pil. 240

Sulerzycki Mieczysław, kpt. pil. 273

Suryn Roman, ppłk pil. inż. 240 
Sword Edward Roland, ppłk 14, 42, 61, 135 $136,138-139,148,153,203,214,227$, 235-236, 261

Szafrański Tadeusz 13

Szakowski Józef, chor. 273

Szembek Jan 53, 55, 148, 158, 214-215, 258, 264

Swiątek Feliks, chor. 273

Tebinka Jacek 13, 42, 55, 138, 227

Tilea Viorel Virgil 49

Troubridge Thomas Hope, kmdr 147

Troutbeck John Monro 266-267

Turnbull Elizabeth 14

Tuśkiewicz Olgierd, ppłk dypl. pil. 284

Ujejski Stanisław, gen. bryg. obs. 26, 28, 179, $183,187,200-201,223-224,226,283,285$ $286,288,290$

Ulatowski Łukasz 26

Vachell John Lyne, płk pil. 42-43, 136-139, 189

Vajda Ferenc A. 208

Valentino Pietro Arone di 241

Valin Martial Henri, gen. pil. 228, 234-236

Vansittart Robert 264, 271

Villelume Paul de, płk 21, 47, 171, 174
Vivier Thierry 13, 26, 33, 36, 170, 182, 185

Vuillemin Joseph, gen. pil. 77, 96-98, 100, $106,110-112,119,125-126,133,139$ $141,168-169,178,183,219,228,233$, 282-283, 286, 292-293, 297, 303

Waley Sigismund D. 241, 263-264, 267, 272 273, 277

Webster Charles 87

Wesołowski Andrzej 60

Wiatr Józef, płk. dypl. 288-289

Wills J.J. 135, 241

Wilson Horace 53, 249, 259

Włodarkiewicz Andrzej, kpt. pil. 258, 287

Wójcik Waldemar 239

Woodward Ernest L. 13

Wszelaki Jan 241-242, 246-247, 263, 271, 277

Wuillaume Jacques Antoine, $\mathrm{kmdr}$ ppor. 228

Wyszczelski Lech 172

Zacharewicz Kazimierz, mjr 180

Zając Józef, gen. bryg. 258, 285

Zarański Józef 55

Zawadzki Tadeusz 188

Zgórniak Marian 12, 33, 83, 126, 141, 153, $164,168,170,173,177,199,208,214$, 291

Żerko Stanisław 13, 21-22 
W serii Societas pod redakcją Bogdana Szlachty ukazały się:

1. Grzybek Dariusz, Nauka czy ideologia. Biografia intelektualna Adama Krzyżanowskiego, 2005.

2. Drzonek Maciej, Między integracja a europeizacją. Kościół katolicki w Polsce wobec Unii Europejskiej w latach 1997-2003, 2006.

3. Chmieliński Maciej, Max Stirner. Jednostka, społeczeństwo, państwo, 2006.

4. Nieć Mateusz, Rozważania o pojęciu polityki w kręgu kultury attyckiej. Studium z historii polityki i myśli politycznej, 2006.

5. Sokołów Florian, Nahum Sokołów. Życie i legenda, oprac. Andrzej A. Zięba, 2006.

6. Porębski Leszek, Między przemoca a godnościa. Teoria polityczna Harolda D. Laswella, 2007.

7. Mazur Grzegorz, Życie polityczne polskiego Lwowa 1918-1939, 2007.

8. Węc Janusz Józef, Spór o ksztatt instytucjonalny Wspólnot Europejskich i Unii Europejskiej 1950-2005. Między ideq ponadnarodowości a wspótpraca międzyrzq̨dową. Analiza politologiczna, 2006.

9. Karas Marcin, Integryzm Bractwa Kaptańskiego św. Piusa X. Historia i doktryna rzymskokatolickiego ruchu tradycjonalistycznego, 2008.

10. Ideas on Tolerance, red. Guido Naschert, Marcin Rebes, 2009.

11. Gacek Łukasz, Chińskie elity polityczne w XX wieku, 2009.

12. Zemanek Bogdan S., Tajwańska tożsamość narodowa w publicystyce politycznej, 2009.

13. Lencznarowicz Jan, Jatta. W kręgu mitów zatożycielskich polskiej emigracji politycznej 1944-1956, 2009.

14. Grabowski Andrzej, Prawnicze pojęcie obowiazywania prawa stanowionego. Krytyka niepozytywistycznej koncepcji prawa, 2009.

15. Kich-Masłej Olga, Ukraina w opinii elit Krakowa końca XIX - pierwszej połowy XX wie$k u, 2009$.

16. Citkowska-Kimla Anna, Romantyzm polityczny w Niemczech. Reprezentanci, idee, model, 2010.

17. Mikuli Piotr, Sady a parlament $w$ ustrojach Australii, Kanady i Nowej Zelandii (na tle rozwiazań brytyjskich), 2010.

18. Kubicki Paweł, Miasto w sieci znaczeń. Kraków i jego tożsamości, 2010.

19. Żurawski Jakub, Internet jako współczesny środek elektronicznej komunikacji wyborczej i jego zastosowanie w polskich kampaniach parlamentarnych, 2010.

20. Polscy eurodeputowani 2004-2009. Uwarunkowania dzialania i ocena skuteczności, red. Krzysztof Szczerski, 2010.

21. Bojko Krzysztof, Stosunki dyplomatyczne Moskwy z Europq Zachodniq w czasach Iwana III, 2010.

22. Studia nad wielokulturowościq, red. Dorota Pietrzyk-Reeves, Małgorzata Kułakowska, Elìbieta Żak, 2010.

23. Bartnik Anna, Emigracja latynoska w USA po II wojnie światowej na przykladzie Portorykańczyków, Meksykanów i Kubańczyków, 2010.

24. Transformacje w Ameryce Łacińskiej, red. Adam Walaszek, Aleksandra Giera, 2011.

25. Praszałowicz Dorota, Polacy w Berlinie. Strumienie migracyjne i spoleczności imigrantów. Przeglad badań, 2010.

26. Głogowski Aleksander, Pakistan. Historia i współczesność, 2011.

27. Brążkiewicz Bartłomiej, Choroba psychiczna w literaturze $i$ kulturze rosyjskiej, 2011. 
28. Bojenko-Izdebska Ewa, Przemiany w Niemczech Wschodnich 1989-2010. Polityczne aspekty transformacji, 2011.

29. Kołodziej Jacek, Wartości polityczne. Rozpoznanie, rozumienie, komunikowanie, 2011.

30. Nacjonalizmy różnych narodów. Perspektywa politologiczno-religioznawcza, red. Bogumił Grott, Olgierd Grott, 2012.

31. Matyasik Michał, Realizacja wolności wypowiedzi na podstawie przepisów i praktyki w USA, 2011.

32. Grzybek Dariusz, Polityczne konsekwencje idei ekonomicznych w myśli polskiej 1869$-1939,2012$.

33. Woźnica Rafał, Bułgarska polityka wewnętrzna a proces integracji $z$ Uniq Europejska, 2012.

34. Slufińska Monika, Radykałowie francuscy. Koncepcje i działalność polityczna w XX wieku, 2012.

35. Fyderek Łukasz, Pretorianie i technokraci w rezimie politycznym Syrii, 2012.

36. Węc Janusz Józef, Traktat lizboński. Polityczne aspekty reformy ustrojowej Unii Europejskiej w latach 2007-2009, 2011.

37. Rudnicka-Kassem Dorota, John Paul II, Islam and the Middle East. The Pope's Spiritual Leadership in Developing a Dialogical Path for the New History of Christian-Muslim Relations, 2012.

38. Bujwid-Kurek Ewa, Serbia w nowej przestrzeni ustrojowej. Dzieje, ustrój, konstytucja, 2012.

39. Cisek Janusz, Granice Rzeczypospolitej i konflikt polsko-bolszewicki w świetle amerykańskich raportów dyplomatycznych $i$ wojskowych, 2012.

40. Gacek Łukasz, Bezpieczeństwo energetyczne Chin. Aktywność państwowych przedsiębiorstw na rynkach zagranicznych, 2012.

41. Węc Janusz Józef, Spór o ksztalt ustrojowy Wspólnot Europejskich i Unii Europejskiej w latach 1950-2010. Między idea ponadnarodowości a wspótpraca międzyrządowa. Analiza politologiczna, 2012.

42. Międzycywilizacyjny dialog w świecie słowiańskim wXX $i$ XXI wieku. Historia - religia kultura - polityka, red. Irena Stawowy-Kawka, 2012.

43. Ciekawość świata, ludzi, kultury... Ksiega jubileuszowa ofiarowana Profesorowi Ryszardowi Kantorowi z okazji czterdziestolecia pracy naukowej, red. Renata Hołda, Tadeusz Paleczny, 2012.

44. Węc Janusz Józef, Pierwsza polska prezydencja w Unii Europejskiej. Uwarunkowania procesy decyzyjne - osiagnięcia i niepowodzenia, 2012.

45. Zemanek Adina, Córki Chin i obywatelki świata. Obraz kobiety w chińskich czasopismach o modzie, 2012.

46. Kamińska Ewa, Rezeption japanischer Kultur in Deutschland. Zeitgenössische Keramik als Fallstudie, 2012.

47. Obeidat Hassaym, Stabilność układu naftowego w warunkach zagrożeń konfliktami w świetle kryzysu w latach siedemdziesiątych XX i na progu XXI wieku, 2012.

48. Scigaj Pawel, Tożsamość narodowa. Zarys problematyki, 2012.

49. Głogowski Aleksander, Af-Pak. Znaczenie zachodniego pogranicza pakistańsko-afgańskiego dla bezpieczeństwa regionalnego w latach 1947-2011, 2012.

50. Miżejewski Maciej, Ochrona pluralizmu w polityce medialnej Wloch, 2012.

51. Jakubiak Łukasz, Referendum jako narzędzie polityki. Francuskie doświadczenia ustrojowe, 2013. 
52. Skuteczność polskiej prezydencji $w$ Unii Europejskiej. Zalożone cele $i$ ich realizacja, red. Krzysztof Szczerski, 2013.

53. Stosunki państwo-Kościót w Polsce 1944-2010, red. Rafał Latka, 2013.

54. Gacek Łukasz, Trojnar Ewa, Pokojowe negocjacje czy twarda gra? Rozwój stosunków ponad Cieśning Tajwańska, 2012.

55. Sondel-Cedarmas Joanna, Nacjonalizm wloski. Geneza i ewolucja doktryny politycznej (1896-1923), 2013.

56. Rudnicka-Kassem Dorota, From the Richness of Islamic History, 2013.

57. Fudala Piotr, Fyderek Lukasz, Kurpiewska-Korbut Renata, Budowanie parlamentaryzmu. Doświadczenia z Afganistanu, Iraku i Kurdystanu irackiego, 2012.

58. Dardziński Piotr, Kapitalizm nieobjawiony. Doktryna ladu spolecznego, politycznego i ekonomicznego w myśli Wilhelma Röpkego, 2013.

59. The Taiwan Issues, ed. Ewa Trojnar, 2012.

60. Kopyś Tadeusz, Stosunki polsko-węgierskie w latach 1945-1980, 2013.

61. Kurpiewska-Korbut Renata, Spoleczność międzynarodowa wobec Kurdów irackich, 2013.

62. Pietrzyk-Reeves Dorota, Ład rzeczypospolitej. Polska myśl polityczna XVI wieku a klasyczna tradycja republikańska, 2012.

63. Matykiewicz-Włodarska Aleksandra, Marion Gräfin Dönhoff. Idee i refleksje polityczne, 2012.

64. Reczyńska Anna, Braterstwo a bagaż narodowy. Relacje w Kościele katolickim na ziemiach kanadyjskich do I wojny światowej, 2013.

65. Wspólczesne transformacje. Kultura, polityka, gospodarka, red. Monika Banaś, Joanna Dziadowiec, 2013.

66. Grott Olgierd, Instytut Badań Spraw Narodowościowych i Komisja Naukowych Badań Ziem Wschodnich w planowaniu polityki II Rzeczypospolitej Polskiej na Kresach Wschodnich, 2013.

67. Teoretyczne i praktyczne problemy kultury politycznej. Studia i szkice, red. Monika Banaś, 2013.

68. Podejścia badawcze i metodologie w nauce o polityce, red. Barbara Krauz-Mozer, Paweł Scigaj, 2013.

69. Narratives of Ethnic Identity, Migration and Politics. A Multidisciplinary Perspective, eds. Monika Banaś, Mariusz Dzięglewski, 2013.

70. Promoting Changes in Times of Transition and Crisis: Reflections on Human Rights Education, eds. Krzysztof Mazur, Piotr Musiewicz, Bogdan Szlachta, 2013.

71. Bar Joanna, Po ludobójstwie. Państwo i społeczeństwo w Rwandzie 1994-2012, 2013.

72. Whochy wielokulturowe. Regionalizmy, mniejszości, migracje, red. Karolina Golemo, 2013.

73. Stany Zjednoczone wczoraj $i$ dziś. Wybrane zagadnienia spoleczno-polityczne, red. Agnieszka Małek, Paulina Napierała, 2013.

74. Plichta Pawel, Estera w kulturach. Rzecz o biblijnych toposach, 2014.

75. Czekalska Renata, Wartości autoteliczne w kulturze symbolicznej na przykładzie indyjsko- polskich spotkań literackich, 2014.

76. Włodarski Bartosz, Szkoła Nauk Politycznych UJ 1920-1949, 2014.

77. Abassy Malgorzata, Russian Mason on the Paths of His Native Culture. A Case Study of Nicolas Novikov, 2014.

78. Bajor Piotr, Partnerstwo czy czlonkostwo. Polityka euroatlantycka Ukrainy po 1991 r., 2014. 
79. Gabryś Marcin, Kijewska-Trembecka Marta, Rybkowski Radosław, Soroka Tomasz, Kanada na przelomie XX i XXI wieku. Polityka, spoleczeństwo, edukacja, red. Marta Kijewska-Trembecka, 2014.

80. Trojnar Ewa, Tajwan. Dylematy rozwoju, 2015.

81. Glogowski Aleksander, Policja Państwowa $i$ inne instytucje bezpieczeństwa na Wileńszczyźnie w latach 1918-1939, 2015.

82. Krzyżanowska-Skowronek Iwona, Teorie zmiany na przykładzie włoskiej polityki wschodniej, 2015.

83. Rysiewicz Mikołaj, Monarchia - lud - religia. Monarchizm konserwatywnych środowisk politycznych Wielkiej Emigracji w latach 1831-1848, 2015.

84. Szymkowska-Bartyzel Jolanta, Nasza Ameryka wyobraziona. Polskie spotkania z amerykańska kultura popularnq po roku 1918, 2015.

85. Napierała Paulina, In God We Trust. Religia w sferze politycznej USA, 2015.

86. Paluszkiewicz-Misiaczek Magdalena, Szacunek $i$ wsparcie. Kanadyjski system opieki nad weteranami, 2015.

87. Детерминанты и перспективы политики европейской интеграции Республики Молдова, под научной редакцией Петра Байора, 2015.

88. Eastern Chessboard. Geopolitical Determinants and Challenges in Eastern Europe and the South Caucasus, ed. Piotr Bajor, Kamila Schöll-Mazurek, 2015.

89. Mazur Wojciech, Pod wiatr. Francja i lotnictwo wojskowe II Rzeczypospolitej (1921-1938), 2015.

90. Węc Janusz Józef, Traktat lizboński. Polityczne aspekty reformy ustrojowej Unii Europejskiej w latach 2007-2015, 2016.

91. Fyderek Łukasz, Autorytarne systemy polityczne świata arabskiego. Adaptacja i inercja w przededniu Arabskiej Wiosny, 2015.

92. Kwieciński Rafal, Zjednoczenie Chin? Proces reintegracji Wielkich Chin na przelomie $X X$ i XXI w., 2016.

93. Grabowski Marcin, Rywalizacja czy integracja? Procesy i organizacje integracyjne $w$ regionie Azji i Pacyfiku na przelomie XX i XXI wieku, 2015.

94. Laidler Pawel, Turek Maciej, Cena demokracji. Finansowanie federalnych kampanii wyborczych w Stanach Zjednoczonych Ameryki, 2016.

95. Bajor Piotr, Contemporary Azerbaijan in Social and Political Dimension, 2016.

96. Balwierz Ida, Czasopismo "Apollo". Jego miejsce i rola w odrodzeniu poezji i kultury arabskiej, 2016.

97. Bajor Piotr, Kierunek Zachód. Polityka integracji europejskiej Ukrainy po 1991 r., 2016.

98. Polska i Rumunia w Europie Srodkowej w XX i XXI wieku. Studia, materialy i eseje poświęcone pamięci prof. dra hab. Wojciecha Rojka. Polonia şi România in Europa Centralá in secolele XX si XXI. Studii, materiale si eseuri dedicate in memoriam prof. univ. dr. Wojciech Rojek, red. Agnieszka Kastory, Henryk Walczak, 2017. 



Wojciech Mazur (ur. 1963 r.) - doktor nauk humanistycznych w zakresie historii, adiunkt w Instytucie Studiów Międzykulturowych Uniwersytetu Jagiellońskiego w Krakowie. Jego zainteresowania koncentrują się wokół związków łączących siły zbrojne II Rzeczypospolitej z międzynarodowym otoczeniem. Jest autorem książek Na krawędzi ryzyka. Eksport polskiego sprzętu wojskowego w okresie międzywojennym (wspólnie z dr. Markiem P. Deszczyńskim) oraz Pod wiatr. Francja i lotnictwo wojskowe II Rzeczypospolitej 1921-1938, a także kilkudziesięciu innych publikacji naukowych i popularnonaukowych.

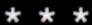

U progu II wojny światowej lotnictwo wojskowe stanowilo jedną z nielicznych sfer, w których możliwa zdawała się współpraca coraz bardziej zagrożonej przez agresję Rzeszy Polski oraz Francji, z którą leciwy już alians nie bez trudu próbowano reanimować, i Wielkiej Brytanii, niespodziewanie skłonnej szukać związków z mało dotychczas znanym partnerem ze wschodu. Tym samym zagadnienia lotniczej kooperacji Warszawy, Paryża i Londynu stawały się jedną z kwestii rozważanych wówczas przez najważniejszych aktorów wydarzeń, a także swoistym probierzem ich rzeczywistych intencji. To właśnie analiza kolejno dochodzących w tej sferze do głosu koncepcji oraz towarzyszących im procesów decyzyjnych stała się glównym celem podjętych przez autora prac.

Fragment Wstępu
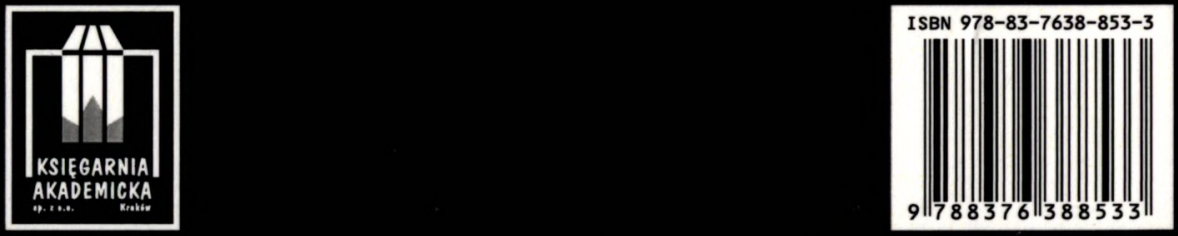